STATE OF ILLINOIS

DEPARTMENT OF REGISTRATION AND EDUCATION

DIVISION OF THE

NATURAL HISTORY SURVEY

STEPHEN A. FORBES, Chief

Vol. XVIII.

BULLETIN

Article I.

\title{
The Native and Naturalized Trees of Illinois
}

ROBERT BARCLAY MILLER

Chief Forester, Department of Conservation

and

L. R. TEHON

Botanist, State Natural History Survey

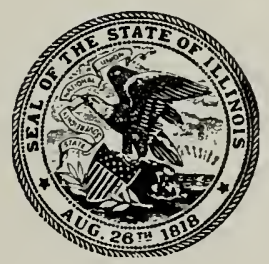

PRINTED BY AUTHORITY OF THE STATE OF ILLINOIS

URBANA, ILLINOIS

1929 


\section{STATE OF ILLINOIS \\ DEPARTMENT OF REGISTRATION AND EDUCATION}

A. MI. Sileltox, Director

\section{BOARD OF}

\section{NATURAL RESOURCES AND CONSERVATION}

A. M. Snertox, Chairman

Williay Trelease, Biology

Hexry C. Cowles, Forestry

Eusox S. BAstix, Geology

Williaj A. Nores, Chemistry
Johx W. Alvord, Engineering

CuARLis M. Tirompsox, Representing the President of the University of Illinois

THE NATURAL HISTORY SURVEY DIVISION

Stephex A. Fonbes, Chief

H. C. Oesterling. Eirlitor

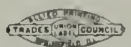

Schyepp \& Barnes, Printers

SPRtAgFIELd, ILL.

1929

$1493-3 \mathrm{NI}$ 


\section{FOREIYORD}

The following report on "The Native and Naturalized Trees of Illinois" is a part of the product of a forest survey of the State begun by the State Natural History Survey in 1919) and ended, as to the collection and organization of its data, in 1925. The senior author was a member of the State Survey from its commencement until June 30th of the latter year, and towards the end of this period he assembled the data of this report from all available sources, including, of course, those of the Survey itself, and prepared and filed for publication a comprehensive manuscript, to which some additions were nade by him after his appointment as Chief Forester of the State Department of Conservation. In order to make this the best possible product of the botanical resources of the Natural History Survey and of the University of Illinois, it was submitted, for critical revision and completion to the junior author, who was favored with the unstinted advice and assistance of Dr. William Trelease, professor cuncritus and former head of the Department of Botany of the University of Illinois: and with all these agencies in cordial cooperation, it can be confidently offered to its public as an authoritative compend of the existing state of our knowledge concerning the trees of lllinois.

Stephen A. Forbes 



\section{CONTENTS}

PAGE

Foreword $\ldots \ldots \ldots \ldots \ldots \ldots \ldots \ldots \ldots \ldots \ldots \ldots \ldots \ldots \ldots$

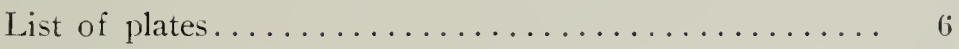

Introduction $\ldots \ldots \ldots \ldots \ldots \ldots \ldots \ldots \ldots \ldots \ldots \ldots \ldots \ldots \ldots$

Acknowledgments $\ldots \ldots \ldots \ldots \ldots \ldots \ldots \ldots \ldots \ldots \ldots . \ldots \ldots$

Keys to the trees for the four seasons........... 15

Description of the species............... 23

Botany and forestry:

The botany of trees................2s\%

Forest interest and forest preservation......... 325

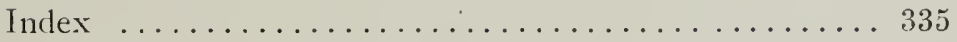


1. Pinus Strobus (White Pine) ....................... 25

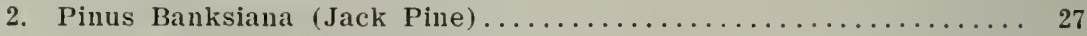

3. Pinus echinata (Yellow Pine) ...................... 30

4. Larix laricina (Tamarack) ....................... 34

5. Taxodium distichum (Bald Cypress).................. 38

6. Thuja occiclentalis (Arbor Vitae) ................... 42

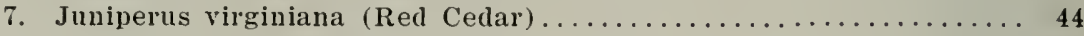

S. Populus tremuloides (Aspen)..................... 48

9. Populus grandidentata (Poplar) ...................... 49

10. Populus heterophylla (Swamp Cottonwood) ............... 53

11. Populus balsamifera var. virginiana (Cottonwood) ............ 57

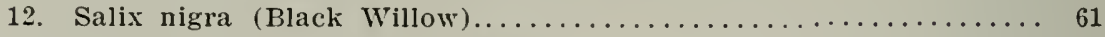

13. Salix amygdaloides (Peach Willow) ................... 63

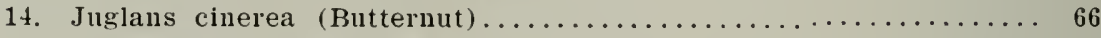

15. Juglans nigra (Black Walnut) ..................... 69

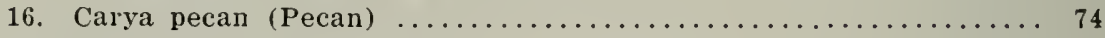

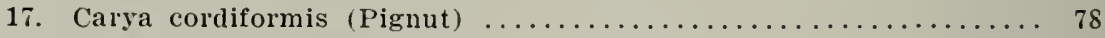

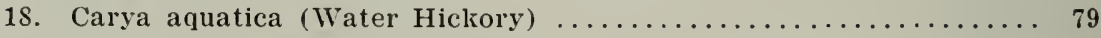

19. Carya ovata (Shagbark Hickory) .................... 82

20. Carya laciniosa (Big Shellbark Hickory) ............... 84

21. Carya alba (Hickory) $\ldots \ldots \ldots \ldots \ldots \ldots \ldots \ldots \ldots \ldots \ldots \ldots \ldots \ldots \ldots$

22. Carya glabra (Pignut) $\ldots \ldots \ldots \ldots \ldots \ldots \ldots \ldots \ldots \ldots \ldots \ldots \ldots \ldots \ldots \ldots \ldots$

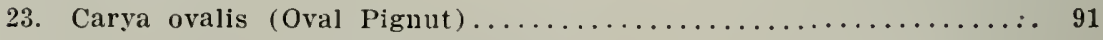

24. Carya Buckleyi (Buckley's Hickory) .................... 92

25. Carpinus caroliniana (Hornbeam) ................... 95

26. Ostrya virginiana $($ Hop Hornbeam) .................. 97

27. Betula nigra $($ Red Birch) $\ldots \ldots \ldots \ldots \ldots \ldots \ldots \ldots \ldots \ldots \ldots \ldots \ldots \ldots . \ldots \ldots$

28. Betula papyrifera (Canoe Birch) .................... 102

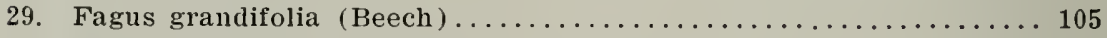

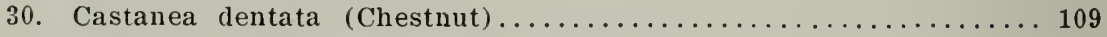

31. Quercus borealis var. maxima (Red Oak) ............... 113

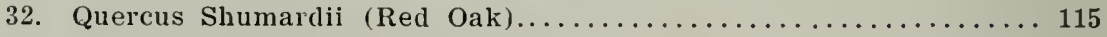

33. Quercus ellipsoidalis (Black Oak)...................... 118

34. Quercus palustris (Pin Oak)........................ 119

35. Quercus velutina (Black Oak)....................... 123

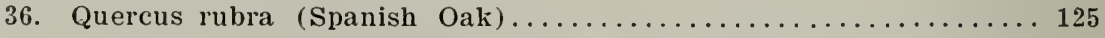

37. Quercus rubra var. pagodaefolia (Swamp Spanish Oak) ......... 127

38. Quercus marilandica (Black Jack) ....................... 129

39. Quercus Phellos (Willow Oak) ...................... 132

40. Quercus imbricaria (Shingle Oak) ................... 133

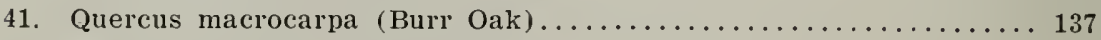

42. Quercus lyrata (Overcup Oak) ....................... 139

43. Quercus stellata (Post Oak) ....................... 141

44. Quercus alba (White Oak) ........................ 143

45. Quercus bicolor (Swamp White Oak) ..................... 147

46. Quercus prinus (Basket Oak)..................... 150

* Excepting Nos. 3, 21, 31, 37, 39, 53, 65, 73. $\$ \$, 90$, and $9 \$$, the plates listed above are from C. C. Deam's "Trees of Indiana," and are used through the courtesy of $\mathrm{Mr}$. Deam and the Indiana Department of Conservation. 
47. Quercus montana (Chestnut Oak) .................. 151

4S. Quercus Muehlenbergii (Yellow Oak).................... 154

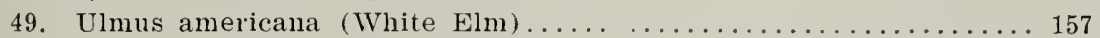

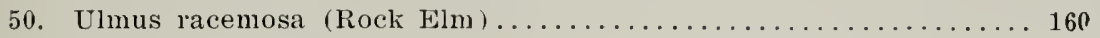

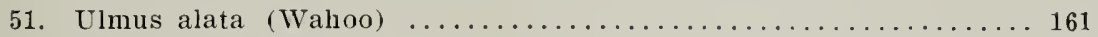

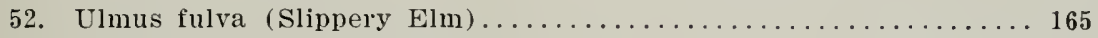

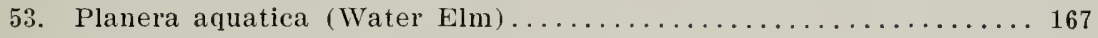

54. Celtis occidentalis (Hackberry)..................... 170

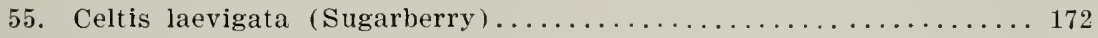

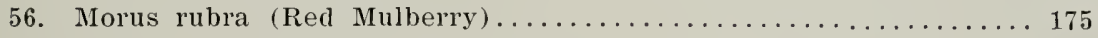

57. Maclura pomifera (Osage Orange) .................. 178

58. Magnolia acuminata (Cucumber Tree)................. 181

59. Liriodendron tulipifera (Tulip Tree) .................. 183

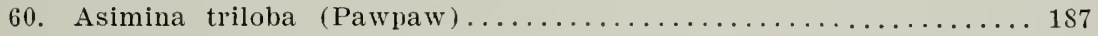

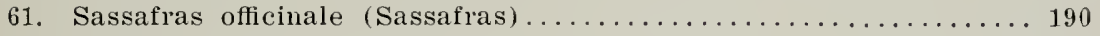

62. Liquidambar Styraciflua (Sweet Gum) ................... 193

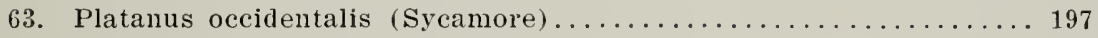

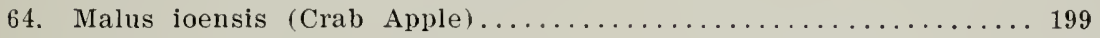

65. Sorbus americana (Mountain Ash) ................... 201

66. Amelanchier canadensis (Service Berry) .................. 204

67. Crataegus Phaenopyrum (Washington Thorn) . . . . . . . . . 207

68. Crataegus Crus-galli (Cock-spur Thorn)................. 208

69. Crataegus mollis (Red Haw) ...................... 209

70. Prunus americana (Wild Plum) .................... 211

71. Prunus hortulana (Wild Goose Plum) .................. 214

72. Prunus penusylvanica (Wild Red Cherry)................. 215

73. Prunus virginiana Choke Cherry)................... 218

74. Prumus serotina (IVild Black Cherry)..................... 219

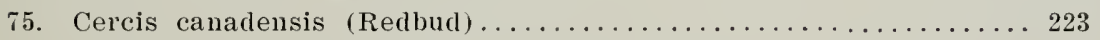

76. Gymnocladus dioicus (Kentucky Coffee Tree) . . . . . . . . . . . 225

77. Gleditsia triacauthos (Honey Locust) . . . . . . . . . . . . . . . . 227

78. Gleditsia aquatica (Water Locust) .................. 230

79. Robinia pseudoacacia (Black Locust).................. 233

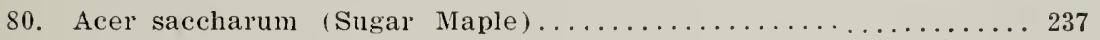

81. Acer nigrum (Black Maple) ...................... 239

82. Acer saccharinum (Silver Maple) .................... 241

83. Acer rubrum (Red Maple) ....................... 245

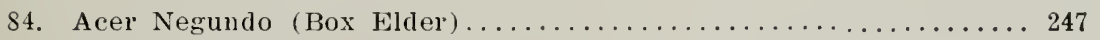

85. Aesculus glabra (Ohio Buckeye) ...................... 249

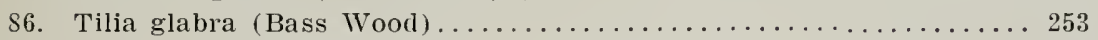

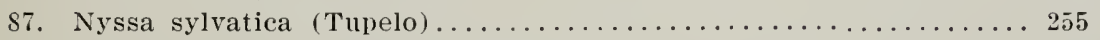

8S. Nyssa aquatica (Tupelo Gum) ..................... 258

89. Cornus florida (Flowering Dogwood) .................. 262

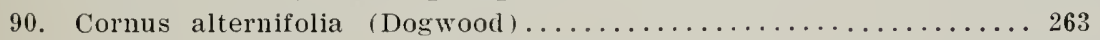

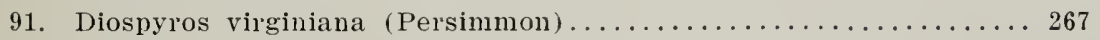

92. Fraxinus americana (White Ash) .................. 269

93. Fraxinus Biltmoreana (Biltmore Ash) ................ 272

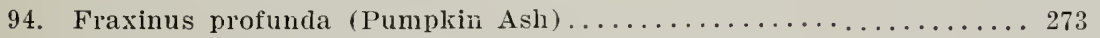

95. Fraxinus pennsylvanica $v a r$. lanceolata (Green Ash) . . . . . . . 276

96. Fraxinus quadrangulata (Blue Ash) . . . . . . . . . . . . . 279

97. Fraxinus nigra (Black Ash) ...................... 281

98. Catalpa speciosa (Cataipa) .............................. 283 



\section{INTRODUCTION}

In presenting this book to the people of Illinois, it has been the authors' aim to furnish not merely a manual of the trees of the State but to give as complete an account of them as our present linowledge would permit. Consequently, the reader will find in the following pages not only a means for identifying trees but also the important facts concerning their distribution, their history, their uses, their past and present inportance in commerce and industry, and many other things.

As a background for the book, there have been available not only the large collections of specimens made by previous workers and now widely scattered among the herbaria of our universities, colleges, and museums but also a great fund of data and observations gathered by the Natural History Survey's staff of foresters during the course of a thorough and painstaking survey of the forests and wooded lands of the State. From these records and observations, and from the printed reports and communicated experiences of the botanists now actively engaged in studying our trees, it has been possible to select a fund of information bearing upon the distribution of each species, upon its relations to soil, topography, and situation, upon its form and habits, and upon its commercial usefulness, so large that it has had to be sifted and condensed carefully. Nevertheless, it is believed that the interest and usefulness of the book will be greatly enhancer by the inclusion of this information, which tends to make it particularly a book of the trees of Illinois.

In order to encourage a wider and deeper interest in our trees, a final section has been added, in which the lover of trees, the anateur botanist, and teachers and students in high schools and colleges will find instructions for preparing and keeping collections of the trees of their localities, as well as stggestive material regarding the botanical classification of trees, their gross and microscopic structure, and a short account of the study of trees and the present interest in forest preserves in Illinois.

The body of the book is, quite naturally, devoted to a discussion of the individual trees. The plan for this part is simple. On page 15 the reader will find a section entitled "Keys to the Trees for the Four Seasons." These were prepared by Dr. William Trelease, an eminent. botanist who was for years head of the Botany Department in the University of Illinois. He also prepared the lucid statement of how to use them. In spring, in summer, in fall, or in winter, the genus to which a 
tree belongs can be determined easily by means of these keys. Ifter the genus has been determined, a reference directs the user of the book to a page where a fuller account of the characteristics of the genus is given. Here one will also find a statement of the total number of species belonging to the genus, their general distribution over the world, the history of the genus, and the number of its species occurring in Illinois. If there are more than one species native to Illinois, a key is given for them, by means of which the exact species may be determined. and a reference leads the user from the liey to the page where the botanical characters of the species are printed.

The materials used in the description of each species lave been put in a definite order. First comes the scientific name and its author, as a heading; this is followed by a line made up of one or more common names; and the text begins with a catalog of the botanical characteristics. which is succeeded in turn by a discussion of distribution, and this in its turu is followed by a statement of the uses to which a tree may be plit.

The scientific names and authors are those given in C. S. Sargent's "Manual of the Trees of North America." second edition" : and the common names are also given largely on the same authority, though we have not hesitated to employ other names when we know them to be used conmonly in Illinois. Simplicity has been the aim in omitting all except the commonest and most easily recognizerl varieties, although now and then a variety customarily recognized as a distinct kind of tree has been given an individual place. The pleasant task of distinguishing the less readily recognized varieties is left to the reader, as a means of proving his increasing interest and knowledge.

In the botanical description of the species, the use of technical words has been avoided as much as possible, as fine botanical distinctions relating to variations in the shape of leaves and fruits and in the relative abundance and texture of plant hairs are apt to be confusing not only to the novice but also to those of wider experience. The full-page plates used to illustrate each species will show the shapes of leaves and fruits and suggest the differences in hairiness far better than words could describe them. There is, however, a more complete description of other characteristics of trees than is usually found in manuals. The twigs, buds, pith. and other structures are described with respect to their size, their color, and their other characteristics. with the intention of leading the reader to observe closely and to become intimately acquainted with all the parts of the trees he identifies. It is supposed that, for the few

1 Houghton Mifflin Company. 1922. 
trees where it is necessary, the reader can distinguish between the sepals, the petals, the stamens, and the pistils, without any special explanation: and the use of a large array of botanical terms for various flower arrangements has been avoided also. The term inflorescence will be understood to mean a large collection or cluster of flowers; the catkin, familiar on the willows, will be recognized easily on other trees; the spike is an inflorescence in which the individual flowers sit on a central axis; and a raceme is an inflorescence in which the individual flowers are joined to a central axis by pedicels.

The range in North America, as given by C. S. Sargent and others, is stated briefly for each species, so that the reader may sce how the Iilinois range fits in; and the particular features of clistribution, range, and habitat peculiar to Inlinois are discussed in as much detail as possible, in order to include such interesting facts as former occurrences, unusual sizes, present abundance, and the like.

The maps indicating the distribution of species show by counties, and in two instances by localities, the proved occurrence in each case. The meaning of the symbols on the maps is as follows: Cross-hatching by solid lines running diagonally in a connty indicates that the occurrence of a species in that connty has been proved by a specimen deposited in a herbarium; similar cross-hatching by broken lines means that the species was found in a county during the course of our forest survey, though no specimen has been kept; and cross-hatching by horizontal lines shows an occurrence reported in some published article, for which a confirmatory specimen has not been seen. The approximate localities in which two of our rarest trees occur are marked by black circles.

Though accurate in themselves, these maps are intended to be regarded also in a broader sense. Even though a species is not recorded for a certain county. its proved occurrence in adjoining counties may be taken to mean that it occurs in the first, provided suitable habitats exist. if the timber has not been cut and destroyed. On the other hand, there are certain species which have only a limited distribution in the State, and these will be found only in their proper habitats in the counties narked for then. Maps such as these could not be complete unless collectors and observers had covered the entire State and had made linown the results of their work both by printing their observations and by preserving herbarium specimens as verifications. Herein lies the opportunity for the tree enthusiast ; for by collecting in his own locality he will be able to add several trees to the list for his county and will also be contributing worthily to the knowledge of tree geography in Illinois. 
As an introduction to the paragraphs concerning the uses of each of the trees, the reader will find a brief statement of the technical qualities of the woods derived from them. From this he nay see why the woods from certain trees are desirable for fine building, while the woods of others can serve only for posts or the roughest kinds of construction. To this brief statement, he may add a further understanding by referring to the photomicrographs of woods given on the closing pages of the book.

The inclusion of data obtained by the Natural History Survey's staff of foresters upon the present stands of the important timber species and the potential yields from these stands will serve as a warning of the clanger in which Illinois now stands with respect to its future supply of lumber. There was a time when more than 40 per cent of the area of the State was covered by magnificent hardwood forests. Today there is but $s$ per cent of its area in forests, and even these have been depleted by the axe and by fire.

Yet at the present time there are 19 large and important industries, constituting in themselves nearly 18 per cent of all the manufacturing enterprises of the State, which are almost completely dependent upon wood as a raw material. And there are, besides, 14 other industries to which a supply of wood is exceedingly important. In the aggregate, these manufactories give employment to more than 163,000 persons; they have an invested capital amounting to $\$ 5 \pm \%, 000,000$ : they purchase annually $\$ 100,-$ 000,000 worth of raw material, sell their manufactured products for $\$: 34,000,000$, and add to the wealth of the State the sum of $\$ 334,000,000$ each year.

The amount of wood actually produced in Illinois' forests and woodlots is only one-fifth of the amount consumed in the State. The remaining four-fifths is shipped in. As the supply of timber becomes depleted elsewhere, it will become more and more difficult to bring into Illinois a quantity of wood adequate to the needs of her industries, unless definite steps are taken to preserve and improve the remmants of our forests.

Though our present forests are becoming pitifully small and poor in species, when compared with the extensive virgin forests, wealthy in hardwood species, which once existed here, there still remain to us 5 million acres of potential woodland, which can be made to produce from 250 million to 400 million cubic feet of wood, or from one-half to two-thirds of our present consumption. By proper management, the percentage of valuable wood produced can be increased greatly; and from this conservation of her potential forest resources, the State of Illinois will derive tremendous benefits in all lines of industry. 


\section{TREES INCLUded}

Although it is fruitless to try to draw a line of demarcation between trees and shrubs, we have endeavored to include every species that attains tree size, whether or not the tree yields lumber, bark-products, fruit, or any other commercial product. Several species, such as the flowering Dogwood and the Hop Hornbean, which by many would be considered only as large shrubs, have been inclucled, partly because they form a characteristic understory in our forests and partly because they furnish small amounts of often very valuable and useful woods. The treatment accorded the hawthorns is by no means adequate; but they form so difficult a group botanically that we have thought it best only to provicle a key by means of which the common tree-like species may be identified.

The number of species given individual trcatment in the text is exactly 94 ; but in addition 3 varieties are treated separately, giving a total of $9 \%$ trees. If the 16 species of Crataegus, the $S$ less important varieties mentioned, the 9 oak hybrids, and the $;$ other species mentioned as probably native are added, the total number of tree species in the State nuy be placed at $13 \%$. If all the species of Crataegus which attain tree size had been included and if more had been known concerning the kinds of Malus present in the State, this number would undoubtedly have been much larger; and the number could still be increased by counting in no less than 18 additional varieties. the occurrence of which we have been unable to validate, though they are reported fron Illinois.

\section{Trees Excluded}

The exclusion of trees from this account has had to be based in part on the question of expediency. Of the very numerous species of hawthorns, we have retained in the book only such as are relatively common: in handling varieties, we have had to leave out those not easily distinguishable as well as those not capable of being validated. To have included more of this type of information than we have done would have served only to confuse those for whom the book is intended.

Certain other species have been excluded from the book, though they do occur within the State, on grounds that are purely arbitrary. One of the sumachs, Rlus copalina Linnaeus, attains tree size on rare occasions in southern Illinois, but in the main it is shrubby and yields at present no valuable product. The Black Haw, Tiburnum prunifolium Linnaeus, occurs in Richland, Pope, and Johnson counties; but we leave it to be treated as a shrub with the other Viburnums. The Button Bush, Cephalanthus 
occidentalis Linnacus, though tree-like in its northern range, is only a small shrub less than 1 i) feet high throughout most of Illinois. The Silver Bell Tree. Hulesia carolina l.imnaeus, is small and shrubby in Massac County, its only known locality in Illinois, though in the South it becomes tree-like: and Hercules' Club, Aralia spinosa Limnaeus, also a tree in the South, attains a height of only $1 \bar{j}$, or at most ?(), feet in Pulaski, Johnson, and Pope comntics, where it is fairly common. The Iromwood, Bumclia lycioides Gaertner, which occurs in Alexander, Pulaski, Pope, and Hardin counties, attains a height of 20 feet or so but yiclds no valuable wood.

A list of the varieties and species not mentioned in the body of the text but variously reported as native or naturalized in Illinois will be found on pages 28.5 and 286 .

\section{ACKNOWLEDGMENTS}

Throughout the preparation of this book, the authors have benefited by the advice, encomagement, and help of many people who have taken a real interest in the work, and to them all we are deeply indebted. Appreciation is due especially to Dr. William Trelease, cmcritus Professor of Botany in the University of Illinois, for the keys on the first pages of the book and also for the critical opinions, the valuable suggestions, and the unwearied assistance that he gave so freely. Charles Sprague Sargent, recently deceased, and Mr. E. J. Palmer, both of the Arnold Arboretum, rendered valuable help by suggesting species to be added to or onitted from our list. Mr. H. Teuscher. Botanist of the Morton Arboretum. gave freely not only his personal help but also the results of his many hours of labor in herberia; and the Curators of the Field Musemu of Natural History, the Arnold Arboretum, the Herbarim of the University of Illinois, and the Shaw Botanical Garden have been miversally courteous and generous. To the Field Museum of Natural History thanks are due for the use of tree and bark photographs; to the Forest Products Laboratory at Madison, Wisconsin, for permission to reproduce photomicrographs of wood sections; and especially to Charles C. Deam and the Indiana Department of Conservation for the many full-page plates made from Mr. Deam's excellent photographs.

R. B. Miller

L. R. TEHON. 


\section{KEYS TO THE TREES FOR THE FOUR SEASONS}

\section{By William Trelease}

A "key" is a means of finding out simply and directly the name of a plant, without having to look over and compare many descriptions or illustrations. Anyone who can use one kind of key will quickly learn how to use another with a little study.

\section{How to Use the Keys}

In the kind of keys used here, one passes by a succession of subdivided steps from the beginning of the key to a point where the name of his tree is found, just as he might go from the bottom floor of a large building to any room he wished by choosing properly-labeled stairways. As an example of their use. we may take the beautiful and important Tulip Tree.

In the "foliage" key (page 16): The leaves of our specimen are not evergreen, as required in the first full line, a, so we go to the second full line, aa: they are not small and narrow, as required in $b$, so we go to the second principal subdivision, $\mathrm{bb}$; there is only one leaf at a joint of the stem, so the plant must be confined to the c subdirision: the leaves are not "compound" like those of a locust or a hickory, so we confine ourselves to the next subdivision, d; they are cut into sereral rather large parts, "lobes," which takes us into subdivision eee under $d$; they have several ribs or veins radiating from the base, which tells conclusively that the name of the tree can be found under subdivision $\mathrm{i}$ of this group: the absence of a milky sap, the broad leares, and the fact that they seem to have been cut off in a shallow notch at the end leads unquestionably to the Latin name Liriodendron that botanists give to the Tulip Tree.

If one were to find the same tree with its tulip-like flowers blossoming, the foliage key would still lead to its name: but on the basis of its flowers, it would be even more quickly named by the "flower" key (page 18), for the flowers are so large and showy that it must go into the first general division, a; its petals are not grown together. which places it in subdivision bb; since its flowers resemble neither pea nor apple nor cherry blossoms, we go on down to subdivision cccc of bb; and the fact that the tree is already in foliage and the flowers large and particolored leads directly to Liriodendron.

In autumn, when its "seecls" are being scattered by the wind, though neither leaves nor flowers are present, the "fruit" key (page 19) leads to its name almost as directly. The dry fruit puts it in division aa: 
What are called seeds really are separate pistils massed about a spikelike axis, but not at all of the "cone" type of the pine or hemlock, so we pass first to the $\mathrm{d}$ subdivision and under it to the ee subdivision; and as the fruits are not nuts, have a thin wing at the end, and overlap in what was one flower, we pass directly into the subdivision ggg and to the name Liriodendron.

In winter these fruits are seen commonly, yet a Tulip Tree which lacks leaves. flowers, and fruits can be named with equal certainty by the "winter" key (page :1). Not being evergreen, it falls into the division aa of this key; one leaf-scar at a joint and the fruit not a pine-like "cone" lead to the subdivision d; and the very narrow scar-line around the twig and the wonderful 2-edged buds, in which next year's growth is already found, take one again to Liriodendron.

\section{KEY TO THE TREES WHEN IN FOLIAGE}

PAGE

a. Leaves evergreen, small and narrow.

Leaves needle-like; fruit a large cone.................. Pinus

Leaves not needle-like nor fruit large.

Fruit a thin-scaled cone, leafy branches flat and fan-like.. Thuja

Fruit like a dry berry; branches not fan-like..........Juniperus

aa. Leaves falling in autumn.

b. Leaves small and narrow; fruit a small cone.

Scales of cone thin; leaves needle-like............... Larix

Scales of cone thickened; leaves flat.............. Taxodium

bb. Leaves never very small nor fruit a cone.

c. One leaf at each joint (node) of the stem.

d. Leaves of one blade or piece (simple).

e. Margin of leaf entire.

Sap milky; twigs spiny..........................

Sap not milky, nor twigs spiny.

Leaf as broad as long...........................

Leaf longer than broad.

A narrow scar around the twig at each node.Magnolia 179

Without such a scar.

Leaf widest above the middle...........Asimina

Widest at or below the middle.

Underside finely hairy.............Quercus

Leaves not hairy.

Twigs very slender.................... 168

Twigs moderately stout.

Pith with cross-plates...............Nyssa

Pith without cross-plates......... Diospyros

ee. Margin of leaf toothed.

f. Leaf with several strong veins from the base.

About as broad as long.................... Tilia 251

Longer than broad.............................. 168

ff. Leaf with only one strong vein from the base.

Twigs rather spiny............................. 198 
Twigs not spiny.

PAGE

g. Leaves single toothed (the teeth entire).

h. Teeth coarse.

Leaf about as broad as long........... Populus

Longer than broad.

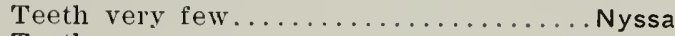

Teeth many.

Buds long and sharp............. Fagus

Buds short.

Leaves widened upwards.........Quercus

Leaves widest at middle..........Castanea

hh. Teeth fine.

Leaf-stalk with small glands..........Prunus

Leaf-stalk without glands.

Leaves 5 times as long as broad........ Salix

Leaves broader.

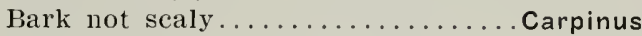

Bark scaly.

One side of leaf-base smaller......Planera

Leaf base symmetrical......Amelanchier

gg. Leaves doubly toothed (the teeth again toothed).

One side of leaf-base smaller............. Ulmus

Leaf-base symmetrical.

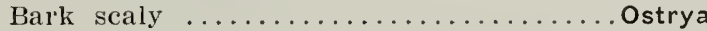

Bark not scaly, often papery.....................

eee. Margin of leaf cut more deeply (lobed)

i. Leaf with several strong veins from the base.

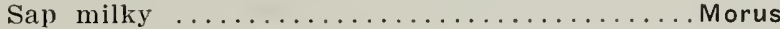

Sap not milky; leaves as broad as long.

Leaves notched at end............. Liriodendron

Leaves maple-like.

With a narrow scar around each node.....Platanus

Without such a scar.................. Liquidambar

ii. Leaf with only one strong vein from the base.

Mucilaginous and aromatic...........................

Not mucilaginous nor aromatic.

Pith star-shaped when cut.............Quercus

Pith round; twigs often spiny........... Crataegus

dd. Each leaf with several blades or leaflets (compound)

Prickles at base of leaf; leaflets simple........... Robinia

Branched spines on stem; some leaflets compound.Gleditsia Without either prickles or spines.

Pith round in cross-section............... Gymnocladus

Pith star-shaped when cut across; leaflets simple.

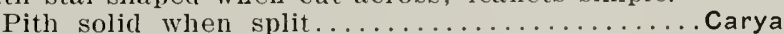

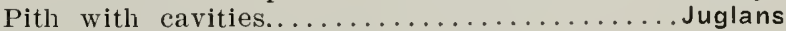

cc. Two leaves at each joint (node) of the stem.

Leaves simple (of one blade).

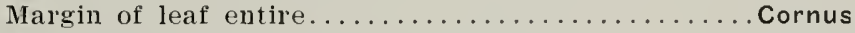

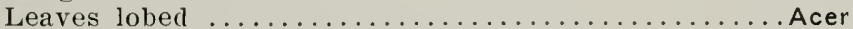

Leaves compound (of several leaflets).

Leaflets spaced along the stalk.............. Fraxinus

Leaflets all from one point.

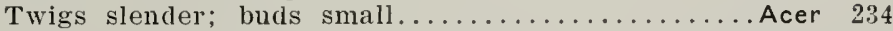

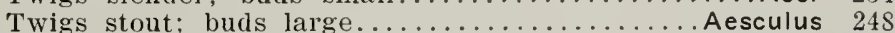

ccc. Three large simple leaves at each node..................... 


\section{KEY TO THE TREES WHEN IN FLOWER}

a. Flowers showy, with botl stamens and pistils.

b. Petals united.

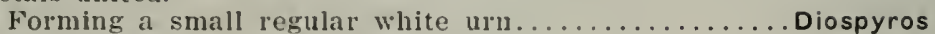

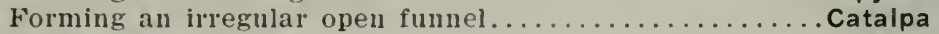

bb. Petals not grown together.

c. Flower resenubling a pea-blossom.

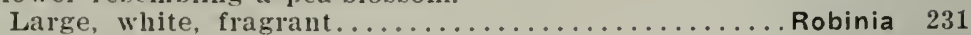

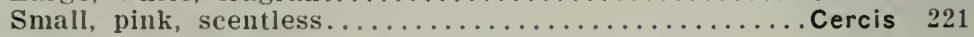

cc. Flower like an apple-blossom.

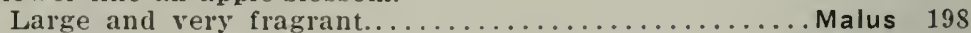

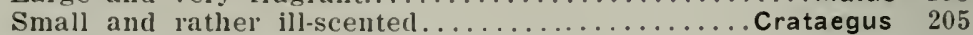

ccc. Flower a small cherry-blossom....................Prunus 210

cccc. Flower neither pea-, nor apple-, nor cherry-like.

d. Appearing before or with the leaves.

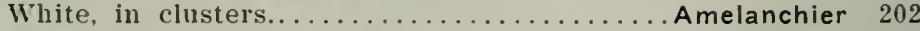

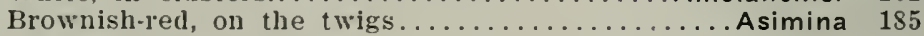

dd. Appearing after the leaves.

Small, several on a one-bracted stalk.............................. 251

Moderate, clustered, irregular............................... $24 \mathrm{~S}$

Large, not clustered, regular.

Uniformly yellowish ..................................... 179

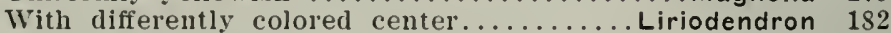

aa. Flowers small, not very showy.

e. In a flower-like cluster with 4 large white bracts.......... Cornus 260

ee. Without petal-like bracts.

f. Leaves evergreen, small and narrow.

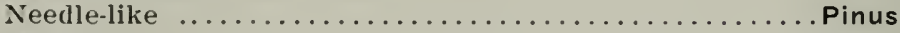

Not needle-like.

On fan-like branches; scale-like................ Thuja

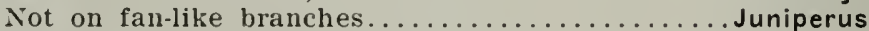

ff. Leaves falling in autumn.

g. Leaves narrow and very small.

Needle-like ........................... Larix

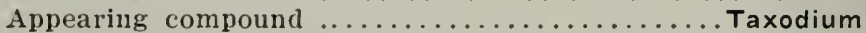

gg. Leaves larger and veiny.

h. Some or all of the flowers in catkins.

i. Stamens and pistils on the same tree.

j. Leaves simple (of one piece).

k. Pistillate flowers 1 to 3 together.

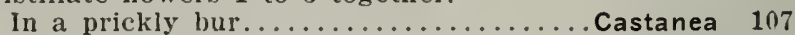

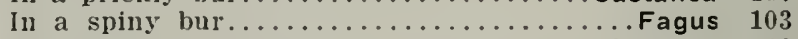

Each in a small cup...............Quercus 110

$k k$. Pistillate flowers in catkins.

Each flower in a small but enlarging and scale-like sac ................... Ostrya

Each flower with a scale at base.

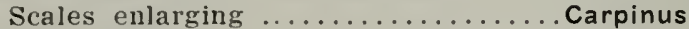

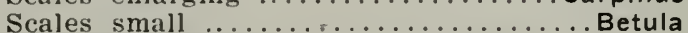

kkk. Pistillate flowers in a round stalked head.

Twigs with a narrow scar around each

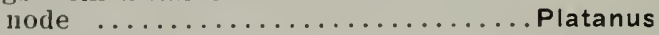

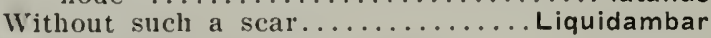

jj. Leaves compound (of several leaflets).

Pith solid when split.............. Carya

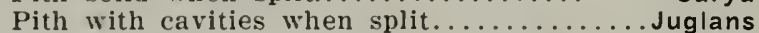


ii. Stamens and pistils on different trees. PAGE Sap milky.

Twigs somewhat thorny............................. 177

Twigs not thorny; some leaves lobed..........Morus 174 Sap not milky.

Each flower with a small cup at base.......Populus 46

Without a cup at base.......................... 59

hh. Flowers not in catkins.

I. Branches mostly spiny...................editsia 226

II. Not spiny.

m. Leaves simple.

n. Mucilaginous and aromatic.............Sassafras 188

nn. Neither mucilaginous nor aromatic.

o. Flowers in compact clusters on the twigs; appearing before the leaves.

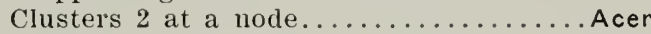
One cluster at a node.

Leaves double-toothed ............ Ulmus 156

Leaves single-toothed ........................... 164

oo. Flowers or flower clusters stalked.

Leaves two at a node................... 234

Leaves one at a node.

Twigs moderately stout.......... Nyssa 254

Twigs very slender..................... 168

$\mathrm{mm}$. Leaves compound.

p. Two at a node.

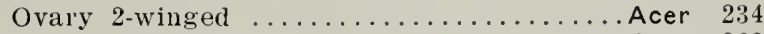

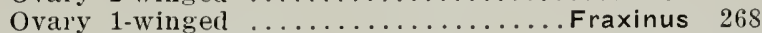

pp. One at a node; leaflets compound.... Gymnocladus 222

\section{KEY TO THE TREES WHEN IN FRUIT}

a. Fruit fleshy when ripe.

b. Flesh thin, drying.

Leaves evergreen, small; fruit bitter.............Juniperus 42

Leaves falling in autumn; fruit with thin sweet flesh............ 168

bb. Fruit a mass of pistils with fleshy calyxes; sap milky.

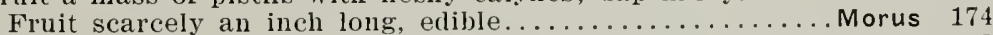

Fruit round, large, not edible......................................... 177

bbb. Fruits several from each flower, large; seeds large.......Asimina 185

bbbb. Fruit one from each flower.

c. With a stony "pit"; only one seed.

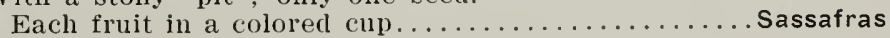

Fruits not in colored cups.

Edible $\ldots \ldots \ldots \ldots$. Prunus

Not edible.

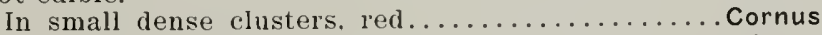

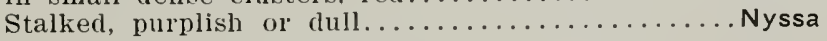

cc. Without a stony "pit"; seeds several.

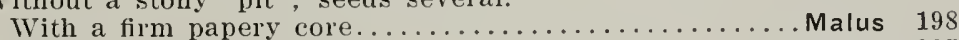

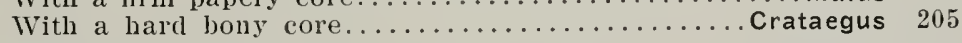

Without a core.

Small and sweet, purple................................................ 202

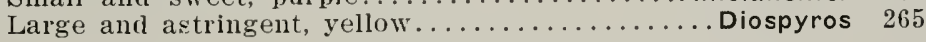


aa. Fruit dry when ripe.

d. Fruit not opening to let the seed ont.

e. Fruit forming a scaly "cone."

f. Leaves evergreen.

Cones long, leaves needle-shaped................Pinus

Cones scarcely an inch long; leaves like scales......Thuja

ff. Leaves falling in winter; cones small.

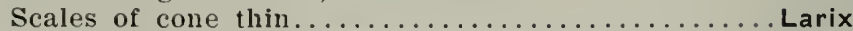

Scales of cone thickened................ Taxodium

ee. Fruit not a cone.

g. Fruit a nut, with large seed.

Nuts in large, very prickly burs......................

Nuts in small, warty or spiny husks.............. Fagus

Nuts (acorn) with a cup at base.............. Quercus

Nuts enclosed in a smooth husk.

Husk finally opening; pith solid when split......... Carya

Husk not opening; pith with cavities...........Juglans

gg. Fruits small, not winged; seed small.

Solitary on the ends of fascicled stalks, ridged

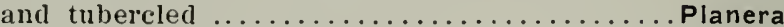

Several on a one-bracted stalk..................... Tilia

Massed in a naked, slender-stalked, round ball....Platanus In catkins.

Each fruit in a large scale-like sac............ Ostrya

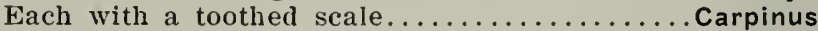

ggg. Fruits with thin wings.

Many, overlapping in each flower........... Liriodendron

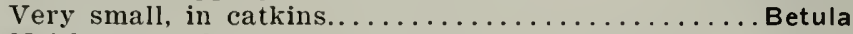

Neither very large nor very small nor overlapping.

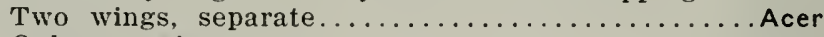

Only one wing.

Fruit circular, flat...................mus

Fruit elongated, flat.................. Fraxinus

dd. Fruit opening to let the seed escape.

h. In a cucumber-like mass from each flower............. Magnolia

$h$ h. In round bur-like heads................... Liquidambar

hhh. In catkins; seeds very small and feathery.

Each fruit with a thin cup at base...............Populus

Without a cup at base................................

hhhh. Neither in heads or catkins nor massed.

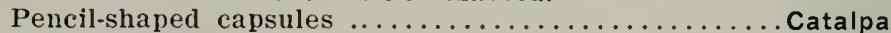

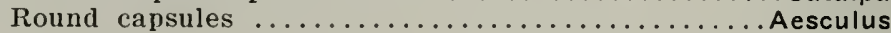

Flat pods.

Pods large and hard...................mnocladus

Pods hard-papery.

An inch or two wide.................... Gleditsia

Scarcely half an inch wide.

Clustered at the nodes..............................

In terminal clusters. 


\section{KEY TO THE TREES IN WINTER}

a. Leaves evergreen, small and narrow. PAGF

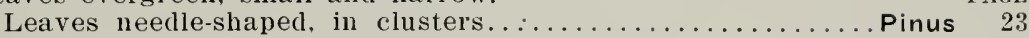

Leaves not scale-like, spreading...................niperus 42

Leaves scale-like, not spreading.

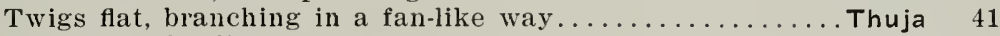

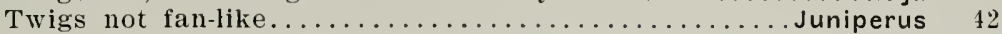

aa. Leaves falling in winter, leaving evident scars.

b. Three scars at a node, or joint, of the stem (whorled)..... Catalpa

bb. Two scars at a node (opposite).

End bud half an inch or more long; twigs thick...... Aesculus 24S

Buds much smaller.

Leaf-scar's very small, on raised bases; twigs slender...Cornus

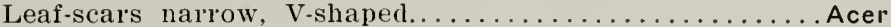

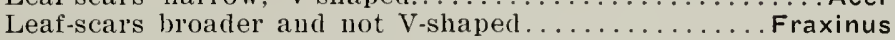

bbb. Only one scar at a node (alternate).

c. Fruit a "cone."

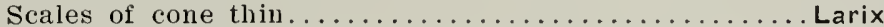

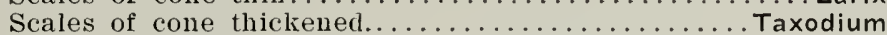

cc. Fruit not a "cone."

d. With a narrow scar around the twig at each node.

Buds long, sharp and spreadiug.............. Fagus

Buds not long and sharp.

Buds with 2 scales meeting at the edges.... Liriodendron Each bud covered by one scale.

Buct hairy; leaf-scal U-shaped.............. Magnolia

Bud not hairy; leaf-scar encircling the bud...Platanus

dd. Without a narrow scar around each node.

e. Pith usually with cavities, when split.

Twigs very slender.......................

Twigs moderately thick.

Twigs and pith angular; leaf-scars large......Juglans

Twigs round; leaf-scar's small............ Diospyros

ee. Pith solick.

With firmer cross-lines when split.....................

Without firmer cross-plates.

f. Sap milky.

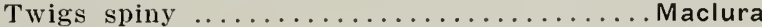

Without spines $\ldots \ldots \ldots \ldots \ldots \ldots \ldots \ldots \ldots \ldots \ldots \ldots \ldots$ Morus

ff. Sap not milky.

g. Twigs very thick; leaf-scars large...... Gymnocladus

gg. Twigs slender or moderate.

Twigs mucilaginous and aromatic....... Sassafras

Twigs not aromatic.

h. The small buds covered by the leaf-scars.

Two prickles at each node............. Robinia

Often with branched thorns............... Gleditsia

hh. None of the buds covered by the leaf-scars.

End bud without scales (naked).......Asimina 185

End bud, if present, with specialized scales.

i. Lowest bud-scale directly over the leaf-scar.

Only one bud-scale; pith round...... Salix

Several scales; pith angular.......Populus 
ii. Lowest scales at the side of bud.

PAGE

j. Pith star-shaped when cut across.

Three large scars on each leaf-scar... Liquidambar 191

Small scars clustered in groups on each

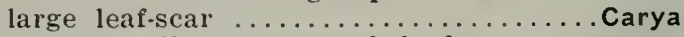

Numerous small scars on each leaf-scar.

Twigs angular at end................ Quercus

Twigs round .................................

jj. Pith flattened, 3-sided: twigs very slender....Betula 98

jjj. Pith round when cut across.

k. Commonly with spiny twigs.

Bud scales fleshy and colored........ Crataegus

Bud scales dry.....................Malus

kk. Twigs not spiny.

Buds becoming sharp and relatively long ...................... Amelanchier

Buds short or blunt.

Twigs 3-ridged at the nodes..............

Twigs not prominently ridged.

1. Each leaf-scar with 3 scars on it.

$m$. Scales in 2 rows on each bud.

Fruit winged ................. Ulmus

Fruit ridged and warty............. Planera

$\mathrm{mm}$. Scales of buds not in 2 rows.

Trunk fluted, with smooth bark..Carpinus

Trunk uniformly rounded; bark scaly.

Twigs with bitter almond flavor..Prunus

Not suggesting bitter almonds.... Ostrya

II. Leaf-scars without 3 separate small scars.

Twigs and buds somewhat hairy.... Diospyros

Not hairy, often colored red...........Tilia 


\title{
'THE NATIVE AND NATURALIZED TREES OF ILLINOIS
}

\author{
Robert Barclay Miller and L. R. Tehon
}

\section{Description of the Species}

\author{
PINUS Linnaeus The Pines
}

Family Pinaceae

Evergreen, cone-bearing trees, with needle-like leaves in bundles of 2 to 5. Flowers in the form of cones, which are of two kinds: the pollen-bearing cones clustered at the base of the season's shoots; the seedproducing cones on the sides or near the ends of the shoots, maturing at the end of their second or third season and bearing two small, winged seeds at the base of each scale.

There are about 66 species of pines, with a range that includes a very large part of the Northern Hemisphere. In North America there are 28 species, and in Illinois three. Eight of the North American species are classed as "soft pines" and twenty as "pitch pines." Of the three Illinois species, one belongs to the first class and two to the second.

\section{KEY TO THE ILLINOIS PINES}

Leaves commonly 5 in a bundle; cones long-cylindric, stalked, pendant; cone-scales unarmed ...................... Strobus p. 24

Leaves 2 or 3 in a bundle; cones ovate or oblong-conical, nearly sessile; cone scales furnished with weak, usually deciduous prickles.

Leaves $3-5$ inches long...................... echinata p. 29

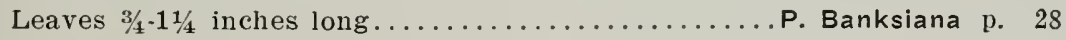




\section{PINUS STROBUS LINNAEUS}

\section{White Pine}

The White Pine is a tall, straight tree. In dense stands the trunk rises straight from the ground, without tapering much and without dividing. to a height of 60 feet or more. It is devoid of branches for a long distance upward, but toward the top it bears a small crown of living

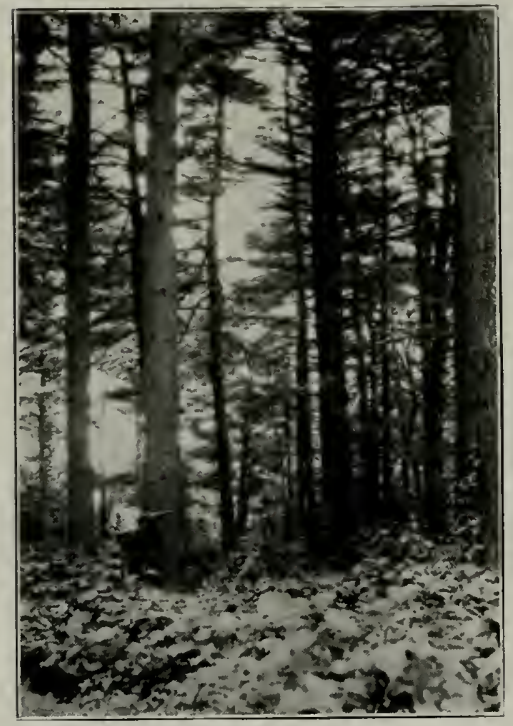

Fıg. 1. White Pine in the State Park near Polo, Ogle County. branches. The branches are produced. usually ; at a time, in a whorl, like the spokes of a wheel, at the top of each year's growth. The long, flexible, blue-green, 3 -sided needles grow in bunclles of 5. Pollen-bearing cones, about $1 / 3$ inch long, are clustered. 12 to 18 together, at the base of the growth of the season. The seed-producing cones occur on other twigs, solitary, or in small groups of 2 to 5 . near the top of the growth of the season. They are at first stalked, upright, cylindric, and about $1 / 2$ inch long, but by July of their second year they have become long-stalked, pendant, cylindrical green cones 4 to 6 inches or more in length. Towards autumn, they turn brown, open, and shed their seeds; and during the following winter and spring they fall from the trees. The bark on mature trees is dark gray, fairly thick, and is divided by shallow, longitudinal, connecting fissures into broad, continuous ridges, such as appear on the trunk of the closest tree in Figure 1.

Distribution: The present range of the White Pine is far to the north and east of Illinois; but in past times this tree was common throughont the northern third of the State. Now it is represented only by a few scattered renunants, the best known being a tract of 193 acres now a State Park near Polo in Ogle County. This grove, similar to the best found in New England, stands at a considerable elevation above Pine Creek, on a rather deep, sandy-loam soil that is fairly well supplied with waterthe characteristic habitat. The trees are about 80 years old. Some of them have attained a height of 90 feet and a diameter of $2 \gamma$ inches; and 


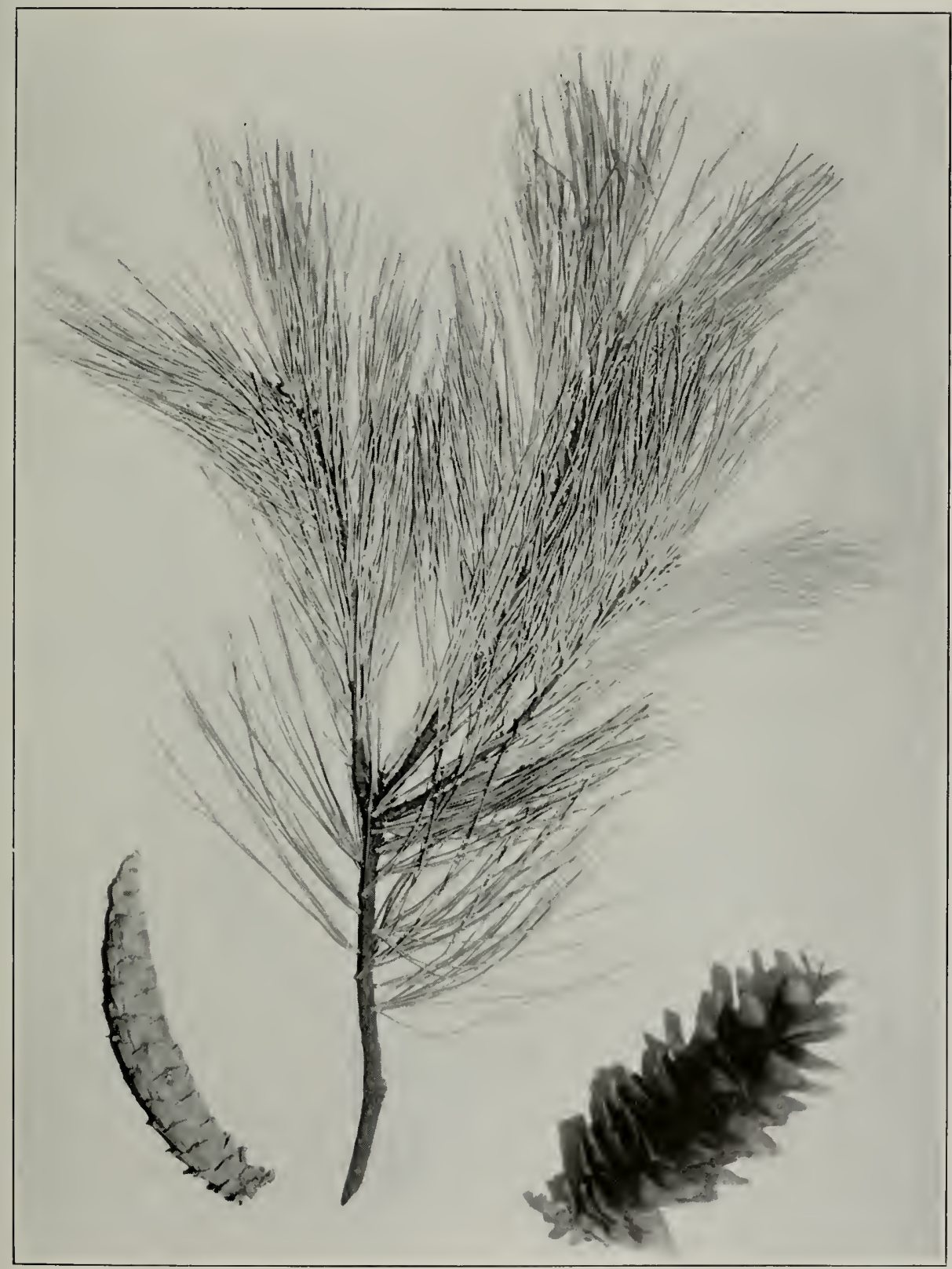

PLATE 1

PINUS STROBUS LINNAEUS

IVHITE PINE 
their volume has increased at a rate of s.j cubic feet per acre anmully. Fine trees which have grown to a height of liv feet in to years and have reached a diameter (at breast height) of $1: 1 / 2$ inches, have been found in sandly land and here and there in the valley of the Illinois River and its

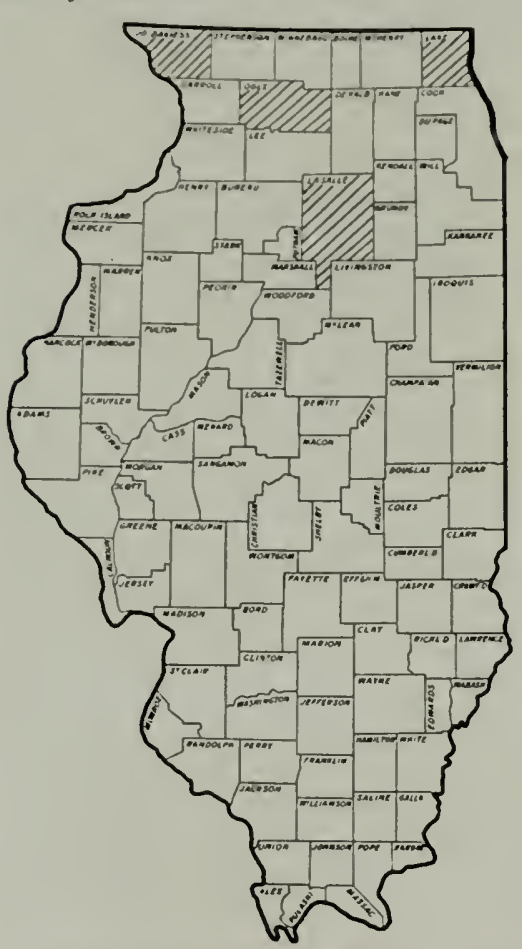

Fig. 2. Distribution of White Pine. tributaries. By way of contrast, black oak becomes only t2 feet high and $s$ inches in diameter in the same time.

A fine grove formerly existed on the banks of the Spoon River, near Dahinda, in Knox County: but it has been cut, and no trees can be found there now. In the Apple River Canyon in Jo Daviess County; the trees are faring better. for though some of the original stand has disappeared, there is at least one large area where numerous seedlings have taken root and are making a good growth.

The White Pine has been grown successfully at Oregon, Illinois, and it promises to be a useful tree for planting on sandy lands.

Uses: The White Pine, loy the lumber trade called also "northern pine" and "eastern white pine", is one of the soft pines. Its wood is soft, light in weight, even-textured, and easily worked. It is excellent for planing-mill products, boxes, crates, novelties, matches and many other things. It is one of the best woods for pattern making, but on account of its high price in Illinois, California sugar pine and other woods are being used in its place. It dries easily and does not shrink or swell greatly when its moisture content changes. It is remarkably durable. Nany of the oldest houses in New England were built of it, even to the shingles on the roof. 


\section{PINUS BANKSIANA L.A.HERT}

\section{Jack Pine Gray Pine}

The Jack Pine is a tree of varied habit. Lsually it is small, 1ij to 40 feet high, with an open, stunted, irregular crown, which begins nearly at the ground. Its stout, stiff leaves, letween $3 / 4$ and $11 / 4$ inches long. grow in bundles of 2 and generally are curved and twisted. The oblong stam-

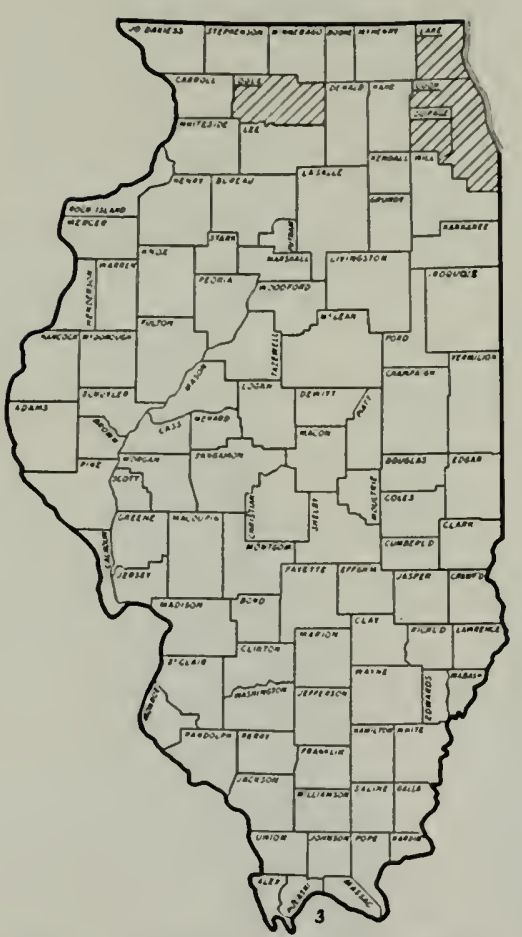
inate cones occur in large clusters at the base of the new growth. The smaller, globular ovulate cones stand in clusters of 2 to 4 on the sides of the shoots and, as they grow, they become oblong-conical, $1 \mathrm{I} / 2$ to ? inches long. strongly curved, and turn to a light yellow. They remain closed for several years, but after they have shed their brownish-black, winged seeds, they cling to the tree for a decade or more. The trunlis of fine trees may reach a height of 60 or 80 feet and a diameter of 15 inches, or more; and the thin, red-tinted, dark-brown bark is divided irregularly into narrow, rounded, scaly ridges.

Distribution: The records that have been available show that the Jack Pine has been found in Lake. Cook, DuPage, and Ogle counties. The present range of the tree is to the north of Illinois, but it has been able Fıg. 3. Distribution of the Jack Pine. to survive in favoral,le situations in this State. Preferring sunlight for the germination of its seeds and for growth, the Jack Pine is to be found on poor, sandy soils and on burned-over barren land. Pepoon ${ }^{1}$ states that the tree still occurs near Lake Michigan on the Waukegan sand moors.

Uscs: When growing in open stands on barren lands, the Jack Pine luas the form of an orchard tree, with a short bole and an open, spreading crown. Its wood is then of little value; but in denser stands the trunk is

${ }^{1}$ Flora of the Chicaso Region, p. $15 \%$. 
fairly tall and straight, with only a small crown, and gives logs of value for rough uses. In the Lake States, the tree was looked upon formerly as a weed tree. for the wood, which is light, soft. weak, and close-grained, was not durable in the soil and could not be used for posts. But after the development of methods for treating timber to prevent rotting, the wood could be used for railroad ties; and it is now employed, mixed with other woods, in manufacturing paper pulp.

In Minnesota, stands are producing annually six railroad ties and a cord of other merchantable material per acre; and Allison² says that on second-rate agricultural soils it should grow to a height of 45 or 50 feet and a diameter (at breast height) of 11 inches. In Canada, ${ }^{3}$ it is depencled upon to produce not less than $3 / 4$ of a cord of wood per acre annually through its growth period of 40 to 50 years. In Illinois, its usefulness is limited, however, as other pines appear more suitable for our sand barrens.

\section{PINUS ECHINATA Miller}

\section{Yellow Pine Short-leaf Pine}

The Yellow Pine is a tall, straight, slender-trunked tree, capped by a large, oval or round head of living branches. The dark blue-green leaves are soft and flexible, finely toothed, abruptly pointed. 3 to 5 inches long, and bound in fascicles of two or three. The nearly sessile staminate cones are about $3 / 4$ inch long. Pistillate cones occur in pairs, or in groups of 3 or 4 , near the end of the season's growth on short, stout stalls. At maturity they reach a length of $1 \frac{1 / 2}{2}$ to 2 inches (the smallest of all the pine cones), and become chestnut-brown. Old cones remain attached to the branches for several years. The ends of the cone scales are slightly thickened and bear weak, deciduous prickles. The trunk reaches a height of 80 to 100 feet and a diameter of 3 to $t$ feet. The cinnamon-red bark. sometimes an inch thick, is divided into irregularly angular, scaly plates by a network of deep fissures.

Distribution: The present range of the Yellow Pine, or Short-leaf Pine as it is also called, lies chiefly to the south and west of lllinois, but the tree occurs in two localities in the southern part of the State. The larger stand occupies a tract of about 200 acres on the hills in Union County near Wolf Lake, and the smaller stand grows in a sandstone ravine of Piney Creek, near the town of Wrest Point in Randolph County. The

\footnotetext{
canada.

Forestry Quarteriy 21: 796. 1923.

3 Tree Pamphlet No. $i$. Forestry Branch, Department of the Interior. Ottawa,
} 


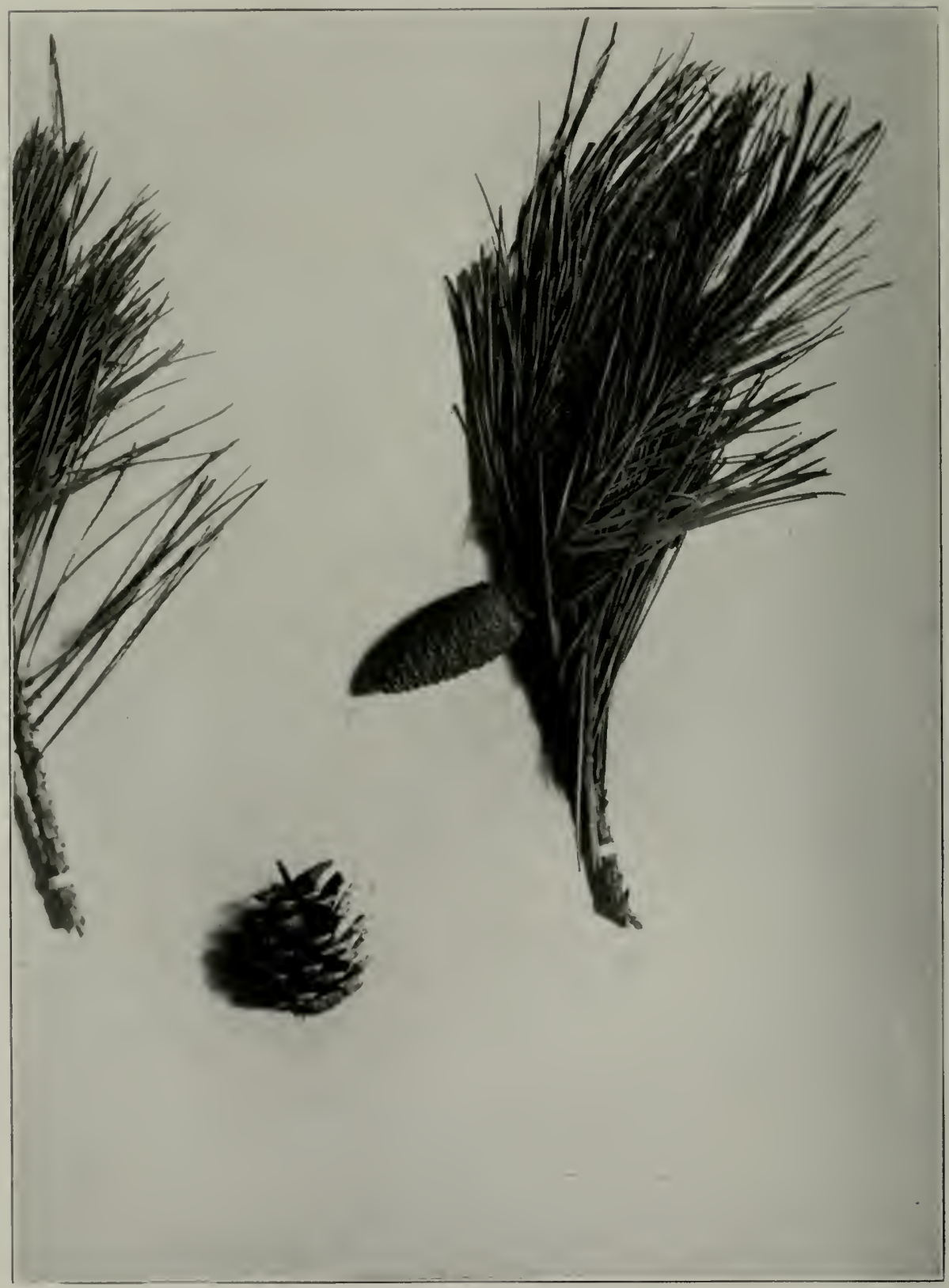

ILATE 3

PINUS ECHINATA MILIER

SHORT-LEAE PINE 
Wolf Lake stand was mentioned years ago by Dr. S. A. Forbes under the name Pinns mitis. According to Dr. Schneck. the Short-leaf Pine formerly grew on the hills in Gallatin County, near the mouth of the Wabash River; but Sargent believes that the tree must have been Pimus rirginima, the eastern Scrub Pine, which is found on the "knobs" of sonthern Indiana, and Deam ${ }^{1}$ refers all records of the Short-leaf Pine in Indiana to this species.

The Short-leaf Pine usually grows in pure stands, though east of the Mississippi River it often is mixed with hardwoods. It thrives in well-drained, light, sandy, and gravelly soils. The "P'ine Hills" of Union County, on which it grows, are cherty or gravelly.

Uses: The Short-leaf Pine belongs to the hard pine group, and its wood is difficult to distinguish from the wood of the Long-leaf and Loblolly pines, both of which have similar growth rates. The quality of Short-leaf Pine wood is variable, some of it being almost as light as white pine, and a certain grade is sold under the name "Arliansas soft pine." It is a very useful wood, being utilized commonly for the interior and exterior finishing of houses, for general construction, for manufacturing paper pulp, excelsior, and cooperage stock, as well as mine props, and for numerous other purposes. The small stands of this pine in Illinois naturally are of no economic importance; but some of the trees were cut for lumber in the early days, and there is an old $\log$ house, still standing just below the edge of the bluff at IVolf Lake, that was built entirely of hewed Shortleaf Pine logs.

\section{Naturalized Pines}

In the region just soutl of the outlet of Dead River, on the sands known as the Waukegan Moorland. there is, in the words of Pepoon", "a veritable miniature forest of conifers,

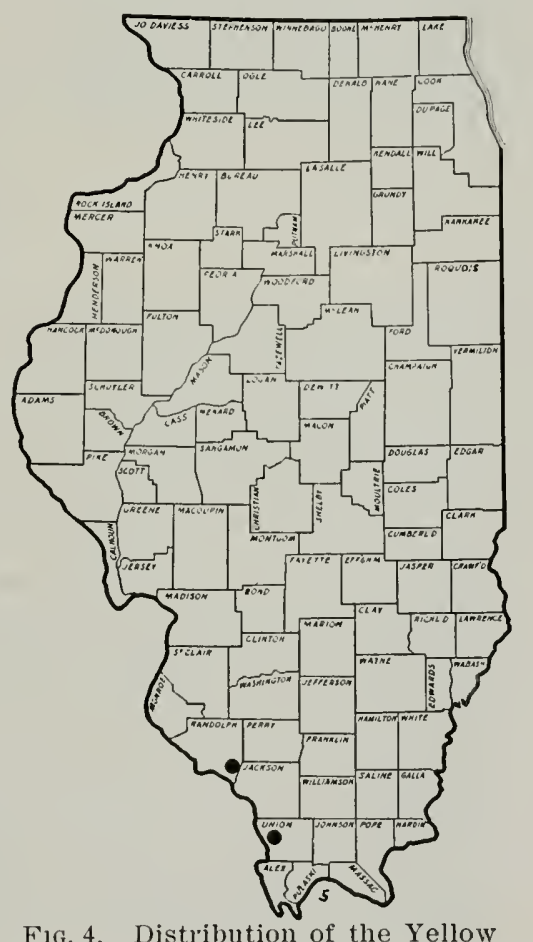

Fig. 4. Distribution of the Yellow Pine.

${ }^{1}$ Trees of Indiana, 1. 290.

Flora of the Chicago Pegion, p. 5. 
of many species, the result of wholesale seed sowing some sixty years ago" of Robert Douglass, Who "traversed the area on horseback, carrying a

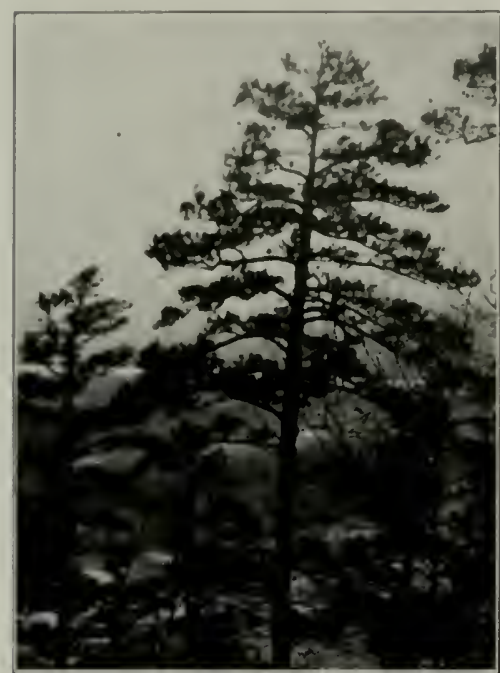

Fig. 5. Yellow Pine on the bluffs overlooking the Mississippi bottoms at Wolf Lake, Union County. bag of mixed seeds, and threw them into the wind, thus scattering the seed far and wide...... Today some parts are covered with a most vigorous forest growth." The pines now present are the White Pine, the Austrian Pine (P. laricio), the Scotch Pine (I'. sylacstris), the Table Mountain Pine (P. pungens), and the Pitch Pine ( $P$. rigida). "To the umobservant or to the poorly informed observer." says Pepoon, "this growth has every appearance of being natural, and in fact is so for all practical purposes: and if no disturbance occurs in the next generation, the evidence will all point to Nature instead of Art as the causation of the peculiar coniferous flora."

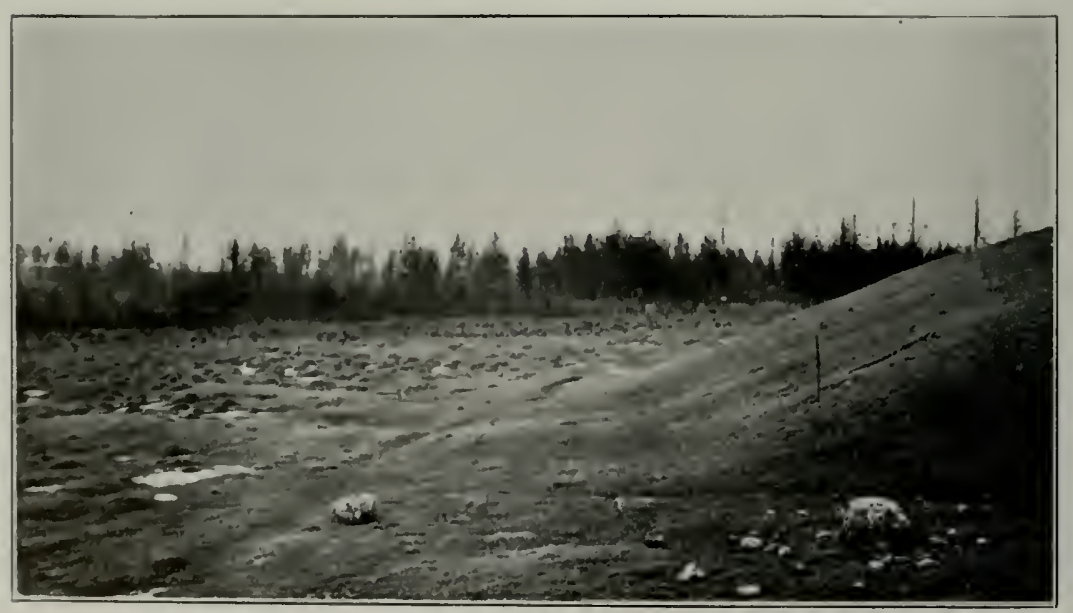

Tamarack bog, Lake County. Photo by W. G. Waterman. 


\section{LARIX ADANson Larch Tamarack}

\section{Family Pinaceae}

Tall, pyramidal trees with awl-like, deciduous leaves which occur separately, in a spiral arrangement, on the leading shoots but are held, 20 to 50 together, in crowded fascicles on the older branches. Flowers in the form of cones, the staminate cones on leafless, and the pistillate cones on leafy branches; both kinds terminal and solitary, the latter at maturity bearing 2 winged seeds at the base of its scales; each scale in the axis of a persistent bract.

Of the three American species, only one occurs in Illinois.

\section{LARIX LARICINA K. KOCH}

\section{Tamarack Larch}

The Tamarack is a straight tree of moderate height, with long, drooping branches that form an extended, narrow, spire-like head in open stands or, in close stands, a short, open crown. The awl-like, sharply pointed leaves are from $3 / 4$ to $1 \mathrm{I} / 2$ inches long and are borne in characteristic compact bundles of 20 to 50 at intervals on the older twigs and singly, in a close spiral, on the season's shoots. The staminate cones are borne singly on the tips of short lateral branches on the one- or two-year-old twigs. The ovulate cones are borne at the tips of short, leafy shoots along the sides of one- to three-year-old twigs; and, when they attain maturity in the autumn of the first year, they are chestnut-brown and $1 / 2$ to $3 / 4$ inch long. Their 20 or so cone-scales are concave, nearly round, irregularly and

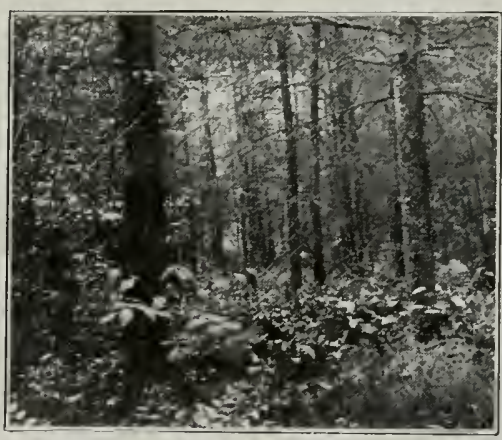

Fig. 6. Tamarack in a Lake County bog. Photo by II. G. Waterman. shallowly toothed along the margins. The bracts are persistent and only half as long as the scales. The slightly tapering trunk, which rises to a height of 40 or 50 feet and attains a diameter of 15 or sometimes 20 inches, is covered by a reddishbrown, thin, scaly bark. 


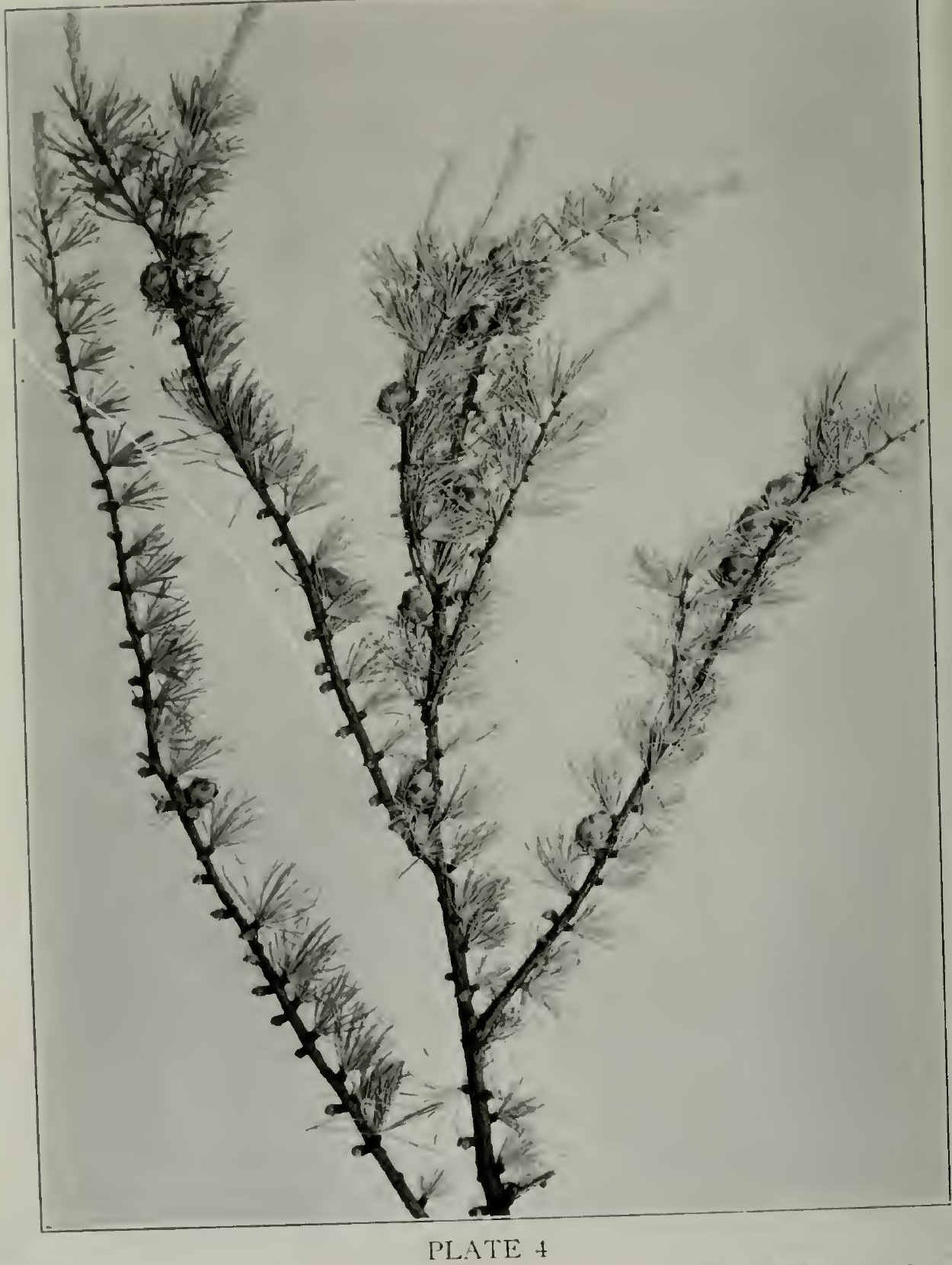

LARIX LARICINA K. KoCII

TAMARACK 
Distribution: The Tamarack ranges as a rare and local tree from Newfoundland westward to Alaska and southward into the north of illinois and Indiana. Its occurrence in Illinois is limited to two counties, McHenry and Lake, where it grows in the interior of deep sphagntum swamps and bogs and along the edges of lakes. Professor W. G. Waterman $^{1}$ reports that in the Lake County bogs "the Tamarack forest has been cut in places, but where relatively untouched the growth is dense and there are many trees up to 10 and 1 .) inches in cliameter." The growth of these trees is slow, for Professor Waterman says that "a $t$-inch stump showed to to 50 very narrow rings while one 10 inches in diameter showed $\%$. rings." In the southern part of its general range, the Tamarack grows in cold, deep swamps, in association with black spruce and Arbor Vitae; but in Lake County the trees that accompany it are the Birch, the Aspen, and the Nountain Ash.

Uses: The wood of the Tamarack resembles the wood of the hard pines. It is brownish, coarse-

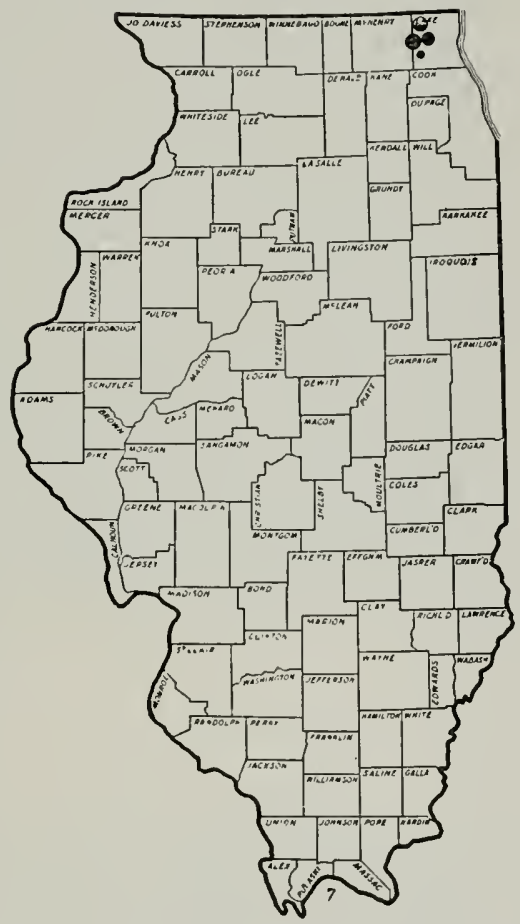
grained, and fairly durable, and Fig. 7. Distribution of the Tamarack has a thin sapwood. It is used in Illinois.

for fence posts, telegraph and telephone poles, and railroad ties; and the large roots are sometimes dug out and, together with a part of the trunk, hewed to form "ship's linees," which are used in the keels of wooden ships. However, the few trees in Illinois have no usefulness beyond the fact that they stand as representatives of an ancient Illinois forest, now long vanished through changing soils and climates.

1 Trans. Illinois St. Acad. Sei. 16: 220.1923. 


\section{LARIX DECIDUA I/ILLER European Larch}

The European Larch, at tree much like the Tamarack, has been grown quite commonly in lllinois for windlorealis and as shade trees: and in farorable situations it makes a good growth. In 18:1 l'rofessor T. J. Burrill, of the Lniversity of lllinois, planted a plot of $1 \frac{1}{4}$ acres in the Forest Tree Plantation at Lrbanat with one-year-old seedlings: and 48 years later (in 191!), when a $1 / 4$-acre plot was measured, the trees were found to have grown an average of 111 cubic feet per acre annully. The trees on higher ground hat done very much better than those planted in the wetter plices.

The nsefulness of this tree in northern Illinois is indicated by the fact that in 18 : $:$ Rolert Donglas. a nurseryman of Waukegan already mentioned in connection with the naturalized pine forest near that city, exhibited, at at meeting of the Illinois Horticultural Society, some specimens of the European Latrch, one of which was about a foot in diameter -an average growth of nearly an inch for each of the tree's thirteen years.

It is stated by Pepoon ${ }^{1}$ that the European Larch is now "occasionally spontaneons about towns and along railways" in the Chicago region, "where it is planted as a snow protection."

\section{TAXODIUM RICHARD Bald Cypress}

Family PINACEAE

Deciduous, cone-bearing trees, with scale-like and needle-like leaves that are borne singly and disposed respectively in close spirals or in two rankis on the lateral twigs. Flowers in the form of cones: staminate cones in terminal, scaly-leaved panicles; ovulate cones scattered on the ends of year-olel branches, maturing the first year. Seeds in pairs under each cone-scale: each seed with :3 thick lateral wings and a long slender point.

Although in ancient geological ages the genus was widely distributed over North America and Europe, it is confined now to the North American continent, where there are two species, one of which occurs in the United States.

Filora of the Chicago liegion, p. 157. 


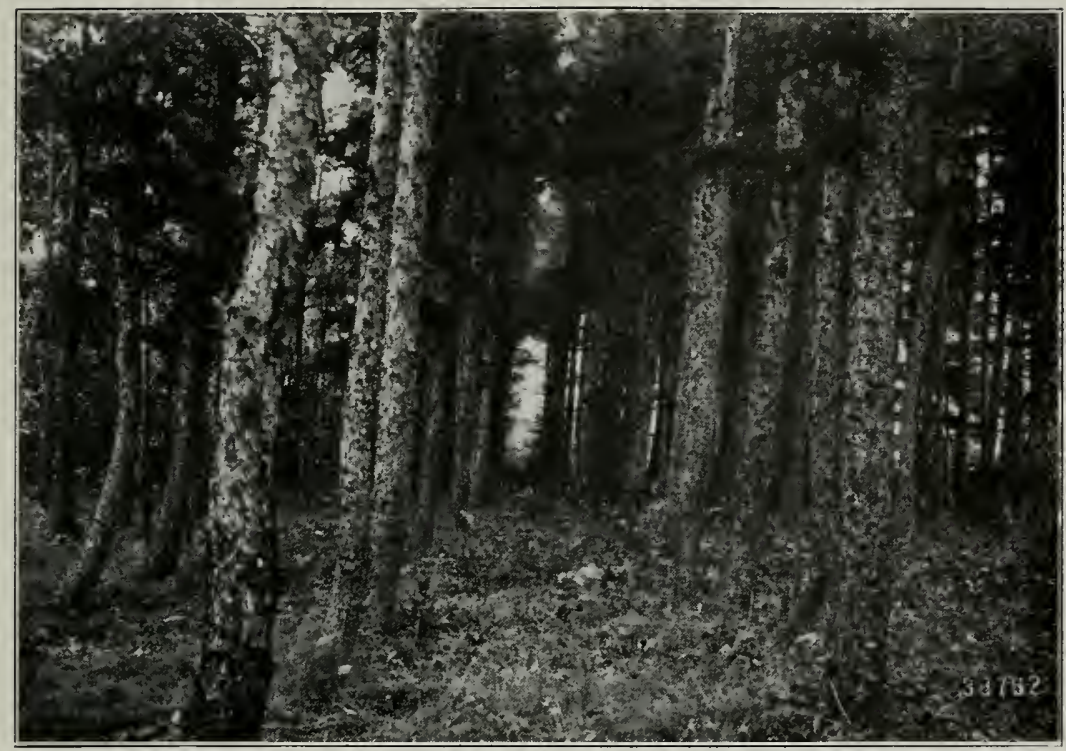

FIG. S. European Larch in the Forest Tree Plantation of the University of Illinois.

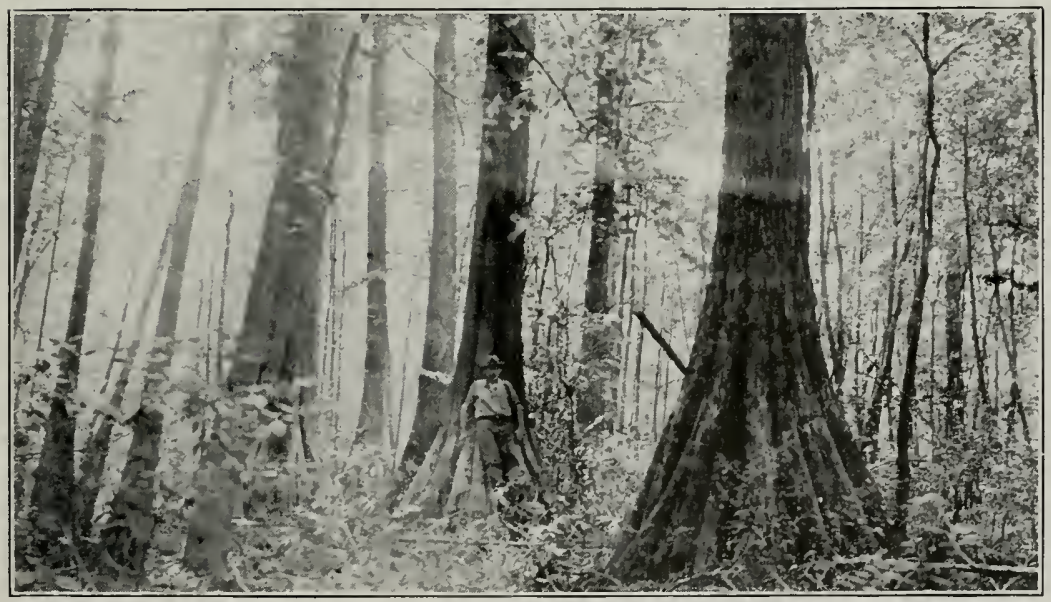

Fig. 9. Bald Cypress trunks in a virgin forest, Massac County. 


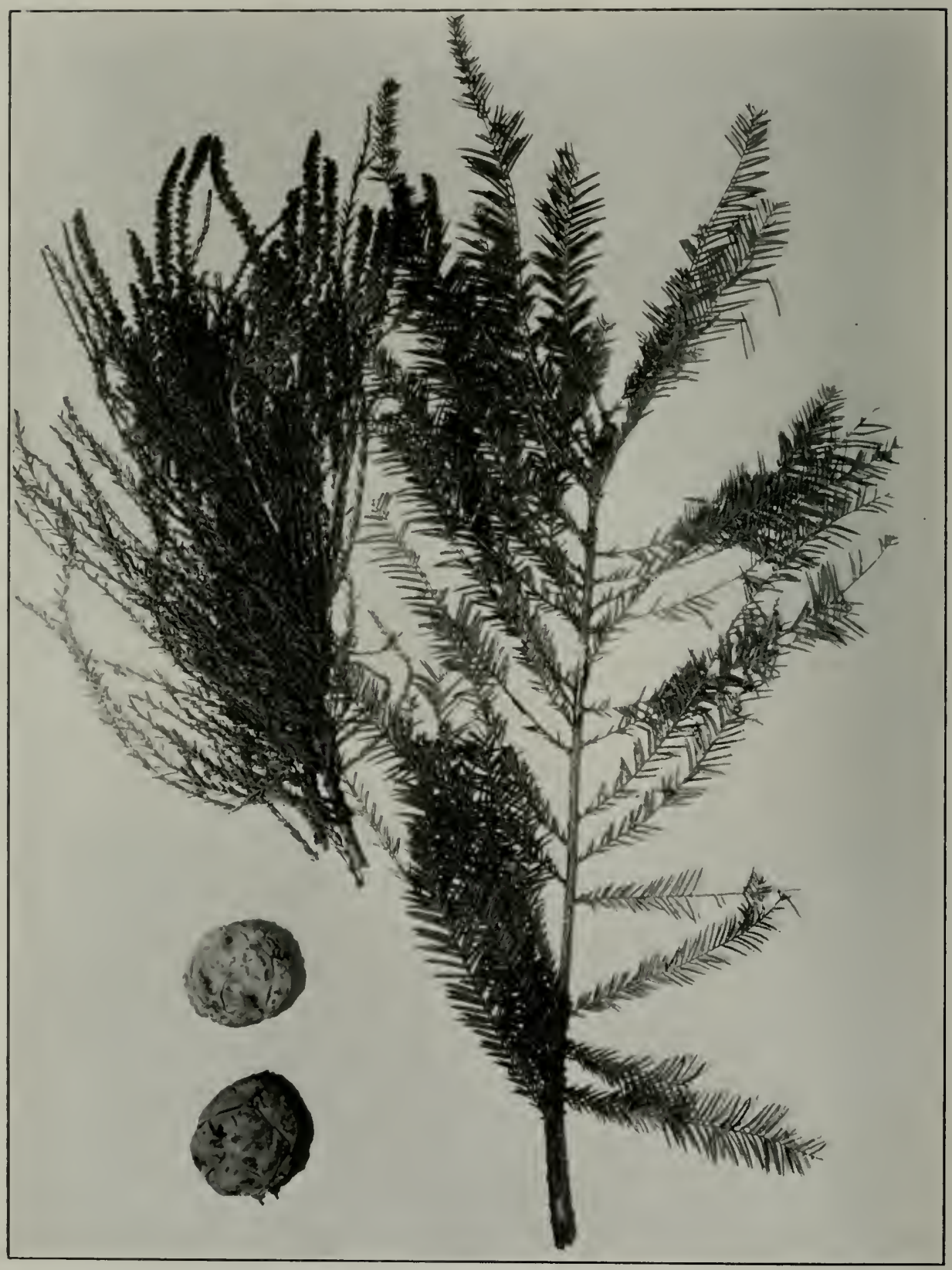

PLATE :

TAXODIUM DISTICHUM RICHARD BALD CYPRESS 


\section{TAXODIUM DISTICHUM RICHARD}

\section{Bald Cypress Deciduous Cypress}

The Bald Cypress is a tall, straight tree. with long. slender branches that give young trees a narrow, pyramidal shape. but on old trees spread out to form a very broad, low crown. The short lateral branchlets usially extend nearly at right angles to their supporting branch and fall from the tree at the end of the season. The leaves are of two hinds, appearing on some vegetative twigs in ? ranks as linear, pointer, yellowish-green needles $1 / 2$ to $3 / 4$ inch long, and on the staminiferous panicles and other vegetative twigs as spirally-arranged, appressed scales. The numerous staminate cones are borne on long panicles on the season's growth. The ovulate cones usually are borne in pairs (but not opposite each other) toward the ends of one-year-old branches; and at maturity they appear as woody balls about 1 inch in cliameter. made up of closely fitted scales. The straight trunk, which often attains a height of 150 feet and a riameter of $t$ or 5 feet above its broad and buttressed hollow base, is clother with cinnamon-red bark 1 to ? inches thick, which is divided by narrow fissures into broad, flat ridges. In natural situations, the roots send up woody growths, the "cypress knees," through the ground and water above.

Distribution: The range of the Bald Cypress extends from southenn Delaware southward along the Atlantic coast to Florida, westward through the Gulf region to Texas, and northward by way of the valleys of the Mississippi and its tributatries to southern Ininois and Indiana. In Hlinois, at the present time. it is growing in the Mississippi bottons in Alexander and Union connties and is. besides, an important tree in the bottomland forests of the Ohio, the Cache, and the Nabash rivers. It extends northward along the Wabash River to the southern part of IIabash County and, according to Hall and Ingall', it grew in Hamiiton County previous to 1909.

Throughout its range in Illinois. the Bald Cypress is associated, as a dominant tree, with the Tupelo and the Red and Black gums in the forest that occupies the low and swampy bottomlands of the Mississippi, the Ohio. and the lower Mabash: and in these situations grow also the Pecan, Water Hickory, Soft Maple, Sycamore, Ash, Elm. Hackerry. Honey Locust, cottonwoods, and the water-tolerating oaks.

Uses: The wood of the Bald Cypress is light. soft, and straightgrained, and has a characteristic greasy feeling when it is rubbed. The growth rings are often double, and there are numerous resin cells but 110 resin ducts. The lumber trade recognizes a special grade, known as

\footnotetext{
istate Lab. Nat. Hist. Bul. Tol. \&, Art. 4. 1911.
} 


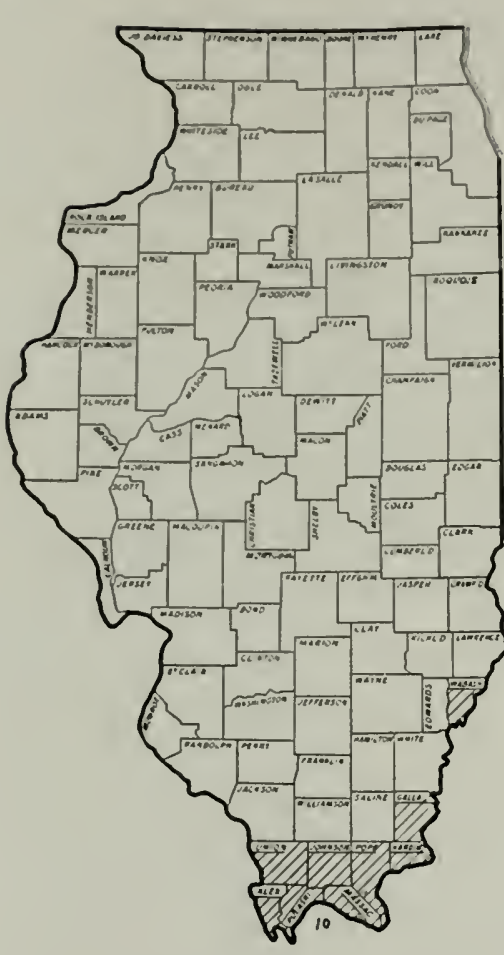

Fig. 10. Distribution of the Bald Cypress. "pecliy" or "peggy" cypress, which comes from trees attacked by a parasitic fungus. Trees so diseased can not he recognized hefore they are cut: but, as the decay stops with the death of the tree, the lumber is still usable for crating and other purposes where strength is not refuired.

Since cypress responds well to paints, enamels, and varnishes, it is in denand for ceilings, wainscoting, and Hooring: and, as striking effects can be secured, it is in demand also for panels and doors. Its durability when exposed to water and weather makes it a desirable wood for drain-boards and kitchen cupboards in homes, as well as for constructing greenhouses, silos, tanks, coffins, boats, and ships, and for posts. poles, and railroad ties. Cypress shingles ${ }^{2}$ last for 15 to 30 years, equaling the clurability of cedar and exceeding the durability of all other American woods used for that purpose.

The Bald Cypress has been cut for lumber in all the comnties marlied in Figure 10, and according to the Census Reports the yield of lumber has ranged from $1.435,000$ board feet in 1899 to $2,228,000$ board feet in 191!. The original cypress forest. estimated to have covered, in mixed and pure stands, an area of approximately 2.50,000 acres", has been reduced by cutting to about 21,000 acres of commercial timber, and the yield in $192 . ;$ was only $: 00,000$ board feet. The settlement of the forest land and its reclannation to agricultural purposes ly drainage are setting up conditions that not only prevent the re-establishment of cypress in the cut-over forest but even result in the death of estal)lished trees. Where the forest land is not otherwise wsed, the new soil conditions allow hardWonds stuch as the Maple, Ash, Elm, and Cottonwood to take precedence. Already this once alsundant tree has been exploited to the full; and it is, indeed, but a matter of years till the cypress will exist only in the small and isolated remuants of a once magnificent forest.

S See x. C. Brown's I.orest Products: Their Manufacture and Use. 1919. Page :369.

${ }^{3}$ Stale Nat. Hist. Surv. Bul, 16: 12. 1926. 
THUJA LINNAEUS

\section{Arbor Vitae White Cedar}

\section{Family PinAcEae}

Evergreen. cone-bearing trees, with small, scale-like leaves flatly compressed on the smaller branchlets. Flowers in the form of cones and of two kinds, the pollen-bearing and ovulate cones, terminal and solitary on separate short lateral branches grown from buds of the previous autumm. The erect seed-bearing cones mature the first year. Seeds in pairs, erect on the base of the cone-scales, and (in our species) with broad lateral wings.

There are five recognized species of Thuja, all confined to North America, Japan, Korea, and Northern China. Of these, only two are North American, one native in the East, the other in the Vest.

\section{THUJA OCCIDENTALIS LINAAEUS}

\section{Arbor Vitae White Cedar}

The Arbor Vitae is a rather small tree, with a straight or divided trunk and short branches that bend upward to form a narrow and conpact conical head. On the leading branches there are long-pointed leaves $1 / 4$ inch long: but on the lateral branches the much-flattened, short-pointed. 4-ranked leaves are abont $\mathrm{I} / 8$ inch long. Both kinds of cones are terminal and solitary on short laterai branches, the globular staminate cones and the ovoid ovilate cones both about $1 / 16$ inch long, the former with 4 to 6 pollen-bearing scales, the latter with $t$ to 6 pairs of scales. The maure seed-bearing cone, from $1 / 3$ to $1 / 2$ inch long, though opening in the antumn of its first year, clings to the tree through the following winter. The thin, cinnamon-brown cone-scales are somewhat woody and, though the outer pair usually are sterile, bear ? lightbrown seeds, each about $\mathrm{s} / \mathrm{s}$ inch long and nearly encircled by a broad wing. The trunk, which commonly attains a height of 30 to 50 feet and a diameter of 1 to 2 feet, usually divides into two

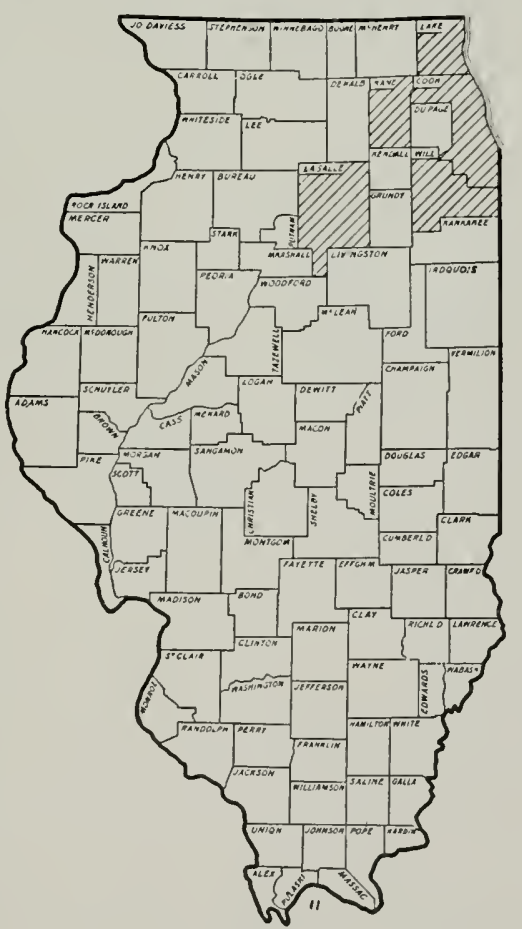

FIG. 11. Distribution of the Arbor Vitae. 
or three stont, upright secondary stenss. and it often is lobed and buttressed at the base. The light, red-tinted mature bark. $1 / 4$ inch thick, is broken into narrow ridges by shallow fissures.

Distribution: The range of the Arbor Vitae extends westward from Nowa Scotia to the Saskatchewan and sonthward, along the momntains. to North Carolina. Virginia, and Tennessee; but the tree is found in Inlinois only in the northeast corner of the State, where it is associated with the Tamarack in the bogs of Lake Comnty and persists as an isolated remnant of larger stands in the Figin City Park, as one of the trees clothing historic Starved Rock. "and on 'springy' bluffs" at Highland Park in Cook County. These situations are characteristic of its natural habitat in the far north.

Uscs: The aromatic, brown-tinted, yellow wood of the Arbor Vitae. known in the lumber trade as "northern white cedar," is light, soft, brittle, and straight though coarsely grained. Like the wood of other swampinhabiting evergreens, it is durable; and because of this it serves excellently for railroad ties, poles, posts, and shingles, as well as for manufactured articles, such as canoes, where its lightness is also an asset.

\section{JUNIPERUS LINNAEUS}

\section{Family Pinaceae}

Small, aromatic, evergreen trees and shrubs, with slender branches. The leaves are awl-like or scale-like and are borne in whorls of three. oppositely in pairs, or alternately. Flowers in the form of cones, axillary, or terminal on short axillary branches grown from buds of the previous autumn; orulate cones maturing into a fleshy, berry-like fruit.

This is a genus of many species and with a range that extends throughout a great part of the Northern Hemisphere. There are about a dozen species in North America, some being trees and some low shrubs. Of the two species in Illinois, one is a tree.

\section{JUNIPERUS VIRGINIANA LINNAEUS \\ Red Cedar Savin}

The Red Cedar is a small, straight tree, with slender, horizontal or ascending branches that form a narrow, compact, conical crown. The dark blue-green, sharply pointed leaves, which stand in four ranks formed by the alternate placement of pairs, are of two kinds, one scale-like and about $1 / 16$ inch long, the other awl-like and from $1 / 4$ to $3 / 4$ inch long. The

${ }^{1}$ Flora of the Chicago Region, p. 157. 


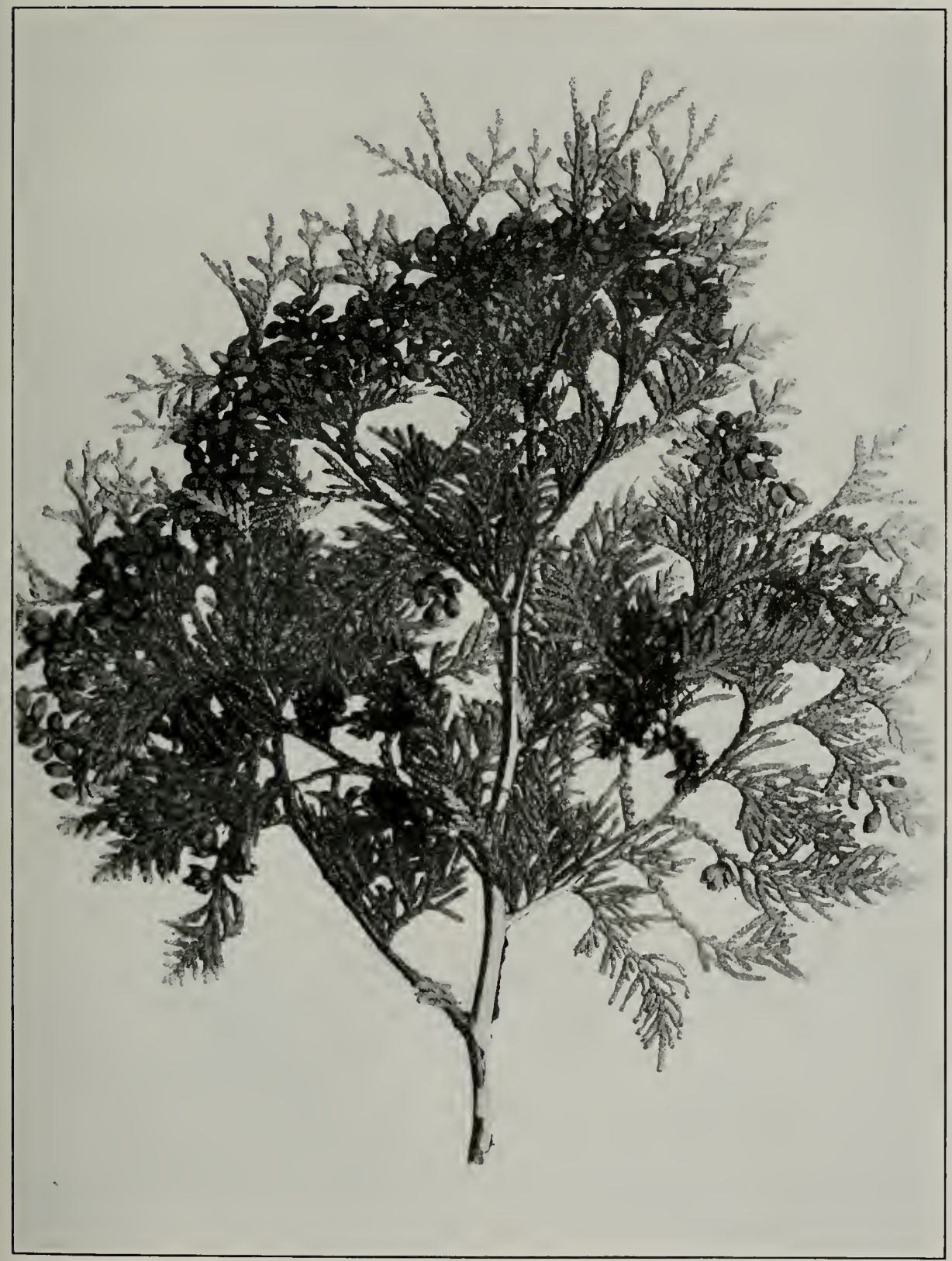

PLATE 6

THUJA OCCIDENTALIS LINNAEUS

ARBOR VITAE 


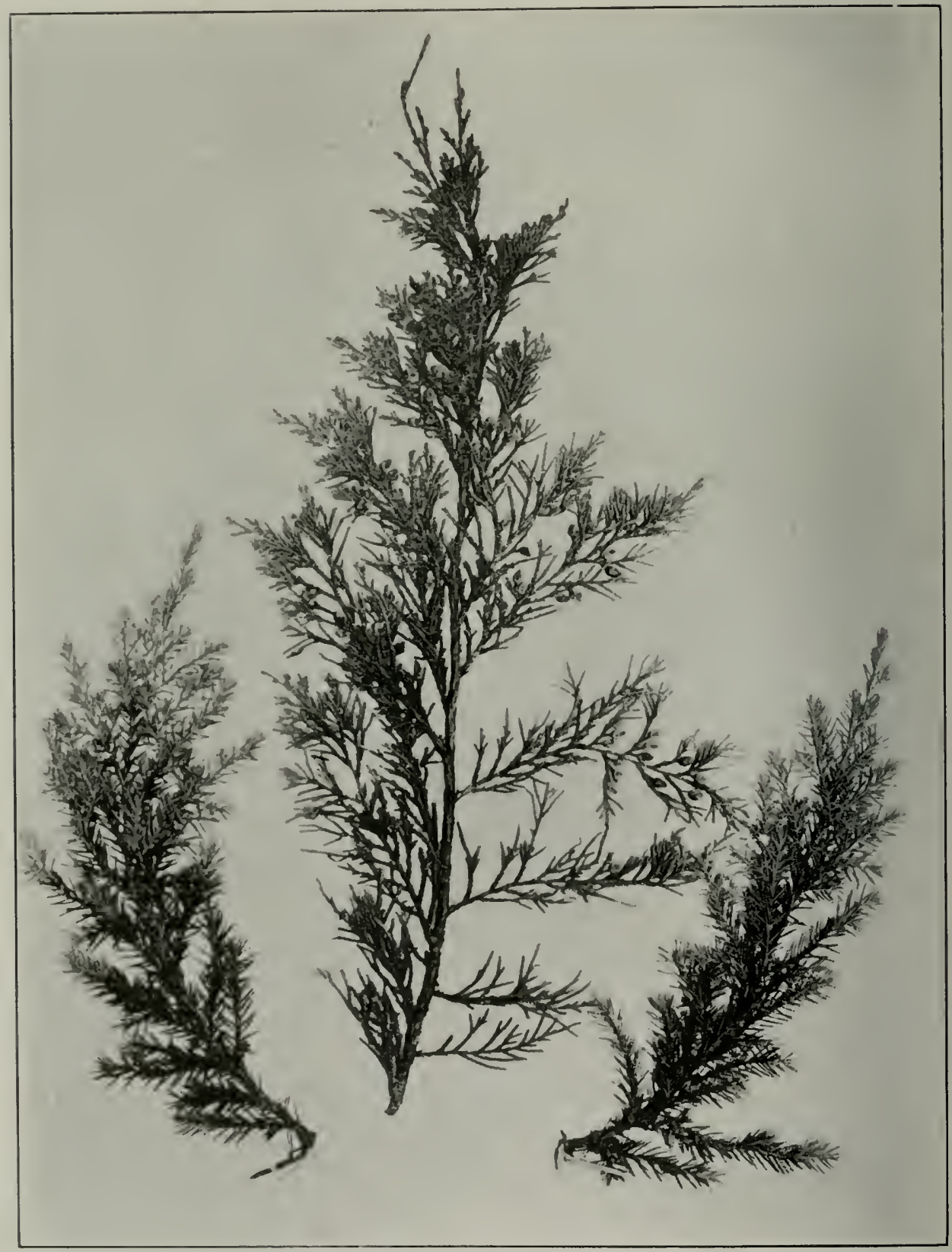

PLATE :

IUNIPERUS VIIRGINIANA LINAAEUS

RED CEDAR 
staminate and ovulate cones are borne on separate trees; and the ovulate cones mature, in autumn of the first year, as globose. dark-blue, glaticous berries, which bear 1 or 2 small, brown, wingless seeds on each of their fleshy, coherent scales. The straight trunk, which attains a height of 20 to 50 feet and a diameter of 1 to 2 feet, often is lobed, eccentric, and buttressed at the base; and its thin, red-tinted, brown bark peels off in long, narrow, fibrous strips.

Distribution: The Red Cedar ranges from Nova Scotia southwestward to eastern North Dakota and southward to Florida and Texas. Throughout this territory it thrives in a wide range of situations, preferring abandoned fields, wastelands, and rocky, limestone cliffs, but growing well in swamps and bottomlands. It is found throughout the length and breadth of Illinois, where it is by far the commonest and best known of the evergreens. It grows very abundantly on barren and sterile soil. In hilly country, it often forms an evergreen rim on the edges of cliffs.

In southern Illinois, where the Red Cedar is most abtundant, it is found frequently in association with the Black Locust and the Black Oak, and farther north, as in Adams Comnty, it grows with the Black and White oaks and hickory.

Uscs: The light, fragrant, finegrained wood of the Red Cedar is soft and brittle but exceedingly durable. and serves well for fence posts, poles, railroad ties, and in the manufacture of wooden articles which must withstand the weather. Red Cedar railroad ties, untreated, are reported ${ }^{1}$ to have a durability of from 12 to 15 years-a record exceeded only by the Black Locust and equalled only by the Northern White Cedar and the Redwood.

The contrast in color between the red heartwood and the white sap wood makes it possible, by proper sawing. to secure a variegated lumber beautifully adapted to certain types of interior finishing. The essential oils that the lumber contains make it useful for moth-proof chests and clothes closets. Although 600,000 board feet of

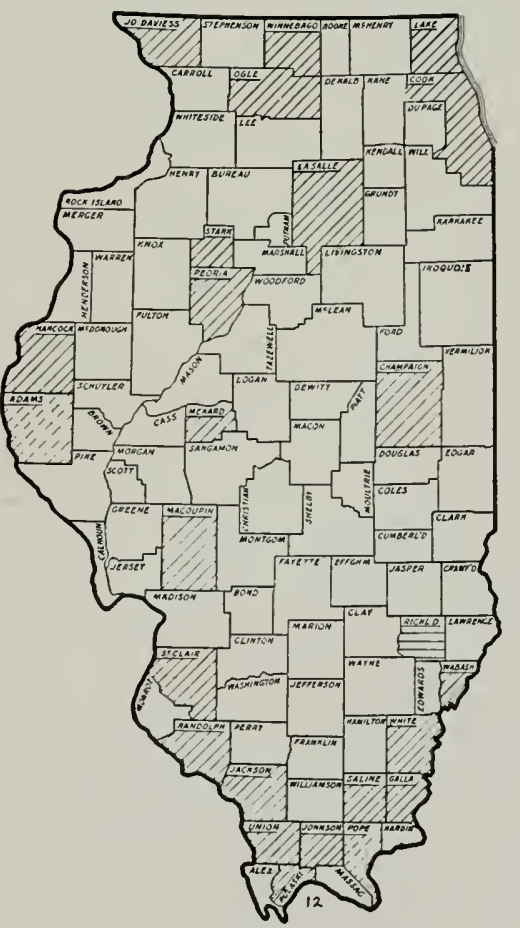

FIG. 12. Distribution of the Red Cedar.

${ }^{1}$ See N. C. Brown's Forest Products: Their Manufacture and Use, p. 292. 
Red Cedar lumber was produced in Illinois in 1922. the tree camnot be reconmendect as profitable, for an analysis of the stems of 200 trees taken in $1 ! ? 0$ from pure and mixed stands showed that the tree grows very slowly, requiring an average of an years to produce ? fence posts.

The Red Cedar acts as an alternate host for a destructive fungous disease of apples, the apple rust: and for this reason is not recommended for planting, even as an ornamental tree, in the vicinity of apple orchards.

\section{POPULUS LINNAEUS}

\section{The Poplars}

\section{Family SALiCACEAE}

Large, rapidly growing, deciduous trees, with broad-bladed, alternately arranged leaves. Flowers in large, pendulous catkins, and of two kinds: the pistillate and staminate flowers appearing on separate trees before the leaves, each flower surrounded by a cup-shaped disk. Twigs of moderate size, round or 5-angled, with small, 5-angled pith and with sessile, solitary. medium-sized buds covered by several thin, resinous scales.

There are 31 recognized species of Populus, ranging through the Northern Henisphere from the Arctic Circle south into Mexico and Northern Africa; and of the 15 species that occur in North America, 4 are found in Illinois.

\section{KEY TO THE ILLINOIS POPLARS}

Leaves 2-3 inches long, with 12 or fewer stout teeth on each side of the blade; buds divergent, hardly resinous, hairy at least on the thin margins of their scales.............. grandidentata p. 50

Leaves generally in excess of 3 inches long, and with more than 12 teeth on each side of the blade; buds generally appressed, distinctly resinous, and without hairs.

Leaf-petioles round; buds small and brown; young twigs and leaves heavily coated with white wool............. heterophylla p. 52

Leaf-petioles flattened laterally; buds red- or chestnut-brown, lustrons; leaves at most hairy; young twigs sometimes woolly.

Leaves rather finely toothed, usually less than $3 \frac{1}{2}$ inches wide; buds slightly resinous, less than $3 / 8$ inch long..P. tremuloides p. 47

Leaves more coarsely toothed, usually $3 \frac{1 / 2}{2}$ inches wide; buds gummy with resin, more than $3 / 8$ inch long....P. balsamifera p. 54 


\section{POPULUS TREMULOIDES Michaux}

\section{Aspen Quaking Asp}

The Aspen is a small tree, with a narrow, open, round-topped crown consisting of slender, up-tilted branches that droop at the tips. The thin. firm, smooth, lustrons leaves are broadly ovate and have a sharp point and a rounded base. Their margins are finely and regularly toothed, and the petioles are strongly flattened. The cylindrical. hairy catkins. which appear late in March or early in April. are from $1 \frac{1}{2}$ to $: \frac{1}{2}$ inches long, the staminate catkin reddened by its pollen-sacs. The pistillate catkin matures in May or June, bearing minute brown seeds, each with a tuft of white hair at one end, in curved, thin-rvalled capsules, about $1 / 4$ inch long, situated at intervals along the now elongated (:) to 4 inches) stalk. The twigs are slender, smooth, and lustrous, turning recklish-brown and finally gray. The conical, slightly resinotss. curved, and pointed leaf-buds, about $1 / 4$ of an inch long, are covered by 6 or 7 lustrouts, hairless, reddish scales and are closely appressed to the twigs, while the larger but otherwise similar flower buds are rather divergent. The trunk. which may attain a diameter of 1 or even 2 feet, is clothed at maturity by nearly black, fissured bark with broad,

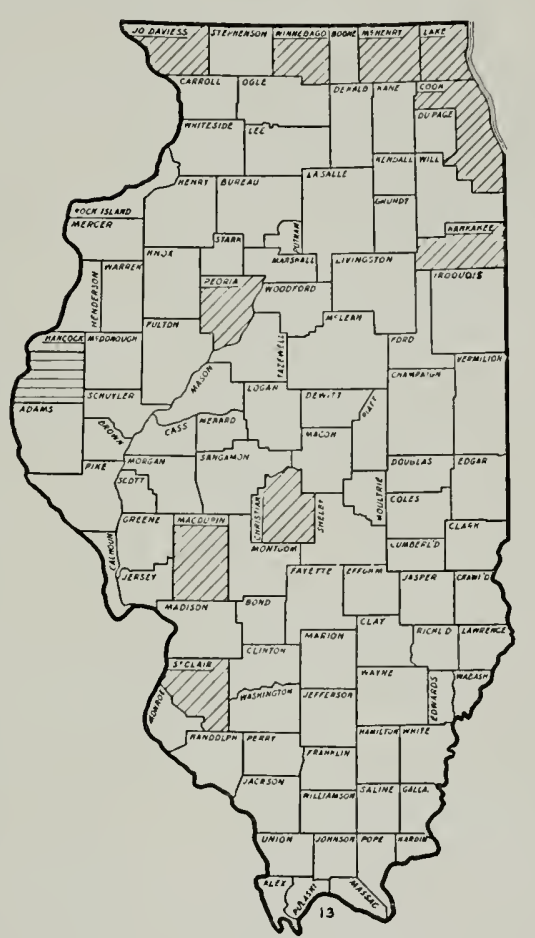

Fig. 13. Distribution of the Aspen. flat ridges; but on younger trees and higher on the boles of mature trees the bark is thinner. yellow-green to gray, and ronghened by wart-like growths. The tree nsually attains a height of from 30 to 60 feet.

Distribution: The Aspen in the north has a transcontinental range that extends from southem Labrador westward to Alaska. but southward. on the plains, it extends only through northern Indiana and Illinois into northeastern Missouri. In Illinois it is not a common tree. It has been found as far south as St. Clair County in the west, but according to Robert Ridgway it cloes not occur in the roods of Wabash County. In the 


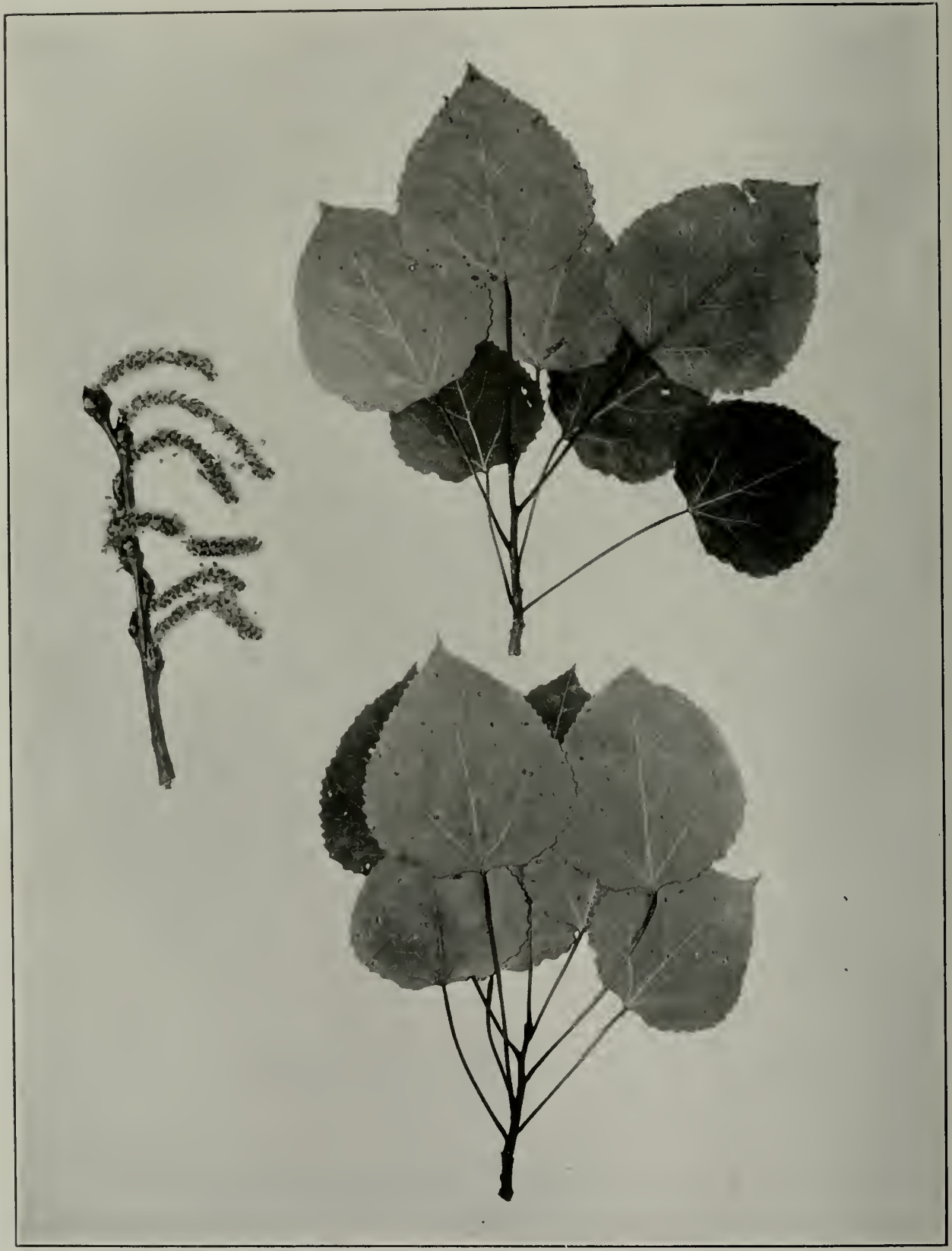

PLATE 8 


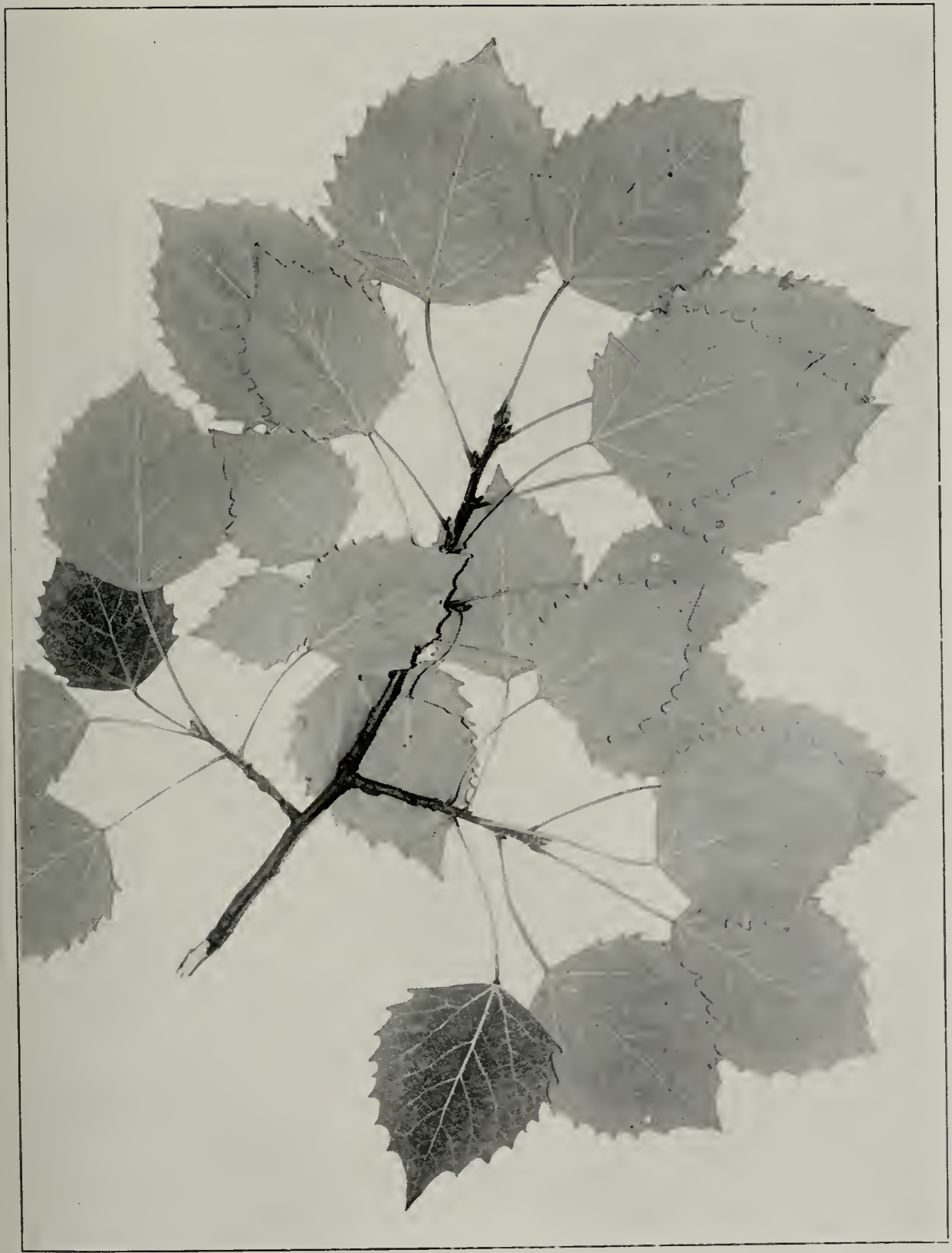

PLATE？

POPULUS GRANDIDENTATA MICHUX

POPLAR 
beach region north of Wankegan, Gates found Aspen with Burr Oak and hickory. In Lake County he found it on the edges of boggy prairies, while (ileason ${ }^{1}$ says that the Aspen is an inhabitant of the swampy swales between the sandy hills and that an occasional tree is found in the Burr Oak association in the sand areas of Winnebago. Lee, and Kankakee Comnties. In Whiteside County, we have found it in young stands of oak, hickory, ash. cherry, and Black Locust, presumably on burned-over land, and we have found it in company with poplars on the sides of eroded gullies in Lce and Carroll counties, where it seemed as much a pioneer as on sand and burned-over land.

Uscs: The light-brown, close-grained wood of the Aspen is light, soft, and weak, and has few commercial uses. When mixed with spruce and fir, it is used in the manufacture of "sulphate-pulp," and its lumber is used occasionally in turnery. As a fuel wood, it is fair, but it does not have the heating and lasting qualities of birch and maple. The wood is not durable in the soil and so is not satisfactory for fence posts, poles, or ties. But the ability of the tree to establish itself quickly on burned-over or denuded land makes it useful as a protecting cover for slower-growing and more valuable trees.

\section{POPULUS GRANDIDENTATA Michaux}

\section{Poplar Large-toothed Aspen}

The Poplar is a small to medium-sized tree, with slender, rather rigid branches and stout twigs, which form a narrow, round-topped, and open crown. The thin, firm leaves, though at first white-woolly, are at length smooth and yellow-green, with sharp points and rounded or broadly wedge-shaped bases and petioles strongly flattened at the sides. The cylindrical, hairy catkins, at first $1 \frac{1}{2}$ to $21 / 2$ inches long, appear in late March and April, the staminate and pistillate catkins being on separate trees. The fruit, which matures in May as the leaves come out, consists of a small, curved capsule, many of which are disposed loosely on the stalk of the mature pistillate catkin, which is then 5 to 6 inches long. The minute brown seeds set free from the capsules are provided at one end with a tuft of white hair. The divergent flower and leaf buds are separate, the broally ovate, rather pointed leaf buds, which are covered by 6 or $i$ rounded, somewhat hairy, chestnut-brown scales, being about $1 / 8$ inch long, and the flower buds, which are similar, being larger and more divergent. The twigs are rather stont and, though mostly smooth and lustrous,

${ }^{1} 11$. State Lab. Nat. Hist. Bul. Vol. 9, Art. 3. 1910. 
often gray-hairy toward the tip, with a dark reddish or yellowish brown bark. The trunk, which on old trees is covered by thick, dark-brown bark roughened by irregular fissures and broad, flat ridges, attains a diameter of from 1 to 2 feet. The tree usually is from 25 to 50 feet tall.

Distribution: The Poplar is an inhabitant of rich. sandy soils near the borders of swamps, from Nova Scotia westward to northern Minnesota and southward to central Kentucky and Tennessee. In Illinois. it is to be found in most of the counties in the northern tier; and its range extends southeastward as far as $11 \mathrm{i}$ bash County, where it has been collected by Jacob Schneck and Robert Ridgway. According to Gleason, it grows with Burr Oak in the sand area at Amboy, Lee County, and also as an occasional pioneer in the Black Oak woods. In the main, the tree prefers rich, sandy soil in the vicinity of streams and swamps, although it is reported in the dry, upland woods of Peoria County and nay be fonnd on eroded land and sand dunes.

Uscs: The close-grained, pale-

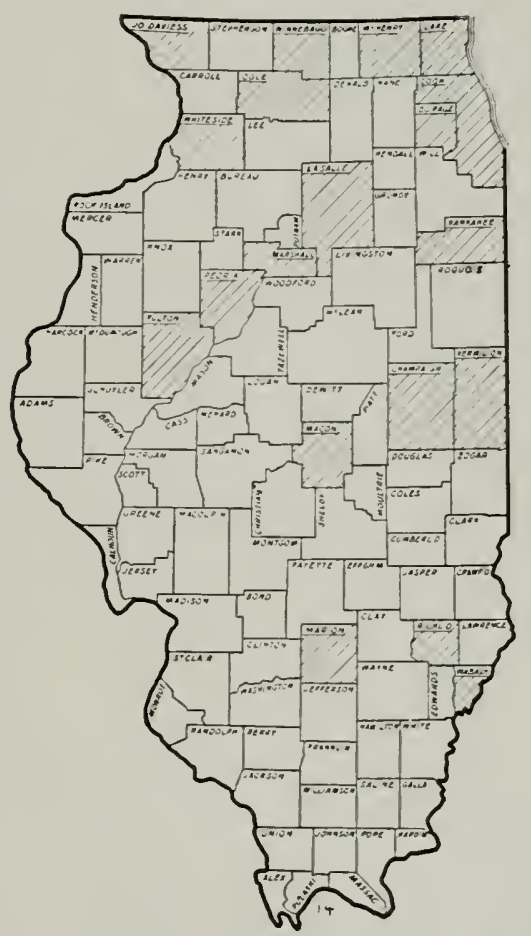

Fig. 14. Distribution of the Poplar. brown heartwood and nearly white sapwood of the Poplar (see page 301) is light, soft, and weak. Though used for excelsior and pulp and in the manufacture of small wooden articles, it has little commercial value. The tree itselt, because it grows rapidly on burned or barren land, is useful as a corering beneath which more valuable trees can establish themselyes. 


\section{POPULUS HETEROPHYLLA ILINAEUS}

\section{Swamp Cottonwood Black Cottonwood}

The Swanp) Cottonwood is a small tree, with a few irregularly arranged, large limbs which form a narrow, open, round-topped crown. The thin, fim leaves, which are at first densely hairy but later become dark-green and smooth above and paler and woolly beneath, are broadly

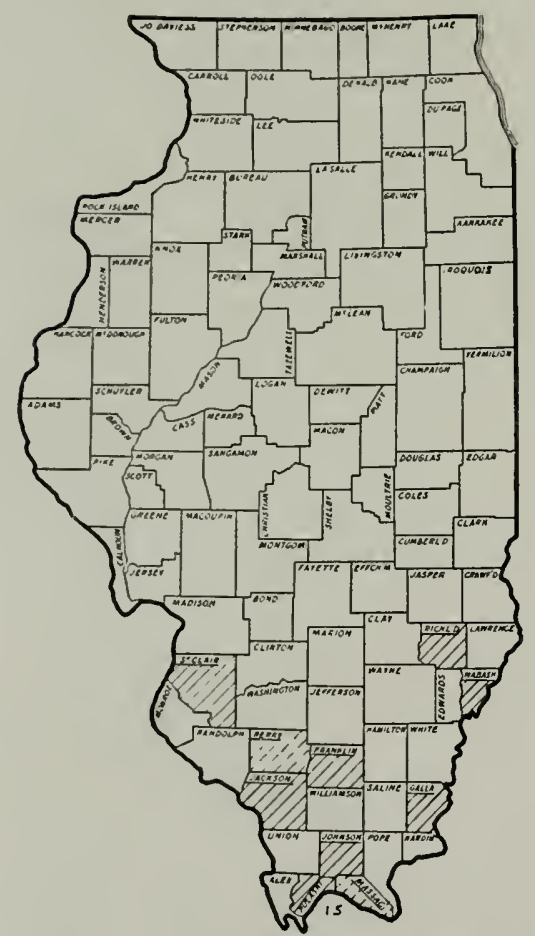

Fici. 15. Distribution of the Swamp Cottonwood. ovate, with rather obtuse points, round or heart-shaped bases, and finely toothed margins. The stout, densejy flowered staminate catkins, which appear in April or May, are about 2 or $2 \mathrm{I} / 2$ inches long. while the broad, few-flowered pistillate catkins, which occur on other trees, are from 1 to 2 inches long. The fruits, thick-walled, long stalked, reddish-brown capsules about $\mathrm{I} / 4$ inch long. open in May, when the leaves are about half grown, and set free the minute, dark-brown. white-hairy seeds. The twigs are stont and, though at first velvety, soon become lustrous: and their angled pith is a conspicuous orange. The flower and leaf buds are distinct, the ovate, sharply pointed, reddish-brown leaf buds, which are covered by 4 to i slightly hairy scales, being about $1 / 4$ inch long, and the flower buds, though otherwise quite similar, about $\mathrm{t} / 2$ inch long. The straight, tapering trunk, which at maturity is covered by light reddish-1)rown, thick bark roughened by narrow, shallow fissures and long, narrow, flat ridges. rarely attains a diameter of $1 \%$ inches: and the height of the tree usually is from 2.) to 10 feet.

Distribution: The natural range of the Swamp Cottonwood extends from Connecticut sonthward to Georgia and Florida, westward along the Gulf to Lonisiana, and northward again along the Mississippi Valley into Michigan. In Illinois, it is a distinctly sonthern tree, for it extends northward only to Richland County in the east and to St. Clair County in the 
west. It is a lover of low, rich lands subject to the overflow of rivers and makes its best growth on the flood plains of the Mississippi and in the valleys of the Big MInddy, the Cache. and the Little Wabash rivers.

Iccording to Ridgway, it occurs with the Black Willow on the borders of swamps and attains a height of 90 feet and a diameter of $21 / 4$ icet in the Wabash Valley.

L'ses: The dull-brown heartwood and the thin, pale-brown sapwood of the Swamp Cottonwood are close-grained, soft, and weak, and have little commercial value. In Arkinsas and Missouri, however, the tree is cut and sawed ; and the lumber derived from it, known in the lumber trade as "black poplar" and "black cottonwood," is used in the interior finishing of houses. In Union and Alexander Counties, where the Swamp Cottonwood is cut, along with other swamp inhabiting trees, its lumber is sold, chiefly in the Cairo market, for use in the manufacture of box boards and egg crates: and in this region, natural stands are capable of yielding over $i, j 00$ board feet per acre.

\section{POPULUS BALSAMIFERA LINNAEUS}

\section{Cottonwood}

The Cottcnwood is a large tree, with a narrow, open, irregular crown made up of a few massive, erect branches which are bushy at the ends. The dark-green, lustrous leaves, which are thin and firm, from 3 to 6 inches long and about half as broad, very sharply pointed, and rounded or heart-shaped at the base, have finely toothed margins and long, slender, round petioles; and there are 2 glands on the lea $\bar{f}$ blade at its union with the petiole. The pendulous, densely flowered catkins, which appear in April and May before the leaves, are hairy, cylindrical structures from $21 / 2$ to 4 inches long. The pistillate catkins, which mature in late May or June, bear a considerable number of rather closely placed, oval, pointed, brown capsules, which open by $\gtrsim$ opposite seams and set free the minute, pale-brown, white-haired seeds. The stout, lustrous twigs, at first bright reddish-brown, finally become yellowish and often angular. The sharply pointed, gummly buds, which are $1 / 2$ to 1 inch long, are rather divergent from the twig and are covered by clark-red scales. The trunk, which is covered by clark, red-tinted, gray, thick bark that is roughened by narrow fissures and broad, scaly ridges, attains a diameter of 1 to 3 feet; and the height of the tree is from $(j 0$ to $i 0$ feet. 
Distribution: The Cottonwood is rather widely distributed over the northeastern part of the United States, but it is everywhere a rare and local tree. In Illinois, it is found here and there through the length and breadth of the State, in small groups on rich. moist river banks and bottomlands.

Uscs: The pale-brown heartwood and the thick, white sapwood of the Cottonwood are light and weak, soft and close-grained, and of little value. except that when mixed with the wood of other trees they serve in the manufacture of paper pulp. Cottonwood can be used also for excelsior; and when the tree is large, it can be made into match stock. Although the wood is tongher than that of the Aspen, it does not make a desirable fuel.

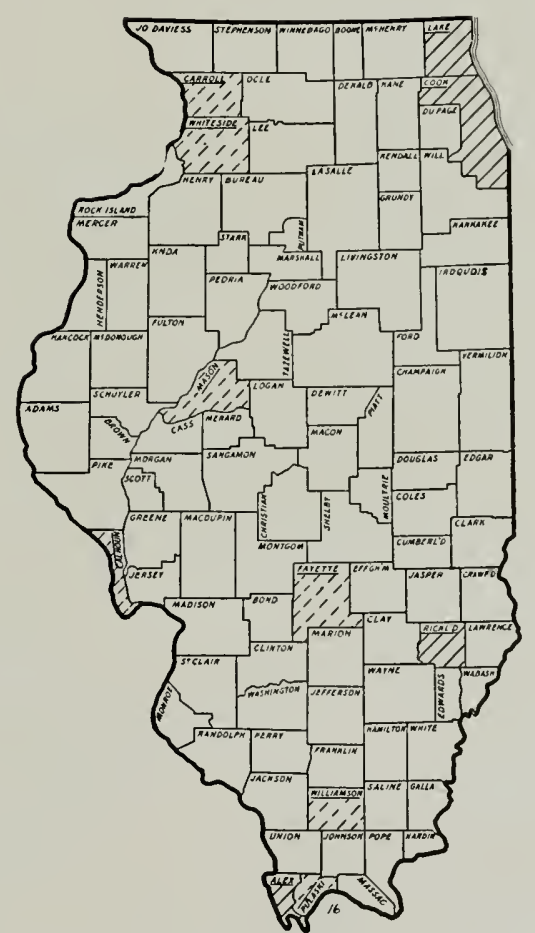

FIG. 16. Distribution of the Cottonwood. 


\section{POPULUS BALSAMIFERA LINNAEUS}

\section{laricty VIRGINIANA Sargent}

\section{Virginia Cottonwood}

The Iirginia Cottonwood is a fairly large tree, with a broad, rounded, and open crown formed of several massive, spreading limbs that are pendulous at the ends. The smooth and lustrous, light-green leaves, which at maturity are thick and firm and somewhat triangular, have sharply

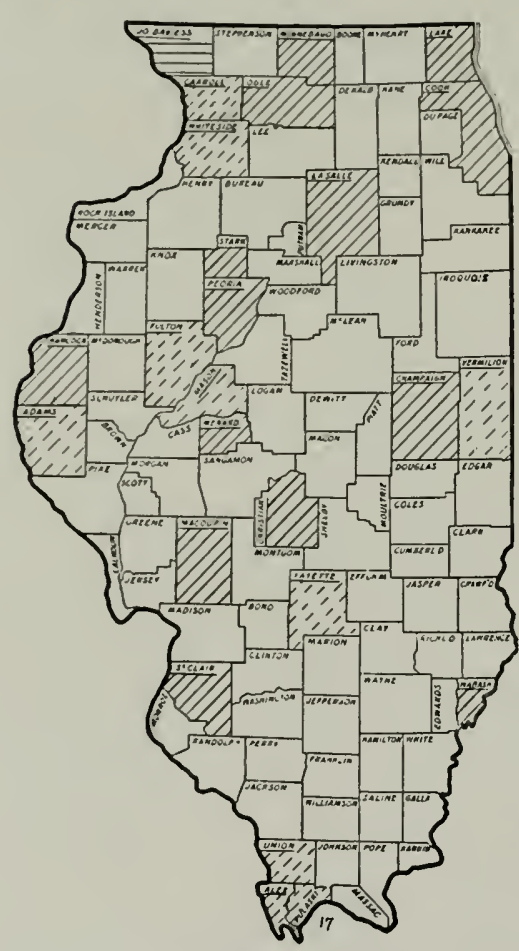

FIc. 17. Distribution of the Virginia Cottonwood. pointed tips, nearly square or wedgeshaped bases, and rather coarsely toothed margins; and the long, slender petioles are smooth and flattened on the sides. The stont, cylindrical staminate catkins, from 3 to 4 inches long, are densely flowered. The long and pendulous pistillate catkins are fewflowered and produce, in May or early June, a number of ovoid, sharply pointed capsules, $1 / 4$ to $1 / 2$ inch long, which open by 3 or 4 partitions and liberate the tiny, pale-brown, whiteor rusty-hairy seeds. The stout and smooth, green-tinted, yellow, and lustrous twigs are round, or, just below the buds, a little angular; and the ovate. sharply pointed, and divergent butls, $1 / 2$ to $3 / 4$ inch long, are inclosed

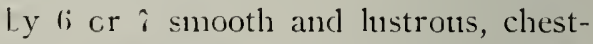
nut-brown scales that bear a yellow, fragrant resin on their inner surface. The trumk, which is clothed by asinygray bark $1 \frac{1}{2}$ to 2 inches thick, with broad, rounded, scaly ridges, reaches a diameter of 2 to 3 feet: and the height of the tree is from 50 to 20 feet.

Distribution: The range of the Virginia Cottonwood extends from the l'rovince of Quebec westward to southern Minnesota and southward to Florida, the Gulf States, and western Texas. It is found, often in extensive, open groves, along the banks of streams. In Illinois, it occurs in suitable situations throughout the State and is far more common than Populus balsamifora itself. On the islands of the Mississippi River 


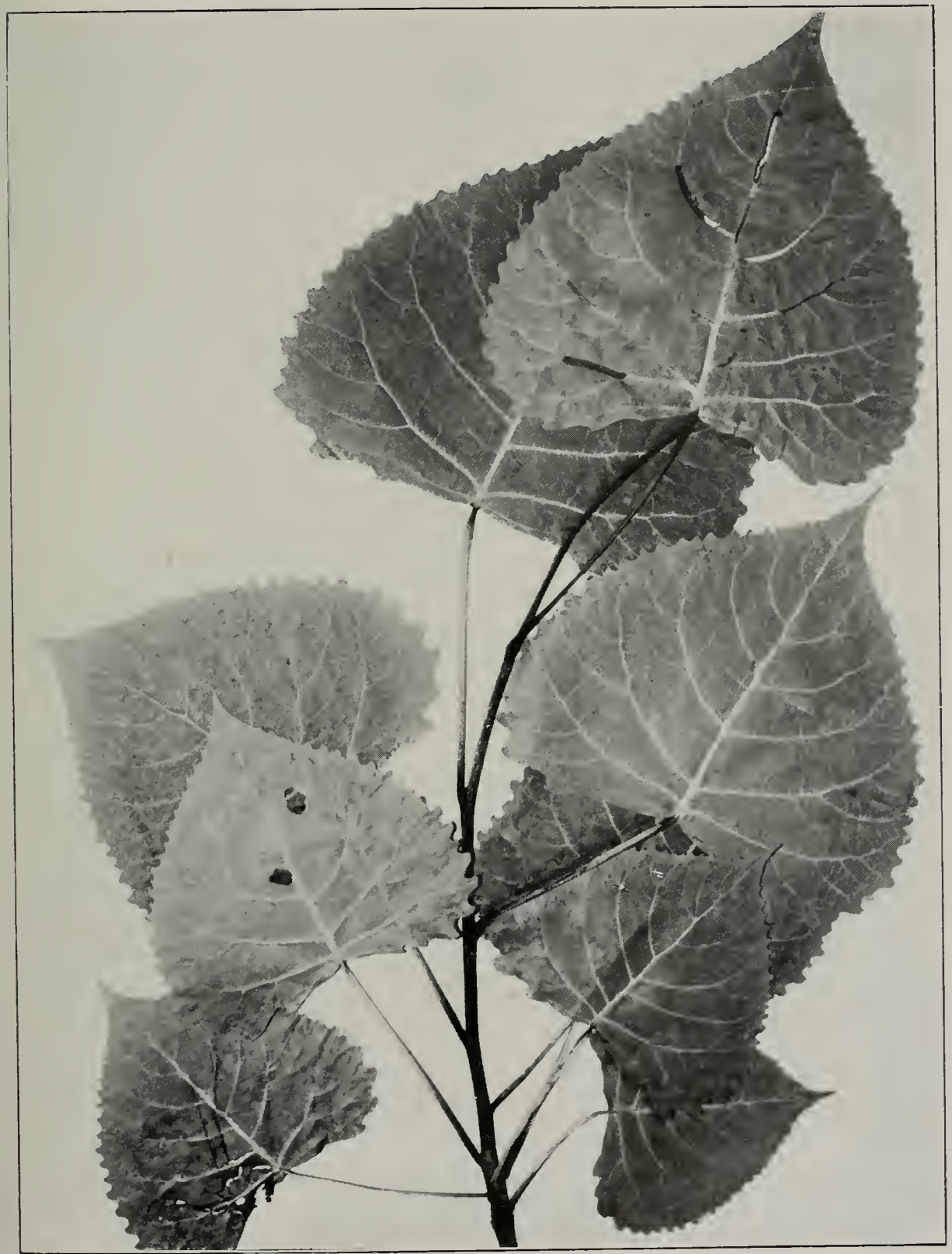

PLATE 11

VIRGINIA COTTONWOOD POPULUS BALSAMIFERA VIRGINIANA SARgent 
in Whiteside Comnty. Virginia Cottonwood is found with Soft Maple, Eln1, Willow, kiver Birch, Tin Oak, and Ash, where it forms a growth per acre of 88 trees over $(i$ inches in diameter and yields 18 cords per acre. The tallest tree in this region measured so feet in height. To the sonth, this tree grows, with the Swan1p Cottonwood, along the levees of the Mississippi River in Lnion and Alexander counties, where it often is mixed with maples. gums, Sycanore. Elm, and Willow, though the stand at times máy be almost pure.

Uses: The wood derived from the Virginia Cottonwood is light and soft as well as weak and fine-grained, but tongh. The heartwood is dark-brown, and the sapwood is thick and nearly white. In the main, it is used for manufacturing pulp and packing cases and for light fuel. The lumber is hard to season. due to a tendency of the wood to warp excessively, and though casily worked and finished, it often has a "woolly" texture when planed. It is especially valuable for crating uncanned foods, for besides making a strong container it does not impart a woody taste or odor to the foods. As a result, the trees that are cut in Union and Alexander counties are used mainly in the manufacture of egg crates. baskets, berry boxes, and the like. Because of its toughness, it is used also in three-ply veneer, from which trunks, musical instruments, and furniture clrawers are made; but it is most acceptable for wagon boxes, scoop-boards, barn floors, the lining of refrigerator cars, and for bridge floors, in all of which its toughness is its main asset. Its minor uses include pyrography, where its whiteness is of value, and the manufacture of excelsior and slack cooperage, that is, the staves and heads of barrels. Grown on the Mississippi, Ohio, and Illinois rivers, trees of this variety are being cut into logs, or "bolts," $4 \mathrm{~T} / 2$ feet long with a minimum diameter of 3 inches, and are sold in Ohio for pulpwood.

Because of its softness, this is one of the few woods not acceptable for railroad ties, but it provides serviceable fence posts when treated with coal-tar creosote against decay.

In southern Illinois, this tree grows very rapidly, for there the overflowed land and the rich, alluvial soil afford its ideal conditions; but even on sand it will make a fair growtis. Its seeds require abundant sunlight and moisture for germination; and it proves a useful tree for planting on "blow sand" and in eroded regions. But. being intolerant of shade. the stand rapidly thins out as it grows; and at maturity there may not be over 80 or 90 good-sized trees to the acre. 


\section{Other Poplars in Illinois}

Populus tacamahacea Miller, the Tacamahac, is possibly not native to Illinois, though numerous collections have been so reported. Populus canadensis Muenchhausen, which is believed to be a hybrid between $P$. balsamifera and $P$. nigra, is best known by the variety Eugcnic Schelle, the Carolina Poplar of the American nurseries. It occasionaliy escapes from cultivation. The Baln of Gilead, Populus candicans Aiton, is reported by Pepoon ${ }^{1}$ near the shore of Lake Michigan in the vicinity of Montrose Boulevard and northward; and the Lombardy Poplar., Populus nigra Italica du Roi, is also reported by Pepoon ${ }^{1}$ as having been "originally abundant near Lake Michigan for one-fourth of a mile north of Wilson Ave."

\section{SALIX LinnaEus The Willows}

\section{Family Salicaceae}

Deciduous trees or shrubs, with broad- or narrow-bladed, featherveined, alternately arranged leaves. Flowers in sessile or stalked catkins placed laterally or terminally on leafy branches: pistillate and staminate catkins on separate trees, appearing before the leaves; each flower with a small, gland-like disk. Twigs slender and round, with small and round white pith. Buds mostly small, sessile, appressed, covered by a single exposed scale. Fruit a small, sharply pointed, one-celled capsule, which separates at maturity into 2 recurved parts.

There are between 160 and $1 \% 0$ species of Salix, and the range of the genus extends from the Arctic region southward to Brazil and Chili in the Americas, and to Madagascar, southern Africa, the Malay Penisula, Java, and Sumatra. About 90 species attain tree size; and of this number, 24 occur in North Anerica and? in Illinois.

\section{KEY TO THE ILLINOIS WILLOWS}

Leaves narrow ( $1 / 4 \cdot$ : $_{-1}^{\prime}$ inch wide), green on both sides; petioles short; twigs dark green................................... nigra p. 60 Leaves broader (5/8-11/4 inches), whitened beneath; eptioles longer $\left(1 / 4^{-1 / 2}\right.$ inch $) ;$ twigs yellowish....................... amygdaloides p. 62

${ }^{2}$ Flora of the Chicago Region, pp. 272-273. 


\section{SALIX NIGRA MARSHALL}

\section{Black Willow}

The Black Willow usually is a sulall tree, with a broad, open crown of stont. alscending brancles that droop at the ends. The thin, lightgreen, and lustrons leaves, 3 to 6 inches long by $1 / 8$ to $3 / 4$ inch wide, have long, attenuated tips, rounded or wedge-shaped bases, and finely toothed

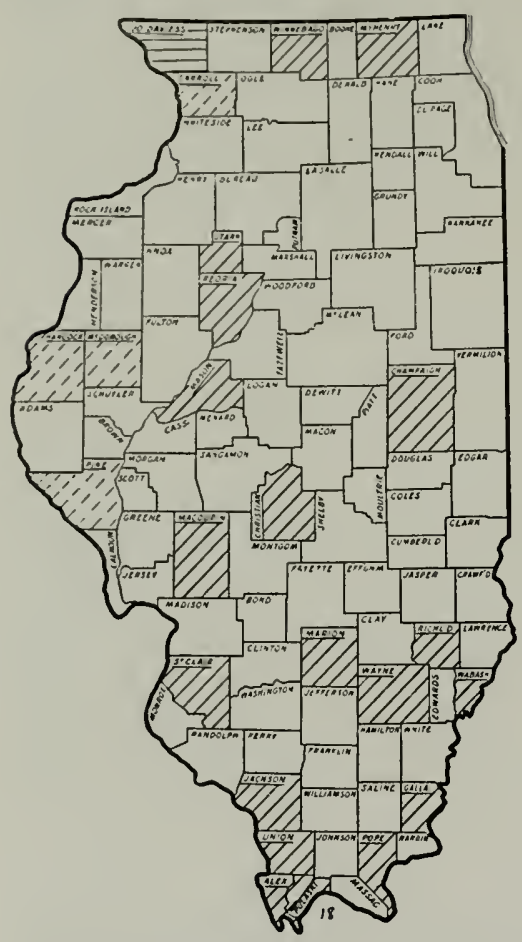

FIG. 18. Distribution of the Black Willow. margins. The petioles are short and straight. Narrow, cylindrical catkins, 1 to 3 inches long. appear in May on the ends of short leafy branches, the pistiilate catkins maturing smooth, reddish-brown capsules about $1 / 8$ inch long. which contain the minute, whitehairy seeds. The slender, reddisbrown to pale-orange twigs are brittle at the base and have 110 end bud; but the sharply pointed lateral buds are about $\frac{1}{16 i}$ to $1 / 8$ inch long and are covered by one reddish-brown scale. The trunk, which occasionally attains a diameter of 2 or 3 feet, is covered by thick, brown or nearly black bark deeply furrowed into narrow, connected ridges. The height of the tree usually is from 30 to 40 feet.

Distribution: The Black Willow ranges from southern New Brunswick westward to the north of Lake Superior and southward to Georgia in the East and Texas in the West. It is a tree of low, alluvial ground, and occurs in such situations throughout Illinois. It is particularly prevalent along the course of the Mississippi, and increases in size and abundance toward the south.

Uses: The fine-grained, soft wood of the Black Willow, pa'e reddish-brown in the heart and nearly white in the sapwood, is light and weak and yields only a low grade of lumber, suitable in the main for crates and boxes, because of its toughness and pleasant odor. But a fine grade of charcoal is obtained from it, which is particularly in denland for medicinal and chemical purposes, especially the manufacture of gun powder. The wood is suitable also for paper pulp; and the tree is now cut on the 


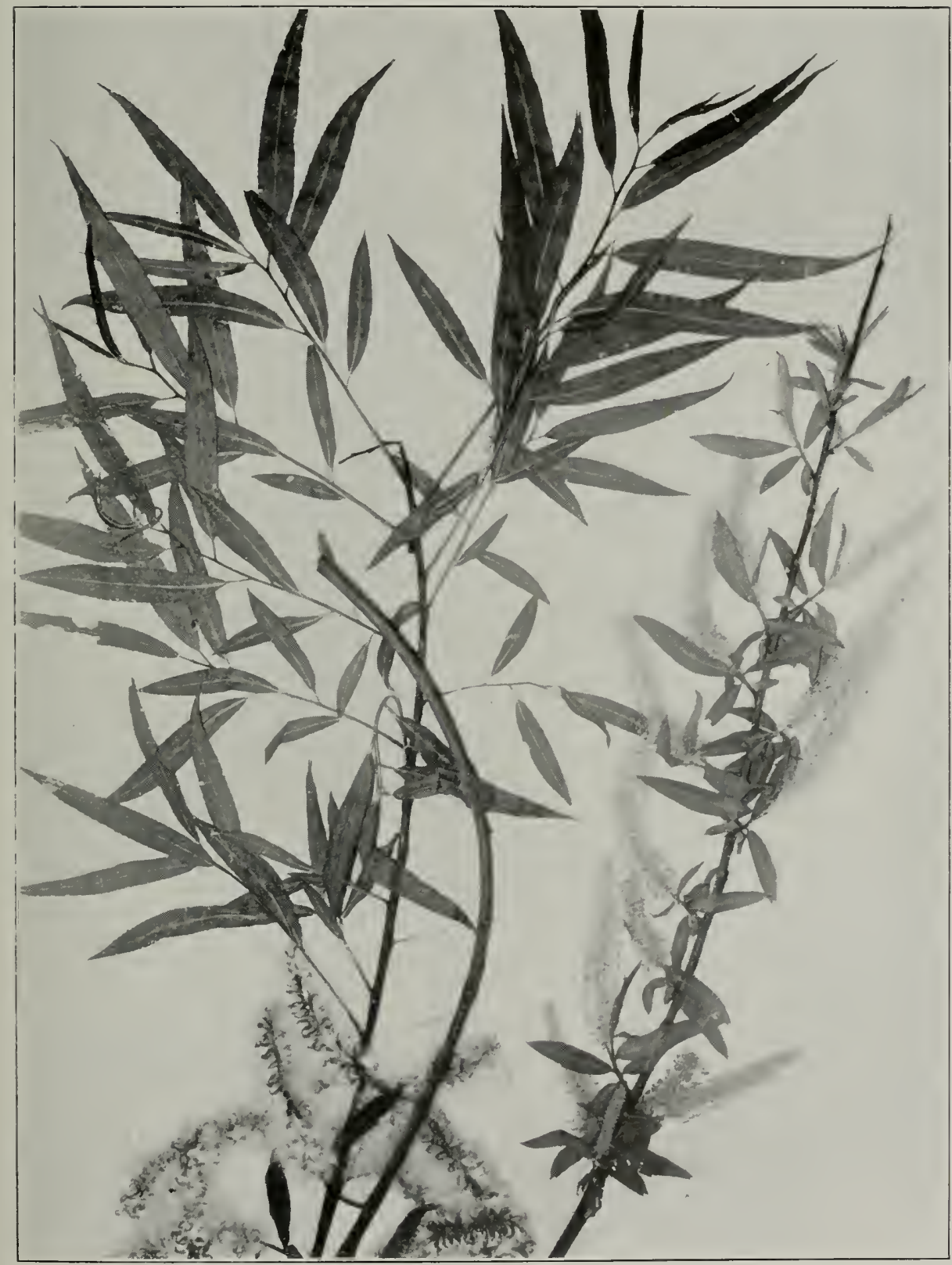

PLATE 1\%

SALIX NIGRA MARshall

BLACK WILLOIV 
islands and shores of the Mississippi, the Illinon, and the Ohio River up to Shawneetown and delivered by barge to the markets, where it is purchaseal at a fair price by an Ohio pulp manufacturer. For this use, the willow $\operatorname{logs}$ must be sound and must be at least 3 inches in diameter at the small end.

The Black Villow also has an important agricultural use, for the cuttings sprout readily and grow rapidly, and when they are planted in erocled gullies and along stream banks they successfully combat the destructive action of water.

\section{SALIX AMYGDALOIDES ANDERSSON \\ Peach Willow}

The Peach Willow is a rather tall tree, with a narrow, rounded head of straight, up-tilted branches. The broad and firm but thin leaves are green and lustrous above but whitened with bloom beneath, and they have long. slender points, rounded or wedge-shaped bases, and finely toothed

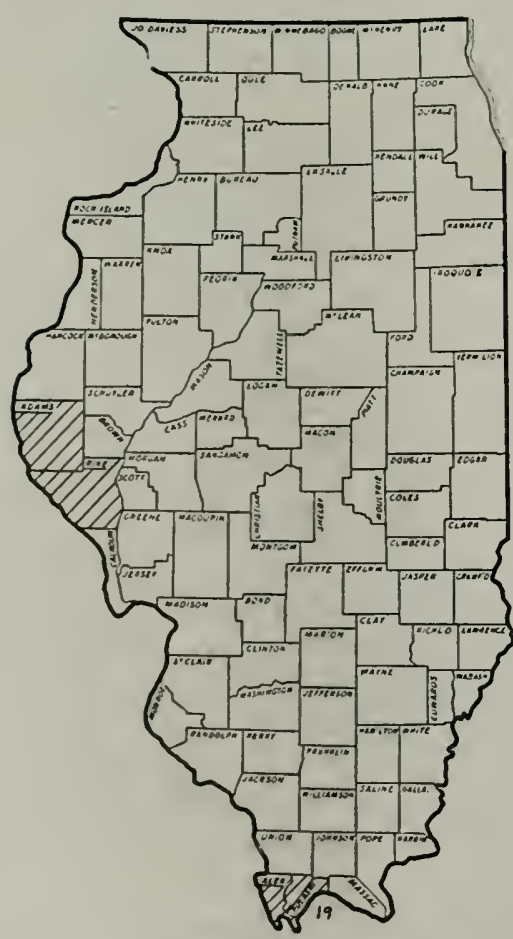

Fig. 19. Distribution of the Peach Willow. edges. Their slender petioles are round, $1 / 4$ to $1 / 2$ inch long, and usually twisted. The catkins, which are long and erect, appear in May with the leares: and the pistillate catkins bear at maturity a considerable number of short-stalked, yellowish, conical capsules $1 / 4$ inch long, which open along 2 seams to liberate the tiny, hairy seeds. The slender, yellowish twigs, which are not brittle at the base, are smooth or rarely a little hairy and are marked with scattered, pale lenticels. There is no end bud. The lateral buds are about $1 / 8$ inch long, rather blunt. and are inclosed in one shiny brown scale. The trunk, which extends high into the crown, attains a diameter of 1 to 2 feet; and the brown bark with which it is covered is divided by fissures into flat, connected ridges. The tree customarily attains a height of 60 to $\approx 0$ feet. 


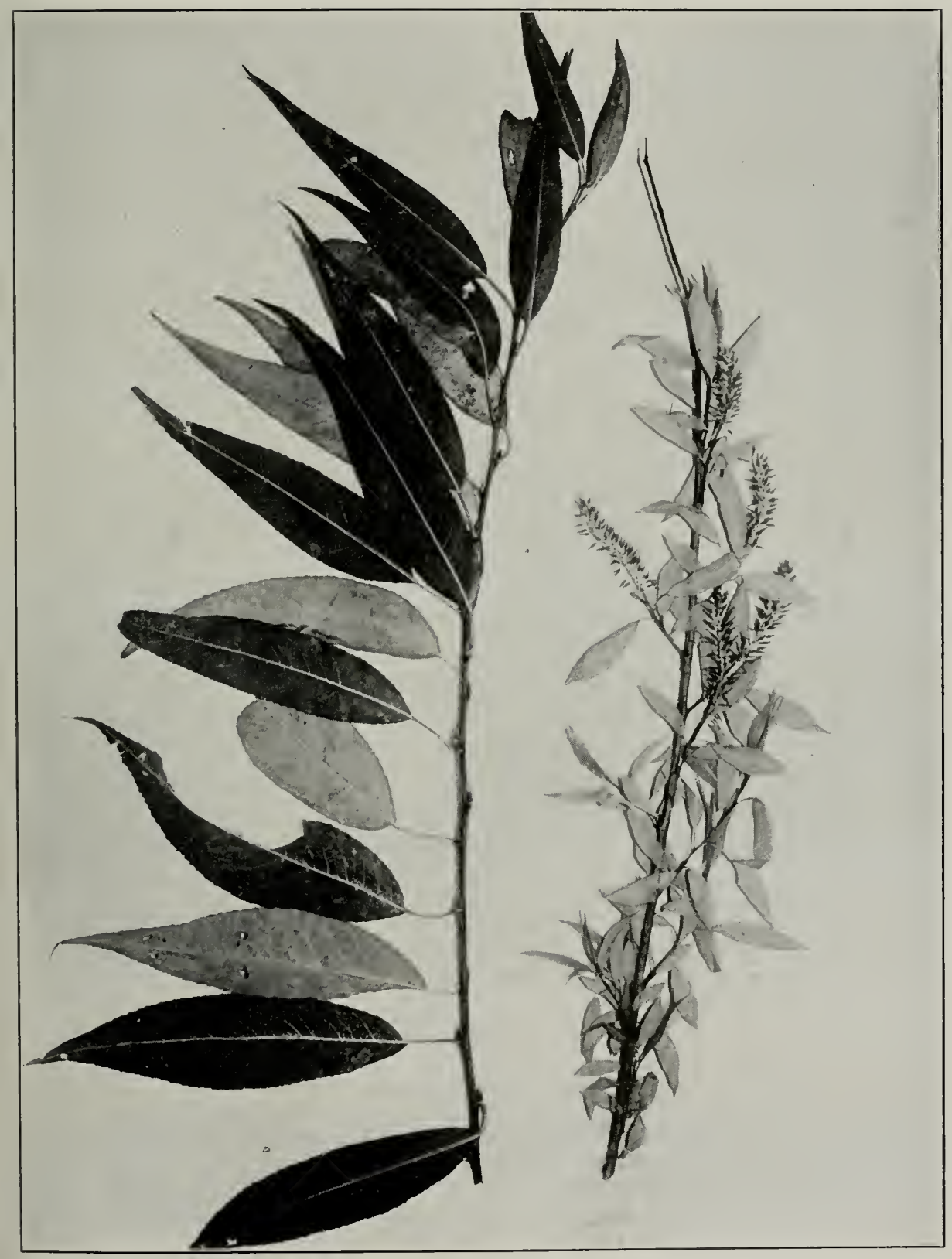

PLATE 13

S.ALIX AMYGDALOIDES ANDERSSON

PEACH WILLOW 
Distribution: The Peach Willow, sometimes called the Almond Willow. is a tree of stream banks. It ranges from Mlontreal westward into Oregon and 11 ashington and southwestward into Texas. In Illinois, it is confined to the southwestern section of the State, with the exception of Arlams and l'ike counties.

Uses: The close-grained, weak wood of the Peach Willow, which is light-brown in the heart and white in the thick sapwood, is soft and inferior and is only occasionally sawed into cheap lumber. But it furnishes a good sonrce of charcoal and is cut in Illinois for the same purposes as the wood of the Black Nillow.

\section{JUGLANS LinNaEUs The Walnuts}

\section{Family JuglandaceAe}

Large, decirlnous trees, with very large, alternate leaves divided into a number of leaflets arranged in pairs at intervals on the petiole, which is tipped by a single leaflet. Flowers of two kinds, both produced by the same tree: the staminate flowers in catkins; the pistillate flowers solitary or in clusters. Fruit consisting of a pulpy husk and, within it, a globuse, roughly fissured, hard, and thick-walled nut. Twigs stout and more or less fluted, their brown and angular pith chambered by thin plates, their large end buds covered by 2 pairs of opposite scales, and their blunt and scmewhat flattened axillary buds standing above large, 3-lobed leaf scars.

The 11 species of this genus are widely distributed in the temperate and subtropical regions of North and South America, in China, Japan, and Formosa. Of the 6 North American species, 2 are natives of Illinois.

\section{KEY TO THE ILLINOIS WALNUTS}

Leaflets 7-19; twig-pith dark-brown; terminal bud elongated; leaf-scars hairy at the upper edge; husk and nut much longer than widle; bark gray, with smooth ridges......................... cinerea p. 65

Leaflets 11-23; twig-pith light-brown; terminal bud globular; leaf-scars without hairs; husk and nut nearly spherical; bark dark-brown, with rough ridges $\ldots \ldots \ldots \ldots \ldots \ldots \ldots \ldots \ldots \ldots \ldots \ldots \ldots \ldots \ldots \ldots \ldots$ nigra p. 68 


\section{JUGLANS CINEREA LINNAEUS}

\section{Butternut}

The Butternut, called also White Walnut, is a tree of moderate size, with a trunk that divides into several stout limbs which spread horizontally and form a broad and symmetrical, round-topped crown. The compound leaves, which are 15 to 30 inches long, are made up of from 6 to 18 nearly sessile leaflets arranged in pairs (not necessarily opposite) along the stout, hairy petiole and a single terminal, long-stalked leaflet. The leaflets themselves are 3 to 4 inches long by $1 \frac{1}{2}$ to 2 inches wide, their blades unequally expanded on the two sides of the main nerve, the upper face yellow-green and wrinkled, and the lower face pale and covered with soft hairs. The pendulous, cylindrical staminate catkins grow from lateral buds on year-old twigs, and the pistillate flowers, which are about $1 / 3$ inch long and without a stalk, are found in spikes of 6 to 8 flowers at the tip of the new growth. Both kinds of flowers are borne on the same branchlet, usually near each other. The fruit, an ellipsoid, 4ridged, roughly corrugated, pointed nut, lies within an indehiscent, green. pulpy husk covered with glandular hairs. The stout, lustrous twigs, at

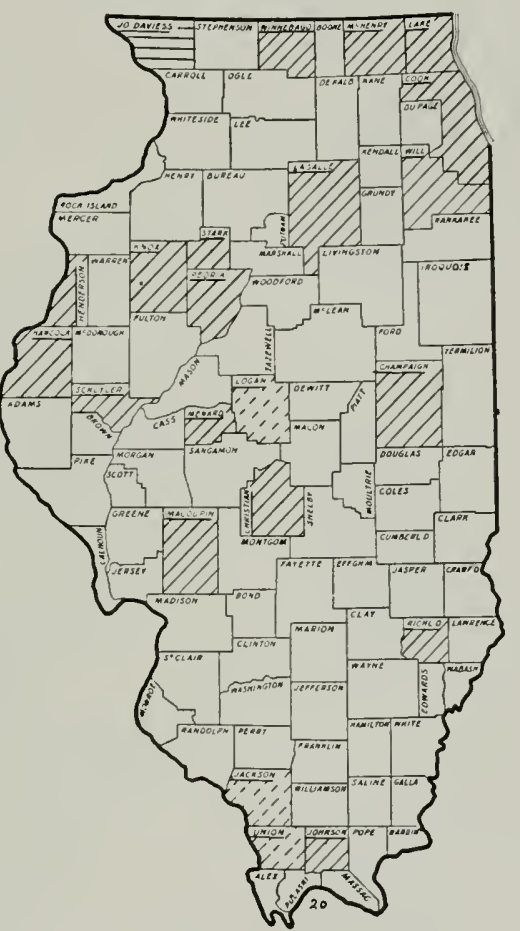

FIG. 20. Distribution of the Butternut.

first greenish but becoming reddish-or orange-brown, have dark-brown pith divided by firm diaphragms and carry small, blunt, lateral buds often superposed above the hair-fringed tops of the 3 -lobed leaf scars. The terminal bud is $I / 2$ to $2 / 3$ inch long and very bluntly pointed. The short, stout trunk, which is clothed by a thin, light-gray bark fissured into broad, scaly ridges, attains a diameter or 1 or 2 feet and usually divides at a height of 15 to 20 feet, but under good conditions often forms a tall, straight bole with very little taper. The tree is ustally 30 to 50 feet high, but it may attain a height of 100 feet. 


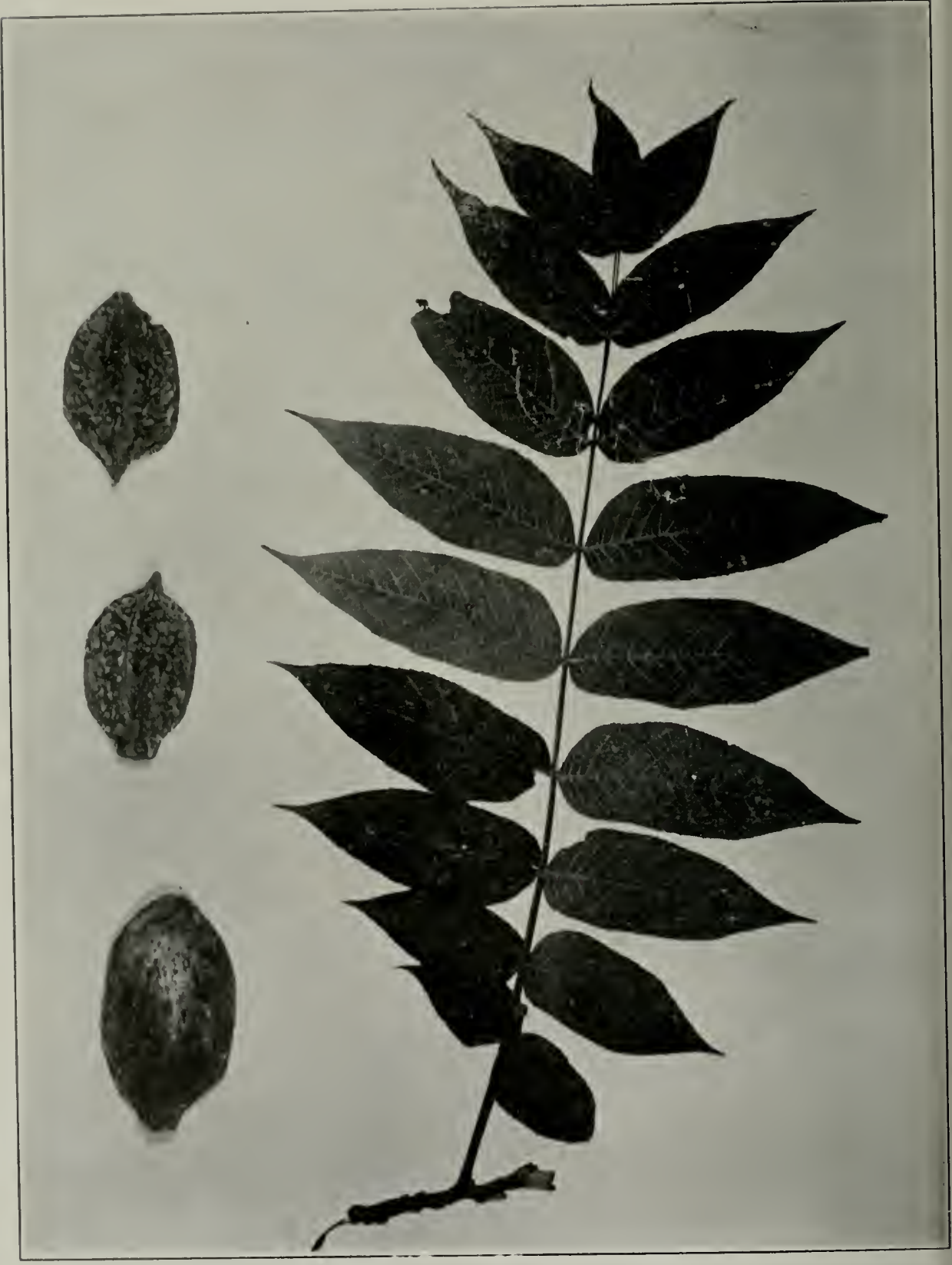

PLATE 14 
Distribution: The Butternut has a range that extends from New Brunswick, in eastern Canada. westward into Minnesota and southward into Georgia and Arliansas. It is found throughont Illinois, in the rich, moist soils of ravines and on drier and poorer hilly ground along streams. In the northern counties, in which it is not encountered frequently, it occurs in small, scattered, and often isolated groups; but in the southern counties, which are nearer the center of its distribution in Kentucky and Tennessee, it is common and even conspicuous in the ravines. It is reported by Pepoon", however, as "common along the north branch of the Chicago River and in the Niles Woods," as well as "along the Des Plaines Valley from Riverside northward." The Butternut forms no distinct forest type, for the individua! trees are scattered and are never dominant; but it is associated with the Tulip Tree, Bass Wood, Black Cherry, Black Gum, and the Beech in the ravines and bottomland, and with oaks and hickories on the uplands.

Uscs: The light, rather coarse-grained wood of the Butternut is soft and weak, but it is easily worked and polished. The heartwood is lightbrown and darkens with exposure, and the sapwood is thin and lightcolored. Although the tree is not an important source of timber, its lumber is used occasionally for the interior finishing of houses and also for the lining of furniture drawers and cabinets. The husks of the nuts, when they are boiled, yield a yellow or brownish dye which is used now for dyeing carpets and rugs and was employed by the pioneers for coloring cloth. The brown color so obtained is called "butternut." The oily and nutritious nuts are highly prized in their wild state, and Colby ${ }^{2}$ says that "promising varieties originating in the East. such as the Manchester, should be tried ont under our conditions."

i Flora of the Chicago Region, p. 274 .

2 Trans. Ill. St. Acad. Sci. Vol. 1s, p. 142.1925. 


\section{JUGLANS NIGRA LINNAEUS}

\section{Black Walnut}

The Black Waluut is a large, high tree, with a straight and continuous trunk which gradually breaks up, as it ascends, into stout, spreading limbs to form a round-topped crown. The large, compound leaves, which are from 1 to 3 feet long, are made up of 10 to 22 very short-stallied leaf-

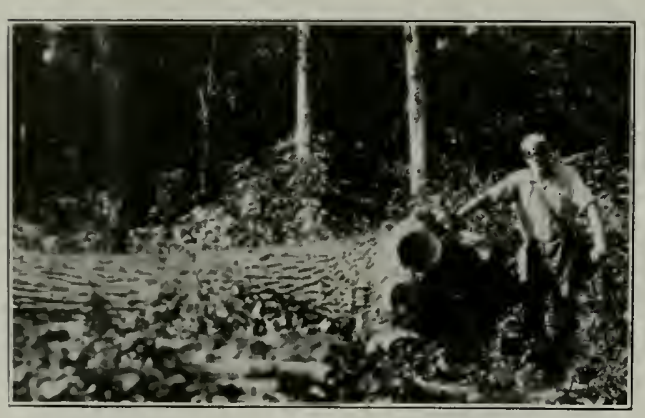

Fig. 21. Black Walnut cut at Allendale. In felling Waluut, no stump is left, for the veneer obtained from the base of the trunk is beautifully figured.

lets set in pairs along the hairy petioles and one longstalked leaflet at the end. The stout, unbranched catkins, 3 to 5 inches long, which bear the staminate flowers, are found on the one-year-old growth; and the sessile pistillate flowers, I/4 inch long, are in 2- to 5flowered spikes at the end of the new growth. Both kinds occur on the same branchlet. The fruit is a spherical, slightly flattened, hard- and very rough-shelled nut, 1 to $1 \frac{1}{2}$ inches in diameter, borne in a thick, indehiscent, pulpy husk covered with clusters of pale hairs. The stout, orange-brown, soft-hairy twigs, which eventually become light-brown, have their pith cavities divided into numerous small chambers by persistent, pithy partitions. The nearly spherical, pale-gray terminal bud, $1 / 3$ inch long, is covered by 2 pairs of scales, the outer pair lobed and the inner pair somewhat divided at their tips. The lateral buds are smaller and stand, often superposed, above a notch in the somewhat 3-lobed and hairless leaf scar. The trunk, which usually attains a diameter of 2 to 3 feet, is clothed by dark-brown to blackish bark 2 or 3 inches thick, which is divided by deep fissures into broad, scaly-topped, rounded ridges. The tree usually attains a height of 75 to 100 feet, but it is sometimes 150 feet high and 5 to 6 feet in diameter at the trunk.

Distribution: The Black Walnut is an inhabitant of rich bottomlands and hillsides from Massachusetts westward to Minnesota and southward to Florida and Texas. In Illinois, it grows in suitable situations throughout the length and breadth of the State, but it is found in pure stands only occasionally, in small areas where the soil and moisture con- 


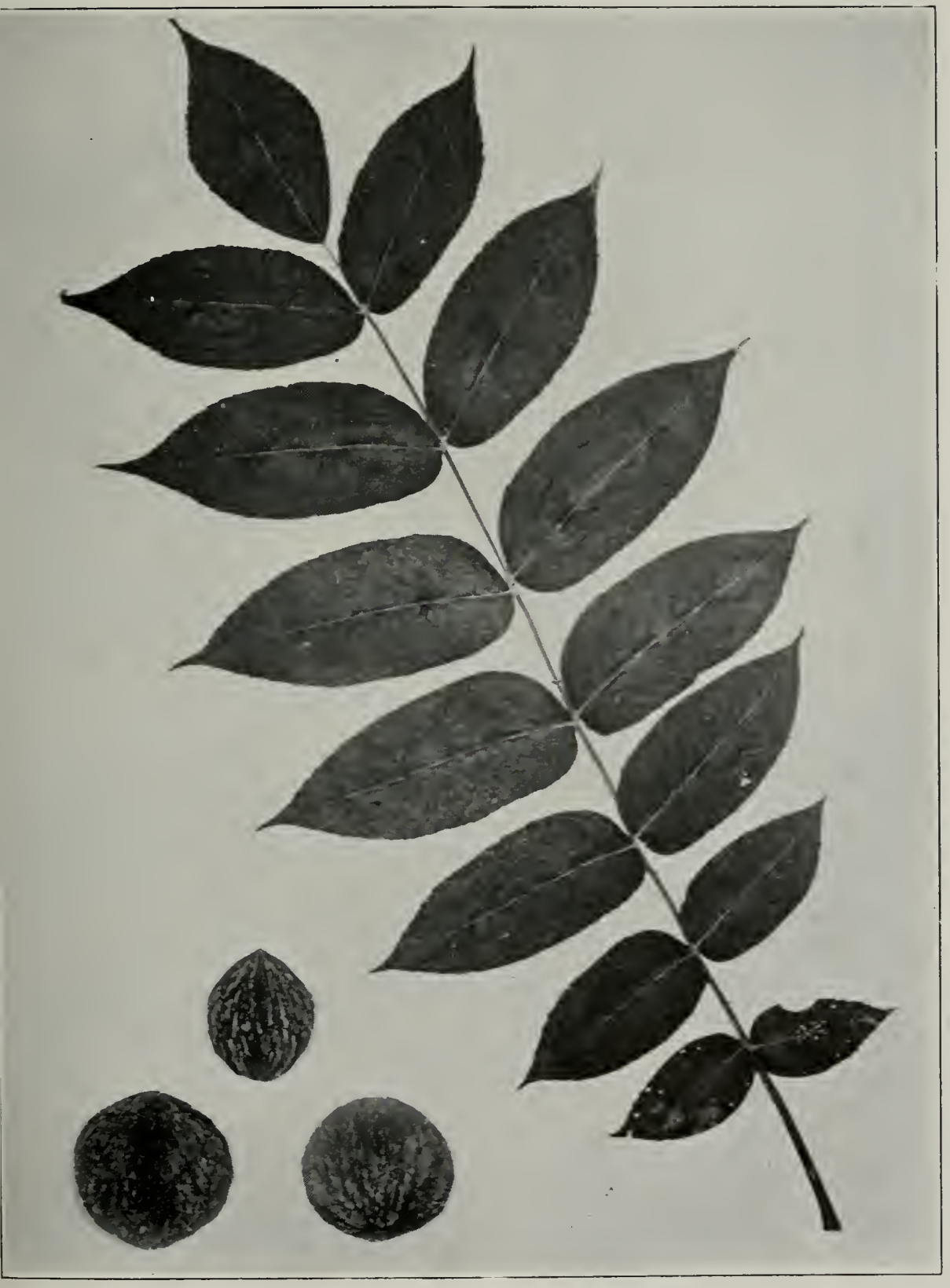

PLATE 15

JUGLANS NIGRA LINNAEUS

BLACK WALNUT 
ditions are particularly favorable. Usually it grows in company with sucli trees as the ashes and hickories, the Tulip Tree, Red Gum, Hackberry, and Honey Locust.

Uscs: The heavy, hard, coarse-grained, rich-brown wood of the Black Walnut, with its thin. pale sapwood, is not only strong and durable but also easily worked and capable of being highly and beautifully polishecl. As a consequence, the Black Walnut is one of the most valuable of our timber trees. It is in great demand in the manufacture of furniture, gunstocks, steering wheels, and automobile wheel spokes, and during the World War it was one of the woods used in airplane propellors. For wood carving, it always has been our finest native stock. At the present time, the greatest demand is for logs 16 inches or more in diameter, which can be sawed into reneer.

Trees that have been grown rapidly in small groups furnish vencer wood with striking figures, which is used extensively in the finishing of organs, pianos, and cabinet articles such as desks, as well as for panels in the interior decoration of houses. Between 50 and 60 years ago, the

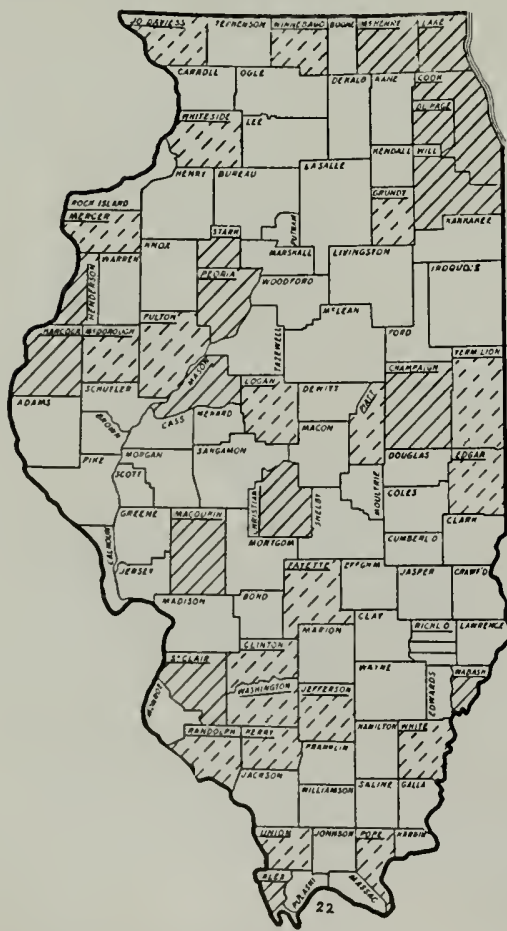

F16.22. Distribution of the Black Walnut. Black Walnut trees in the Wabash Valley, many of which were 125 feet high, with a clear bole 50 feet long and 15 feet around, were grubbed out, instead of being cut as they are now, in order to obtain lumber bearing the fantastic patterns formed by the contorted grain of the wood where the roots and trunk join. Native trees sometimes bear large deformities on their trunks, to which has been given the name "burl"; and these structures are so much in demand that they can be sold by the pound, for they furnish a pattern-grained veneer which, when carefully matched, produces decorative effects very similar to the expensive, imported Circassian walnut.

The consumption of walnut lumber in Illinois is very large, and the price which the logs will bring at the mill, given by Chapman and Miller ${ }^{1}$ as $\$ 85$ per thousand board feet in 1920 , is the highest of any Illinois

1 Nat. Hist. Surv. Eul. Vol. 15, p. 143. 1924 
woods. In 1925, Illinois sawmills produced $4.589,000$ board feet of walnut lumber. According to W. D. Brush", there were approximately i9 million board feet of walnut in our standing trees in 1920 , though Missouri had at the same time some $10 \%$ million board feet.

Although it is not suited to sandy, gravelly, poorly drained, or thin soils, the Black Walnut thrives on good, deep, well-drained, clayey or loamy soils. A plantation in Pope county, near Rose Bud, situated on a yellow silt-loam soil of poor quality, has not made a satisfactory growtl ; but in the rich lands along the Mississippi and in flat valleys of nnany secondary streams it grows well, requiring about 36 years to attain the minimum 10-inch sawlog size, while other trees uncler the sane conditions require from 42 to 86 years.

The bark and nut-husks of the Black TValnut yield a yellow dye: and the oily and nutritious nuts, collected and prized for their flavor, are used commercially in candies, cakes, and salads. It is also possible to secure nuts of more commercial value by "top-working," that is, grafting the tops of the native trees with the improved varieties (which nay also be planted), such as the Stabler, the Ohio, and the Thomas, which have more easily cracked nutshells and larger kernels.

\section{CARYA Nuttall The Hickories}

Family Juglandaceae

Moderate to large, deciduous trees, with large, alternate, compound leaves composed of an odd number of toothed leaflets disposed in pairs along the petiole, which is terminated by the odd leaflet. Stmminate and pistillate flowers separate: the former in slender catkins borne, 3 together, on the 1-year-old wood; the latter in 2 - to 10 -flowered spikes at the end of the new growth; both kinds on the same tree and usually on the same branchlets. Fruit a globose to oblong, thick and tough or thin and brittle, hard-shelled nut with 2 or 4 more or less evident seams, borne in a globose to pear-shaped, woody husk that splits into 4 parts.

Excepting a single species, which has a restricted range in China, Carya is confined to the eastern part of the North American Continent, where 17 species are known, 15 of which occur in the eastern part of the United States. Our present-day hickories are remnants of a much larger group, which was distributed during ancient geological times over much of North America, Europe, Northern Africa, and possibly Asia. Except in North America, the hicliories were exterminated during the Ice Age;

${ }^{2}$ L. S. Dept. Agric. Bul. 109. 1921. 
and some of the species, such as the White Hickory, the Water Hickory. and the Shaglark, now present in Illinois, are known, by fossils taken from ancient clay deposits and river terraces, to have lived in the Pleistocene epoch of the Quaternary Period.

There are, at the present time, 8 species of Carya in Illinois. As some of the species are variable. they have been divided into several varieties, which, if considered as distinct trees, raise the number of Illinois hickories to 16 . As the varieties are difficult to identify, only the species are given in the key.

\section{KEY TO THE ILLINOIS HICKORIES}

Buds with opposite scales; leaflets generally curved backwards; nut husks usually winged.

Leaflets 9 to 17; catkins short-stalked; nuts elongated, with sweet meat .................................. pecan p. 73

Leaflets fewer; catkins long-stalked; nuts globose to oval, with bitter meat.

Leaves 6 to 10 inches long; leaflets 5 to 9 ; nut husk 4 -winged in its upper half; nut gray................. cordiformis p. 77

Leaves 9 to 15 inches long; leaflets 7 to 13 ; nut husk 4 -winged from top to base; nut brown to black......... aquatica p. 80

Bud scales not in pairs; leaflets not recurved; nut husks usually wingless, meat sweet.

Terminal buds $1 / 2$ to 1 inch long; branchlets stout; twigs hairy; nut husks thick.

Leaflets 5; leaves 8 to 14 inches long; nut nearly white, compressed, more or less 4 -ridged.............. ovata p. 81

Leaflets usually 7 , but sometimes 5 or 9 .

Leaves 15-22 inches long; nuts yellow to reddish-brown, somewhat compressed, 4- or 6-ridged......... laciniosa p. 83

Leaves 8 -12 inches long; nuts reddish-brown, more or less compressed and 4 -ridged....................... alba p. 86

Terninal bucls not over $1 / 2$ inch long; branchlets slender; twigs smooth; nut husks thin.

Leaflets usually 5 ; leaves 8 to 12 inches long; nut obovate, compressed, not ridged; shell thick and hard....... . glabra p. 88

Leaflets usually 7 , rarely 5 .

Leaves 6-10 inches long; nut pale, ridged in the upper half; shell thin .................................. 90

Leaves 8-12 inches long; nut dark reddish-brown, 4-angled in the upper, or in both halves; shell thin, conspicuously reticulate-veined ................... Buckleyi $p$ 


\section{CARYA PECAN Ascherson \& Greene}

\section{Pecan}

The Pecan is a very tall tree, with stout, spreading branches which form a narrow crown in close stands but a broad, round-topped head in the open. The alternate, compound leaves, 12 to 20 inches long, are composed of from 8 to 16 falcate, toothed leaflets set in pairs close upon the petiole, which is capped by the odd leaflet. The soft-hairy or smooth leaflets are dark-green on the upper face, pale beneath, 4 to $S$ inches long by 1 to 3 inches wide, with narrow, yellow midribs and conspicuous veins. The staminate-flowered catkins, 3 to 5 inches long, grow in bundles of 3 from buds situated toward the tip of the 1-year-old wood, and the pistillate flowers develop in few to many flowered spikes at the end of the new growth. The ellipsoid, elongated nuts which are borne in $t$-winged and t-angled, dark-brown, yellow-scaley, brittle husks 1 to $2 \mathrm{I} / 2$ inches long by $1 / 2$ to 1 inch broad, are found in clusters of 3 to 11 at the twig ends. The branchlets, at first hairy and redtinted but later smooth, are marked by orange lenticels and bear pointed terminal buds about $1 / 2$ inch long. The compressed lateral buds, which are covered by clusters of bright-yellow

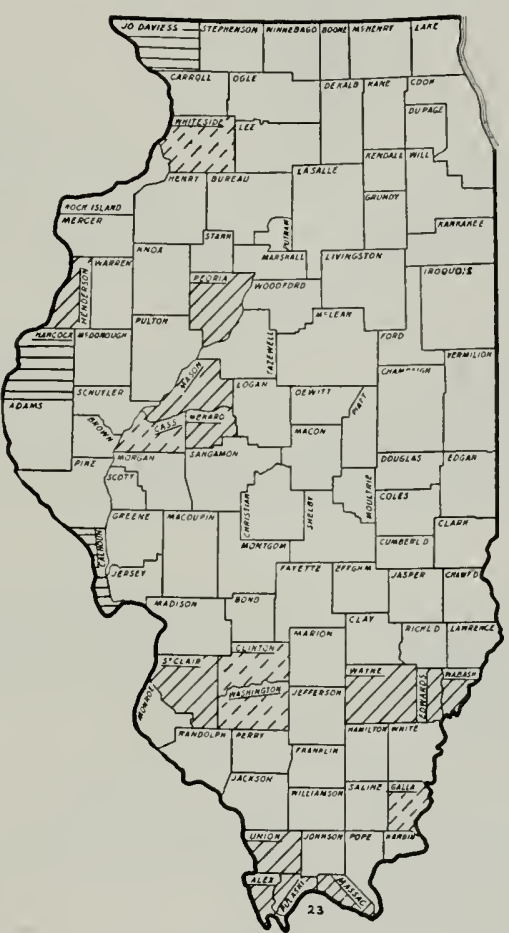

Fig. 23. Distribution of the Pecan. hairs, stand above large, lieystone-shaped leaf-scars. The massive trunk, often 6 or 9 feet in diameter above the buttressed base, is clothed by redtinted, brown bark deeply fissured into narrow, forked ridges. The tree often attains a height of over 100 feet.

Distribution: The Pecan is an inhabitant of low, rich ground throughout the Mississippi Valley, from Iowa and southern Indiana southward to Mississippi, Louisiana, and Texas. In Illinois, it extends northward along the Mississippi to Jo Daviess County and up the Illinois River into Peoria County, while in the southern part of the State it grows in 


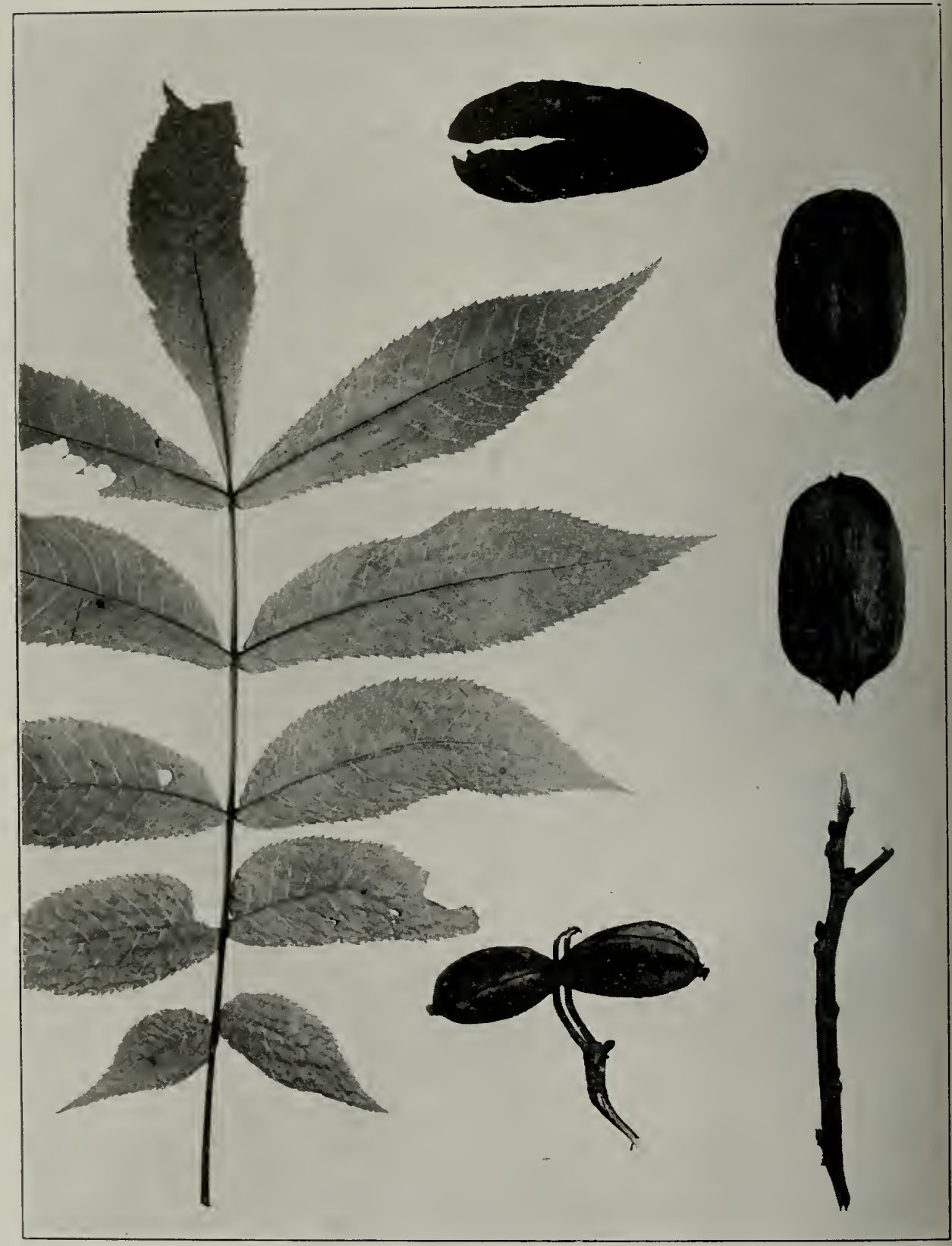

PLATE 16

CARYA PECAN Ascherson \& Greene

PECAN 
the bottomlands of the Mississippi, the Big Muddy, the Kaskaskia, the Ohio and the Wabash rivers, extending up the Wabash to Wabash County.

On the bottomlands of the Illinois River in Mason County, the Pecan is found in association with the Pin, Red, and Burr oaks, the River Birch, Black Walnut, Persinmon. Shagbark Hickory, Elm, Soft Maple. Honey Locust, Ash, and Cottonwood; and in the Kaskaskia bottomlands of Washington County, it grows with Black and White oaks, hickories, Soft Maple, Elm, Ash, Sassafras, River Birch, Sycamore, Black Walnut, Hackberry, and Honey Locust. In the bottomlands of Union County, Pecan is found in company with Soft Maple, Elm, Ash, Box Elder, willows, and Pin Oak.

According to Pepoon ${ }^{1}$, the Pecan grows just within the southern limit of Jo Daviess County ; and in the course of our forest survey, it was found also in the Mississippi bottoms of Whiteside County. In this part of the State, it is associated with Soft Maple, Elm, I'in Oak, Ash, and River Birch.

On the islands of the Illinois River, below Hardin, in Calloun County, the Pecan has been left standing, for the sake of its nuts, though the other hardwoods have been cut for clarcoal ; and on the bottoms of the Mississippi and Big Muddy, trees are allowed to stand in the fields and along the levees, for the same reason.

In the lower Wabash Valley, Ridgway observes that the Pecan "is the most symmetrical and majestic of all the trees, and the largest of the hickories." Ten trees measured by our survey party ranged from $;$. to 95 feet high, with trunk diameters, taken at breast height, of from 16 to 26 inches. The trunks of the trees are long and straight, occasionally extending clear for 80 or 90 feet to the first limb, and bearing a large head with a spread of 100 feet or more. Ridgway reports a very large Pecan 1:0 feet high with a trunk, clear for 90 feet, measuring 16 feet in circumference.

Uscs: The heavy, coarse-grained wood of the Pecan, the heart a light red-tinted brown and the thin sapwood a light brown, is hard but brittle and weak. It has little commercial value, being used mainly as fuel and occasionally for tool handles and for the wooden parts of farming implements. In southern Illinois, Pecan logs are cut into veneer, from which the rims of bushel baskets are made.

The tree's greatest value, however, lies in the nuts it produces. In the Wabash Valley, the average wild tree yields annually about $i 5$ pounds of nuts, which are sold at a price of $1 \%$ to 25 cents a pound. Although

1 Trans. Ill. St. Acad. Sci. Vol. 3, p. 155.1910. 
the tree grows well in northern Illinois, it can not be depended upon to produce an annual crop north of the 39th parallel, which corresponds closely to a line drawn from the mouth of the Illinois River eastward to Robinson. There are, besides the native tree, several excellent varieties such as the Niblack, Busseron, and Posey, which can be grown in our southern counties.

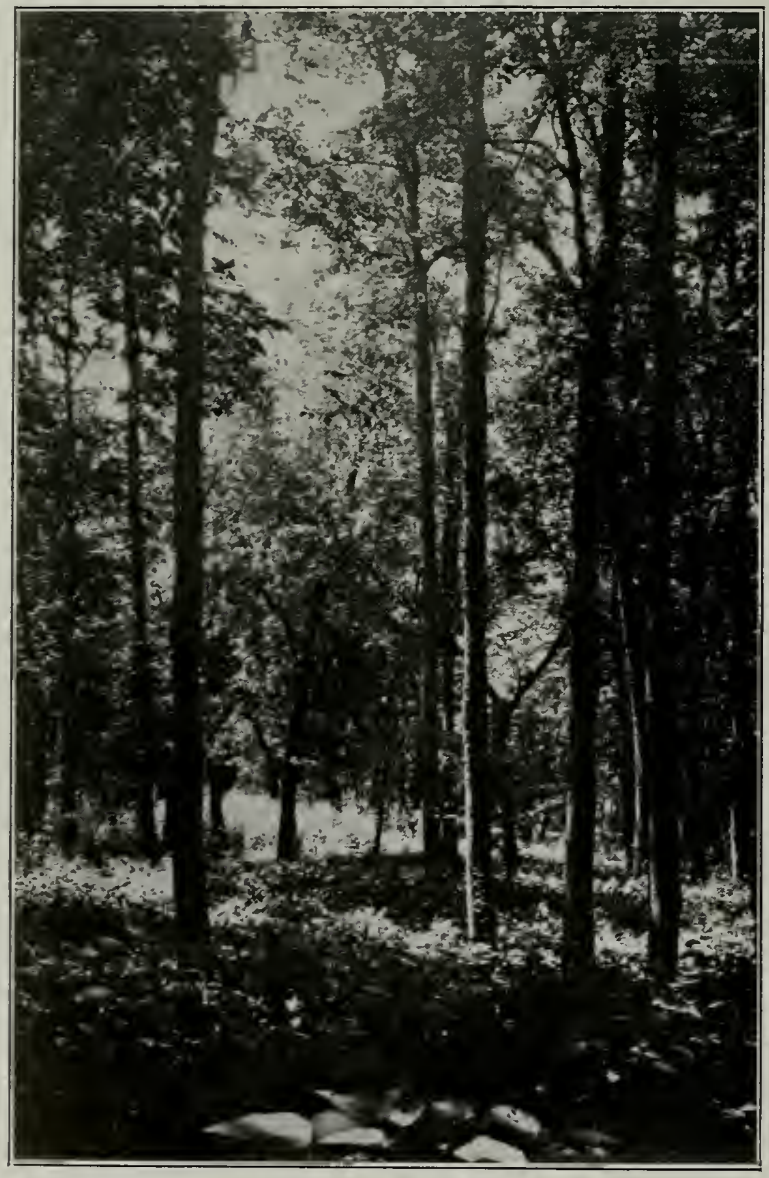

Fig. 24. Forest-grown Pecan ten miles north of Shawneetown. 
CARYA CORDIFORMIS K. KOCH

\section{Pignut Bitternut}

The Pignut is a moderate to large tree, with stout, ascending branches which form a rounded and broad-topped crown. The alternate, compound leaves, usually 6 to 10 inches long, consist of $i$ or !) firm, coarsely toothed leaflets, one set apically on the end and the others sessile in pairs along the petiole. The leaflets, which are 4 to 6 inches long by $3 / 4$ to $1 \frac{1 / 4}{4}$ inches wide, are dark-green and smooth on top but paler and hairy, at least on the miclrib, beneath. The staminate catkins, which are 3 to 4 inches long, are borne 3 together on a long stalk on the 1-year-old growth; and the pistillate flowers are found, 1 or 2 together, at the end of the new growth. The globose to oblong husk of the nut, $3 / 4$ to $1 \frac{1}{2}$ inches long, is thin and a little hairy and bears 4 wings, which extend from the tip about to the middle: and the oval to oblong, reddish-gray or brown nut, which is marked between and along the seams with dark lines, has a thin, brittle shell, within which is a brightbrown, very bitter seed. The glossy, rather slender twigs, which are often hairy and covered with yellow glands at the tip, become at length light-gray and contain angular, brown piths.

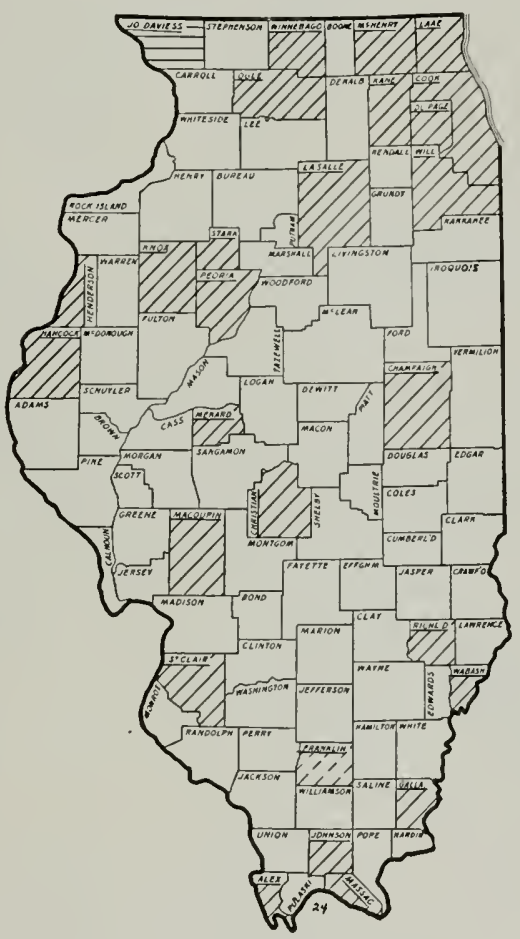

FIG. 25. Distribution of the Pignut.

The yellowish, blunt terminal bud, $1 / 3$ to $3 / 4$ inch long, is inclosed by 4 paired scales ; and the smaller lateral buds, $1 / 8$ to $3 / 4$ inch long, stand superposed above the large, shield-shaped leaf-scars, which are marked by 3 groups of bundle-traces. The trunk, which is covered by thin, light-gray bark with shallow fissures and narrow, flaked ridges, attains a diameter of 1 to $2 \mathrm{I} / 2$ feet; and the tree becomes 40 to 35 , and exceptionally 100 , feet high.

Distribution: The Pignut, a tree of wet, low stream banks and swamps, ranges from Maine westward through Canada into Minnesota 


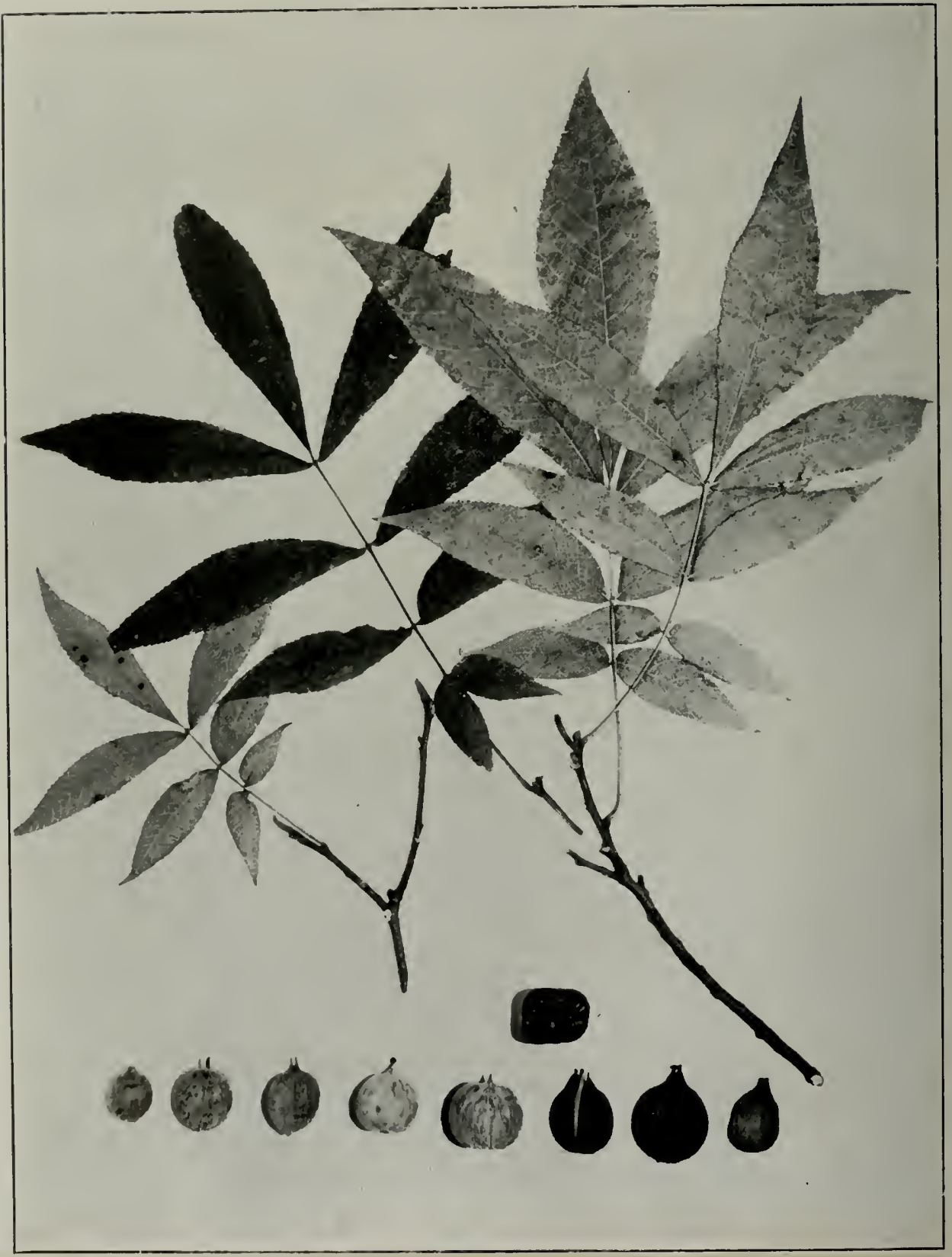

PLATE 17

CARYA CORDIFORMIS K. Koch 


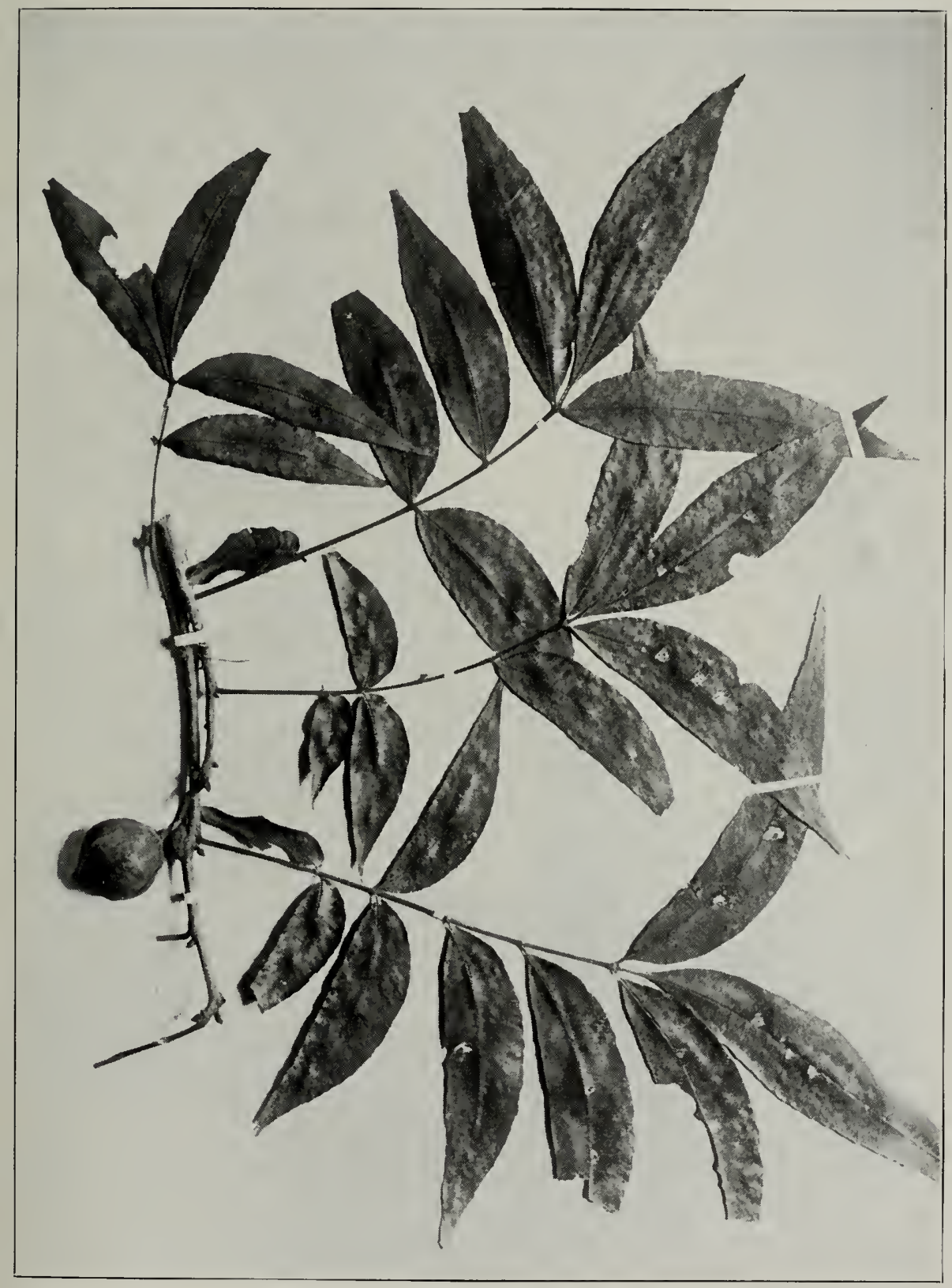

PLATE 18

CARYA AQUATICA Nuttall

WATER HICKORY 
ancl southward into Florida and Texas. It is to be found throughout Illinois, growing along streams and on rich bottomlands, together with elm, the White, Red, and I'in oaks, the White Ash, and the Shagbark and Big Shellbark hickories. In Wabash County, it is associated with the Shagbark and the Pignut Hickory. Three trees between 93 and 106 years old, which stand on a deep, gray, silt-loam soil near Benton, in Franklin County, are from $6+$ to 83 feet high and 16 to 22 inches in diameter.

Uses: The strong, close-grained wood of the Pignut, dark-brown in the heart and pale or nearly white in the sapwood, is heavy, tough, and elastic. It is used in the manufacture of wagon and automobile wheels, for wagon-tongues, whipple-trees, and tool handles, as well as for hoops and for fuel. The tree, which is a valuable timber species, furnishes a part of the hickory lumber of commerce. In Illinois, its commercial range is co-extensive with its botanical range, except for a small region, which includes the southern tip of the State.

\section{CARYA AQUATICA NutTall}

\section{Water Hickory}

The Water Hickory is a moderately large tree, with a narrow head of slender, up-tilted branches. Its alternate, compound leaves, usually from 9 to 15 inches long, are made up of from 7 to 13 long-pointed, falcate leaflets 3 to 5 inches long by $1 / 2$ to $1 \frac{1}{2}$ inches wide, one standing at the end, and the others, sessile or somewhat stalked, in pairs along the slender, dark-red, hairy petioles. These leaflets are thin and dark-green above but brownish beneath. The staminate catkins hang in 3's, from a definite stalk, toward the end of the one-year-old growth; and the pistillate flowers are in spikes at the tip of the new growth. The conspicuously $4-$ winged husk, $1 \frac{1}{2}$ inches long by 1 to $1 \frac{1}{4}$ inches wide, is dark-brown, with a thick sprinkle of bright yellow scales. Within it is the 4-angled and 4-ribbed, dark reddish-brown nut, the thin shell of which is very irregularly wrinkled lengthwise. The dark-brown seed is very bitter. The slender twigs, at first brownish or gray and woolly but later gray and usually smooth, are marked by numerous lenticels. The terminal bud, which often is hairy, measures $1 / 8$ to $1 / 4$ inch in length; and the sharply pointed, reddish-brown lateral buds stand above small, oval leaf-scars. The trunk, which rarely attains a diameter of 2 feet, is clothed in thin, red-tinted bark which separates into long, loose scales. The tree occasionally attains a height of 80 , or even 100 , feet.

Distribution: The Water Hickory, an inhabitant of swamps subject 
to intundation by rivers, ranges from Virginia south to Florida, west to Texas, and north again along the Mississippi to southern Illinois. E. J. Palmer, of the Arnold Arboretum, has collected specimens in Massac County, and C. J. Telford, of our staff, has found the tree in Pulaski County along the Cache River, where it grows with the Pumplin Ash, Cow Oak, Hackberry, Sycamore, and Red Gum.

Uses: The heavy, close-grained wood of the Water Hickory, brown in the heartwood and nearly white in the sapwood, is strong but rather brittle. Other than for fencing and fuel, it has few uses; and its rarity in Illinois places it among our non-commercial species.

\section{CARYA OVATA K. Koch}

\section{Shellbark Hickory Shagbark Hickory}

The Shagbark Hickory is a moderately large tree, with a high and narrow crown of long, stout, ascending limbs. Its leaves, 8 to 14 inches long, are made up of 5 or 7 finely toothed leaflets sessile in pairs along the stout, grooved petiole, with the odd leaflet short-stalked and terminal. The leaflets, which are sharp-pointed and ciliate on the margins, measure 5 to $\because$ by 2 to 3 inches. They are thin but firm, dark-green and smooth above, and pale and often hairy beneath. The staminate catkins, in groups of 3 on long stalks, are 4 or j inches long, and the 2 - to 5 -flowered pistillate spikes cap the new growth. The nearly globose, dark reddishbrown nut husk, 1 to $2 \mathrm{I} / 2$ inches long, holds a variously shaped, pale to nearly white, thin-shelled, more or less 4ridged nut with an aromatic, sweet seed. The stout, reddish-brown or grayish twigs bear dark-brown, hairy terminal buds $\mathrm{T} / 2$ to $3 / 4$ inch long. The white-woolly lateral buds, $1 / 3$ to $1 / 2$ inch long, stand above large, shield-

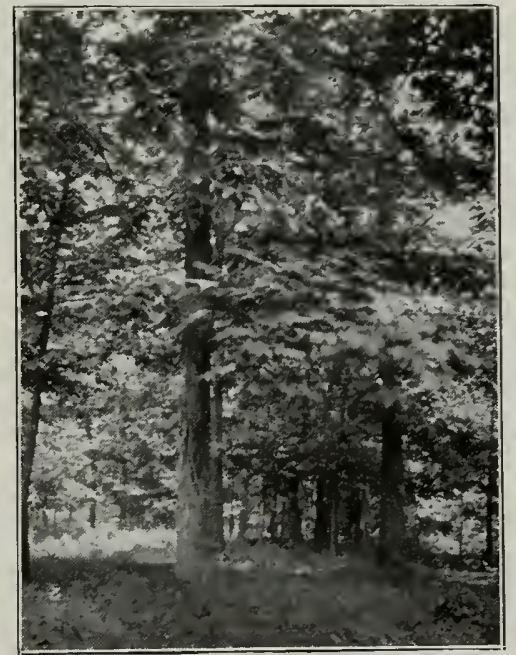

Fig. 26. Shagbark in the oakhickory forest near West Frankfort. shaped to oblong leaf-scars. The trunk, which is usually 2 to 3 feet in diameter, is covered by light-gray bark which separates into rough plates aften a foot long and 6 or 8 inches wide, giving the "shaggy" appearance. 


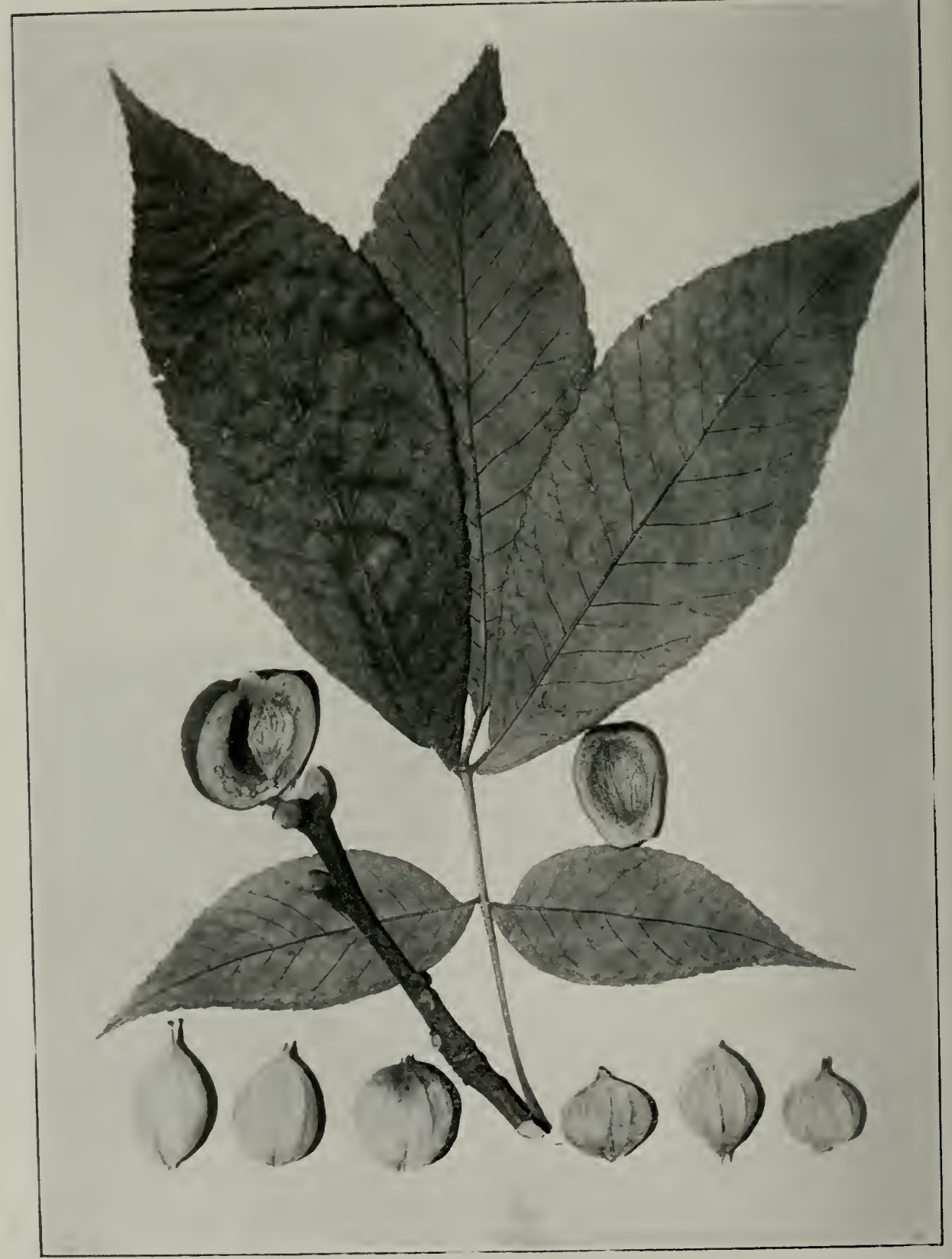

PLATE 19

CARYA OVATA K. KOCII 
Distribution: The Shagbark Hickory, found in rich, deep soil on low hills and near streams and swamps, ranges from Maine to Minnesota and south to Florida and Texas. It grows in suitable situations throughout the length and breadth of Ilinois and is one of the chief trees of our oak-hickory forests, its most common associates being the White and Black oaks. In LaSalle and other nortliern counties, the Shagbark grows with White. Red, and Burr oals, Eim, Maple, and other trees: in Chanpaign County it is found with IIard Maple, Buckeye, other hickories, Bass Wood, and Elm: and in Franklin County it is accompanied by the Post. White, and Burr oaks, Persimmon, Ash, and the Black and Sweet gums.

Uses: The strong, very hard, and heary wood of the Shagbark, light-brown in the heart and nearly white in the sapwood, is tough, elastic, and close-grained. It is used in the manufacture of wagon and automobile wheels, farm implements, axe helves, and tool handles. Small trees. once used for barrel hoops, are now used to make rustic furniture. The wood has a high fuel value and is used by packing plants to prepare smoked meats.

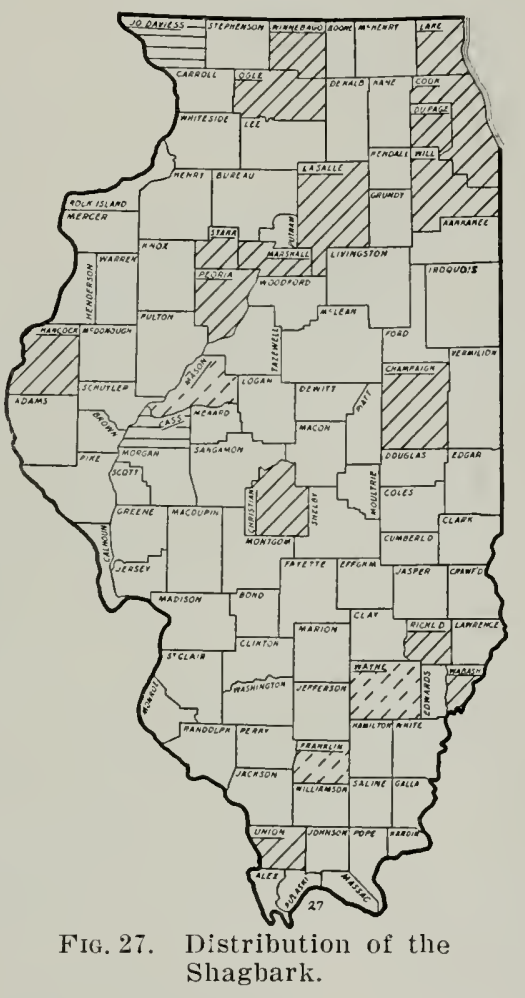

\section{CARYA LACINIOSA SCHNEIDER}

\section{Big Shellbark King Nut}

The King Nut is a large tree, with short, spreading branches that form a narrow, oblong crown. The large, compound leaves, 15 to 22 inches long, are made up of 5 , istually $:$, or 9 , sharply pointed and finely tootherl leaflets + to 9 inches long by 3 to 5 inches wide, which are sessile and in pairs along the stout, somewhat flattened, and grooved petiole. The odd leaflet is narrowed into a short stalk. The leaflets are dark-green and lustrous above and pale and soft-hairy beneath. The staminate catkins, which are 5 to 8 inches long, hang in clusters of 3 from rather short, pen- 


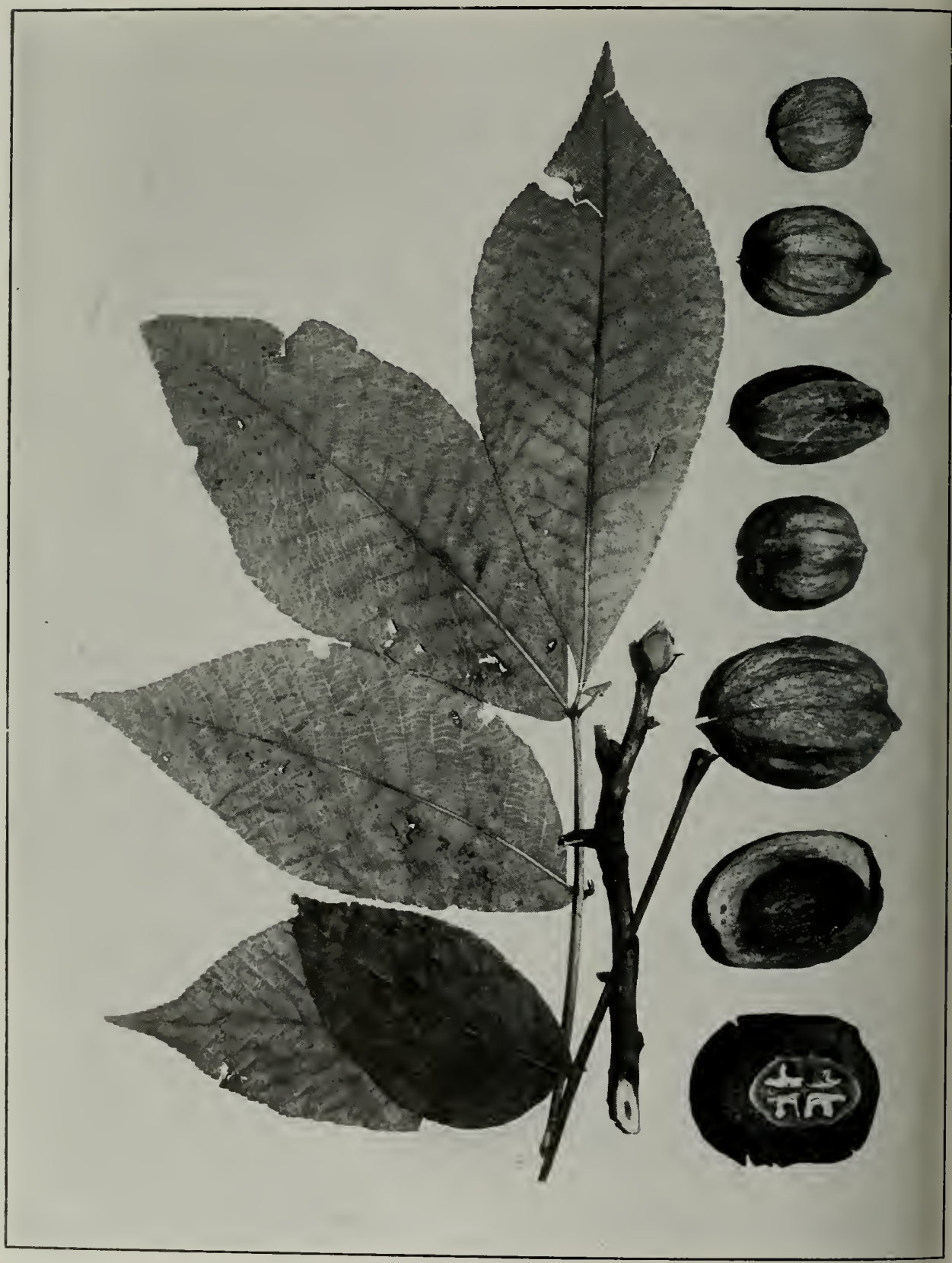

PLATE 20

CARYA LACINIOSA SchneIder BIG SHELLBARK HiCKORY 
dulous stalks, and the pistillate flowers form ? - to i-Howered spikelets at the tip of the new growth. The more or less globose. woody nut-husks. which are roughened by orange-colored lenticels, are $11 / 4$ to $21 / 2$ inches in diameter and light-orange or dark chestnut-brown. The prominently 4to 6-ridged, light-yellow to reddishbrown nuts, $11 / 4$ to $? 1 / 2$ inches in cliameter, have hard. bony shells and chestnut-brown. sweet seeds. The stout, somewhat hairy twigs are roughened by orange lenticels and bear somewhat triangular leaf-scars. above whose indented upper margins stand the small lateral buds. The blunt, dark-brown terminal bud is sometimes 1 inch long. The trunk. which attains a diameter of ? to 3 feet. bears a light-gray. shaggy bark. The height of the tree. usually from 50 to 90 feet. is occasionally 1:01) ieet.

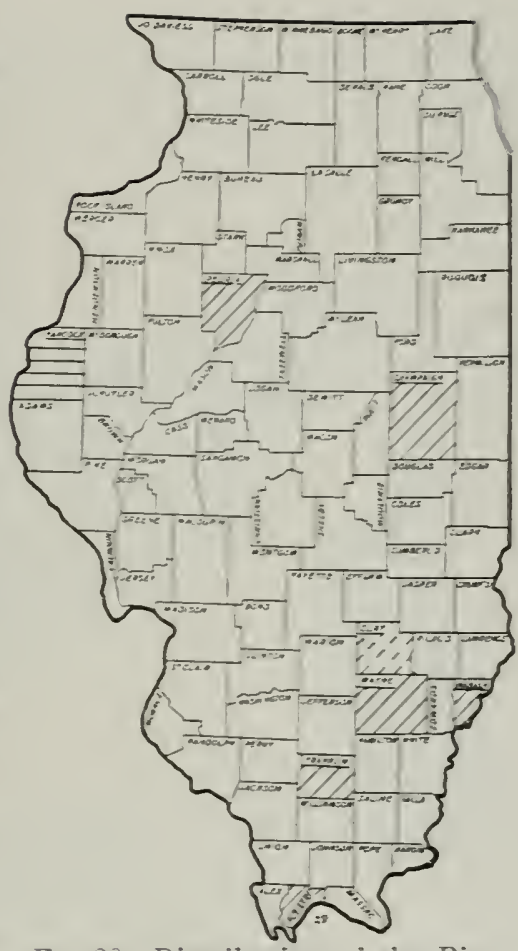

FIG. 2S. Distribution of the Big Shellbark.

Distribution: The King Nut, usually a tree of rich bottomlands subject to the spring overflow of rivers. ranges from New Fork and Ontario westward into Iowa and Nebraska and southward in Louisiana. In Iilinois. it is commonest in the south. Eut cccurs as far north as Peoria County. It does not often form pure stands, but grows with other trees. anong which are ordinariy the Elm, the White Ash, the White. Cow. and Overcup oahs and the Shagbark. In the Skillet Fork bottoms of Wayne County however, the forestry survey discovered it in nearly pure stands, associated only with some Pin Oak. Soit Maple. Elm. and Shagbark. And in Logan County, it grow = with Pin Oak, Sott Maple. and Ash.

Lses: The very hard, close-grained wood of the King Nut. which is not distinguished in the lumber trade from that of the Shagbark. is very Hexib'e. heary. and dark-brown, with a rather thin. whitened sapwood. Though not of more than medium strength. it is equal in toughness to other species. and is used for the same purposes as the wood of other hickories. 
The nuts, which are larger than Shagbark nuts, though not so plcasantly flavored, are sold frequently on the market. Though hard to crack, they can be wetted and then dricd by heat-a process which renders them easy to crack.

\section{CARYA ALBA K. KoCH}

\section{Hickory}

The tree commonly called Hickory, but known also as White Hickory and Mockernut, is of moderate size, with either a narrow, oblong crown of upright, rigid branches or a broad, round-topped crown of graceful, somewhat drooping branches. Its alternate, compound leaves,

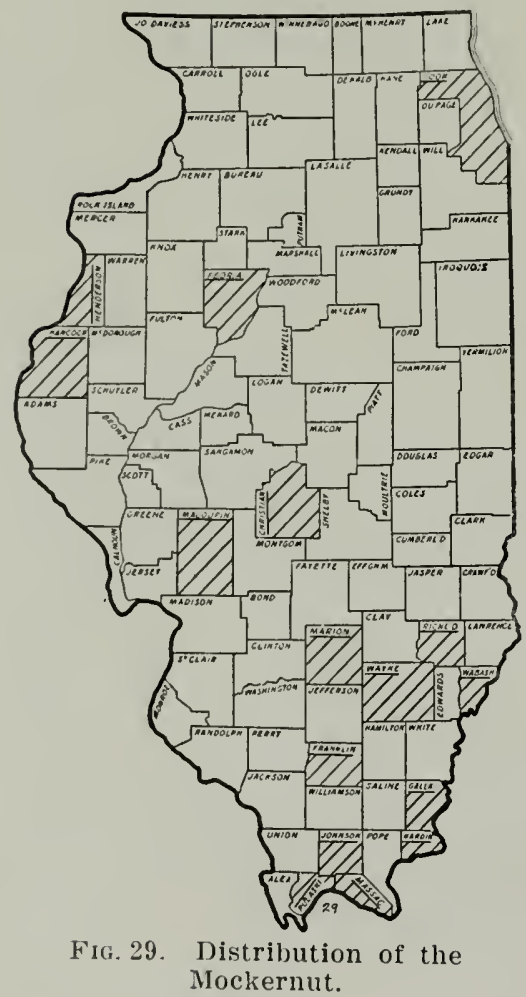
8 to 12 inches long, have 5 or $\%$, sometimes 9, sharply pointed, toothed, and lustrous leaflets sessile in pairs, the odd one being at the end of the rather stout, hairy, flattened, and grooved petiole. The staminate catlins hang in 3's from rather short, hairy stalks, and the pistillate flowers stand in 2to 5-flowered spikes. The ellipsoid to obovate, reddish-brown nut-hus!s, $1 \mathrm{I} / 2$ to 2 inches long and about $1 / 8$ of an inch thick, holds the more or less globose and more or less 4-ridged, light reddish-brown, thick- and hard-shelled nut. The dark-brown seed is small and sweet. The very stout, hairy twigs, gray in the second season, bear large, 3-lobed leaf-scars, above which stand the dark-brown lateral buds. The reddish-brown or yellowish trunk, which attains a diameter of 2 or 3 feet. is clothed with rather thin, gray bark with shallow, irregular fissures. The tree is usually 50 to 80 feet high, but may attain 100 feet.

Distribution: The Hickory ranges from Massachusetts to Iowa, Florida, and Texas, finding suitable situations on dry slopes and ridges more often than on bottomlands. In Illinois, it occurs throughout the State, but is most abundant toward the south. It rarely occurs in pure stands, and it is found usually in the oak-hickory forests. 
Lscs: The hard, close-grained wood of the White Hickory, a rich dark-brown at the heart and nearly white in the thick sapwood, is strong, heary. and elastic. The toughness of White Hickory is almost proverbial. This tree furnishes the best grade of commercial hickoiy stock, which is put to the same uses as other hickory woods. It ranks especially high as fuel.

\section{CARYA GLABRA SWEET}

\section{Pignut}

The Pignut, or Pignut Hickory, is a moderate to large tree, with a narrow crown of short, spreading branches, the lowest of which have a tendency to droop. The alternate, compound leaves, usually from 8 to 12 inches long, have 5 , or less often $\%$, sharp-pointed and sharp-toothed,

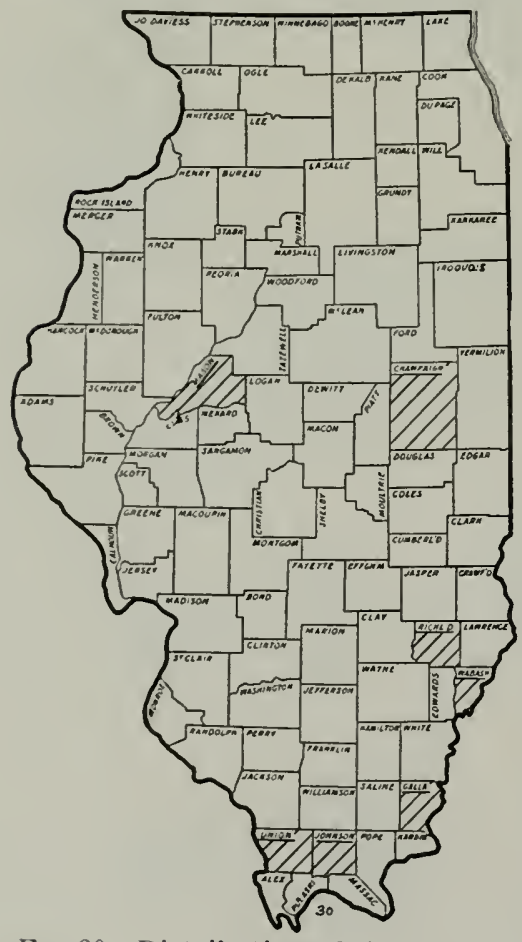

FiG. 30. Distribution of the Pignut Hickory. dark-green, smooth leaflets 3 to 8 inches long by 1 to $2 \mathrm{I} / 2$ inches wide, which are arranged in sessile pairs along the slender, slightly grooved petiole. The terminal leaflet sometimes has a short stalk. The slender staminate catkins, 3 to 8 inches long, hang in groups of 3 from long, drooping stalks, and the pistillate flowers are in few-flowered spilies. The globose to pear-shaped, reddish-brown nut-husk, about 1 inch long and not usually over $1 / 8$ inch thick, contains a brownish-white nut with a hard and thick shel. The seet is small and swee:- The slender, reddish branchlets are marked by pale lenticels and large, triangular leaf scars, above which stand pointed, light-brown buds $1 / 3$ to $1 / 2$ inch long. The lustrous, reddish-brown terminal bud, usually a little larger than the lateral buds, is covered by rather closely fitted scales. The trunk attains a diameter of 2 or $2 \mathrm{r} / 2$ feet and is covered by gray, fissured bark. The height of the tree is from 60 to 90 feet, or rarely 120 feet.

Distribution: The Pignut Hickory, a tree of hillsides and dry ridges, ranges from Vermont to Delaware and westward into southern Illinois, 


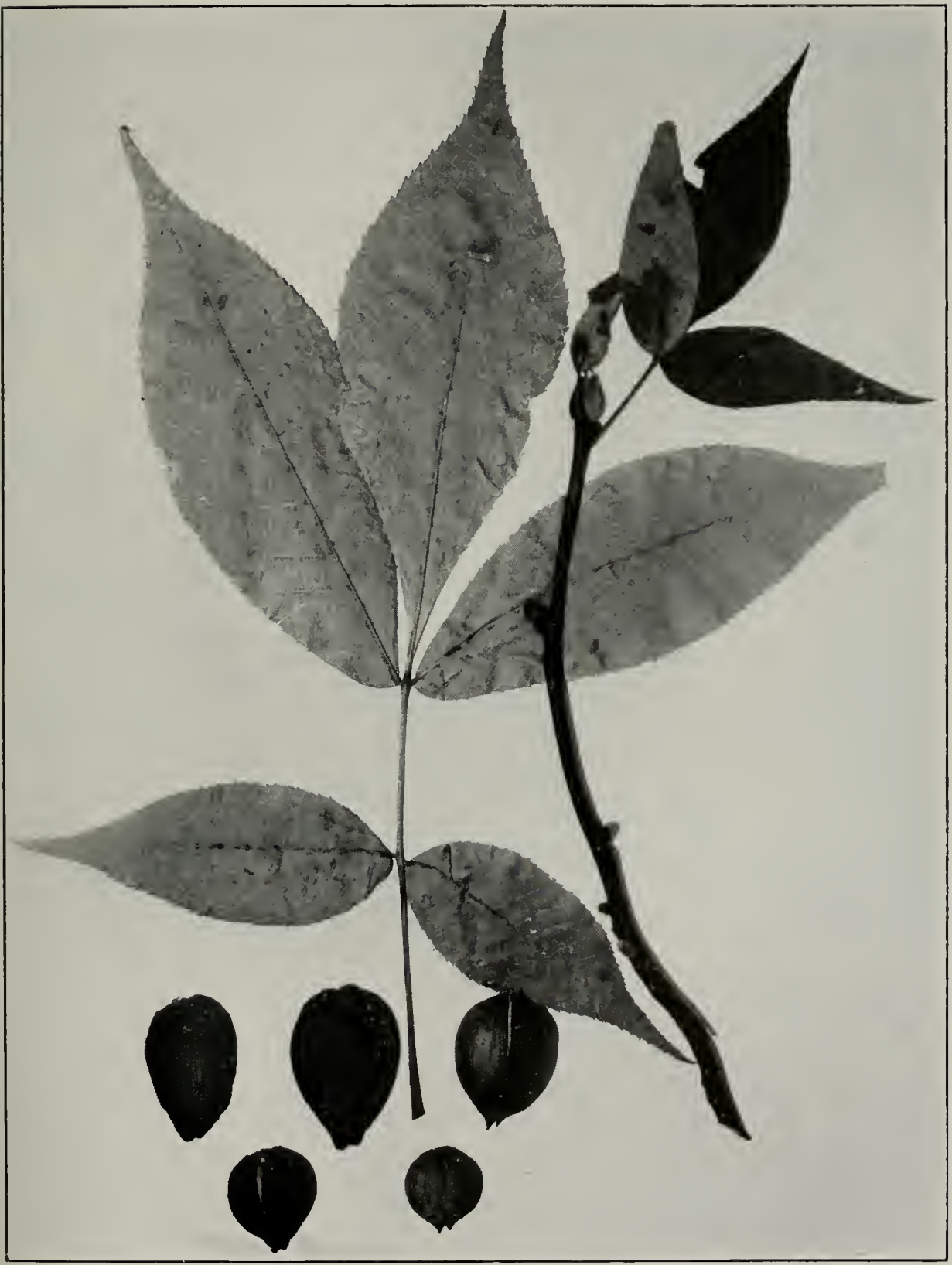

PLATE 22

CARYA GLABRA SwEET

PIGNUT 
where it is one of the trees of the oak-hickory forest on the uplands. The tree secuns to be nuore alumdant in sonthern than in central Illinois.

Lses: The hard, close-grained wood of the Pignut Hickory, strong. tough, and elastic, furnishes a valuable grade of hickory timber. which is used, like other hickory woods, for tool handles, farming imjlements, and the like.

\section{CARYA OVALIS SARGENT}

\section{Oval Pignut}

This Pignut is a tree of considerable height, with small, spreading branches which form a nurrow head. The alternate, compound leaves, usually 6 to 10 inches long, have $;$, less often $;$, longr-pointed, finely toothed leaflets arranged on the sides of the slender, smooth petioles in

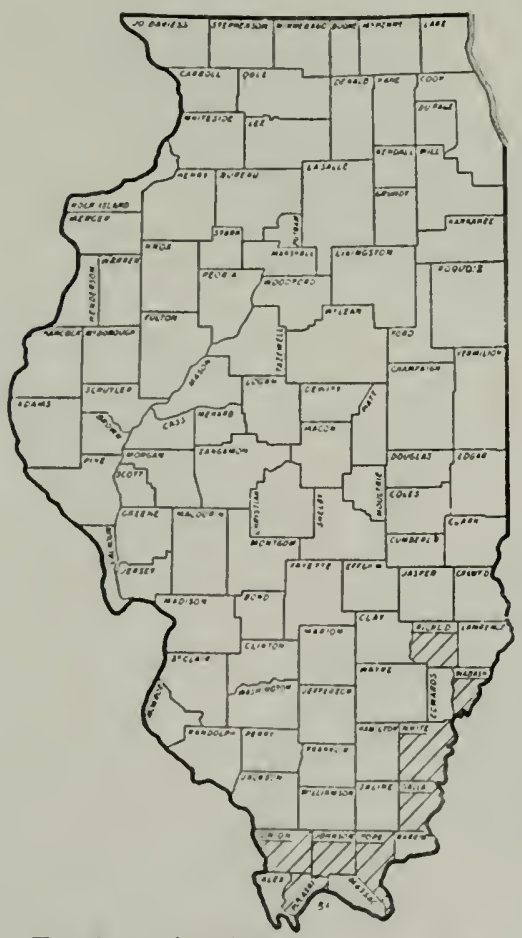

Fic. 31. Distribution of the Oval Pignut. sessile pairs. The odd leaflet, which stands at the end of the petiole. is 6 or ? inches long by $1 \mathrm{~J} / 2$ to 2 inches wide, with a $1 / 4^{-}$to $1 / 2$-inch stalk. The staminate catkins, 6 or $\tau$ incines long. hang in 3's from drooping, hairy stalks, and the pistillate spikes are 1or 2 -flowered. The ellipsoid nut-husk, 1 to $1 \frac{1}{4}$ inches long, is finely hairy and very thin, and it incloses a pale, thin-sleelled nut with a $t$-angled top. The seed is small and sweet. The slender, lustrous branchlets are redbrown and marked with pale lenticels. The red-brown, Justrons, hairless terminal bud is often $1 / 2$ inch long-twice the size of the lateral buds. The trunk. only occasionally 3 feet in diameter, is covered by gray, slightly ridged bark. which separates freely into small plate-like scales. The tree is sometimes 100 feet high.

Distribution: This Pignut, a tree of hillsides and rich woods, ranges iron New York to Iowa and southward to Georgia and Alabama. In Illinois, it is confined to the southern third of the Stite. There are three varieties of the species, each of which occurs in the State; but the distribution of all is shown without distinction on the map. 


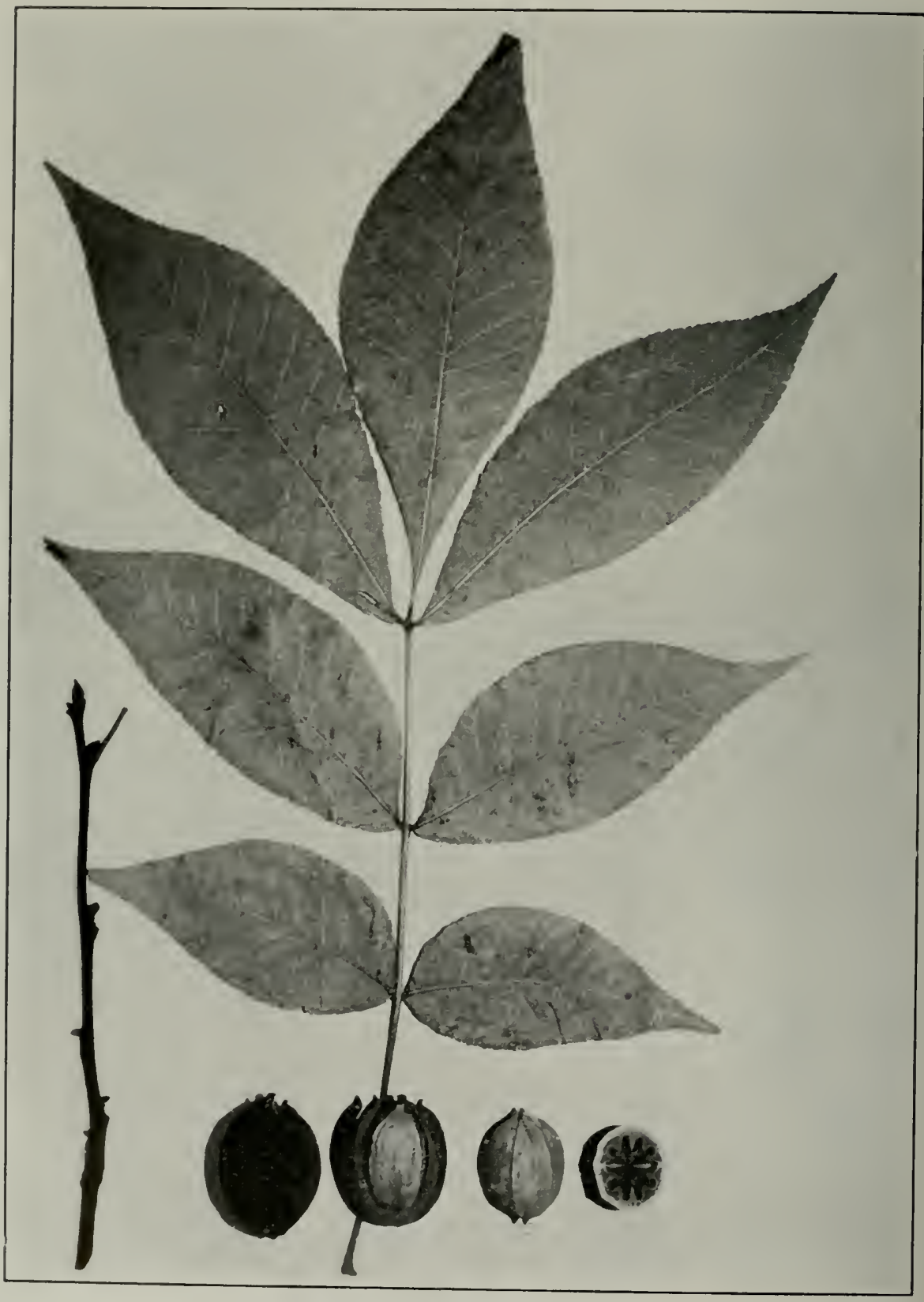

PLATE 24

CARYA PLCKLEYi DURAND

BUCKLEY'S HICKORY 
Uscs: The wood of this Pignut has the usual characteristics of hickory and is serviceable for tool handles and agricultural implements. The tree is not common in Illinois and has little if any commercial significance.

\section{CARYA BUCKLEYI DURAND}

\section{Buckley's Hickory}

Buckley's Hickory is a small tree, with spreading and contorted branches which form a narrow crown. The leaves, which are $\delta$ to 12 inches long, have $\%$ or, less often, 5 sharply pointed, blunt-toothed leaflets sessile on the rusty-haired, slender petioles. The staminate catkins are 2 to 3 inches long. and the pistillate spikes have 1 or 2 flowers. The nearly globose, finely hairy nut-husk, $1 \frac{1 / 4}{4}$ to $13 / 4$ inches long, is thin and contains a dark-reddish, 4-angled nut with a thin shell marked by conspicuous, pale veins. The slender, red-brown branchlets are capped by longpointed terminal buds $2 / 5$ to $1 / 2$ inch long and 2 or 3 times as large as the flattened lateral buds. The trunk, usually 1 to 2 feet in diameter, bears thick, deeply furrowed, nearly black bark. The usual height of the tree is from 30 to 45 feet.

Distribution: Buckley's Hickory, a tree of the sandy uplands to the southwest, is known in Illinois by two of its varieties, arkansana Sargent having been collected by E. J. Palmer in Randolph and Gallatin counties. and villosa Sargent having been found by Ridgway in Richland County and by Palmer in Gallatin County.

\section{CARPINUS LINNAEUS Hornbeam}

\section{Family Betulaceae}

Small, deciduous trees, with alternate, broad-bladed, simple leaves. Flowers in catkins; the staminate catkins arising from buds near the end of the year-old growth; the pistillate catlins terminal on the new growth. Fruit a longitudinally ribbed nut, which separates in the autumn from a leaf-like, 3-lobed envelope. The fluted trunks have smooth, close, gray bark and hard, close-grained wood. The zig-zag twigs are slender, with small, roundish, pale pith, and bear buds covered by about twelve 4-ranked scales. There is no terminal bud.

About 15 species of Carpinus are recognized, all of them in the Northern Hemisphere. The range of the genus includes southeastern North Anerica, much of Europe, and southeastern Asia. There is, however, only one species native to North America. 


\section{CARPINUS CAROLINIANA WALTER}

\section{Hornbeam Blue Beech}

The Hombeam is a bushy tree, with slender, slightly zig-zag, spreading branches that droop near the ends. The alternate, long-pointed, double-toothed leaves, 2 to 4 inches long by 1 to $13 / 4$ inches wide, the blarles of which often are falcate, are dull blue-green above and light-

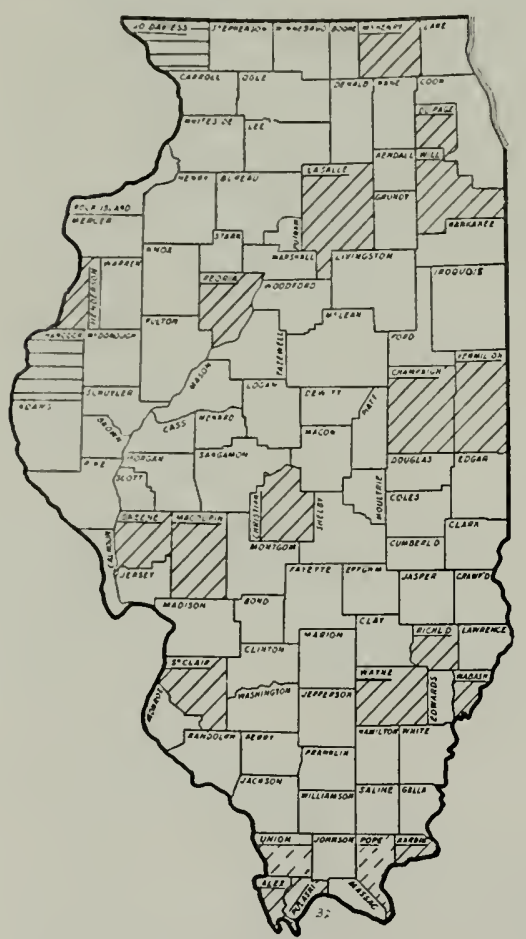

F1g. 32. Distribution of the Hornbeam. yellow beneath. The staninate catkins, about $1 \frac{1}{2}$ inches long, have ovate, pointed scales which are green below the middle and red above; and the nearly erect pistillate catkins, $1 / 2$ to $3 / 4$ inch long, have hairy, green scales. The broadly oval, pointed nuts, about $1 / 3$ inch long, are crowded on slender twigs 5 to 6 inches long and hidden within their envelopes, which are 1 to $1 \mathrm{I} / 2$ inches long by nearly 1 inch wide. The pointed buds, about $1 / 8$ inch long, are covered by chestnut-brown scales. The trunk, occasionally 2 feet in diameter, is fluted and covered by thin, gray bark sometimes marked by brownish, horizontal bands. The tree is seldom 40 feet high.

Distribution: "The Hornbean inhabits rich, moist, wooded soils from Nova Scotia and Florida westward to Minnesota and Texas. In Illinois, it grows throughout the length and breadth of the State in moist woods.

Uscs: The hard, close-grained wood of the Blue Beech, light brown in the heart and white in the thick sapwood, is strong and very heavy. Although it may be used for levers, tool handles, mallets, and other small manufactured articles, it has little commercial value.

\section{OSTRYA SCOPOLI Hop Hornbeam \\ Family Betulaceae}

Snall to medium-sized, deciduous trees, with alternate, broad-bladed, simple leaves. The flowers in catkins; staminate catkins long and clusterect, irom lateral buds near the end of the 1-year-old growth; pistillate 


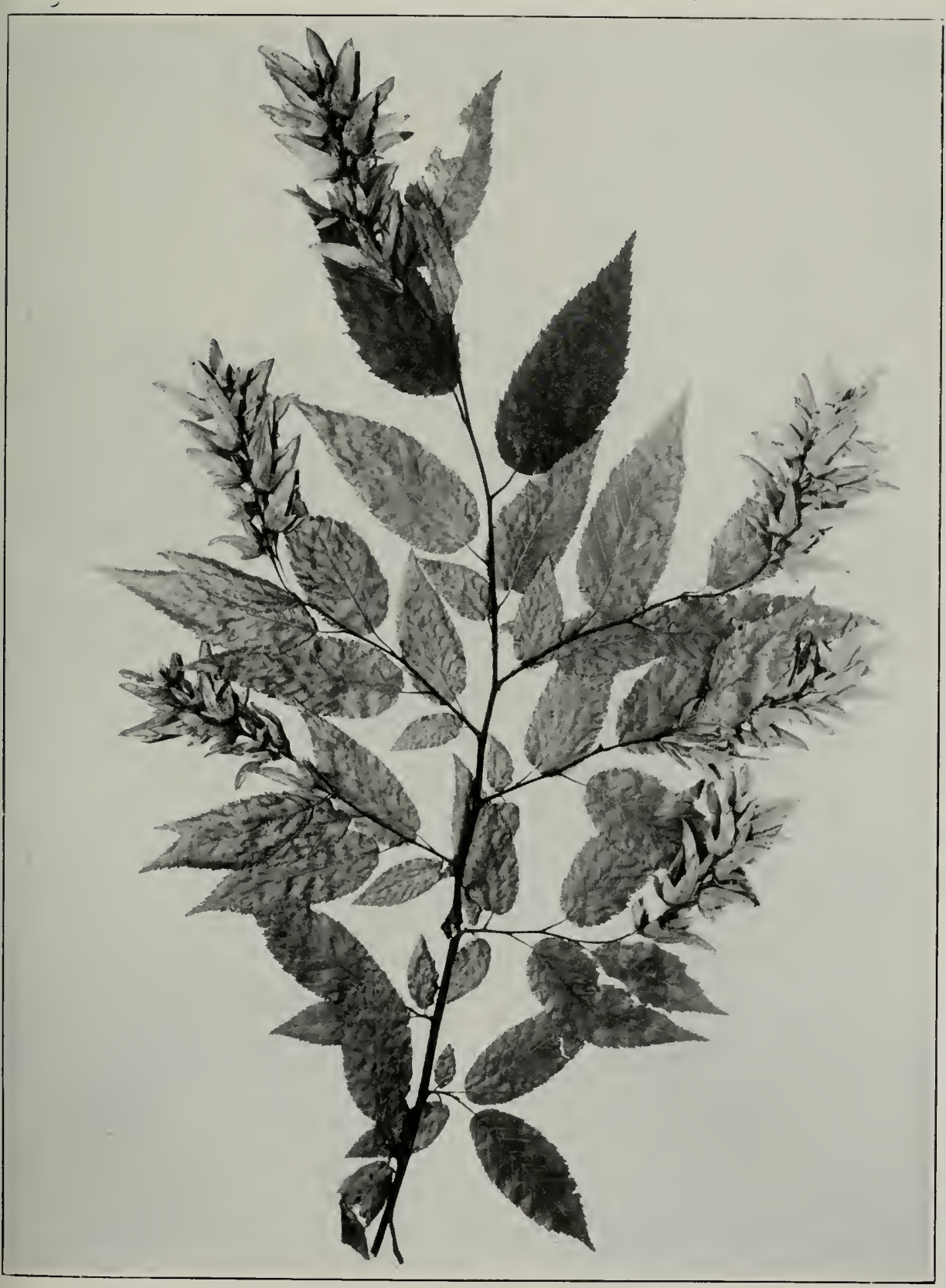

PLATE 25

CARPINUS CAROLINIANA WALtER

HORNBEAM 
catkins terminal on the new growth. Fruit an obscurely ribbed nut inclosed by the much-enlarged, papery scales of the catkins. The slender, zig-zag twigs are round and have small, round, pale pith. There is no terminal bud, but the lateral buds are inclosed in about (i spirally arranged scales. The trunk is covered with scaly bark.

This grenus, which has four known species, is widely distributed in eastern North America and southern Europe and is found also in Japan. Two species occur in the United States, one of them limited to the high altitules of the southern Rocky Mountains.

\section{OSTRYA VIRGINIANA K. KoCH}

\section{Hop Hornbeam Ironwood}

The Hop Hornbeam is a small tree, with an open, round-topped crown of slender branches. The alternate, finely double-toothed, sharp-pointed leaves, 3 to 5 inches long by $1 \frac{1}{2}$ to 2 inches broad, are thin but leathery, dull yellow-green and smooth above and pale-green beneath, with pale

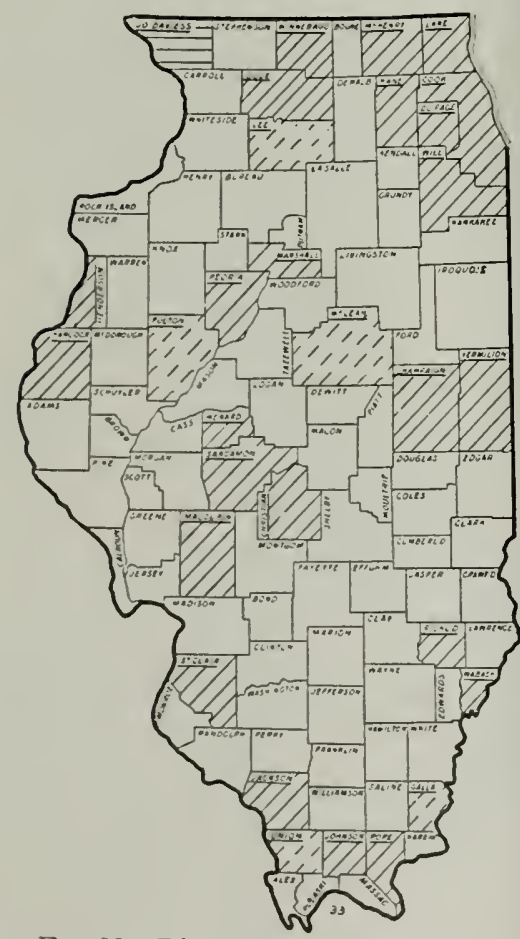

FIG. 33. Distribution of the Hop Hornbeam. hair in the angles of the veins. They have slender, round petioles about $1 / 4$ of an inch long and rounded or somewhat heart-shaped bases. The reddish-brown, hanging, clustered staminate catkins are cylindrical and about 2 inches long, and the pale-green pistillate catkins are $1 / 2$ to $3 / 4$ inch long. The fruit is a long-stalked, pendulous, cone-like structure, suggestive of the hop, with stinging hairs at the base of the papery scales, which incloses the pointed, flattened, chestnut-brown nutlets. The slender, zig-zag twigs, smooth and lustrous at first, become dull and dark reddish-brown. The trunk, which commonly attains a diameter of 8 to 15 inches, is covered by a thin grayish bark of narrow, oblong scales which are loose at the ends. The tree reaches a height of 25 to 40 feet.

Distribution: The Hop Hornbeam is a common tree on dry, gravelly, and stony soils from Nova Scotia 


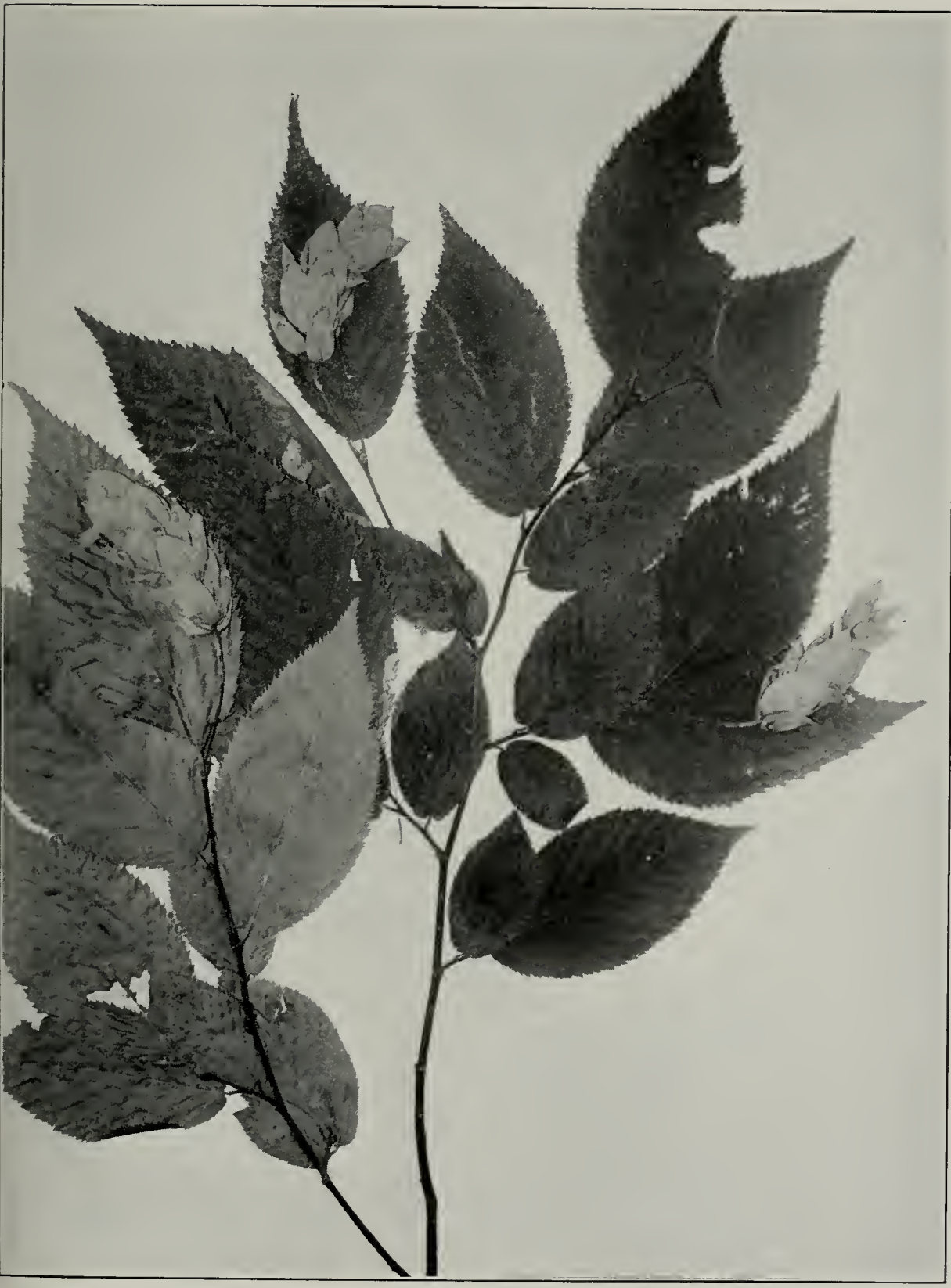

PLATE 26 
to South Dakota and southward to the Gulf of Mexico. It is found throughout Illinois except in the sonthern tip of the State. It is tolerant of shade and grows commonly among the oaks and other high trees on the high banks of streams.

L'scs: The very hard, close-grained wood of the Hop Hornbeam. light-lorown to nearly white in the heart and pale-white in the thick sapwood, is strong and tough but not very durable in the soil. Though used for fence posts, it is more serviceable for fuel and furnishes material for tool handles, mallets, and levers.

\section{Betula Linnaeus The Birches}

Family Betulaceae

Small to large, deciduous trees and shrubs, with alternate, broadbladed, simple. petioled leaves and staminate and pistillate flowers in separate catkins; the staminate catkins long and pendulous; the pistillate catkins short and erect. Fruit an erect, cone-like structure, sessile or shortstalked on the ends of short branchlets, with oval nutlets nearly surrounded by lateral wings. The trunk covered with smooth, sometimes papery, resinous bark marked by long, longitudinal lenticels.

There are about 30 species of Betula, and the genus ranges throughout much of the Northern Hemisphere, some species forming great forests in the far north. Of the 12 species in North America, 9 are trees; and 2 of these are found in Illinois.

\section{KEY TO THE ILLINOIS BIRCHES}

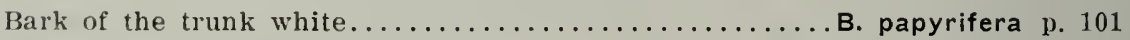
Bark of the trunk dark red-brown................... nigra p. 98

\section{BETULA NIGRA LiNNAEUS}

\section{Red Birch River Birch}

The Red, or River. Birch is a moderately large tree, divided at a height of 1.5 or 20 feet into 2 or 3 up-tilted limbs which divide in turn into slencler branches that form a narrow, picturesque crown. The pointed. ovate, irregularly toothed leaves. $1 \frac{1}{2}$ to 3 inches long by 1 to 2 inches wide. which are smooth above but hairy beneath, stand on slender. hairy, somewhat-flattened petioles about $\mathrm{t} / 2$ inch long. The staminate 


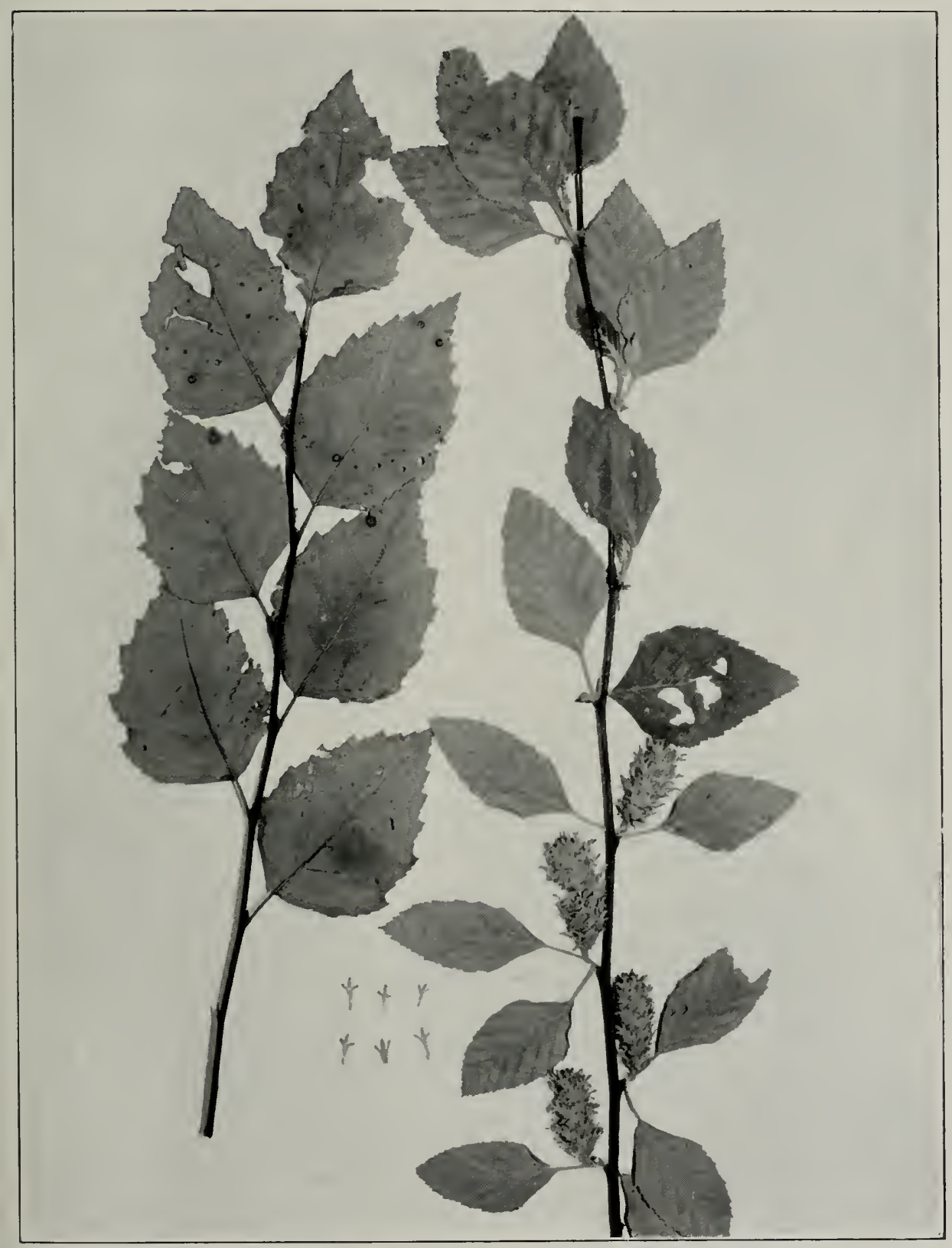

PLATE 2i

BETULA NIGRA LinNaEUS

RED BIRCH 


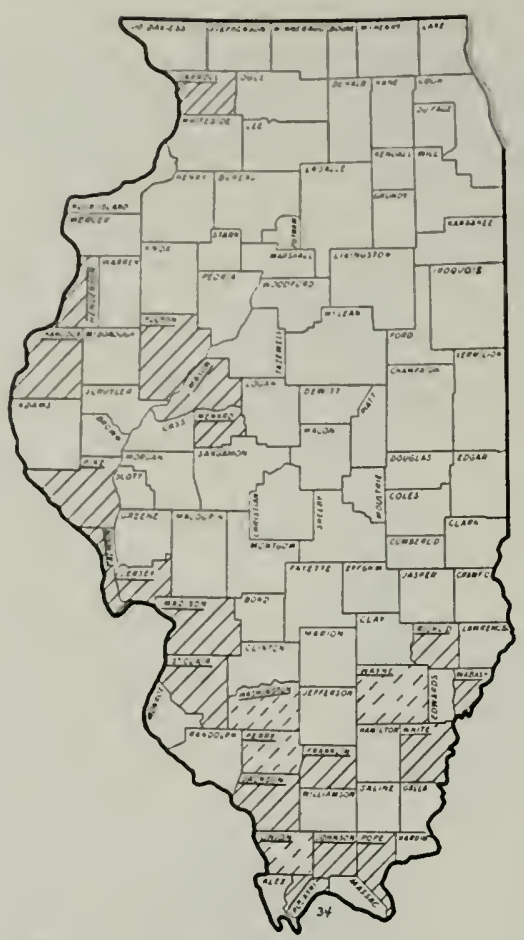

Fic. 34. Distribution of the River Birch. catkins beconne: to 3 inches long; and the pistillate catkins, at first brightgreen and about $/ 3$ inch long, ripen in May and Jume into woody, cylindric, hairy cones 1 to $1 \frac{1}{2}$ inches long, which stand erect on stout woolly stalks $1 / 2$ inch long. The little brown nuts, about $\mathrm{s} / \mathrm{s}$ inch long, are hairy toward their tips and are surrounded by ? thin and hairy marginal wings. The smooth and lustrous, slender twigs. eventually dark reddish-brown, are covered with bark which peels off in thin, papery scales. The pointed. oval, hairy buds, which are appressed to the twigs, are covered by from 3 to i scales. The bark on young trees peels off in reddish-brown strips, but on mature trunks, which have attained a diameter of 2 or $21 / 2$ feet, it often is dark brown and fissured and separates in plates. The tree is ordinarily 40 to 50 feet high, but sometimes it grows to 80 feet.

Distribution: 'The Red Birch, a tree of strean banks, ponds, and swanps, ranges from New Hampshire to Florida and westward into Minnesota and Texas. In Illinois, it grows throughout our sonthern and western regions; but though Dean has found it most abundantly in Indiana along the Kankakee River, it is not known along the lower reaches of this river in lllinois. In Hancock County, it is reported by Miss Kibbe as abundant along streans and in moist lowlands; and, in the south, it occurs on the Kaskaskia bottons with Black and White oaks, hickories, maples, and others. In Wayne County, it grows with the Red and Black gums and the Pin and Swamp White oaks, while in Perry County it is associated also with the Black Cottonwood and a number of other oaks.

Uscs: The fairly hard, close-grained wood of the Red Birch, lightbruwn in the heart and pale in the wide sapwood, is light but strong. It is used very largely in the manufacture of cheap furniture and other wooden articles, in turnery, and, especially in Illinois, as fuel and for the production of charcoal. 


\section{BETULA PAPYRIfERA Marshall}

\section{Canoe Birch Paper Birch}

The Canoe, or Paper, Birch, recognizable especially by its creamywhite, papery bark, is a moderate-sized tree, with short, slender, spreading branches which form a narrow, pyramidal or round-topped crown. The pointed, irregularly double-toothed leaves, 2 to 3 inches long by $1 / 2$ to 2 inches wide, are thick and firm, darkgreen above, and pale-yellowish beneath and stand on stout, yellow petioles $1 / 2$ to $3 / 4$ inch long. The cylindrical, brownish-yellow staminate catkins occur 2 or 3 together, and the pale-green pistillate catkins, 1 to $11 / 4$ inches long. are solitary and terminal on short, lateral branches. The fruit is a pale-brown, cylindrical "cone" about $1 \frac{1}{2}$ inches long, with elliptical. brown, wing-margined nuts about $1 / 16$ inch long at the base of each of its scales. The stout, smooth twigs becone light orange and bear smocth. pointed buds, which are covered by 3 to j brown scales with downy margins. The trunk attains a diameter of 2 feet, and the tree grows to a height of 60 or 10 feet.

Distribution: The Paper Birch ranges from Labrador and the southern shores of Hudson Bay southward to Long Island in the east and Wyom-

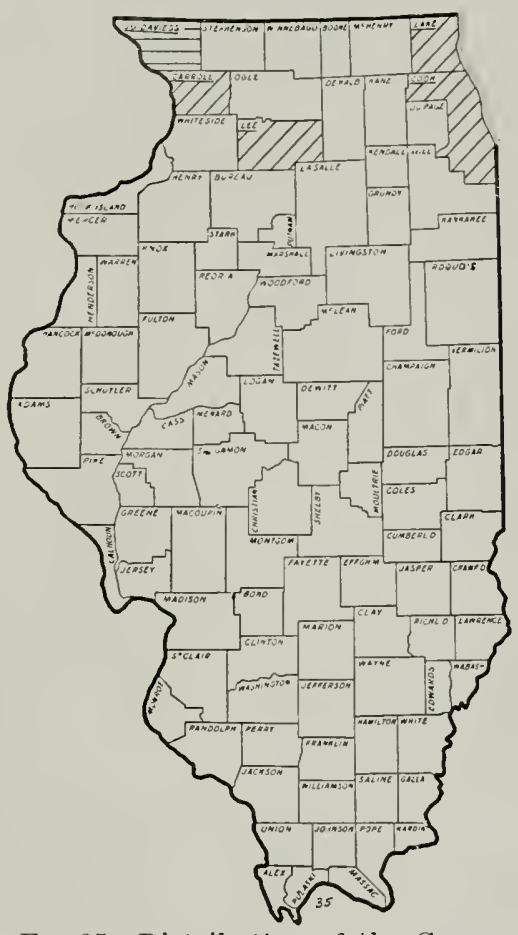

FIG. 35. Distribution of the Canoe Birch. ing in the west. In Illinois, it is a rare tree and has but a limited range. According to Pepoon ${ }^{1}$ it is abundant at Rogers Park and north of Riverside. Good specimens have been seen, which were taken in Lake, Cook, and Carroll counties, and it is reported in Pepoon's ${ }^{2}$ list of the trees of Jo Daviess County.

Uses: The hard, close-grained wood of the Paper Birch is strong and light, reddish-brown at the heart and pinkish in the thick sapwood. It is used for fuel, as it burns well when green. The degree of hardness

${ }^{1}$ Flora of the Chicago Region, p. 277.

2 Trans. Ill. St. Acad. Sci. Vol. 3, p. 155.1910. 


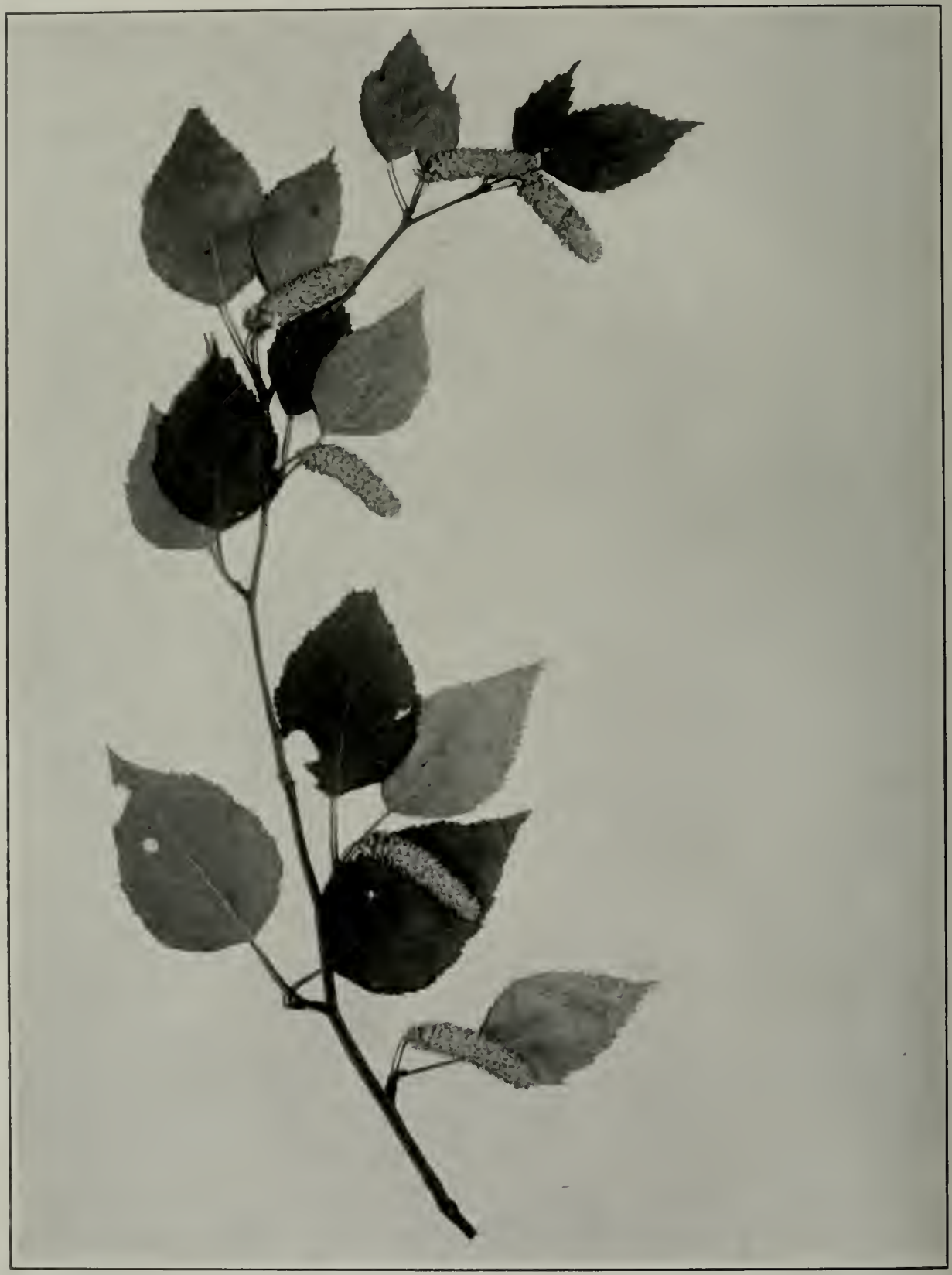

PLATE 28

BE'TULA PAPYRIFERA MARSIIALL

CANOE BIRCH 
of the wood is such as to make it very suitable for lathe work, and many small articles are made from it, such as shoe-shanks and shoe pegs, dowels, toothpicks, and many novelties. It is sawed into bars also, and these, after being seasoned, are shipped to Scotland, where they are made into spools.

\section{Other Birches in Illinois}

Bctula lutea Michaux, the Yellow Birch, has been collected by H. de Forest in Lee County. Two specimens were taken in September, 1!12:, from small trees at Whirlpool Rock and Marshmallow Rock, opposite Grand Detour, on the Rock River. This species is said by Waterman ${ }^{1}$ to occur also in the bogs of Lake County, where he found trees with trunks 10 inches in diameter.

Betula lenta Linnaeus, the Cherry Birch, is represented in the herbarium of the University of Illinois; but it is to be noted that this specimen, collected by T. J. Burrill at Princeton, was taken from a cultivated tree in Bryant's Nursery.

\section{FAgUS LinNaEus}

Beech

Family FagaCEAE

Large, deciduous trees, with alternate, broad-bladed, short-stalked, simple leaves and slender, round, zig-zag twigs containing small, round pith. Staminate and pistillate flowers separate but on the same tree; the staminate in long-stalked, globular heads near the base of the new growth, and the pistillate in 2 - to 4 -flowered, stalked clusters toward the end of the new growth. The fruit is a woody, prickly, 4-parted burr containing 3 three-angled nuts.

The 8 species of Fagus are all in the temperate regions of North America, Europe, and Asia, although a dozen beech-like trees and shrubs classed in the genus Nothofagus are known in southern Australia, New Zealand, and in Chile and Terra del Fuego. There is but one North American Beech.

\footnotetext{
1 Trans. Ill. Acad. Sci. Vol. 16, p. 217.1923.
} 


\section{FAGUS GRANDIFOLIA EHRHART}

\section{Beech}

The Beech is a moderate to large tree, with a compact, narrow crown borne high on the long, straight trunk. The alternate, sharply pointed, sharply and coarsely toothed leaves, $2 \mathrm{I} / 2$ to 5 inches long by 1 to 3 inches wicle, are thin but leathery, dull-green above and pale-green and shiny be-

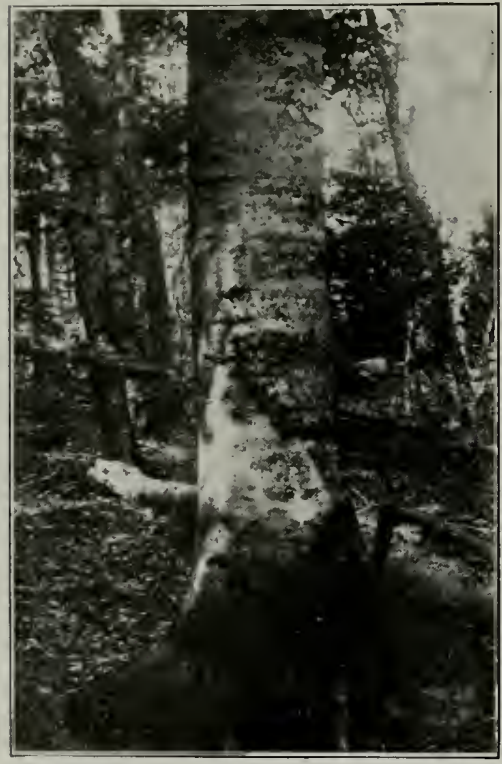

Fig. 36. A ty pical American Beech. Photo from the Ficla Museum of Natural History. neath, where the rib-like veins have tufts of hairs in their axils. The short, round, stocky petioles are about $1 / 4$ inch long. The globular heads of staminate flowers, an inch in diameter, hang on slender stalls 2 inches long. and the pistillate flowers usually stand in pairs, each on a short, woolly stalk. The fruit is a short-stalked, prickly burr $3 / 4$ inch long, which splits into 4 parts, setting free the 2 shiny, brown, 3-sided nuts. The slender, zig-zag, bright-brown twigs bear narrow, conical, sharply pointed, divergent buds $3 / 4$ to 1 inch long, which are covered by 10 or more hairy-margined scales. The columnar trunk, which becomes 2 to 4 feet in diameter, is covered by dull-gray bark that is thin and smooth and often mottled with dark spots. The ordinary height of the tree is between 60 and 80 feet.

Distribution: The Beech ranges from Nova Scotia southwestward into Minnesota and southward into Florida and Texas. In Illinois, it is now a tree of limited distribution, rare in the north and by no means abundant in the south. Formerly, it may have been more abundant, for early writers say that cattle thrived amazingly on beech mast, their flesh acquiring a superior flavor; and A. H. Worthen, in his Geology of Illinois, published in 1866, says that "the steep, rugged hills in the southwest corner of Pulaski County were covered with beech timber," the beech extending "on the slopes of the bluff hills a short distance east of the Illinois Central railroad and also southward into the bottom."

In northern Illinois, the Beech is found only in Lake County, where there are groups of trees in a ravine near Highland Park and in the Petti- 


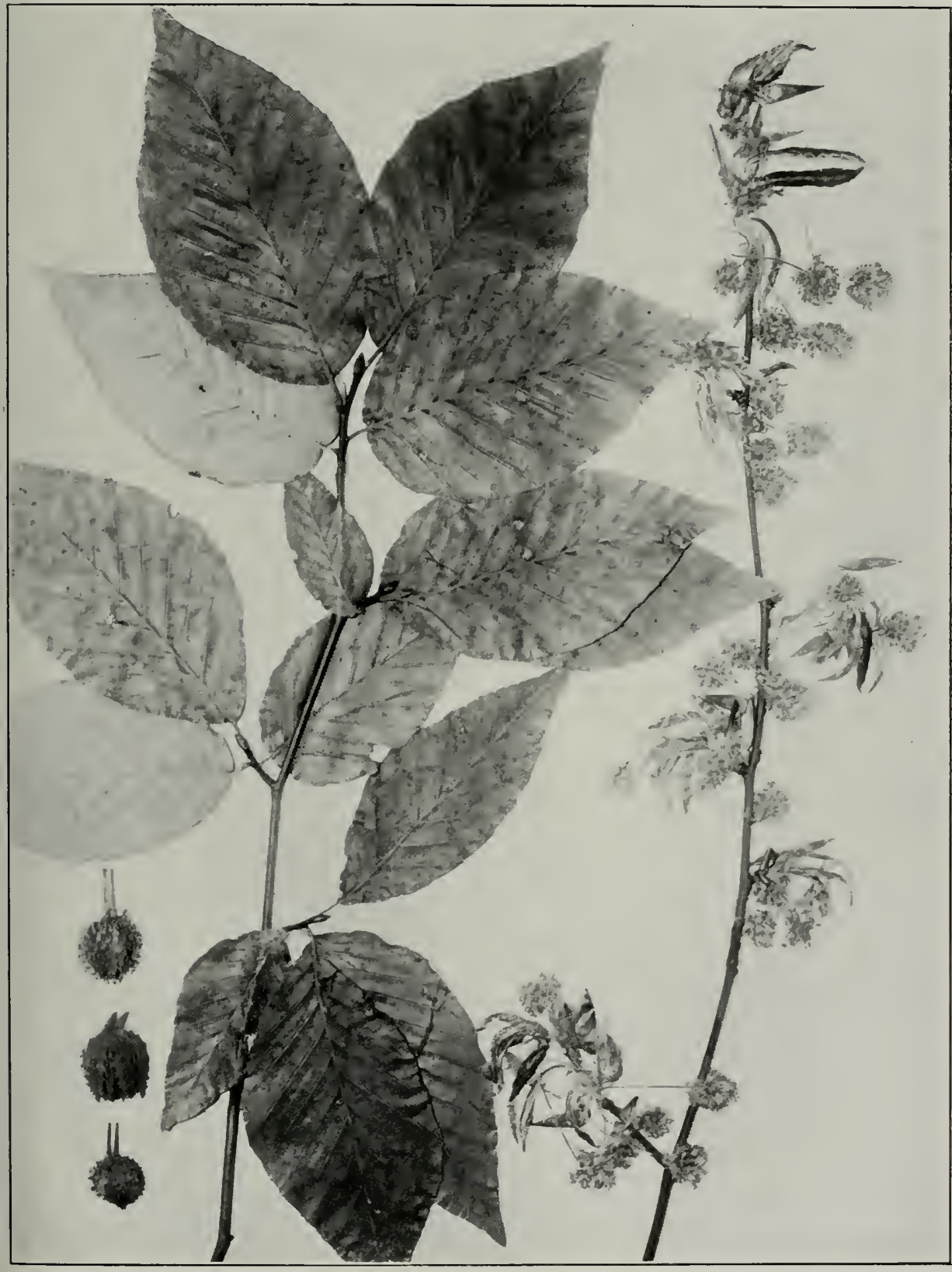

PLATE 29

FAGUS GRANDIFOLIA EHriIART

BEECH 
bone Creek ravine at Fort Sheridan. There was at one time a climp, of Beech in a wood one mile north of Edgebrook; but Pepoon states that in 1926 the wood had been cut over and the trees lost.

In southern Illinois, the range of the Beech, which is much the same as the range of the Tulip Tree, extends from Vermilion County southward around the State and up the Mississippi into Randolph County. Throughout this territory, the tree appears to find small areas in the bot-

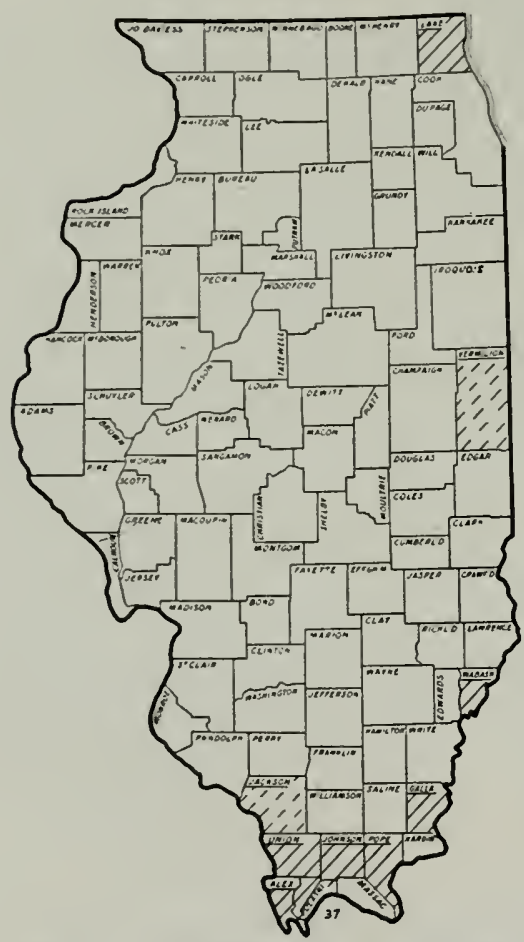

Fig. 37. Distribution of the Beech. toms of small valleys and the sicles of ravines, where cherty and gravelly soils occur, suitable for its growth; and in these situations it is associated commonly with the Tulip Tree, oaks, hickories, maples, gums, and the Elm. In Ubedam Hollow, in Union County, where Beeches grow with Tulip and Cucumber trees, one tree had a diameter of 28 inches and a clear, merchantable trunk 62 feet long.

Uscs: The hard, close-grained wood of the Beech, light- to dark-red in the heart and nearly white in the thin sapwood, is tough and strong; but it is hard to season and is not durable in the ground. Since it takes a high polish, it is used considerably for furniture and tool handles. It is used also for veneers. distillation and fuel, ranking with birch and hard maple for the last purpose. It has a slight, silver grain on the radial surface, which gives it a pleasing effect when used for flooring and stairways. Since the development of wood-preserving processes, beech is being used for railroad ties; and in 1925 about 120,000 board feet were cut, of which a large amount probably was used for ties. 


\section{Family Faciaclear:}

Deciduous trees or shrubs, with alternate, broad-bladed leaves on short petioles. Staminate and pistillate flowers separate. the former grouped, 3 to $;$ together, at small intervals along the axis of a long catkin, which grows sing'e or several together toward the base of a spike-like structure arising from the axil of the new leaf. Fruit a stalkless, globose burr densely covered with sharp spines, splitting into 2 or 4 parts to liberate 1 to 3 globular, chestnut-brown, hairy-tipped nuts. Twigs of moderate size, more or less fluted, with star-shaped pith and stalkless, oval buds covered by 2 or 3 exposed scales. The trunk has furrowed bark.

Castanea, with its $;$ species, is wide-spread in the Northern Hemisphere. ranging through eastern North America, southern Europe, and Northern Africa to China. Korea, and Japan. This genus, like Carya, is ancient. Fossils found in many parts of Europe as well as in New Jersey, Colorado. Wyoming, and Oregon, in British Columbia, Alaska, and Greenland, indicate that there were not less than 11 species in the wor'd previous to the Ice Age. Two of the modern species, one European and one American, are survivors of these ancient trees.

There are 3 native species of Castanea in the United States, one of which occurs in Illinois.

\section{CAstanea DENTATA Borkhausen}

\section{Chestnut}

The Chestnut is a moderately large, very bulky tree. usually with a few stout, horizontal limbs which form a broad, round-topped crown. The large, sharply pointed, coarsely and very sharply toothed leaves, $b$ to 8 inches long by 1 to $1 / 2$ inches wide, are thin and dull, dark-green above and pale-yellow heneath. The stout, hairy petioles are about $1 / 2$ inch long. The flowers appear in late June or July, the staminate flowers in erect. stalked catkins 6 to 8 inches long, the pistillate flowers in clusters of 2 to 5 toward the base of slender, hairy catkins $21 / 2$ to 5 inches long. The stalkless, globular, brown burr, which is densely covered with long, branched, sharp spines, splits into 4 parts. Within it are from 1 to 3 lustrous brown nuts with sharp, hairy tips and with bases marked by large pale scars. The stout, lustrous, dark-brown twigs, which are more or less 
Huted. have no terminal bud: but the hali-round leaf-scars, flanked by lung stipule scars, are sturmounted by obliquely formed. pointed, divergent buds covered by 2 or 3 exposed scales. The trunk, often 3 to 4 feet in diameter, is covered by graly bark divided by shallow fissures into broad. flat ridges which often have a distinct spiral course around the trunk.

Distribution: The range of the Chestnut extends from Maine westward to Michigan and sonthward to Delaware and Tennessee. In Illinois, it is found native only near Olnustead, in Pulaski County, where there is a grove of trees, some 80 acres in extent, on rolling clay ridges. These trees were mentioned by Flagg and Burrill ${ }^{1}$ and were described by the Rev. E. B. Olnustead in $18 \% 6$ in the following words: "I suppose that these trees are indigenous. They grow on a ridge in section 23 , town 15, range 1 east, about a quarter of a mile from the Ohio River and overlooking it...I took a position in their midst today, and counted, without moving. thirty-five beatiful and symmetrical trees, averaging in diameter about 22 inches, and in height 50 or 60 feet. When I came to this place in 1839 there were a great many more than at present. About 25 years ago I saw a tree cut down and worked up into rails. It was immensely tall and four or five cuts were taken off for rails ten feet long. I measured the stump of that tree today... and making allowance for sap and bark which are gone, found it six feet, two inches, three feet from the ground. Comparing this with a small one the concentric rings of which we counted, the noble tree was 250 years old when it was cut down ... These trees did not originate with any civilized nation. No doubt, the Indians for many generations built their council fires under their branches, but they dicl not plant them."

Among a collection of woods prepared by Mr. B. T. Gault, of Glen Ellyn, in 1900 , and presented to the University of Illinois, there is a specimen taken from a limb of one of these trees; and the photograph which accompanies it shows a tree $4 \frac{1}{2}$ to 5 feet in cliameter, indicating an age of between 200 and 250 years. After a visit to these chestnuts in 1916 , Dr. William Trelease ${ }^{2}$ reported that most of the large trees had been destroyed but that an abundant seeding had resulted in a considerable growth of young trees. He reports also that at present Box Elder. Red Maple, hickories, Iackberry, Persimmon, Beech. White Ash, and numerous other trees are associated with the Chestnut, and give the Illinois location much the same aspect as the usual habitat of the tree to the east and south.

Uses: The soft, coarse-grained wood of the Chestnut is light and weak, but durable in the soil. It is used largely for railroad ties, posts,

\footnotetext{
${ }^{1}$ Ninth Report 111. Ind. University, 1s78. Page 268.

2 Trans. 111. St. Acad. Sci. Vol. 10, p. 143.1917.
} 


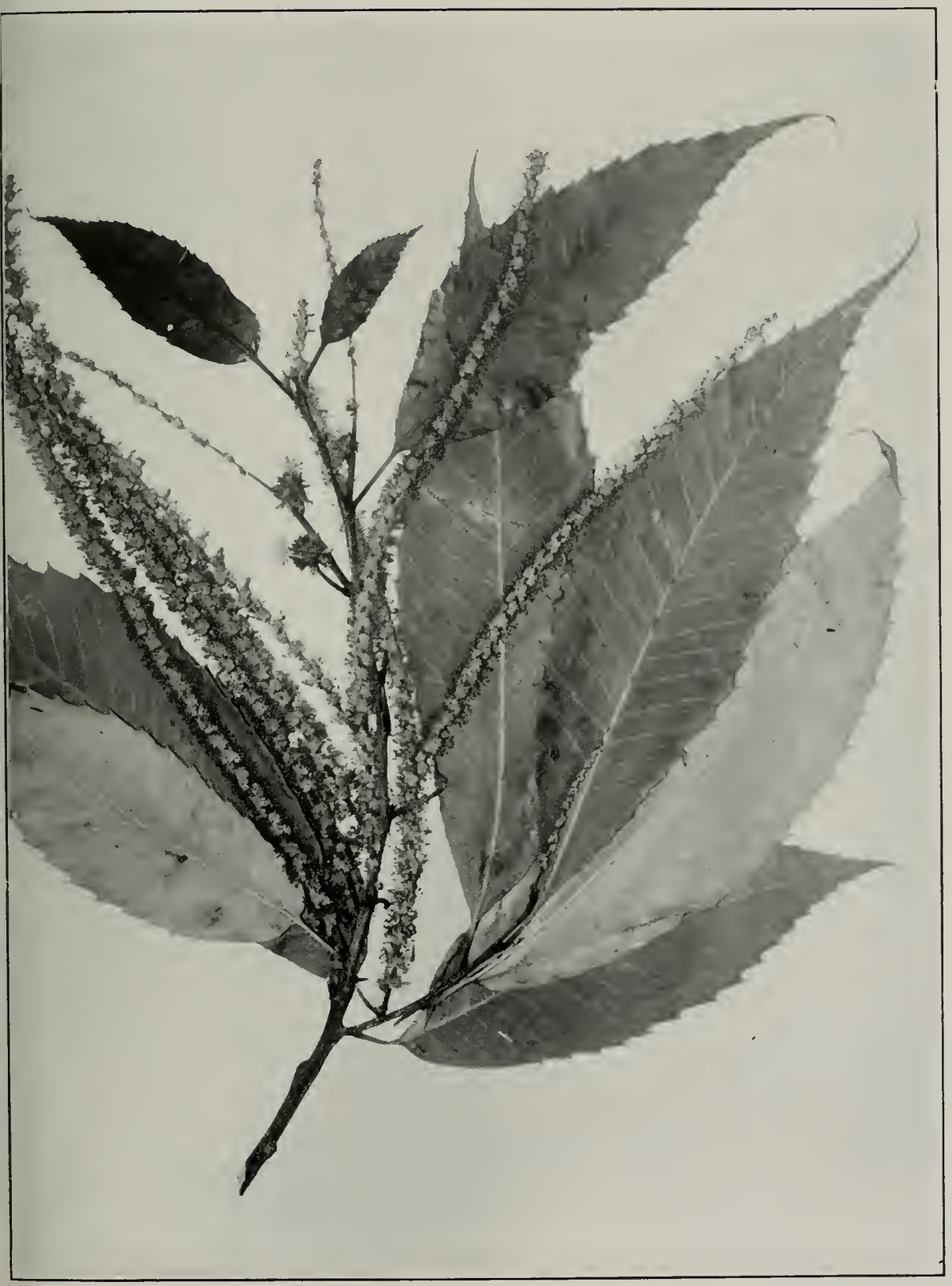

PLATE 30 。

CASTANEA DENTATA Borkiausen

CHESTNUT 
poles. and for cheap furniture and interior finishing of houses. The tree is also the source of a tamnin extract used in tamning hides. The commercial chestunts of the eastern Lnited States also conce from this tree.

\section{QUERCUS IINNAEUS}

\section{The Oaks}

\section{Family FAGACEAE}

Small to large trees with alternate, varionsly lobed or entire, usually deciluons leaves, which are disposed in 5 vertical ranks along the branchlets. Staminate and pistillate flowers separate but on the same tree; the former in long, pendulous, clustered catkins, the latter solitary, in fewflowered spikes from the axils of the new leaves. Fruit a nut, called an acorn. which is more or less inclosed ly a persistent cup. Twigs moderate to slender and fiuted, with moderate, star-shaped pith. Buds with numerous, 5-ranked scales, sessile above moderate to small, half-round leaf-scars. Trunk of hard and close-grained, but sometimes porous and brittle. wood, covered by a scaly or furrowed bark.

The genus Quercus, of which more than 350 species exist, inhabits the temperate regions of the Northern Hemisphere and extends into the tropics in situations of a high altitude. Our modern oaks are the descendants of very ancient trees. Between 20 and 30 forms have been recorled. from fossils, as existing at about the time of the Ice Age, and of these only:; or $t$ are now extinct. There are, at present, $s \pm$ species in the United States: and of these. Illinois contains 19 tree forms, 8 being white oaks and 11 black oaks. 


\section{KEY TO THE ILLINOIS OAKS}

Leaves with bristle tips; bark dark, furrowed; acorn-shells silky-hairy inside; acorns mature at the end of 2 seasons (Black Oaks).

Leaves entire, bristle-pointed (Willow Oaks).

Leaves and buds without hairs; acorns stalked......Q. Phellos

Leaves hairy beneath; buds more or less hairy; acorns prac-

tically sessile............... Q. imbricaria p. 134

Leaves more or less distinctly lobed, the lobes also bristle-tipped.

Leaves shallowly lobed, blade much expanded toward the tip

Q. marylandica p. 128

Leaves deeply and pinnately lobed.

Leaves pale and velvety beneath.

Leaves deeply cut..................... rubra p. 124

Leaves shallowly cut......... . rubra pagodaefolia p. 126 Leaves green on both sides.

Leaves dull above, 7 - to 11 -lobed........... borealis p. 112

Leaves shiny on both faces, generally 5 - to 9-lobed.

Acorn cup shallow, saucer-shaped.

Leaves generally 7-lobed; acorn oval........

Q. Shumardii p. 116

Leaves 5- to 7-lobed; acorn globose...........

Q. palustris p. 120

Acorn cup deep, cup-like.

Cup-scales tightly appressed....Q. ellipsoidalis $\mathrm{p} \quad 117$

Scales forming a loose fringe at the cup's edge

Q. velutina p. 122

Leaves never with bristle tips; bark gray and more or less scaly; acorn shells not hairy inside; acorns maturing at the end of 1 season (White Oaks).

Leaf-margins sinuate, coarsely toothed only (Chestnut Oaks).

Acorns sessile or very nearly so........... Muehlenbergii p. 153 Acorus long-stalked.

Acorn stalks much longer than the petioles....... bicolor p. 146 Acorn stalks not longer than the petioles.

Cup scales separate and distinguishable; end buds distinctly red-tinted............... Prinus

Cup scales appearing grown together, distinguishable ouly at the tips; end buds light-brown to tan

Q. montana p. 152

Leaves more or less deeply lobed.

Leaves not hairy beneath, usually 7 - or 9 -lobed......... a. alba p. 144 Leaves hairy beneath.

Scales forming a conspicuous fringe around the rim of the cup.................... macrocarpa p. 135

Cup scales not forming a conspicuous fringe.

Cups nearly inclosing the acorn............ Iyrata p. 138

Cups covering only $1 / 3$ to $1 / 2$ of the acorn.... Q. stellata p. 140 


\section{QUERCUS BOREALIS MiCIIAUX}

\section{Variety MAXIMA Ashe}

\section{Red Oak}

The Red Oal is a tree of large size, with a narrow head of stout branches. The smooth leaves, dull-green above and yellow-green below. which are from 5 to 9 inches long by 4 to 6 inches wide, are divided al. most half way to the midrib into $\hat{i}, 9$, or usually 11 lobes each of which

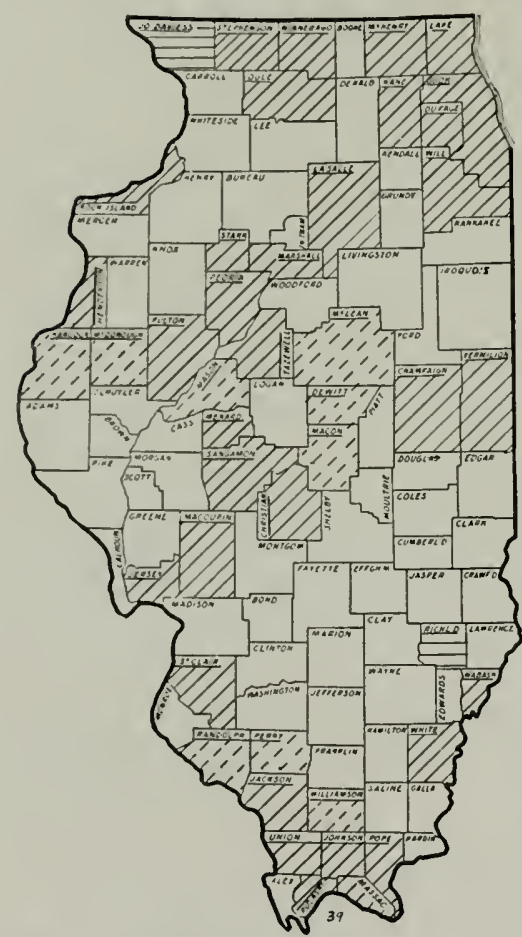

Fig. 38. Distribution of the Red Oak. (Quercus borealis var. maxima) usually has 3 smaller, bristle-tipped lobes at its point. The staminate catlins are 4 or 5 inches long, and the pistillate flowers stand on short, hairless stalks in the axils of the new leaves. The pale-brown, lustrous acorns, 1 to $11 / 4$ inches long by $1 / 2$ to $2 / 3$ inch wide, stand alone or in pairs and are sessile or very short-stalked. Their shallow cups are covered with red-brown, hairy scales, which have thin, dark-colored margins and tips. On the dark-red to brown branchlets, the oval, pointed buds, about $1 / 4$ inch long, are covered by thin, pointed, chestnut-brown scales. The trunk, covered by dark-brown bark which is fissured into low, continuous, flattopped ridges, becomes 3 to 4 feet in diameter, and the tree attains a height of 80 to 80 feet.

Distribution: The Red Oak is known in Illinois only by this variety, which differs from the typical tree in its greater size and the larger acorns borne in shallow cups. One of the most generally distributed trees of the Northern States, east of the Great Plains, it occurs throughout Illinois, choosing porous, sandy or gravelly clay soils in preference to swamps or clry slopes and ridges. A. G. Vestal' ${ }^{1}$, in a careful study of the forests on sandy ridges, became convinced that a process of succession has taken place, ranging from Black Jack Oak, when the soil was young and poor, to a Red Oak and Hard

${ }^{1}$ Ill. St. Lab. Nat. Hist. Bul. Vol. 10, Art. 1. 1913. 


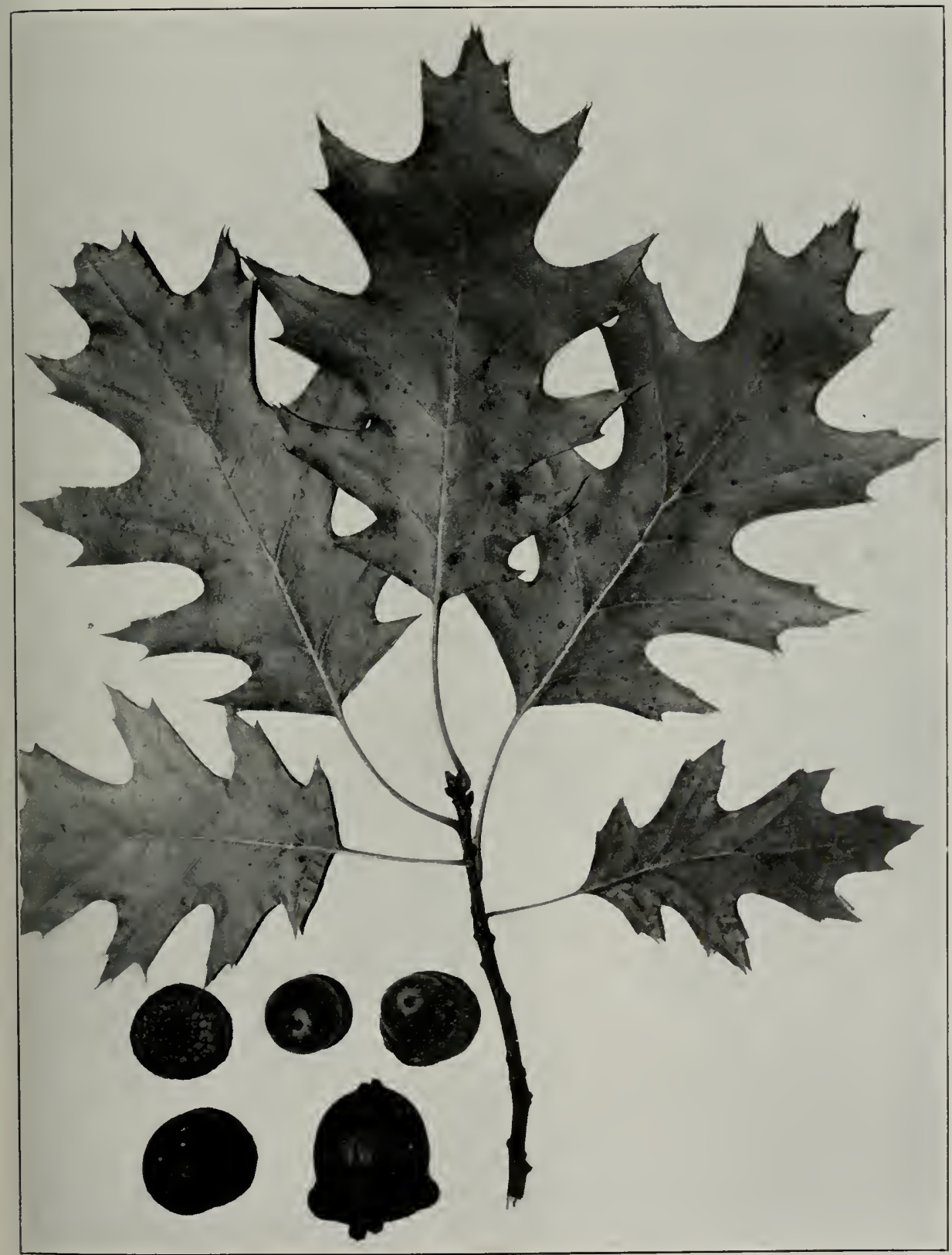

PLATE 31

QUERCUS BOREALIS MAXIMA ASHE

RED OAK 
Maple stand. as the soil was improverl and the latter he believes to be the clinax, or highest type of forest possible, in such situations. In 13 counties, strip lines run by our survey party showed the Red Oak to be associated most commonly with the White and Black oaks and with hickory, as well as with other trees such as Elm, Ash, Burr Oak, Beech, and

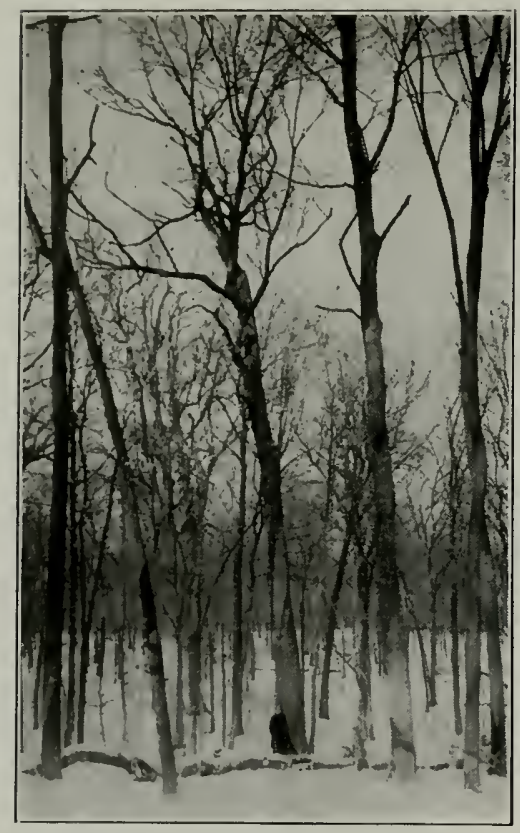

F16. 39. Red Oak growing with maples and ashes in Brownfield Woods, Champaign County.
Mulberry. The largest Red Oak encountered had attained a height of 10 ; feet. with a trunk diameter of 38 inches.

Uscs: The hard, close-grained wood of the Red Oak, light red-brown in the heart, is heavy and strong. but it is not durable in the soil. Red Oali fence posts last, on an average. only about $j$ years in Illinois. But the lumber, next to white oak, is the most common oak on the market. It is used extensively in manufacturing furniture and for interior finishing in buildings. for the "silver grain" so conspicuous in quarter-sawed material lends the wood a distinctive and p.easing pattern. The strength of Red Oak timbers makes them valuable for construction and for mine timbers and, when treated, for railroad ties and fence posts. 


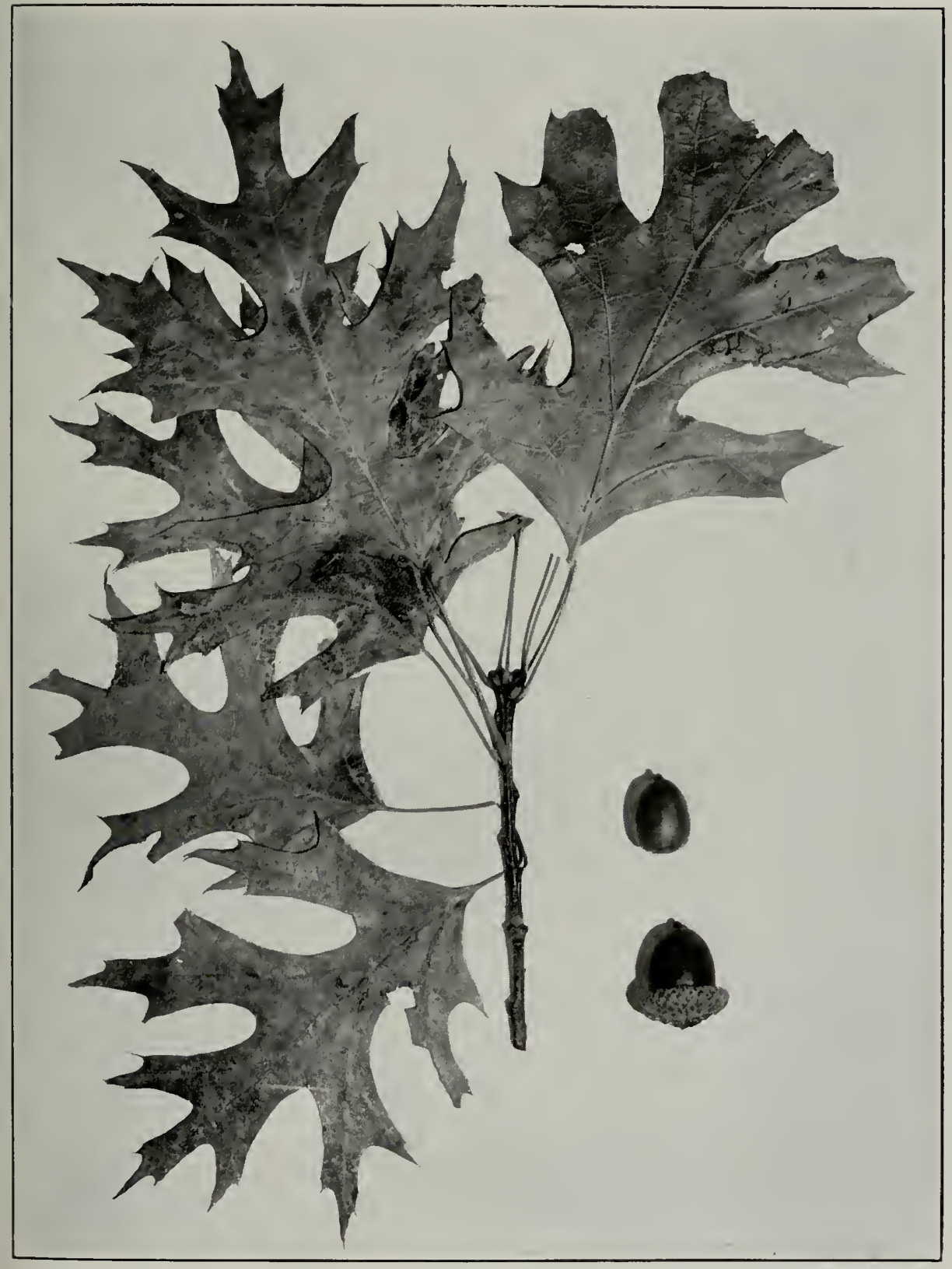

PLATE 32

QUERCUS SHUMARDII BUCKIEY

RED OAK 


\section{QUERCUS SHUMARDII BUCKIFE-}

\section{Red Oak}

This Red Oak is a tall tree, with a broad, open head of stont, spreading branches. The dark-green and lustrous leaves, 6 to 8 inches long by $t$ to 5 wide. which are paler beneath and have tufts of pale hairs in the axils of their veins, are deeply divided into $\gamma$, less often 5 , lobes. The

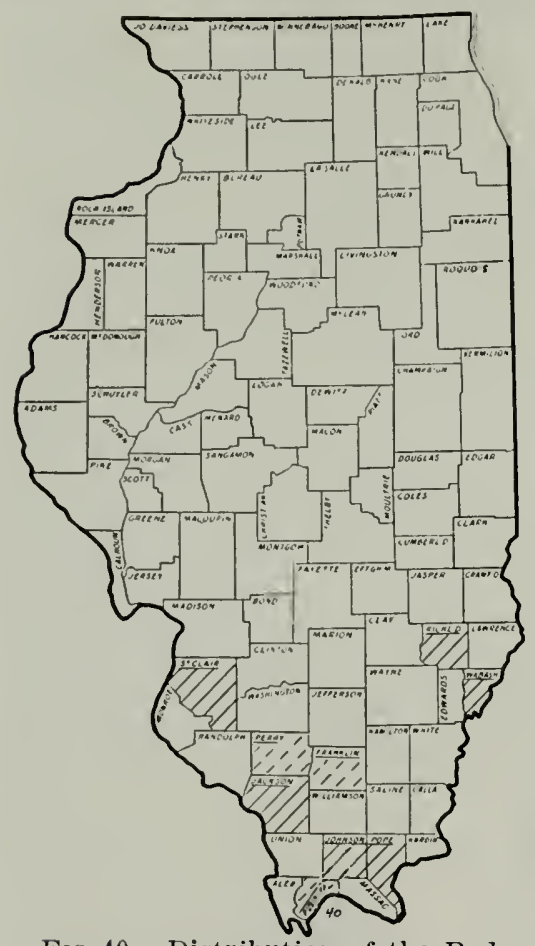

FIG. 40. Distribution of the Red Oak (Quercus Shumardii) and its variety, Schneck's Oak. slender, hairless petioles are 2 to $2 \mathrm{~T} / 2$ inches long. The slender staminate catkins are 6 or 7 inches long, and the pistillate flowers stand singly on hairy stalls. The long-oval acorn, $3 / 4$ to $1 \mathrm{I} / 4$ inches long by $1 / 2$ to 1 inch wirle, is held in a thick, saucer-like cup covered by closely appressed, thin, and usually hairy scales. The grayishbrown, smooth branchlets bear pointed buds about $1 / 4$ inch long, which are covered by gray, smooth scales. The trunk, which is inclosed by thick, ridged bark, sonetimes grows to a diameter of 5 feet ; and the tree may become 120 feet high.

Distribution: Inhabiting the moist soils of stream banks and swamps, this Red Oak ranges from Texas to Florida and northward into Iowa and southwestern Michigan. In Illinois, it is to be found only in the southern counties, where it occurs with its variety, Schncckii Sargent, known as Schneck's Oak, along the borders of streams and swamps. It is associated in these situations with Black, White, Pin, Cow and Swamp Spanish oaks, as well as Elm, Sycamore, Black Gum, ashes, and hickories.

Schneck's Oak, named in honor of Dr. Jacob Schneck of Mt. Carmel. is distinguished by the fact that the acorn cups are deep and cup-shaped. It has the same general range in Illinois as the species; but in point of fact it has not been found in Perry, Franklin, Johnson, Richland, and St. Clair counties, while it is recorded from Pope and Jackson counties.

Uses: The hard, close-grained wood of this oak, light reddishbrown in the heart, is heavy and strong. It is used for furniture, the in- 
terior finish of houses, and heavy construction. In southern Illinois, it furnishes mining materials such as props. One average 80 -year-old tree growing on the Big Muddy bottoms near Benton, Franklin County, produced ? railroad ties, worth $\$ 1.60,15$ mine props, valued at $\$ 2.25$, and 2 motor ties worth $\$ 0.50$, the entire tree having a total value of $\$ 1.35$.

\section{QUERCUS ELLIPSOIDALIS E. J. HILL Black Oak Jack Oak}

The Black Oak, called also Hill's Oak and Jack Oak, is a tree of only moderate size, with a narrow, oblong crown of ascending. forked branches. The 5 - to i-lobed, deeply divided leaves, 3 to 5 inches long by $21 / 2$ to $t$ inches wide, are bright-green above and paler and almost entirely hairless below. The slender petioles are $1 / 2$ to 2 inches long. The staminate catkins become $1 \frac{1}{2}$ to 2 inches long, and the pistillate flowers stand alone or 2 or 3 together on stout, hairy stalks. The nearly globular, chestnutbrown acorns, supported on very short stalks, are half-buried in deep cups, which are thin, light red-brown, and closely covered by narrow, hairy scales. The twigs, covered at first by matted pale hairs, become dark-brown. The buds. $1 / 8$ inch long, are covered by lustrons, brown, hairy-nnargined scales. The trunk, which is corered by thin, brown bark divided by shallow fissures into thin plates, may become 3 feet in diameter; and the height of the tree is usually between 60 and $i 0$ feet.

Distribution: Hill's Oak is a tree of very limited distribution in the North-central States. In Illinois, it grows commonly throughout the

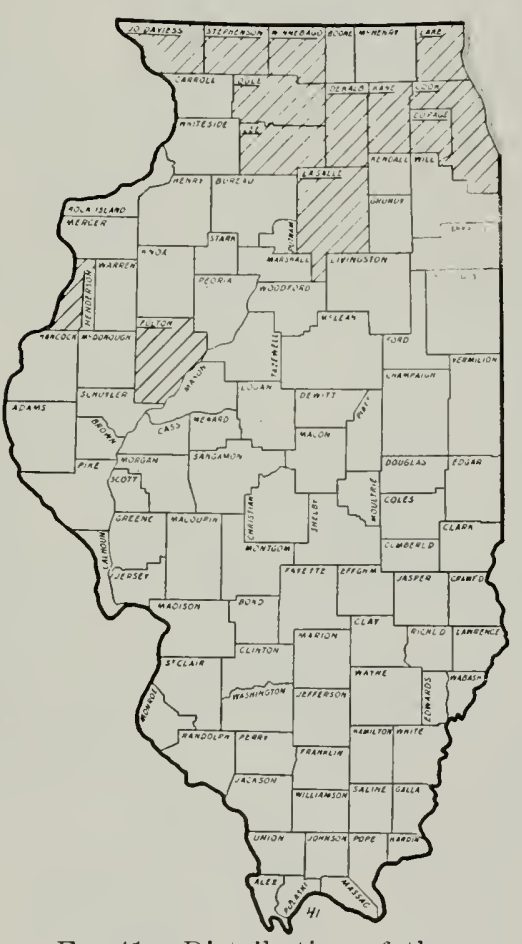

F1G. 41. Distribution of the Black Oak. northern fourth of the State. According to Trelease ${ }^{1}$, it does not go farther south than a line drawn from Rock Island to Kankakee, but through this territory it abounds on sandy and clayey uplands as well as in moister,

1. Trans. 111. St. Acad. Sci. Vol. 12, pp. 10\$-118. 1919. 


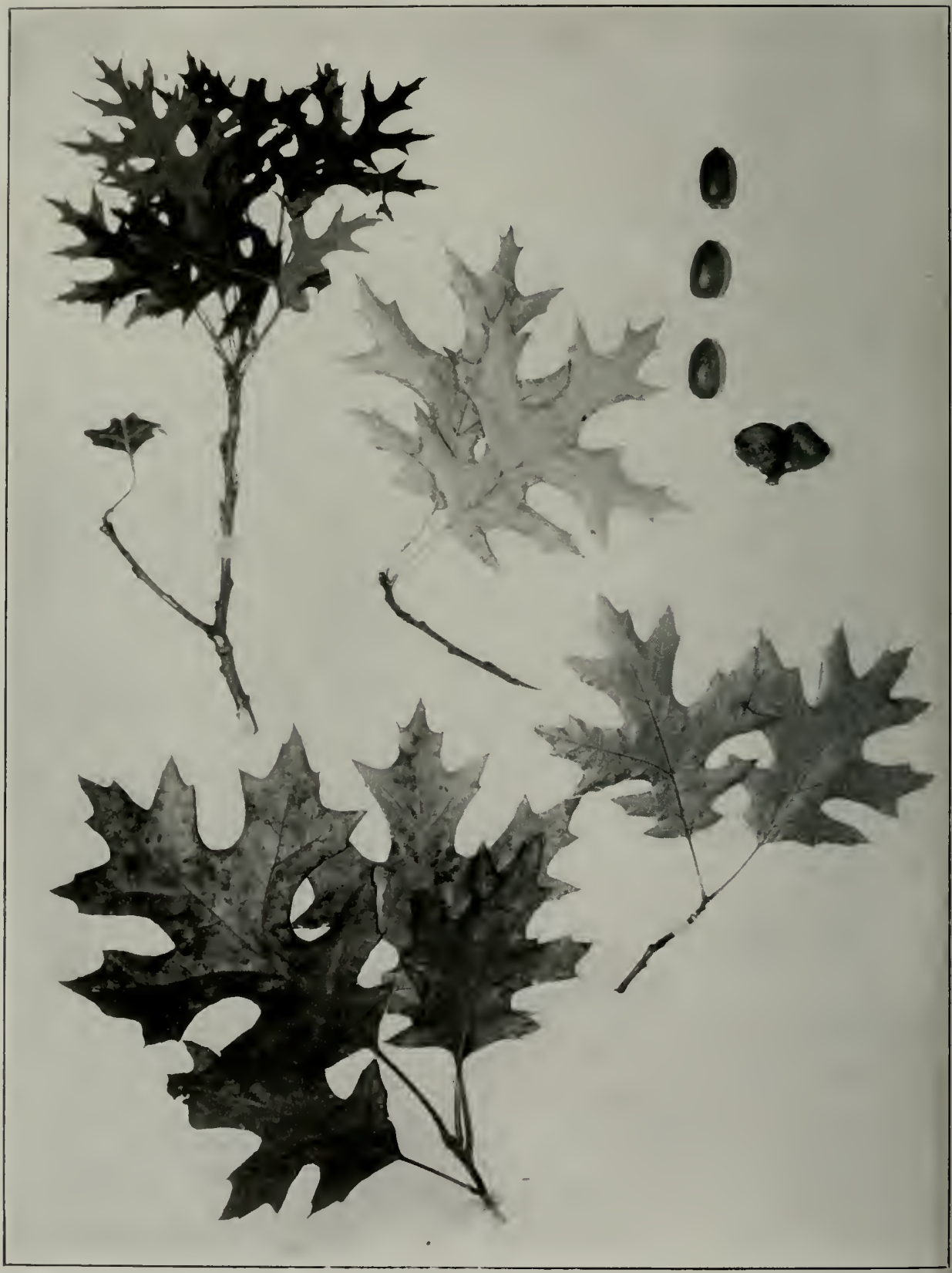

PLATE 33

QUERCUS ELLIPSOIDALIS E. J. HiLI.

BLACK O.AK 


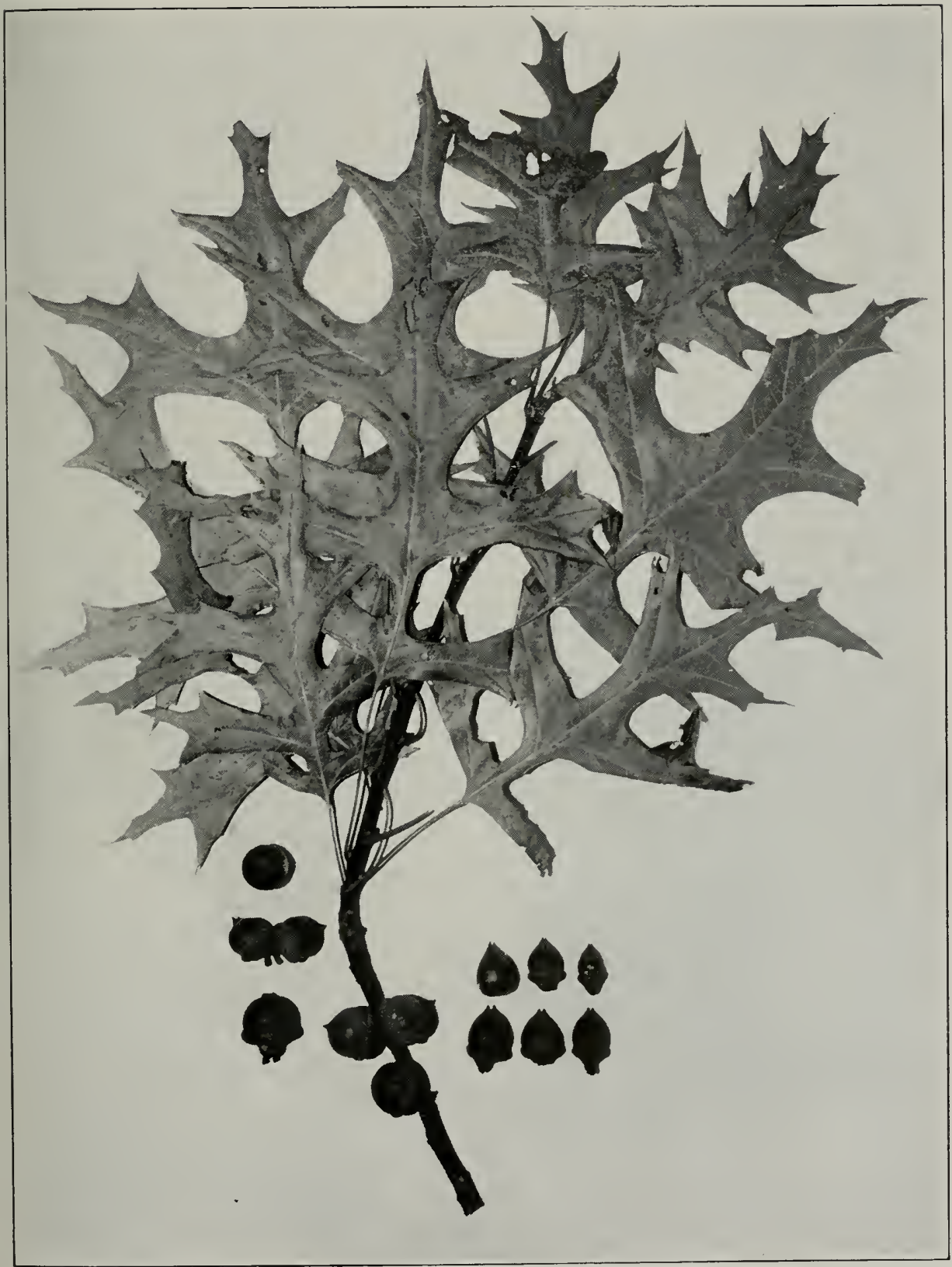

PLATE 34

QUERCUS PALUSTTRIS MUENCIIHAUSEN

PIN OAK 
sandy situations. On the pure sands of Lee County, where it is a pioneer tree, it grows large enough to be cut for railroad ties. It grows on the l.ee County sands with hickory, Black and Scruls oaks, and sometimes with Burr Oak, while in La Salle County it is common in the dry oak forests, called locally "woodland pastures," in company with the Black, White, Chinguapin, and Shingle oaks.

Usis: The wool of the Jack Oak is similar to that of the Black Oak and can be used for such purposes as posts, railroad ties, rough construction. and fucl.

\section{QUERCUS PALUSTRIS MUENCHIHAUSEN \\ Pin Oak Swamp Spanish Oak}

The Pin Oak is a moderately large tree, with an open head of drooping, ridged branches, upon which are numerous small, drooping branchlets. The deeply 5 - to $\%$-lobed leaves are 4 to 6 inches long by 2 to 4 inches wide; they are thin and firm, dark-green and very shiny above,

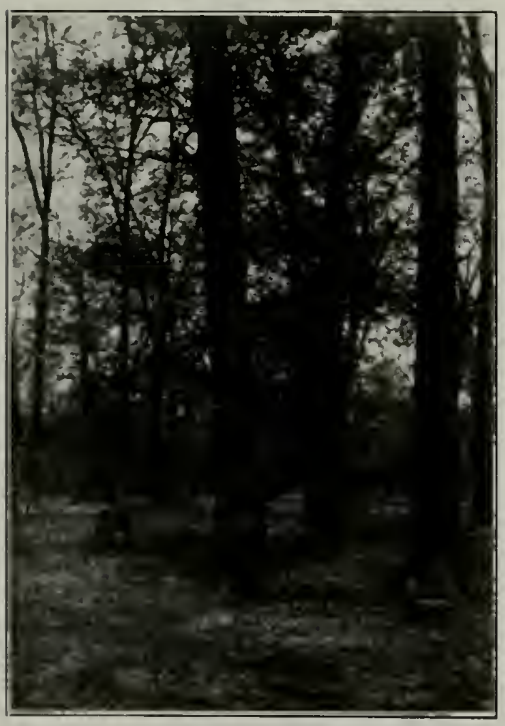

FIg. 42. Characteristic stand of I'in Oak on the bottomland of the Kaskaskia River. olina in the East and Oliahoma in the West. It is found in characteristic situations throughont Illinois, but grows most commonly in the extreme south, although trees of a good size occur also on some of the older and the axils of the large veins below; and they stand on slender, yellow petioles $1 / 2$ to 2 inches long. The staminate catlins are 2 or 3 inches long, and the pistillate flowers are often in pairs on short, hairy stallis. The globose acorns, about $1 / 2$ inch in diameter, rest in thin, saucer-like, shallow cups, which are closely covered by thin scales. The bucls on the slender, tough twigs are about $\mathrm{r} / \mathrm{s}$ inch long and are covered by light-brown, finely hairy scales. The trunk, commonly not over 2 to 3 feet in dianeter, is generally smooth. The tree attains a height of :0 or 80 feet.

Distribution: The Pin Oak is found on the borders of swamps and on river bottoms from Connecticut west to Iowa and south to North Carpaler and with tufts of pale hairs in 
better established islands of the Mississippi and Illinois Rivers. In the Kaskaskia bottoms, there are trees $i 5$ years old and $\% 5$ feet high which have a diameter of 20 to 24 inches; while the largest tree that has been measured was 112 feet high and 45 inches in diameter.

With the Pin Oak grow such trees as ash, maples, hickories, the Swamp White, Cow, and Burr oaks, Cottonwood, River Birch, Black Walnut, the Red and Black gums, and several others.

Uscs: The hard, though coarse-grained, light-brown wood of the Pin Oak, often called "water oak" in the southern counties, is strong and heavy. It is suitable for all kinds of rough construction, such as barn sills, bridge planking. mine cars, and the like; but, because the tree prunes itself very poorly, pin oak lumber contains a considerable number of knots and is, on that account, not so good for interior finishing or for beams, when strength is required. Its outstanding use is for piles.

In the early days Pin Oak was used for shingles and clapboards. The logs were cut in short lengths of 3 or \pm feet and then quartered. Pieces with straight grain were selected, and from them the shingles and clapboards were split, or "rived," by means of a knife-like tool which was driven through the wood with a mallet. The shingles and clapboards so produced were durable, but in the sun and wind they had a tendency to curl, which gave the roofs made of them a shaggy appearance.

The Pin Oak is not an abunciant tree in our upland forests, but on the bottomland it is more common, FIG. 43. Distribution of the Pin Oak. constituting 3.3 per cent of the stand in the Cypress and mixed hardwood type and 13.3 per cent of the stand in the mixed hardwoods of main streams. In the virgin bottomland forests, the Pin Oak on a sample acre amounted to 2,360 board feet, a quantity exceeded only by the Elm, Soft Maple, and the Red Gum. As the tree grows rapidlv, its use should be encouraged both for forest planting and for decorative purposes. 


\section{QUERCUS VELUTINA LAMARCK \\ Black Oak Yellow-bark Oak}

The B!ack Oak is a moderately high to very high tree, with an irregular. (b)long crown of rather s!ender branches. The deeply 5 - to i-lobed, thick, and leathery leaves, which stand on petioles 3 to 6 inches long, are clark-grecn and lustrous above. paler and more or less hairy beneath, and

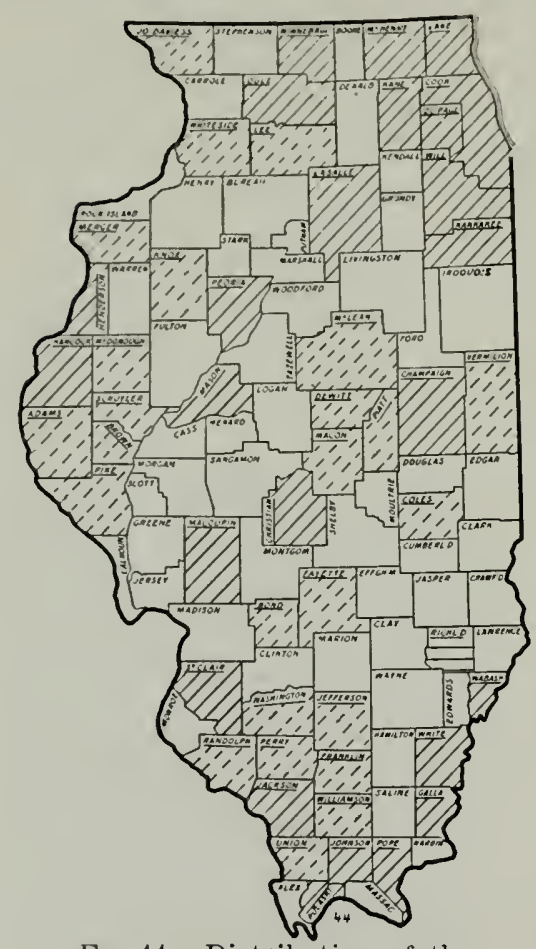

FIg. 44. Distribution of the Black Oak. measure generally 5 to 6 inches long by 3 to 4 inches wide, though they may be either very much smaller or larger. The hairy staminate catlins are 4 to 6 inches long; and the pistillate flowers usually stand in groups of 2 or 3 on short, hairy pedicels. The oval, reddish-brown acorn, $1 / 2$ to $3 / 4$ inch long, is about half imbedded in a thin, rather deep cup, the scales of which form a fringe-like border at the rim. The stout, dull-brown twigs bear yellowish-gray, 5-angled, hairy buds $1 / 4$ to $1 / 2$ inch long. The mature bark on the trunks, which attain a diameter of less than 3 feet, is nearly black and divided by fissures into broad, rounded ridges; but the inner bark is orange. Though usually growing 65 to 75 feet high, the tree may attain a height of 125 feet.

Distribution: The Black Oak ranges, on dry and gravelly uplands and ridges, from southern Maine to Nebraska and southward to Florida and eastern Texas. It is not surprising, therefore, to find it generally distributed through the entire State of Inlinois. It occurs most commonly with White Oak and hickories. In the dry oak forests of the uplands, 28 per cent of the trees are Black Oak. In La Salie County it constitutes about 20 per cent of the oak-hichory forest. In Mason, Lee, Kankakee, and other counties, according to Vestal $^{1}$, it grows with Jack Oak as one of the pioneer trees on sand ridges.

Uses: The hard, coarse-grained, reddish-brown wood of the Black Oak is strong and heavy, but is not durable in the soil. Black oak fence 


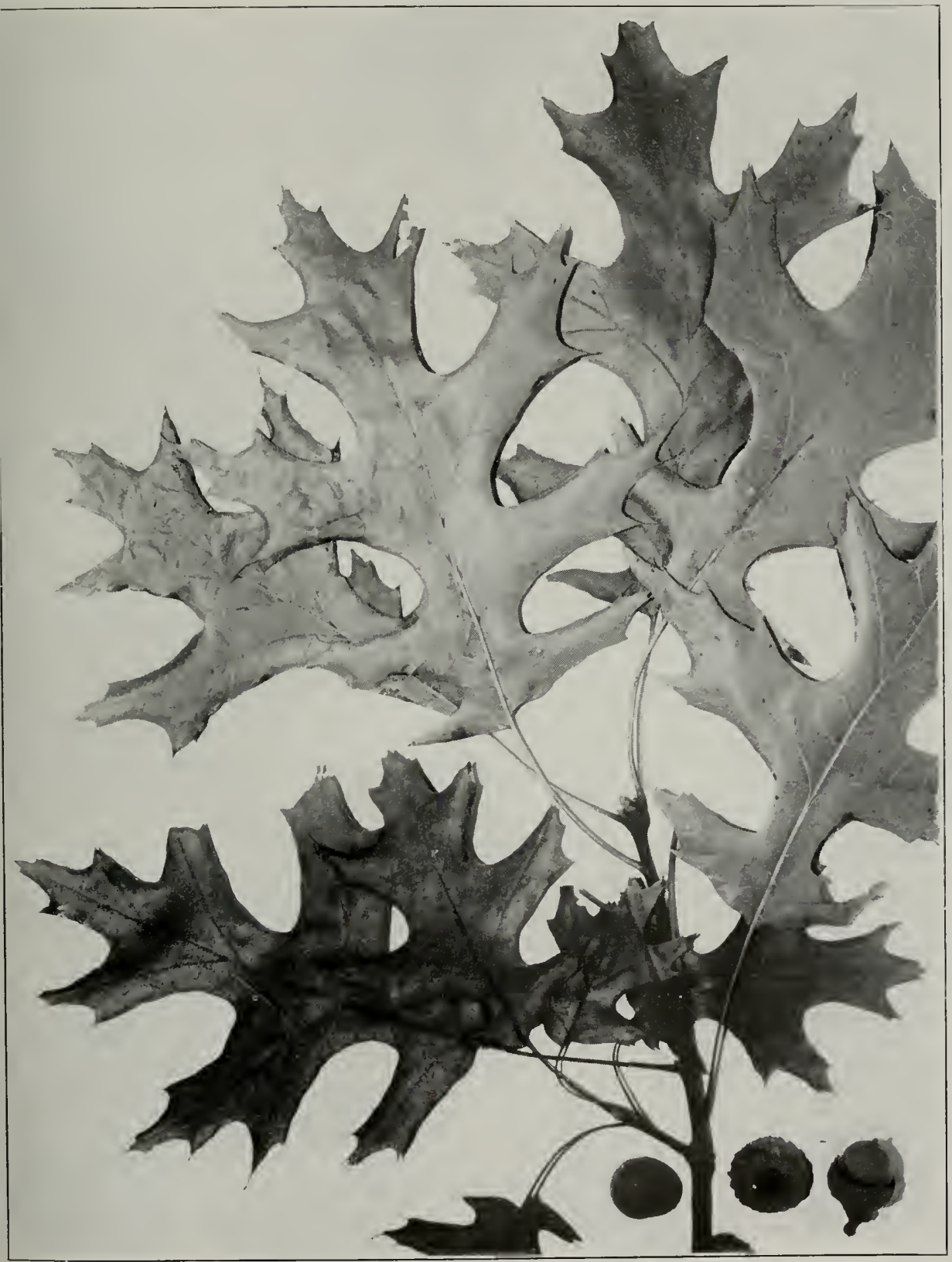

l'LATE 3j

QUERCUS VELUTINA LAMARCK

BLACK O.AK 
posts last about joars-one lialf as long as post oak and white oak posts-but with preservative treatments, which the structure of the wood renders effective, it can be used profitably for both posts and railroad ties. lt serves also for all kinds of rough construction, such as bridges, railroad and mine cars, piling. and props.

In the virgin forests of the Wabash Valley bottomlands, the Black Oak yields over 2,000 board feet per acre. In White County, on the bottomlands, a Black Oak tree, the largest seen in the State, measured 12.5 feet high and $3 \%$ inches in diameter.

\section{QUERCUS RUBRA LinNaEUS}

\section{Spanish Oak}

Red Oak

The Spanish Oak is a large tree, with a broad, round-topped crown of stout, spreading limbs. The deeply 5-lobed leaves, which are dark and lustrous above but pale and velvety beneath, are 6 or 7 inches long and 4 or 5 inches wide. The side lobes of the leaves gradually narrow to

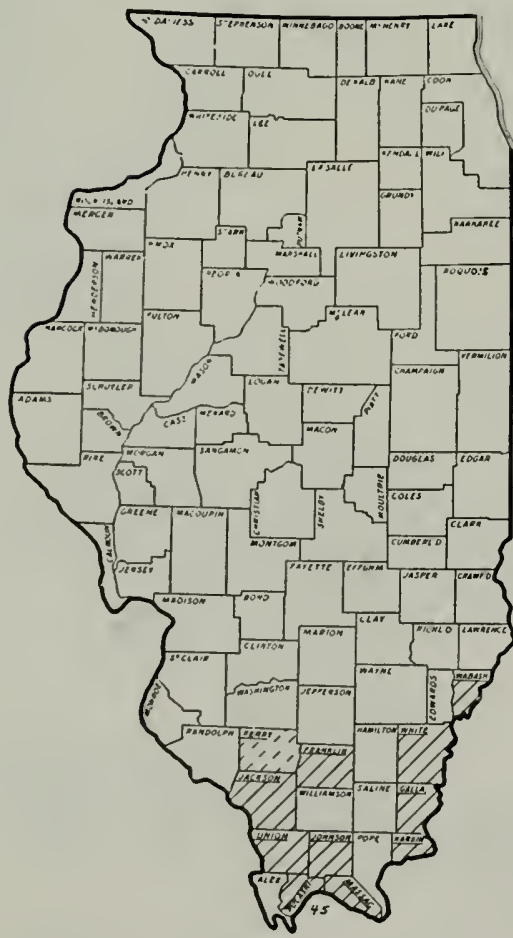

FIg. 45. Distribution of the Spanish Oak. a point, usually without being toothed or lobed near the end. The woolly staminate catkins are 4 or $\check{j}$ inches long; and the pistillate flowers stand singly on short, woolly pedicels. The bright, orange-brown acorns, about $\mathrm{J} / 2$ inch long. stand in cups of various shapes, sometimes flat and saucer-like, sometimes deep and cup-like. The slender, dark-red or brown twigs bear pointed, chestnut-brown buds about $1 / 4$ inch long; and the trunks, which become : or 3 feet in diameter, are covered by dark, thick bark, which is shallowly fissured into regular, flattopped ridges. The usual height of the tree is between $: 0$ and 80 feet.

Distribution: The Spanish Oak is a southern tree with a range that extends from southern Pennsylvania to Florida and westward to Missouri in the north and Texas in the south. In Illinois, it occurs as a native only in the southern third of the State, where it is found on dry hills. 


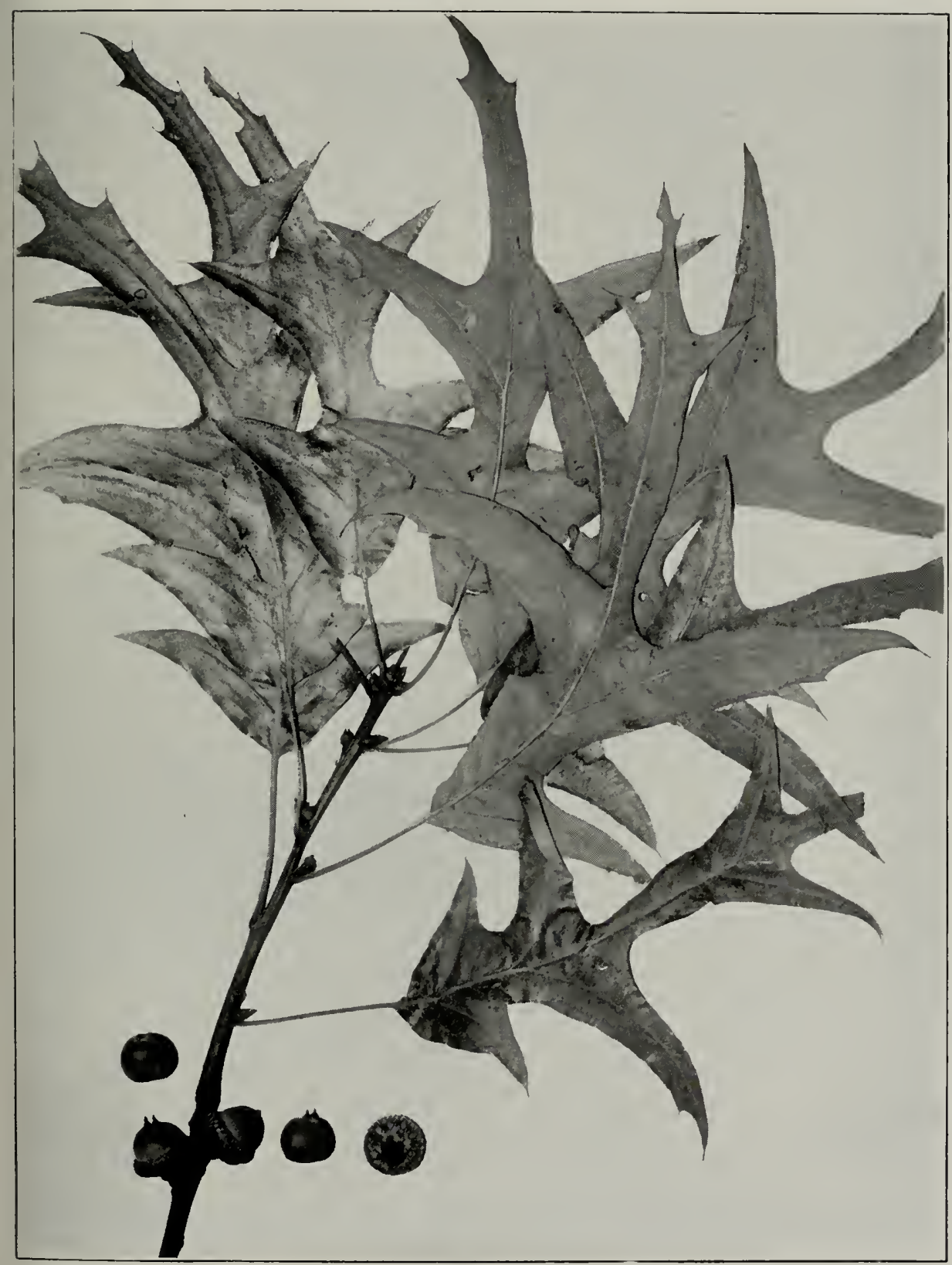

PLATE 36

QUERCUS RUBRA LinNaEus

SPANISH OAK 
Lses: The hard and coarse-grained but not very durable, light-red wood of the Spanish Oak is made into rough lumber; and, because it is less subject to defects than lumber from other red oaks, it finds considerable use in the manufacture of chairs. tables, and similar articles. The hark is rich in tamnin.

\section{QUERCUS RUBRA LINNAEUS \\ Variety PAGODAEFOLIA Ashe \\ Swamp Spanish Oak Red Oak}

The Swamp Spanish Oak, though held as a variety of the Spanish Oak, is sufficiently different from it to be considered as a separate tree. It is much larger than the Spanish Oak; and, though of the same habit of growth, its leaves are from 5 - to 11-lobed and are much less deeply cut

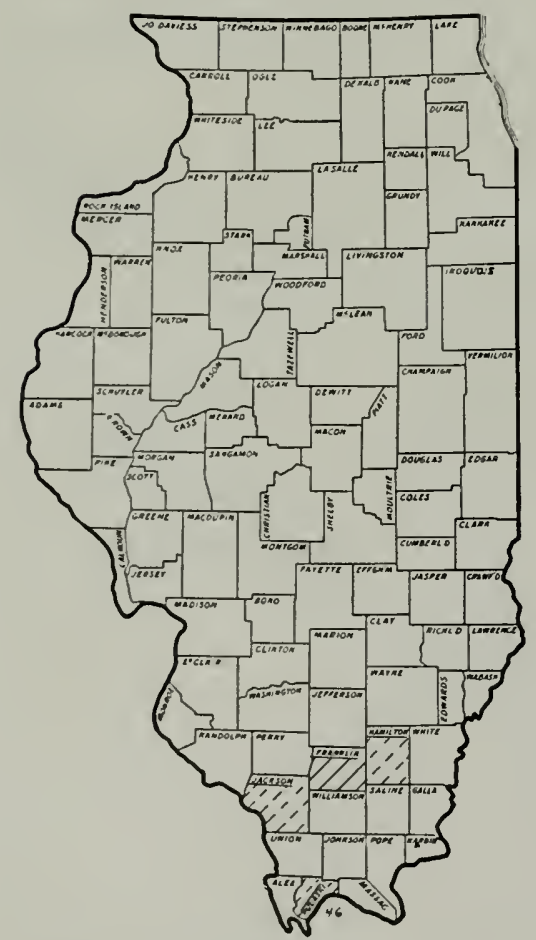

Fifi.46. Distribution of the Swamp Spanish Oak. between the lobes. They measure 6 to 8 inches long by 5 to 6 inches wide and, before falling, they turn brightyellow. The flowers and acorns are similar to those of the Spanish Oak: but the fine-hairy, reddish-brown branchlets bear prominently 4 -angled buds $1 / 4$ inch long. The bark on the trumks, which sometimes grow to a diameter of 4 or 5 feet. is about an inch thick and breaks, on the surface, into plate-like scales. The height of the tree is often 100 feet or more.

Distribution: The Swamp Spanish Oak, a tree of rich bottomlands. ranges from Virginia southward to Florida and westward to Arkansas and Missouri. In Illinois, it is confined to the southern part of the State; but there, though apparently less widely distributed than the Spanish Oak, it is a much more important tree. According to Hall and Ingall's ${ }^{1}$ report of 1911, it made up 20 per cent of the bottomland stand in White County. 12 per cent in Franklin County. and 10 per cent in Hardin, Gallatin, and Saline counties. In these regions

\footnotetext{
111. St. Iab. Nat. Hist. Bull. Vol, 9, Art. 4.
} 


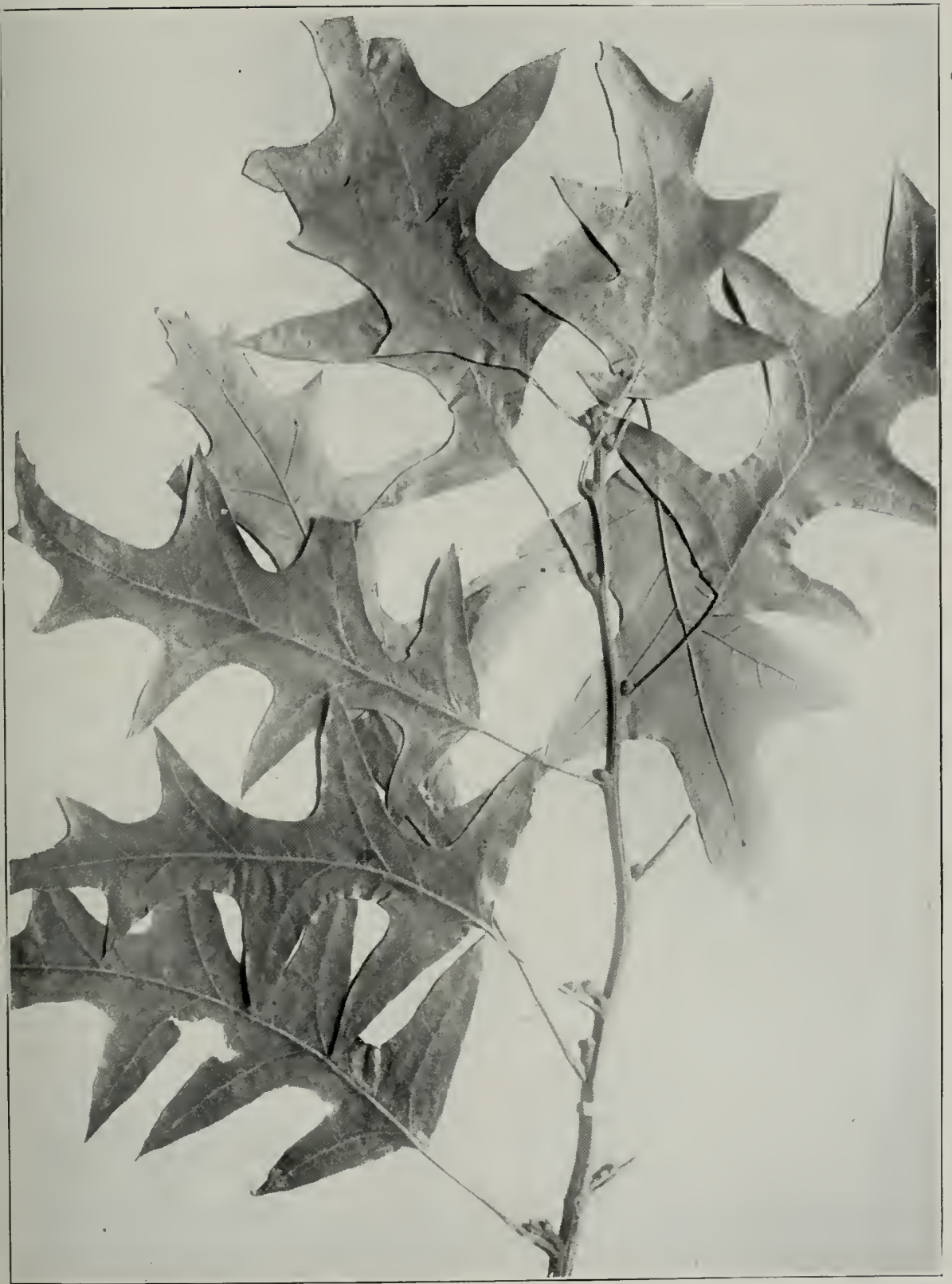

PLATE $3 i$

UERCUS RUBRA PAGODAEFOLIA ASIE SIVIMP SPANISH OAK 
it is associated especially with Pin Oak. Elm, and Black Gum, but it grows also with the Black, White, and Burr oaks, the Red Gum, and several other trees. Robert Ridgway reports the average measurements of 6 "Spanish Oaks" in the lower Wabash Valley as 120 feet high, 1;1/2 feet in circumference, and is to 59 feet in trunk length. He says that this tree is "the most symmetrical and stately of all our oaks : trumk straight and columnar and top massive and dense, reminding one in its appearance of the pecan. A more usual size is 150 feet high, the trunk fifty feet long and 15 feet in circumference four feet from the base."

During recent years, the largest tree seen has been only 100 feet high and $3 t$ inches in diameter, but in the virgin bottomland forests this oak is still capable of yielding some 1500 board feet per acre.

Uscs: The light reddish-brown wood of the Swamp Spanish Oak is made into lumber, and for this purpose it is valued nearly as highly as the wood of the IVhite Oak.

\section{QUERCUS MARILANDICA MUENCHIIALSEN}

\section{Black Jack Scrub Oak}

The Black Jack, commonly called Scrub Oak in Illinois, is a small tree with an open, narrow, round-topped crown of drooping branches. The thick and leathery, dark-green leaves, yellow-green beneath, are characteristically 3 -lobed, but the lobes, which form the much-expanded top of the leaf, often are not cut out deeply. From the lateral lobes, the leaf blade slopes regularly to a narrow, rounded base. The leaves are 6 to $i$ inclies long and equally broad. The staminate catlins are 2 to 4 inches long; and the pistillate flowers, of ten in pairs, stand on the ends of short. rusty-woolly pedicels. The light-brown acorns about $3 / 4$ inch long, are buried for $1 / 3$ to $2 / 3$ of their length in deep, reddish-brown, stalked cups. the upper scales of which form a thick rim around its inner surface. The stout, gray to Lrown branchlets bear pointed, prominently angled buds, which are covered by rusty-haired scales. The dark-brown to black bark, which is deeply fissured into square plates 1 to 3 inches long. covers small trunks, which seldom exceed a diancter of 12 inches. The usual height of the tree is from 20 to 40 feet.

Distribution: The Black Jack is a tree of sandy and clayey barren lands. It ranges from New York into Florida and westward into Illinois, Arkansas, and Texas. In Illinois, it is found throughout a large part of the State on sterile soils, sands, and waste lands. Its most north- 


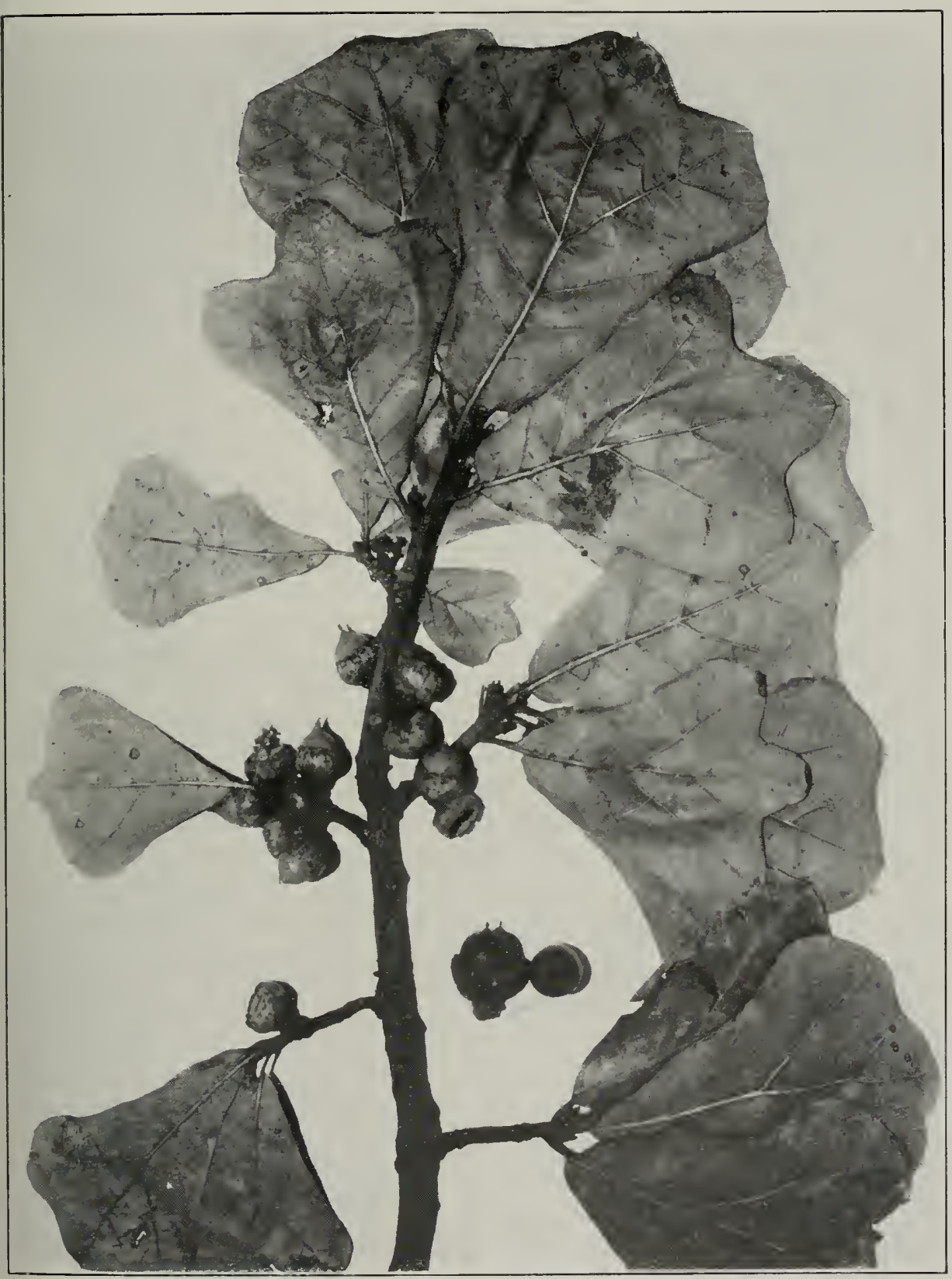

PLATE 38

QUERCUS MARILANDICA Muenchiausen

BLACK JACK 
ern stations are in Henderson and Woodiord connties, but southward it becomes a common tree. Its associates are commonly the Black, Burr, and Post oaks, hickories, and Sassatras. In the sonthern counties, it is most frepuently seen on the light gray silt loam soils that are underlaid ly tight clay-situations commonly called post oak flats-and, according to llall and Inesall ${ }^{1}$ the Post Oak, which normally is most abundant, is (1110umbered by the Black Jack where fires have occurred. Vestal ${ }^{2}$ also

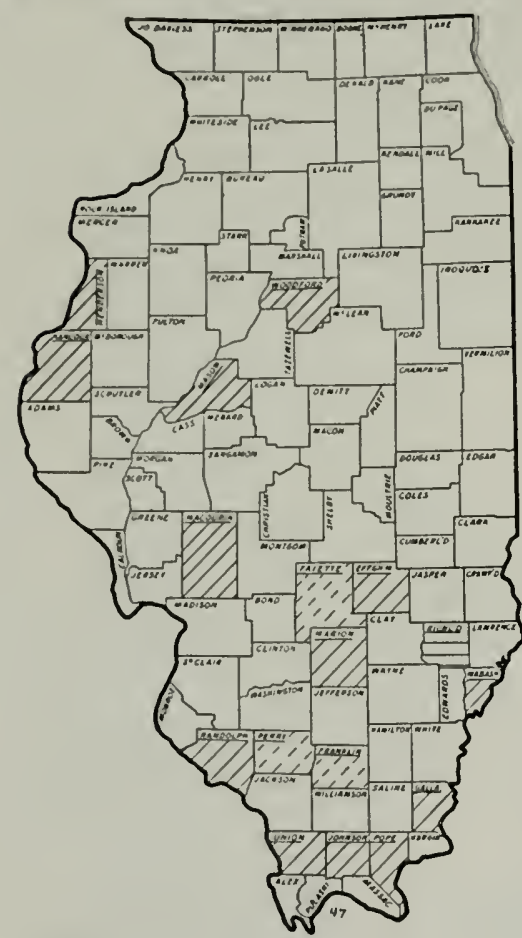

Fig. 47. Distribution of the Black Jack. reports that, in the succession from bunch grass to forest on the sands of Mason County, it and the Black Oak are anong the first to become established on the dry sand ridges.

There is a considerable difference letween the leaves of the Black Jack in the northern and the southern part of the State. On the sandy plains in Henderson County, about Oquawka. its leaves are 3-lobed and not very velvety beneath, except for the petioles and veins. But southward, the leaves are often i-lobed and almost felty beneath.

Lses: The rich-brown wood of the Black Jack, though heavy. hard, and strong, has but little commercial value, for the tree does not attain any considerable size and the wood is not sufficiently clurab!e in the soil to make good fence posts. Its chief uses are as fuel and in the manufacture of charcoal. Nevertheless, there are now alout !).(0)(0) acres of sandy soils wouded with Scrub Oak, and the preservation of these stands is justified by the ability of the trees to prevent the drifting of sands onto neighboring fields. In these situations Scrub Oak, or lBlack Jack, constitutes between 25 and 20 per cent of the stand, but it attains no great size, the largest tree measured being 4. feet high and 1.5 inches in cliameter, in comparison with the average i) (1)-font height of Black Oak in the same situations.

13ul. 111. St. labl. Nat. Hist. Vol. 9, Art. 4. 1911.

2 Iul. 111. St. 1all. Nat. Hist. Fol. 10, Art. i. 1913. 


\section{QUERCUS PHELLOS LiNNAEUS}

\section{Willow Oak}

The Willow Oak is a moderate to large tree, with small branches which form an open, rather narrow crown. The light-green, shiny leaves, the blades of which are not lobed, measure $2 \frac{1}{2} 2$ to 5 inches long by $1 / 2$ to 1 inch wide and usually are smooth beneath. Their petioles are only about $1 / 8$ or $1 / 4$ inch long. The loosely flowered staminate catlins are 2 or 3 inches long: and the pistillate flowers stand, alone or in pairs, on slender, smooth pedicels. The yellow-brown, pale-hairy acorns, which are almost henispherical and $3 / 8$ to $\mathrm{J} / 2$ inch long. stand in rather shallow, somewhat woully cups. The stout, reddish-brown twigs bear sharply pointed, chestnutbrown buds about $\mathrm{I} / \mathrm{s}$ inch long. The trunk, which usually has a diameter of about 2 feet, is covered by thin. smooth, brown bark, which eventually divides by narrow fissures into iriegular plates. The usual height of the tree is io to 80 feet.

Distribution: Inhabiting the wet borders of streams and swamps, the IVillow Oak ranges from southern New Jork into Florida and westward to Texas and Illinois. It is, however. it rate tree in Illinois, being found only in the four southermmost counties. Its

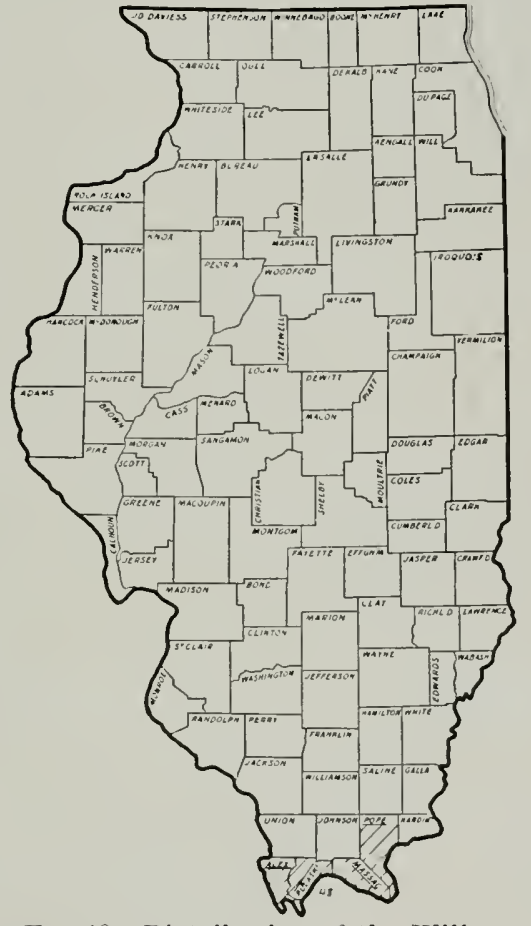

FIg. 4S. Distribution of the Willow Oak. occurrence in Pope and Massac counties is reported by C. S. Sargent, and E. J. Palmer has collected specimens of it in Alexander County. It has been found by C. I. Telford in Pulaski County also. on the bottomlands of the Cache River. where it is associated as an occasional tree with the Pin and Shingle valis, the Sweet Gum, Soft Maple, and Elm. Henry Engelnann, the geologist, writes" that in 1866 he "found several north of Broolilyn," in Pope County, "in a wet flat, along with post oak, water oak, Spanish oak, laurel oak, black oak, barren hickory, scaly-bark hickory. sweet gum, and similar trees."

${ }^{1}$ Geology of Illinois, Vol. 1, p. 433. 


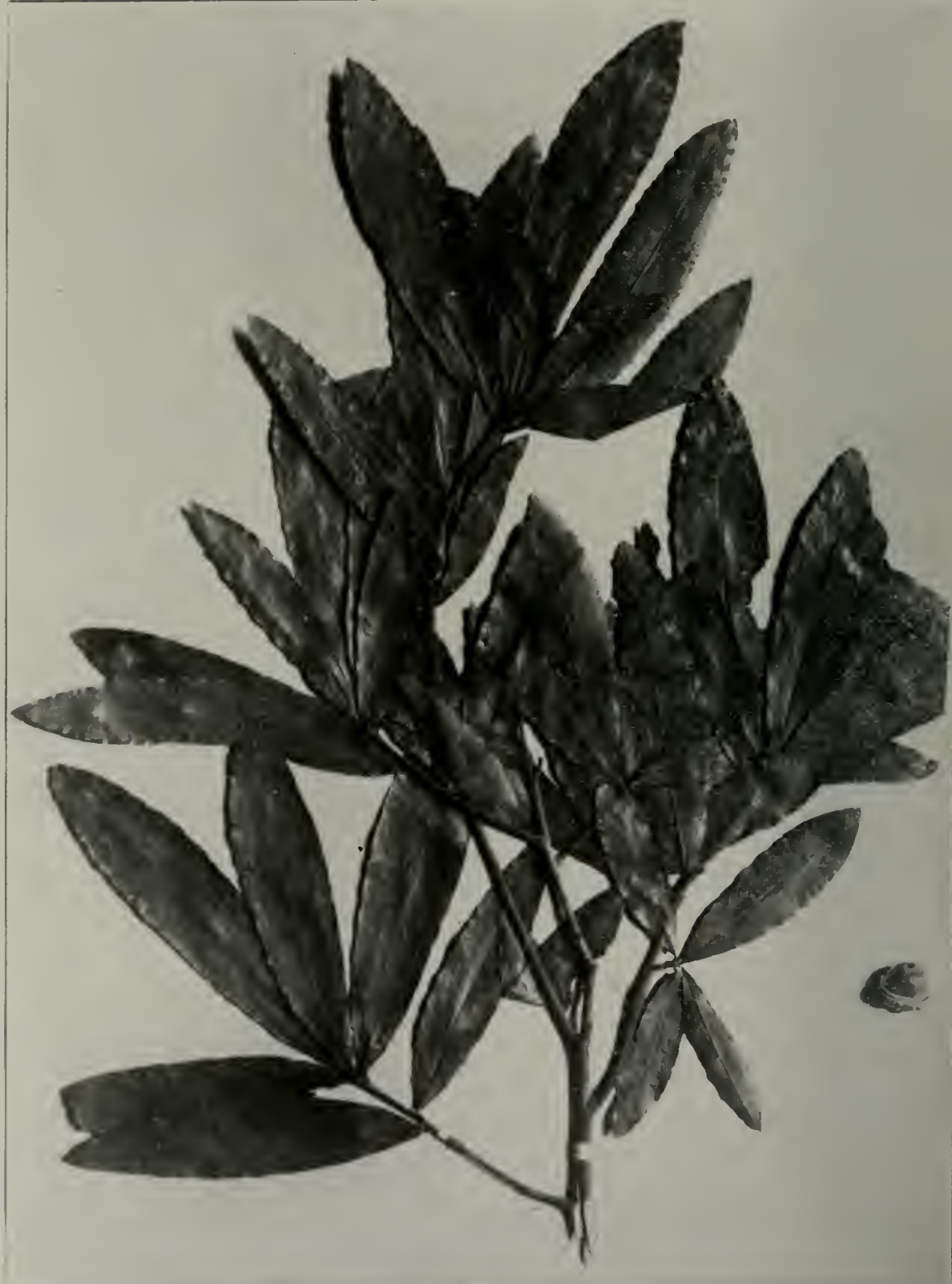

PLATE 3!)

QUERCLS PHELLOS LiNNaEUS

WIILLOW OAK 


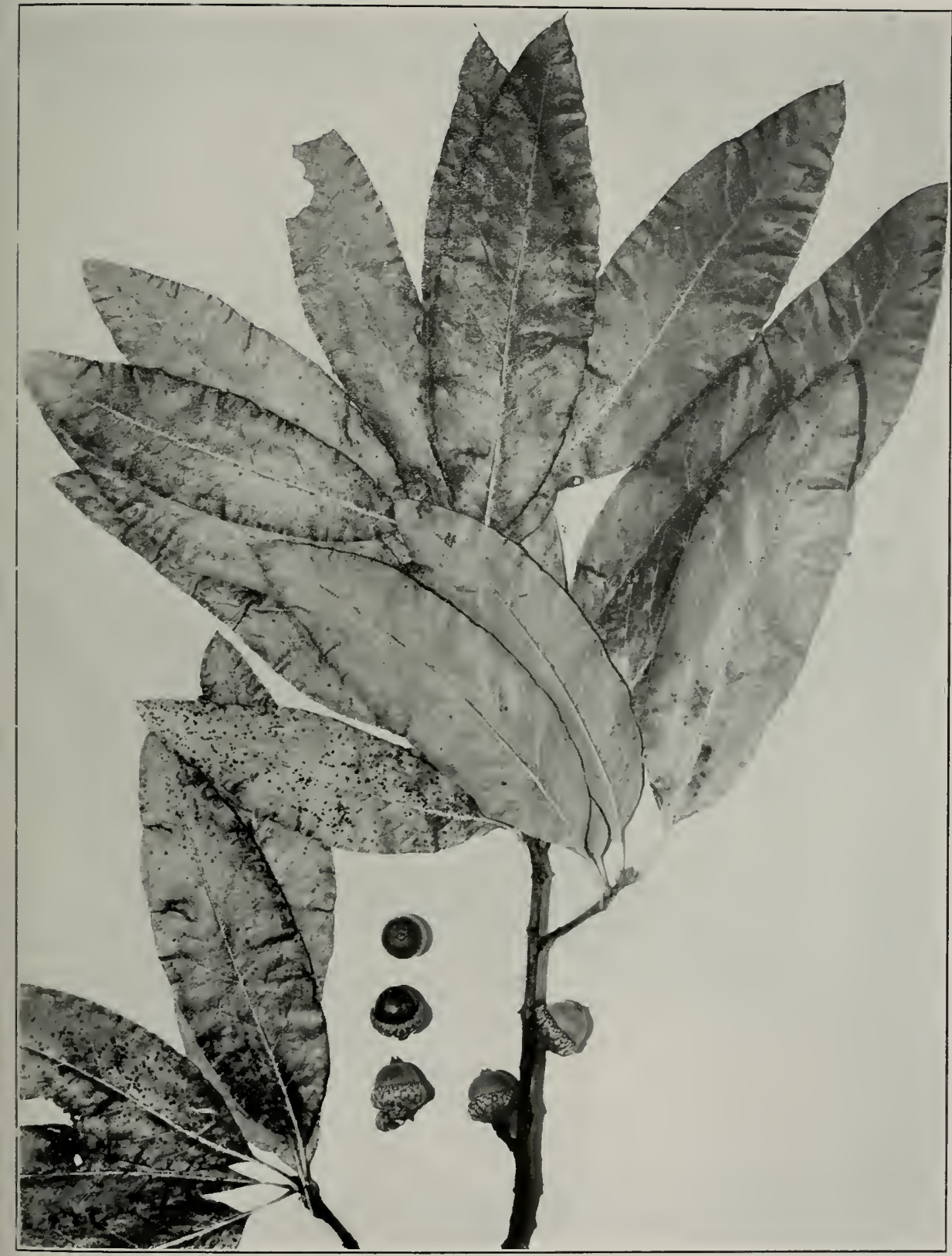

PLATE 40

QUERCUS IMBRICARIA MICHAUX

SHINGLE OAK 
Lscs: The heavy and rather coarse-grained wood of the Millow Oak is strong. though not hard, and is used in North Carolina for railroad ties, bridge planks, and general rough construction. In lllinois, the tree is so rare that it has no commercial value.

\section{QUERCUS IMBRICARIA MICIAUX}

\section{Shingle Oak Laurel Oak}

The Shingle Oak is a tree of moderate size. with a long. clear bole from which the s!ender. horizontal branches grow to form a narrow, round-topped head. The thin, dark-green, shing leaves, 4 to 6 inches long by 1 to : inches wide, have entire, or rare!y somewhat 3 -lobed.

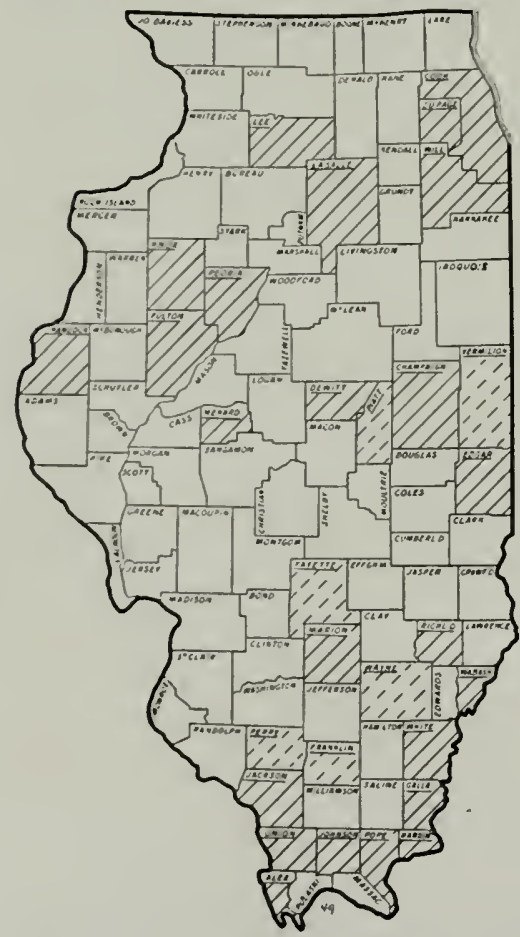

Fic, 49. Distribution of the Shingle Oak. blades covered with hair beneath. The stout, hairy petioles are about $1 / 2$ inch long. The white-woolly staninate catkins are 2 or 3 inches long; and the pistillate flowers stand on slencler. woolly pedicels. The dark chestnutbrown acorns, $1 / 2$ to $3 / 4$ inch in diameter, are buried for about $1 / 3$ of their length in a thin cup, which is sup)ported by a stout stalk often $\mathrm{I} / 2$ inch long. The slender. light-brown branchlets bear somewhat angled, light-brown buds about $1 / 8$ inch long. The trunk, which is covered by lightbrow'1, shallowly fissured, broadridged bark, becomes 2 or 3 feet in diameter, and the tree attains a height of jo) feet or more.

Distribution: The Shingle Oak, which is a tree of rich hillsides and strean bottomlands, ranges from Pennsylvania westward into Iowa and southward into Georgia and Arkansas. It is to be found practically throughout Illinois, for though there are as yet no records of it in the northern tier of counties, it is found farther to the north in Wisconsin. The tree grows to its greater size in the southern counties, where, with the Pin Oak, it is one of the commonest trees along streams tributary to the large rivers. The biggest tree found in this region was 80 feet high and 23 inches in diameter. 
Uses: The heavy, rather close-grained, and hard wood of the Shingle Oak often is used for clapboards and shingles, but the trees which are cut in southern Illinois are sold as black oak for the furniture and veneer trade.

\section{QUERCUS MACROCARPA Michaux Burr Oak Mossy Cup Oak}

The Burr Oak is one of the largest oaks. Its massive, spreading limbs arise at a considerable height from the ground and form a broad open crown. Its thick and lustrous leaves, $;$ to 12 inches long by 3 to 6 inches wide, have decply $\check{\text { j- to }}$-lobed, characteristic blades, covered with soft pale hair beneath, which expand from a wedge-shaped base to the very large and wavy-toothed end lobe. The rather sparsely flowered staminate catlins are 4 to 6 inclies long, and the solitary or paired pistillate flowers stand on short or long woolly pedicels. The chestnut-brown acorns, which are finely hairy at the top and often 2 inches long, are buried to half their length or more in a deep, bowl-shaped cup whose upper scales are prolonged into a distinct mossy fringe. The stout, pale-orange twigs, which develop into dark-brown, often corkywinged branchlets, bear pale-brown, oval, hairy buds $\mathrm{I} / \mathrm{s}$ to $\mathrm{I} / \mathrm{t}$ inch long. The trunk, which is covered by palebrown, deeply furrowed, plated bark, attains a diameter of $t$ feet or more, and the tree is often more than 100

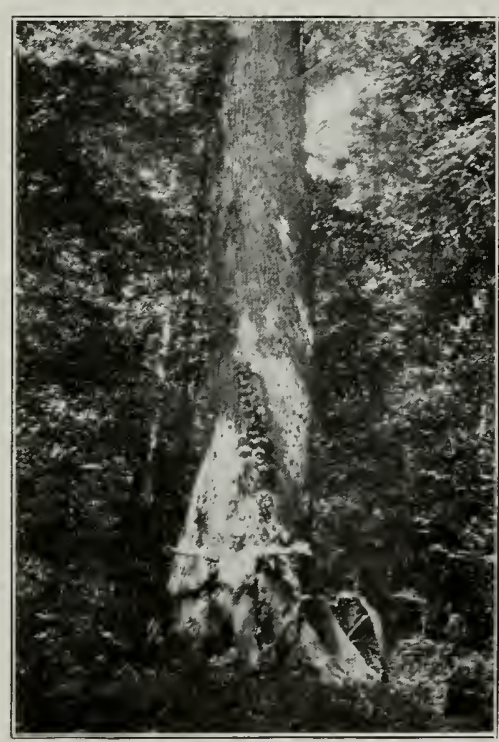

FIG. 50. A large Burr Oak in Union County. feet high.

Distribution: Inluabiting the deep. moist soils of bottomlands and swales, the Burr Oak ranges from Nova Scotia westward into Manitoba and Montana and southward to Pennsylvania. Tennessee, and Texas. In Illinois, it grows throughout the State, finding satisfactory conditions for growth on the sands of the north, in the gravelly moraines of the central part, and in the bottomlands not only of the south but of the north as well. According to G. D. Fuller ${ }^{1}$, it is found commonly in the

${ }^{1}$ Trans. I1l. State Acad. Sci. Vol. 12, pp. 251-252. 1915. 
upland oak and dry oak forests of La Salle and adjoining counties, where it is associated with such trees as the Red. White, and Black oaks and hickory. It occurs also in the bottomland forests of the same region With Blaci: Walnut, Black and Green ashes, Pass Wood, and others.

In the northern parts of Illinois, it has a short bole, which often makes but one good log length; but in the bottomlands of southern Illinois it towers massively above the other trees. The photograph, Figure 50, shows a tree ?20 years old, on the Spann tract near WVare.

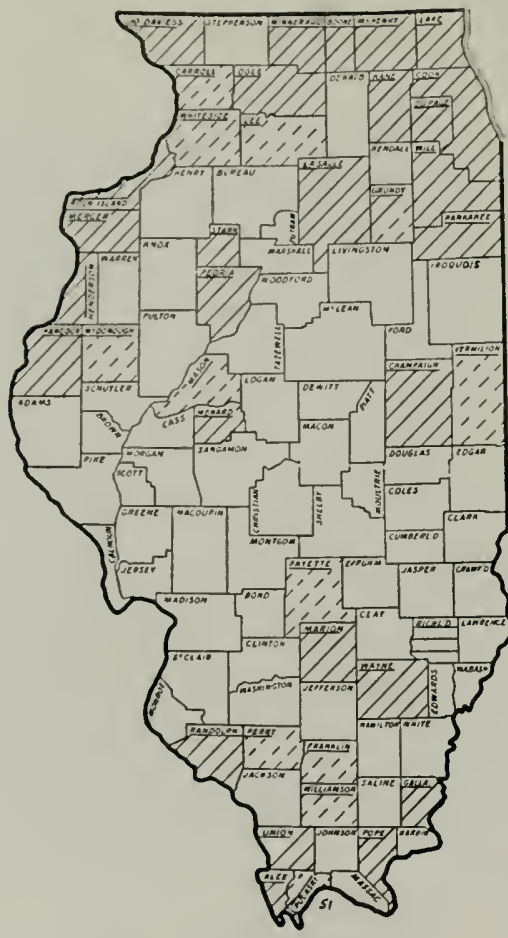

FIg. 51. Distribution of the Burr Oak.

Union County, which when measured in $19 \cdot 2 \pm$ had a height of $1: 1$ feet. a crown 63 feet wide and a trunk circumference of 15 feet. The bole had a $\log$ length of $5 j$ feet and a lumber content of 5,000 board feet. A standing but dead tree thrce miles east of Belle Prairie. Hanilton County, had a height of 90 feet and a trunk circumference of 1 i feet.

The largest living tree that has been measured in Illinois is a Burr Oak in Brownfield Woods near Urbana, which has a height of 104 feet and is 1.5 feet and 9 inches in circumference $t^{\mathrm{T}} / 2$ feet above the ground.

Uscs: The close-grained, tough wood of the Burr Oak, which is lard and heavy, strong and very durable, is put to a great variety of uses, which range from fuel to ship building and cabinet making. In durability and strength, it ranks with white oak and is seldon separated from it on the market.

In the Cypress forests of southern Illinois. Burr Oak constitutes only a very small part of the stand, but it is a little more common in the mixed hardwood forests of the main streams and is most abundant in the upland mixed hardwood forests. But nowhere in the State does it become an important lumber tree. 


\section{QUERCUS LYRATA WALTER}

\section{Overcup Oak Swamp White Oak}

The Overcup Oak is a tree of rather nore than medium size, with a bole that splits. 15 feet or so above the ground, into rather small and somewhat drooping branches which form a fine, round-topped crown. The deeply or shallowly j- to 9-lobed leaves, ? to 10 inches long by 1 to -1

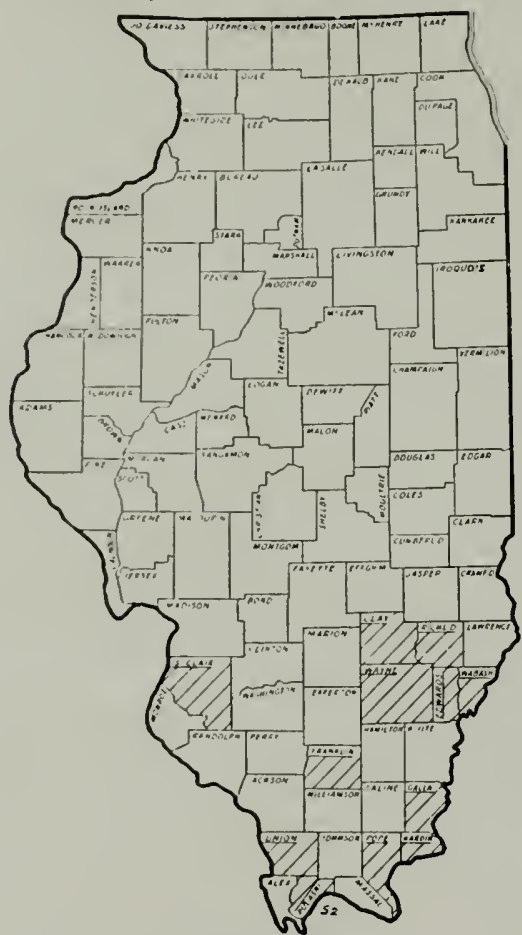

FIG. 52. Distribution of the Overcup Oak. inches wide, are thin but firnt, darkgreen and smooth above and green and more or less hairy or velvety beneath. Their petioles are $I / 4$ to 1 inch long. The hairy staminate catlins are from 4 to 6 inches long; and the pistillate flowers stand alone or in pairs, either sessile or on stalks thickly covered with pale, short hair. The globular, light-brown acorn $\mathrm{I} / 2$ to 1 inch long, is almost completely buried in a deep, spherical cup which stand. on a slencler. hairy stalk sometimes $1 \mathrm{r} / 2$ inches long. The edge of the cup) is thin and often irregularly split. The slender. orange or gray-brown twigs bear pale-brown buds about $\mathrm{I} / \mathrm{s}$ inch long, the scales of which are more or less hairy. The trunk, which is seldom more than 2 feet in dianeter, is clothed by red-tinted gray bark, which is broken into thick plates. The usual height of the tree is from 60 feet $u p$.

Distribution: Through river swamps and wet bottomland hollows, the Overcup, Oak ranges from New Jersey to Florida and westward to Missouri and Texas. In Illinois, it is confined to the southern third of the State, where, though relatively rare, it is one of the characteristic trees of the bottomland Cypress forests of the Cache River, especially on the better-drained parts of the overflowed land, and of the Mississippi bottonland in Union County.

Uscs: The wood of the Overcup Oak is very durable in the soil and is, in general, very sinilar to the wood of the White Oak, with which it is sold without commercial distinction. It is not commercially important in Illinois. 


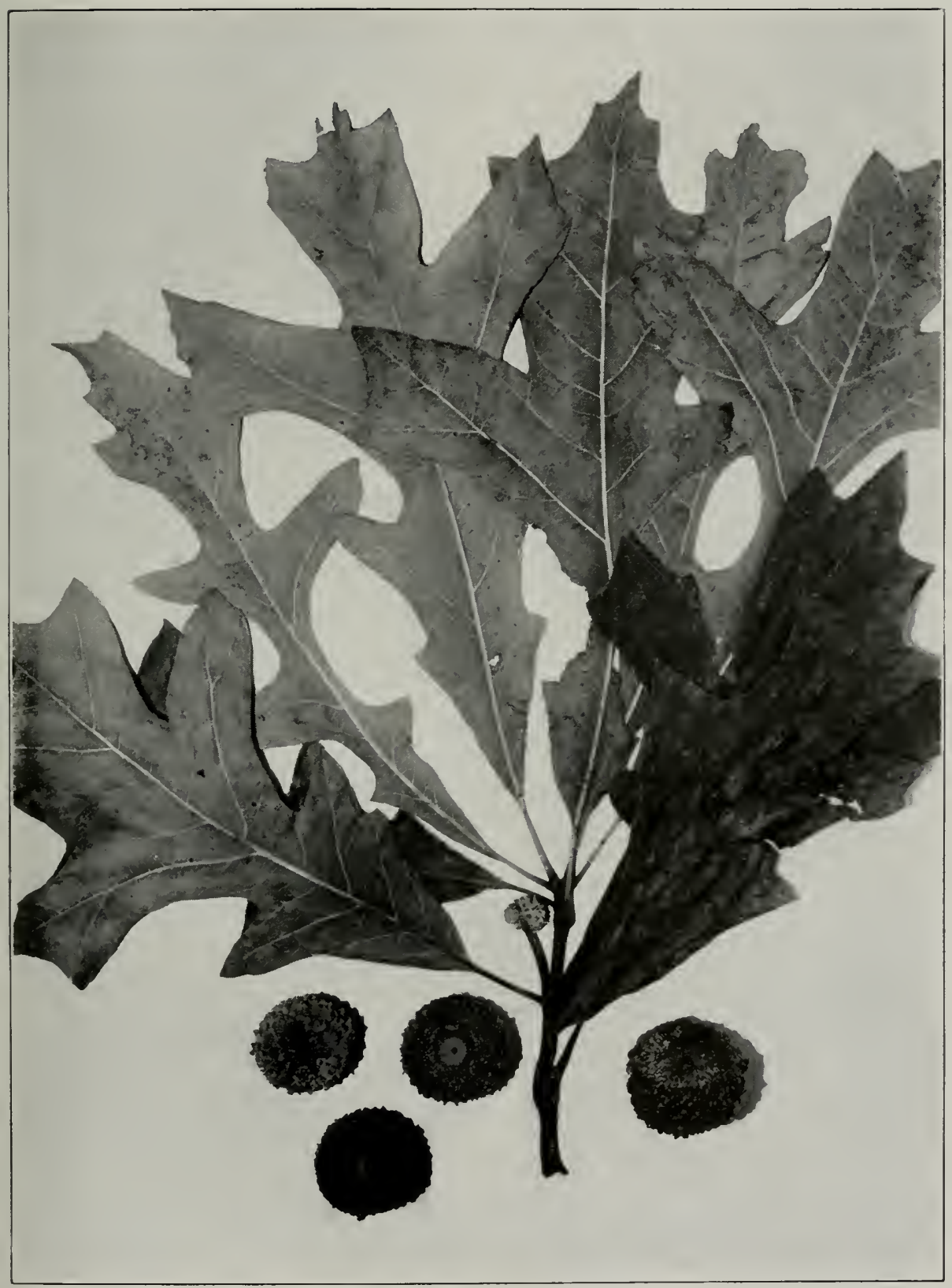

PLATE 4?
QUERCLS LYRATA WALTER
OVERCUP OAK 


\section{QUERCUS STELLATA WANGENHEIM}

\section{Post Oak}

The Post Oak is a tree of only moderate height, with a broad crown of stout, dense branches. The deeply j-lobed leaves, 4 to 5 inches long by 3 to 4 inches wide, are thick, dark-green above, and covered beneath by velvety hair. Their stout petioles are from $1 / 2$ to 1 inch long. The

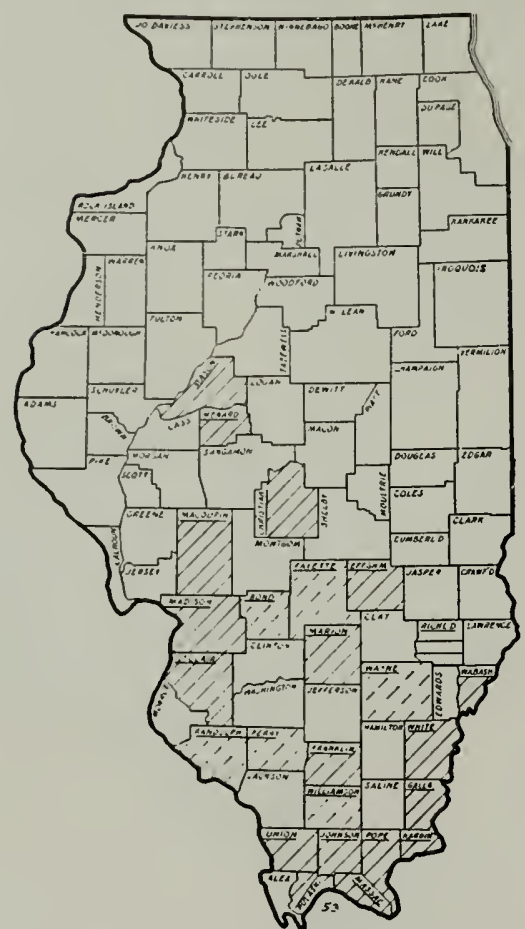

FIG. 53. Distribution of the Post Oak. staminate catkins are $\ddot{z}$ or 4 inches long. and the pistillate flowers stand alone on very short stalls. The lightbrown, hairy-tipped acorns, $1 / 2$ to 1 inch long, are, for about $1 / 3$ of their length, held within fairly deep cups. which are sessile or short-stalked. The stout, orange, velvety twigs bear oval buds $\mathrm{T} / \mathrm{s}$ to $\mathrm{T} / 4$ inch long. Which are covered by bright, brown, hairy scales. The trunk, which is seldom over $1 \mathrm{t} / 2$ feet in diameter, is covered by redbrown, deeply fissured, broad-ridged bark. The tree, in age, usually attains a height of 50 or 60 feet.

Distribution: The Post Oak ranges from Massachusetts southward to Floricia and westward to Mississippi and Iowa. In Illinois, it is a common oak of the uplands from Mason county southward, and throughout this region it is found on light-gray silt-loam soils underlaid by tight clay, where it forms characteristic "Post Oak flats."

Where the conditions are uniform. Post Oak forms pure stands; but the poorly formed trees have short, rapidly tapering trunks. On the poorest soils, it is mixed with Black Jack; on better soils, it grows with Black and White oaks and hickory; and if the ground is wet, there may be Pin and Shingle oaks also. In southern Illinois, its most common associates have been observed to be the Black and Scrub oaks and hickory, with Swanp Spanish. White, Schneck's, Pin, Burr, and Shingle oaks, as well as Ash, Elm, and Sycamore less common.

Post Oak grows very slowly-probably more slowly than any other tree in Illinois--producing not over 16 cubic feet per acre annually. The 


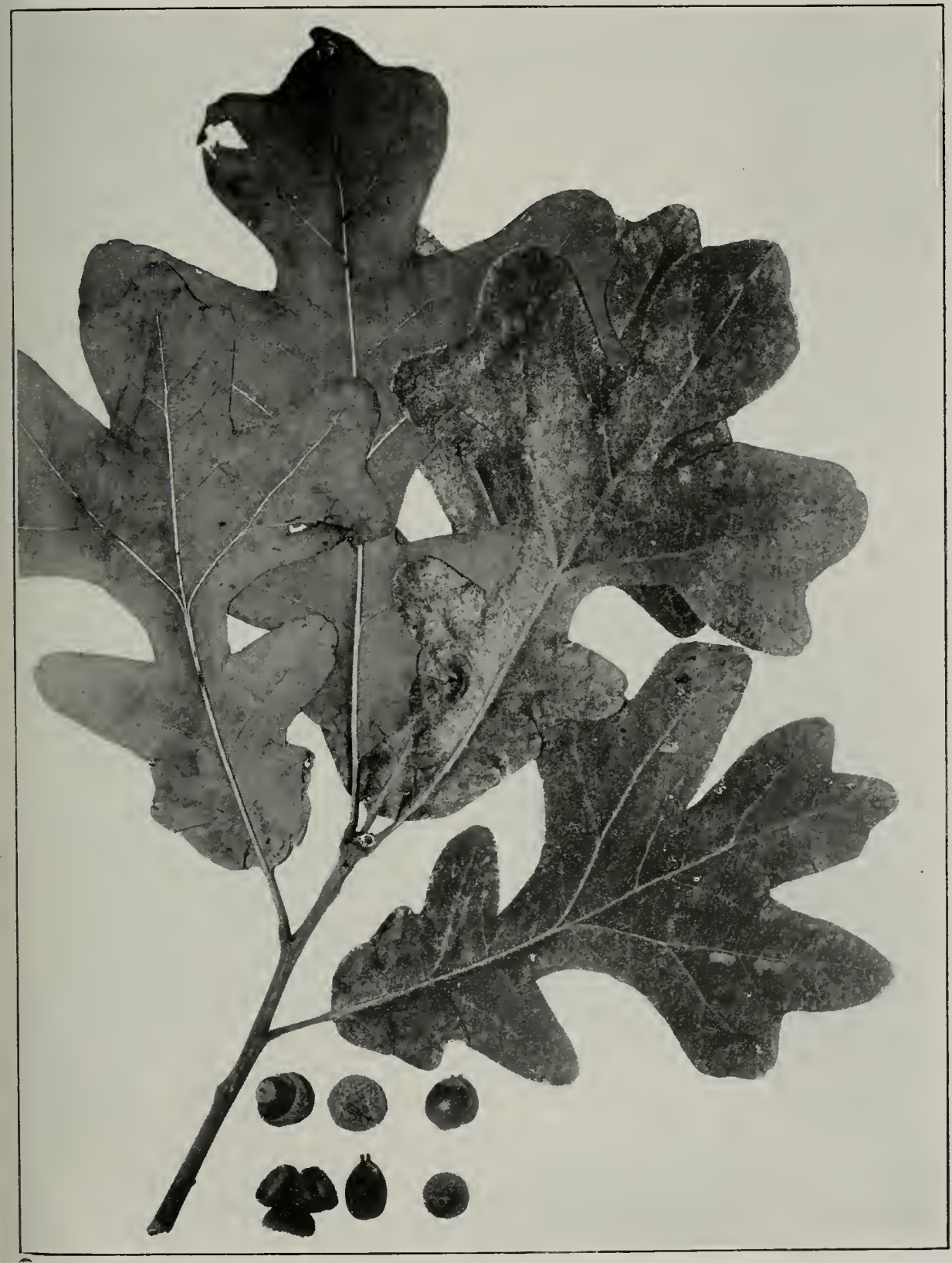

PLATE 43

QUERCUS STELLATA WANGENIEIM POST OAK 
largest tree found in this State was i0 feet high and 25 inches in dianeter. Prees i.j feet high and 12 to 14 inches in diameter are usually 100 years old. and trees which have attained a height of 6. .) feet and a cliameter of 30 inches may be as old as :300 years.

Usis: The hard, close-grained wood of the Post Oak is very heavy and is durable in the soil. Though sometines employed in rough construction, in cooperage, and in carriage-making, it is used chiefly for fuel, fence posts, railroad ties, and mine props.

The Post Oak flats, thongh stocked with a considerable number of trees per acre, do not yield any consiclerable amount of lumber. When the trees are cut for fence posts and mine props, they barely pay the taxes on the land; and when they are cut into cordwood, they do not even do this.

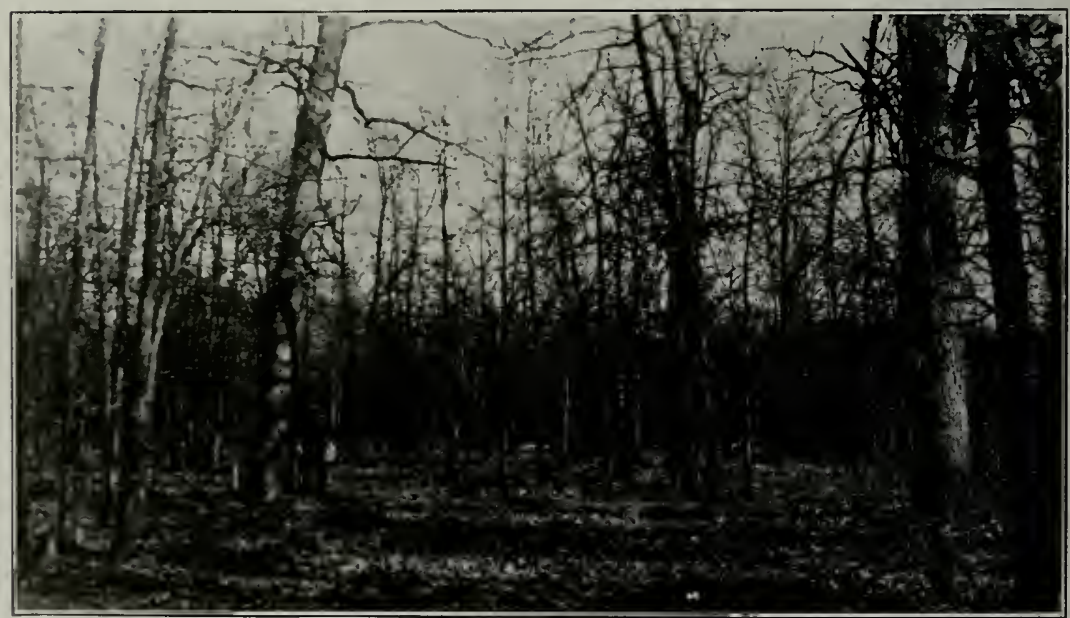

Fic. 54. Virgin stand of Post Oak on uplands in Perry County. The smaller trees are as much as a century old, and the larger trees three centuries. 


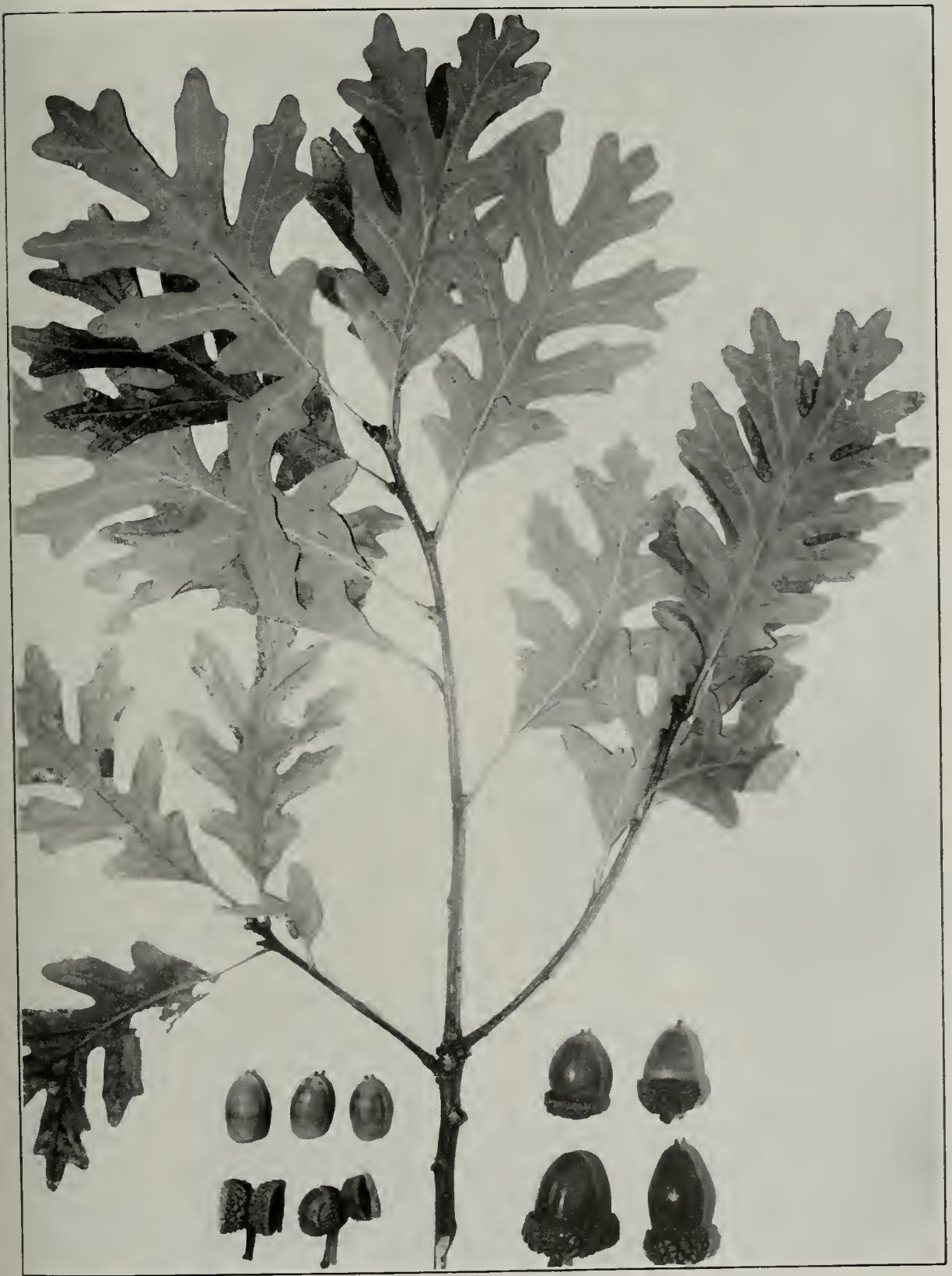

PLATE 14

QUERCUS ALBA LiNNAEUS

WHITE OAK 


\section{QUERCUS ALBA LINNAEUS}

\section{White Oak}

The White Oak is a molerately large tree, with a tall, clear bole and a narrow crown of stout branches. The thin, bright-green leaves, 5 to !) inches long by 2 to + inches wide, have shallowly or deeply $;$ - to 9 -lobed hlades which, though paler, are not hairy beneath. The stout petioles are

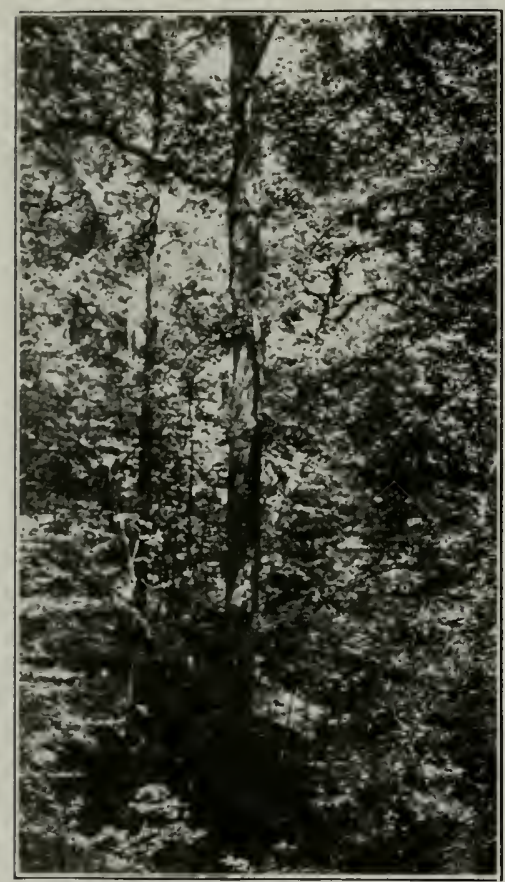

Fir. 55. White Oak in a ravine near Alto l'ass. Photo by $H$. $H$. Chapman. smooth and $1 / 2$ to 1 inch long. The staminate catkins are $21 / 2$ to 3 inches long; and the bright-red pistillate flowers stand alone on very short stalks. The oval, light-brown, shiny acorns, $3 / 4$ inch long, stand in rather shallow cups, which are either sessile or provicled with stalks 1 or 2 inches long. The red or gray twigs bear dark reddish-brown buds about $1 / 8$ inch long. The trunk, ordinarily $2 \mathrm{or}$ 3 feet in diameter, is covered by lightgray to nearly white bark, which is clivided by shallow fissures into long, irregular, thin scales. The tree is usually 60 to 80 feet high.

Distribution: The White Oak ranges, in a great variety of habitats. from Maine southwestward to Nebraska and southward to Florida and Texas. In Illinois, it has been fomnd by collectors and foresters in it 4 comm ties and undoubtedly occurs throughout the State. It often grows in prirc stands of some extent, on rolling 11 )lands and in ravines, dipping from them into the valleys, where it mixes gradually with other species, such as Beech. Tulip Tree, and Red Gum. The tallest and straightest trees, most suitable for sawlogs, piling, and railroad ties, are found on the sides of ravines. In the grazed woodlots of the northern and central counties, it often grows to a large size; but though the crown of heavy limbs may be immense, the bole is short and not of great value. In the upland timber of Union Connty, in the neighborhood of Jonesboro and Alto Pass, the White Oak constitutes from 20 to 23 per cent of the stand; on the western bluffs, from St. Clair 
County northward, it constitutes $3 t$ per cent; and it makes up about tis per cent of the trees in the woodlots in the central and northern counties. In the Kaskaskia bottoms, between 1; and 18 per cent of the trees are White Oak, while in the adjeining bottoms of the secondlary streams 1; per cent are White Oaks. The forest along the Big Muddy River is letween 5 and 6 per cent White Oak; but the tree is not common along the large rivers in the north nor on the sterile sands and acid soils farored by the Post Oak. Its most common associates have been found to be Black Oak, hickory, Elm, ashes, Mild Black Cherry, Walnut, Hard Maple, Red Oak, Honey Locust, Bass IVood, and Sycamore, in about the order given, with Shingle Oak. Black Jack, Red Gum. Mulberry, and Hackberry less irequent.

The White Oak reaches its greatest size in the southern counties. The largest tree measured in our survey was 130 feet tall and to inches in diameter; and there are still fine trees, like the one shown in Figure 5.5. growing in the ravines of Union County.

The original White Oalis of the Wabash Valley also attained a great size. Ridgway gives the average height of 6 trees as $11, \mathrm{j}$ feet, the clear length of the bole as 48 feet $t$ inches. and the circumference as 14 feet ? inches. Is compared with other species, such as the Red and Pin oaks, the White Oak grows slowly; but in its stands the trees are of many ages, and occasional trees can be cut to supply the demands of the market without destroying the forest.

Uscs: The strong. cloce-grained, light-brown wood of the White Oali ranks highest among the oak woods for its technical qualities. It is hard, very heavy, tough, and durable: and as it is suitable for such a wide variety of uses, ranging from fuel and fence posts to ship-building and cabinet work, that the supply is not sufficient for the demand. efforts are being made constantly to substitute for it the infcrior woods of the black oak class.

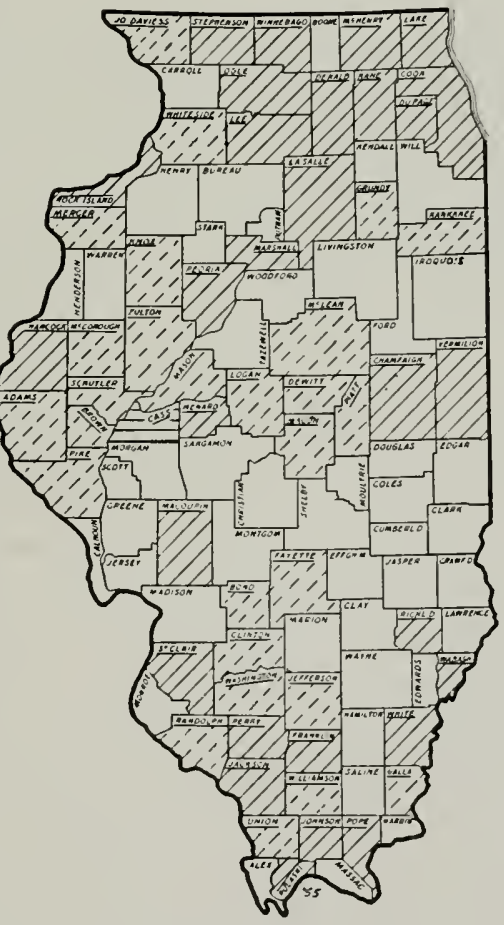

Fig. 56. Distribution of the White Uak. 
In the early days, a large amount of white oak was made into heading and staves for oaken barrels: but most of the stave mills have disajpeirecl. It is used extensively for fence posts, rural line telephone poles. rough construction, and briclge planking. and it is a leacling wood for furniture, interior finishing of houses, railroad car construction, and wagon maling. Some of the best logs go also into the manufacture of highgrarle veneer.

The getting out of ship timbers was a flourishing industry at Mt. (armel about 188.), as is attested by a photograph, given us by Robert Kidgway, which shows the loading of flat cars with squared white oak timbers clestined for the British Nayy. As an inclication of the excellence of the carly Wabash Valley White Oak. Mr. Ridgway reports a Iog 60 iect long which, when squared, was 36 inches wicle.

White oak logs are used also for piles; and, according to the best estimates we can obtain, about one-third of the piling produced in Illinois is of this lind.

\section{QUERCUS BICOLOR WILLDENOW}

\section{Swamp White Oak}

The Swamp White Oak is a tree of somewhat more than medimm size, with a narrow, open crown of rather small branches, those lower down mstally somewhat drooping. The thick, firm leares, j) to 6 inches long ly: to $f$ inches. widle, have clark-green, shiny blades that are rather densely covered beneath with white hair and are usually very shallowly nlany-lobed or sintate-toothed on their margins. The stout petioles are $1 / 2$ to $3 / 4$ inch long. The hairy staminate catkins are 3 to $t$ inches long; and the pistillate flowers stand, 2 or more together. on long, hairy stalks. The chestuut-brown. hairy-tipped, oval acorns. $3 / 4$ to $1 \mathrm{I} / 4$ inches long. twaklly in pairs on stalks $1 \frac{1}{2}$ to $t$ inches long, are immersed for about $1 / 3$ of their length in thick, rather deep cups, around the rims of which the scale-points often form a short fringe. The light-brown to yellowish twigs, from which the bark can be pulled in thin strips when they become older, hear biunt. oval buds $1 / 8$ to $1 / 4$ inch long. The trunk, which grows to a clianseter of 2 ieet, is covered by a thick, gray-brown bark deeply fissured into long flat ridges. The usual heiglit of the tree is 60 to $r 0$ feet.

Distribution: From southern Maine to Mimesota and southward to Georgia and Arkansas, the Swamp White Oak grows in moist, fertile soils along the borders of streams and swamps. In Illinois, it occurs in scattered counties throughout the State, except the northwest corner, and 


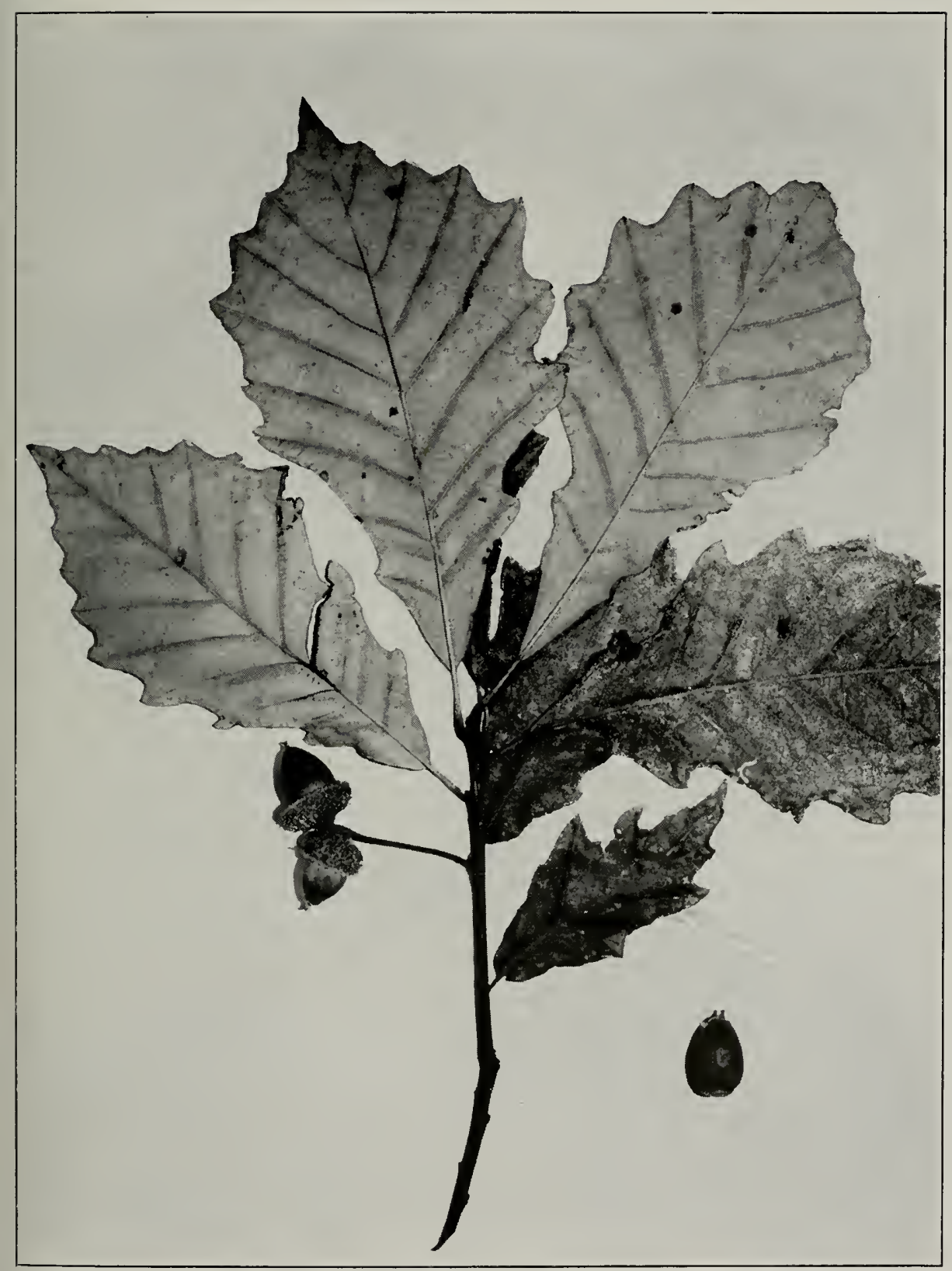

PLATE 45

QUERCUS BICOLOR WilldeNow

SWVAMP WHITE OAK 
very probably is more common than the map scems to indicate. In Coo: and Lake counties, it is reported by Pepoon $^{1}$ as abunclant on the moist Hats. It is common also in similar habitats in the south. In the Cypress forest, 1 tree in $i()$ is Swamp White Oak: in the mixed hardwood forests of the main streans, about 1 tree in 200 . In central Illinois, particularly in logan. Champaign, and Vermilion counties, its common associates are

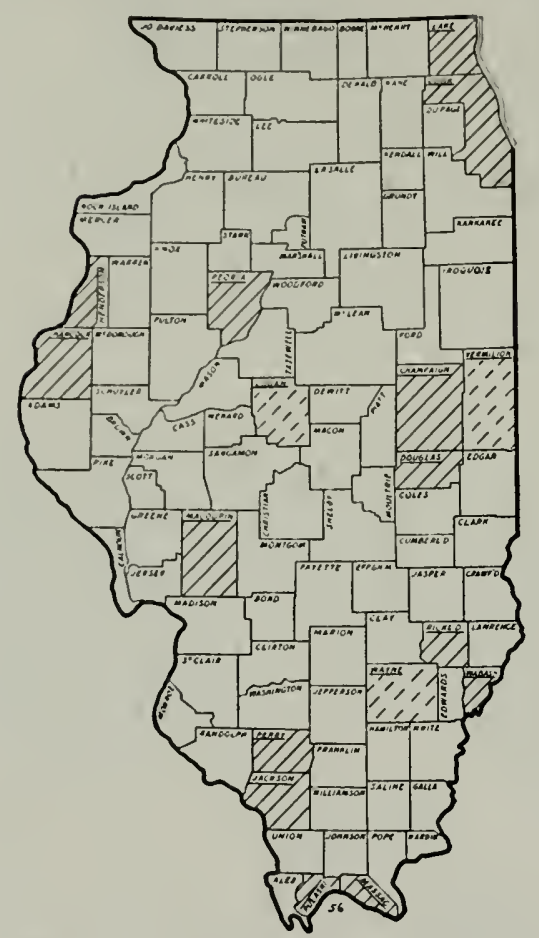

Chinguapin and Red oaks, hickories, ashes, Elm, Hard Maple, Ohio Buckeye, Black Cherry, Bass Wood, Honey Locust, Black Walnut, Hackberry. and Kentucky Coffee Tree; but in the south, notably in Wayne and Pulaski counties, it grows with the Pin and Swamp Spanish oaks, hickories. ashes, Elm, and Red and Black gams.

The largest Swany) IVhite Oak measured in Ilinois was so feet high and $1 \tilde{r}$ inches in dianeter. Trees of this size have reached a very considerable age, for the average tree lives for about 140 years, whi'e a maximum age of +00 years has been recorded.

Uscs: The hard, strong wood of the Swamp White Oak, lightbrown in the heart, is tough and as durable as that of the White Oak. It is employed for a variety of purposes, including fuel, fencing, house Fig. 57. Distribution of the Swamp finishing, boat building, cooperage, and White Oak. cabinet making.

In the better-drained virgin forests of our southern counties, there are about 16 Swamp White Oaks to the acre-the most abundant oak; but the yield is small, being only about 620 board feet per acre as compared to the 1400 board feet of the $\mathrm{Pin}$ Oak, of which there are only half as many trees to the acre.

\footnotetext{
${ }^{1}$ F*lora of the Chicago Region, p. 278.
} 


\section{QUERCUS PRINUS LinNaEUS}

\section{Cow Oak Basket Oak}

The Cow Oak is a tree of moderate size and bulk, with stout, uptilted branches which form a compact, narrow crown. The firm, darkgreen, and lustrous leaves, 6 to 8 inches long by 3 to 5 inches wide, are nale or even silvery-hairy beneath, and their margins are regularly and coarsely toothed. The stout petioles are $1 / 2$ to $1 / 2$ inches long. The slender staninate catkins are 3 or 4 inches long, and the pistillate flowers stand, 2 or nore together, on short hairy stalks. The bright-brown, rather shiny, hairytopped acorns, 1 to $1 \mathrm{~T} / 2$ inches long, are borne in thick and rather deep but flat-bottomed cups with coarse and distinct scales. The red- to orangebrown, stout twigs bear hairy buds about $1 / 4$ inch long, the scales of which are distinctly red-tinted. The trunk, which attains a dianeter of 2 feet or more, is covered by gray bark, which separates into thin, red-tinted scales.

Distribution: The Cow Oak is an inhabitant of the overflow lands of swamps and rivers from New Jersey to Floricla and westward to Texas and Missouri. In Illinois, it is distinctly a southern tree, but it grows occasionally in the central part of the State, as our records for Champaign and Han-

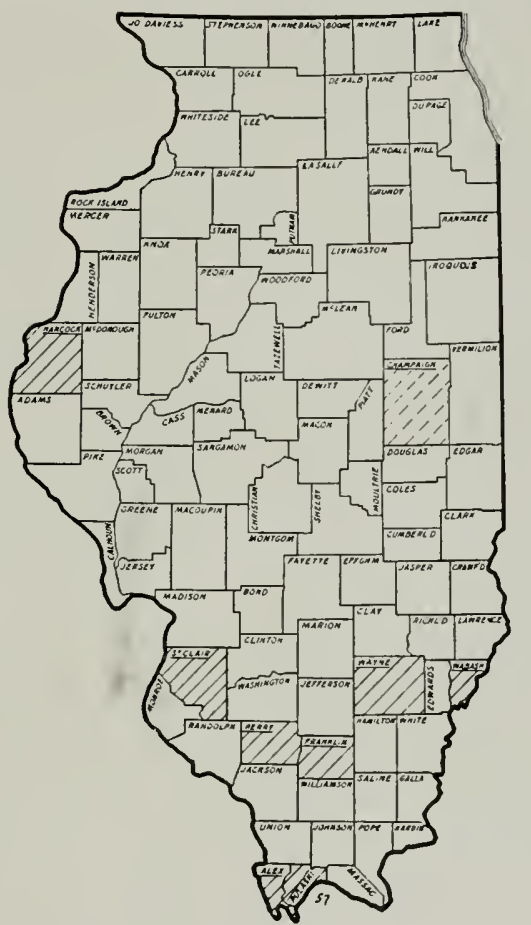

FIG. 58. Distribution of the Cow Oak.

cock counties show. Its chief associates, as indicated by strip survey data in Champaign, Hamilton, Pulaski, and Perry counties, are the Red, Pin, Swamp Spanish, Burr, and Swamp White oaks, hickory, ash, Elm, and the Red and Black gunns, in the order given. The largest Illinois tree measured was 95 feet high and had a trunk diameter of 23 inches.

Uscs: The wood of the Cow Oak, seldom distinguished by the lumber trade from that of the White Oak, is close-grained and hard, as well as tough and durable in the soil. It is of a somewhat lighter brown than White Oak wood and generally has less conspicuous tangential bands of parenchyma fibers in the late wood (see page 306). 


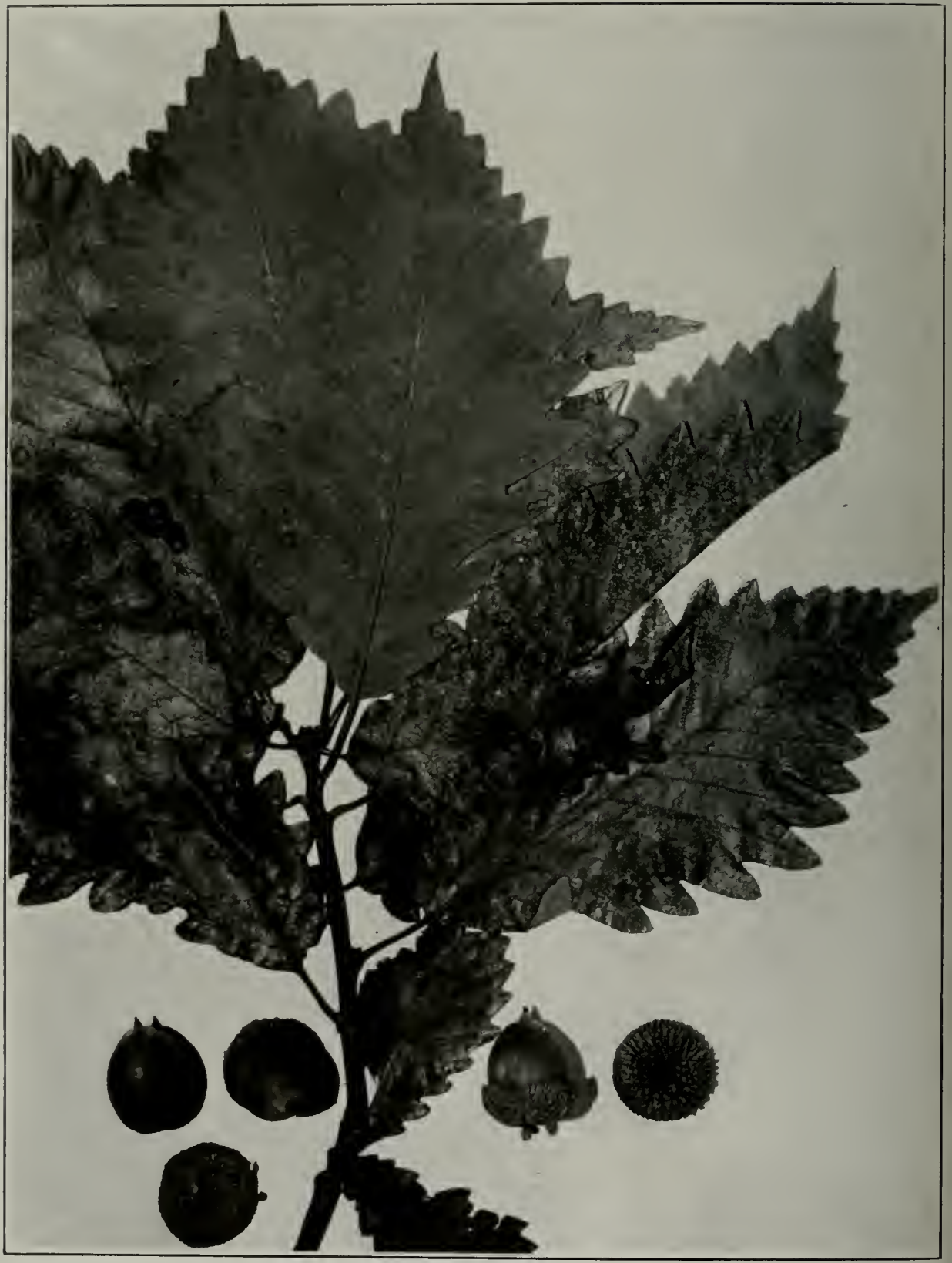

PLATE 40

QUERCUS PRINUS LiNNaEUS

BASKET OAK 


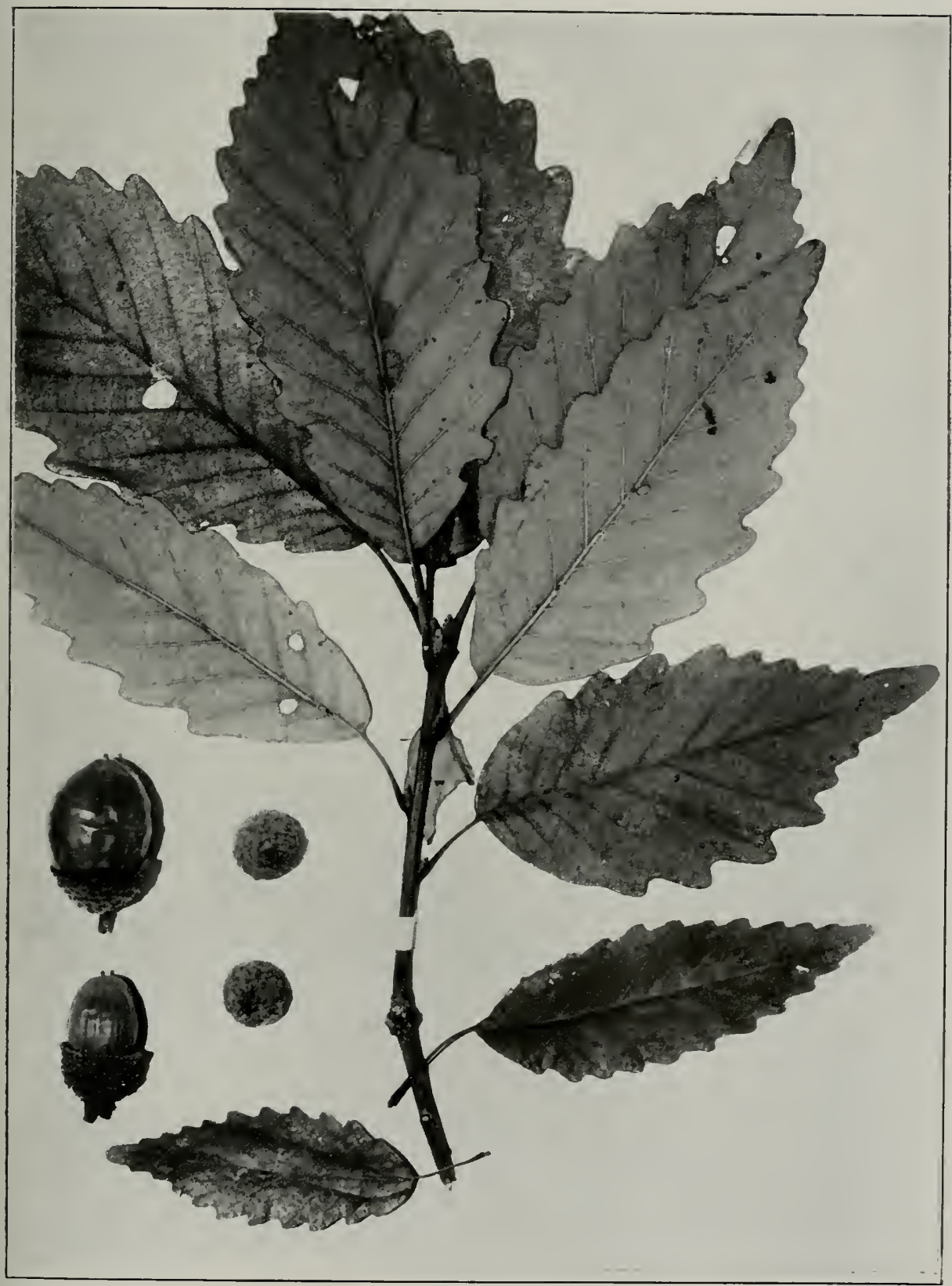

PLATE $4 \%$
QUERCUS MONTANA LINNAEUS
CHESTNUT OAK 
It is used for lumber, shingles, barrel staves, veneer, for fuel and fence posts, and in the manufacture of baskets.

The Cow Oak is not an important timber tree in Illinois, except as it contributes to the general production of white oak lumber. In the uplaucl type of forest it is rare. occurring only at the rate of $\approx$ trees in approximately 29() acres: but in the bottomland forests it is a little more common, there being approximately? trees to 15 acres of Cypress forest and \& trees in the same area of mixed hardwoods on main streams.

\section{QUERCUS MONTANA LINNAEUS}

\section{Chestnut Oak Rock Chestnut Oak}

The Chestnut Oak is a tree of moderate size, with large limbs that spread from the trunk, at a height of 15 or 20 feet, to form a broad, open crown. The firm, leathery leaves, 4 to 9 inches long by $1 \mathrm{r} / 2$ to 3 inches wide, are pale and finely hairy on the lower surface. and the blade is coar sely toothed. Their petioles are $1 / 2$ to 1 inch long. The staminate catkins are long and hairy; and the pistillate flowers stand. 2 or more together, on stout, downy stalks. The oval. lustrous acorns. 1 to $1 \frac{1}{2}$ inches long and usually less than 1 inch broad, are buried for about one-lalf their length in thin, deep cups, the scales of which appear grown together except at their tips. The orange- to red-brown twigs bear pointed. hairytipped, brown buds $1 / 4$ to $1 / 2$ inch long. The trunk, which is often 3 feet in diameter, is covered by dark-brown to nearly black bark fissured into broad, rounded ridges. The height of the tree varies from 20 or 30 up to 60 feet.

Distribution: The Chestnut Oak grows on hillsides and rocky banks from Maine to Georgia and westward to Mississippi. In Illinois, it is found in but one locality-the rocky sides of Atwood Ridge in Union County at elevations of 900 feet. This is of particular interest because it marks the most westerly occurrence of the tree. Before the discovery of this station in Illinois, the native Chestnut Oaks in the "knob" region in the central part of southern Indiana were thought to mark the northwestern limit of the range of the species.

Uscs: The close-grained. hard, heavy wood of the Chestnut Oak, though easily split, is very strong and tough and quite durable. Where the tree grows in abundance, the wood is used for general purposes of construction, as well as for fence posts and fire-wood. It is used also for the manufacture of cooperage, farm implements, and baskets. 


\section{QUERCUS MUEHLENBERGII ENGELMANN}

\section{Yellow Oak Chinquapin Oak}

The Yellow Oak, sometimes called also the Chinquapin Oak, is a tall rree, with a narrow, round-topped crown of small branches capping the tall, buttressed bole. The firm. yellow-green leaves, 4 to ? inches long and 1 to $j$ inches wide and pale or white-hairy beneath, have coarse but uniform teeth with incurved points, and stand on slender petioles $3 / 4$ to $1 / 2$ inches long. The oval, chestnut-brown acorns, $1 / 2$ to 1 inch long, are half-buried in deep, brown cups covered with small, blunt scales. The light-orange to reddish-brown twigs bear pointed ladi 1 s to $1 / 4$ inch long, the scales of which are white and papery on the margins. The trunk, often nearly 3 leet in diameter, is covered by thin bark. the surface of which is broken into loose, silvery scales. The tree is often 80 feet high.

Distribution: From Vermont and Massachusetts to Nebraska and southward to Georgia and Texas, the Yellow Oak grows on ridges, hills, and bottomlands. In Illinois it ranges throughout the State, being most abundant and generally of a larger size in the southern counties. The largest standing tree that has been measured is in Brownfield Woods.

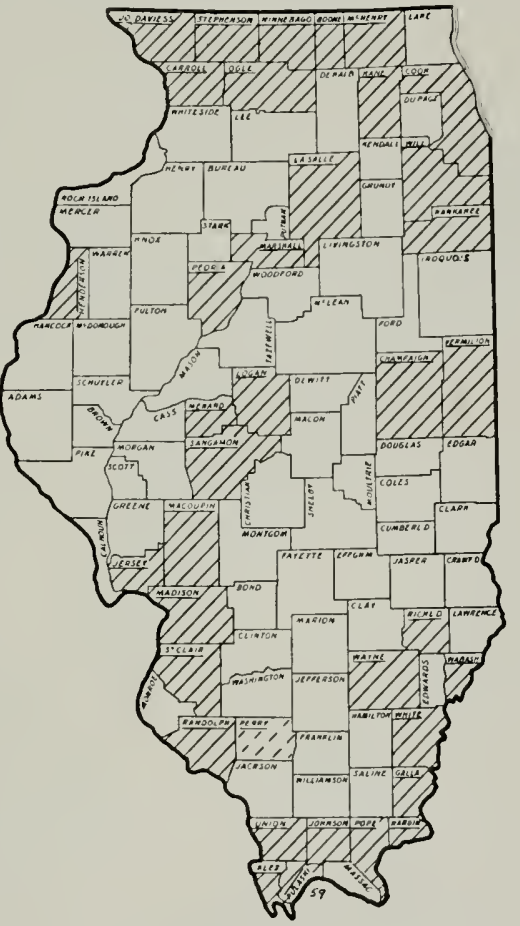

Frc. 59. Distribution of the Yellow Oak. Champaign County; its height is 80 feet and its diameter $2 !)$ inches. In the Coffee Creek locality near Mt. Carmel, a tree measuring 93 feet in height and 24 inches in diameter within the bark was found to be 18.5 years old. It grew on a gray silt-loam soil in company with Burr and White oaks and hickories. In Champaign, Logan, and Vermilion counties, Yellow Oak is associated with Red Oak, hichories, ashes, Elm, Hard Maple, Ohio Buckeye, Nild Black Cherry, and a number of other trees.

Uscs: The hard and close-grained wood of the Yellow Oak is heavy and strong and is, besides, durable in the soil, having a life of 


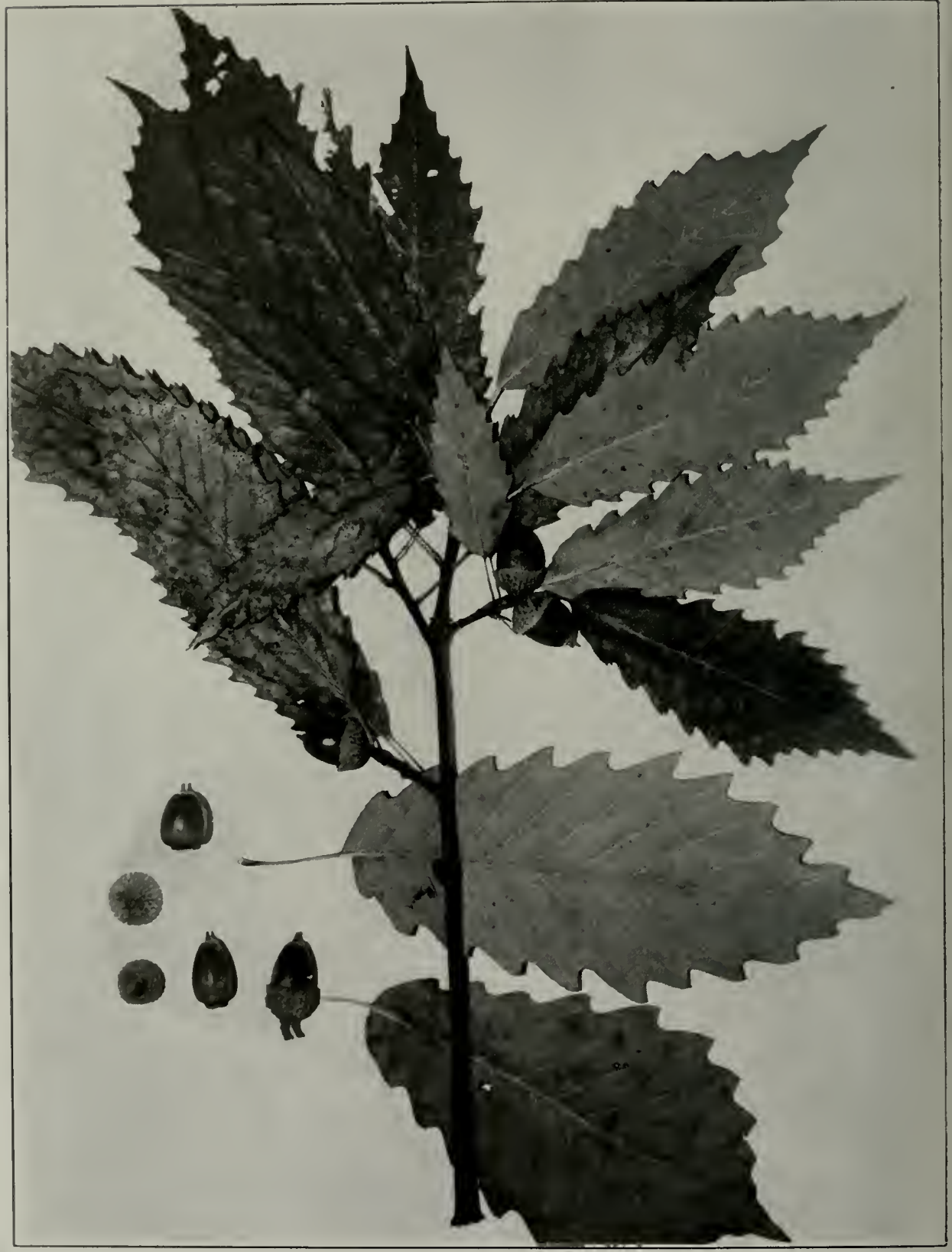

PLATE 48

QUERCUS MUEHLENBERGII ENGLEMANN

YELLOIV OAK 
about 10 years when used untreated. The lumber is made into furniture and is used in the interior finishing of houses. Formerly, however, it was much used in the IVabash Valley by wagon makers, as its wood was considered tougher than white oak.

\section{Other OAKS IN ILLhNOTS}

The Scarlet Oak, Qucrus coccinca Muenchhausen, is known to occur rarely in southern Illinois. A specimen has been collected at Karnak, Pulaski County, by Professor William Trelease, and another at Cobden, Union County, by E. M. Wright. According to Pepoon ${ }^{1}$, trees of this kind are common in dry woods north and west of Chicago; but Professor Trelease regards these trees as forms of Qucrus cllipsoidalis Hill. A flowering specimen collected in 1919 by E. IV. Mattoon in a woodlot near Camp Grant appears to be Scarlet Oak.

The oak hybrids are many, though the individual hybrid trees are widely scattered and rare. Qucrcus X Leana Nuttall, the hybrid of $Q$. imbricaria and $Q$. celutina, is the commonest in the northern reyions. of the State. Specimens have been taken from trees near Marley, IVill County, in the Des Plaines valley by Agnes Chase; near Willow Springs, Cook County, by E. J. Hill; near Peoria, by Frederick Brenclel; and from a tree in Fulton County by Wolf. In southern counties, the hybrid most often encountered is $Q$. X tridcutata Engelmann, a cross between Q. imbricaria and $Q$. marilandica, specimens of which have been preserved from trees growing in Massac, Wabash, Richland, and Champaign counties. Qucrcus X c.racta Trelease, produced by the crossing of $Q$. imbricaria and $Q$. palustris, has been found in Richland County by Robert Ridgway and in Wabash County by Jacob Schneck. Qucreus $\mathrm{X}$ runcinata Engelmann, derived from $Q$. borcalis ma.rima and $Q$. innbricaria, is also apparently a usual form in the south. Specimens show its occurrence in Richland and Wayne counties, and a reported hybrid of Q. inbricaria X rubra, which occurs near Rosiclare and Shawneetown, in Hardin and Gallatin counties respectively, probably is the same form. A hybrid of $Q$. bicolor X lyrata is reported from Pulaski County, in the neighborhood of Mound City: and $Q$. X Schockiana Dieck., from $Q$. palustris X Phellos, and $Q . \mathrm{X}$ Ficrnoaii Trelease, from $Q$. alba X stellata, are also within our State. Qucrcus X Shucttci Trelease, from $Q$. alba $\mathrm{X}$ macrocarpa, has been found in Richland County by Robert Ridgway; and Pepoon ${ }^{2}$ states that $Q$. alba $\mathrm{X}$ bicolor, which is possibly $Q$. $\mathrm{X}$ Jackiana Schneider, is represented by a single tree at Highland Park.

${ }_{1}^{1}$ Flora of the Chicago Region, p. 279.

${ }^{2}$ Loc. cit. 


\section{ULMUS Linxaeus The Elms}

\section{Family Ulmaceae}

Noderate to large, decichous trees. with simple, alternate leaves arranged in ? ranks on the twigs, the blades broad, unequal at the base. and toothed. Stamens and pistils in one flower, the flowers usually several together in stalked or stalkless groups. Fruit a small, winged capsule of a papery texture, within which is one small, flattened, dark-brown seed. The slender, zig-zag twigs. with small round pith. bear solitary, oval, obliquely set buds above nearly half-round, 2-ranked leaf-scars. There is no terminal bud; but the lateral buds are inclosed by a number of ?-ranked scales.

Ulnnus, with its 20 species, ranges through the entire temperate and cold-temperate regions of the Northern Hemisphere, except for western North Americ?, where it is absent. In North America there are six species. Among fossils which date to the Ice Age, eight different species of Elm have been recognized, and most of them, including the three most common of our four Illinois species, exist as living trees today.

\section{KEY TO THE ILLINOIS ELMS}

None of the branchlets with corky wings.............. americana p. 156 Corky wings more or less evident on 2-year-old branchlets.

Twigs rough-hairy: inner bark mucilaginous or "slippery"..U. fulva p. 163 Twigs soft-hairy to smooth; inner bark not mucilaginons.

Buds hairy; wings usually 2, thin, high, and opposite...U. alata p. 162 Buds smooth; wings 1 to 4 , low, thick, discontinuous..U. racemosa p. 159

\section{ULMUS AMERICANA LINNAEUS}

\section{White Elm}

The White Elm, also commonly called American Elm, is a tall and bulky tree, with large. ascending limbs that form a very wide. spreading crown. The pointed, coarsely double-toothed leaves, 4 to 6 inches long by 1 to 3 inches wide, are dark-green and often rough on the upper surface but pale and usually soft-hairy beneath. The flowers grow in short-stalked bundles of 3 or 4 , each on a slender, clrooping pedicel sometimes 1 inch long; and the fruits, which ripen as the leaves unfold, are about $1 / 2$ inch long, the points of the hair-fringed wings bending inward and inclosing the notch between them. The reddish-brown, usually smooth twigs bear oval, slightly flattened buds about $1 / 8$ inch long. which are covered by light-brown, smooth scales. The trunk, which is covered 


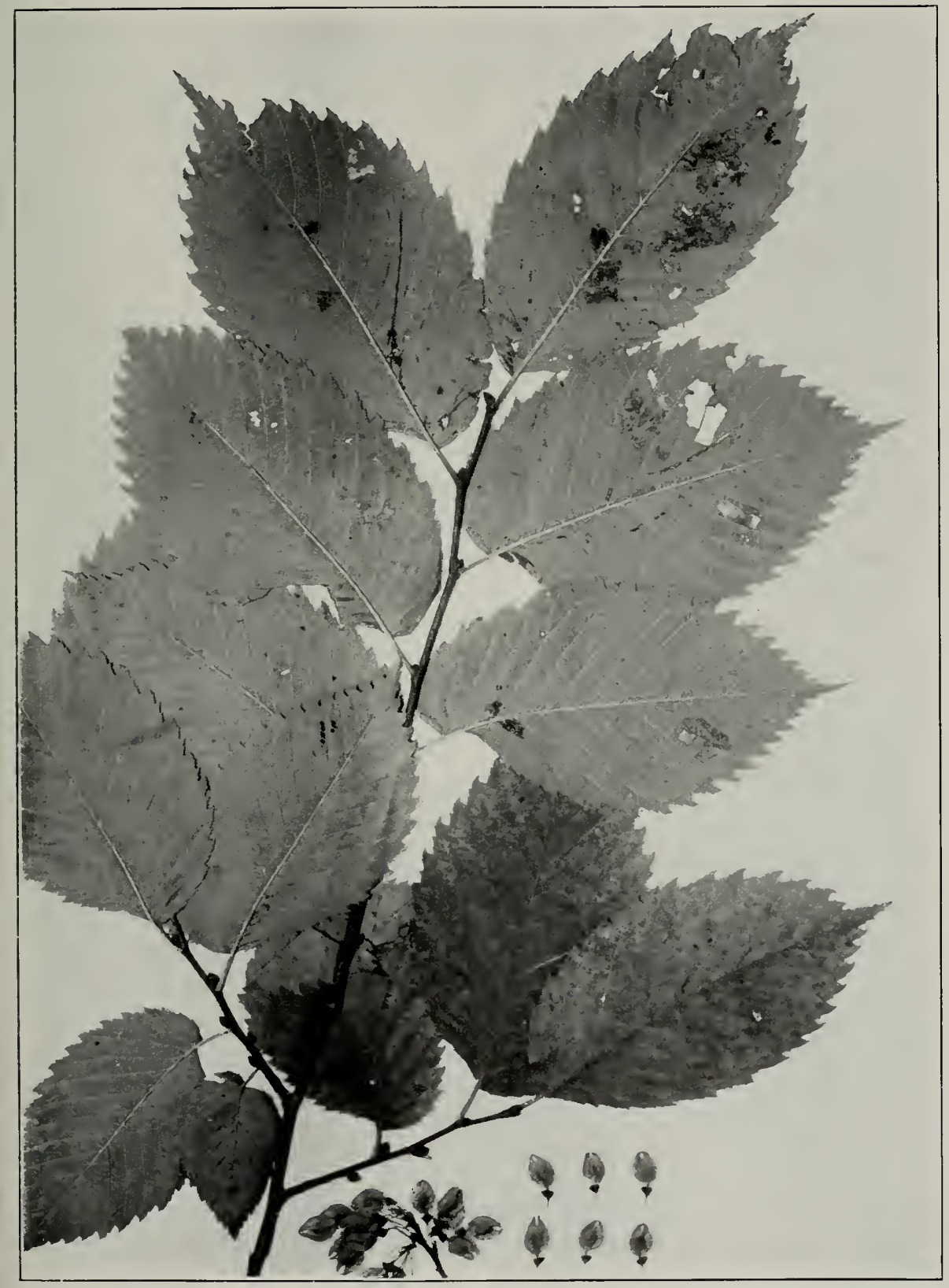

PLATE 49

ULMUS AMERICANA LINNAEUS

WHITE ELM 


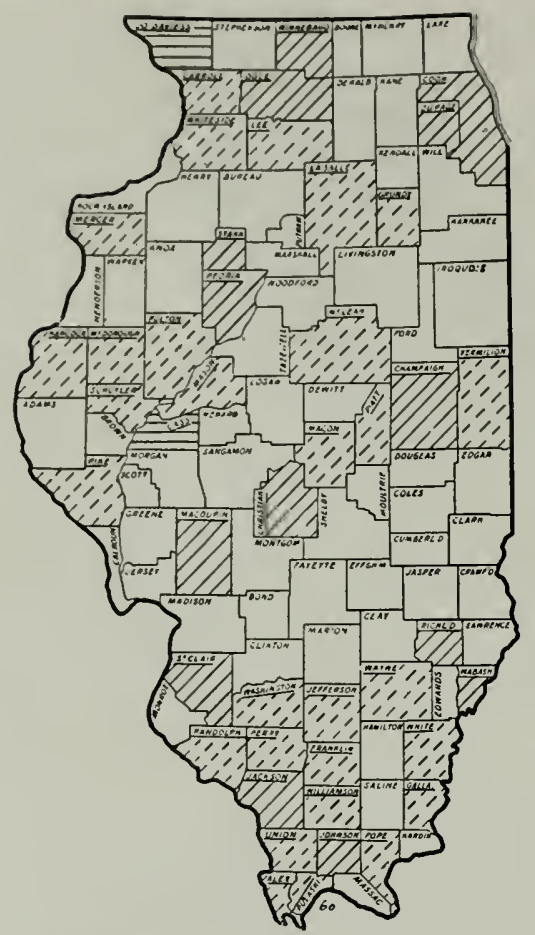

Fig 60 Distribution of white

by thick, deeply fissured, broad-ridged, ashy-gray bark, attains a diameter of $21 / 2$ to 3 feet, and the height of the tree is often between 80 and 100 feet.

Disiribution: On bottomlands, stream banks, and springy hills, the White Elm ranges from Newfoundland far west into Canada and south to Florida and Texas. It is found practically throughout Illinois and reaches its largest size as well as its greatest abundance in the southern counties. In the upland type of mixed hardwood forest it is found at the rate of about 2 trees per acre; amongst the Post Oaks and Scrub Oaks it does not occur; but in the bottomlands it averages $\delta$ trees per acre in the $\mathrm{Cy}$ press forests, 13 to 14 trees per acre along the main streams, and 6 trees per acre along the secondary streams.

The largest measured tree was 10: feet high and 35 inches in cli-

aneter. One near Ware. Union County, though only 60 feet tall, was 30 inches in dianneter and had a clear bole 42 feet long, from which 921 board feet of lumber could be taken. In the Wabash Valley a White Eluı was seen 9.; feet tall, though the trunk diameter was only 15 inches; but on the Kaskaskia bottoms the highest tree measured 80 feet, with a dianeter of 32 inches; while in the north, along the Rock River, a tree was found which was 90 feet high and 30 inches in dianeter. On the uplands of Union County the average height is 50 feet and the average dianteter $91 / 2$ inches.

Robert Ridgway says that fully 90 per cent of the trees in the Wahash Valley that are attacked by mistletoe are IVhite Elms.

I'ses: The white, harcl wood of the American Elni is moderately heavy and tough, but it is apt to twist and warp unless it is handled carefully in scessoning, and it is not durable in the soil. It is used in making barrsl staves, wagon hubs, cheap furniture, veneer for fruit baskets, and sometimes for the bows of carriage-tops.

In 19:5, sone $2.350,000$ board feet of white eln lumber was produced l,y Illinois mills. In the virgin bottomland forests between the Cypress sloughs and the drier benches, the $: 1$ trees per acre are capable 
of yielding about 6.500 board feet per acre, which is about 3000 board feet more than either the Soft Maple or Red Gum can furnish; while cn better-drained ground 3 trees per acre yield about $4 \$ 0$ board feet, as compared to 6800 board feet from the Red Gum. In the IVabash region, the White Elm yield is only 92 board feet per acre, but in the Rock River region it is high, being estimated at about .5300 board feet per acre.

\section{ULMUS RACEMOSA THOMAS}

\section{Rock Elm}

\section{Cork Elm}

The Rock Elm is a moderately tall tree, with a long, straight bole from which short, stout branches spread to form a narrow, round-topped crown. The pointed, coarsely double-toothed, firm leaves, 2 to $2 \mathrm{~T} / 2$ inches long by $3 / 4$ to 1 inch wide, are dark-green and shiny above but pale and soft-hairy beneath. The slenderpediceled flowers stand in groups of 2 to $t$ along the axes of floral stallis up to ? inches long. The oval, palehairy fruit is about $1 / 2$ inch long, with a shallow, open notch between the tips of its hair-fringed wings. The light reddish-brown twigs, eventually furnished. with 3 or 4 irregular, thick. corky wings, bear pointed brown luds about $1 / 4$ inch long. The red-tinted, gray bark is deeply fissured into broad. flat ridges with scaly surfaces. The tree is usually 80 feet high or more and its trunk may be as much as :3 feet in diameter.

Distribution: From Quebec, Wisconsin, and Nebraska, the Rock Elm ranges southward, on limestone ridges, steep hillsides, gravelly soils, and glacial drift, to northern New Jersey, Ohio, and Indiana. In Illinois, it is an infrequent tree, probably limited to our most northern counties.*

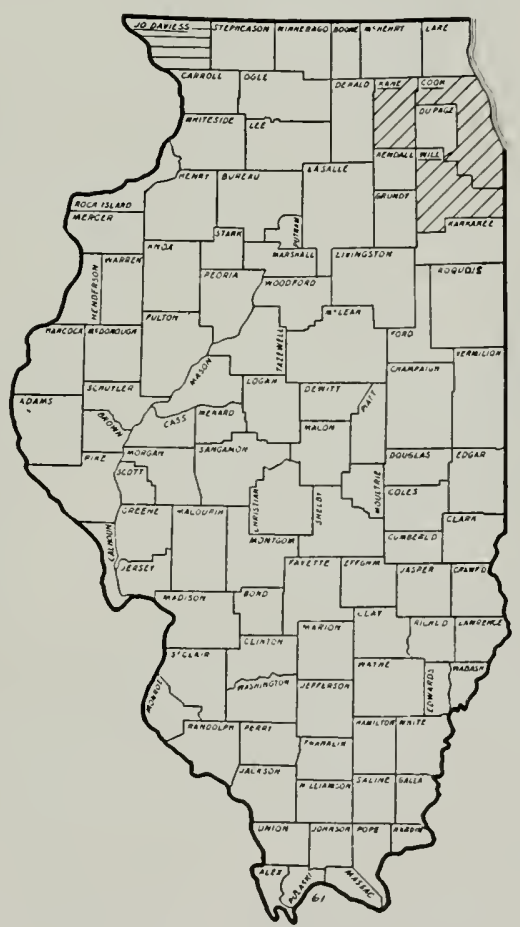

FIG.61. Distribution of the Rock Elm.

* The record for Kane county is based on specimens collected by George $A$. Tasey in 1865 , and that for Will County on a specimen collected by Agnes Chase in 1899. Specimens labeled Llmus racemost, and collected by Jacob Schneck from Johnson County, and by E. W. Mattoon at Olney, are regarded as $L$. rlata. The occurrence marked for Jo Daviess Councy is based on Pepoon's statement (see Trans. Ill. St. Acad. Sci. Vol. 3, p. 155. 1910). 


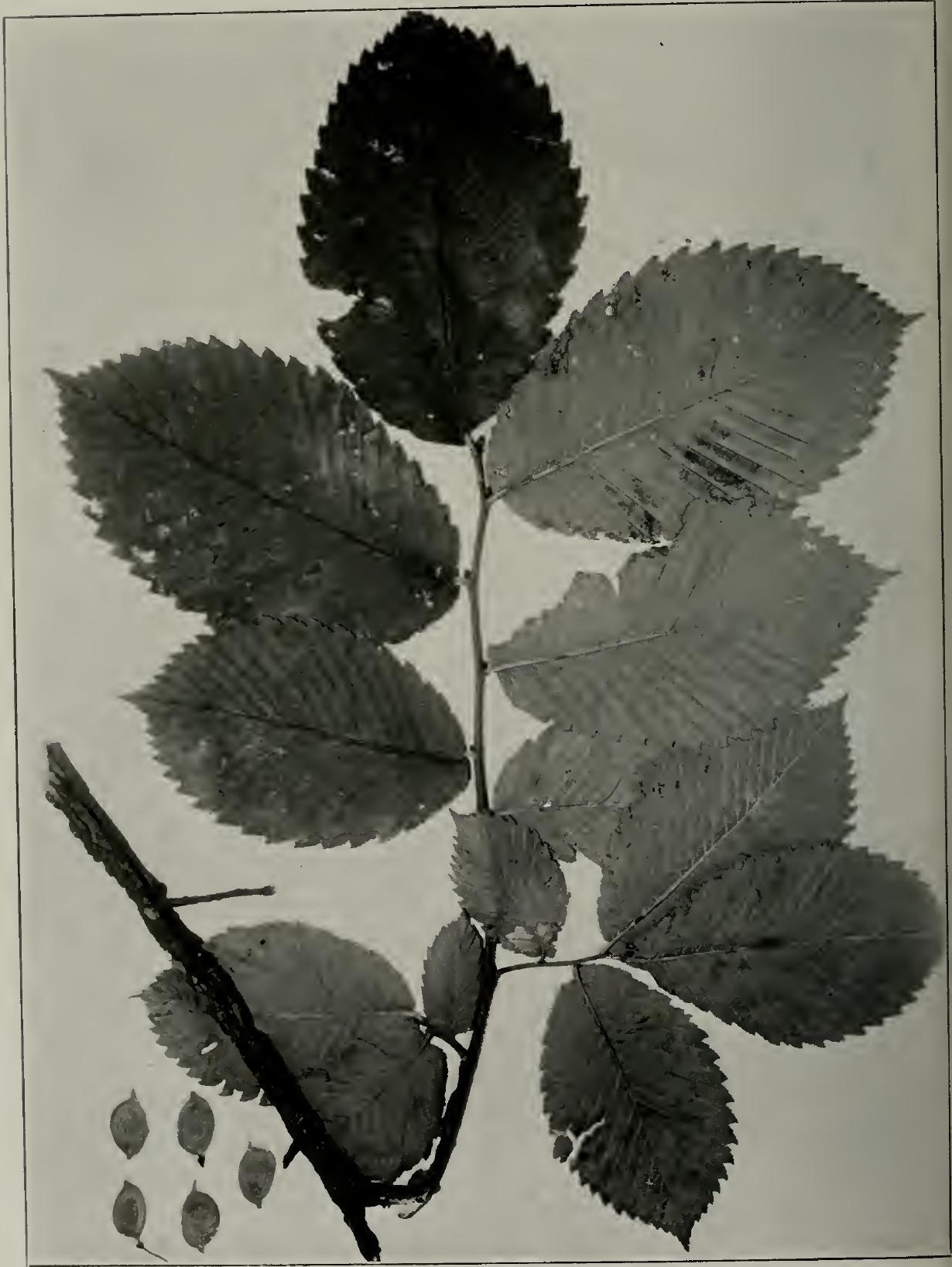

PLATE 50

UTAIUS RACEMIOSA THOMAS 


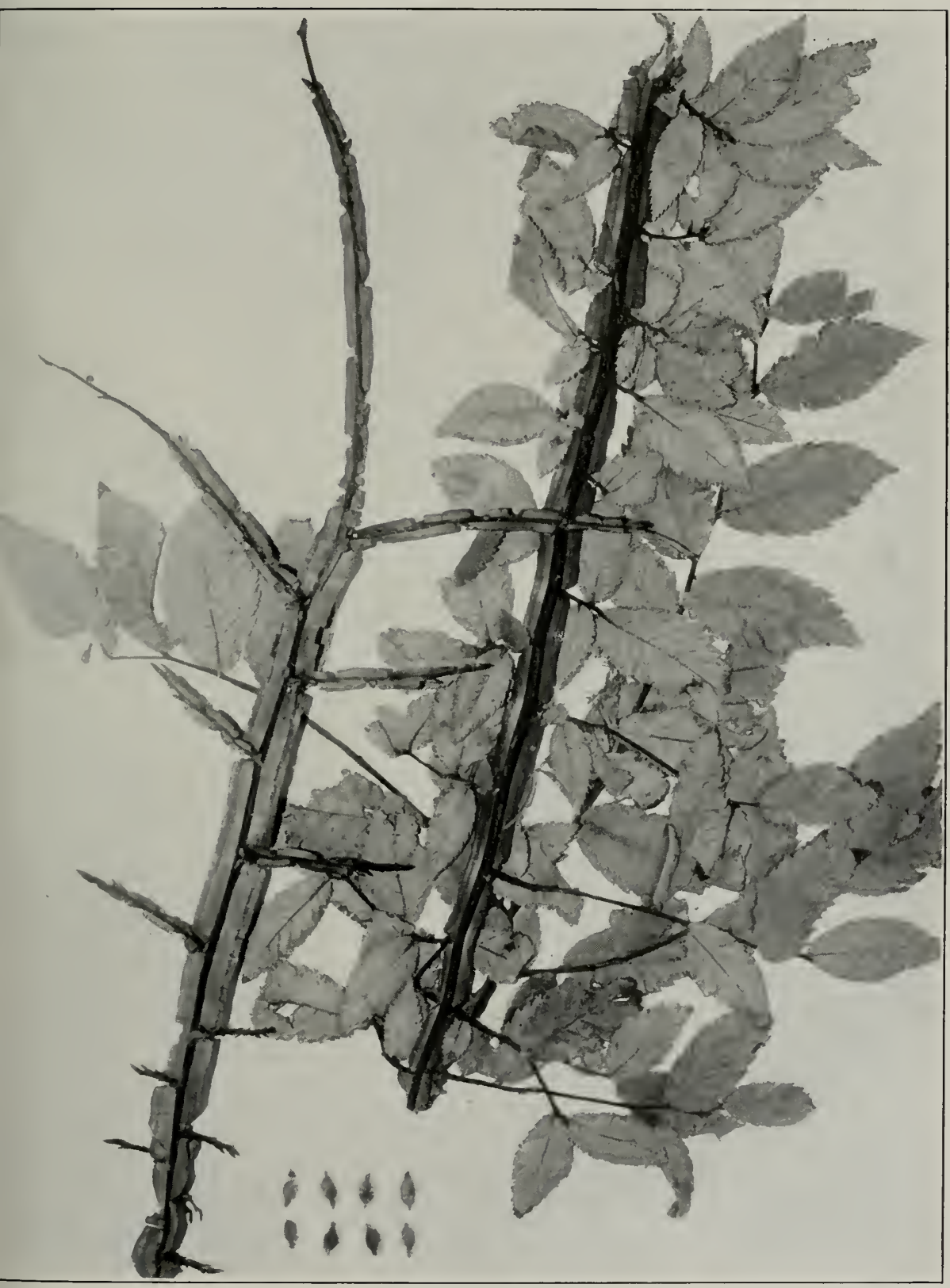

PLATE .) 1

ULMUS ALATA Michaux

IVAHOO 
L'ses: The very tough and close-grained wood of the Rock Fim, light red-brown in the heart. is hard as well as strong and heary. In its technical qualities, it is the finest of the elm woods, and it has in addition the special quality of resisting shocks and jars. As a consequence, it is used largely in agricultural implements, wheel hubs, building sills, and the framework of chairs. It is a fine wood for hockey sticks, which are subject to severe strains and twists, and it is made into plant-presses for botanists. When it can be seasoned without warping, it is one of the best woods for javelins.

\section{ULMUS ALATA MichaUx Wahoo Winged Eim}

The Wahoo is ustrally a small to moderate tree, with a narrow, roundtopped head of stout, straight branches. The somewhat sickle-shaped. coarsely double-toothed leaves, $1 \mathrm{r} / 2$ to $3 \mathrm{I} / 4$ inches long, are dark-green and smooth on the upper surface but pale and soft-hairy beneath. The stout.

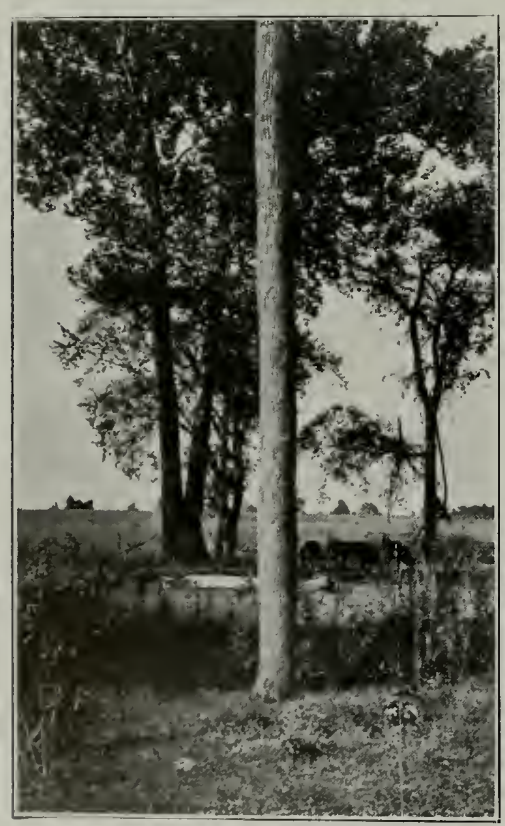

Flg. 62. Wahoo on the Gentry Creek bottoms of Richland County. Photo by Robert Ridguay. hairy petioles are about $1 / 3$ inch long. The flowers are in few-flowered fascicles: and the fruit, which is covered with long, white hairs, is about $1 / 3$ inch long. its base narrowed into a slender stalk and its tip capped by the two long. incurved wing-points. The smooth, reddish-brown twigs, which are marked by a few orange lenticels, become, during their first or second season, supplied with 2 oppositely placed, thin, corky wings. The pointed lateral buds, about $1 / 8$ inch long, are dark chestnut-brown. The red-tinted, brown bark, which incloses a trunk about 2 feet in diameter, is divided by shallow fissures into flat ridges. The tree usually attains a height of 40 or 50 feet.

Distribution: F rom Virginia westward to Missouri and southward to Floricla and Texas, the IVahoo is to be found on gravelly uplands and occasionally along the borders of 
swamps and streams. In Illinois, it is distinctly a southern tree, with a range generally south of the Kaskaskia River. There is a considerable variation in the development of the corky wings on twigs, which appears to be related to the situations in which the trees grow. On the low, moister places, the wings are less well developed, sometimes not appearing until after the twigs are :3 and + years old, and then sometimes having the appearance of the corky ridges of the Rock Elm. Specimens collected in Richland County by E. W. Mattoon and in Johnson County by Jacob Schneck are similar to the Rock Elm in this respect and have been labeled Ulmus raccmosa; but by their buds and by other twig characters they are shown to be specimens of Wahoo. Thus, the natural ranges of the two trees, distinct throughout the United States, are fotmd to be distinct in Illinois also.

Uscs: Though the light-brown wood of the Wahoo is close-grained and hard, it is not very strong. But because it does not split easily, it is ured for wheel-hubs and tool handles.

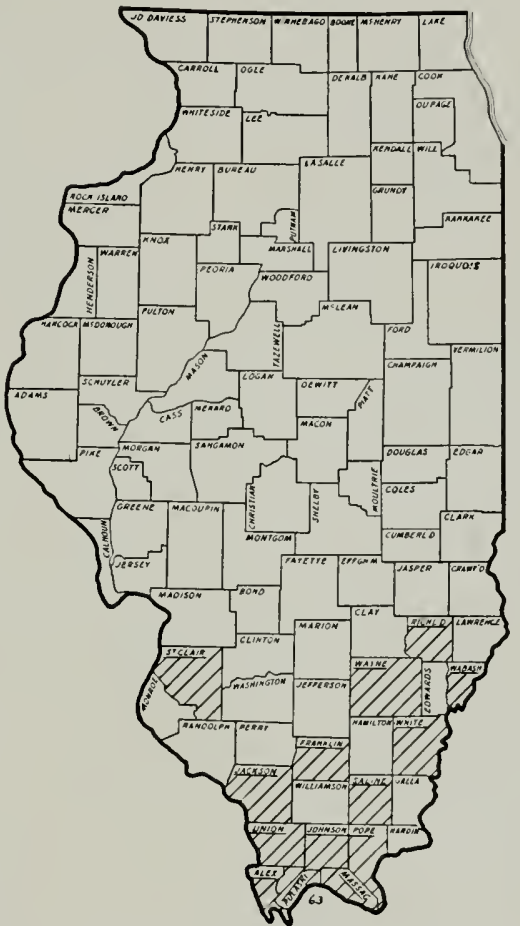

F1G. 63. Distribution of the Wahoo. From the imner bark a rope is made, which is used for fastening the covers of cotton bales. The Wahoo is not, however, abundlant enough in our inuthern forest to rank as a conmercial tree.

\section{ULMUS FULVA Michaux}

\section{Slippery EIm Red Elm}

The Slippery Elm is a tree of only very moderate size, with an open and rather flat-topperl crown of spreading branches. The slender-pointed, coarscly clouble-toothed leaves, 5 to $\{$ inches long by 2 to 3 inches wide. are clark-green and very rough to the touch above but pale and rather soft-hairy beneath. The stout, hairy petioles are about $1 / 3$ inch long. The crowded fascicles of flowers stand on very short pedicels. The round fruits, $1 / 2$ inch wide, have no hairs on the margins of the broad, thin wings. 


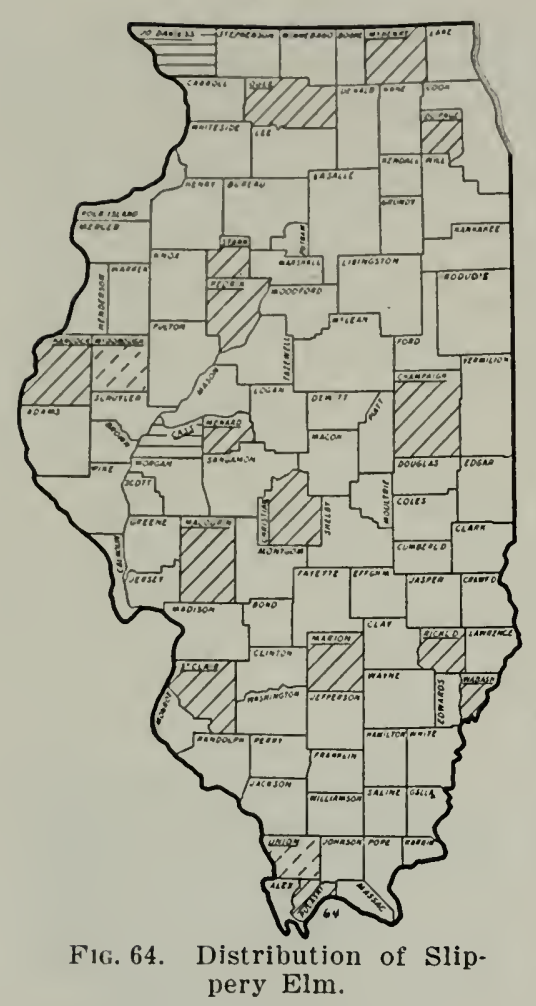

the tips of which are well mited and leave no notch at the end of the seed capsule. The stout, light-brown branchlets, always quite conspicuously hairy on the new growth, bear blunt, oval buds about $1 / 4$ inch long above rather large, half-round, raised leaf-scars. The trunk, which is covered by redtinted, dark-brown, shallowly fissured bark, attains a diameter of 2 feet ; and the height of the mature trees is usually between 60 and 80 feet.

Distribution: From the St. Lawrence Valley, in Quebec, to South Daliota, the Slippery Elm ranges, on stream banks and rocky hills, southward to Florida and Texas. Though not a common tree in Illinois, it occurs in practically every part of the State. It is an occasional tree in the hardwood forests, making its best growth on fertile bottomland soils. In Wabash County, a tree was measured and found to be 8 !) feet high, with a trunk diameter of $2 q$ inches and a merchantable bole 48 feet long. The average trees on poorer land in other parts of the State are, however. much smaller.

Uscs: The heavy and very close-grained wood of the Slippery Elm. dark-brown to red in the heart but lighter in the thin sapwood, is easily. split but durable and serves well for fence posts and railroad ties. It is also hard and strong and it is used in making agricultural implements and wheel-hubs, as well as for the sills of buildings. A medical preparation made from the mucilaginous bark is used in the treatment of inflammations, such as boils and carbuncles.

Although not an abundant tree in the forests of Illinois, it is cut and marle into lumber along with the White Elm, from which it usually is not distinguished. 


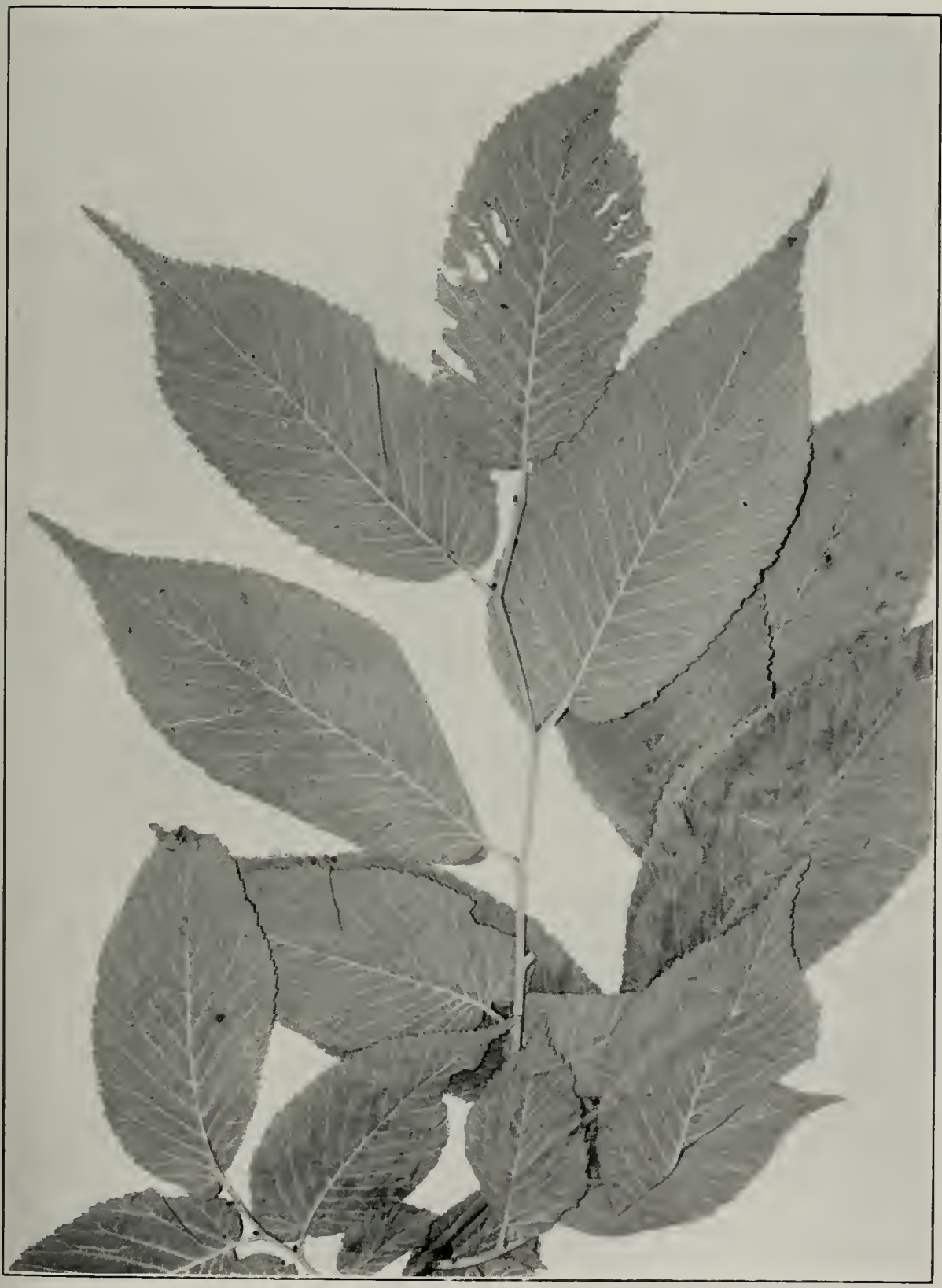

PLATE 52

ULMUS FULVA MICHAUX

SLIPPERY ELAI 


\section{PLANERA GaleLIN Water E'm}

\section{Family Ulmaceae}

Small, decicluous trees with alternate, : 2 -ranked, broad-bladed simple leaves. Flowers alike but functioning separately as staminate and pistillate flowers, the former borne in bundles on the year-old wood, the latter 1 to 3 together in axils of the new leaves. The fruit an oblong, pronitnently ribbed and tuberculate, light-brown drupe with a dark-brown to blackish, shiny, oral seed.

There is but a single species, which lives only in the southeastern Uniterl States, the sole living representative of an ancient genus, which appears, from its fossil forms, to have had a wide range in North America. Europe and Asia, during the geological epochs preceding and succeeding the Ice Age.

\section{PLANERA AQUATICA GMELIN Water Elm}

The Water Elm is a small tree, with a broad, low crown of slender. spreading branches. The dull-green, coarsely toothed, leathery leaves.

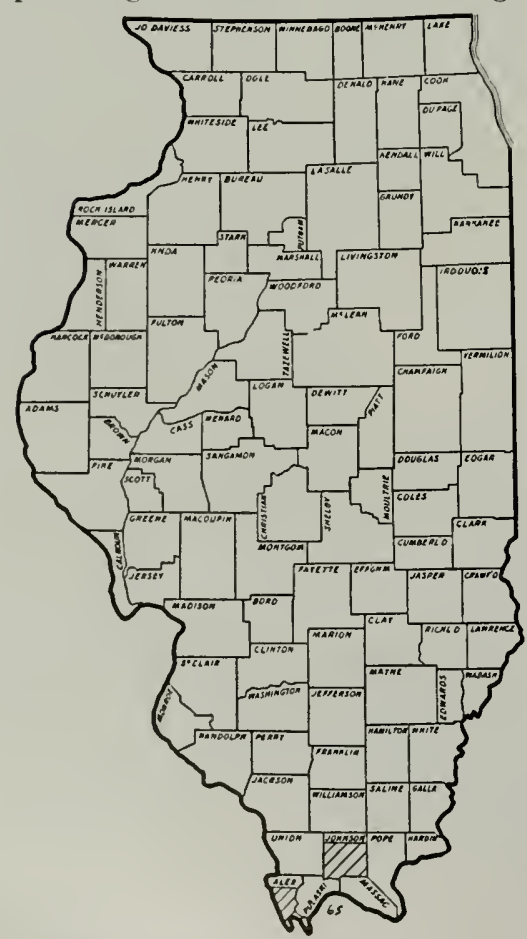
2 to $2 / / 2$ inches long by $3 / 4$ to 1 inch wide. stand on slender, hairy petioles $1 / 8$ to $1 / 4$ inch long. The flowers, borne at the same time as the leave: appear, stand on s'ender, erect pedice!s, and the fruit, which is about $1 / 3$ inch long, ripens in April. The hairy. brown branchlets bear fine. globular buds above nearly round leaf-scars. The trunk, which is covered by thin, brown to gray bark with large scales on the surface, may become 2 feet in diameter, and mature trees are tsually 30 to 40 feet high.

Distribution: In swamps that are water-covered for several months of the year, the Water Elm ranges from North Carolina southward into Florida, westward to Texas, and northward again to the lower valley of the Wabash River. In Illinois, it is a very rare tree and is known to us only Fig. 65. Distribution of Water Elm. through specimens collected by E. ]. 


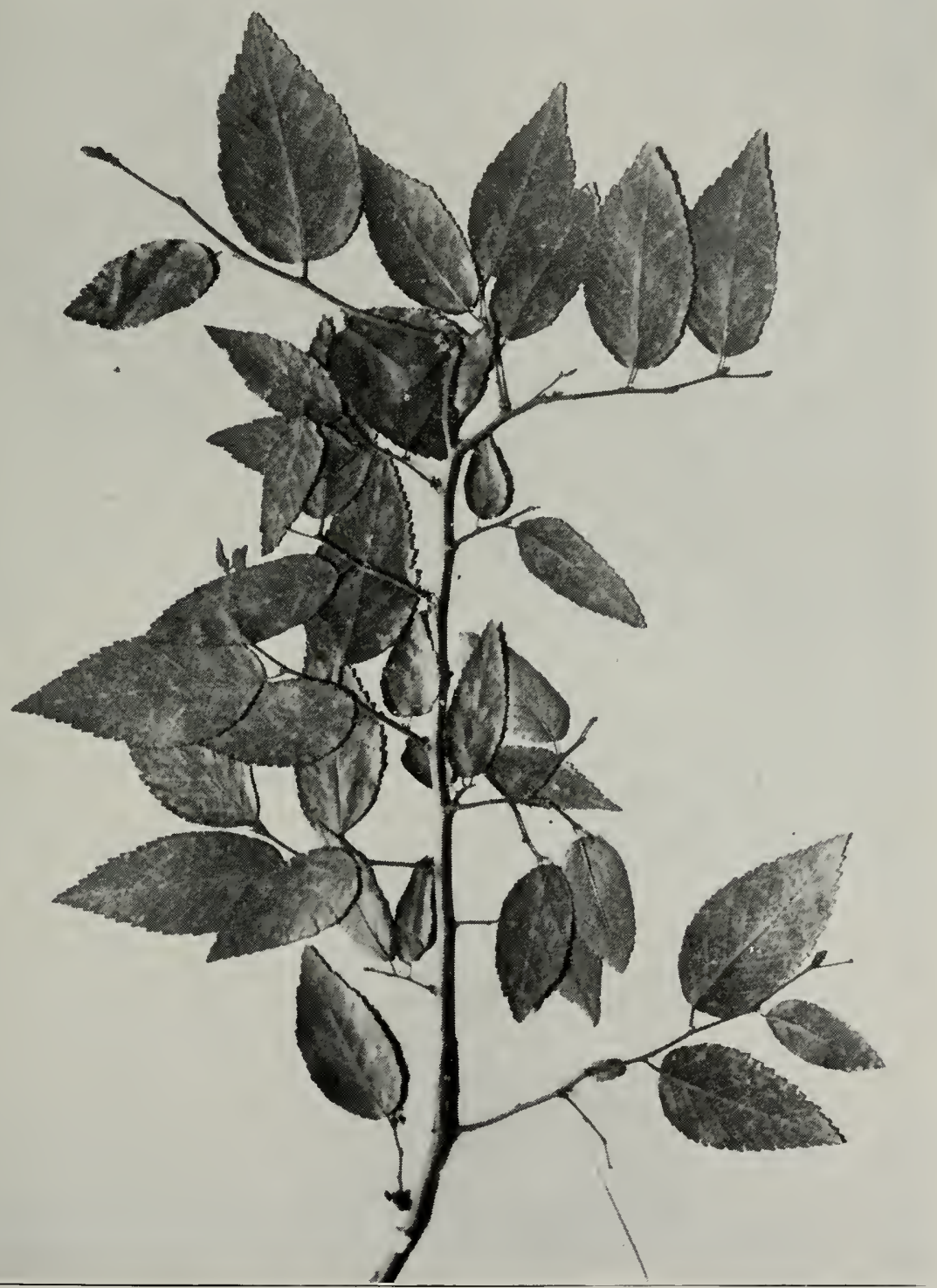

PLATE 53

PLANERA AQUATICA GIELIN

WATER EI.AI 
Palmer at Cairo and in Johnson County. A specimen collected from Hancock County and originally identified as this tree proves to be spicebush.

Uscs: Though close-grained, the light-brown wood of the Water Elm is light as well as soft and weak. It is of little commercial value, not only because of its poor technical characteristics but also because the small trees yield but little salable wood.

\section{CELTis Linnaeus The Hackberries}

\section{Family Ulmaceae}

Deciduous trees and shrubs, with broad-bladed, simple leaves. The pedicelled flowers on the season's new growth; the staminate flowers in fascicles at the base of the growth, the pistillate flowers solitary or a few together in the axils of the upper leaves. Fruit a globular drupe, with thin flesh and a bony inner shell surrounding the seed. Twigs rounded, slender, and more or less zigzag, with small white, round, closely chambered pith and with solitary, stalkless, oval buds covered by 2 or 4 two-ranked scales; the end bud absent.

With its 60 or more species, Celtis is widely distributed through the north temperate and tropical regions of the world. In North Anerica there are 6 species of tree form. but of these only two occur in Illinois.

\section{KEY TO THE ILLINOIS HACKBERRIES}

Leaves half as broad as long; berry stems half as long again as the petioles; buls about $1 / 4$ inch long................ occidentalis p. 169 Leaves one-third as broad as long: berry stems half as long as the petioles; buds up to $1 / 8$ inch long................... laevigata p. 171 


\section{CELTIS OCCIDENTALIS LINNAEUS}

\section{Hackberry Sugarberry}

The Hackberry is a tree of only very moderate height, with a roundtopped head of spreading or drooping branches. The sharply pointed and usually sharply toothed leaves, $2 \mathrm{I} / 2$ to $3 \mathrm{I} / 2$ inches long by $1 \frac{1}{2}$ to 2 inches broad, are thin and somewhat hairy beneath on the midrib and reins, with petioles usually less than $1 / 2$ inch long. The flowers are not distinctive. but the dark-purple, globular fruits, about $1 / 3$ inch in diameter, have darli orange flesh and hang from stems $\mathrm{I} / 2$ to $3 / 4$ inch long. The slender, redbrown branchlets bear oval, flattened pointer buds about $1 / 4$ inch long, anc the trunk, usually not over \& feet in diameter, is covered by dark-brown bark roughened by irregular, wartlike excrescences or by long ridges. The tree is usually between 10 and 50 feet high.

Distribution: From New England to Virginia and westward to Nebraska and Kansas, the Hacliberry is a fairly common tree on rocky hills and ridges, but it is not found often on low sround. It ranges over the entire State of Illinois. Excepting the Post Oak and Scrub Oak types of upland woods, all of our hardwood forests contain Hackberry. It is most abun-

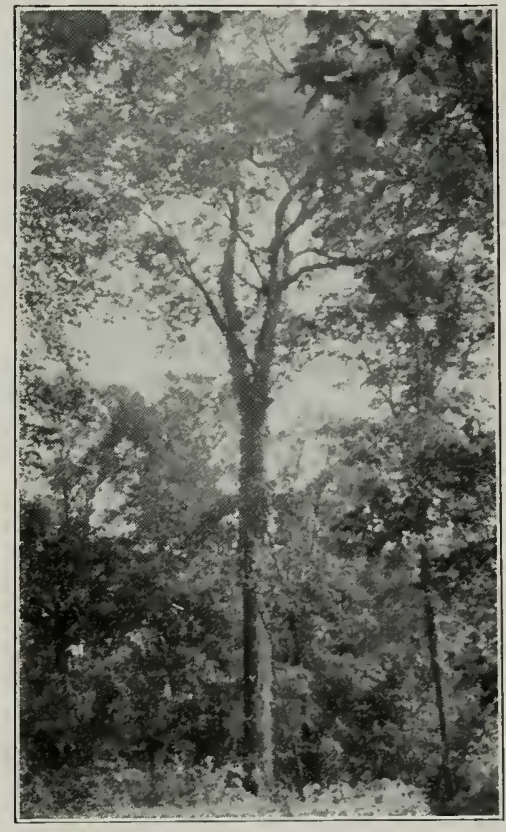

Frg. 66. A fine Hackberry in the upland woods at Allendale. This tree was 112 feet high and had a trunk diameter of 3 feet. dant in the drainage basin of the Ohio River, and occurs commonly with Pin Oak, Elm, Honey Locust. Soft Maple, cottonwoods, Burr Oak, Ash, Red Gum, and hichories. In the northern part of the State, its commoner associates are Elm. Ash, maples, Walnut, Burr Oak, and Bass Wood. Vestal ${ }^{1}$ describes a welldefined Elm-Hackberry forest in Cumberland County, in which also occur Honey Locust. Black Haw, and, in some places, Shingle Oak. He believes that, as the Hackberry seeds are readily dispersed to considerable distances, "these forests are of independent and comparatively recent origin in locally favorable spots in the prairie uplands."

${ }^{1}$ Trans. Ill. St. Acad. Sci. $12: 237.191 \%$ 


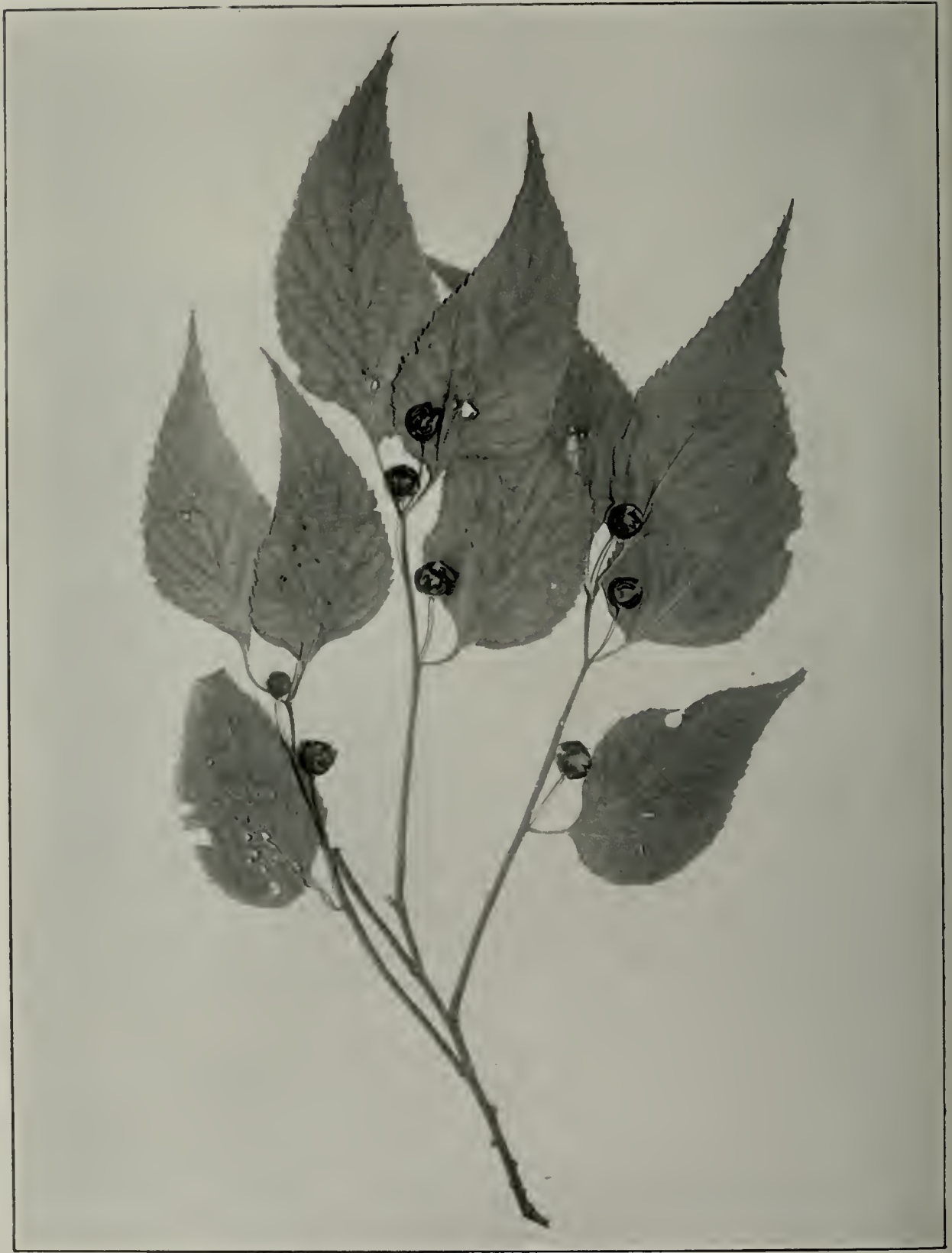

PLATE jt

CELTIS OCCIDENTALIS LINNAEUS

HACKBERRY 
In northern Illinois, at the present time, the Hacliberry grows to a maximum height of $i ;$ feet and a diameter of 1 i inches. In the extreme south it grows no taller; but in the IVabash Valley, the trees growing on rich bottoms are described by Robert Ridgway as very tall and beautiful, frequently attaining heights of $1 \geq 0$ to 130 feet and (liameters of 3 feet, with tall, straight boles, reaching 60,0 , and even 80 feet to the first limb.

I'ses: The heavy, close-grained, light-yellow wood of the Hackberry is neither very strong nor very hard, but in durability it ranks with white elm. Unless it is carefully seasoned, it warps and twists: and so, beyond those of fencing and cheap furniture. it has few commercial uses.

As a source of lumber in Illinois. the Hackberry is of little importance. In the Cypress forests, there is about 1 tree to every 2 acres; in

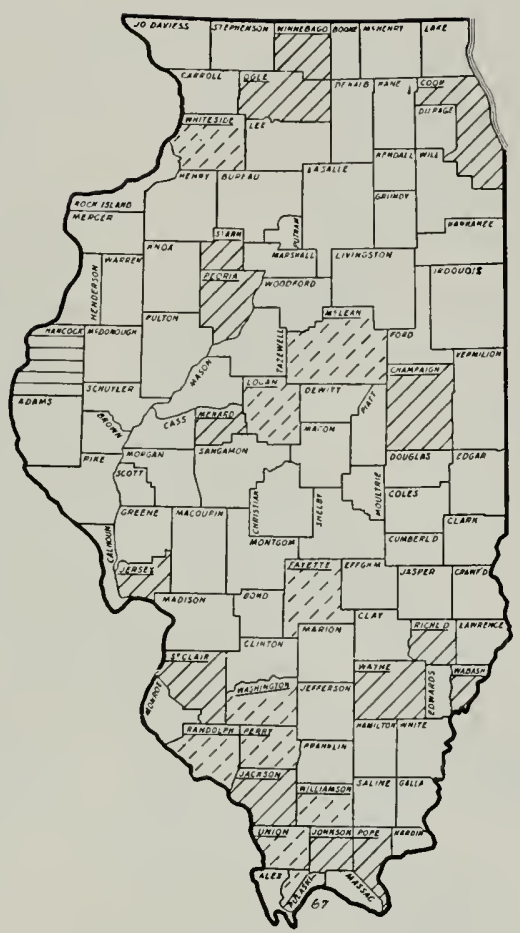

Fig. 67. Distribution of the Hackberry. the mixed hardwood growths of the main streans, about 3 trees on every 2 acres; along secondary streans it is of no consequence at all; and in the upland hardwood forests, there are only about 1; trees to 100 acres. Along the Rock River, where the Hackberry numbers about \pm trees per acre, the yield is estimated at approximately 400 board feet to the acre.

\section{CELTIS LAEVIGATA $K$. КосH \\ Sugarberry Mississippi Hackberry}

The Sugarberry, also called the Mississippi Hacliberry, is a tree of moderate size, with a broad crown of spreading or pendulous branches. The long and sharply pointed, thin leaves. $21 / 2$ to $j$ inches long by $3 / 4$ to $1 \frac{1}{2}$ inches wide, are light-green on both surfaces, generally smooth above and below, and stand on slender. hairless petioles $1 / 4$ to $1 / 2$ inch long. The flowers terminate smooth, slender pedicels: and the orangered to yellow fruits, $1 / 4$ inch in diameter, hang from the axils of the leaves on stems about as long as the petioles. The reddish-brown, shiny branchlets bear pointed, brown buds up to $1 / 8$ inch long. The trunk, inclosed by 


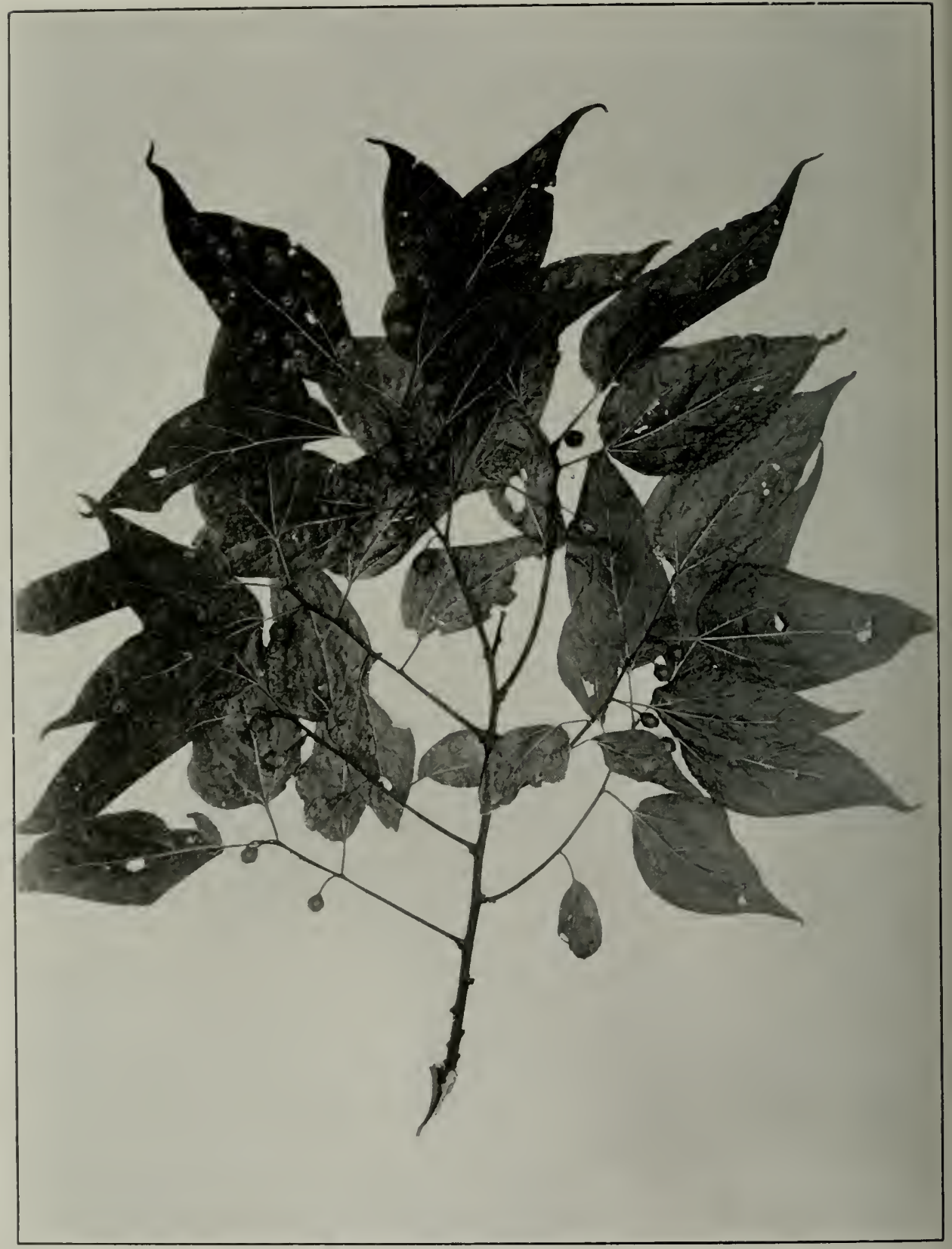

PLATE 5J

CELTIS LAEVIGATA K. KocH

SUGARBERRY 
thin, pale-gray bark covered by prominent excrescences, attains a dianteter of 2 feet or more; and the tree may become 60 to 80 feet high.

Distribution: The range of the Sugarberry extends from Virginia southward to the Everglades, westward to Texas and northward again into Inlinois and Indiana. In Illinois, it is found on the bottomlands of the large rivers, and is limited in its distribution practically to the southern third of the State. Two specimens have been taken from Pike County, perhaps from the same tree, the locality given for them being on the Mississippi bottomland in the extreme northwest corner of the county. This represents, in comparison with our other records, not only the most northerly station for the tree but also a rather remarkable norihward extension of its range.

In the Cache River bottomlands in Massac County, the Sugarberry grows with ash, Eln1, Pin and Swany) Spanish oaks, Soft Maple, Red and Black gums, and hickory-a list which does not differ greatly from that of the Hackberry. In the Wabash Valley, a tree measured by Robert Ridgway was 60 feet high and 11 inches in diameter.

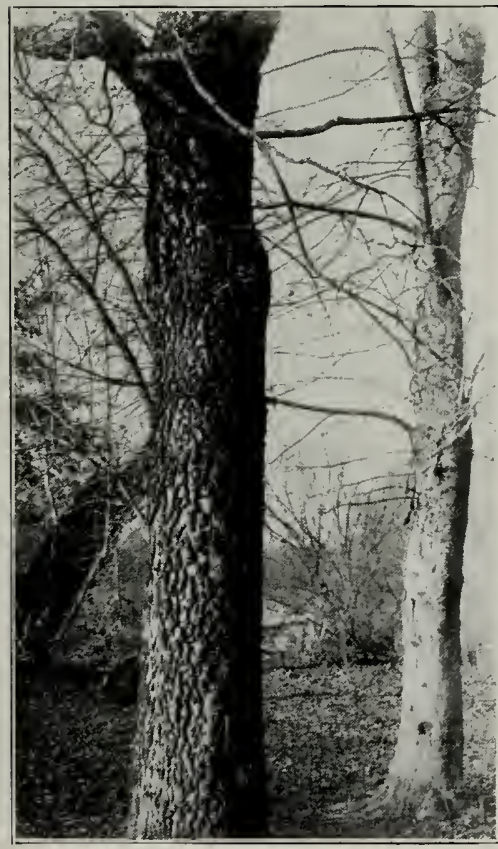

Fig. 68. Trunk and bark of the Sugarberry. Photo from the Field Museum of Natural History.

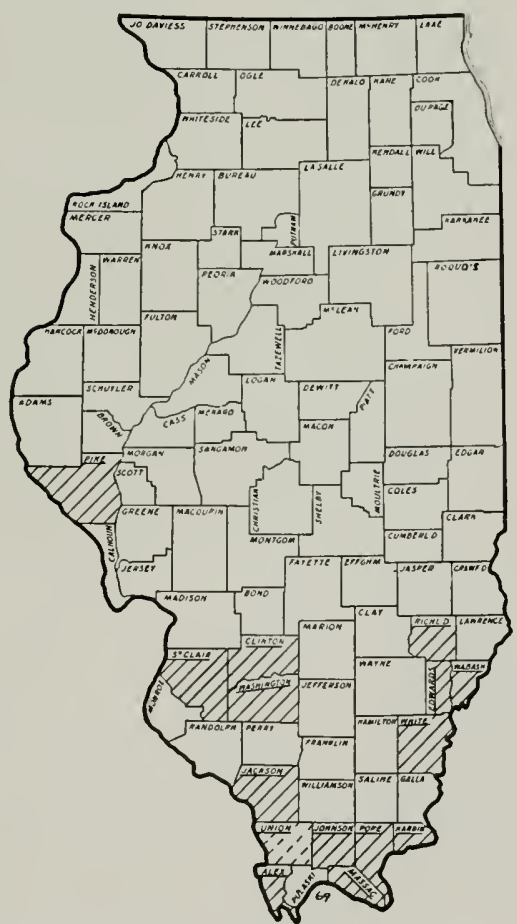

Fig. 69. Distribution of the Sugarberry. 
Lscs: The close-grained, light-yellow wood of the Sugarberry is neither strong nor hard and has but few commercial uses. In Illinois, it is not a common tree and. when cut, it is sold along with Hackberry, as the wood of the two trees is not distinguished in the lumber trade.

\section{MORUS LiNNAEUS Mulberry}

\section{Family Moraceae}

Deciduous trees or shrubs, with simple, alternate, broad-bladed leaves, 3- to 5 -nerved from the base. Staminate and pistillate flowers on difierent branches or even different trees, both in stalked clusters from the axils of bud scales or the lower leaves of the new growth; staminate flowers in long, cylindrical spikes, each with a 4 -lobed calyx, 4 stamens opposite the lobes, and a rudimentary pistil; pistillate flowers sessile, in densely flowered, oblong spilies, each with a persistent, 4-lobed calyx, a flat, oval ovary capped by ? spreading stigmas. Fruit a succulent "berr." composed of numerous tiny drupes developed from the ind1vidual flowers.

There are about nine species of Morus, and the genus ranges through the temperate regions of eastern North America, south along the highlands into Sonth America, and from the southwest of Asia into Iapan and the Indian Archipelago. There are two species in North America, nne of which grows in Il!inois.

\section{MORUS RUBRA LINNAEUS}

\section{Red Mulberry}

The Red Mulberry is a tree of moderate size, with a dense, roundtopped head of stout, spreading branches. The entire, or often deeply ;-loberl, bluish-green, thin leaves, ; to 5 inches long by $2 \frac{1}{2}$ to 4 inches wide, are smooth or a little roughened above but pale and more or less hairy beneath, and have coarse. incurved teeth along their margins. The spikes of staminate flowers are narrow and 2 to $2 \mathrm{r} / 2$ inches long, and the dense pistillate spikes, about 1 inch long. stand on short, hairy stalks. The sweet. juicy fruit, a little over an inch long, is at maturity nearly black. On the light, red-brown to orange, slender, zig-zag branchlets, the oval buds, 


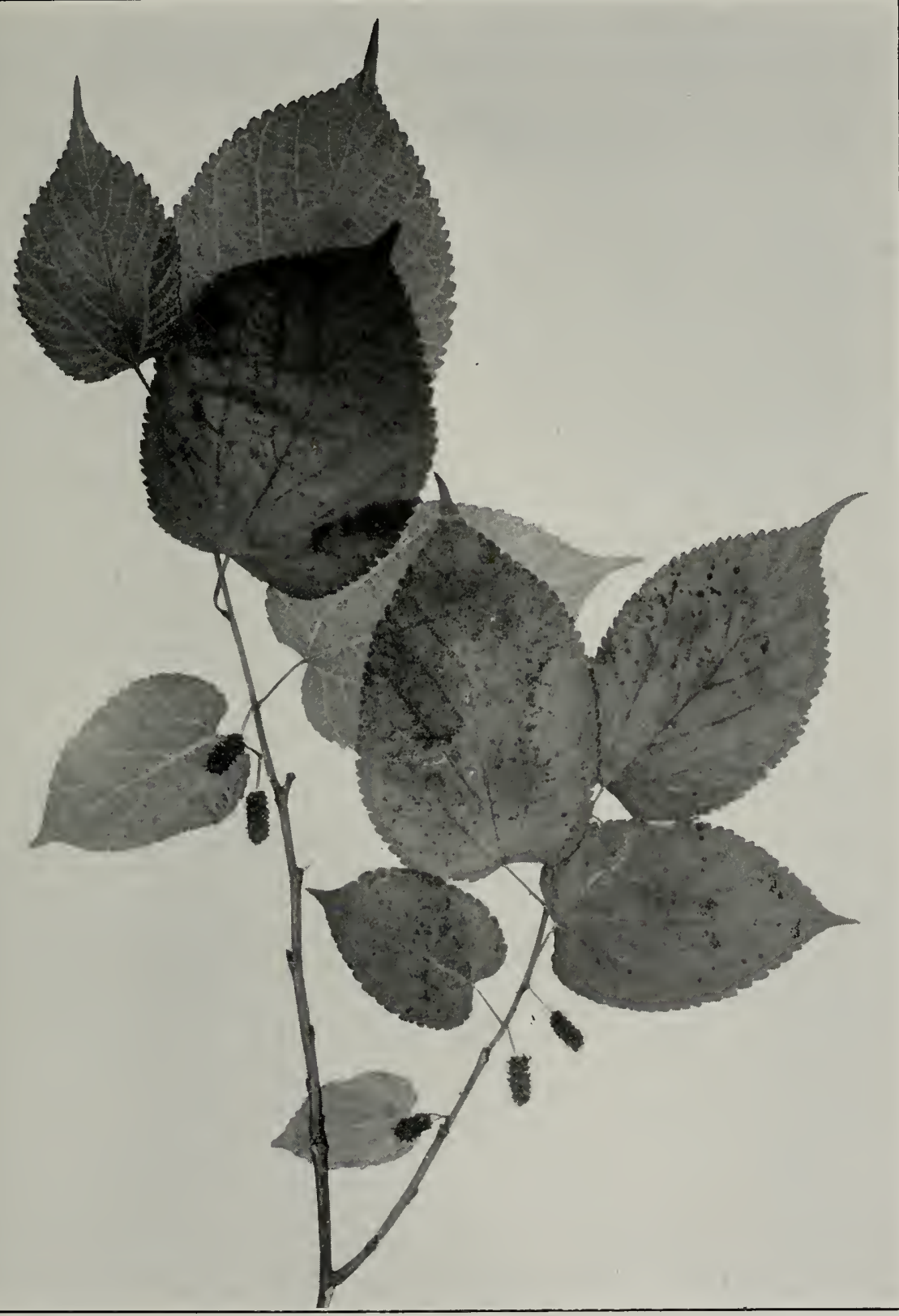

PLATE 56

MORUS RUBRA LinNaeus

RED IIULBERRY 


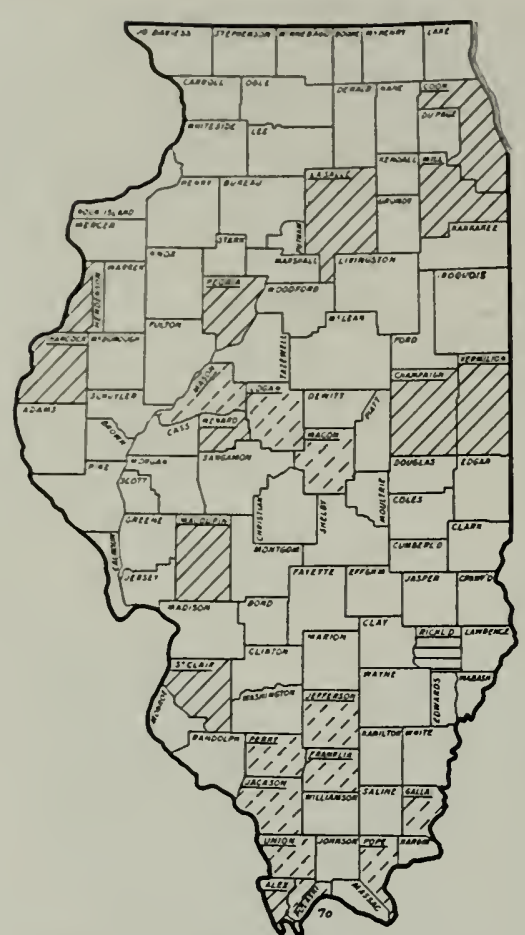

FIG. 70. Distribution of the Red Mulberry.

about $1 / 4$ inch long. stand above rather large and nearly circular leaf-scars. The trunk, which is covered by fairly thin, red-tinted, brown bark divided at the surface into elongated plates, may reach a diameter of :3 feet, and the mature tree is usually 60 to $: 0$ feet high.

Distribution: The Red Mulberry ranges from Massachusetts westward into the Dakotas and southward to Florida and Texas. It grows throughout Illinois, being more numerous, and the individual trees larger, toward the south. In the northeast, as reported by Pepoon", it is "very local and rare or overlooked" along the DesPlaines River. In Hancock County, Alice Kibbe says, the tree grows in rich woods, there being few large trees but many small ones. Ustally the Red Mulberry grows alone or in small groups, in association with Black, White. Pin, Swamp White. Swamp Spanish, and Cow oaks, together with hickory, Elm, ash, Hackberry, and numerous other trees, the particular mixture being determined by the location.

Before the Wabash region had been cut over for lumber, a tree measured by Jacob Schneck was found to have a height of 62 feet, a circumference of 10 feet 6 inches, and a bole reaching 20 feet to the first limb. The maximum height of Red Mulberry trees recently measured in a virgin stand of hardwoods in Union County was 30 feet, with an accompanying diameter of $r$ inches.

Uses: The golden-brown wood of the Red Mulberry, which darkens with age and exposure, is soft and weak, though coarse-grained and tough. Because of its durability in the soil, the farmers of southern Illinois frequently reserve the mulberry trees when selling the other timber, in order to convert them into fence posts for their own use. Occasionally, the wood gets to the sawmills, and is cut into lumber for use in boat building and barrel making.

${ }^{3}$ Flora of the Chicago Region, p. 282. 


\section{MACLURA Nuttall}

\section{Family MORACEAE}

Deciduous, spiny trees, with alternate, broad-bladed, simple leaves. Staninate flowers with long pedicels, grouped on slender stalks which arise from the axils of the leaves : pistillate flowers sessile in dense. globular heads, which cap stout stalls arising from the axils of the new leaves. Fruit a large, globose, milky "orange" composed of the united fruits of the individual flowers. Twigs round, with axillary spines, round, pale pith, and small, globular buds which stand above somewhat triangular leaf scars.

There is but one species, the well-known Osage Orange. It is confined to eastern North America.

\section{MACLURA POMIFERA SCIINEIDFR}

\section{Osage Orange Bow Wood}

The Osage Orange is a tree somewhat over medium height, with an open, round-topped head of stout, uptilted, spreading branches. The sharply pointed, smooth-margined leaves, with blades 3 to 5 inches long by ? to 3 inches wide, stand on slender petioles $1 \frac{1}{2}$ to 2 inches long. The clusters of staminate flowers are 1 to $1 \mathrm{~J} / 2$ inches long, and the globular heads of pistillate flowers are $3 / 4$ to 1 inch in diameter. The globular, orange-like, green fruit, which ripens in the autumm, is $t$ or 5 inches in diameter. The rather stout, pale-orange, zig-zag twigs bear pointed spines or small globular buds in the axils of the leaves. The trunk, which may attain a diameter of more than 2 feet, is covered by dark-orange bark deeply fissured into broad, rounded ridges. The height of the mature tree is between 50 and 60 feet.

Distribution: The Osage Orange has been planted widely as a hedge tree in all kinds of situations, but its natural habitat is the rich bottomland

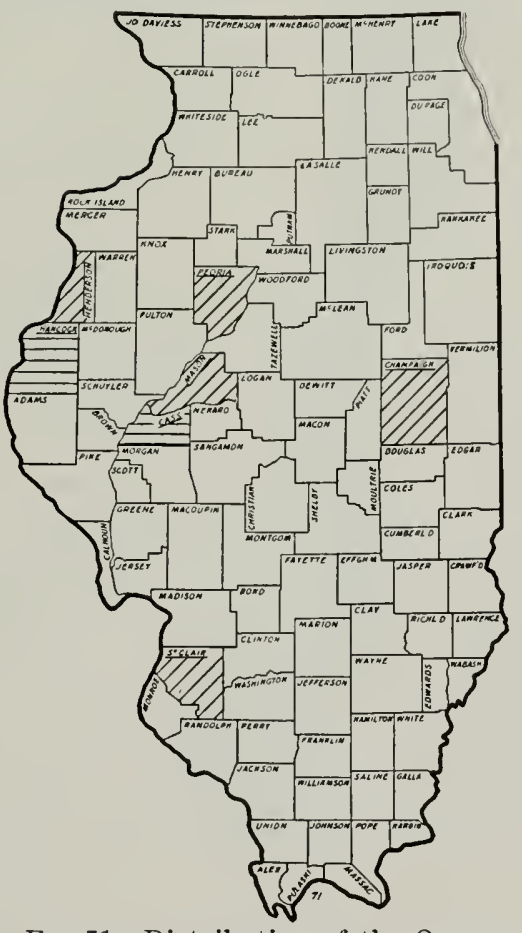

FIG. 71. Distribution of the Osage Orange. 


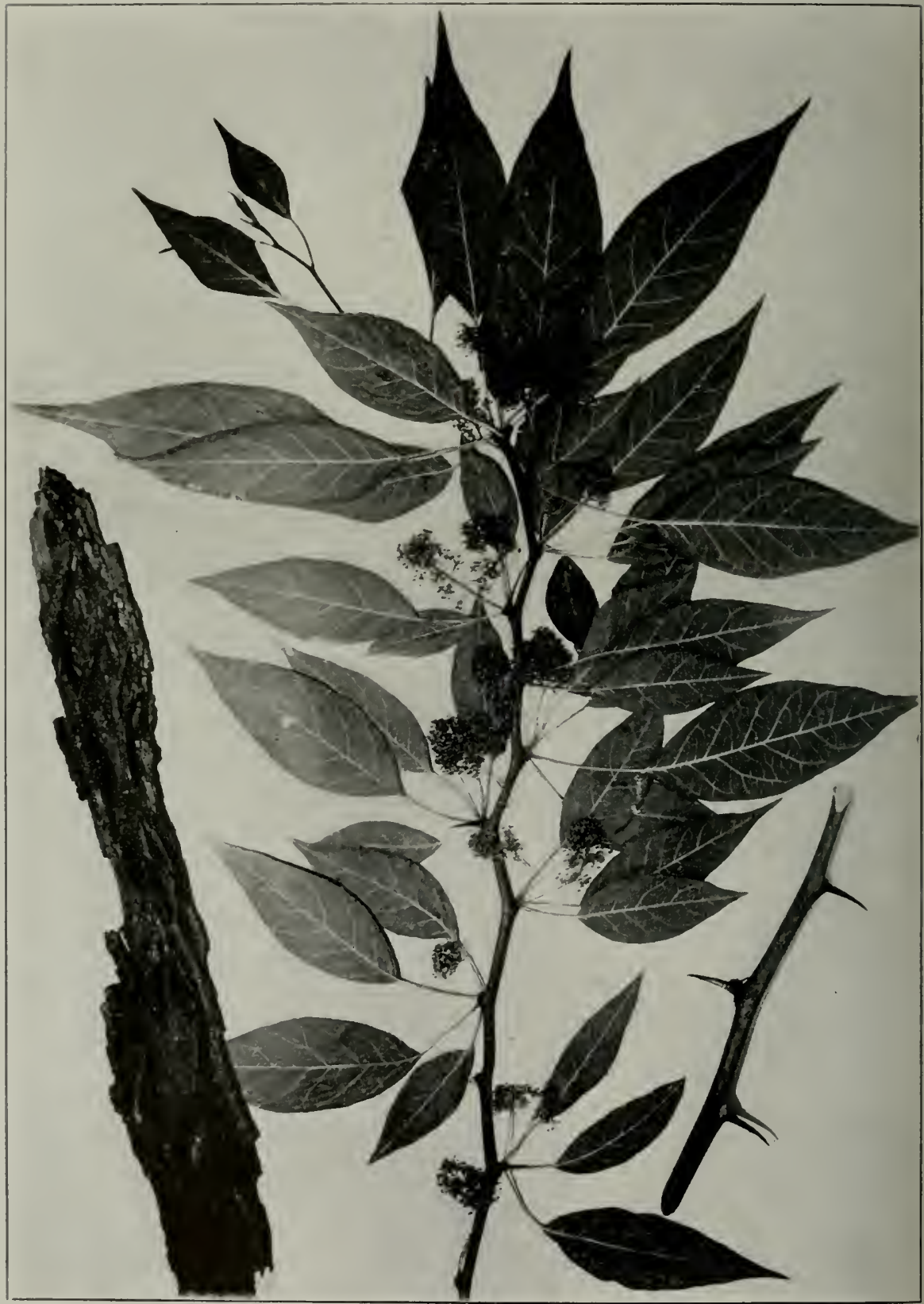

PLATE $5 ?$

MACLURA POMIFERA SCHNEIDER

OSAGE ORANGE 
of streams, and its native range extends from southern Arkansas and Olilahoma southward into Texas. In Illinois it is found occasionally as an "escape" from cultivation.

I'scs: The bright, orange wood of the Osage Orange, though coarsegrained. is exceedingly hard and strong. Its durability in the soil exceeds that of all other woods used for fence posts and railroad ties. Fences of Osage Orange have stood for more than .50 years without a rotten post, whi'e only to per cent of the posts in black ash fences remain sound for 10 years.

The Osage Indians called it "Bois d'arc," or bow-wood, and used it in their finest bows. It does not shrink with weather changes, and for this reason it was used in the early days to make the felloes of wagon wheels. At the present time, it finds some use in the manufacture of wooden machinery, insulator pins, and tool handles.

The bark of the roots contains an important dye, made up of moric and moritannic acids. which gives a yellow color; and the bark of the trunk, which yields the same substances, is employed in tanning leather.

\section{MAGNOLIA LinNAELS Magnolia}

Family Magnoliaceae

Small to very large trees and shrubs, with deciduous or persistent, broad-bladed, alternate, and simple leaves. Flowers rather large and showy, consisting of 3 sepals, 6 to 12 petals in series of 39 s, and numerous stamens and pistils with 2 recurved stigmas. Fruit a dry, cone-like structure, made up of numerous 2 -seeded capsules, the seeds with thick, reddish, pulpy coats. The rather stout twigs, which contain large, round, sometimes diaphragmed pith, bear oval buds covered by a single scale. The bark is ashy-gray or brown and either smooth or scaly.

Represented by about 30 species, Magnolia is found in eastern North America and southern Mexico, and in eastern and southern Asia. But in the geological epochs succeeding the Ice Age, the number of species, judged from the fossils that have been found, must have been much larger. Certainly, the range of the genus was greater, for it is known to have been represented in southern Europe and Japan. as well as British Columbia, Alaska, and Greenland. At the present time there are in the United States $i$ species, one of which is native to Illinois. 


\section{MAGNOLIA ACUMINATA Linnaeus}

\section{Cucumber Tree Mountain Magnolia}

The Cucumber Tree is of moderate to large size, with a pyramidal crown of rather small, spreading or erect branches. The pointed, yellowgrcen leaves, 6 to 10 inches long by 4 to 6 inches wide, are smooth on the upper surface but paler and soft-hairy beneath. The slender and eventu-

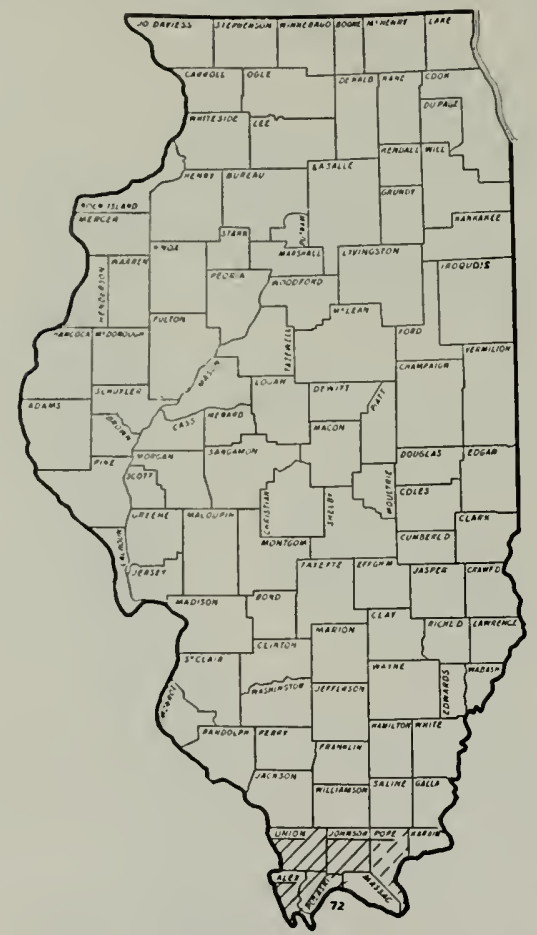

Fig. 72. Distribution of the Cucum. ber Tree. ally smooth petioles are 1 to $11 / 2$ inche: long. The flowers, which stand on pedicels $1 / 2$ to $3 / 4$ inch long, have 3 pointed, reflexed, membranous sepals and 6 erect, greenish-yellow petals $2 \mathrm{~T} / 2$ to 3 inches long. The oblong. sometimes curved, "cucumber-like" fruit is dark red and between 2 and 3 inches long. The bright red-brown branchlets are slender, with sharp-pointed and hairy terminal buds $1 / 2$ to $3 / 4$ inch long-about thrice as long as the blunt lateral buds which are set in the curve of the narrow. moon-shaped leafscars. The trunk, which is clothed by thin, furrowed, dark-brown, scaly bark, becomes :3 or 4 feet in diameter: and the tree grows to a height of 60 to 90 feet.

Distribution: From Ontario to Georgia and westward to Louisiana and Missouri, the Cucumber Tree grows on hillsides, mountain slopes. and along streams. In Illinois, it is native only in the extreme southern part of the State, where it is to be found as an occasional tree among other hardwoods on the richer and cooler northern slopes as well as on the bottomlands. In its moisture requirements, it is rather exacting, preferring deep, loose, moist soils and avoiding situations where the upper soil layers tend to become dry. Although it never forms pure stands, it makes up a considerable proportion of the new stand on the cut-over and partially drained bottomlands of Union County. Its common associates inclucle the White, Pin, and Black oaks, Hickory, Black Gum, Beech, Ash, Tulip Tree, and numerous others, both on uplands and bottomlands. 
('sis: The yellow-brown wood of the Cucumber Tree, though cluse-grained, is neither hard nor strong: and though occasionally sawed into lumber for flooring and calinet-making, it is used chiefly for veneers and carriage and automobile bodies-purposes for which its durability malies it suitable.

\section{LIRIODENDRON LINNAELS}

\section{Yellow Poplar}

\section{Family MagiolackaE}

Very tall, deciduous trees, with aiternate, broad-blated, t-lobed leaves with broad, notcherl tips. Flowers large and conspicuons, with :i sepals. (i petals, and numerous stamens and pistils, the latter developing together into a narrow, woody, cone-like fruit with 1 or 2 seeds in each of its capsules. The twigis are round and moderately thick. with light-brown, diaphragmed pitli and flattened, 2-edged buds above nearly round leaf-scars. The brown bark is decply furrowed and bitter.

At the present time, there are 2 species of Liriodendron, one native in eastern North Imerica, the other in Central China; but in ancient greological times there existed a great variety of species, which flourished thronghont most of the North Temperate Zone and even in Greenland a!nd lee'ancl.

\section{LIRIODENDRON TULIPIFERA LINNAEUS}

\section{Tulip Tree Yellow Poplar}

The Tulip Tree is exceedingly tall, rising at maturity to a height of 1,j0 feet or more, and its straight bole is capped with a narrow, conical crown of rather small branches. The dark-green and shiny leaves, is to 6 inches long, equally broad, and pale on the lower surface, are variable in shape hut have quite commonly + distinct, pointed lobes, the npper 2 lobes leing so arranged as to give the lea $f$ end a flat or notched appearance. The fowers, which are $1 \frac{1}{2}$ to 2 inches deep, stand on slender pedicels nearly an inch long, the greenish-white sepals spread or turn downward and fall soon, and each of the 6 petals is conspicuously marked with orange at its base. The mature, cone-like frut it from $21 / 2$ to $: 3$ inches long by about $1 / 2$ inch thick and ripens in September or October. The shiny, reddish-brown branchlets, which contain pale, diaphragned pith, are terminated by a Hat, 2-edged, and somewhat stalked bud about $1 / 2$ inch long, and the darkred lateral buds, smaller than the terminal one, stand above large, round leaf-scars. The trunk, covered when young by thin, scaly bark but when old by deeply furrowed brown bark 2 inches thick, often attains a diameter of if feet or more. 


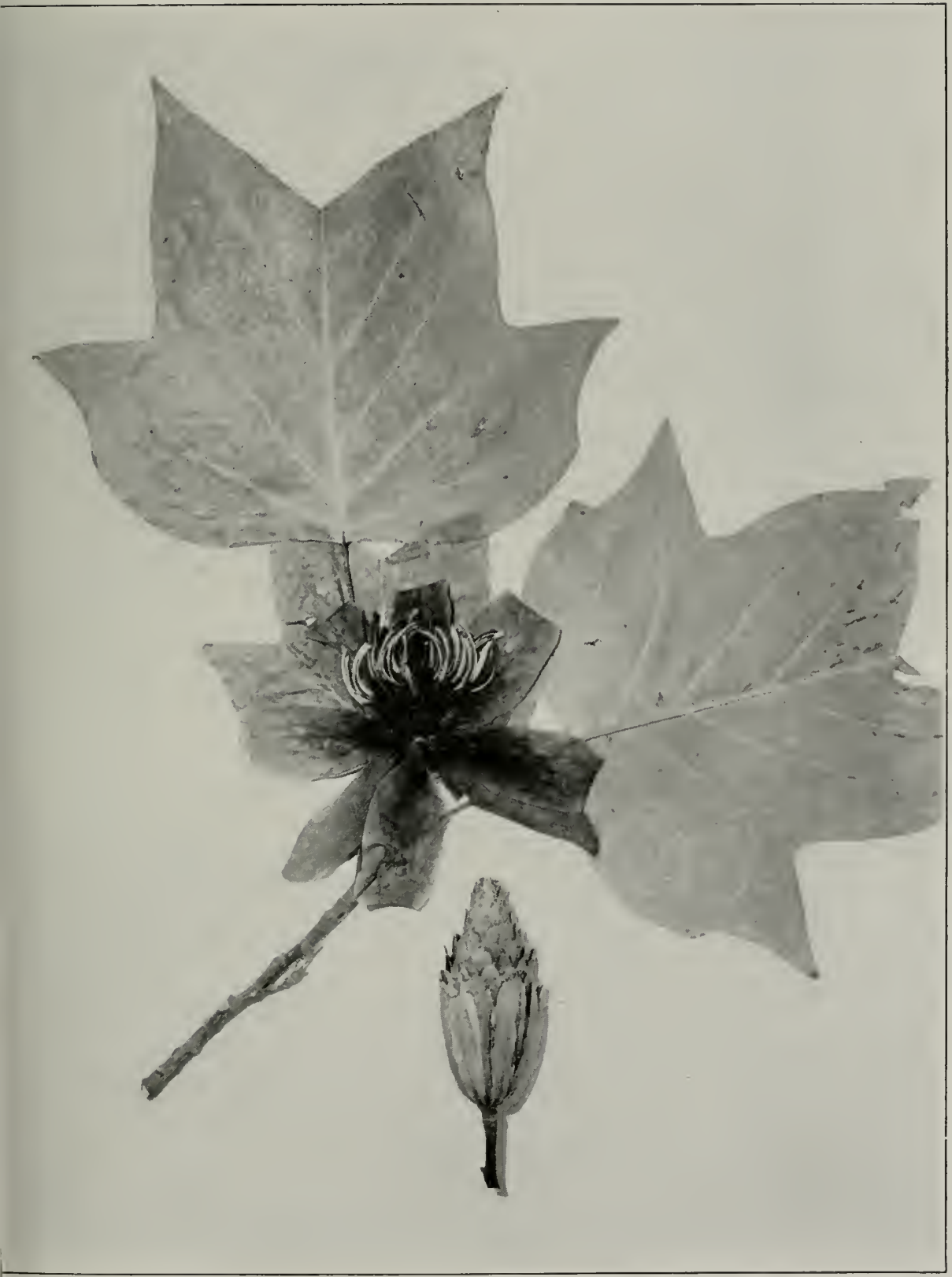

PLATE 59

LIRIODENDRON TULIPIFERA LINNAEUS

TULIP TREE 


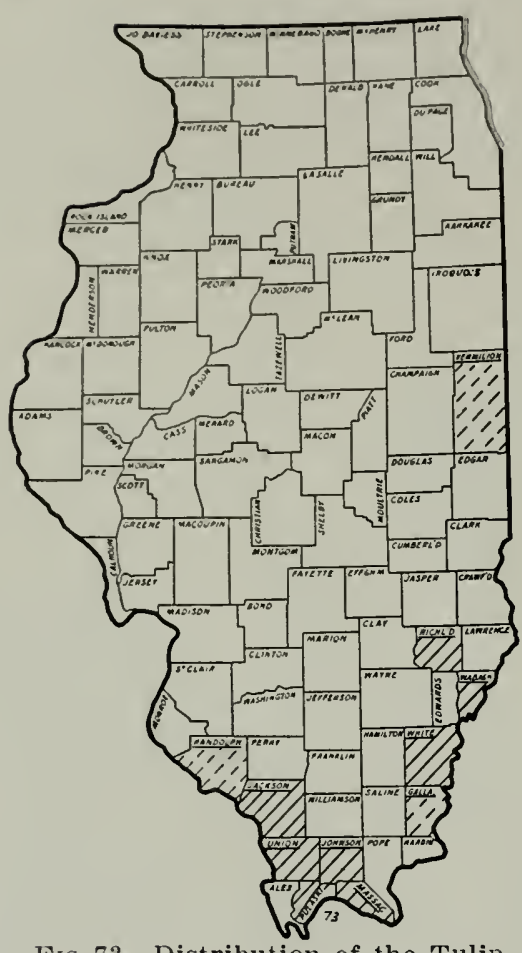

Fig. 73. Distribution of the Tulip Tree.

Distribution: On slopes and in stream valleys, but always on (leep and moist but well-drained soils, the Tulip Tree ranges from Massachusetts south to Florida and westward to Missouri, Arkansas, and Louisiana. In Illinois, it is distinctly a southern tree, its range reaching northward in the west only as far as Piney Creek in St. Clair County and in the east to Richland County. Its occurrence in the southeast corner of Vermilion County is undoubtedly a local extension of its range in Indiana, where it is known to have been native in the north as well as in the south. In the southern Illinois counties which line the Mississippi, Ohio, and Wabash rivers, the Tulip Tree finds favorable sites on the deep, moist soils of cool ravines and along the lesser streams; but it does not venture far into the interior counties.

Its conmon associates are White, Black, and Red oaks, hickories, Sycanore, Black and Red gums, Beech. White and Slippery elms, the maples, ashes, and Black Walnut. In Pulaski County, it grows on the terraced soils of the bottonlands, just above the Cypress swamp, with Hard Maple, ashes, Bass Wood, hickories. and elms; and at the Piney Creek station, it grows with Beech. Black Gum, and Short-leaf Pine. About 65 years ago. A. H. Worthen ${ }^{1}$ observed that "at points in Johnson County where sandstone does not prevail, the limestone and shales have added to the soil by their disintegration and this change of soil can be recognized by a somewhat changed growth of timber, especially by the presence of yellow poplar."

The original Tulip Trees of the Wabash Valley, according to Robert Ridgway², ranked next to the Sycamore in the size, height, and symmetry of their trunks. He measured 20 standing trees and found them to have an average height of $14 i$ feet, a trunk circumference of 19 feet + inches, and a clear bole (i: feet long. He states, also, that "the finest

1 (;eology of Illinois, Vol. 1, p. 377.

2 American Naturalist, Vol.6, pp. 658-665 and 724-732. 1872. 
tree measured was one cut for lumber near Timberville . which measured 158 feet in total length while the trunk was 23 feet in circumference 3 feet from the base, and 18 feet at a point it feet further up where the first branch grew. The trunk was perfectly sound and symmetrical throughout." The largest Tulip Tree measured in our recent forest survey was only 90 feet high, with a diameter of $2 \%$ inches.

Uses: The wood of the Tulip Tree, often called "whitewood" in the lumber trade because of its creamy-white sapwood, is yellowishbrown with a green tint in the heart. Being light and soft and easily worked, though somewhat brittle and weak, it finds numerous uses in the manufactured articles of commerce. Because of its durability and receptiveness to paint, it is used extensively in the exterior trim of houses. as in cornices, bevel siding, and veranda columms; and, though it has no decided grain pattern, the color contrast between its heart and sapwood lends a pleasing effect for interior finishing. Formerly, a considerable amount of yellow poplar was used in the manufacture of buggy boxes and wagon beds; but the present cut finds its way into automobile bodies, boats, shingles, drawing boards, tables, and veneers. It is an ideal wood for turnery, and much of it is used in making toys, novelties, and cabinets. Tulip Tree shavings, together with other waste wood, are shipped from St. Louis mills to Chillicothe, Ohio, to be made into paper pulp.

Though still valuable, the Tulip Tree no longer holds an inportant place among the commercial trees of our forests. In the bottomland forests, it grows only in the south; and there it is to be found only along the secondary streams at the rate of about 1 tree per acre. In the upland forest, it grows only with the mixed hardwoods, 1 tree to the acre on an average; but even when it is more numerous, as in the upland stands of Union County, it makes up, only about 3 per cent of the stand and cven then only 1 tree in 3 has reached merchantable size, and the merchantable trees yield only $; 0$ to $1 \% 0$ board feet to the acre.

\section{ASIMINA AdAnson Pawpaw}

\section{Family AnONACEAE}

Deciduous small trees or shrubs, with alternate, broad-bladed, simple, and entire leaves. Flowers, borne alone on pedicels from the old leaf axils, have 3 green sepals, 6 dark petals in 2 series of 3 each, many stamens, and 3 to 15 pistils crowded in the center of the flower. The fruit is berry-like and edible. The round twigs contain white, green-diaphragmed pith, end in a naked terminal bud, and hear smaller lateral 
bucls above half-round or crescent-shaped leaf-scars. The branchlets give off a disagreeable odor when bruised.

The genus is found only in eastern North America, where 6 species are recognized; but of these only 1 attains the size and form of a tree. the others being low shrubs of the far south.

\section{ASIMINA TRILOBA DUNAL}

\section{Pawpaw}

The Pawpaw is a decidedly small tree, with a straight bole and small spreading branches. The sharply pointed, smooth-margined, conspicuously obovate leaves, 10 to 12 inches long by $t$ to 6 inches wide, are lightgreen on the upper surface, paler beneath, and not at all hairy. The

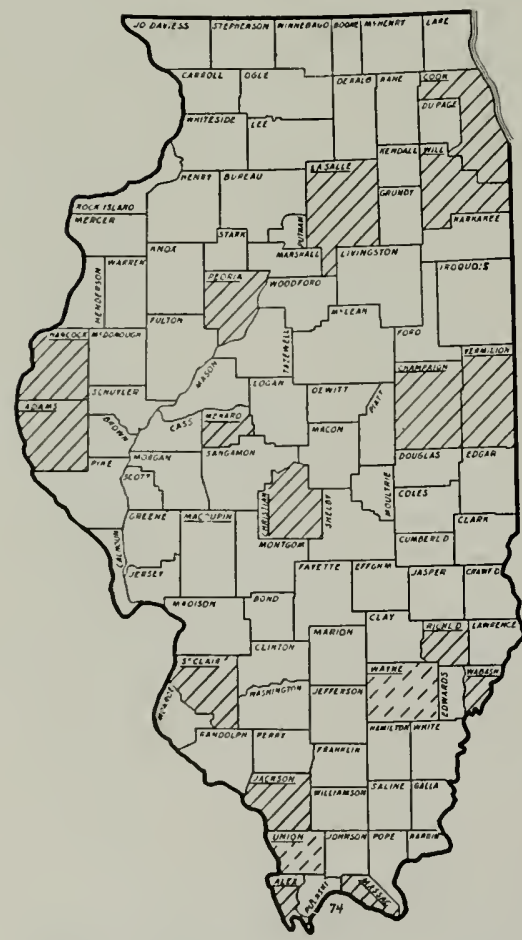
flowers, which are nearly 2 inches in diameter and stand singly on stout, hairy pedicels an inch or more long. have 3 pale green sepals, which are densely hairy on the outside, and 6 brown to deep-red petals 2 or 3 times as long as the sepals. The dark-brown to blackish fruit, 3 to 5 inches long by $1 \mathrm{I} / 2$ to 2 inches long, has a whitish to orange, edible flesh, within which are the large seeds. The finely grooved. dark-red twigs bear pointed, somewhat flattened, hairy buds about $1 / 8$ inch long. The small trunk is inclosed by thin, dark-brown, blotchy bark. The tree usually attains a height of between 30 and 40 feet.

Distribution: From New York westward to Iowa and southward to Florida and eastern Texas, the Pawpaw is to be found in woods on deep. moist soils. It occurs throughout Illinois except in the northwestern corner FIG. 74. Distribution of the Pawpaw. of the State, and it is most abundant in the southern counties, where it grows in dense clumps beneath the larger hardwood trees. In Edgar County, in the rough uplands woods, its associates are Black IValnut, oaks, and hickory; in Wabash County, Sycamore and Burr Oak; and along Coffee Creek in Wabash County, it is common among the bottomland hickories and oaks. 


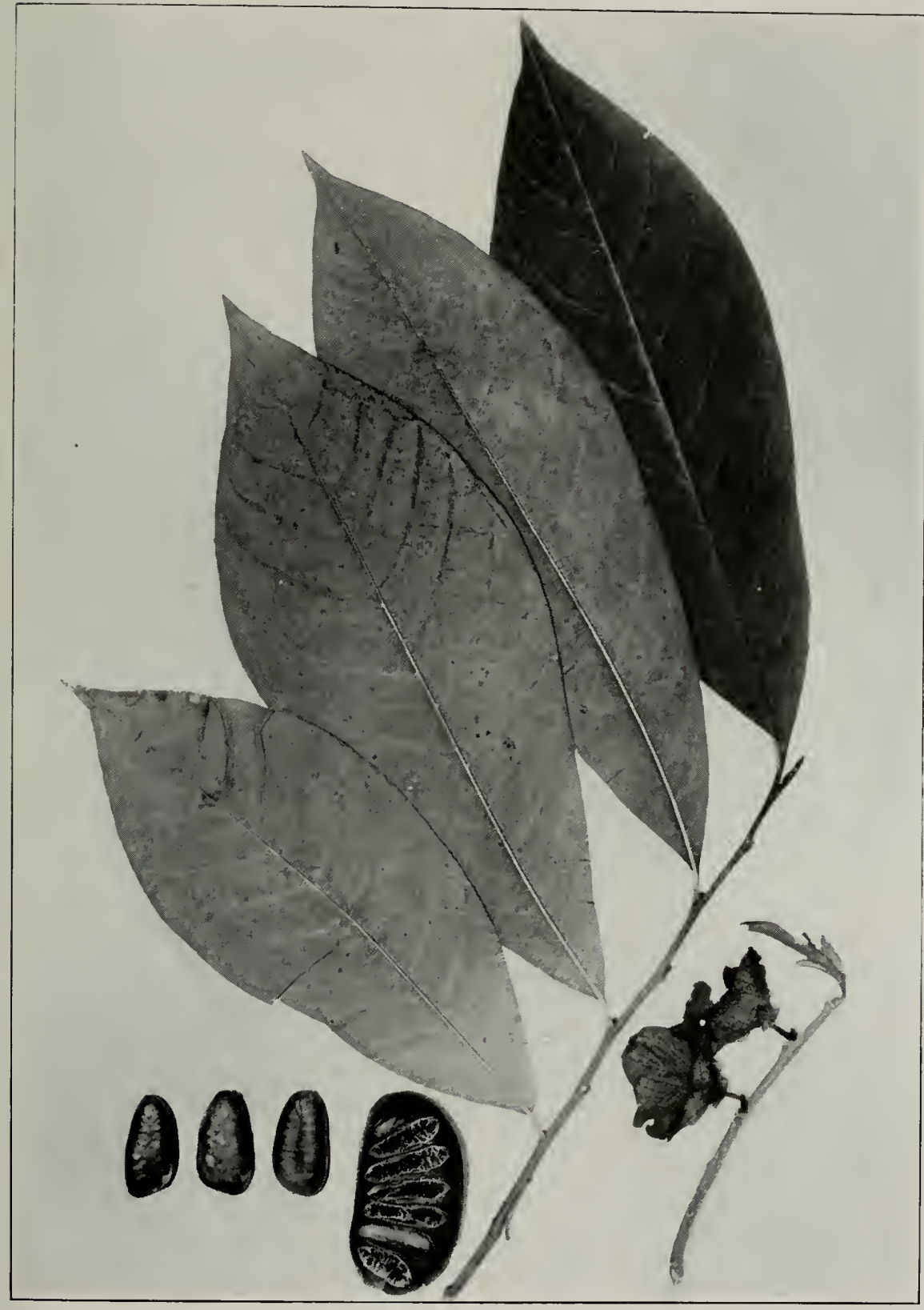

PLATE 60

ASIMINA TRILOBA DUNAL

PAIVPAW 
Robert Ridgway reported, in 1882 , that he had seen pawpaws in the 11 abash Valley with a height of 48 ieet and a trunk circumference of 3.) inches. but at the present time one seldom sees a tree more than 30 feet high and 21 or $2:$ inches in circumference.

Lscs: The coarsely grained, spongy wood of the pawpaw, which is not only light but soft and weak as well, has no commercial value. The tree is used to some extent in decorative planting; but its chief value lies in its fruit. which matures about the middle of September. As its poor keeping qualities do not allow it to be shipped to fruit markets, its sale is limited to the localities in which it is grown. There are two varieties of fruits, one with white and one with yellow flesh, and it is the latter that is considered the more desirable for eating.

\section{SASSAFRAS NeEs}

\section{Sassafras}

\section{Family LAURACEAE}

Sinall to moderate, deciduous trees, with alternate, simple, variously lobed leaves and terminal flower buds. The staminate and pistillate flowers on different trees, each usually in few-flowered racemes, and each flower with six sepals, no petals, 9 stamens (poorly developed in the pistillate flowers), and one ovary (absent in the staminate flowers). Fruit a dark blue to black berry, with thin flesh surrounding the dark brown seed. The rounded. green twigs contain white, somewhat angled pith and bear solitary, subglobose lateral and terminal buds above small, nearly semicircular leat-scars. The bark red-brown, thick, and deeply furrowed.

With its 3 species. Sassafras now grows in southeastern North America, southeastern Asia, and Formosa; but in pre-glacial ages, several species, some of which had leaves quite similar to those of our one modern American form. were in existence, and the range of the genus included southern Europe, South America, Australia, Greenland, and northwestern North America.

${ }^{1}$ Proc. U. S. Nat. II useum, Vol, 5, pp. 49-Ss. 


\section{SASSAFRAS OFFICINALE NEES AND EBERMAIER}

\section{Sassafras}

The Sassafras tree is generally of only very moderate size, with a flat-topped head of rather stout branches which extend almost horizontally from the trunk. The firm and often rather leathery, dark-green leaves, 4 to 6 inches long by 2 to 4 inches wide and more or less hairy beneath, commonly have 2 or 3 very distinct. large, and characteristic apical lobes. The petioles are from $3 / 4$ to $1 / 2$ inches long. The small, greenish flowers stand on short stalks along a central axis and form racemes about 2 inches long. The blue berries, which ripen in the fall, are between $1 / 4$ and $1 / 2$ inch long and stand in scarlet cups at the tips of stalks $1 \frac{1}{2}$ to 2 inches long. The bright-green, shiny branchlets bear globular buds about $1 / 4$ inch long. The trunk is generally not over 6 inches in dianeter. The tree rises to an ordinary height of 30 or 40 feet; but much larger trees may be found.

Distribution: From Maine to Iowa and southward to Florida and Texas, Sassafras finds a natural home on rich and sandy, well-drained soils, often invading abandoned agricultural land. With the exception of our 3

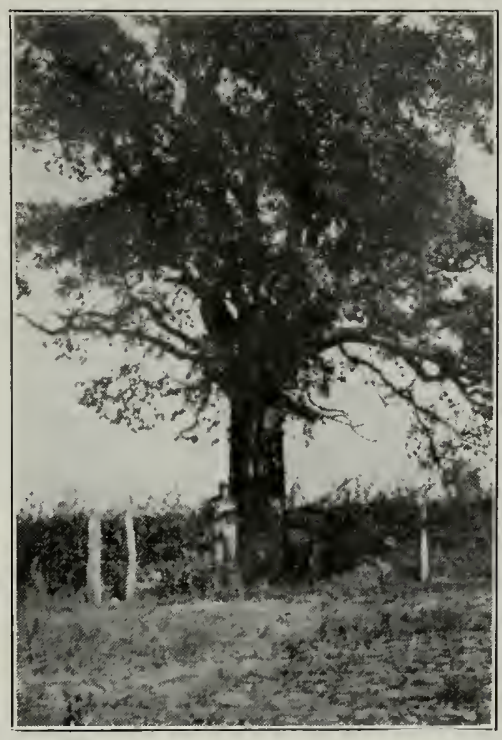

FIg. 75. Largest Sassafras in Illinois. This tree, situated in Pike County, near Maysville, has a trunk diameter of 33 inches. northern tiers of counties, it ranges throughout Illinois, but it is most frequently met with to the south of the Illinois River. Though generally a small tree, it is linown to have attained a height of $i 1$ feet and a trunk circumference of over $;$ feet, with a clear bole 52 feet 6 inches long. in the Wabash Valley. A tree standing 3 miles northwest of Maysville, Pike County, measured 33 inches in diameter but, being on open ground, it has a short trunk.

Sassafras sometines grows in pure stands, as at Foley's Mill, near Paris, Edgar County; but it is usually accompanied by other trees. On poor or abandoned land, its associates often are Persimmon and Sumach; but on bottonlands, as in Wayne County, they are Red Gum, River Birch, hickories, ash, and Swamp White Oak. In Fulton County, it was found with hickories, Elm, Bass Wood, White and Shingle oaks, Wal- 


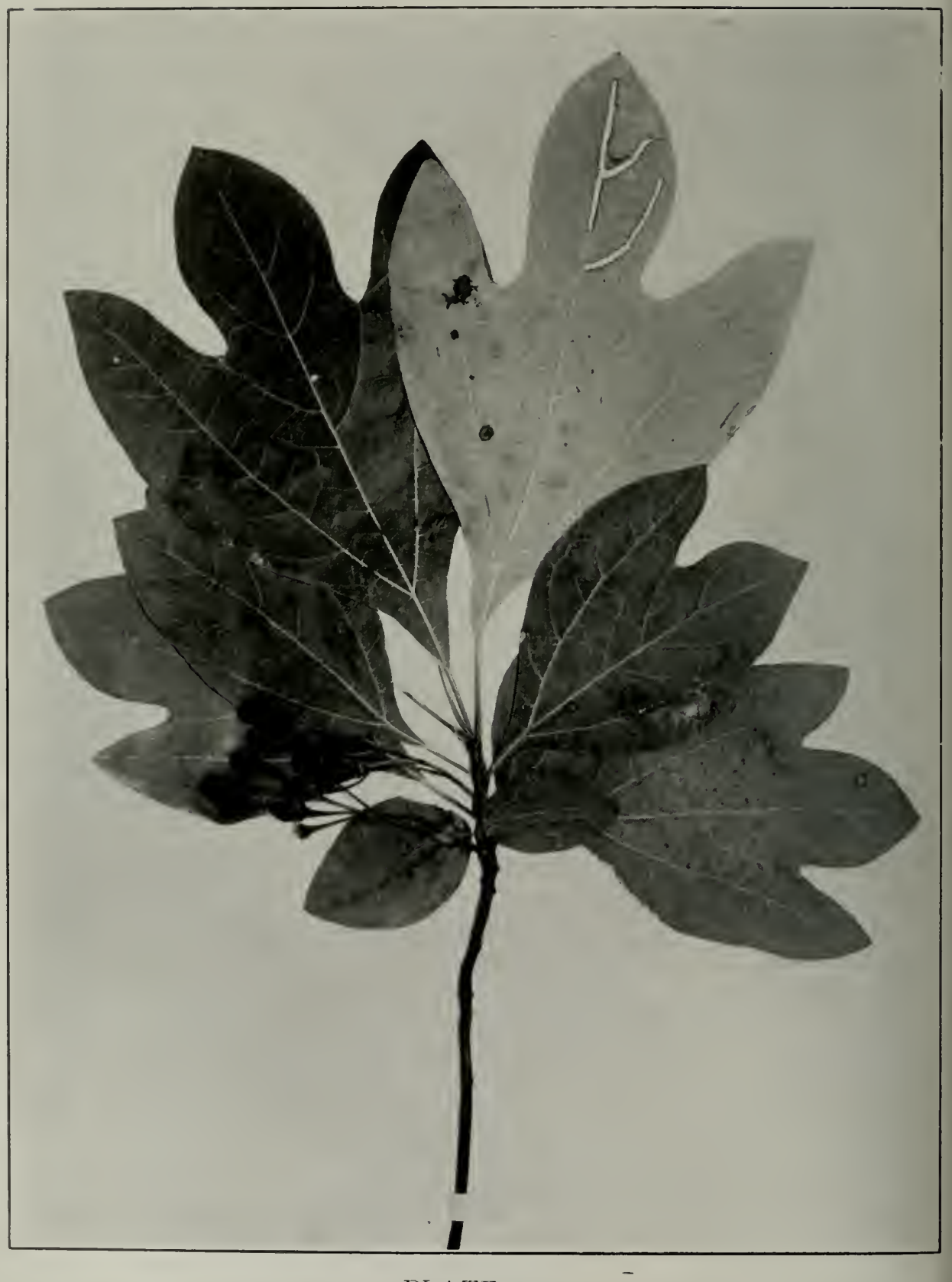

$$
\text { PLATE } 61
$$

SASSIFRAS OFFICINALE NeES \& EBERMAIER

SASSAFRAS 
17ut, and Ironwood: in Kankikliee County with the Black and White oaks and Black Cherry; and in Mason County with the B!ack, IVite and Jack oaks and Red Mulberry.

Uses: Though soft and light, the wood of the Sassafras, which is lightbrown with a yellowish thin sapwood, is very durable in the soil and is used not only for fence posts and rails but also for railroad and mine ties. The roots furnish the material for sassafras tea, and sassafras oil, distilled from the bark, is an ingredient of certain medicines and perfumes.

In the Wabash Valley, where trees so feet high, though only 14 inches in diameter, have been seen. Sassafras furnishes about 30 board feet per acre, while anong the upland timber of Union County, where the maximum height is $: 30$ feet and the greatest diameter $S$ inches, the boardfont yield is negligible.

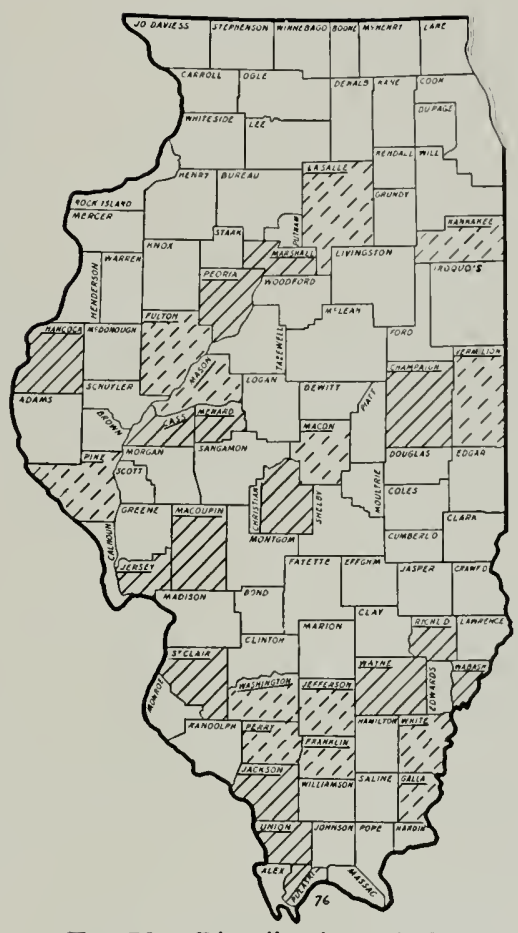

Fic. 76. Distribution of the Sassafras.

\section{LIQUIDAMBAR LINNAEUS}

\section{Family HamaMeldDACEAE}

Tall, deciduous trees, with alternate, broad-bladed, palmately lobed leaves and flowers with rudimentary sepals and no petals. The staninate and pistillate flowers separate, the former in terminal racemes, the latter in globular heads at the ends of stalks arising from the axils of the upper leaves. Fruit a globular collection of capsules, armed by harclened and incurved, warty spines, usually containing a flatened, ieminaily winged seed.

The 4 species of this genus give it a disconnected range which includes southeastern North America and Central America, southeastern and southwestern Asia, and Formosa. But from fossils, about 20 species, now extinct, are known to have existed during the world's history and to have grown, at various times, in Asiatic Russia, southern Europe. western North America, and even Alaska and Greenland. There is now but one species in the United States. 


\section{LIQUIDAMBAR STYRACIFLUA LINNAEUS}

\section{Sweet Gum}

The Sweet Gum is a tree of considerably more than moderate height, with a small and oblong crown of slender branches. The thin, brightgreen, fincly toothed leaves are divided into 5 or $千$ large, pointed lobes, so that each leaf has the appearance of a star. The slender petioles are 5

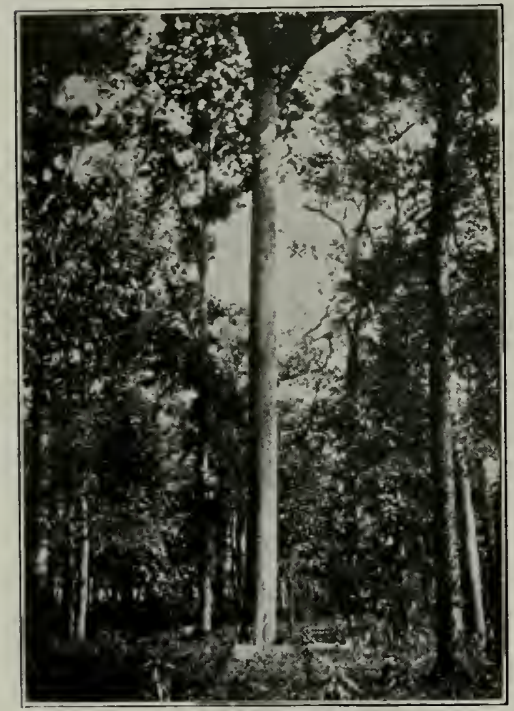

Fig. 77. A Sweet Gum in the forest near Mt. Carmel. This tree had a clear bole 78 feet long, a crown spread of 85 feet, and a trunk circumference of 12 feet 6 inches. Photo by U. S. Forest Service. or 6 inches long. The terminal racemes of staminate flowers are 2 or :3 inches long, the flowers being arranged in compact heads along the axis; and the pistillate flowers are grouped in globular heads $1 / 2$ inch in diameter on the ends of drooping perlicels. The globular fruits attain a diameter of 1 to $1 \mathrm{I} / 2$ inches, the capstules opening in the autumn to set free brown, resinous, winged seeds about $1 / 2$ inch long. The round and often corky-ridged twigs contain brown, star-shaped pith and bear oval buds above more or less triangular leaf-scars. The trunk, covered by deeply furrowed, light-gray bark, attains a diameter of $t$ feet or more; and the tree often grows to a height of 100 feet or over.

Distribution: On rich, inundated bottomlands and in swamps, the Sweet Gum ranges from Connecticut to Missouri and to Florida, Texas, and Mexico. In Illinois, it is native only in the southern counties, coming up the Wabash and its tributaries to Richland County and up the Mississippi to Jackson County. Of all the trees in the virgin forests of the Wabash Valley, according to Robert Ridgway, Sweet Gum, or Red Gum as it is often called, had the tallest and straightest shaft, in proportion to its girth. The two largest specimens seen by him had trunks $1 \hat{\imath}$ feet in circumference, and one of these had a clear bole sil feet long; and the tallest tree he saw cut for lumber had a total length of $16+$ feet. In our forest survey, we measured a Sweet Gum in Massac County, which had a height of 122 feet, a bole 62 feet long, and diameters of 34 inches at the base and 26 inches at the top of the bole. 


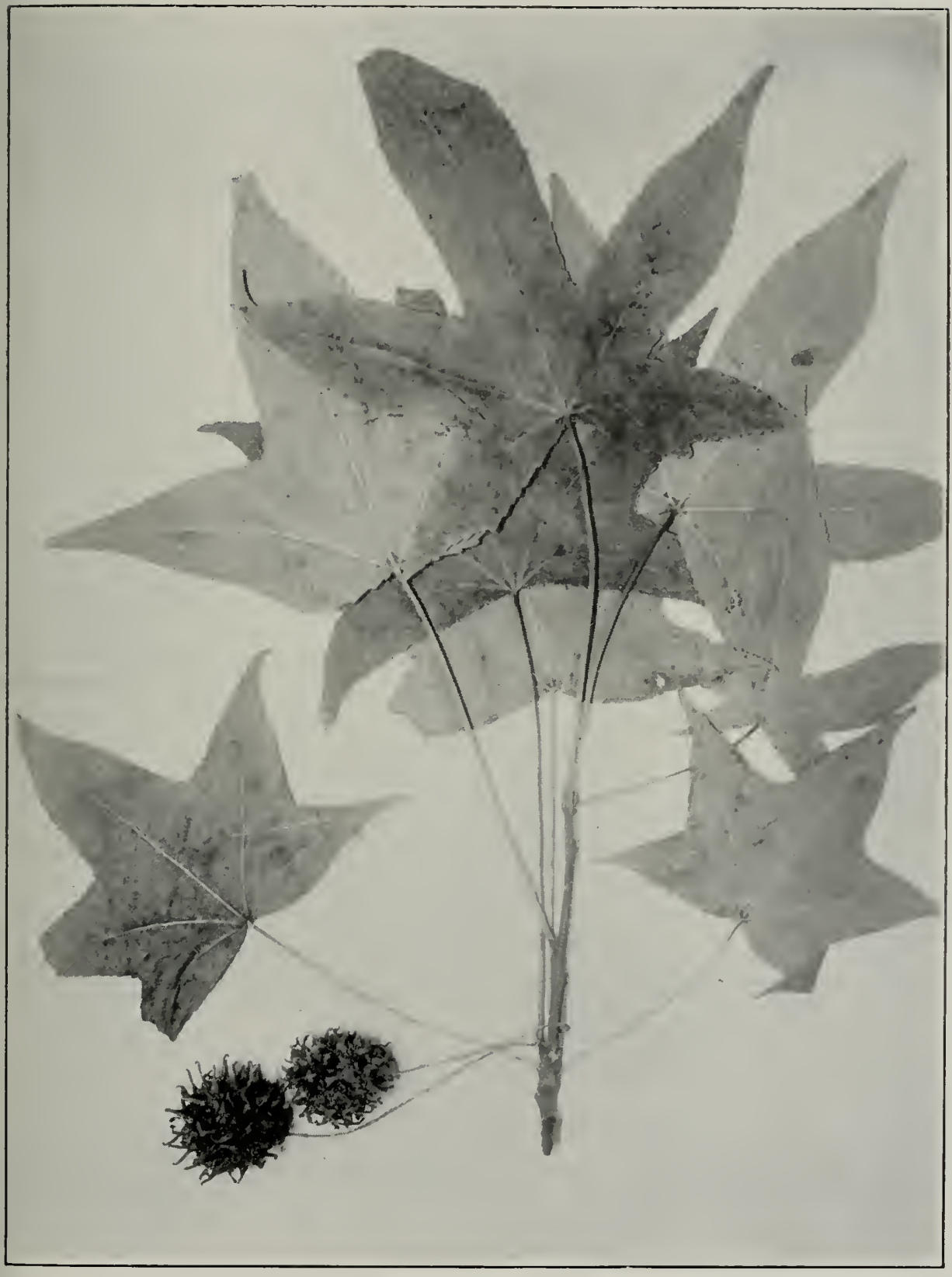

PLATE 62

LIQUIDAMBAR STYRACIFLUA LINNAEUS

SIVEET GUM 
It furnished, when sawed, 2.31; feet of lumber for egg crates. A fine stand is $110 \mathrm{w}$ in existence on the Coffee Creek bottoms near Mt. Carmel, in which the trees vary from $: ?$ to 31 inches in cliameter and average about 11.j feet in height.

On the bottomlands, the siwcet Gum is commonly associated with Sycanore, Cottonwood. Honey I.ocust, the bottomland oalis, Pecan, Hackberry. and Soft Maple.

L'ses: The heary and close-grained wood of the Sweet Gum, though hard. is not very strong: but becanse of its fine texture and the alternating streaks of red and black, which give highly figured patterns, it is used often for interior finishing. especially in the panels of cloors and walls.

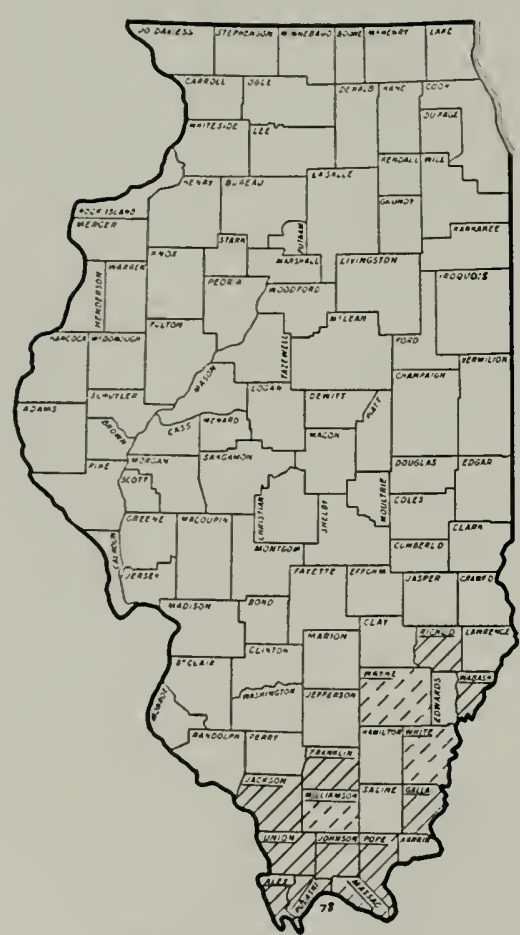

Fig. 78. Distribution of Sweet Gum.

To some extent, it is used in the manufacture of furniture, as a substitute for walnut or mahogany. being. indeed, exported to England under the tracle name "satin walnut."

A "sweet gum" derived from the tree is similar, in its properties and composition, to the storax taken from Liquidambar orientalis in Asia Minor, a substance yielding both cinnamic acid and cinnamic alcohol. These products enter into the manufacture of tobaccos, pharmacentical substances, adhesives, and perfumes. Andre Michaux, in relating his travels between 1693 and 1796 , says that "a Frenchman who traded among the Cheroquois savages cured himself of the itch by drinking for ten days a decoction of chips of that tree which he called copalm and which is the tree Licuniclambar."

In 19\%5, the Illinois cut of Sweet Cinm yielded two and a half million board feet of lumber, and in addition a large amount went into the manufacture of basket and crate veneers. In the Cypress swamps, Sweet Gum is third among the trees in importance and constitutes between 10 and 11 per cent of the stand; among the hardwoods of the main streams, it constitutes between 4 and ; per cent of the stand; but along the seconclary streams, it falls to a low position among the timber trees. In the Wabash 
Valley, there is still a potential yield in the virgin forest of 4,500 board feet to the acre. while in the Cypress swamps the yield is estimated at about 3,600 board feet per acre. Elsewhere, the Sweet Gum is not now of great importance as a timber tree.

\section{PLATANUS Liñaeds Plane-tree}

Family Platanaceae

Small to very large, deciduous trees, with alternate, broad-blacied, more or less distinctly lobed leaves, the petioles enlarged at the base and inclosing the buds. The minute flowers in dense, stalked heads, staminate and pistillate flowers common in separate heads, the former dark-red and the latter light-green. The staminate flowers with 3 to 6 small sepals, 3 to 6 pointed petals, and as many stanens as sepals; the pistillate flowers with 3 to 6 sepals and petals and an equal number both of rudimentary stamens and of pistils. Fruit a long-stalked, dense head of nutlets, within which are the light-brown seeds. The round, zig-zag, moderate-sized twigs contain pale to brownish pith and, though lacking a terminal bud, bear rather large, conical one-scaled lateral buds within the circular leafscars. Thin stipule scars encircle the twigs at each leaf-scar. The bark characteristically exfoliates in large, thin strips, exposing the white under bark.

With its 6 or $?$ modern species, Platanus is now native in North Anerica and southwestern Asia, as well as Mexico and Central America. But the history of the Plane-tree extends far back into the early story of the world's life. Not less than 16 species have been found among American fossils; and these records, which show that North America was the original home of the Sycamore, carry us back to a time when the apeman was still a being of the future and when the gigantic dinosaurs still roamed the earth. Though of most ancient ancestry and once a widely distriluted and numerous tribe, Platanus has succumbed to the march of the ages; and there are now but 3 species in North America, of which one alone is found in Illinois.

\section{PLATANUS OCCIDENTALIS Linnaeus}

\section{Sycamore Buttonwood}

The Sycamore is an exceptionally tall tree, often with several trunks that rise from near the ground to a great height and then give out massive, spreading limbs, which form a very wide and open head. The 3to 5 -lobed, coarsely but sharply toothed leaves are thin but firm; the blade, 


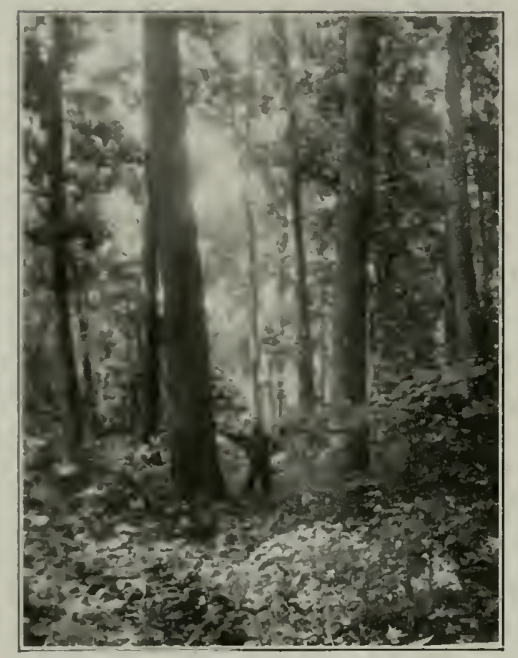

Fig. 79. Sycamore grove on the Mississippi bottcms in $U 11$ jon Coun! y.
1 to : inches long and almost equally broad, is l)right green on top, thongh paler beneath. where the midrib and veins are furnished with fine hair. The stout petioles are between :3 and 5 inches long. The flower heads are solitary, or occasionally 2 together, on the ends of pendulous, pale-hairy pedicels; and the fruits or "button-balls", which develop from the pistillate heads, grow to at diameter of an inch or more, while their slender stems increase in length to 3 or even 6 inches. The branchlets, which are at first hairy and dark-green, become orangebrown and later gray and bear conical. 2 -ranked buts $1 / 4$ inch or more long. The lower trunk, which often attains: a diameter of 10 feet, is covered with thick, dark-brown bark deeply furrowed into broad rounded ridges; but upward on the trunk the thin onter bark falls in scales, exposing the imner bark. The height of the tree often exceeds 100 feet.

Disiribution: Fronı Maine westward to Iowa, southward to Florida, and again westward to Texas, the Sycamore grows on the rich borderlands of streams, rivers, and lakes. It ranges through the length and breadth of Illinois, though in the north, where favorable localities are few, it is not a common tree. In Hancock County it is said to grow, even abunclantly, on rich lowlands, and it is found also on dry limestone ledges at Ceclar Glenn, as well as occasionally on dry, upland slopes. In Vermilion County, on the eastern side of the State, it grows with the Beech an: 1 its associates, while in the University Woods of Champaign Comnty it is found with such trees as maples, hickories, Buckeye. Hackberry, and Honey Locust. In the southern part of the State. Sycamore is, however, a fairly important tree; for though in the upland forests there are only about 2 trees $t 0100$ acres, it increases in abundance on the lowlands and averages 40 trees to 100 acres in Cypress swamps, 66 trees to 100 acres on the lowlands of the main streams, and about 26.5 trees to 100 acres along the secondary streams.

In Thwaite's Early Western Travels', there is this note on the Sycamore: "The Sangamon bottom has a soil of amazing fertility and rears from its (leep, black mould a forest of enormous sycamores; huge, overgrown, unshapely masses, their venerable limbs streaming with moss." 


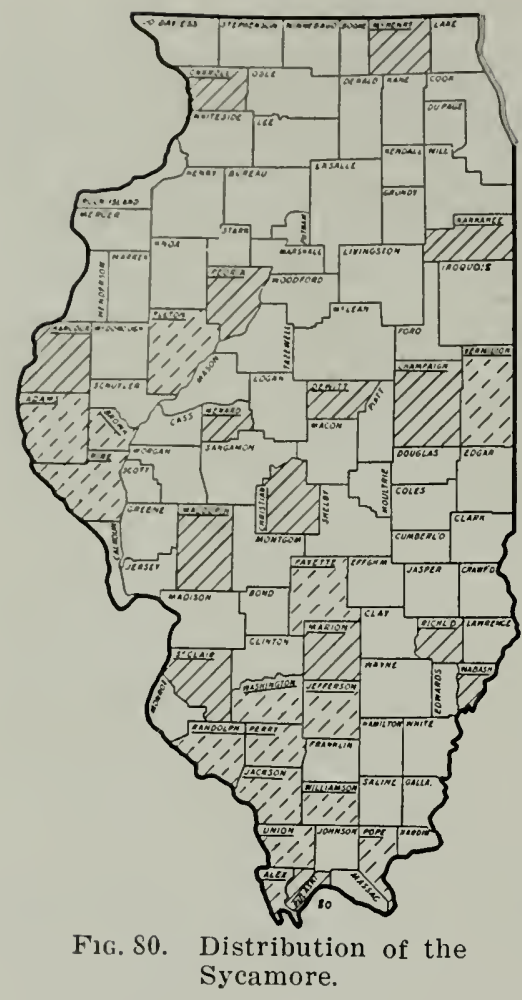

And to Andre Michaux the statement is credited that the Poplar and Sycatmore were of all trees in eastern North America those that attained the greatest diameter.

Uscs: The wood of the Sycat more is hard and heavy but not very strong; its worst quality, however, is the cross-grain, which makes it hard to split and renders it liable to excessive warping and twisting during the seasoning process. The heartwood is redclish and is marked with a silver grain, which gives a pleasing effect when the lumber is used for interior finishing and for furniture. Of the $1,400,000$ board feet of sycamore lumber produced in Illinois during 19.5 , by far the greatest proportion was made into veneers and wooden ware of various kinds, such as tool handles, tobacco boxes, butcher's blocks, and the like.

\section{Apple}

Family RosaceAe

Trees of only small to very moderate size, with alternate, simple. entire, or variously lobed leaves. The flowers, borne in short, terminal racemes, have is green sepals, j white, pink, or rosy petals, about 20 stamens, and :3 to ; pistils united into a single, inferior ovary. The fruit is a small. fleshy apple with a papery core, within which are the brown, lustrous seeds. The round, slender twigs bear small, t-scaled buds above narrow leaf-scars. The bark is only shallowly fissured and usually is scaly.

The wide range of Malus in the Northern Hemisphere includes North America, southern Europe, and much of central and southern Asia. Among alout 15 species, 9 occur in North America, but in Illinois only one species, Malus iocnsis Britton, is common, although certain others, such as M. angustifolia Michaux, M. lancifolia Rehder, and M. platycarpa Hoopesii Rehder occur here and there. 


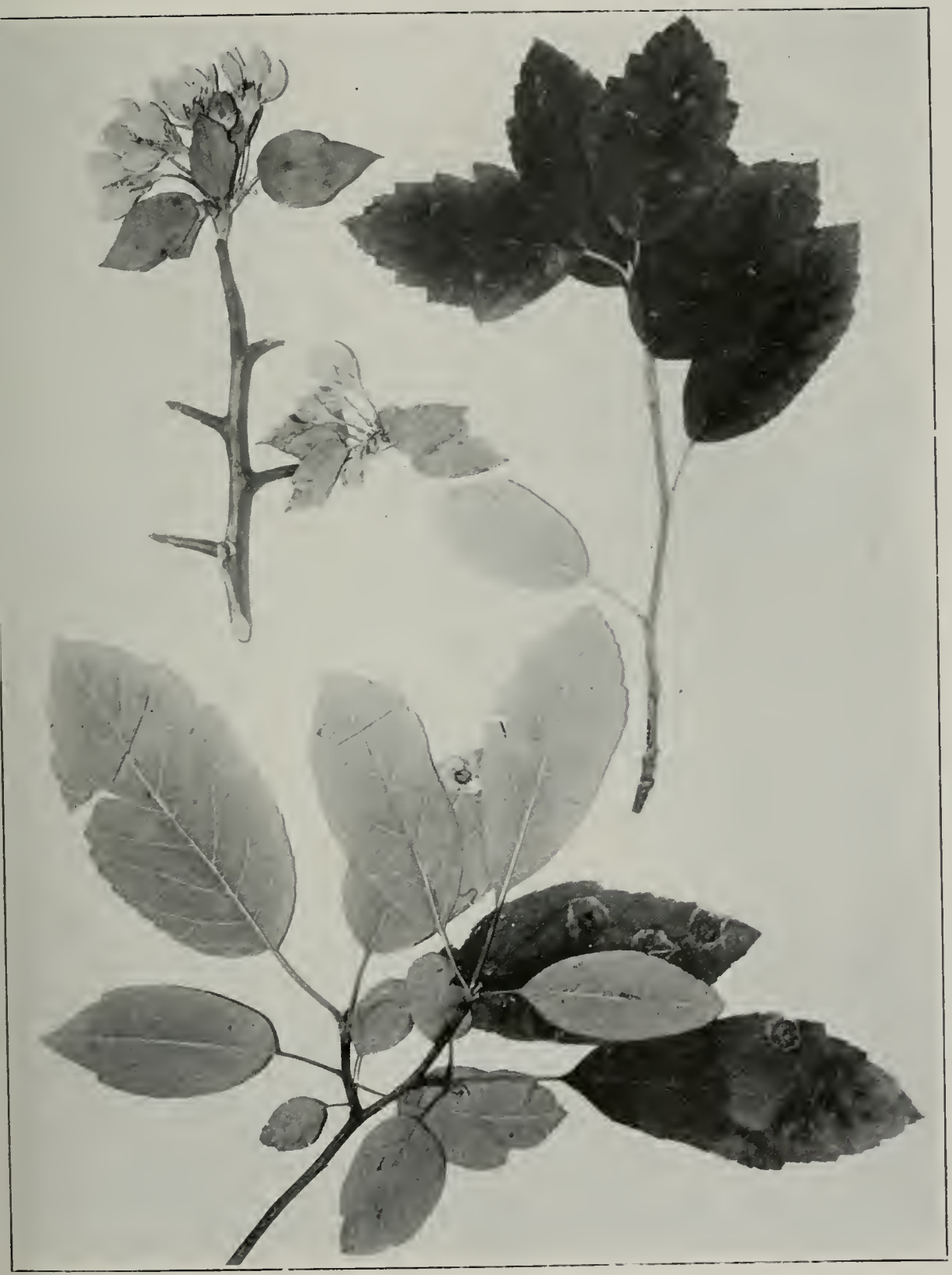

PLATE 64

MALUS IOENSIS BRITTON

CRAB APPLE 


\section{MALUS IOENSIS BRITTON}

\section{Crab Apple}

The Crab Apple is a small, spiny tree, with a wide, open crown of stout branches. The sharply-toothed and sometimes somewhat lobed, firm leaves are dark-green and shiny above but pale, yellowish, and at least somewhat hairy beneatl. The blade is from $2 \mathrm{~T} / 2$ to 4 inches long by 1 to $11 / 2$ inches wide and stands on a slender petiole nearly an inch long. The flowers, which are $1 \frac{1}{2}$ to 2 inches broad, are borne in clusters of 3 to 6 on woolly pedicels an inch or more long, and the white or rosy petals surround the stamens and the 5 styles, which are covered with long, white hairs for a third of their length. The greenish-yellow apples which cap the stout hairy pedicels are from $3 / 4$ to $1 \frac{1}{2}$ inches in diameter. The reddish-brown, bright branchlets bear rather small buds with blunt points and scales hairy over their upper halves. The trunk, inclosed by a thin, "ed-brown, scaly bark, may become a foot or more in diameter; and the mature tree is usually between 20 and 30 feet high.

Distribution: This is a tree of the Central States, ranging, in its typical form, only from Indiana westward to Nebraska and northward to Wisconsin and Minnesota. In Illinois it occurs in many places and is frequently mistaken for the Garland Tree, Malus coronaria Linnaeus.

Uses: The small size of the Crab Apple renders its wood of very little commercial value. A cultivated variety, Malus iocnsis plena Rehder, which is sold by uurserymen under the name of Bechtel Crab, is, however, one of our valuable decorative trees, highly prized for its large, double, rosy-pink blossoms.

\section{SORBUS Linnaeus Mountain Ash}

\section{Family Rosaceae}

Small, deciduous trees or shrubs, with alternate, compound, finely toothed leaves and white flowers in broad, terminal inflorescences. Each flower with 5 persistent sepals, 5 white petals, 20 stanens, and 2 to 5 pistils united at the base into a single ovary. Frtit a small, globular. orange-red, berry-like structure with sour flesh and a papery core containing shiny, brown seeds. Twigs round and slender, with conical buds standing above narrow leaf-scars. Bark usually smooth and aromatic.

Sorbus, with its many species, is widely distributed through the temperate regions of the Northern Hemisphere. Of the $t$ North American species, one attains tree size. 


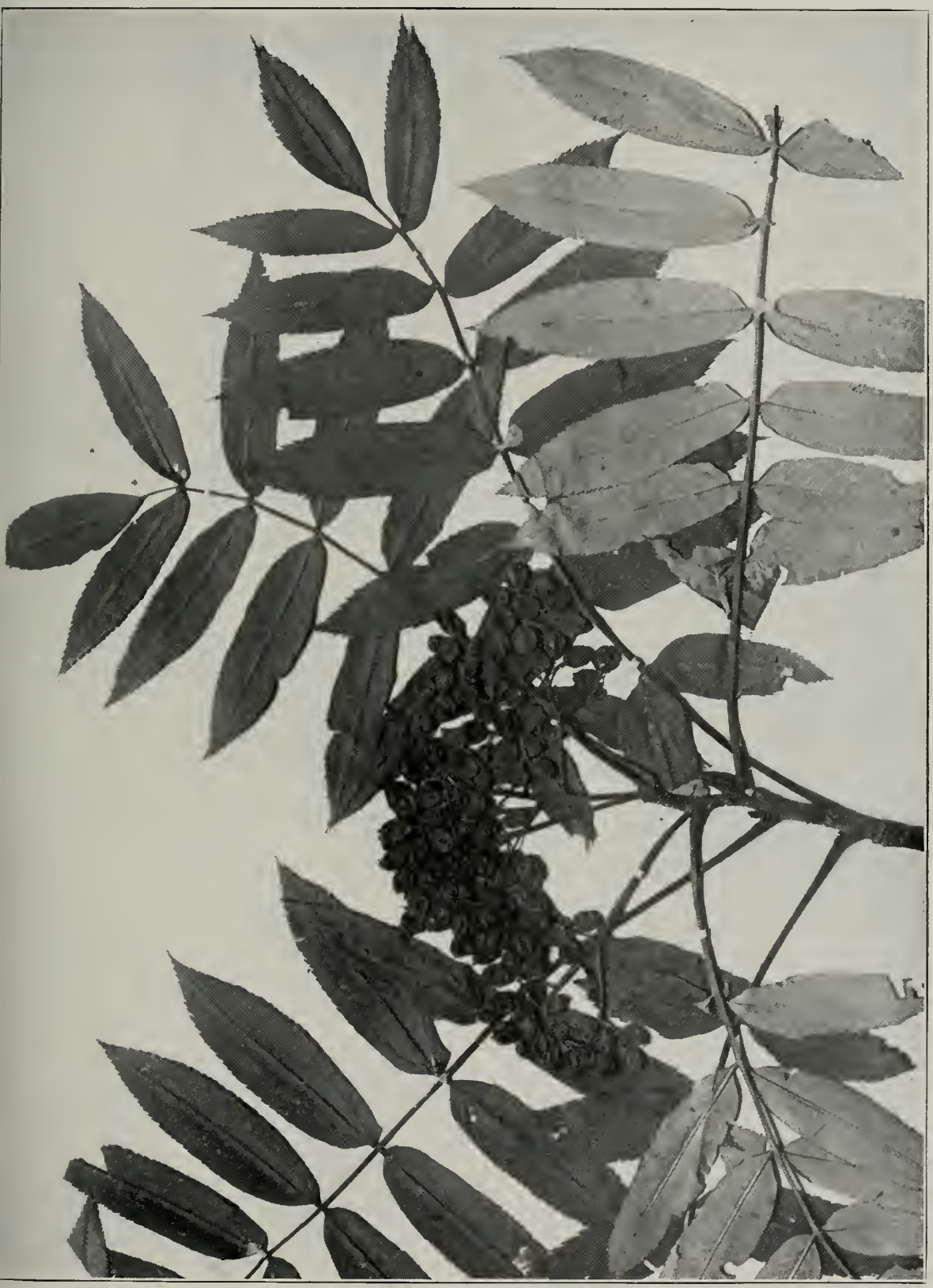

PLATE 65

SORBUS AMERICANA MARSHALL

MOUNTAIN ASH 


\section{SORBUS AMERICANA Marshall}

\section{Mountain Ash}

The Momntain $A, h$ is a small tree, with a narrow, rounded crown of slender, spreading branches. The yellow-green leaves, which are 6 to $\delta$ inches long, are made up of 6 to 8 pairs of sharply pointed finely toothed leaflets set oppositely along the midrib, which is terminated by an odd

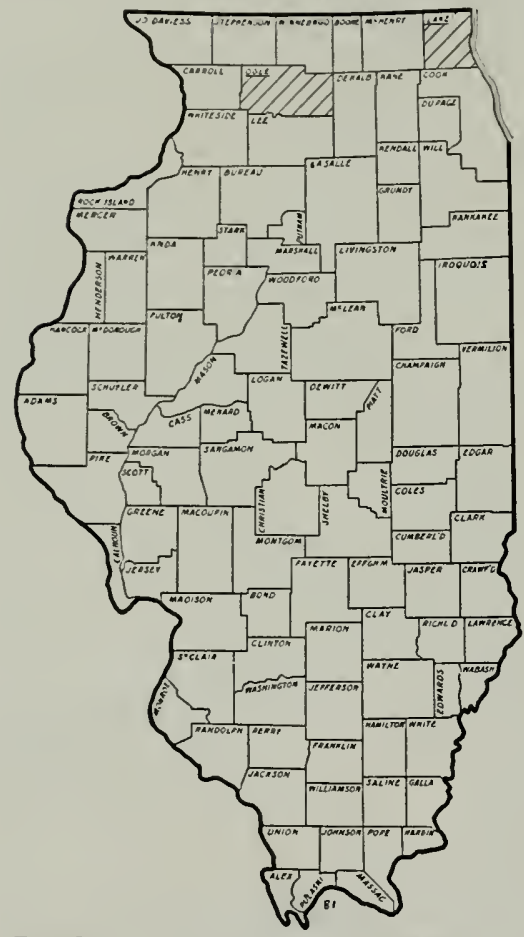

FıG. 81. Distribution of the JIountain Ash. leaflet. The flat inflorescence is 3 or 4 inches wide and is made up of many small flowers, which stand on short. stout stalks. The bright, orange-red. fleshy fruit, which is about $1 / 4$ inch in diameter, contains a brown seed about $1 / 8$ inch long. The trunk, which is covered by thin, smooth, gray bark, is usually less than a foot in diameter; and the tree attains an ordinary height of a little over 20 feet.

Distribution: The Mountain A $:$ h ranges from Newfoundland to Manitoba and southward to North Carolina and Tennessee. In Illinois it is a very rare tree and is known to us by only three records: W. G. Wateman reports it as one of the trees inhabiting the bogs of Lake County; a specimen from Oregon, Ogle County, bears the notation that the tree is "native"; and Pepoon says the tree is rare in the woods along Lake Michigan, being found near Glencoe, Wilnette, and Waukegan.

L'ses: The Mountain Ash has a pale-brown, close-grained, soft wood that is of no commercial value. The chief value of the tree lies in its decorative qualities, though the acid fruits are employed in the manufacture of certain medicinal preparations.

\section{AMELANCHIER MEDICUS}

\section{Service Berry}

Family Rosaceae

Small, cleciduous trees or shrubs, with alternate, broad-bladed, simple leaves and small white flowers borne in erect, terminal racemes. Each

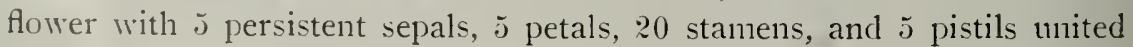


into a single ovary. Fruit a globular, blue to black, fleshy "berry" containing jor 10 dark-brown seeds. Twigs slender, zig-zag. with j-angled, pale pith and long buds covered with twisted scales. Bark usually scaly.

Though there are many species of Amelanchier in North America. there is but one in southern Europe, northern Africa, and southwestern Asia: and another in eastern $\Lambda$ sia. The tree forms, 3 in number, are all American, and one of these grows in Illinois.

\section{AMELANCHIER CANADENSIS MEDICUS}

\section{Shad Bush}

\section{Service Berry}

The Shad Bush forms a tree of only very moderate size. It has a narrow head of small, spreading branches. The sharply pointed, sharply toothed, yellow-green leaves, which are 2 to $t$ inches long by 1 to 2 inches wide, paler and usually a little hairy beneath, stand on slender petioles nearly 2 inches long. The small, white flowers are grouped in drooping racemes, and resemble those of cherries at a distance. The purple fruits, each about $1 / 4$ inch in diameter, are dry and insipid. The slender, redbrown branchlets bear green buds $1 / 2$ inch or more long. The trunk, which is not often more than a foot in diameter, is covered by thin, gray bark shallowly fissured into scaly ridges.

Distribution: The Shad Bush ranges from Maine to Nebraska and southward to Florida and Oklahoma. It is found in many parts of Illinois.

Uses: The heavy, hard wood of the Shad Bush, so called because its blossoning was considered in New England a sign of the proper time to fish for shad, is of little commercial value, although it has been used for tool handles, fishing rods, bows, lances. and other articles generally classed as turnery.

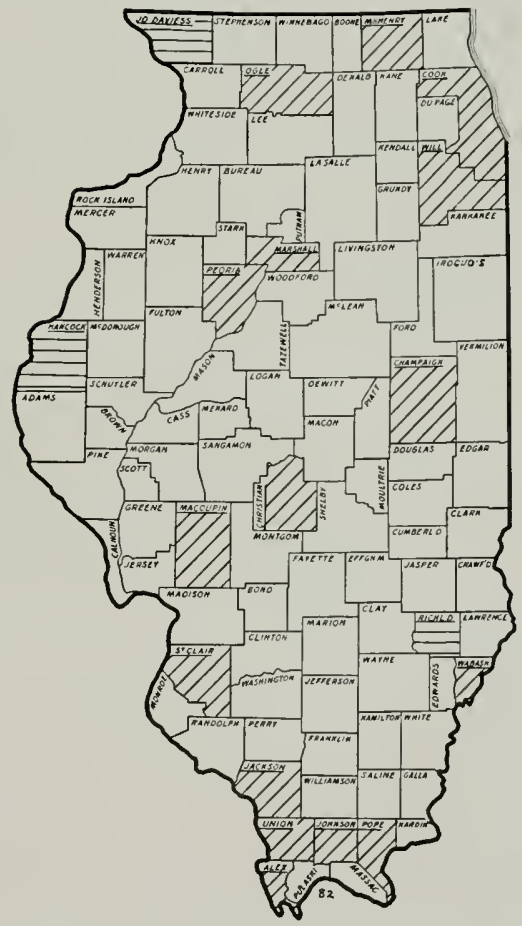

FIG. 82. Distribution of the Shad Bush. 


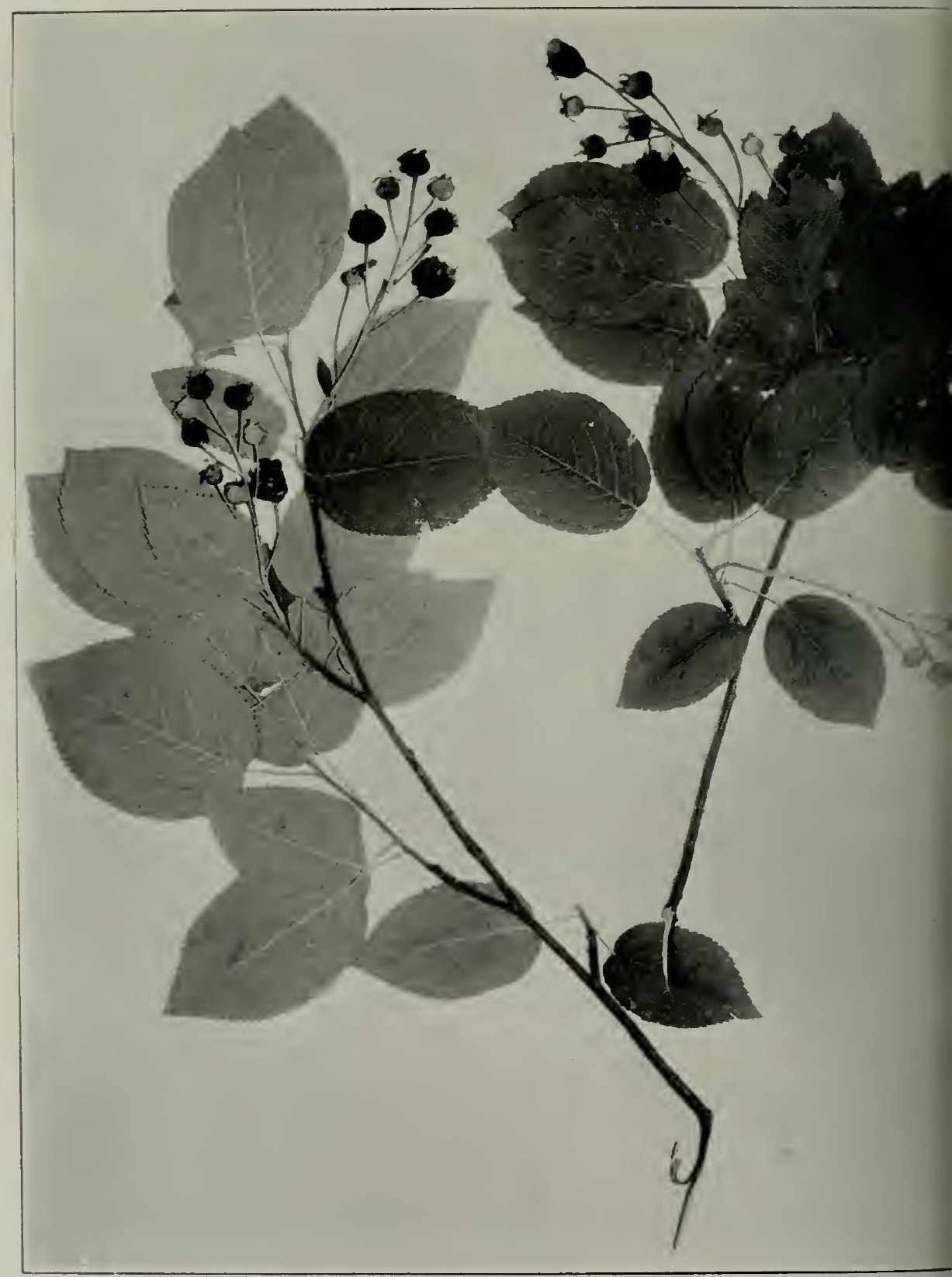

PLATE 66

AMELANCHIER CANADENSIS Medicus

SERVICE BERRI 


\section{KEY TO THE ILLINOIS HAWTHORNS.}

Typical leaves distinctly triangular, their wide, flat bases extending nearly at right allgles to the petioles (Plate 67)........... Phaenopyrum Med. Leaves variously shaped, but their bases distinctly sloping onto the petioles.

Leaves broadest at or above the middle (Plate 68).

Petioles short.

Small veins thin, buried in the leaf, inconspicuous.

Spines 3 to 4 inches long; haws dull red...... C. Crus-galli L.

Spines up to $2 \frac{1}{2}$ inches long; haws scarlet..C. peoriensis Sarg. Small veins prominent, at least below.

Haws longer than wide.............. punctata Jacq.

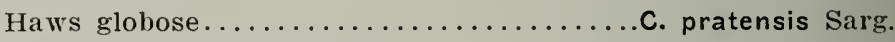

Petioles elongated, generally slender.

Spines long, $1 \frac{1}{2}$ to 4 inches.

Haws small, $1 / 4$ to $1 / 3$ inch long........ macracantha Koehne

Haws larger, about $1 / 2$ inch long.......... illinoiensis Asclie Spines short, $3 / 4$ to $1 \frac{1}{2}$ inches long.

Leaves large, generally more than 2 inches long.

Haws juicy and sweet................. tomentosa L.

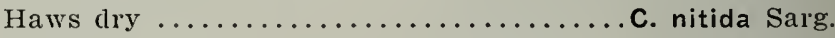

Leaves smaller, generally 1 to 2 inches long.

Haws very small, $1 / 8$ to $1 / 4$ inch long......... viridis $L$.

Haws larger, about $1 / 2$ inch long...C. rotundifolia Moench.

Leaves broadest at the base (Plate 69 ).

Leaves large, generally $2 \frac{1}{2}$ to 4 inches long.

Haws $3 / 4$ to 1 inch long, dry and mealy......... mollis Scheele

Haws about $1 / 2$ inch long, juicy.............. Hillii Sarg.

Leaves smaller, generally not over 2 inches long.

Haws juicy ........................ apiomorpha Sarg.

Haws dry and mealy.

Haws on long, thin, bright-red pedicels...C. pruinosa K. Koch

Haws on short, stout pedicels........... lucorum Sarg. 


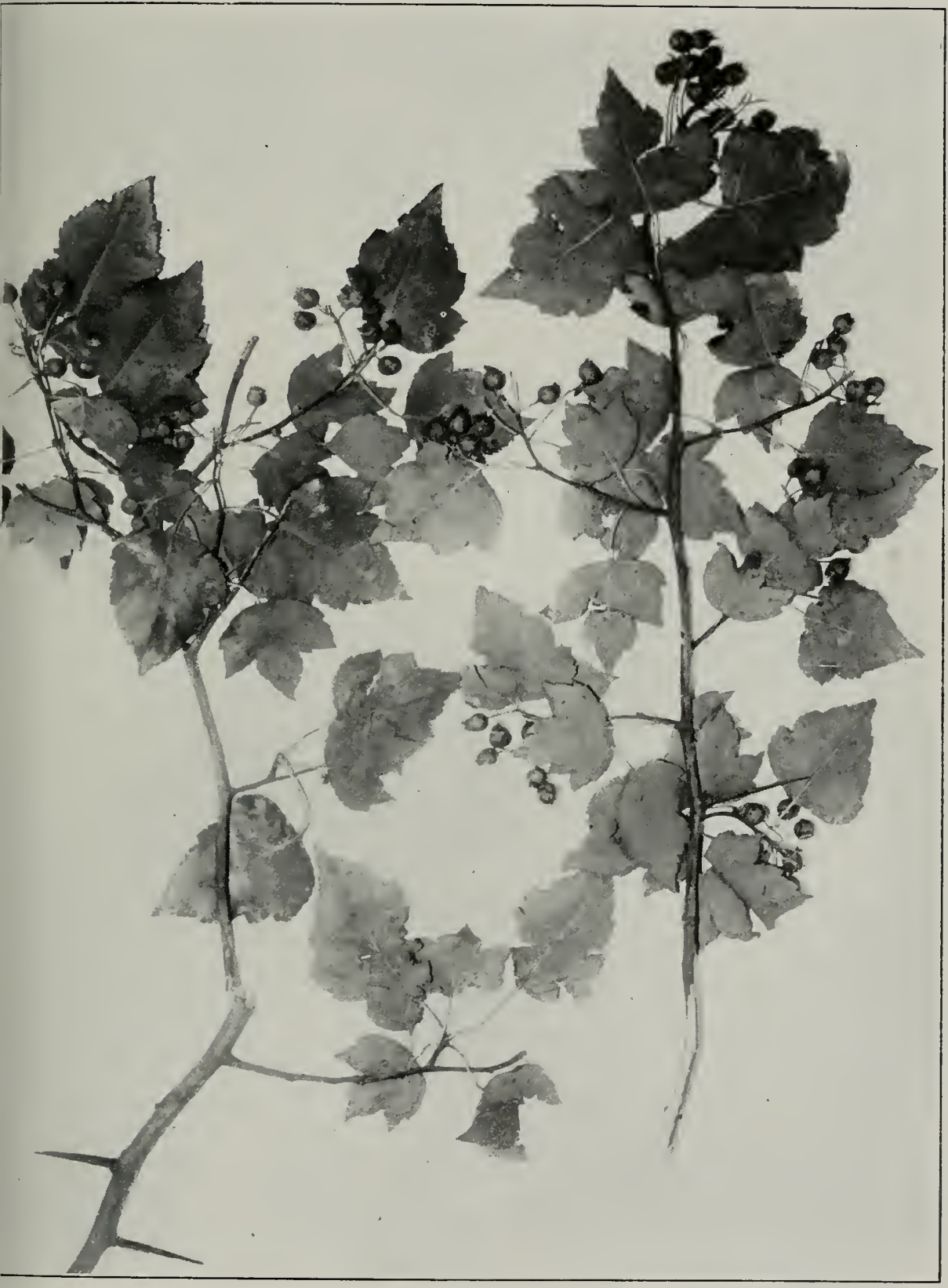

PLATE 6i

CRATAEGUS PHAENOPYRUM NEDICUS WASHINGTON THORN 


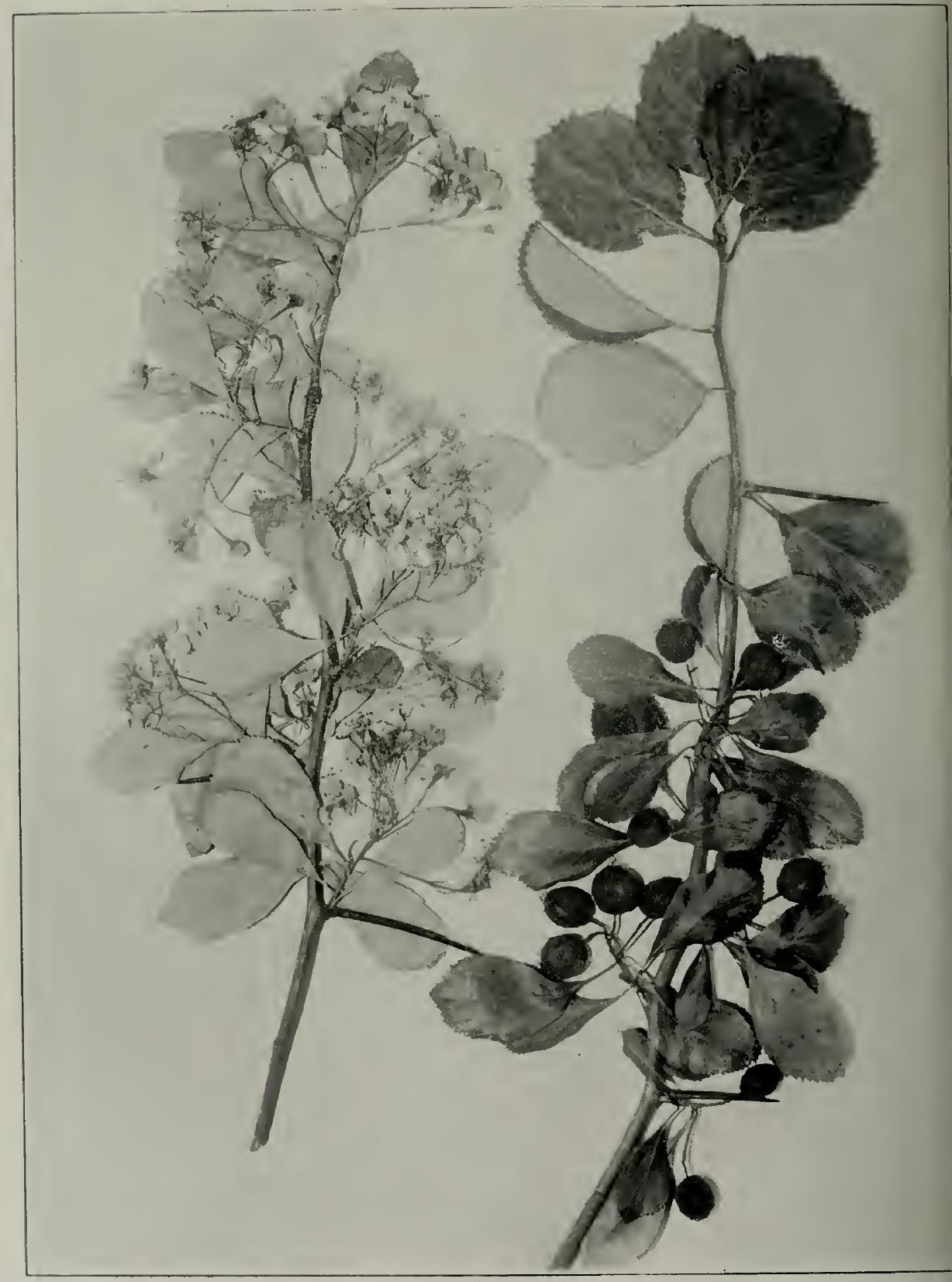

PLATE 68

CRATAEGUS CRUS-GALLI LiNNAEUS COCK-SPUR THORN 


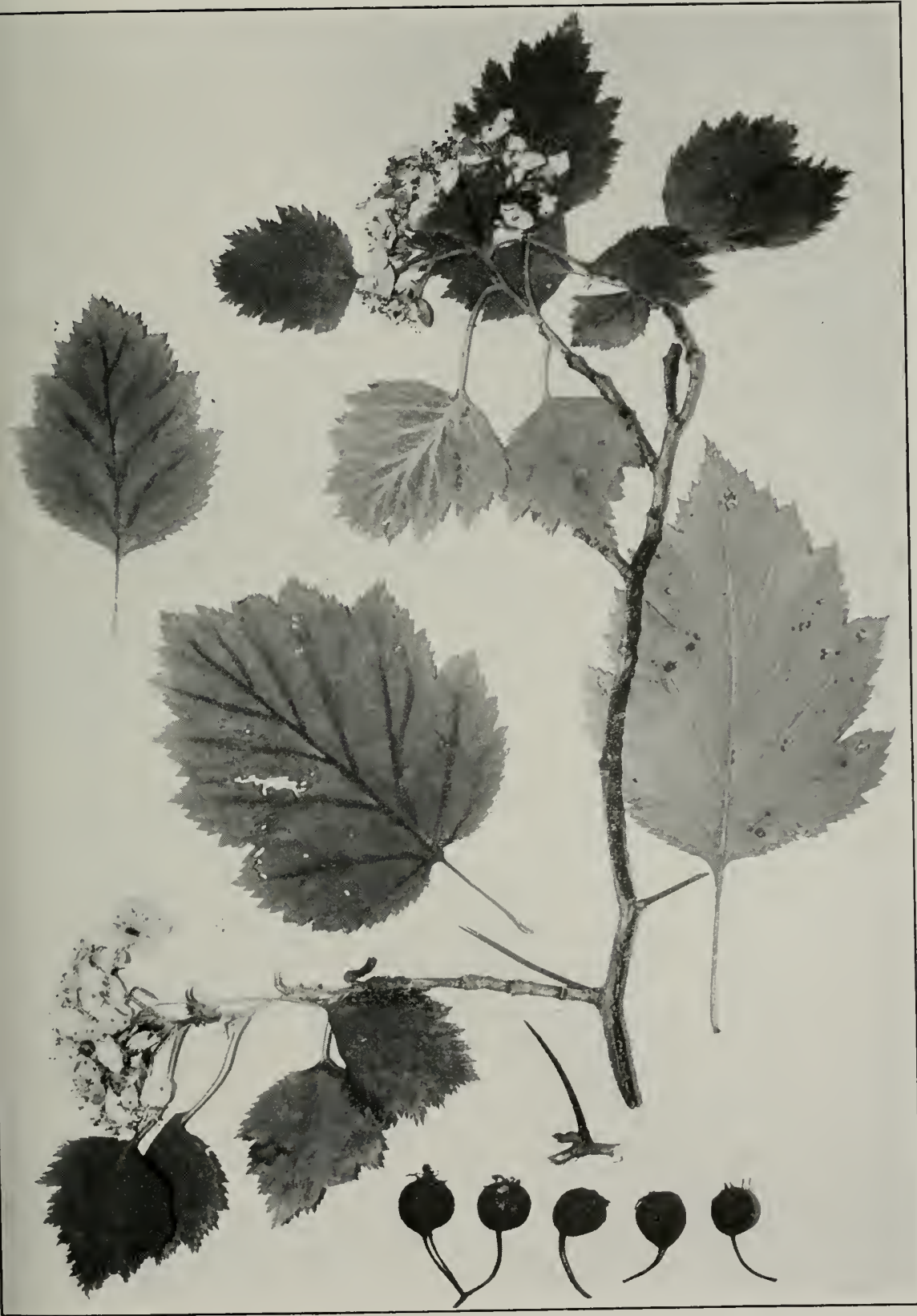

PLATE 69

CRATAEGUS MOLLIS SchEele 


\section{PRUNUS Bextham AND Hooker Plums and Cherries \\ Family Rosaceae}

Small, deciduous trees, usually between 20 and 30 feet high, with alternate, broad-bladed, simple leaves and white flowers in terminal or axillary groups. Each flower with is sepals. 5 petals, 15 to 30 stamens, and a single ovary in the bottom of the calyx tube. Fruit a one-seeded drupe with thick, pulpy, or dry flesh covering the hard, bony pit. Slencler branchlets with small, globular, or conical buds above very small, raised leaf-scars.

With many more than a hundred species. Prunus, which includes both the plums and the cherries, is to be found throughout most of the temperate parts of the Northern Hemisphere, and it ranges southward into tropical America and southern Asia. Of about 22 American treesized species, ¿j are fairly common in Illinois.

\section{KEY TO THE ILLINOIS PLUMS AND CHERRIES}

Terminal buds falling off, fruit a plum.

Leaves sharply toothed, plums bright-red..........P. americana p. 212

Leaves bluntly toothed, plums deep-red or yellow......P. hortulana p. 213 Terminal buds persistent, fruit a cherry.

Flowers and fruit in stalkless clusters irom buds in the axils of leaf-

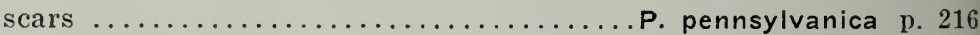

Flowers and fruit on the ends of short, leafy branches.

Flowers $1 / 4$ inch wide, cherries "puckery".......P. virginiana p. 217

Flowers larger, cherries juicy and pleasant......... serotina p. 220 


\section{PRUNUS AMERICANA MARShaLL}

\section{Wild Plum}

The IVild Plum is a small tree, divided upward into many spreading branches which form a broad head. The firm, rather rough, darkgreen leaves. 3 to $t$ inches long by about $1 \frac{1}{2}$ inches wide, are sharply toothed on the margins, pale beneath, and stand on petioles $1 / 2$ to $3 / 4 \mathrm{inch}$

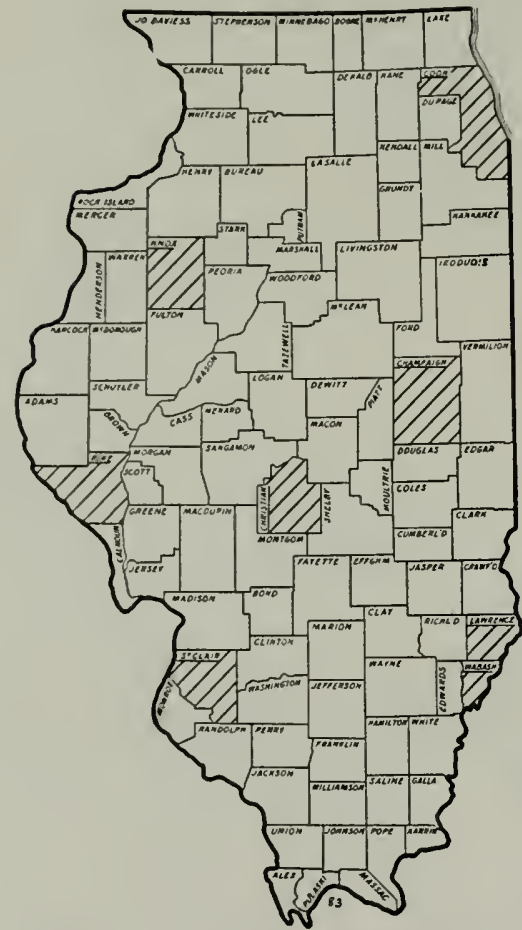

FIG. \$3. Distribution of the Wild Plum.

long. The white flowers, with the petals bright-red at the base, appear in small clusters above the leaf-scars of the previous year. The globular plums, usually about an inch in chiameter, turn bright-red when ripe, and contain rough, oval pits. The brownish branchlets, some of which are spine-like, bear pointed, brown buds $1 / 8$ to $1 / 4$ inch long. The trunk, which is covered by red-tinted, brown, plated bark, seldom is over 10 inches in diameter; and the usual height of the tree is 20 to 30 feet.

Distribution: The Wi.d Plum inhabits a great variety of situations, including both swamps and mountain slopes, and ranges from Connecticut to Montanz and southward to the Gulf States and New Mexico. It is undoubtedly much nore common and more widely distributed in Illinois than our map suggests. In the neighborhood of Lake Mirhigan, and especially in the river thickets, it was once abundant; but Pepoon" says: "This plum's glory has departed from northern Illinois. Fifty years ago every thicket was full of bearing plums of all sizes and colors."

Uscs: The wood of the Wild Plum. though possessed of high technical qualities, is not used extensively. The fruit, picked from the wild trces, makes excellent jellies and preserves.

\footnotetext{
${ }^{1}$ Flora of the Chicago region, p. 352.
} 


\section{PRUNUS HORTULANA BAILEY Wild Goose Plum}

The Wild Goose Plum is a small tree, with spreading branches and a broad crown. The thin, dark-green, shiny leaves, 4 to 6 inches long and an inch or more wide, are finely toothed on their margins and stand on slender, orange petioles an inch or more long. The white flowers, the petals of which are often orangetinted at their bases, stand in small clusters above year-old leaf-scars. The deep-red or yellow plums, rarely an inch in diameter, have rather hard flesh and rough, pitted stones. The dark, red-brown branchlets, which are seldom spine-like, bear tiny, blunt, brown buds. The slender, leaning trunk, covered by dark-brown, thinly plated bark, is not often more than half a foot in cliameter; and the tree may attain a height of 30 feet.

Distribution: This plum, native along stream banks in the Central States and often cultivated, occurs through most of southern and western Illinois and is undoubtedly more prevalent than our records suggest. Records from more northern stations. however, we regard as cases of incorrect identification.

Uses: In common with most plums, the wood of this tree is close-

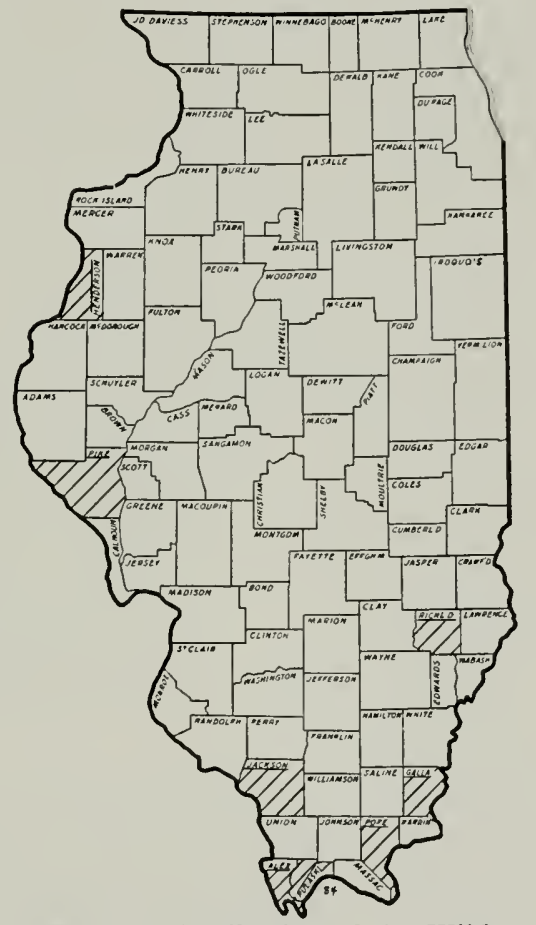

FIG. 84. Distribution of the Wild Goose Plum. grained and durable, though little used commercially. The horticultural varieties are, however, not only numerous but valuable. 


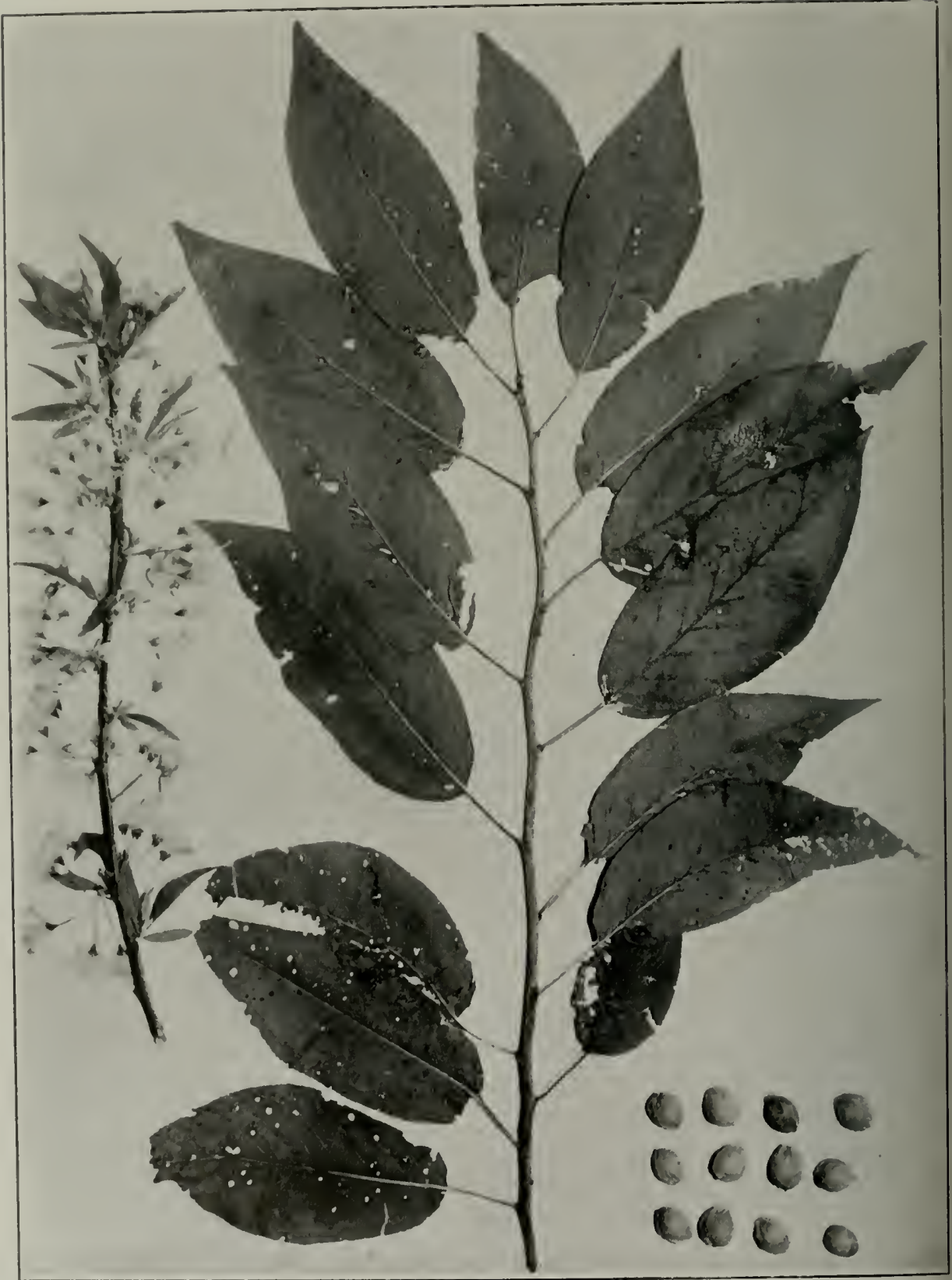

PLATE :1

PRUNUS HORTULANA BAILEY

WILD GOOSE PLUM 


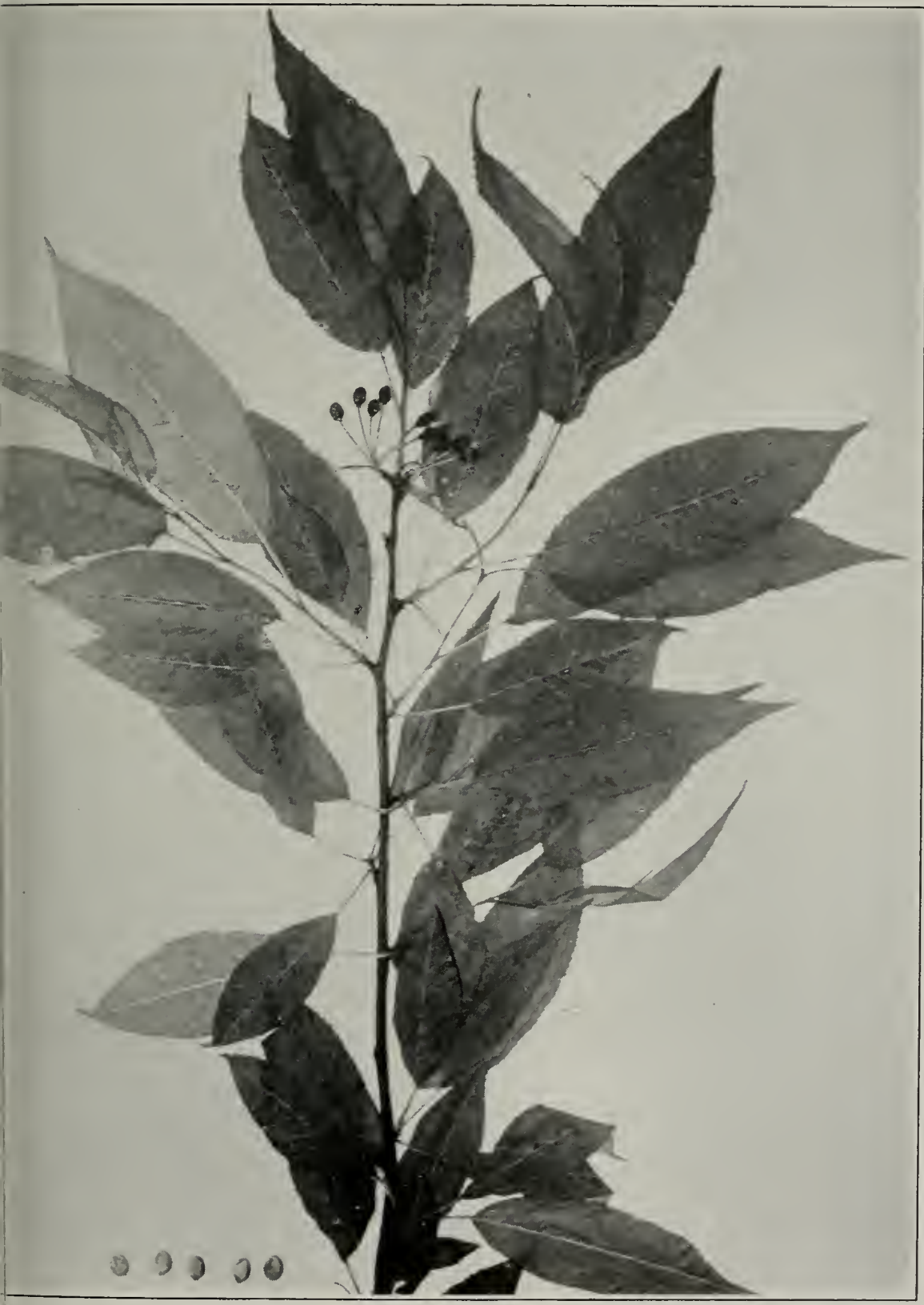

PLATE

PRUNUS PENNSYLVANICA LINNAEUS IVILD RED CHERRY 


\section{PRUNUS PENNSYLVANICA LINAAEUS}

\section{Wild Red Cherry}

\section{Bird Cherry}

The Wild Red Cherry is a moderately small tree, with a narrow crnwn of slender, horizontal branches. The bright, shiny, green leaves, 3 to $;$ inches long by about an inch wide, are finely toothed along their margins, very sharply pointed, and stand on slender petioles generally

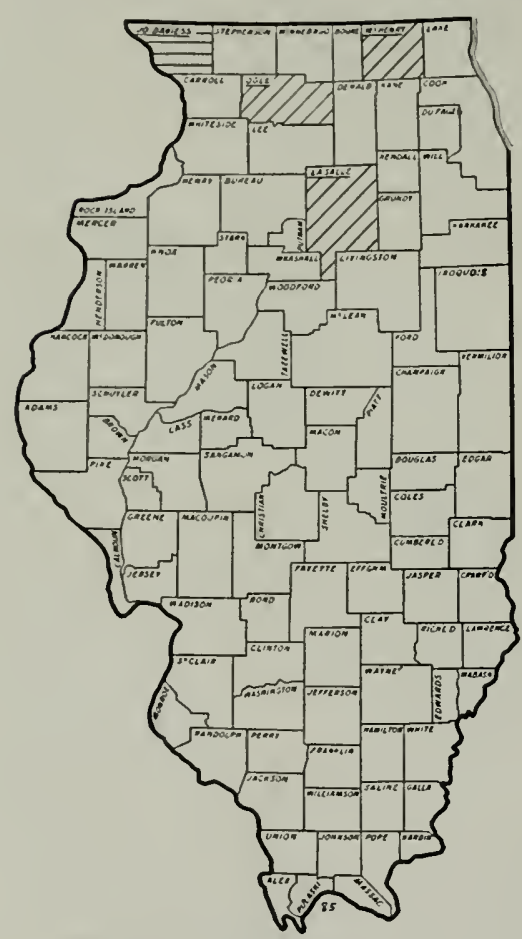

Fia. 85. Distribution of the Wild Red Cherry. less than an inch long. The small clusters of flowers, whose petals bear a band of orange, stand above year-old leaf-scars. The cherries, seldom more than $1 / 4$ inch in diameter, are light-red and have thin, sour flesh surrounding the hard pit. The bright-red branchlets, often spiny, bear tiny, brightbrown buds. The trunk, covered by red-brown bark which separates into broad, horizontal, papery scales, becomes 18 to 20 inches in diameter; and the tree may grow to a height of 30 feet or more.

Distribution: The Bird Cherry grows generally in all the forested regions of North America from Hudson's Bay southward into the mountains of the states bordering the Ohio River. In Illinois, however, it is limited in its distribution to an area comprising about the northern third of the State, and through this region it is undoubtedly more prevalent than the collections from which our map is marked seem to indicate.

Uscs: As the tree is not abundant, it is of little economic importance. The cherries are, however, commonly used in households and they are also employed as an ingredient of cough medicines. 


\section{PRUNUS VIRGINIANA LINNAEUS}

\section{Choke Cherry}

The Choke Cherry is a decidedly small tree, with a small crown of small branches. The sharply toothed, short-pointed, dark-green leaves, ? to 4 inches long by 1 to : inches wide, stand on slender petioles nearly an inch long, which bear : distinct glands near the base of the blade. The white flowers, nearly an inch in diameter, are borne, each on short stalks, in crowded racemes 3 to 6 inches long. The shiny, dark-red to black cherries, the flesh of which is dark, juicy, and "puckery," are usually more than $1 / 4$ inch in diameter and contain a hard pit. The sender, redbrown twigs bear large, brown buds. The trunk, inclosed by ill-scented, warty and scaly, red-brown bark, is not often more than 6 inches in diameter; and the tree is usually 20 or 25 feet high.

Distribution: Shrubby in its northern range, tree-like in the south, the Choke Cherry ranges almost transcontinentally from Hudson's Bay to the Gulf of Mexico. Though more common in the counties of northern Illinois, it is found southward to Madison County in the west and W'abash County in the east.

Uses: The wood of the Choke

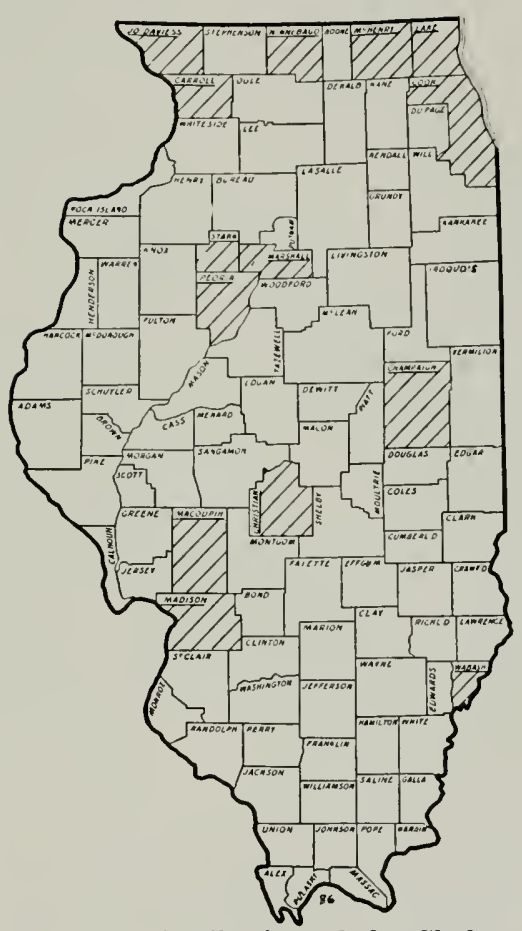

FIG. 86. Distribution of the Choke Cherry. Cherry, though of high quality in some respects, is weak and has little commercial value. The cherries, however, if not gathered too soon, may be made into delightfully flavored jelly. 


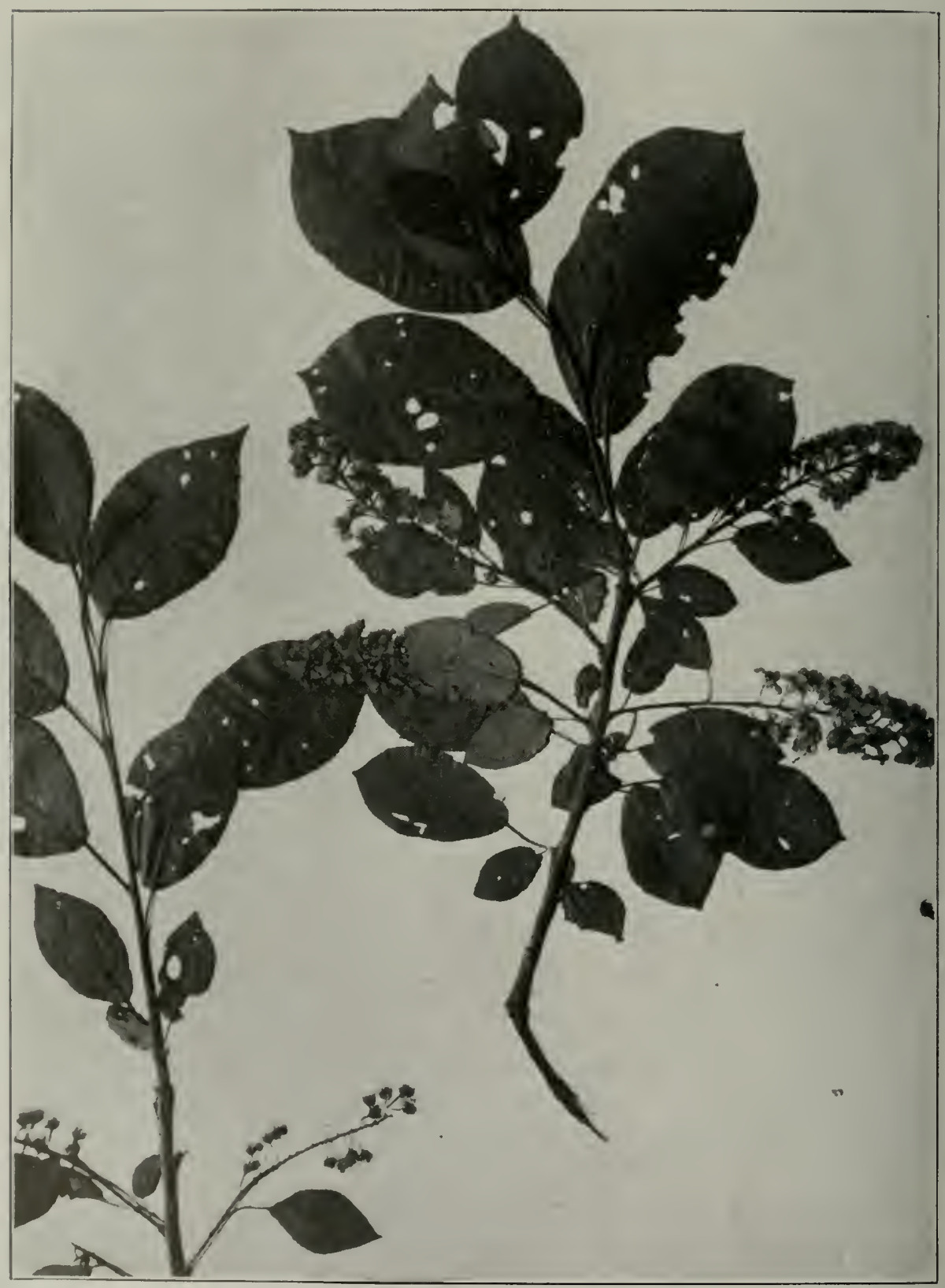

PLATE :3

PRUNUS VIRGINIANA LINNAEUS CHOKE CHERRY 


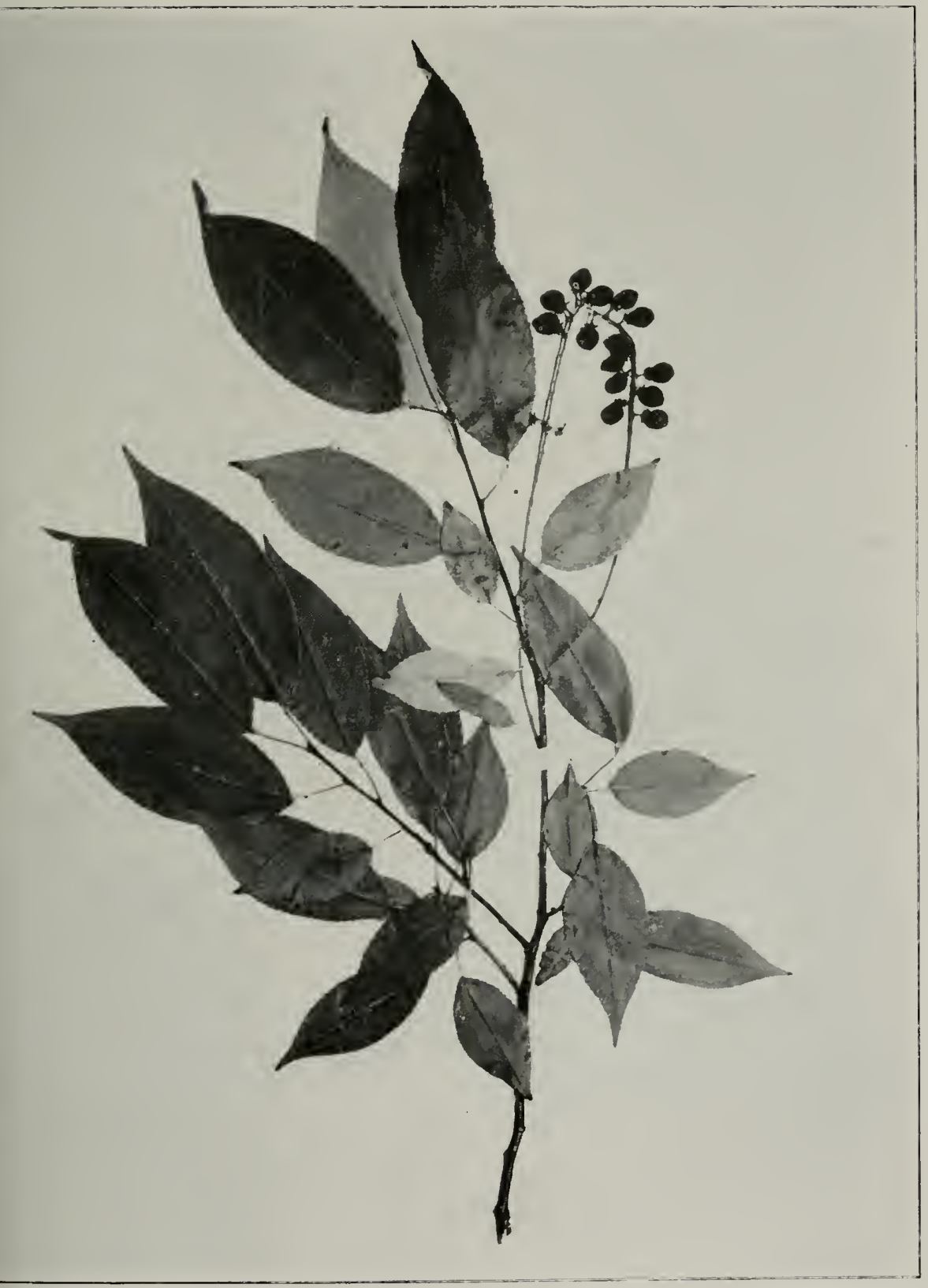

PLATE it 


\section{PRUNUS SEROTINA EIRHART}

\section{Wild Black Cherry Rum Cherry}

The Wild Black Cherry is often a moderate-sized to large tree and has a narrow head of small, horizontal branches. The leathery, (lark-green leaves, 2 to 6 inches long by somewhat more than an inch wide and sharply toothed along the margins, stand on slender petioles

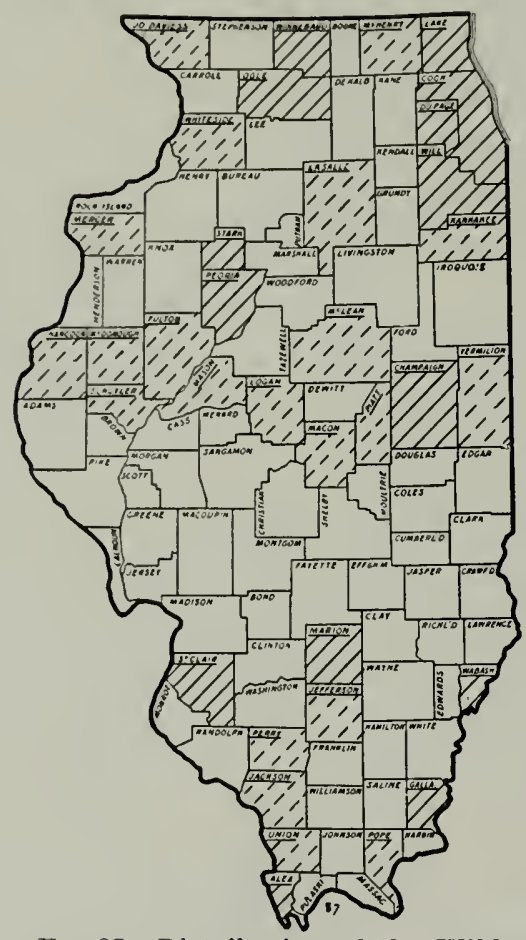

FIG. 87. Distribution of the Wild Black Cherry. half an inch or more long. The manyflowered, white racemes become 4 to 6 inches long, and the cherries, almost black when they are ripe and nearly $1 / 2$ inch in diameter, contain hard pits. The dark-brown to bright-red branchlets bear chestnut-brown buds $1 / 2$ inch or more in length. The trunk, clothed in dark, red-brown, plated bark, may attain a diameter in excess of 2 feet; and the tree may grow to a height of 80 feet or more.

Distribution: The Wild Black Cherry, in its favorite situation along the margins of forests, $\mathrm{r}$ anges throughout much of the eastern half of North America, from Hudson's Bay in the north to Alabama in the south. It is by far the most common cherry in Illinois and ranges throughout the State. Among the hardwoods of the upland forests, it constitutes between 1 and 2 per cent of the stand; along the secondary streams, it averages 1 per cent of the stand; and even on the bottomlands of main streams it still occurs in appreciable numbers. In Jo Daviess County. Black Cherry attains an average height of 50 feet; farther south, in Hancock County, it attains a height of $\gamma_{2}$ feet; and in McLean County the maximum height anong the measured trees was 82 feet.

Uses: The close- and straight-grained, light-brown wood of the IVild Black Cherry possesses many desirable technical qualities. It is light, strong, and rather hard; and, because of the satiny finish it takes, it is used quite extensively in the making of fine cabinet articles as well as for the interior finish of houses. It is the one Illinois cherry with a real commercial value. 
From the bark, hydrocyanic acid is extracted, and this is used in the preparation of sedative and tonic medicines. Formerly, the ripe fruits also supplied flavors for alcoholic beverages.

\section{CERCis Linnaeus Judas Tree}

Family Leguminosae

Small to moderate, deciduous trees, with alternate, entire, simple, broad-bladed, 5 - to $\%$-nerved leaves and somewhat pea-like, colored flowers clustered above the past-year's leaf-scars. Fruit an elongated, flattened, rather woody, purplish pod with bright, reddish-brown seeds. The slender, zig-zag twigs have pale to pinkish pith, no terninal bud, oval, scaly, and often stalked lateral buds, and raised and rather distinctly triangular leaf-scars fringed at the top and marked with 3 bundletraces. The bark is usually scaly.

'This genus, of which there are 8 known species, occurs rather wirlely through the temperate and warmer regions of the Northern Hemisphere. Its original home, in ancient geological times, is supposed to have been in Central Asia, from which a large number of species are thought, from fossil records, to have migrated to many parts of the world, and some of these are considered to be the ancient but direct ancestors of our modern species, which are themselves so o'd that their history extends back to the Ice Age. Our Northern American species are now only 3 in number, 2 of them tree-like; and only the well known Redbud occurs in Illinois.

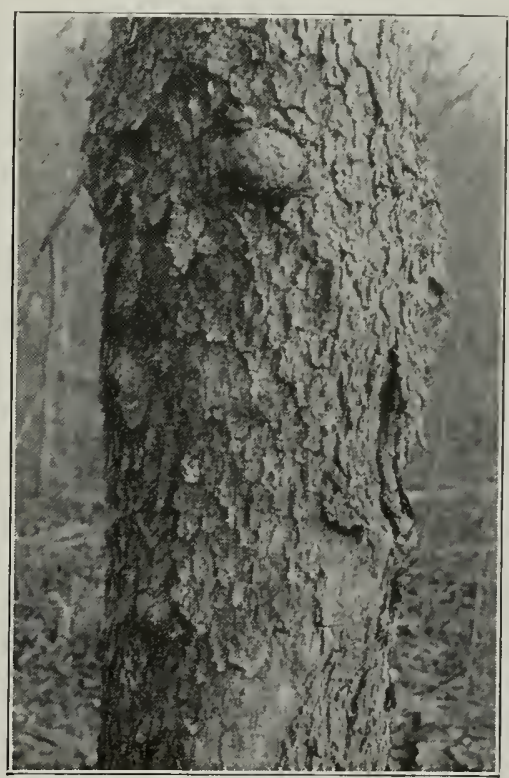

FIg. 87a. Bark of the Red Bud. Photo from the F'icld II sellm of Natural History. 


\section{CERCIS CANADENSIS LINNAEUS}

\section{Redbud Judas Tree}

The Redbud, a tree of only very moderate height, usually branches 10 feet or so upward into a flat, wide crown of stout limbs. The very broad, rounded, and pointed. heart-shaped leaves, 3 to 5 inches in diameter, stand on petioles 2 to 5 inches long. The brilliant, rosy-red

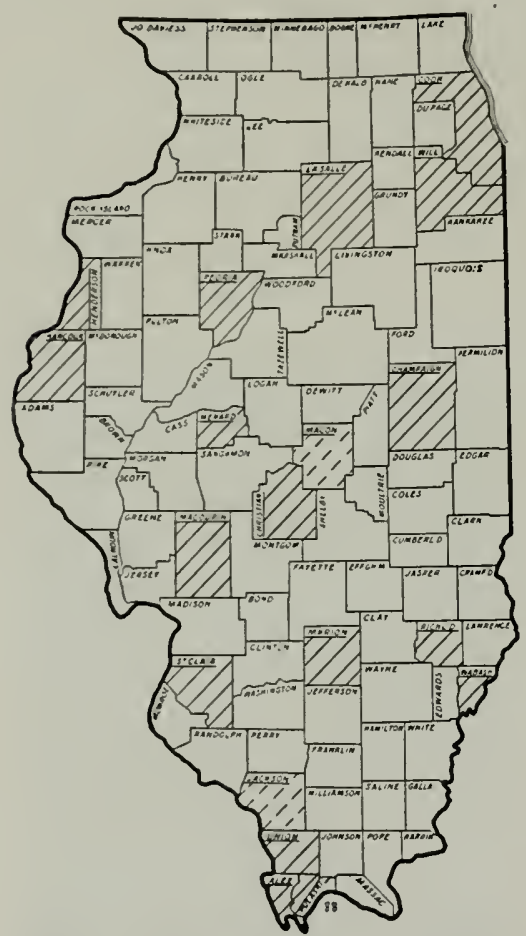
flowers, each about $1 / 2$ inch long, occur, 4 to 8 together, in stalkless bundles above year-old leaf-scars. The pinkish or rosy pod, usually 2 to 3 inches long. contains numerous brown seeds about $1 / 4$ inch long. The dull or shiny, brown branchlets bear small. scaly buds above the triangular, fringed leafscars. The trunk, covered by redbrown. deeply fissured, scaly bark, seldom attains a diameter of more than a foot, while the tree itself does not often exceed 40 feet in height.

Distribution: From Pennsylvania to Florida the Redbud ranges westward, in rich woodlands and along streams, to Nebraska and Texas. It grows practically throughout Illinois and is one of the most striking trees in the understory of our woodlands when its brilliant flowers appear in the spring.

Uses: The rich, brown, redFIG. SS. Distribution of the Redbud. tinted wood of the Redbud. though hard and close-grained, is not strong and has practically no commercial use. As an ornamental tree, however, the Redbud is used extensively and maly be purchased directly from nurserymen, most of whom propagate it artificially in their tree and shrub nurseries.

GYMNOCLADUS LAMARK

Coffee Bean

Family Leguminosae

Rather large, deciduous trees, with large, alternate, doubly compound leaves and greenish, long-stalked flowers, the staminate and pistillate flowers separate and on separate trees. Fruit an elongated, tough, 


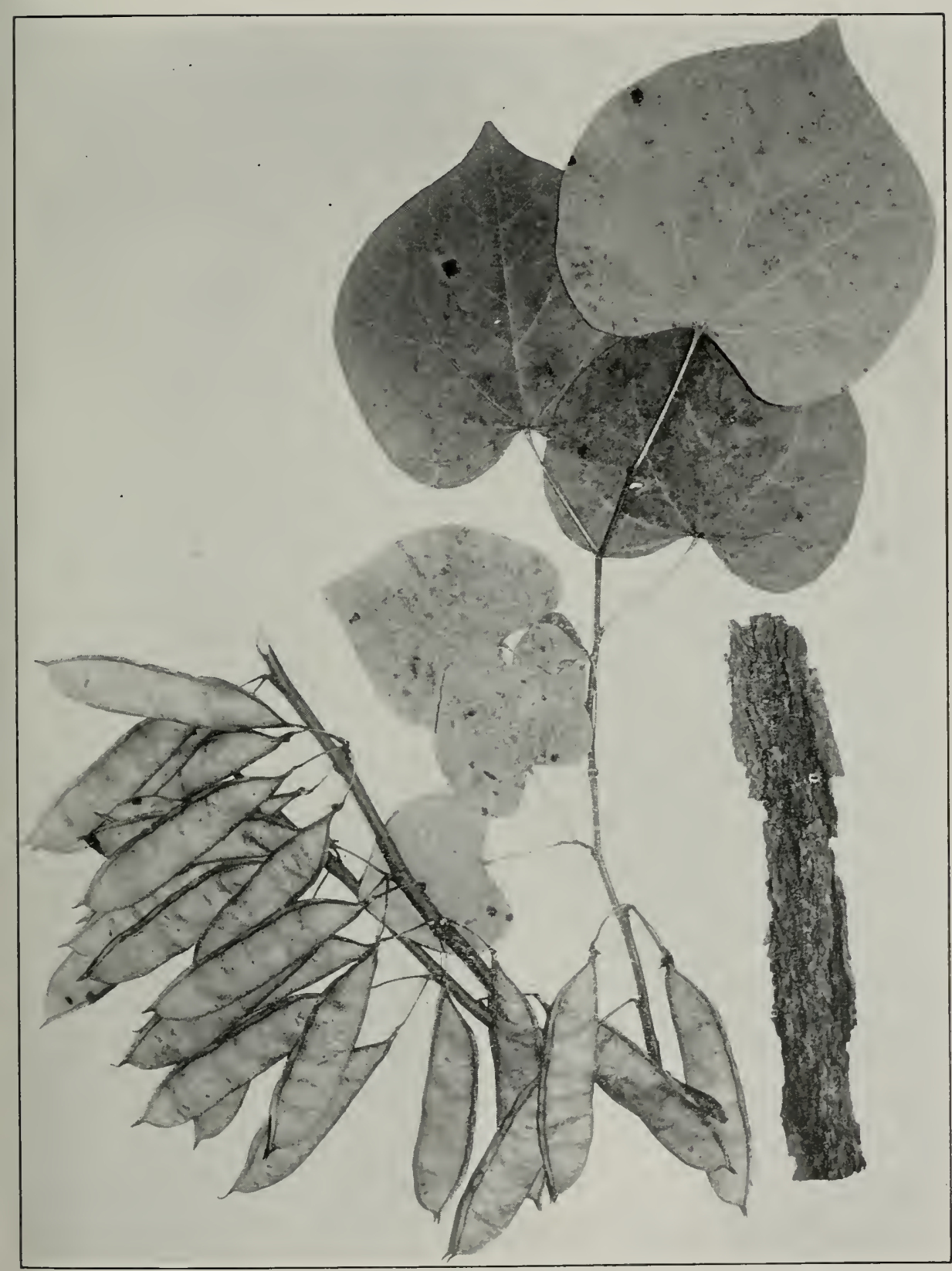

\section{PLATE is}

CERCIS CANADENSIS LINAEUS

REDBUD 
woody pod containing several seeds. The stout, rounded twigs, with large, round, salmon pith, bear \& buds set one above another, each nearly buried in a silky pit, above each large, rather heart-shaped leaf-scar.

There are but 2 species, one in eastern North Anerica and one in Chinil. In this respect, it is like the Tulip Tree and the Sassafras, for all three appear to be isolated survivors of ancient stocks, though little is known of their early history.

\section{GYMNOCLADUS DIOICUS K. KOCII Kentucky Coffee Tree Mahogany}

The Kentucliy Coffee Tree is large and stately, with 3 or 4 upright main stems which form a narrow, round-topped crown. The much-

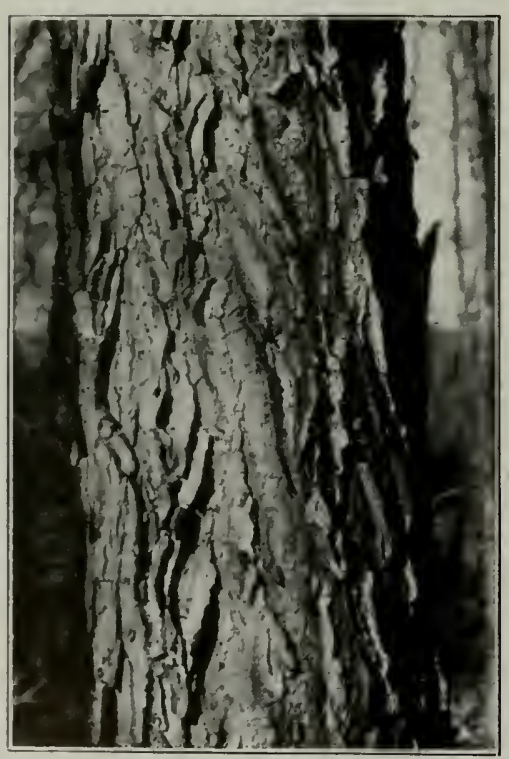

Fig. 89. Bark of the Kentucky Coffee Tree. Photo from the Ficld Juscum of Natural History. divided leaves, usually between : and 3 feet long by $1 \frac{1}{2}$ to 2 feet wide. are made up of numerous dark-green leaflets, 2 to $21 / 2$ inches long by an inch wide, set along the branches of the petiole. The greenish-white llowers stand in terminal racemes, the staminate racemes 3 or $t$ inches long. the pistillate racemes nearly a foot long. The dark-red pods, 6 to 10 inches long by 1 to 2 inches wide, hang from stout stalks 1 or 2 inches long, and remain closed through the winter. The seeds, which are about $3 / 4$ inch long, are separated in the pod by dark, sweet pulp. The trunk, often 2 feet or more in diameter, is covered by red-tinted dark-gray bark, which is decply fissured and scaly. The tree is generally more than $; 0$ feet high.

Distribution: Though not anywhere a common tree, the Kentucky Coffee Tree ranges, particularly on rich bottomlands, from New York westward to Neloraska and southward only to Kentucky and Tennessee. Formerly, at least, it ranged throughout the lowlands of Illinois, but now 


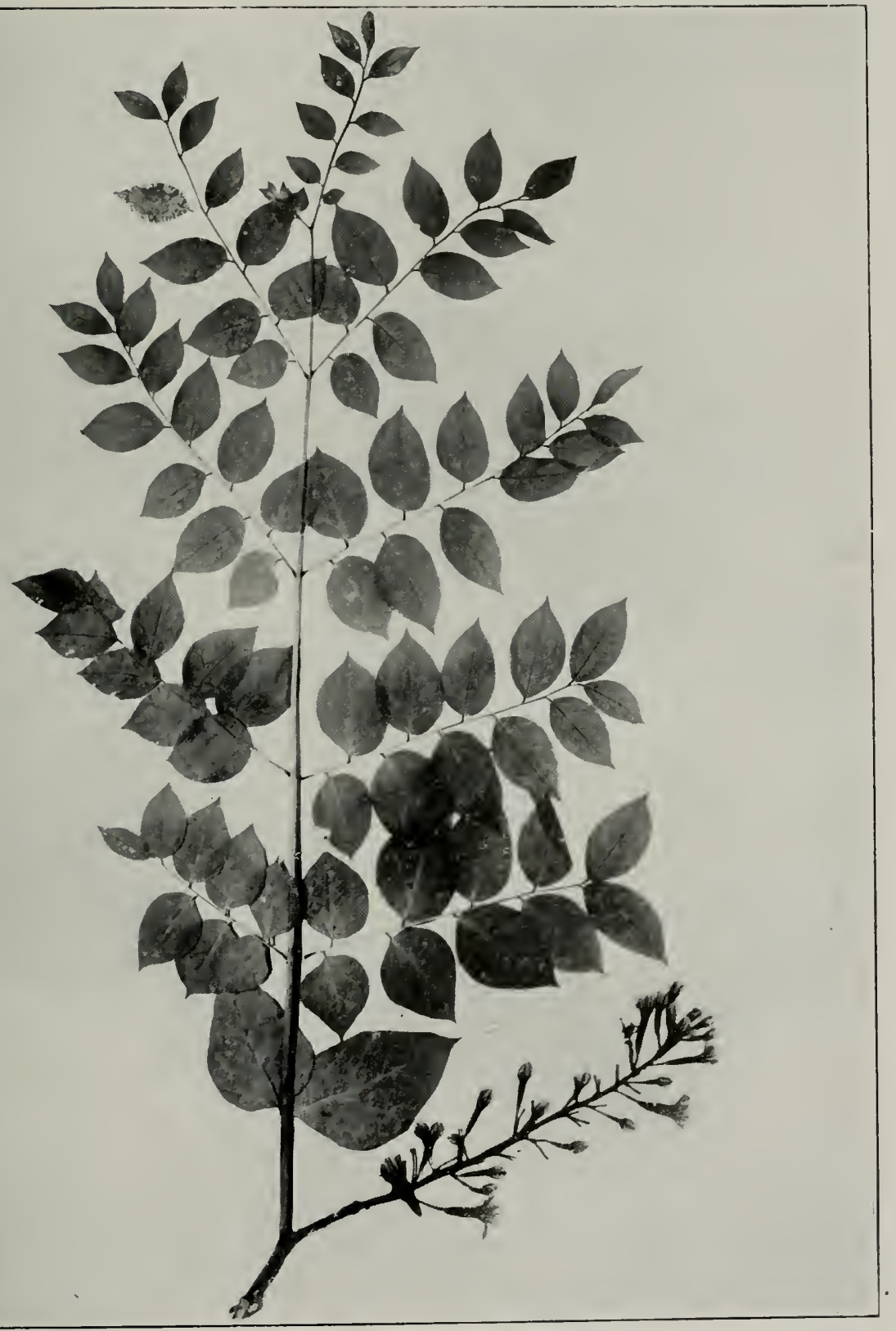

PLATE 96

YYMNOCLADUS DIOICUS K. Kó KENTUCKY COFFEE TREE 


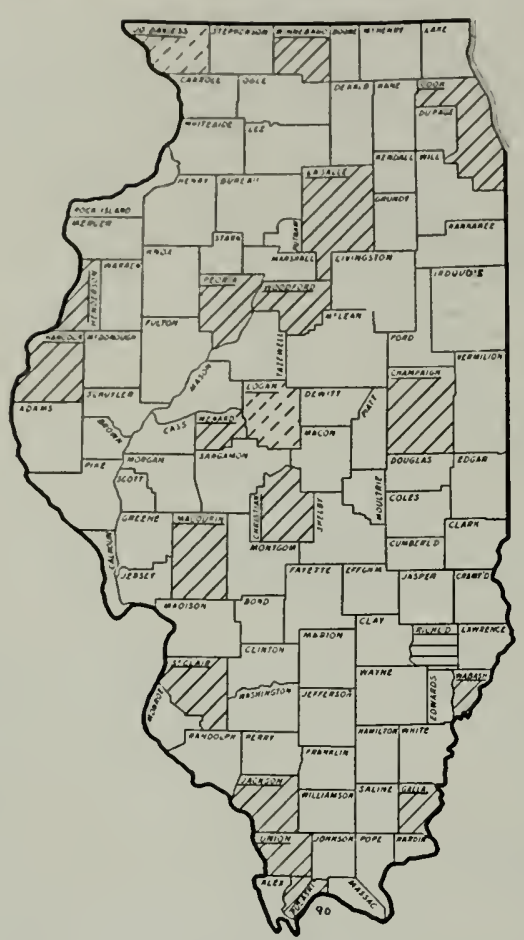

Fı(i. 90. Distribution of the Kentucky Coffee Tree. it is approaching extermination in many places. Its most common associates are hickories. P'in Oak, Soft Maple, cottonwoods, ashes, Elm, Hackberry, Cypress. Black Gimm, and Sycamore, though on higher land it is found also with such trees as the Burr, White, and Black oaks, Bass Wood, Black Wahnt, and Honey Locust.

Uscs: The coarse-grained, heavy wood of the Kentucky Coffee Tree, though not very hard, is strong and is reputed to be rery durable. It is not used to any large extent for any commercial purposes, although it is cut for fence posts and rough timbers and a small amount is used in cabinet making. The seeds, as the name of the tree suggests, once served as it substitute for coffee, though the decoction is said to have been inferior even to chicliory.

\section{GLEDITSIA LiNNAEUS}

\section{Family LeguninOSAE}

Moderate to very large, thorny, deciduous trees, with alternate. compound leaves and regular, somewhat pea-like flowers in racemes on the sides of the twigs. Fruit an elongated, tough pod containing nany or few seeds. Twigs moderate, zig-zag. with pale or pinkish pith, sharp, axillary, persistent spines, and superposed, globular lateral buds above rather large, irregular leaf-scars. Bark furrowed, and the trunk and branches often armed with large. sharp, branched thorns.

This genus, concerning the early history of which little is known, is represented in North America and Asia by (i species, :3 being American. In Illinois, 2 of these occur, one commonly and one rather rarely.

\section{KEY TO THE ILLINOIS LOCUSTS}

Pods a foot or more long, many seeded................ triacanthos p. 228 Pods about 2 inches long, few seeded.................... aquatica p. 229 


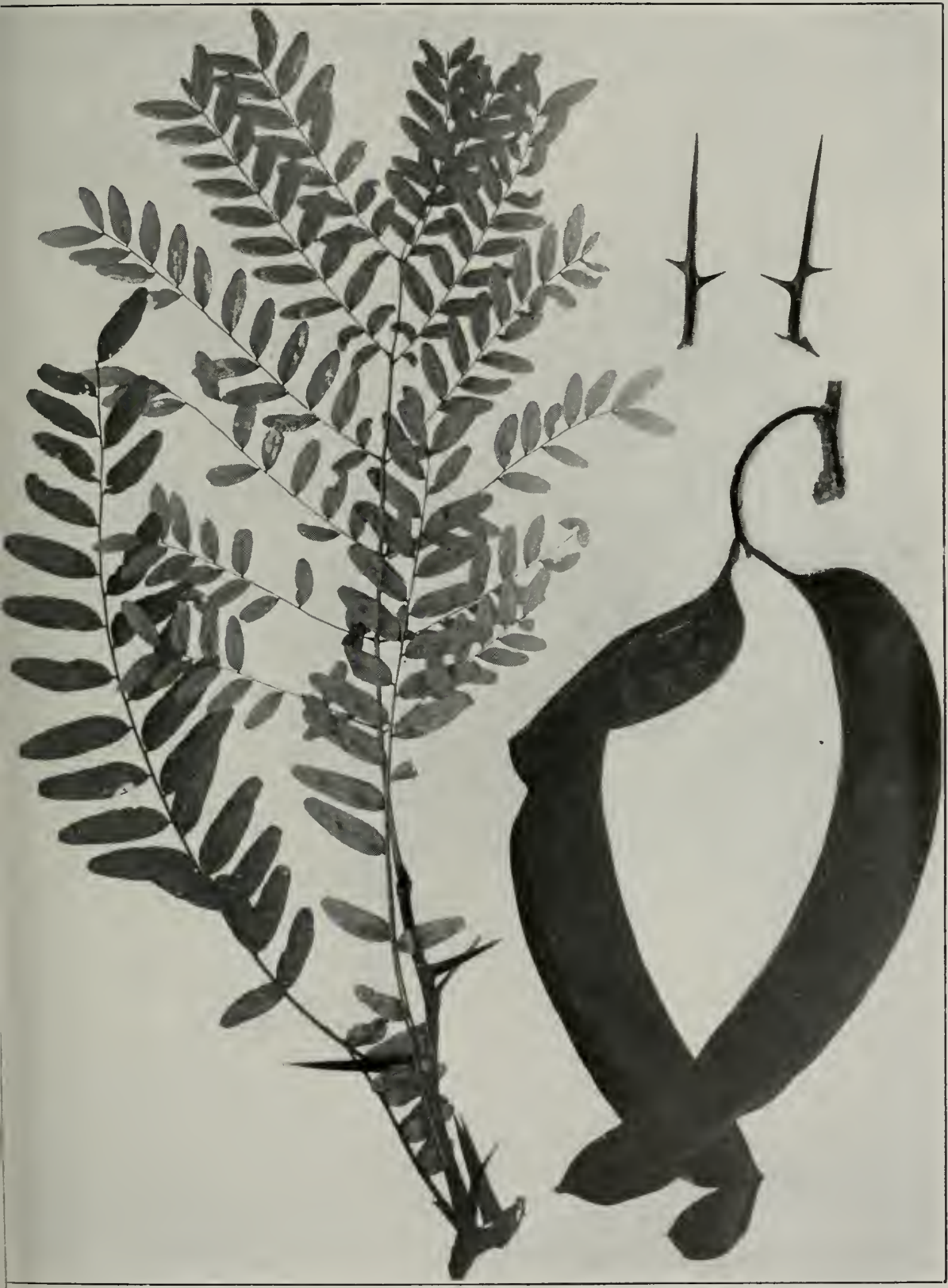

PLATE ¡:

GLEDITSIA TRIACANTHOS LNXAEUS

HONEYT LOCUST 


\section{GLEDITSIA TRIACANTHOS 1.:.:.AEL'}

\section{Honey Locust}

The Honcy Iocust is a large and sraceful iree, with a broad, open head of slender and somewhat drooping brancles. The large leatres, often s inches long. are made up of numerous dark-grcen and shing leaflets, each an inch or more in length and $1 / 2$ inch in width. The grrecnish-

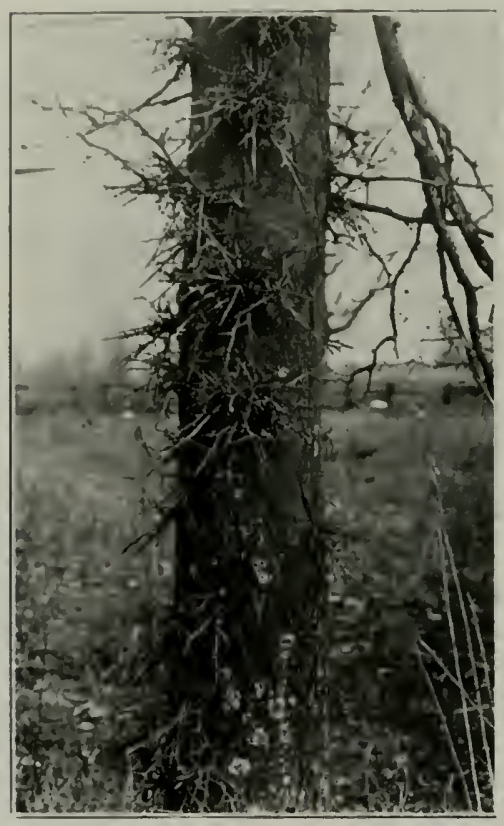

Fig. 91. Trunk of the Honey Locust. The greatly branched spines are a sure means of identification. lhoto from the Ficlil Muscum of Natural History. yellow flowers grow in racemes from the axils of year-old scars, the stiminate racemes often clustererl and crowded with flowers, the pistillate racenes ustually alone, few-Howered. and graceful The dark-brown porks. 12 to 18 inches long, hang in groups of 2 or 3, each on a stont stalk an inch or more in length, and contain a number of c val seeds. The lustrous. greenish-red to brown branchlets bear small buds and bright, red, ;-forked thorns above the leaf-scars. The trumk, the bark of which is divided by (leep fissures into long, narrow, scaly ridges, becomes 2 or 3 feet thick, and the tree grows to a height of $i 0$ to 100 feet.

Distribution: From Pennsylvania westward to Sonth Dakota and sonthward to Florida and Texas, the Honey Locust thrives on moist and fertile soils. It ranges thronghout Illinois, growing not only along streams and on the bottomlands, where the largest and best trees are always found, but also on the uplands. Infrequently, it forms pure stands, which cover small areas, but it is usmally a solitary tree. It grows promiscuously, though nowhere alumelantly, with the White, Black, Pin, and Burr oaks, Elm, Bass Wood, Black Walnut, Wild Black Cherry, Shagbark, Pecan, and numerous other trees. Robert Ridlyway, who measured many of the large trees of the Wabash Valley before they were cut, wives the measurements of a Honey Locust stancling in $18 \% 1$ as $1 \% 0$ feet in 'reight, with 50 feet of clear trunk and a circumference of 1 i feet. 
Uses: The bright, reddish-brown, coarse-grained wood of the Honey Locust is hard as well as strong, and it is very durable in contact with the soil. As a consequence, it is used quite extensively for fence posts and rails and for railroad ties. It also furnishes a fair grade of charcoal. Although the radial surface of its lumber shows a pleasing silver grain, the design is not sufficiently pronounced to give the lumber exceptional value as a finishing material.

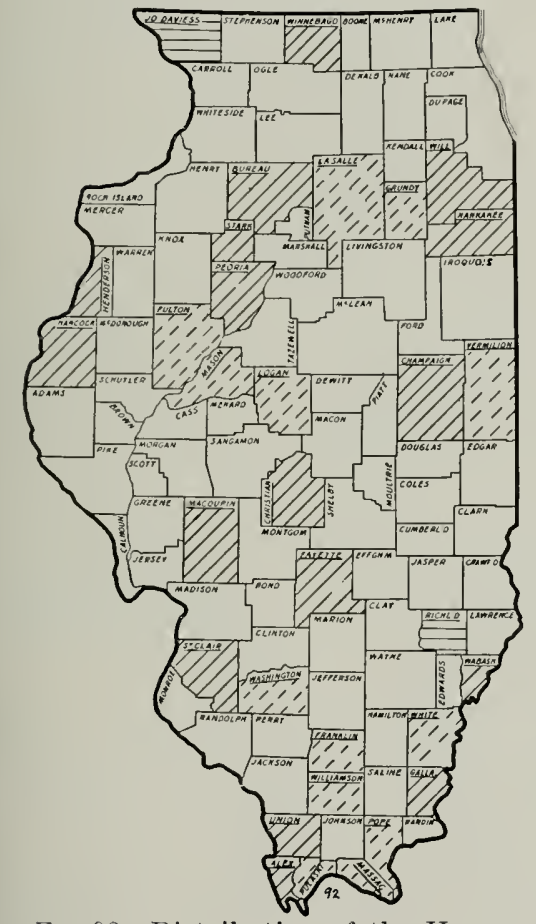

Fig. 92. Distribution of the Honey Locust.

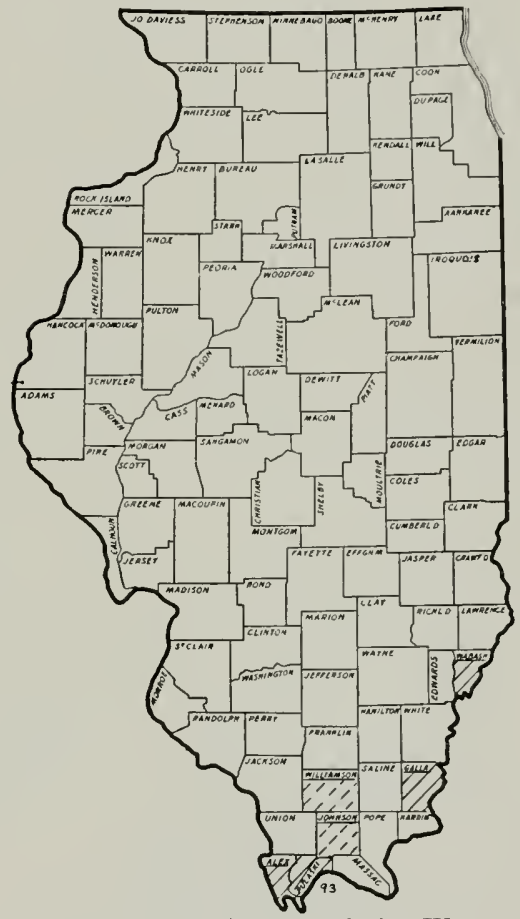

Fig. 93. Distribution of the Water Locust.

\section{GLEDITSIA AQUATICA MARSHALL}

\section{Water Locust}

The Water Locust is a tree of rather moderate size, with a wide, irregular crown formed by stout, spreading limbs which arise very close to the ground. The rather large leaves, 5 to $S$ inches long, are made up of a number of dull, yellow-green leaflets about $1 \mathrm{inch}$ long by $1 / 2$ inch 


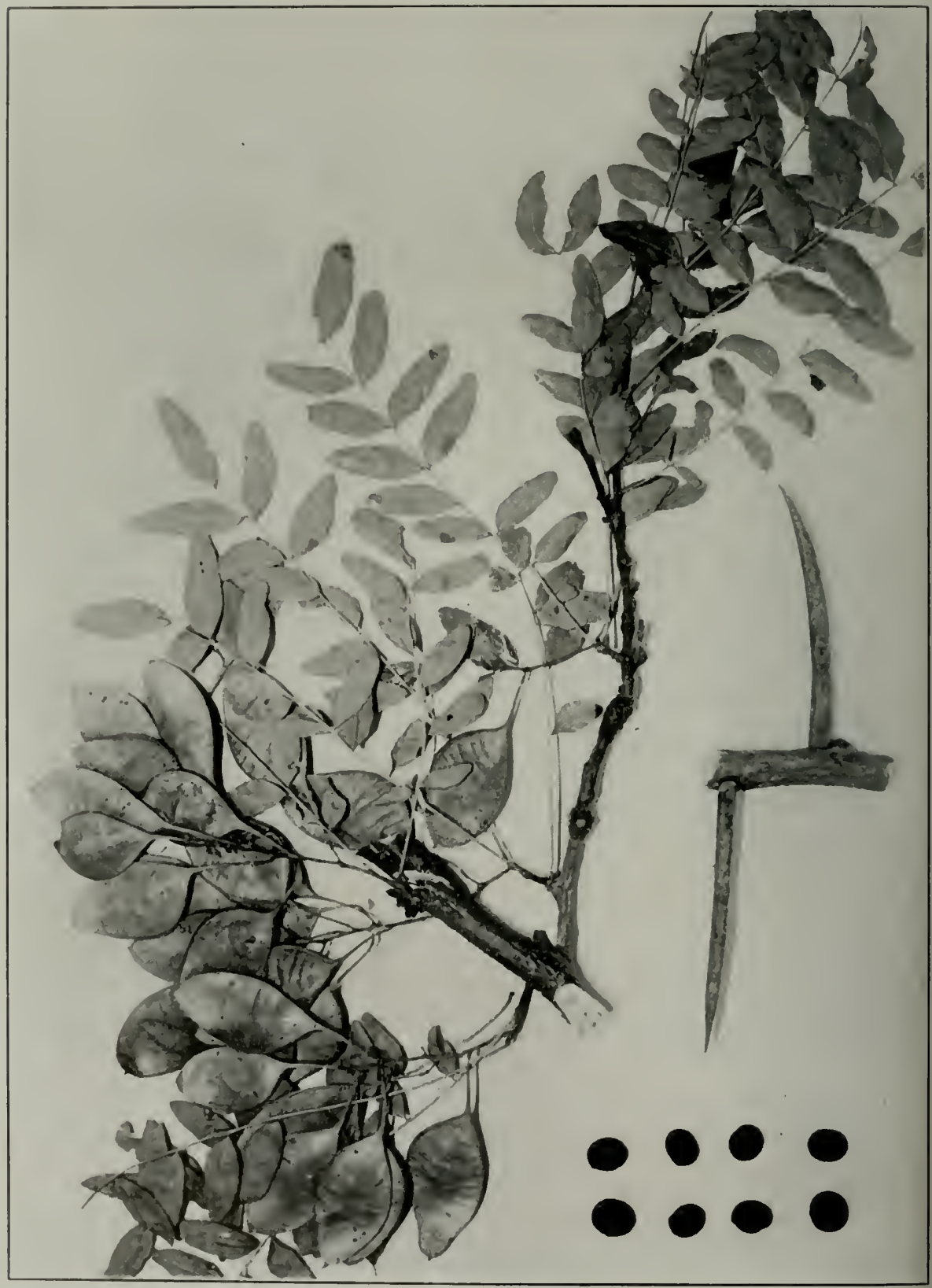

PLATE is

GLEDITSIA AgUtiCa Marshall

WATER LOCUST 
wide, set in pairs along the simple or branched petiole. The greenish flowers stand in slender racemes 3 to \pm inches long. each flower on a short, purple stalk. The bright-brown, oval pods, 1 to 2 inches long by an inch wide, hang from long stalks and contain 2 or :3 nearly round, flat. orangebrown seeds. The orange-tinted, brown branchlets bear unbranched, sharp, rigid spines 3 to $j$ inches long. The short trunk. which is clothed in smooth, dull-gray, shallowly fissured, and plated bark, may become ? feet thick, and the tree rises to a height of 60 feet or more.

Distribution: The Water Locust is distinctly a southern tree and is, moreover, an inhabitant of swampy and overflowed lands. It ranges from South Carolina to Florida, westward through the Gulf Coast region into Texas, and northward again along the Mississippi into southern Illinois. where it grows as an occasional tree on the swampy bottomlands of the Mississippi, the Cache, the Ohio, and the Wabash rivers. Along the Cache River, it grows rapidly attaining a height of so feet and a cliameter of $1 \mathrm{~s}$ inches in 60 years. Its principal associates are the Honey Locust, Tupelo Gum, Elm, Cypress, and ashes.

Uscs: The rich, bright, red-tinted, brown wood of the Water Locust is heavy, strong, and hard, though coarse-grained. When freshly cut, it has an unpleasant odor. In Pulaski County, the Water Locust is cut and sawed into lumber, which is used both in cabinet work and as a finishing wood for the interior of buildings.

\section{ROBINIA LINNAEUS Locust}

\section{Family Leguminosae}

Deciduous trees and shrubs, with alternate, compound leaves and brightly colored. pea-like flowers in stalked racemes arising from the axils of the new leaves. Fruit a long. flat, short-stemmed, membranous pod containing many seerls. Twigs zig-zag and somewhat angled, with round, brown pith, small buds covered by persistent membranes, broadly triangular leaf-scars, and spiny, persistent stipules.

Rcbinia, with its 8 species, is confined to the North American Continent. Although the fossil forms that have been found can be distinguished only with the greatest difficulty from those of sinilar trees. such as the Honey Locust, it is certain that during past ages Robinia was not only much more widely distributed through the world but was also represented by a much greater variety of forms. Our common Black Locust, one of 3 tree forms now present in the United States, is known to have lived. during the interglacial periods, in the Province of Ontario and. at a still later time and for many succeeding centuries, in France. 


\section{ROBINIA PSEUDOACACIA LINANES}

\section{Black Locust Acacia Yellow Locust}

The Black Locust is a tree of only moderate size, with a high, narrow head of small, uptilted tranches. The large leaves, nsually about a foot long, are composed of an odd number of oval leaflets, ranging from i to $1 !$, set oppositely in pairs along the slender. somewhat hairy, and un-

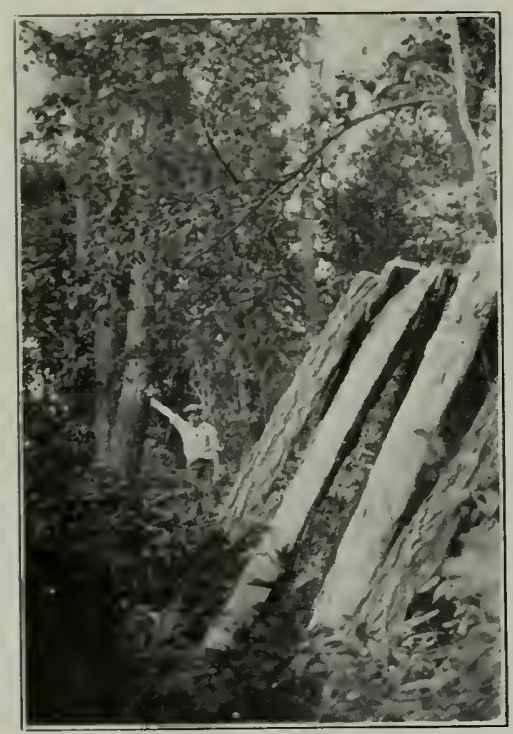

Fig. 94. Fifty-year old stand of Black Locust on sand near Havana. One tree yielded 40 split and 4 round posts. branched petiole. which bears a single leaflet at its tip. The fragrant, nectarbearing flowers, with their pure-white petals and red-blotched, green sepals, hang in beautiful racemes, $t$ or $j$ inches long, from the axils of the leaves. The bright, recldish-brown pods. which are 3 or 4 inches long and half an inch wide. contain from \pm to $s$ orange-brown. darkily marked seeds nearly $1 / 4$ inch long. The light reddish-brown, many-angled to round branchlets have their leaf-scars and buds covered by a persistent membrane, and the stipules persist as sharply pointed spines. The trunk, which is inclosed by deeply furrowed, scaly, reddish-brown bark, grows to a diameter of :) feet or more: and the tree, though sometimes very tall, is usually less than 80 feet high.

Distribution: Though wi dely naturalized and cultivated in a considerable varicty of selected forms, the Black Locust ranges naturally from Pennsylvania to Virginia and westward to the Mississippi River. In Illinois, though far from abundant in any place, it ranges practically throughout the state, selecting light and fairly open situations. It is conmonly associated with such trees as Black Walnut, Wild Black Cherry, ashes, White and Burr oaks, and Tulip Trees. Some of the best of the older stands occur in Whiteside County; where the most common associate is Burr Oal.

Uscs: The heavy, close-grained wood of the Black Locust is exceedingly hard and strong. From it are manufactured the "tree-nails" used for piming together the timbers of ships. Its durability also makes 


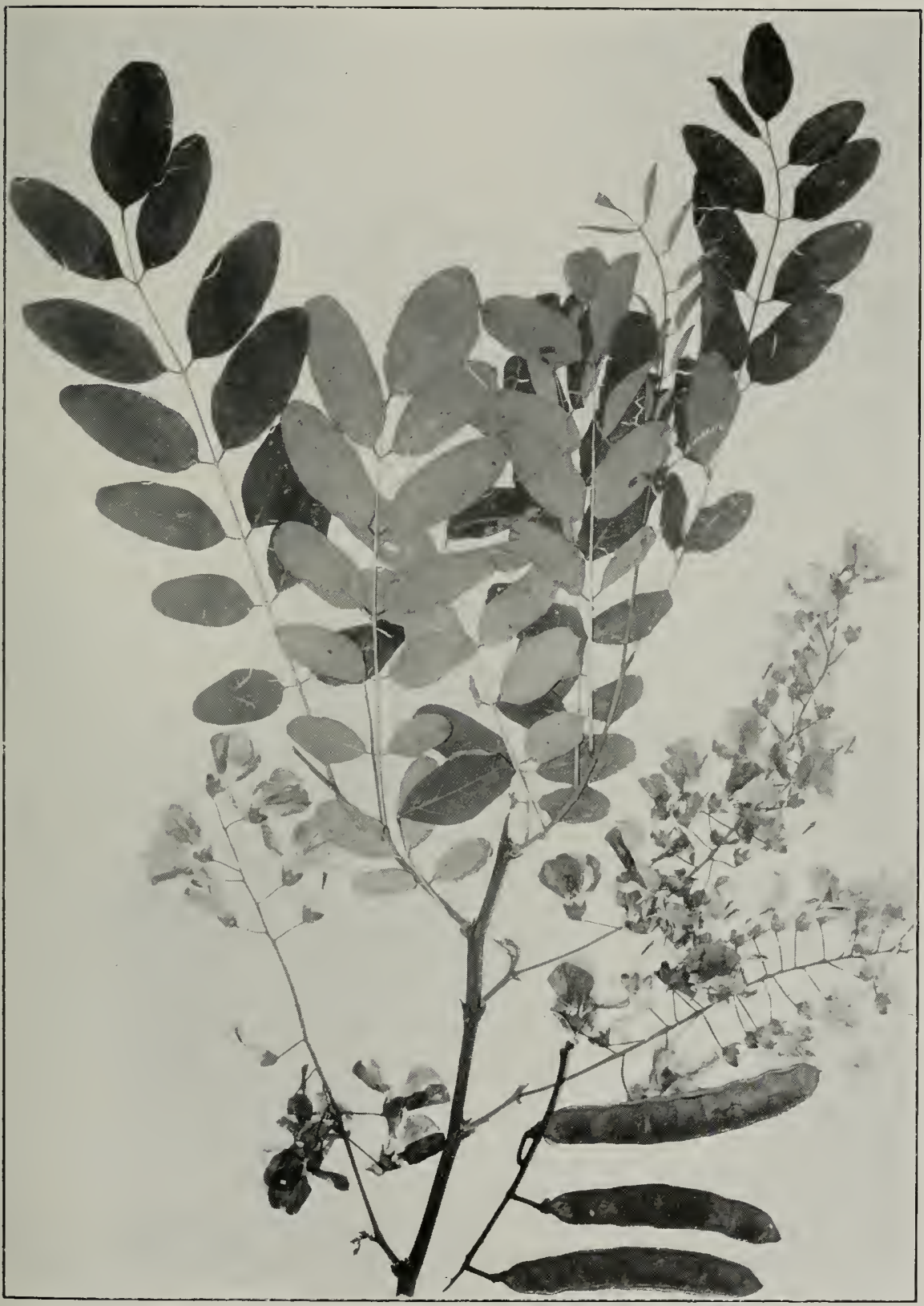

PLATE $: 9$

ROBINIA PSEUDOACACIA LINNAEUS

BLACK LOCLST 


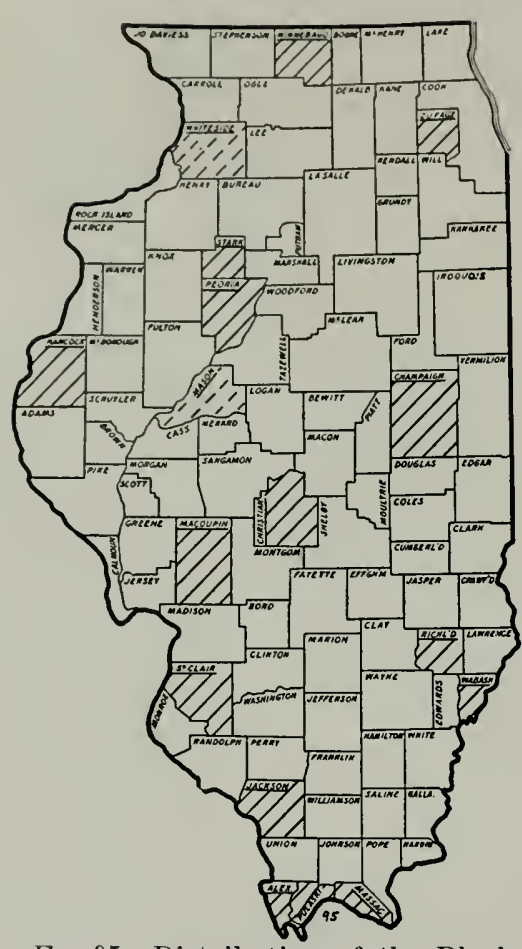

FlG. 95. Distribution of the Black Locust. it very desirable for fence posts, railroad ties, insulator pins, and many other similar articles.

In common with nany other legumes, its widely spreading and shallow roots harbor nitrogen-fixing bacteria: and it is said that barren sand planted to Black Locust will become fit, in 5 years, to support bluegrass. The use of the tree is advocated also for holding and reclaiming badly gullied lands, and its rapid growth makes it a suitable tree for planting on the "spoil banks" of strip mines. wherever there is any quantity of limestone.

The usefulness of the Black Locust is, however, very greatly limited by the fact that it is subject to great damage from an insect known as the Locust Borer, which is particularly destructive in pure stands situated on poor soils.

\section{ACER Linnaeus}

The Maples

Family Aceraceae

Small to very large, deciduous trees, with opposite, simple, palmately lobed, or (in one species) compound, petiolate leaves and regular flowers growing in fascicles or racemes from lateral or terminal flower-buds, the pistils and stamens usually in separate flowers. Fruit, known commonly as maple "keys," a pair of seeds, each with a long, narrow, membranous wing. Twigs round or 6 -sided, with round, pale pith and oval or conical bucls sessile or on stalks above more or less U-shaped leaf-scars. Bark (quite varied in appearance and characteristics.

With nearly 100 species, Acer is at home through almost all of the Northern Hemisphere, and one species, in the mountains of Java, crosses to the south of the Equator. Abundant and varied as the Maples are today, during ancient geological times they were still more numerous and varied in their forms. In the history of man. Chaldea, Assyria, and Babylon, Egypt, Greece, and Rome have risen and fallen, but the heyday 
of the Maples, begun at a time when the polar regions were warm and forest-covered, has persisted through the ages. In our moclern forests, they are among the climax trees, and several of our best known species were already in existence when the great ice sheets of the Glacial Period over-ran the northern world.

Today, the North American maples that attain tree size are $1: 3$ in number, and $\mathrm{s}$ of these, with several of their varieties, are natives of Illinois.

\section{KEY TO THE ILLINOIS MAPLES}

Leaves compound .............................................. 246 Leaves simple but palmately lobed.

Leaves generally 3-lobed.

Flowers and seeds in lateral fascicles. A. rubrum Drummondii p. 244 Flowers anch seeds terminal, or from subterminal buds.

Leaves velvety-hairy beneath............... nigrum p. 238

Leaves pale but not hairy beneath............ saccharum p. 235 Leaves generally 5-lobed.

Flowers almost stalkless; leaves deeply cut, silvery-white beneath; petioles 4 or 5 inches long........ A. saccharinum p. 240

Flowers long-stalked; leaves moderately lobed, hairy beneath; petioles 2 to 4 inches long.................. rubrum p. 243

\section{ACER SACCHARUM MARSIIALL}

\section{Sugar Maple Hard Maple}

The Sugar Maple is a very tall tree. with a high, clear bole crowned with a wide, dome-like head of large branches. The 3-lobed, or less often - -lobed, dark-green, leathery leaves, which are usually $t$ to 5 inches long and pale and smooth beneath, stand on slender petioles $1 \mathrm{I} / 2$ to 3 inches long. The greenish-yellow flowers, with j sepals but no petals, occur in terminal or nearly terminal fascicles and are borne on slender stalks that vary in length from $3 / 4$ to 3 inches. The bright, red-brown seeds, about $1 / 4$ inch long, have broad, thin wings from $1 / 2$ to 1 inch long. The slender, shiny, reddish-brown twigs bear small, pointed, purplish buds. The trunk, with its covering of deeply fissured, gray-brown, scaly bark, grows to a diameter of 3 feet or more, and the tree often attains a height of 100) feet, the bole rising 50 feet or more to the first branches.

Distribution: The range of the Sugar Maple extends from Nova Scotia westward across Canada beyond Winnipeg and southward into Georgia and Mississippi. In Illinois, it grows particularly in the upland hardwood forests throughout the State, selecting moderately deep, welldrained, fertile loam soils. "Sugar tree land," however, is usually rated as poorer than "black walnut land." The common associates of the Sugar Maple are Bass Wood, Black Walnut, White, Black, and Red 


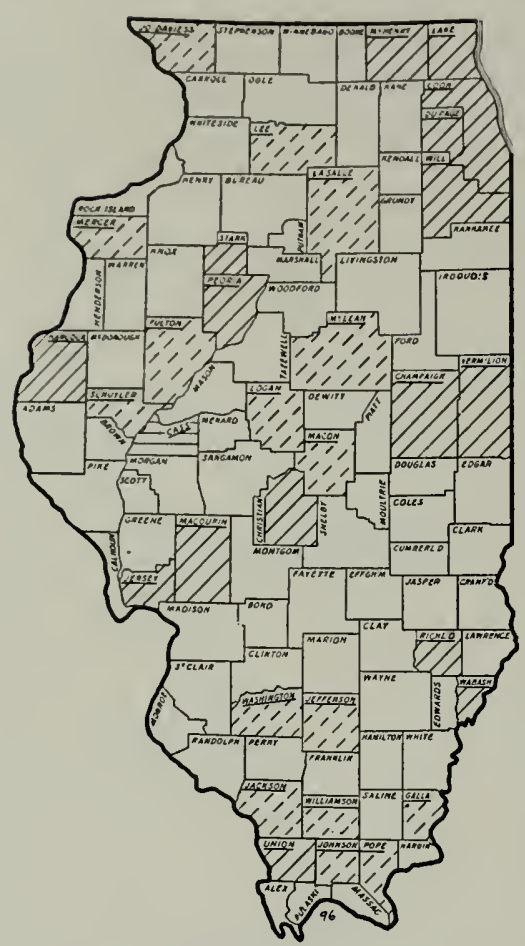

FIG. 96. Distribution of the Sugar Maple.

oaks, hickories, ashes, Eln1, IVild Black Cherry, Mulberry: Hackberry, Kentucky Coffee Tree. Honey Locust, and Redbud. On the high moraines of Vermilion County, however, it is found especially with the White. Red, Black, and Burr oaks, Beech, Sycrmore. Sassafras, and several of the trees previously named.

Besides the typical Sugar Maple. two varieties are known to occur in Illinois. The variety Rugclii Rehder, in which the leaves have 3 long, pointed, smooth-margined lobes, has been found in Richland County by Robert Ridgway, in Wabash and Johnson counties by Jacob Schneck, in Jackson County by L. T. Cranwill, and in White County. The variety Schncckii Rehcler, which is distinguished from the typical Sugar Maple by the presence of hairs on the veins beneath the leaf, has been found in nine southern counties, Richland, Edwards, Wabash, Gallatin, Hardin, Pope, Johnson, Pulaski, and Alexander. Neither of these varieties is. however, abundant; and the distinctions between them and typical trees will not be made by the usual observer.

Uscs: The hard, fine-grained wood of the Sugar Maple is heavy and takes a beautiful polish, to the appearance of which a slight silver grain on the radial surface lends a distinctive touch. It is among the most useful and most valuable of our Inlinois hardwoods. The uses to which it is put make a long list and include furniture, flooring, boxes, crates, shoe parts (such as lasts, shanks. and pegs), farming implements, musical instruments, wooden ware of many kinds, and laundry appliances, as well as wagon axels, tool handles, bobbins for cotton mills, trunks, toys, cutting blocks, slack cooperage, and veneers.

Two very valuable types of lumber are derived from the Sugar Maple. Certain trees, in which the grain has become twisted and contorted during growth, furnish the ornamental "curly" maple so extensively used in cabinets; while other trees, within whose trunks the adven- 


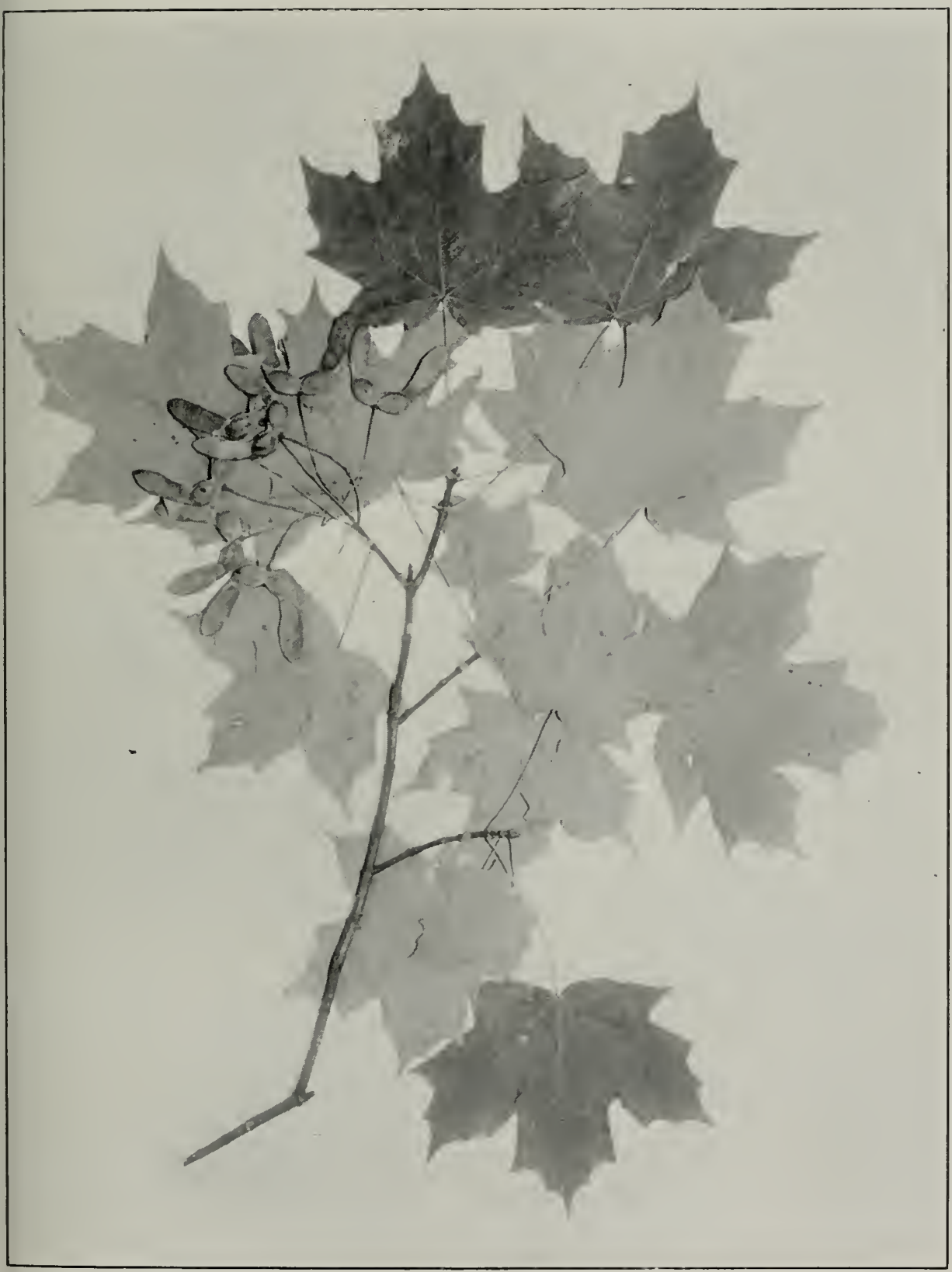

PLATE 80

ACER SACCHARUM Marshall

SUGAR MAPLE 
titious bucls have been huried, furnish the highly clecorative "birdseye" maple so greatly prized for small panels in beds, cabinets. and walls.

sugar llaple logs are easily split, and this, together with their hardness, makes them admirably suited for fuel purposes. The ashes, which were formerly much used in the manufacture of soft soap, contain a considerable amount of phospliate and are valuable as lawn and orchard fertilizers. The wood ranks with beech for distillation purposes.

The maple sugar and the maple syrup of commerce are also obtained from this tree.

\section{ACER NIGRUM MICHAUX}

\section{Black Maple}

The Black Maple is a tree of somewhat more than medium height. with a shallow, flat-topped crown of stout, spreading branches. The thick, firm, dull-green leaves, usually 3 -lobed, but occasionally 5 -lobed, and yellow-green and velvety-hairy beneath, are between 5 and 6 inches long and

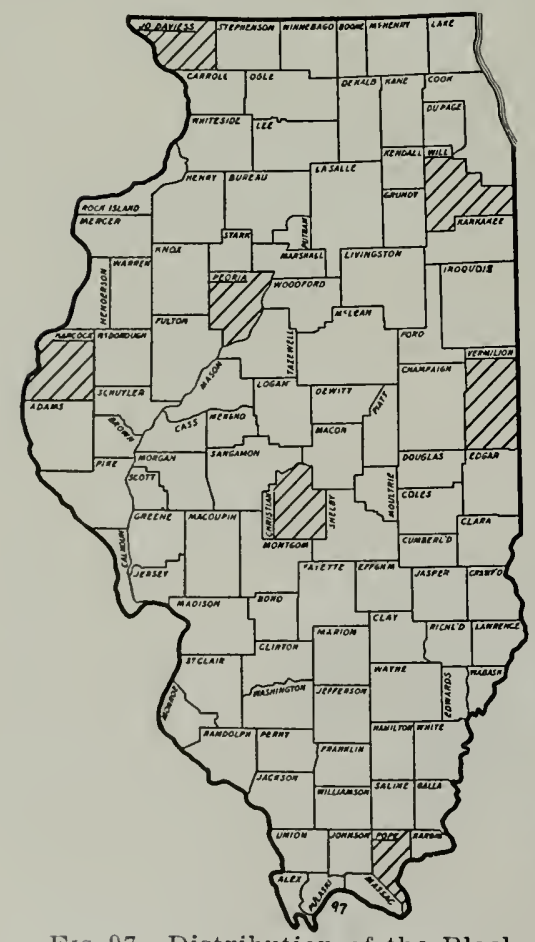

Frg. 97. Distribution of the Black Maple. hang on stout, hairy petioles :3 to 5 inches long, the enlarged bases of which nearly cover the buds. The yetlow flowers, which have 5 sepals but no petals, hang from slender, hairy stallis. $2 \mathrm{~T} / 2$ to 3 inches long, arranged in terminal fascicles. The keys, the wings of which usually spread widely, are between $1 / 2$ and 1 inch long and carry bright, red-brown seeds about $1 / 4$ inch long. The orange-brown branchlets bear very hairy, pointed, clark redbrown buds set deep in the narrow leaf-scars. The thick and deeply furrowed bark covers a trunk which may attain a diameter of $21 / 2$ to 3 feet, while the tree may rise to a height of 80 or 80 feet.

Distribution: Though always a rare and localized tree, the Black Maple ranges from Montreal westward to South Dakota and southward into New York, West Virginia, Kentucky and Missouri. In Illinois, as 
may be judged from the map, it is a widely distributed but not common tree. Its occurrence in the state is known chiefly through the collections of Virginius H. and Ignes Chase, Frank C. Gates, and C. J. Telford, thongh specinens obtained by other collectors have been seen.

Uscs: Though the Black Maple is not sufficiently abundant to be an important timber tree in Illinois, its wood. which is not easily distinguishable fron that of the Sugar Maple, can be used for practically all the purposes for which hard maple is suitable.

\section{ACER SACCHARINUM LINAAEUS}

\section{Silver Maple Soft Maple}

The Soft Maple, or Silver Maple, is a tree considerably over medium height, with a divided bole consisting of 3 or $t$ stout, upright limbs and with a broad head of drooping latera! branches that turn upward toward the ends. The thin, bright, pale-green leaves, which are 6 to $\approx$ inches long

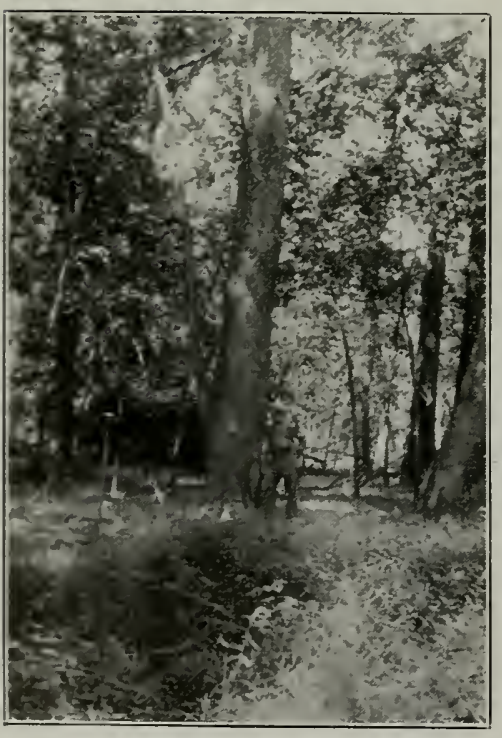

Fig. 98. Silver Maple on the Mis. sissippi bottoms, near A tw o o d Ridge, in Union County. and distinctly white beneath, are divided very deeply into 5 distinctly toothed lobes and hang on slencler. drooping. bright-red petioles $t$ or j inches long. The greenish-yellow flowers, which lack petals, hang on short stalks from the axils of the past year's leaves. The large keys, which are usually between $1 \mathrm{I} / 2$ and 3 inches long, have wings nearly $3 / 4$ inch wide and carry pale-brown seeds $1 / 2$ inch long. The trunk, covered by redbrown, furrowed, scaly bark, may become ; feet or more in thickness. and the tree may grow to a height of 80 feet or more.

Distribution: From New Brunswick westward into South Dakota and southward to Florida and Louisiana, the Silver Maple is found along the banks of streams and on low, often subnuerged, swampy lands. In Illinois, its range includes the entire State and it grows in a considerable variety of situations, with an equally varied assortment of tree species in association with it. On the Mississippi bottomlands of Carroll County, it constitutes 32 per cent of the merchantable 


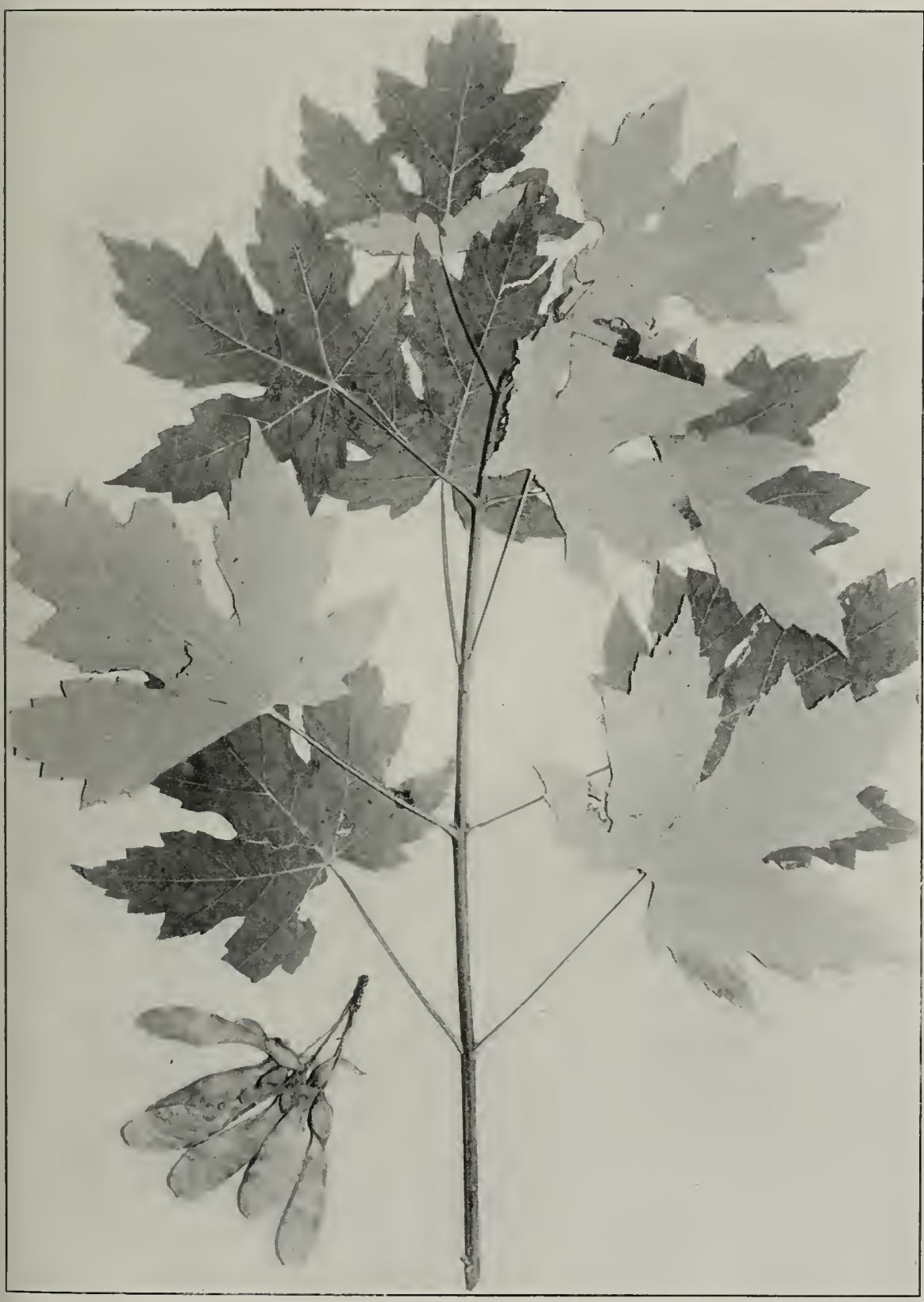

PLATE 8? 
timber, the other important trees being Elm. Pin Oak, and Ash, and the ninor trees willows. River Birch, and cottonwoods. Along the Illinois River, in the region about Havana, it grows on rich land with Elm, Cottonwood, and Sycamore, sometimes attaining a height of 100 feet before the trunk diameter is much over a foot. On the alluvial soils in Mason

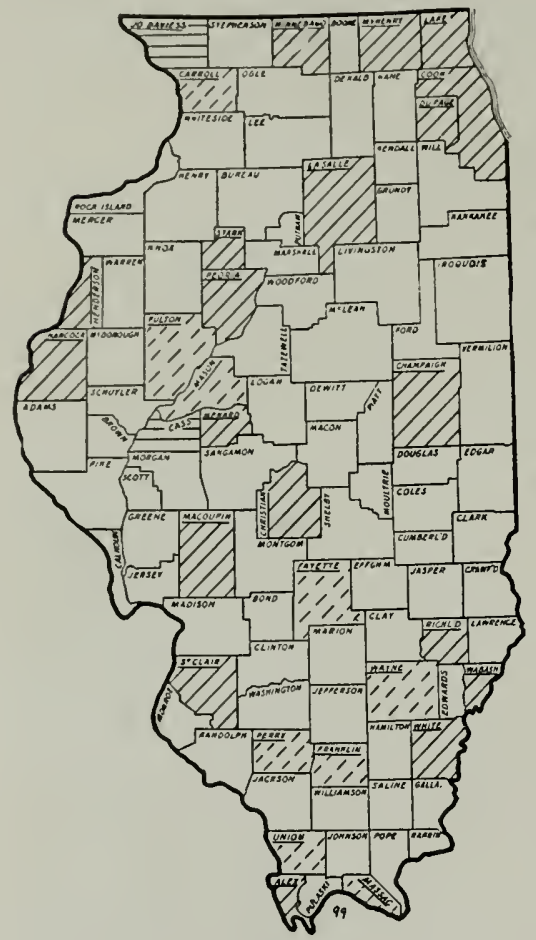

FIG. 99. Distribution of the Silver Maple.

County, where the Illinois often overflows its banks, its associates are usually Cottonwood, IVillow, ashes, and Elm, of which the first two form the "upper story" and Elm and Soft Maple the "lower story" of the forest. Here Soft Maples with trunks 20 inches in diameter attain a height of 90 feet.

On poorly drained, brown, clayey loam in Fayette County, the Silver Maple grows in company with Ash, Elm, Pin, and White oaks, Honey Locust, and Cottonwood; while on the margins of the Kaskaskia River, in the same county, its additional associates are Sycamore, hicliories, Hacliberry, and Black Nalnut. On the flat, overflow land of the Big Muddy River in Franklin County, where the soil is mostly drab clay, there are also Pin Oak, ashes, Honey Locust, and Elm; while the loamy land supports, in addition, the White and Burr oaks and various haws. In Union County, along a small tributary of the Mississippi, the stand that accompanies the Silver Maple is made up of Viater Elm, ashes, Box Elder. Pecan, Pin Oak, and Willow; elsewhere in the sane county additional associates are found, which include Sycamore, Cottonwood, Burr Oak, Hackberry. Honey Locust, and an occasional Cucumber Tree. On the eastern side of the State, in Wayne County, Silver Maple and hickories form the main part of the reproduction on the yellow, silty loams, as for example on the Skillet Fork bottomlands, but there is a considerable variety of other trees. In Massac County, in the area of the Cache River drainage project. where the soil is described as a "mellow, rich-brown loam," the Silver Maple makes up the stand of timber in association with Tupelo, Cypress, and Cottonwood. 
The Silver Maple grows rapidly, in this respect ranking next to Sycamore among the Illinois trees. In a 40 -year-old stand examined by our forest survey party, the Silver Maple had grown at an average rate of 53 cubic feet per year per acre-a rate exceeded only by the Cottonwoods. which had averaged 96.8 cubic feet, and by the Sycamores, which had averaged nearly 63 cubic feet. In Wabash County, near MIt. Carmel. several 100-year-old trees had attained a height of $10 \%$ feet, and their trunk diameters averaged 33 inches. Such trees will each yield nearly 1400 board feet of lumber. On the Mississippi bottonland at Ware, Union County, a tree 86 years old had attained a height of over 100 feet and a trunk diameter of $29 \mathrm{I} / 2$ inches. Robert Ridgway reports that a tree on his estate near Olney added 2 feet $t$ inches to its circunference in 9 growing seasons.

Uses: Though inferior to either Red Naple or Sugar Maple, the pale-brown wood of the Silver Maple is used quite extensively for a variety of purposes. It is close-grained and easily worked, though rather brittle. Besides being sawn into rough lumber and flooring, it is manufactured into furniture, barrel heads and staves, and veneers. When treated against decay, it is serviceable for railroad ties, and a considerable amount is used for piles.

Because of its susceptibility to attack by the cottony maple scale, it does not make a satisfactory shade tree, though a variety with finely divided leaves-the well-known Cut-leaved Maple-is a very handsome street tree, because of its bizarre leaves and its drooping habit.

\section{ACER RUBRUM LINNAEUS}

\section{Red Maple Scarlet Maple}

The Red Maple is a tree of moderate to large size, with a narrow head of more or less upright branches. The coarsely toothed, usually 5 -lobed, light-green leaves, 2 to 6 inches long, are whitened beneath and stand on slender petioles 2 to $t$ inches long. The red flowers, which have both sepals and petals, are borne in dense clusters along the previous year's growth, each flower on a long, slender stalk. The small, red, brown. or yellow keys hang from stems 3 or 4 inches long and have thin wings nearly 1 inch long by $1 / 2$ inch wide. The dark-red, rough-coated seed is about $1 / 4$ inch long. The shiny, red twigs, which are nuarked by white lenticels, bear blunt, dark-red buds Is inch long above the small leaf-scars. The trunk, covered by dark-gray, longitudinally ridged bark that flakes off in large, plate-like scales, attains a diameter of 3 feet or more, and the tree grows commonly to a height of 50 feet or, in favorable situations, even 100 feet. 


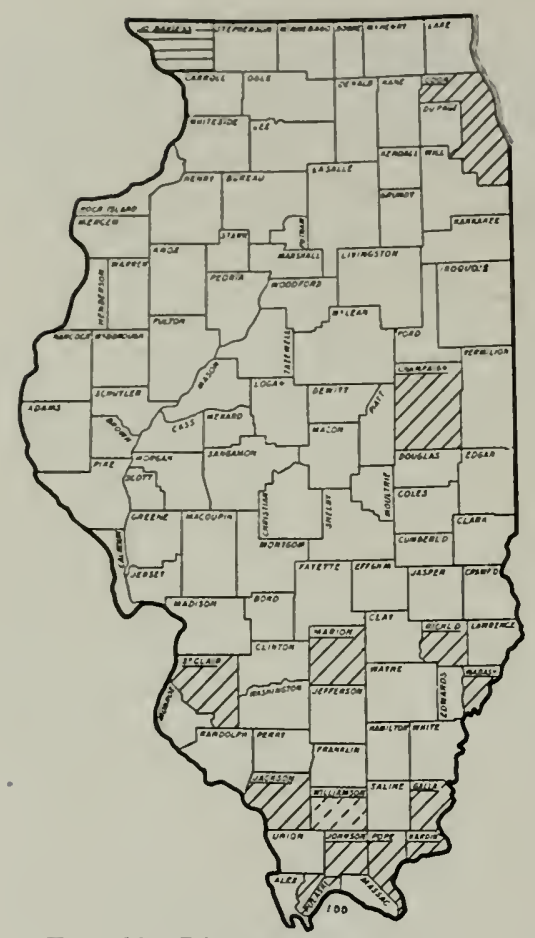

Fig. 100. Distribution of the Red Maple.

Distribution: A tree of streans. swamps, and forests, the Red Maple ranges from Newfoundland to Florida and westward to lowa and Texas. It is generally considered the commonest and most widely distributed tree in eastern North America, but in Illinois it is the least abundant of our maples. Though its range includes the entire State, it is not common in the north and is hardly more abundant, though more often collected, in the south. On mixed loan soil at Allendale. $\mathrm{Wa}$ bash County. one of the finest trees had, at 90 years of age, attained a lheight of 101 feet and a diameter of $2 \pm$ inches inside the bark.

In the northern part of the State, the Red Naple occasionally occurs in pure stands on the borders of streans and lakes, and Pepoon' ${ }^{1}$ remarks that it is abundant in the wet woods at Edgebrook. In northern situations its chief associate is the

Black Ash. In Cumberland County it forms an understory on the Pin Oak flats and is associated also with the Shingle and Swamp White oaks, the Green Ash, and the Honey Locust. In Willianson County it grows with Elm and Hackberry, and still farther south its associates are Red Gum, Cypress, Cottonwoods, and the bottonland oaks.

Two varieties of Red Maple occur in Illinois. Through the southern third of the State, Accr rubrum Drummondii Sargent is fairly frequent. It differs from the species in several respects, chiefly in having hairy twigs. leaves with woolly under-sides, and very large lieys, which may reach a length of $2 \frac{1}{2}$ inches. This is preeminently a swamp-inhabiting tree and has been collected in Richland County by Robert Ridgway, in Richland. Jackson, and IVabash counties by H. Teuscher, and in Pulaski County by C. J. Teliford. The variety tridens Wood has been found in Richland County by Robert Ridgway and E. W. Mattoon. and in Pulaski County, near Karnak, by . C. J. Telford. It differs from the species particularly with regard to its leaves, which are distinctly-3-lobed, remotely toothed, and hairy beneath.

\footnotetext{
"Flora of the Chicago Region, p. 378.
} 


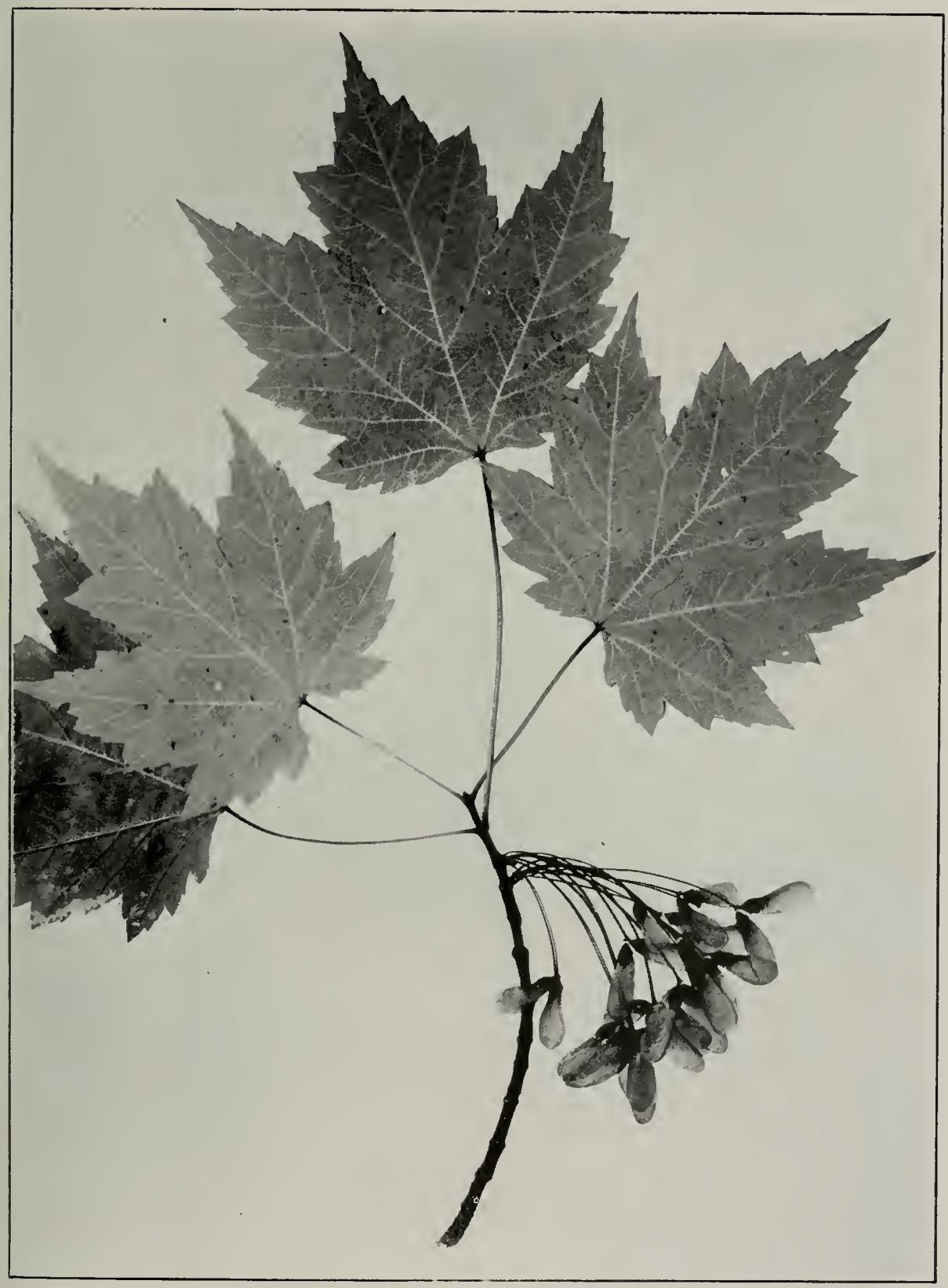

PLATE S:3

ACER RUBRUM LINNAEUS

RED MAPLE 
Lsis: The very heavy and close-grained wood of the Red Maple. which is reddish-brown in the heart and very white in the thick sapwood. stands between hard maple and soft maple in its technical qualities. It is always more or less streaked with dark lines, which mark the beginnings of decay. When carefully seasoned, it makes fair lumber for farm construction, such as sheds, cribs, barn sills, rafters, braces, and even siding. and it is macle into furniture, gunstocks, veneers, charcoal, and numerous turnery articles, as well as being used for fuel.

\section{ACER NEGUNDO LINNAEUS}

\section{Box Elder Ash-leaved Maple}

The Box Elder is a tree of only moderate size, with a number of main stems which arise near the ground and form a broad crown. Its leaves are made up of one or two pairs of leaflets set along the mid-vein and an odd leaflet at the end. Thin, light-green, pale beneath, each leaflet

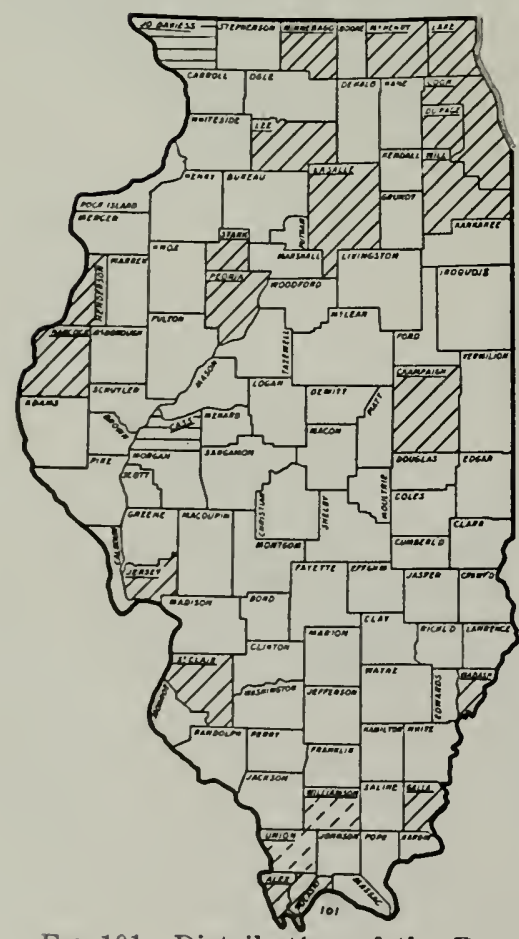

FIG. 101. Distribution of the Box Elder. is 2 to $t$ inches long by 1 to $21 / 2$ inches wide and has a slender stalk. The tiny, yellow-green flowers are subterminal on the year-old growth; each staminate flower borne on a slender drooping stalk, the pistillate ones growing in drooping, fewflowered racemes. The keys, $1 \frac{1}{2}$ to 2 inches long, each pair on an individual stalk, hang in graceful racemes 6 to 8 inches long. The seeds are smooth, bright red-brown, and about $1 / 2$ inch long. The shiny, pale-green, slender branchlets bear blunt or pointed, hairy buds about $\mathrm{T} / 8$ inch long, which are set deep in the hairy, notched tops of the leaf-scars. The trunk, covered by thin, pale-green to brown bark deeply fissured into broad, rounded, scaly ridges, seldom becomes more than 2 feet thick, and the tree is not often more than 40 or 50 feet high.

Distribution: In its natural habitat a tree of stream and lake banks 


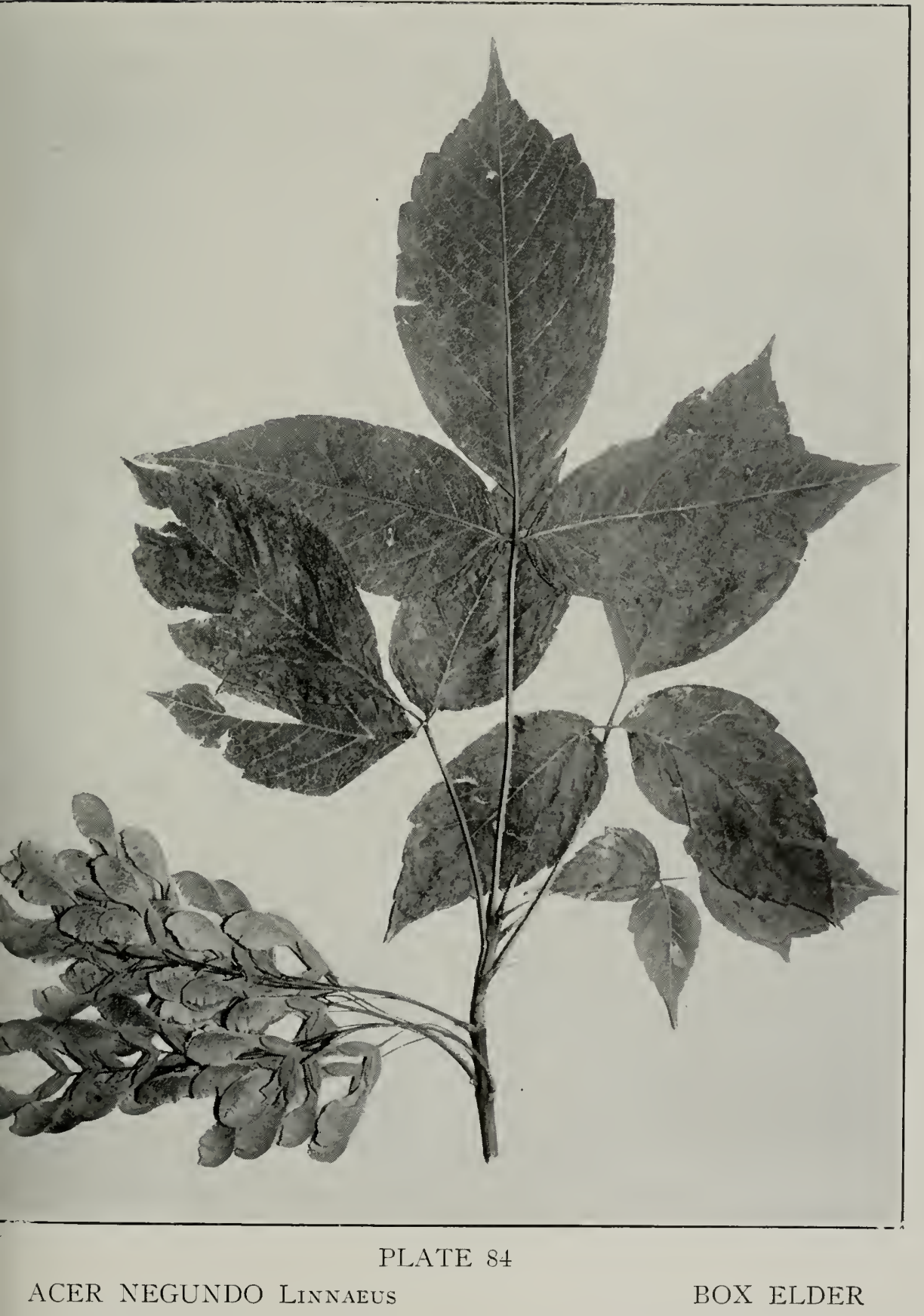


and the borders of swamps, the Box Elder ranges from Vermont westward to Minnesota and southward to Florida and Texas. Through most of lllinois it is to be found in low woodlands and other moist situations. It is a very common escape from cultivation along hedge rows and fences, where the nearby roadsicle ditches undoubtedly favor its growth. It attains its best growth in the southern part of the State. On the Big Mudely bottomlands in Willamson County, it grows in company with Eln, ashes, White Oak, Water Locust, and hickories: and in Union County with Soft Maple. Elm, ashes. Pecan, Willow, and Pin Oak.

Uscs: The creamy-white, close-grained wool of the Box Elder is neither hard nor strong. Its poor technical qualities rencler it rather useless, though it has been employed to some extent in the making of cheap furniture. for the inferior finish of houses, where its whiteness may be used with a decorative effect. and in the manufacture of cooperage and wooden wares of various linds.

Maple sugar can be made from Box Elder sap; and the tree has been used extensively for shade, though the brittleness of its branches renclers it very susceptible to damage from storms and sleet. A cultivated variety with variegated leaves is used for decorative $p^{1}$ anting.

\section{AESCUlus Linnaeus Buckeye}

Family Hippocastanaceat

Small or large, deciduous trees, with opposite, compound leaves consisting of 3 to 9 feather-veined, toothed leaflets arising together from the end of the petiole. Flowers rather showy and colored, in upright racemes on the end of the branchlets, each flower with 5 sepals and 4 or 5 peta!s, (i) to $s$ stamens, and a 3 -celled ovary, which is rudimentary in the staminate flower. Finit a rough or smooth, woody capsule that splits into 3 parts to liberate 1 to 3 pressure-flattened, globular seeds, each of which is marked by a large light scar. Stout, round twigs witl somewhat angular, pale pith and very large, scaly buds set above low, more or less triangular leaf-scars. Bark variable in character, but bitter.

This genus, with its 16 species, is widely distributed in the Northern Hemisphere. In North America there are 6 species, which are most abundant and range, chiefly, through the southeastern part of the United States. But one species extends its range northwestward into Illinois. 


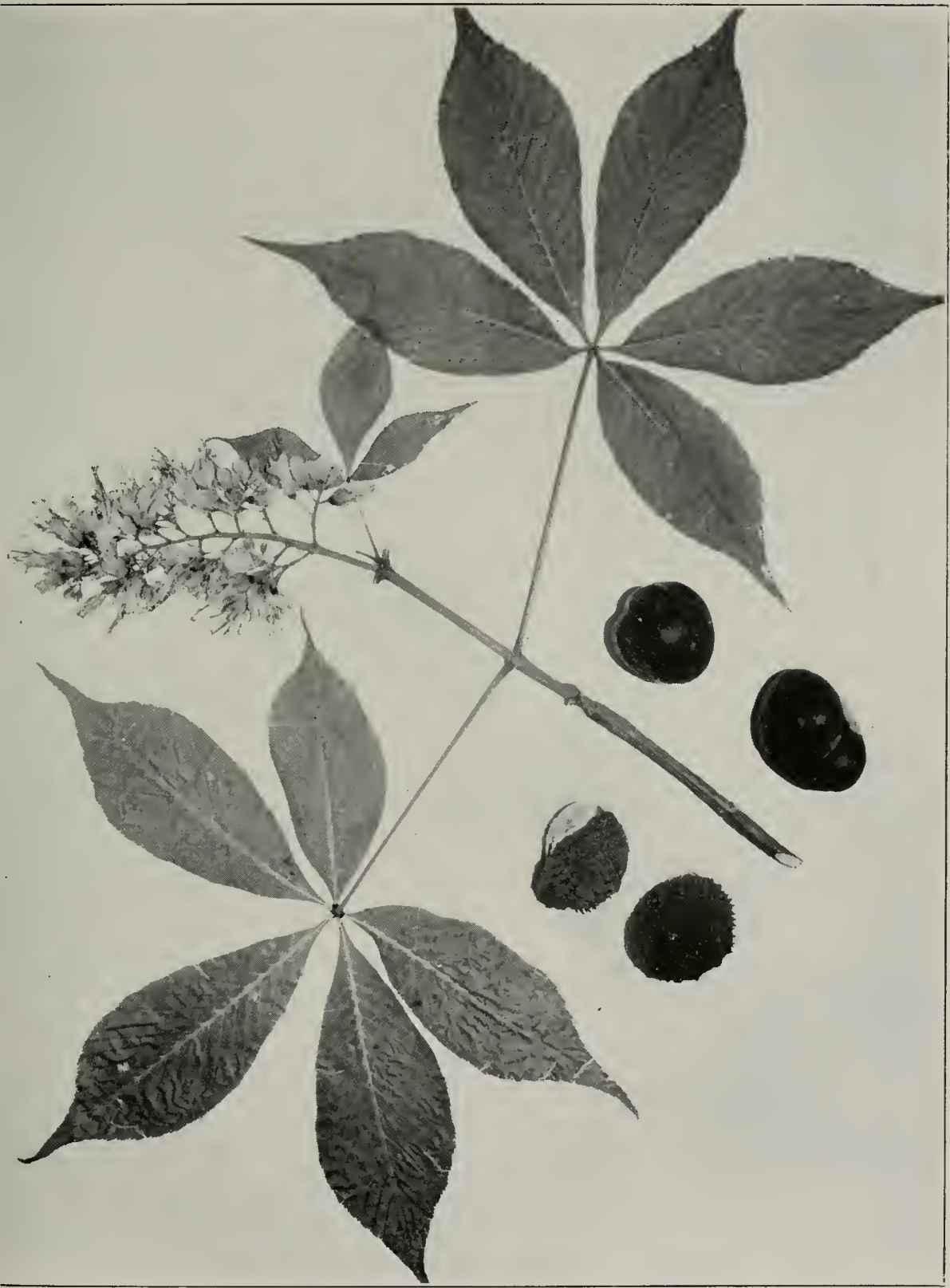

PLATE 8.5
AESCULUS GLABRA Willdenow
OHIO BUCKEYE 


\section{AESCULUS GLABRA WILLDENOW}

\section{Ohio Buckeye \\ Fetid Buckeye}

The Ohio Buckeye, also known as the letid Buckeye, is a tree of considerably less than medium height, with a broad, long. round-topped crown of small, spreading branches. Each leaf consists of it long-oval, pointed, toothed, yellow-green leaflets set like the fingers of a hand at the

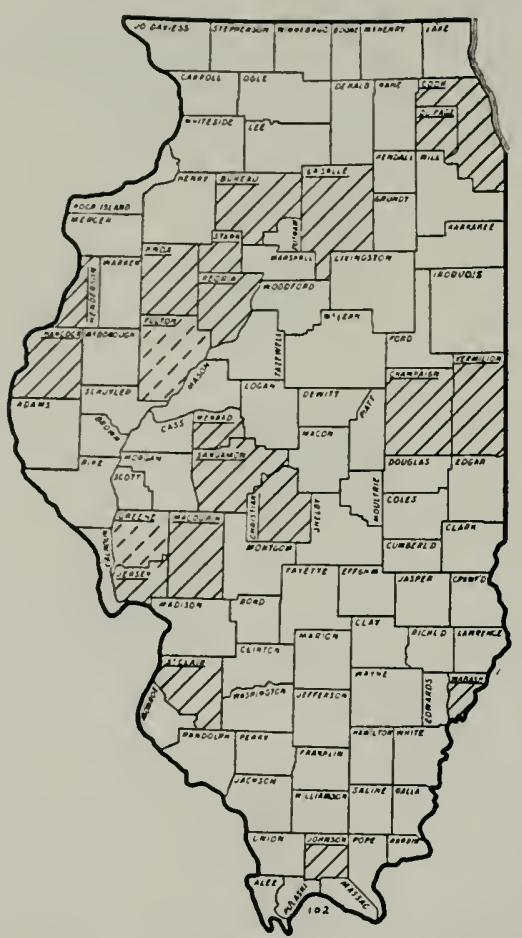

Fig. 102. Distribution of the Ohio Buckeye. top of a slencler petiole 4 to 6 inches long. The pale, yellow-green flowers stand in rather dense, upright, conical racemes, at the ends of the branchlets. The fruit incloses within its sharply warty, brown shell from 1 to 3 shiny. brown, dark seeds usually an inch or more in diameter. The red-brown branchlets, which are covered at first with fine hair, are marked by scattered, orange lenticels and bear large buds, $1 / 2$ to $3 / 4$ inch long above large leafscars. The trunk, which is covered by dark-brown to gray, fissured, scaly bark, attains a diameter in proportion to the height of the tree, which is not often more than 30 or 40 feet.

Distribution: Along the banks and on the bottomlands of rivers and streams, the Ohio Buckeye ranges from Pennsylvania southwestward to Alabama, Kansas, and Nebraska. Excepting only a region in the northwest corner of Illinois, it ranges quite generally through the wooded stream lands of the State, preferring especially the moist sides of low bluffs but growing also on the bottomlands. In these woodlands it is, however, to be counted as among the occasional rather than the common trees. Its associates are Soft Maple, ashes, Cottonwood, Elm, Sycamore and, very often, various haws.

Uses: Though close-grained, the light wood of the Buckeye is both weak and soft. When it is cut, it is sold on the market as bass wood, which it resembles both in its whiteness and the ease with which it can be worked. Its uses include chiefly manufactured articles such as wooden ware of various kinds, drawing boards, artificial limbs, and paper pulp. 


\section{TILIA LinNaEus The Lindens}

\section{Family Tiliaceae}

Snall to very large, deciduous trees, with alternate, ?-ranked, broadbladed, toothed leaves and white or yellow, fragrant, nectar-bearing flowers borne in clusters toward the end of a stalk which arises from the mid-vein of a large, leaf-like structure. Fruit a nut-like, globular, woody body, hairy on the outside and containing 1 or 2 light reddish-brown seeds. Twigs zig-zag, with fibrous bark, pale pink or yellowish pith and red or green buds above nearly half-round leaf-scars. Bark tough and fibrous.

Tilia, with its 30 species, ranges throughout most of the temperate regions of the Northern Hemisphere, with the exception of western North America and central Asia. Though not as ancient as many of our trees, its known fossil forms include perhaps 30 species. It always has been one of the most highly valued trees. To primitive man, its flowers yielded, as they still do, honey of the finest flavor and lightest color; the wood served the homeliest uses, being made into such necessary articles as ox-yokes; and the bark yielded fibers for making cords and ropes.

There are 15 native American species, four of which are reported to occur in Illinois. So far as may be judged from the specimens at hand and the observations of our forest survey, three of these are rare, the wellknown Bass Wood being the common tree. The following key will serve to distinguish them, though only the common species is described.

\section{KEY TO THE ILLINOIS LINDENS}

Leaves velvety or woolly beneath......... heterophylla Michauxii Sargent Leaves smooth or only hairy beneath.

Leaves very large, 5 to 6 inches long............ glabra Ventenat Leaves generally smaller, 3 to 5 inches long.

Leaves pale but smooth beneath............. floridana Ashe Leaves covered with short hairs beneath......... neglecta Spach 


\section{TILIA GLABRA VENTENAT}

\section{Bass Wood}

Linden

The Bass Wood, or American Linden, is ordinarily a tree of moderate height. with a broad and round-topped crown of small and somewhat drooping branches. The broadly oval, slenclerly pointed, coarscly toothed leaves, ; or 6 inches long by: $:$ or + inches wide, dark-green and dull on

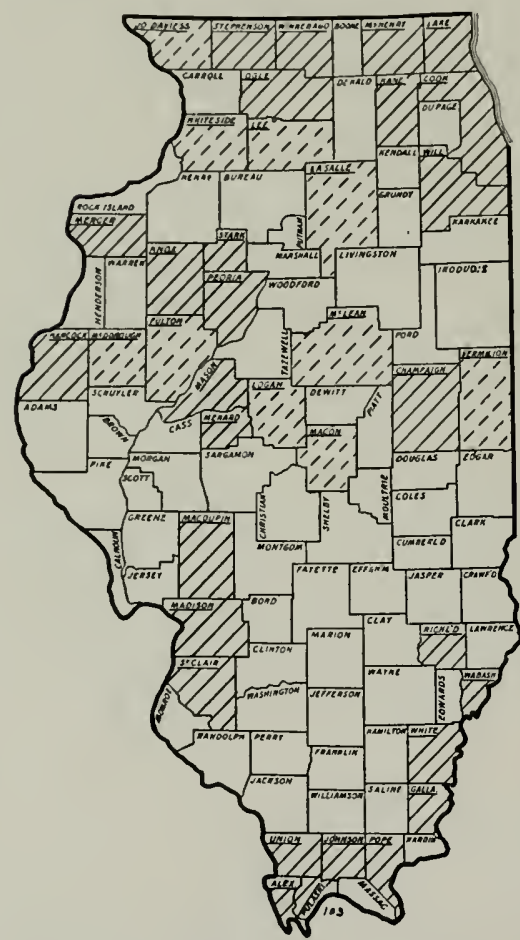

Frg. 103. Distribution of the Bass Wood. the upper face, lighter and shiny beneath, stand on slender petioles $1 \mathrm{I} / 2$ to 2 inclues long. The sweetly fragrant, yellowish-white flowers liang in clusters of 5 to 20 on a long stalk, which arises from the middle of the mid-vein of an axillary, oblong. leaflike structure. The woody, globular fruit, nearly $\mathrm{t} / 2$ inch in diameter, is densely hairy outside. The brown branchlets bear dark-red buds about $1 / 4$ inch long; and the trunk, inclosed by thick, brown, deeply furrowed bark, may become 3 feet thick, while the tree attains a height of 60 feet or more.

Distribution: On rich, mo ist soils, the Bass Wood ranges from New Brumswick westward to Winnipeg and southward to Pennsylvanla, Kentucky, and Nebraslia. It ranges throughout Illinois and may be found wherever rich, wooded slopes, moist stream banks, and cool ravines occur.

Among the large number of its associates are the White, Black, Red, and burr oaks, hickories, the White and Slippery elms, maples, ashes. Black Walnut. Wild Black Cherry, and Tulip Tree. It grows to its largest size on the bottomlands of the Ohio River.

Uses: Though light in weight, the red-tinted, light-brown wood of the Bass Wood is strong and especially suited for such articles as highgrade boxes and crates. Being very easily worked with tools, it is a favorite wood of calsinet makers and manual training teachers. It is not by any means durable and cannot be used for rough building, ties, or fence posts, with the certainty of more than 3 to 5 years of service. Small 
quantitics are used for fuel, though the heating quality is inferior to both bech and oak. Under the name "white wood," however. bass wood is manufactured into a great variety of articles, including cheap furniture, trunks, boxes, musical instruments, picture mouldings, laundry appliances, and beekeeper supplies, as well as paper pulp, veneers, and excelsior. In lumber cut from the butt of the tree, there often is a curly grain, which gives an attractive appearance in cabinets.

\section{NYSSA Linnaeus The Tupelos}

\section{Family Nrssaceae}

Moderate to large, deciduous trees, with alternate, crowded, entirc. broad-bladed leaves and tiny, greenish-white flowers. Staminate and pistillate flowers separate, the former in globular clusters, the latter a few together on the ends of long, slender pedicels which arise from the axils of the leaves. Fruit a fleshy, oval drupe containing a thick-walled, bony, variously roughened pit. Twigs rather stout, with diaphragmed white pith and with oval buds set in the notch of crescent or U-shaped leafscars. Bark gray to brown, furrowed, and roughened with scales.

Besides the four species of southeastern North America, there are but two other Tupelos, one a native of central China, the other native to southern and eastern Asia. Though now so limited both in the variety of its forms and the wideness of its distribution, Nyssa is an ancient genus, the history of which goes far back into our knowledge of the world's life. Previous to the glacial period, as fossils show, it was not only widely clistributed throughout what are now the North Temperate and Arctic zones but was also possessed of a much greater variety of forms, no lese than 30 of which have been found as fossils. In Illinois, at the present inis, we have but 2 species.

\section{KEY TO THE ILLINOIS TUPELOS}

Leaves 2 to 5 inches long; on moist but not inundated soils... N. sylvatica p. 256 Leaves 5 to 7 inches long; on inundated, swampy lands..... N. aquatica p. 257 
NYSSA SYLVATICA MARSHALL

\section{Tupelo Sour Gum}

The Tupelo is a tree of somewhat more than moderate height, with a long. narrow crown of slender. rather chooping branclies capping the straight trunk. 'The firm, shiny, clark-green leaves, ? to i inches long by 1 to : inches wide, stand on romel or winged petioles $1 / 4$ to $1 / 2 / 2$ inches long.

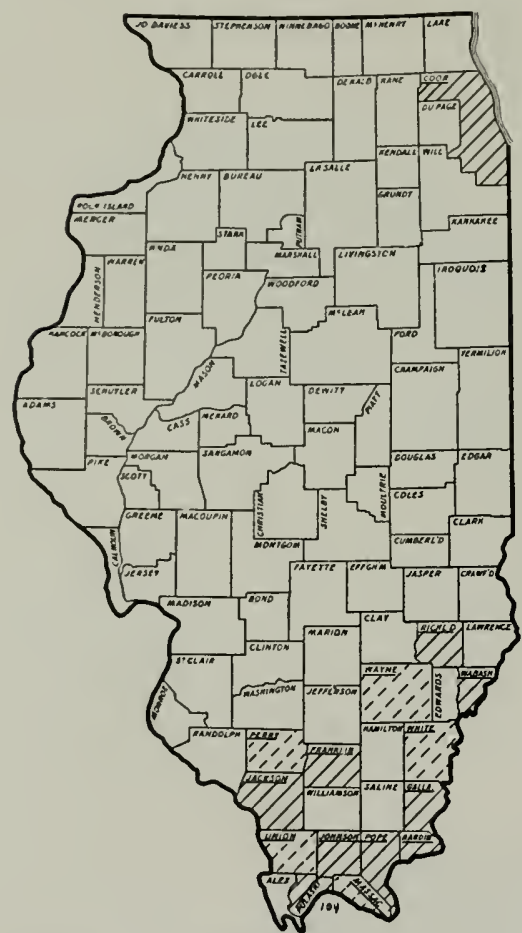

Fig. 104. Distribution of the Tupelo.

The staminate flowers, capping slender, hairy pedicels sometimes $1 \frac{1}{2}$ inclues long, are in dense, globular heads. while the pistillate flowers, on separate pedicels, occur only in two's and three's. The fruits, 1 to 3 in al cluster at the end of a pedicel, are dark-blue, about $1 / 2$ to $3 / 4$ inch long. and contain a light-brown, ribbed stone. The light red-brown branchlets. marked by pale lenticels, bear blunt, dark-1ed buds above lunar leafscars. The trunk, corered by redtinted, brown. deeply fissured bark, has a cliameter proportionate to the height of the tree, which varies according to situation from 30 or 40 feet to more than 100 feet.

Distribution: On wet, poorly drained soils and the edges of swamps, the Tupelo ranges from Maine to Floricla and westward to Texas and Missomi. In Illinois, it is now distinctly a southern tree, coming up the castern side of the State as far as Richland County and up the western sicle into Perry County. The record of its occurrence to the north, in Cook Comnty, is based on some fine trees, now completely destroyed, which grew in a small swamp near Rogers Park previous to 1910. In southern Illinois, the Tupelo is not confined entirely to low or swampy situations, lut is seen not infrequently on hills and dry slopes. It has a large list of associated trees, anong which are numerous oaks and hickories, White Elm, ashes, River Birch. Wild Black Cherry, Sycamore, and Red Gum. 
Uscs: Though heavy, strong, and very tough, the rood of the Tupelo is neither hard nor durable. Exceptional care must be used in seasoning it, because of a pronounced tendency to warp and twist. By the pioneers, who used the hollow trunls for "bee-gums," Tupelo was looked upon as a weed tree; but it is now used very extensively in manufacturing the veneers from which egg crates are made. The toughness of the woorl also has led to its being used for such articles as wheel hubs, gun stocks, rollers, mallets, and rough flooring, while a certain small amount furishes charcoal and pulpwood as well as fuel.

\section{NYSSA AQUATICA MARSHALL \\ Tupelo Gum Cotton Gum}

The Tupelo Gum is a tree of rather more than moderate height, with a wide and buttressed trunk, above which rises a straight bole capped by a narrow, oblong crown of rather small, spreading branches. The shiny, dark-green, firm leaves, 5 to $;$ inches long by 2 to $t$ inches wide and sometimes slightly toothed on the margins, stand on stout, hairy petioles 1 to 3 inches long. The dense, globular clusters of staminate flowers cap their slender pedicels, while the pistillate flowers stand alone on the ends of much shorter pedicels. The darli-purple. conspicuously dotted frutits. nearly an inch long, have thin. sour flesh inside their thick, tough skins, and a flattened pit with 10 wing-like ridges occupies the center. The stout, dark-red branchlets

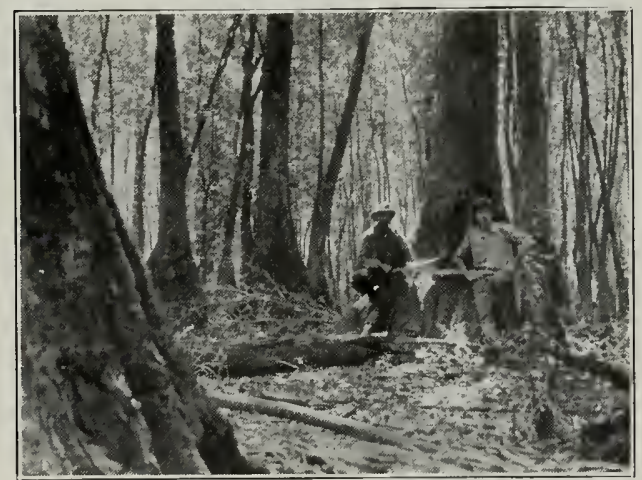

Fig. 105. Tupelo Gum on the Cache River bottoms in Massac County. The swollen, buttressed bases are characteristic of trees inhabiting flooded lands.

bear tiny, blunt buds nearly imbedded in the bark above the conspicuous, nearly round leaf-scars. The trunk, which is covered by dark-brown, furrowed. scale-roughened bark, becomes 3 or $t$ feet thick above the buttressed base; and the tree attains a height of 80 feet or more.

Distribution: From Virginia sonthward to Floricla, westward to Texas, and again northwarc into the lower valley of the Wabash River. the Tupelo Gum is an inhabi ant of low, inundated swanps. Its range 


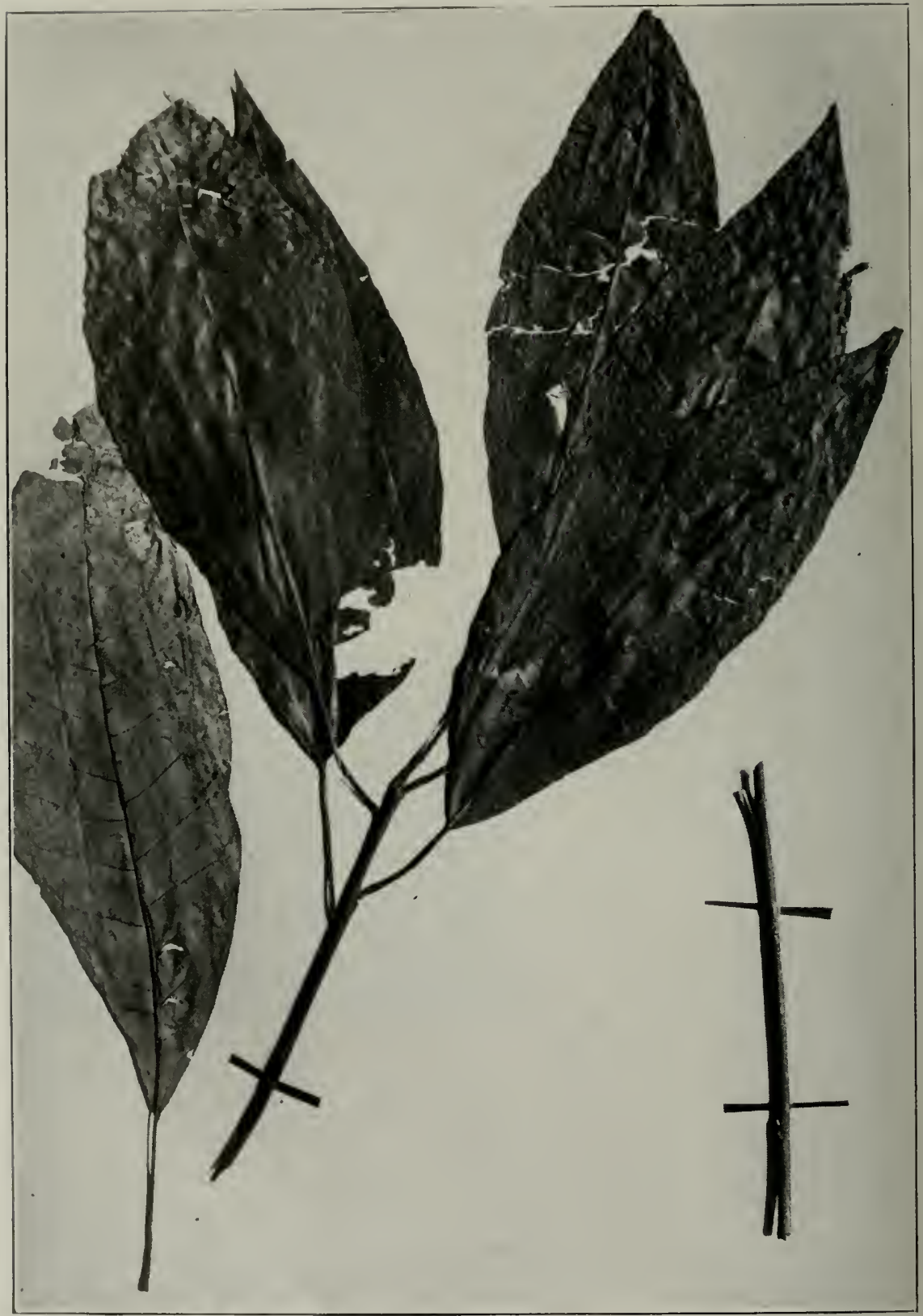

PLATE 88

NYSSA AQUATICA Marshall 
in Illinois is confined to four counties in the southern tip of the State, but even in this region it does not occur outside of the Cypress swamps. Its chief associates are Cypress, Soft Maple, and Black Cottonwod.

Uses: Though close-grained and difficult to split, the light-brown to nearly white wood of the Tupelo Gum is light. soft, and weak. Its best grades resemble yellow poplar, as it has a fine, uniform texture and. though tough, is easily worked with too!s. Much care is require 1 in seasoning the lumber; but the wood talies paint and varnish well and is used for house-flooring and interior finishing. The poorer grades of tupelo gum furnish material for boxes and egg crates, and timbers and planks are used extensively as flooring for depots and warehouses, where there is heavy wear on the floors. Though the wood is not durable in the soil, it has proved satisfactory, when treated against decay, for such uses as cross-arms of telephone poles, cross-ties in mines. and wood paving blocks.

In the bottomland Cypress forests of southern Illinois, the Tupelo (inm constitutes between 19 and $\bullet 0$ per cent of the stand. Anong $2 \cdot$ ? species of trees, it stands second only to Cypress, with an average of 16 trees to the acre. Its potential yield, however, is in excess of all species. amonnting to $15,0(0)$ board feet per Fig. 106. Distribution of the Tupelo acre, or nearly twice the Cypress yield.

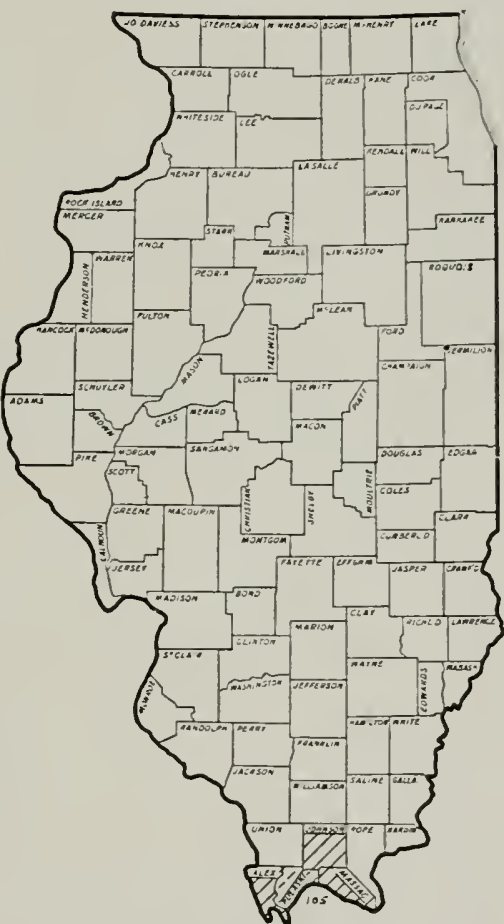

In 1910 , about $9: 8.000$ board feet of tupelo gum was produced in the southern counties of Inlinois; but in 19.25, the amount had fallen to 102,000 board feet. This may be talien to indicate that the Tupelo Gum. like the other trees of the Cypress swamps, are fast disappearing. Indeed, the largest trees measured in our survey were but so feet high and had trunk diameters of only 30 inches. 


\section{CORNUS LIXNAEL'S Dogwood}

\section{Family CORNACEAE}

small and generally bushy, deciduous trees and shrubs. with opposite or alternate, entire, broad-bladed leares and small flowers in loose or densc, teminal heads. Fruit a Heshy drupe with thin, juicy flesh and a hard, often bony pit containing, as a rule, 2 seerls. Twigs rather slender, with more or less angled and sometimes colored pith and with stalked, 2 scaled huds above more or less U-shaped leaf-scars. Bark generally scaly. sometimes fissured.

IVith its 40 or 50 species, Cornus is widely distributed throughout the Northern Hemisphere and extends its range south of the Erpator into Peru, where one species is found. Of the 1s North American species, only + attain tree size; and 2 of these are common in Illinois. Though not so ancient as many of our trees, more than $j 0$ different species have been identified from fossils; and one of these, with large fioral bracts, almost certainly an ancestor of our modern Flowering Dogwood, grew in North America when the polar region was warm and forested and before the ice sheets were formed.

\section{KEY TO THE ILLINOIS DOGWOODS}

Leaves opposite; flower heads surrounded by white, petal-like bracts...

C. florida p. 260

Leaves alternate; flowers in loose. branched heads..

C. alternifolia p. 264

\section{CORNUS FLORIDA LINXAEUS}

\section{Flowering Dogwood}

The Flowering Dogwood is a small, bushy tree, with a flat crown of slender. spreading branches and branchlets up-tilted at the ends. The fim, bright-green, minutely hairy leaves, with oval blades 3 to 6 inches long and 1 to 2 inches wide, are pale beneath and stand on grooved petioles nearly $3 / 4$ inch long. The dense heads of small, greenish flowers stan 1 , on pedicels 1 to 2 inches long, in white, flower-like cups 3 or 4 inches wide, which are so conspicuous in the early spring as to give the tree its common name. The bright, scarlet fruits, about $1 / 2$ inch long by $1 / 4$ inch wide and crowded at the ends of the pedicels, have thin and rather mealy flesh and smooth, hard pits, each containing 1 or 2 pale-brown seeds. The bright-re 1 or yellow-green branchlets terminate in long-stalked, globular buds. The trunk, covered by thin, dark, reddish bark broken into square plates, may 
become a foot thick, and the tree may attain a height of 40 feet, though it is not often over 25 feet high.

Distribution: As one of the nnder-story trees of forests on rich and well-drained land, the Flowering Dogwood ranges from Maine southward to Florida and westward to Kansas and Texas. In Illinois, it occurs in most of our wooded regions, excepting only those in the northeast corner of the State. It is, however, found most frequently in the southern half of the State, where it is associated commonly with Persimmon and Sassafras. Its dark-red autummal foliage, its beautiful, white flowers in the spring, and its brilliaint. red berries give color and character to our woodlands; but in the practice of forestry in our woodlots, it may have to be removed, along with Redbud, Persimmon, Ironwood, and Blue Beech, as its shade is so dense

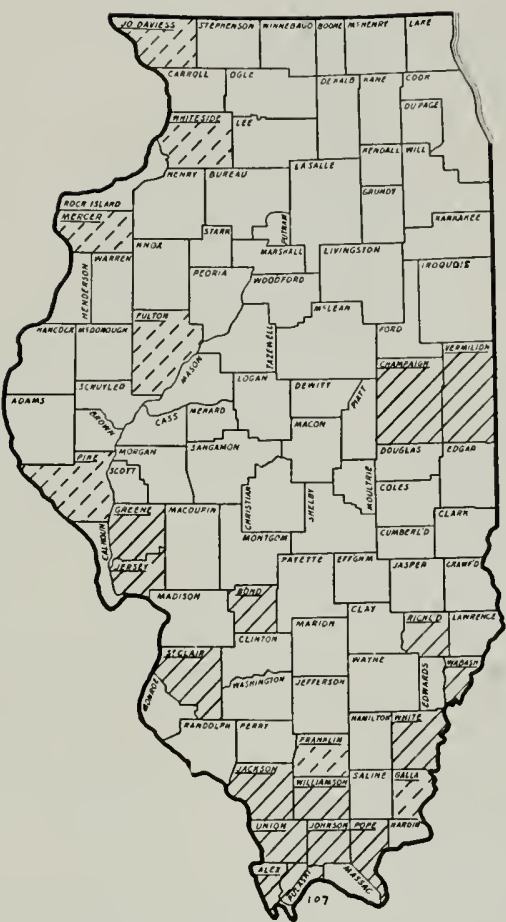

FIr. 107. Distribution of the Flowering Dogwood. that some more valuable trees cannot gain a foothold.

Uscs: The hard, close-grained, brown wood of the Flowering Dogwood is both strong and heavy, and it resembles superficially the wood of the Hard Maple. Through long wear, it becomes highly polished and is, therefore, much used for shuttles, spools, and bobbins in cotton mills. It is a favorite wood for small articles of turnery, and is made also into engravers' blocks, golf-stick heads, brush blocks, and bearings for wooden machines. In the virgin timberland of Union County, Flowering Dogwood now averages about 100 trees to the acre; but the maximum height is only 25 feet and the potential vield only 16 cubic feet to the acre. 


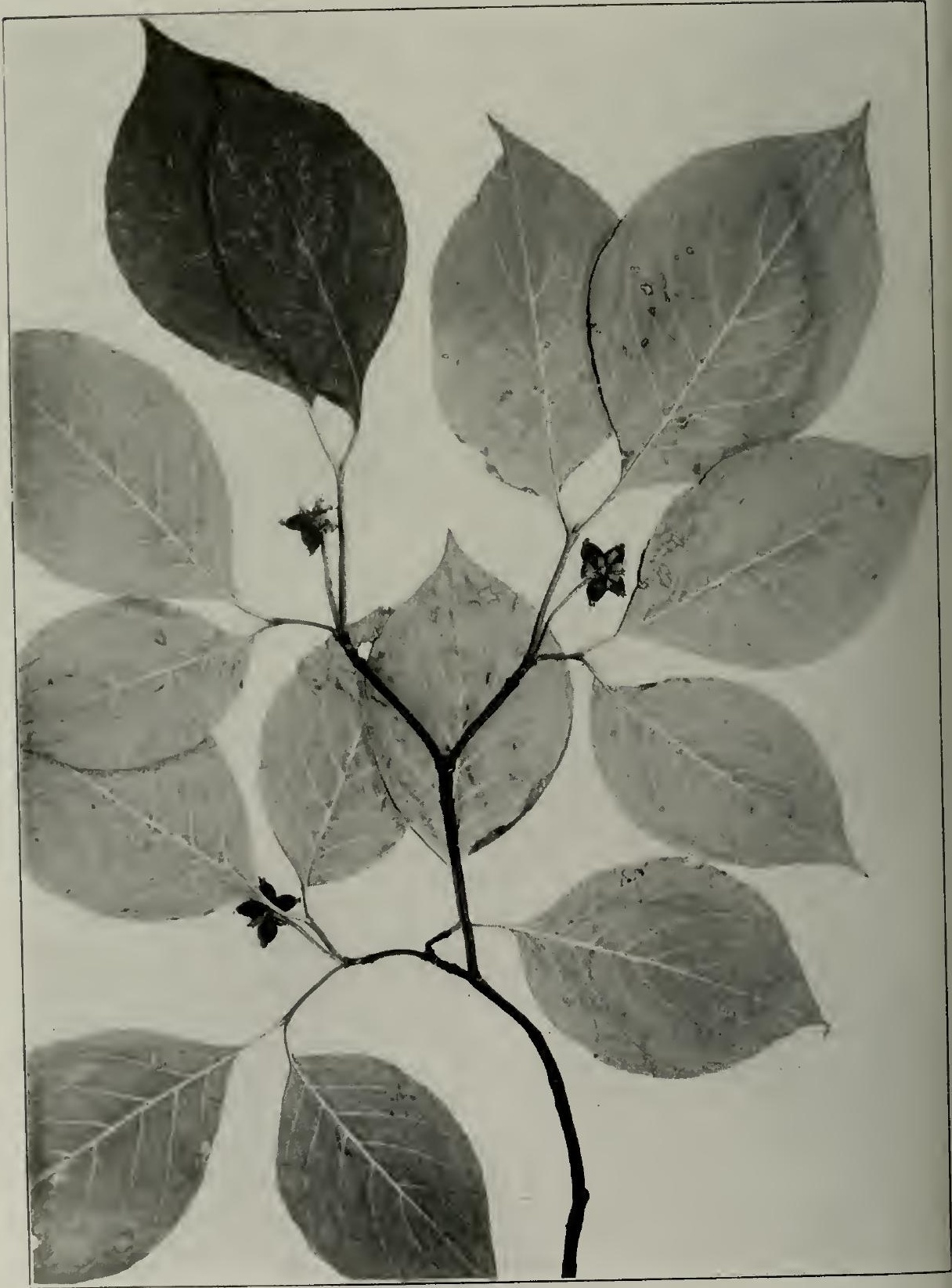

PLATE 89 


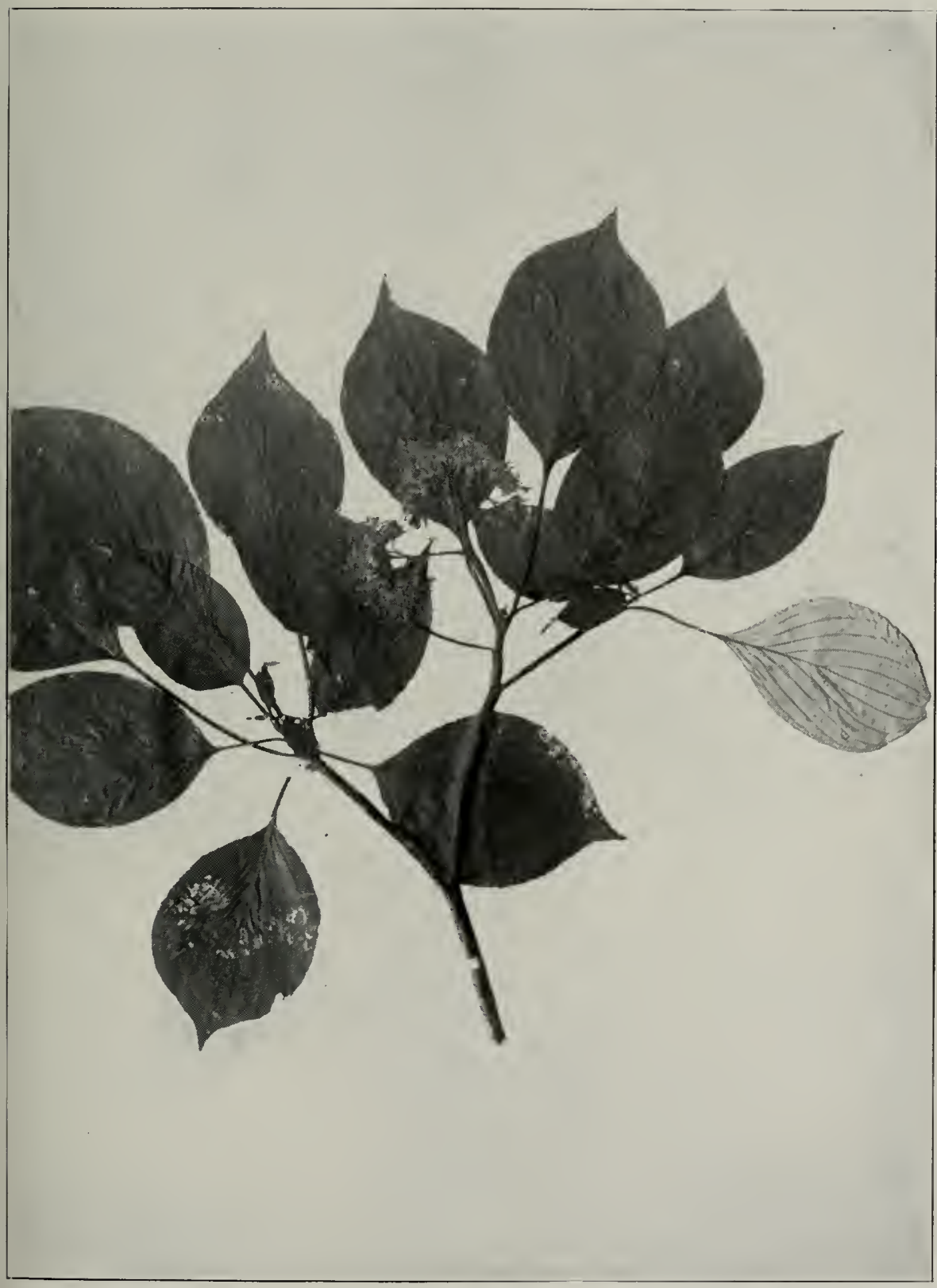

PLATE 90

CORNUS ALTERNIFOLIA LINNAEUS

DOGIVOOD 


\section{CORNUS ALTERNIFOLIA LINNAEUS}

\section{Dogwood}

The Dogwood is a very small tree. with a dense, Hat-topped crown of slencler, spreading branches. The thin, bright yellow-green, pointed leaves, mostly alternate on the branchlets and 3 to 5 inches long by 2 to 3 inches wide, are pale, hairy, and sometimes nearly white beneath and

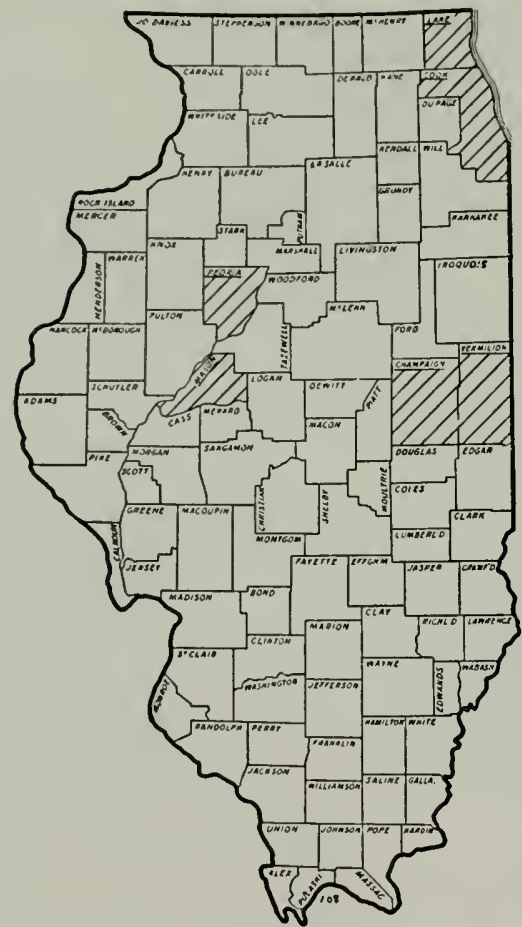

Fir. 108. Distribution of the Dogwood. stand on slender, hairy petioles nearly 2 inches long. The small, creamywhite flowers stand in loose, branched heads on the tips of lateral branchlets. The loose, spreading, red-stemmed clusters of globular, dark-blue fruits ripen in October, each fruit being somewhat less than $\mathrm{T} / 2$ inch in diameter, with thin, bitter flesh and a thick-walled, many-grooved pit containing 1 or 2 curved, pale seeds. The light-green to brownish twigs bear sharply pointed, chestnut-brown buds above the raised, moon-shaped leafscars. The trunk, clothed with thin. reddish-brown bark which is smooth or shallowly fissured and ridged, seldom becomes more than 6 inches thick; and the tree, though arborescent in form, is usually only about 20 feet tall.

Distribution: From Nova Scotia westward to Minnesota and southward to Florida, the Dogwood inhabits the rich soils of the forest edge, stream borders, and swampy swales. In Illinois it is distinctly northern in its range, reaching only as far south as Vermilion, Champaign, and Mason comnties. It is particularly common in the lake-shore woods of our northeastern counties, where it grows as a member of the elm-maple association.

Uses: The heavy, red-tinted, brown wood of the Dogwood is both hard and close-grained. In its technical qualities it is comparable to the wood of the Flowering Dogwood and, like it, is used to some extent in the manufacture of small wooden articles. It also yields charcoal. The tree, however, is so small that it camnot be called profitable. 


\section{The Ebonies}

Fanily Ebenaceae

Trees or shrubs with leathery, alternate, entire leaves and 4-parted, greenish to creany-white, bell-like flowers from the axils of year-old leaf-scars. Staminate and pistillate flowers separate, the former the smaller and in few-flowered heads, the latter usually solitary. Fruit a rather large, fleshy, one- to many-seeded berry. Twigs slender and round, with greenish pith and broadly conical buds, each covered by 2 overlapping scales, set close on the flat tops of the nearly half-round leafscars. Bark variable.

With more than 200 modern species. Diospyros ranges through a great part of the tropical regions of the world; but a few of the species live in the more temperate climates of eastern North America, the lands bordering the Mediterranean Sea, and southern Asia. Varied and widely distributed as it is today, the genus was, in immensely remote ages, at least as varied and certainly far more widely distributed. The fossils that have been found up to the present time show that previous to the great Ice Age the Ebonies lived not only where they are today but even as far north as the northern coasts of Asia and North America and the southern part of Greenland.

Of the? North American species, the Persimmon alone grows in Illinois.

\section{DIOSPYROS VIRGINIANA LINNAEUS}

\section{Persimmon}

The persinmmon is a tree of rather less than moderate height, with a round-topped crown of spreading and somewhat drooping branches. The shiny, dark-green, leathery leaves, 4 to 6 inches long by half as broad. are pale beneath and stand on stout petioles nearly an inch long. The staminate flowers grow, 2 or 3 together, on hairy stalks, while the greenish or creamy-white pistillate flowers are solitary on the ends of short. recurved pedicels. The globular, yellow to orange, bright-cheeked fruit, often $1 \frac{1}{2}$ inches in diameter, contains sweet and juicy, yellow-brown flesh which surrounds the flattened, hard-coated seeds. The light-brown to gray twigs, marked with orange lenticels, bear broadly conical, red-brown to purplish buds above the half-round leaf-scars. The trunk, covered by dark-brown to dark-gray bark which breaks up into characteristic, square plates, is seldom over a foot thick, and the tree is ordinarily not more than 2.5 to 30 feet tall. 


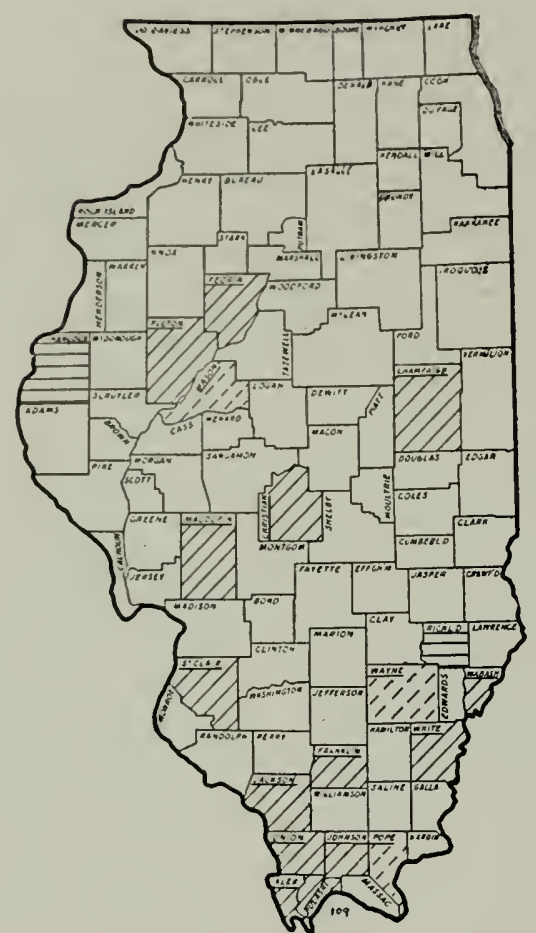

FIG. 109. Distribution of Persimmon.

Distribution: The Persimmon grows. in a great variety of situations. from Connecticut in the Northeast to Iowa in the West and to Florida and Texas in the South. In Illinois, it is chiefly a southern tree. Its northern linit is in Peoria County as far as available records show; but it becomes increasingly common southward, and formerly, at least, trees of considerable size grew in the Wabash Valley. Robert Ridgway ${ }^{1}$ describes them in the following words: "When growing in the thick bottomland forest, the persimmon is frequently 100 or more feet in heiglit. The tallest specimen measured 115 feet high, 80 feet to the first limb, but only $5 \mathrm{I} / 2$ feet in girth at the base, or less than 2 feet in diameter." No such trees as these have been seen in recent years.

Sometimes the Persimmon grows in small, pure groves, but more often it is mixed with a variety of other trees. In the southern counties, where it frequently invades abandoned fields and eroded lands, it is associated with Sassafras and Sumach, while in the woodlands of the Wabash Valley its commonest associates are Water Locust, Buttonbush, and Swell-butted Ash. Northward, as in Vermilion County, it grows in woods where the White, Black, and Red oaks and hickories are the principal trees.

Uses: Exceptionally high in technical qualities, the dense, hard, heavy wood of the Persimmon is in great demand for wooden articles which must be strong and able to withstand wear. The black heartwood, called American ebony, is used extensively for rollers and the heads of golf clubs. It is preferred above all other American woods for shuttles.

Although the wild trees often furnish excellent fruit, there is considerable variation among them both as to the quality and time of ripening. It is possible, however, to plant selected varieties, or to top-graft the native trees with them, and secure fruit superior in flavor and earlier in ripening. 


\section{FRAXINUS IINXAEUS}

The Ashes

\section{Fanily. Oleacene}

Sull to very large. deciduous trees, with opposite, mostly compound leares consisting of an odd number of broad-bladed, toothed leaflets. Stanens and pistils in separate flowers: the inconspicuous flowers 2.- or t-parted, in open or compact. pedicelled, branched heads in various positions on the new growth or from the axils of leaf-scars. Fruit a key with 1 , or rarely 2 or 3 , much elongated wings and 1 or more brown sceds. Twigs rather stout, with oval pith and often globular, superposed lucks set above the broadly crescent-shaped leaf-scars. Bark usually thick, furrowed, and scaly.

W'ith more than 50 species, Fraxinus ranges through most of the temperate regions of the Northern Hemisphere, extending into the tropics in Cuba and Java. It occurs in a particular abundance of forms in southeastern North America and southeastern Asia. America appears to have been its first home, and the American trees are usually larger and furnish more valuable wood. Not only is the Ash familiar in the songs and stories and in the superstitions, the joys, and the labors of the human race, lut even millions of years before the history of mankind began. the Ash was present in the world, as fossils show, in a great variety of forms and with a distribution stretching from Greenland and Alaska to Louisiana. Some of these ancient Ashes escaped destruction during the lce Age and are perpetuating themselves today in our forests. The White $A$ sh and the Bhe Ash are two such American trees.

The modern North American Ashes comprise 17 species, and 6 of these, with a few distinguishable varieties, inhabit Illinois.

\section{KEY TO THE ILLINOIS ASHES}

Twigs round or only slightly angular; buds brown to blackish.

Leaflets without stalks; leaf-scars oval, longer than broad; buds blackish........................ nigra p. 280 Leaflets stalked; leaf-scars more or less lunar; buds brown.

Wings of the lieys arising from the upper third of the seed.

Twigs and petioles hairy............... Biltmoreana p. 271

Twigs and petioles smooth............... americana p. 270

Wings of the keys arising at least half-way down the seerl.

Leaflets toothed along at least the upper half of their

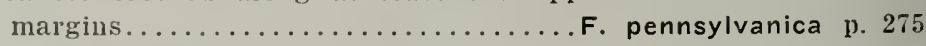

Leaflets not toothed, or only wavy........... profunda p. 274

Twigs square, with 4 sharp angles; buds gray........F. quadrangulata p. 278 


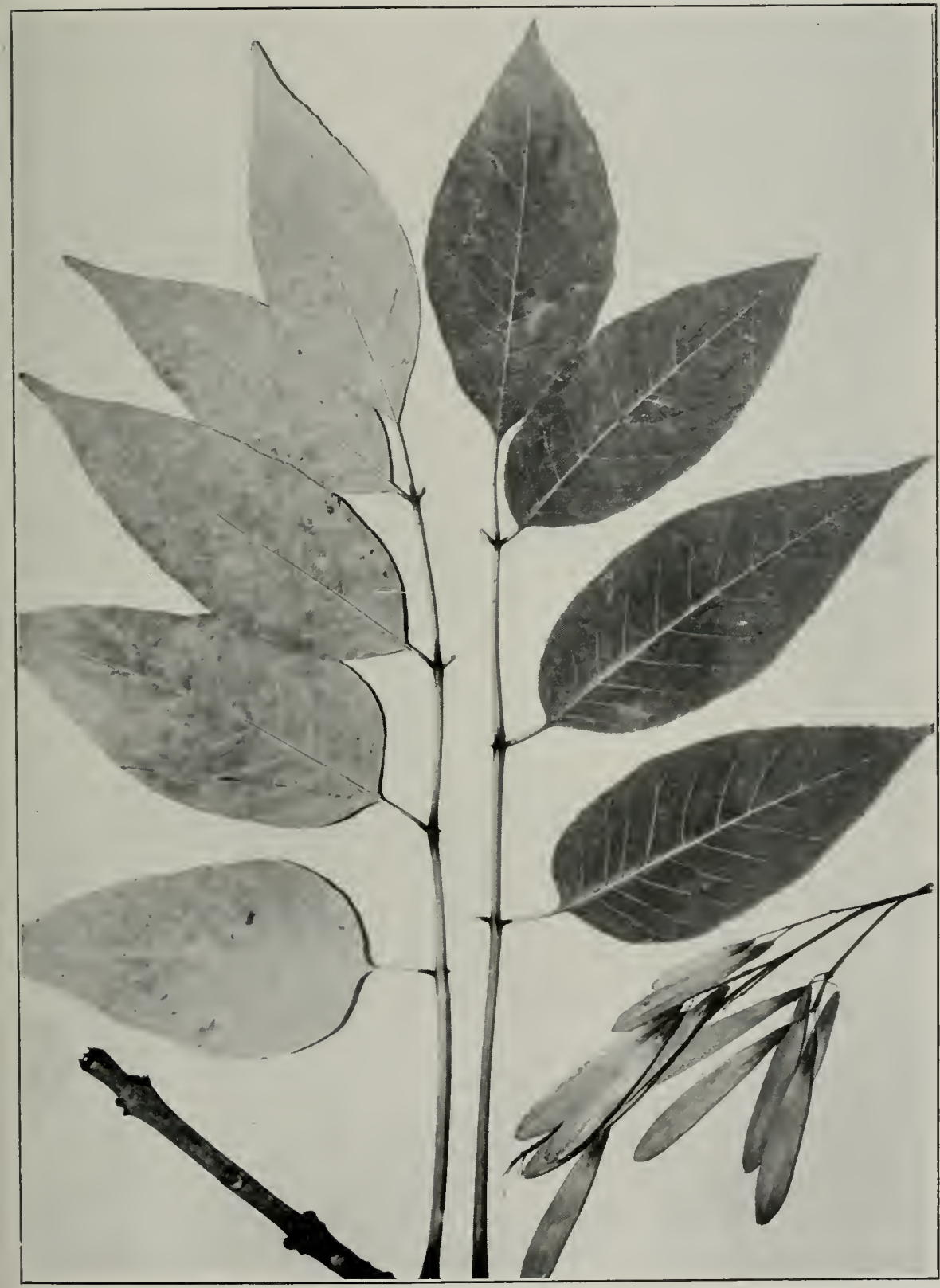

PLATE 92

FRAXINUS AMERICANA LINNAEUS

WHITE ASH 


\section{FRAXINUS AMERICANA LINNAEUS}

\section{White Ash}

The White Ash is a tree commonly of somewhat more than moderate height, with a narrow crown of stout and upright, or somewhat spreading branches. The firm, but thin, dark-green leaves, between 8 and 12 inches long. consist of $\hat{\imath}$, sometimes $\tilde{j}$ or 9 , sharply pointed, nore or less

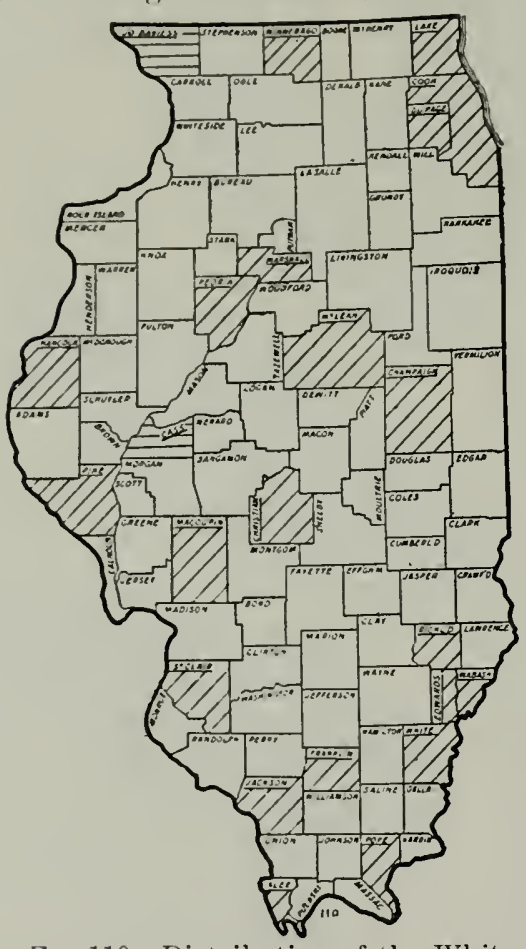

Fig. 110. Distribution of the White Ash. toothed leaflets, 3 to 5 inches long by half as wide, set oppositely in pairs, the odd one terminal, on the stout petiole. The flowers grow in compact or elongated groups from lateral buds. The keys stand in crowded clusters 6 to 8 inches long, each liey with its terminal wing, 1 to 2 inches long by $1 / 4$ inch wide. The gray to brownish branchlets bear dark-brown buds in the hollows of the deeply lumar leafscars. The trunk, inclosed by thick, dark-brown, deeply fissured bark with rounded, scaly ridges, becomes 2 or 3 feet thick, and the tree grows to a usual height of 70 or 80 feet.

Distribution: From Nova Scotia, the White Ash ranges westward into Minnesota and Nebraska and southward to Florida and Texas. In Illinois, it grows throughout the State, preferring the moist soils of stream banks and bottomlands, though never occurring in mucky swamps. It never forms pure stands of any extent, though it often occurs in small groups, which may be gradually enlarged by opening up the area to better light. In IIabash County, near Allendale, where the upland woods have been cut over recently, the assnciates of the White Ash include Hackberry. Hard Maple. Shellbark and other hickories, Tulip Tree, Bass IVood, Red Gum, Slippery Elm, Black Walnut, and Kentucky Coffee Tree, while nearer the strems Pin Oak and Schneck's Oak also occur. Ridgway measured some White Ash growing in the lower Wabash Val'ey in 1882, one of which he found to be 1.10 feet high, 14 feet in trunk circumference, and 59 feet 6 inches to the first limb. 
Uscs: The hard, close-grained wood of the White Ash is strong and tough. It is used wherever strength and elasticity are required, as in the manufacture of tool handles, oars, paddles, bows for the tops of automobiles and carriages, and axles of artillery carriages and farm wagons. Next to rock elm. white ash is the finest wood obtainable for javelins, and a great many sporting and athletic goods are made of it. such as baseball bats, tennis racquets, and snowshoes. In the manufacture of airplanes, white ash serves ideally for the bent wood of wings and fuselage. for landing skids, and for the framework. In addition, it serves adnirably Fig. 111. White Ash growing with for the interior finishing of houses.

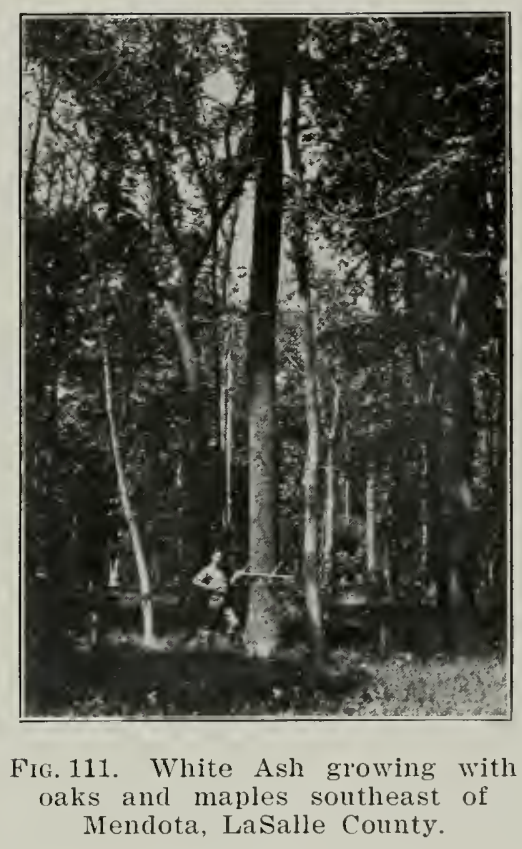

\section{FRAXINUS BILTMOREANA BEADLE}

\section{Biltmore Ash}

The Biltmore Ash is a tree of considerably less than medium height with an open head of stout and up-tilted branches. The thick, dark-green leaves, 10 to 12 inches long. consist of i or !) stalked, toothed leaflets, each 3 to 6 inches long and a third as wide, set along the stout, hairy petioles. The flowers stand in compact, lateral clusters, and the keys, when they develop, hang in long clusters, each key, with its terminal wing, measuring $1 \frac{1}{2}$ to $13 / \frac{1}{4}$ inches long by about $1 / 4$ inch broad. The stout, gray branchlets, always softly hairy during their first summer, bear brown buds above the large, shallowly notched, round leaf-scars. The trunk. inclosed by its rough but shallowly furrowed, dark-gray bark, becomes a foot or more in diameter; and the tree commonly attains a height of 40 or 50 feet.

Distribution: The Biltmore Ash, a tree of low stream sides, ranges from New Jersey southward to Georgia and westward to Missouri. In Illinois, as its general range suggests, it is found only in the southern part of the State, where it occurs so infrequently as to have been collected only in Richland and Gallatin counties. 


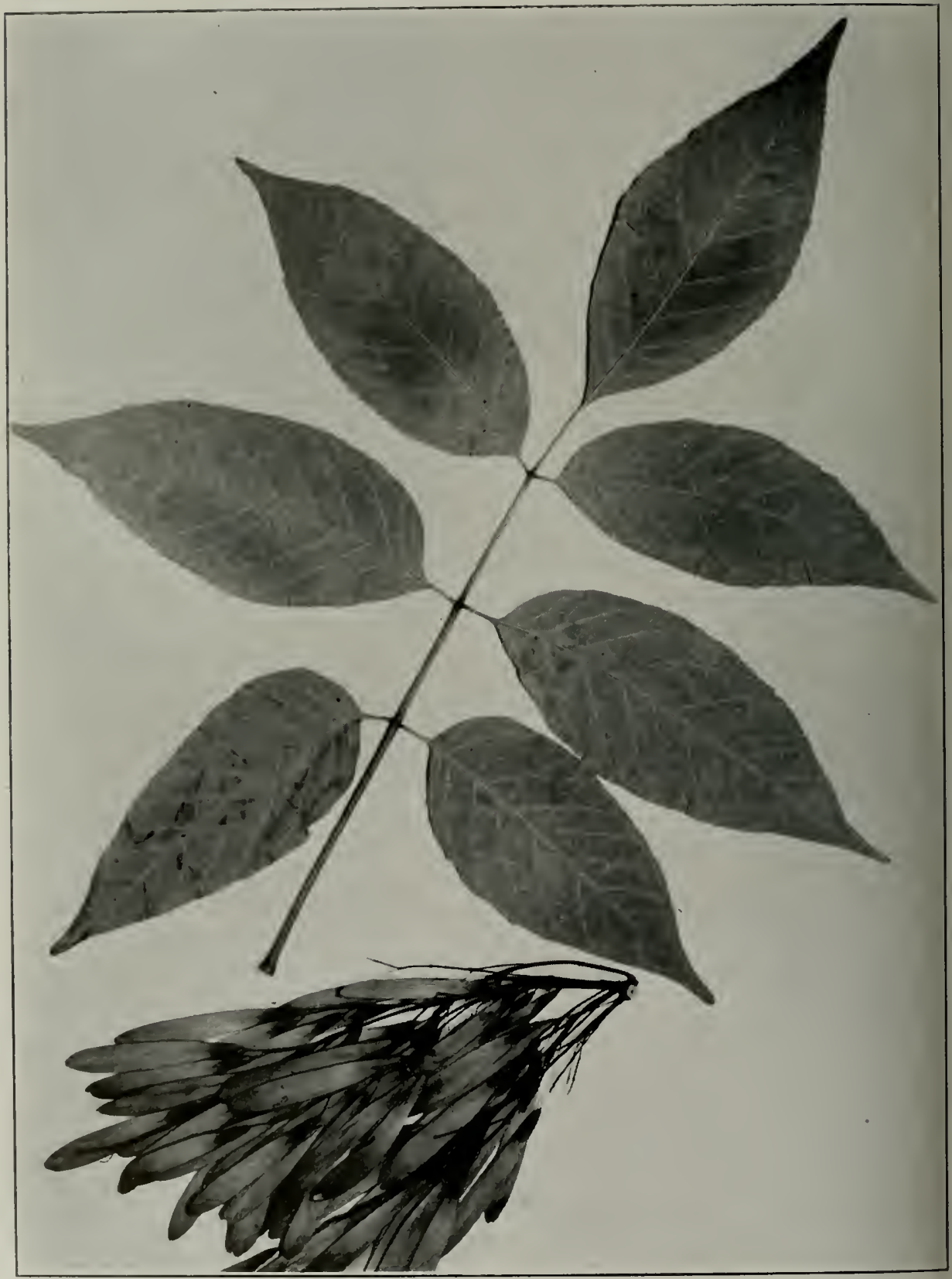

PLATE 93

FRAXINUS BILTMOREANA BEADLE

BILTMORE ASH 


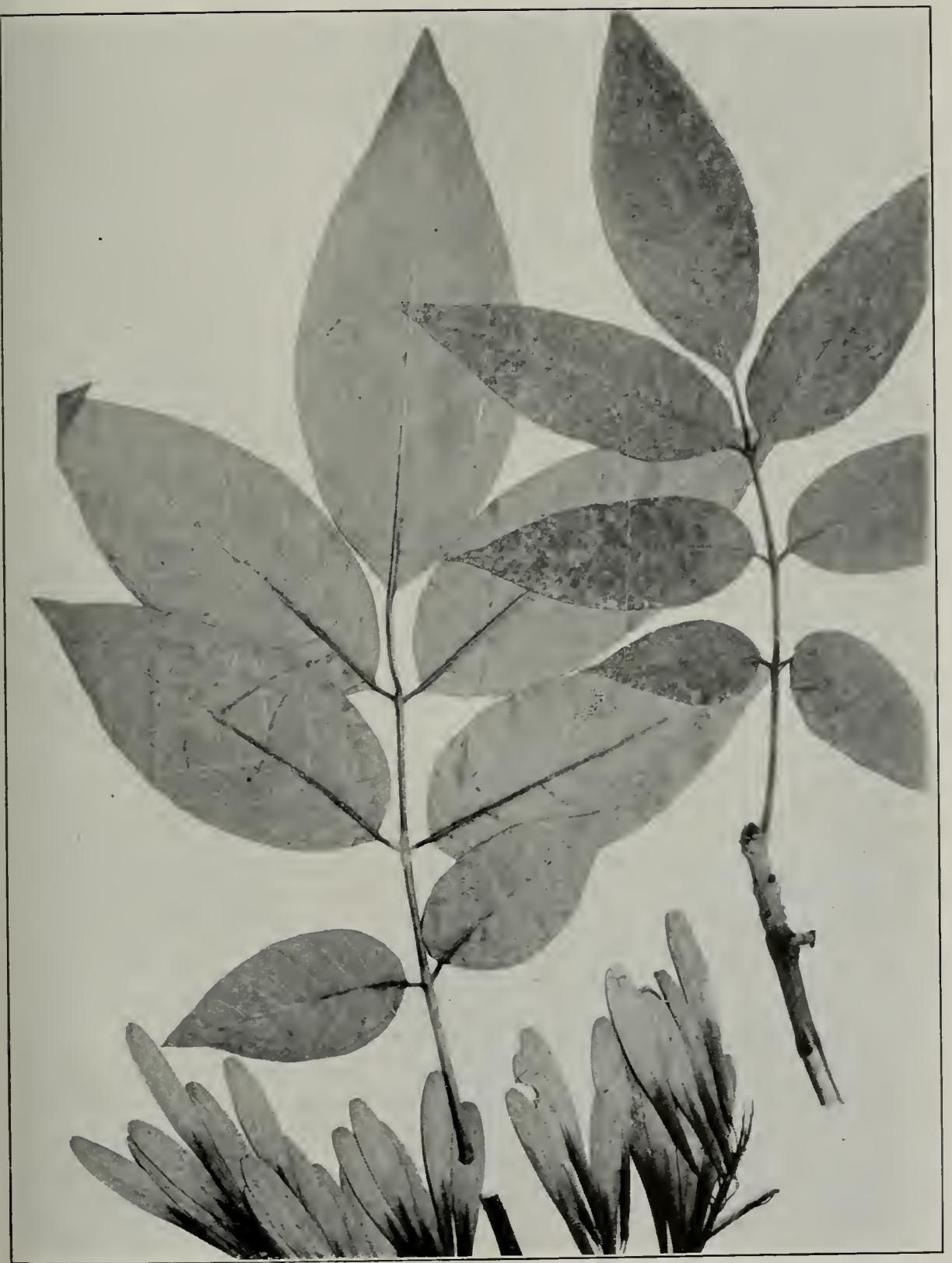

PLATE 94

FRAXINUS PROFUNDA BUSH

PUMPKIN ASH 
Uses: Although the commercial range of the Bilmore Ash ends to the east of the Illinois line, it is probable that the tree was formerly more ahundant in our State. Though its wood ranks a little below that of the White Ash in its technical properties, it is known and sold in the lumber trade as white ash and is used indiscriminately for the same purposes.

\section{FRAXINUS PROFUNDA BuSII}

\section{Pumpkin Ash}

Swell-butted Ash

The Pumplin Ash is a tree of rather more than moderate height. with a swollen, buttressed trunk, from which rises a slender bole capped by a narrow, open crown of small, spreading branches. The exceptionally large, yellow-green, thick leaves, 10 to 18 inches long. consist of $\therefore$. less

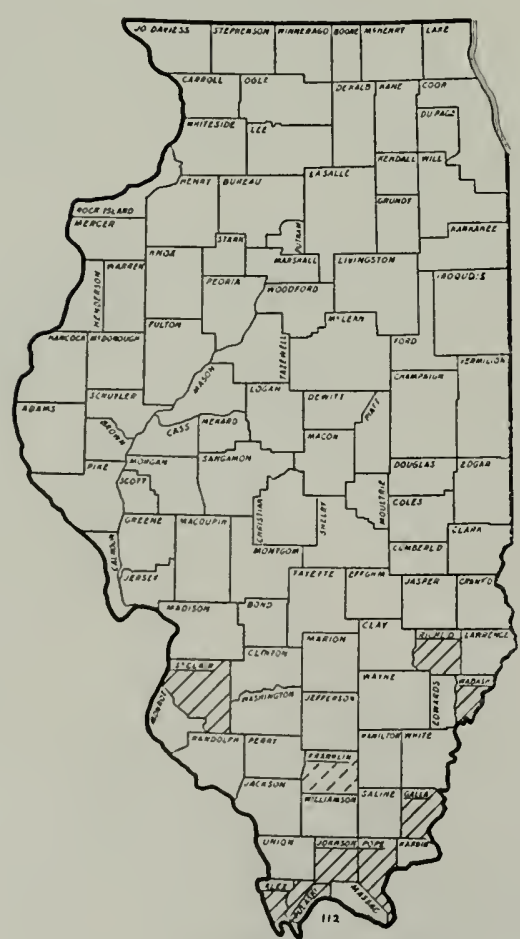

Fic, 112. Distribution of Pumpkin Ash. often 9, elliptic, smooth- or wavymargined, stalked leaflets set on stout, woolly petioles, each leaflet 5 to 10 inches long by nearly half as wicle. The flower clusters are elongated, and the keys, many together in pendulous clusters are 2 or 3 inches long by about $\mathrm{I} / 2$ inch wide. The light-gray branchlets bear light redelish-brown budcleeply set in the upper margin of the lumar leaf-scars. The trunk, inclosed in thin, light-gray bark shallowly fissured inio broxd, scaly ridges. may hecome 2 feet thick; and the tree may rise to a height of 90 feet or more.

Distribution: A tree limited almost entirely to deep swamps and river bottomlands subject to periodic overflows, the Pumpkin $\lambda$ sh grows only in the valley of the Mississippi River and its tributaries, from Indiana and Illinois southward to the Gulf of Mexico, and in the valley of the Appalachicola River in Florida. As its range is distinctly southern, it occurs in Illinois only in the southern third oi the State. coming northward in the east to Richland County, in the west to St. Clair County, and extending inland along the Cache and Big 
Muddy rivers to Johnson and Franklin counties. Its associates in this region include especially the lowland oaks and the Hard Maple. In Pulaski County, the Pumpkin Ash varies in height from 69 to 98 feet, with a corresponding variation in trunk diameter from 16 to 26 inches, and the age of the trees ranges between 80 and 10.5 years. Northward, on the Big Mutdy bottomlands of Franklin County, the height of the Pumpkin $A$ sh is from (i) to !) feet, the diameter from 10 to 1 !) inches, and the age from 38 to $; 6$ years.

Uscs: Though similar in many respects to white ash, the wood of the Pumpkin Ash lacks its hardness and toughness and cannot be used for such purposes as tool handles, oars, and farming implements. But its fine grain and its slow growth make the wood desirable for crates and boxes, as a source of charcoal, and for paper pulp, while some is used also as fuel.

\section{FRAXINUS PENNSYLVANICA MAISIIALL}

\section{Red Ash Green Ash}

The Red Ash is a small to moderate tree, with an irregular but compact crown of stout, upright branches. The light, yellow-green leaves, 10 to 12 inches long, are made up of $i$ or !) thin but firm, oval, stalked leaflets, each 4 to 6 inches long by 1 to 2 inches broad, set along the stout, hairy petioles. The flowers are borne in greenish-or purplish-red clusters, the staminate and pistillate flowers unwaly on separate trees. The keys, with their long, slender seeds and thin wings, are from 1 to 2 inches long by $1 / 4$ to $1 / 2$ inch wide. The ashy-gray to brownish twigs bear small, brown buds set in a shallow inclention on the upper margin of the half-round leaf-scars. The trunk, inclosed in rettinte 1, brown bark slightly furrowed and scaly on the surface. may become 18 inches thick: and the tree ustually attains a height of .50 or 60 feet.

Distribution: On the low, moist plains along rivers and

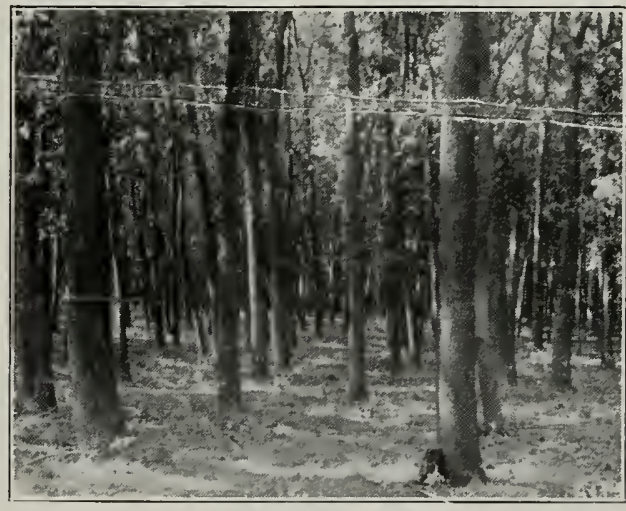

Fig. 113. Green Ash in the Forest Tree Plantation at the University of Illinois. The plantation dates back to 1871 . Photo from the U. S. Forest Service. 


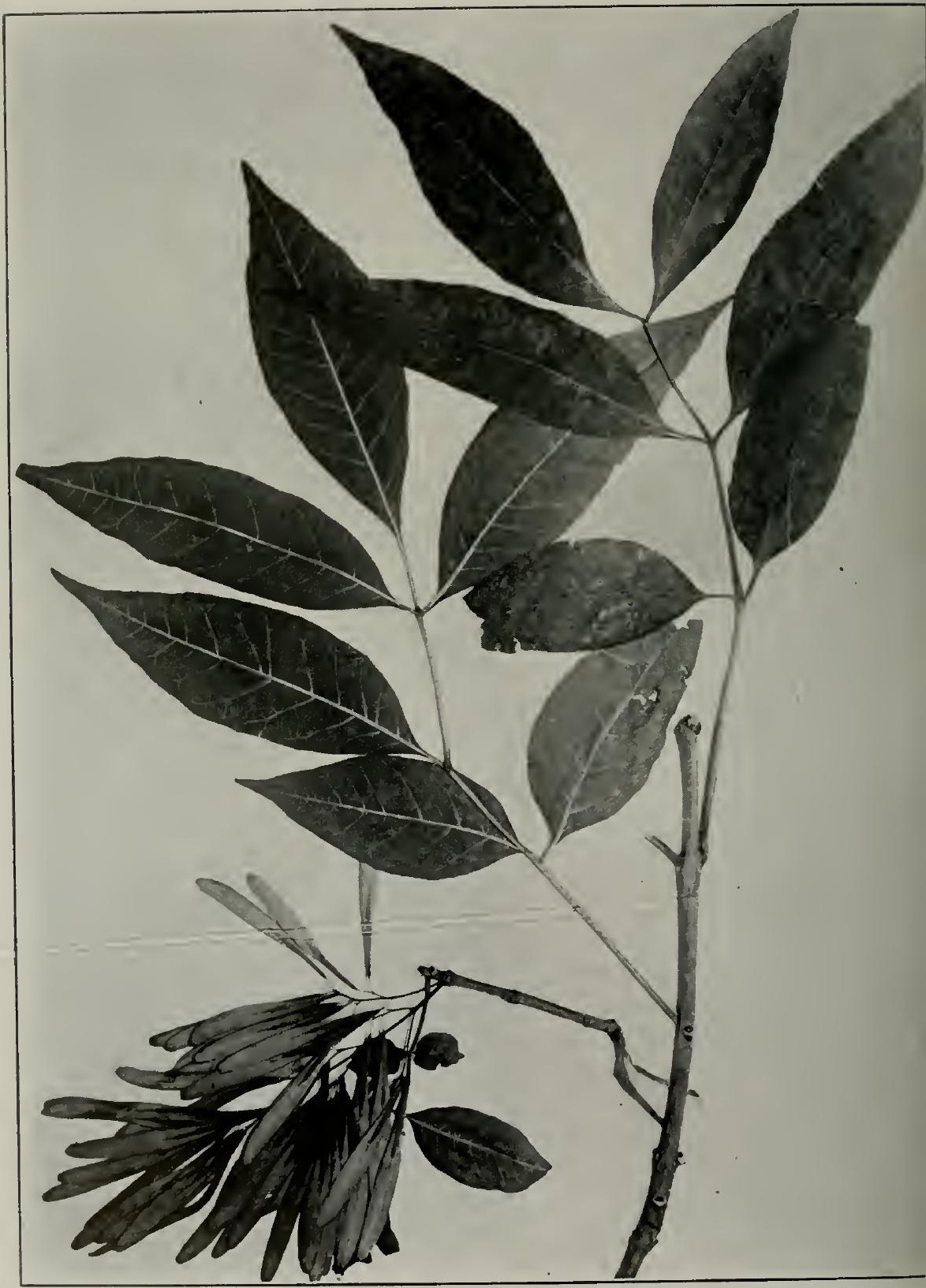

PLATE 95

FRAXINUS PENASYLVANICA LANCEOLATA SARGENT GREEN 
about lakes, the Red Ash ranges from Nova Scotia southward to Georgia and westward to Kansas and Mississippi. It is found in Illinois along all the rivers except the low, swampy streans of the far south, but is neither so common nor so widely distributed as the varietal form lanccolata Sargent, known as the Green Ash. The variety is distinguished with difficulty from the species by its bright-green leaflets, which are more sharply toothed, and its taller, more robust growth. The distribution shown in the accompanying map inclucles both the species and the variety. The Red and Green ashes are found together in greatly differing habitats: for example, in the Wabash Valley they occur on the borders of ponds, on river bottoms, and on swampy land, while farther north, as in Champaign County, they grow on upland soils in rather dry situations. Their moist bottomland associates include Cow and White oaks, Sycamore, Persimmon, cottonwoods, and maples: on drier bottomlands they grow with gums, Cow, Red, and Swamp White oaks, Pecan, hickories, Slippery and Cork elms, River Birch, cottonwoods, and Cypress; and on drier plains with White Eln. Hackberry, Sycamore, Wild Black Cherry, and Burr oak.

Uses: The hard but coarsegrained wood of the Red and Green

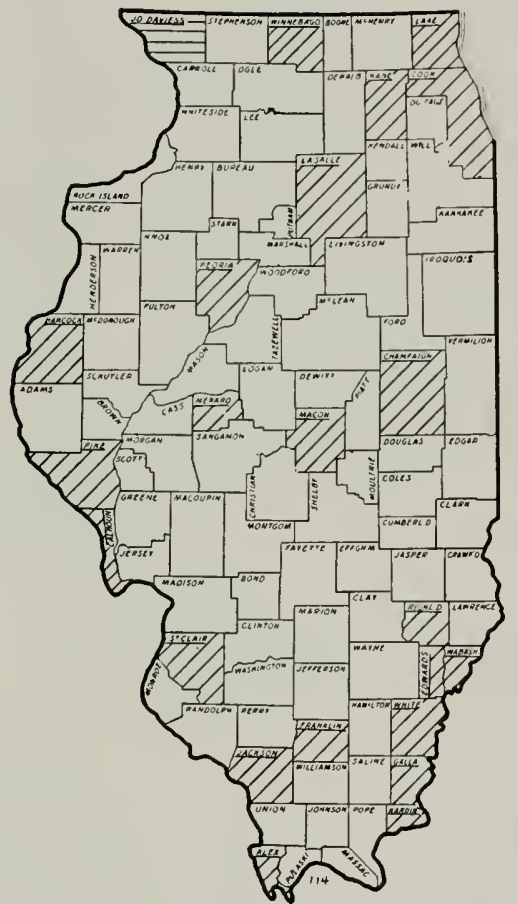

Fig. 114. Distribution of the Red and Green Ashes. ashes, though handled commercially as white ash, is not so tough and, being more brittle, has not so wirle a range of uses. It is employed chiefly in the manufacture of farming implements, carriage and automobile bodies, and furniture.

The Green Ash has been planted extensively as a shade tree, but it is subject to serious injury by the oyster-shell scale and cannot be recommencled as a durable ornament. 


\section{FRAXINUS QUADRANGULATA MICIIAUX}

\section{Blue Ash}

The Blue . Wh is a tree of moderate to rather large size, with a small and slender crown of spreading hranches. The rellow-green leaves, s to 1: inches long. consist of ij to 11 pointed. coarsely toothed leaflets, :; to i) inches long loy a third as wicle, set on short stallis along the slender pet-

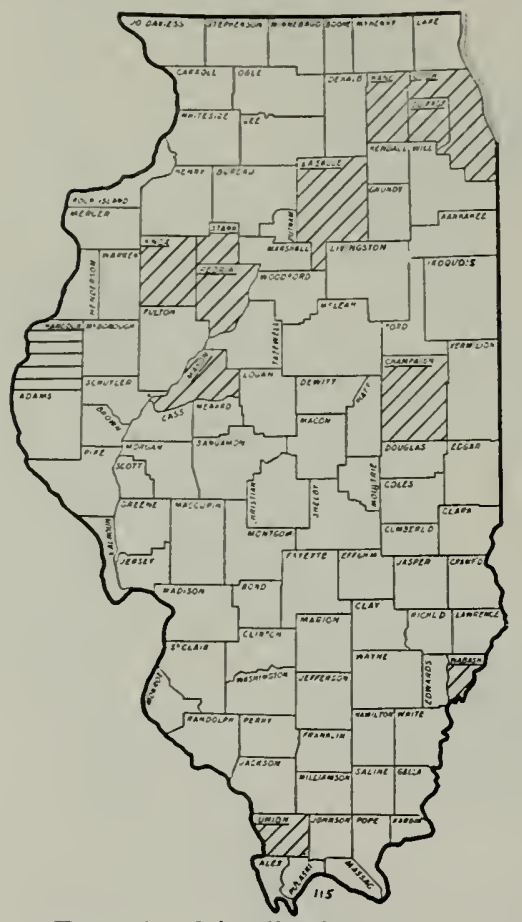

Fli. 115. Distribution of the Blue Ash. ioles. The flowers, which contain both stamens and pistils, are borne in loosely branched clusters from lateral buds. The keys, with twisted wings that surround the seed, are 1 to ? inches long by nearly $1 / 2$ inch wide. The stout, red-tinted, gruy banchlists, being distinctly t-sided and havin; four small, corky wings, one at eách angle, provide the outstanding characteristic of the tree. The gray buds are very round and set close within the ho!low of the broadly lunar leaf-scars. The trunk, covered by rather thin. light-gray bark broken into large plates, grows to a diameter of 2 ieet or more; and the tree usualy atlann a height of more than 60 feet.

Distribution: The Blue Ash ranges, on hills, in valleys, and on bottomlands, from Ontario westward to Iowa and southward to Alabama. Its range in Illinois includes the entire State, but in the south it is rare, hrving been found only in Union and Wabash counties. In the northern half of the State, though still an infrequent tree, it grows on the flood plains of smaller creeks and in the upland woods. In Union County it grows on limestone bluffs; in Champaign County it occurs in the University Wooris along with White and Green ashes, maples, Buclieye, hickories, Bass Wrood, and several oaks; and in LaSalle County George D. Fuller and P. D. Strausbaugh ${ }^{1}$ report it, along with the Kentucky Coffee Tree. Sycamore. White Elm, and Pawpaw, as one of the survivors on the cut-over land along Big Indian Creek.

\footnotetext{
${ }_{1}^{1}$ Trans. Ill. St. Acad. Sci. Vol. 12, pp. 246-272. 1919.
} 


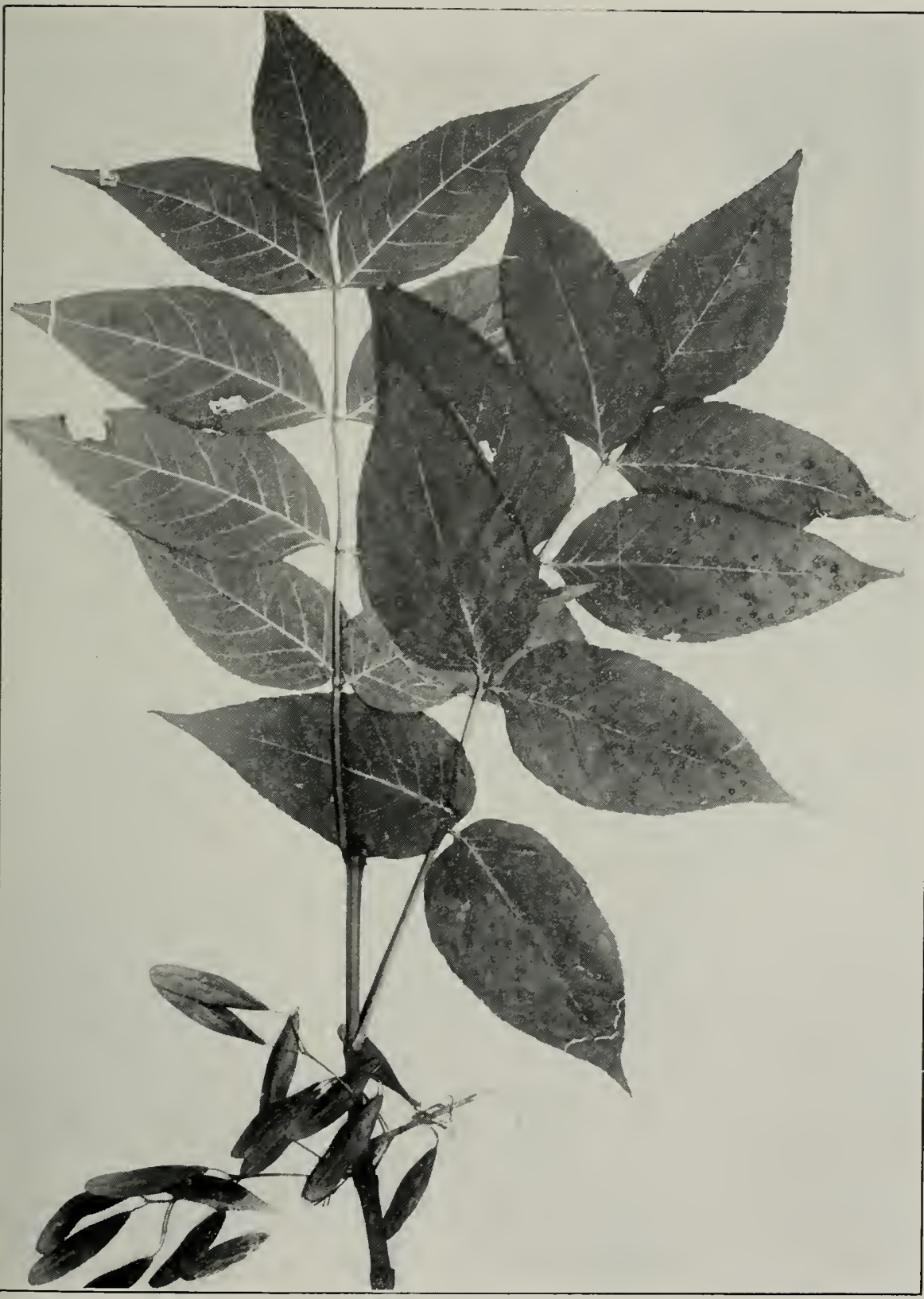

PLATE 96

FRAXINUS QUADRANGULATA Michaux

BLUE ASH 
Lses: The brown-streaked, light-yellow wood of the Bhe Ash, close-grained and hard, is both heavier and denser than the wood of the White Ash, though the lumber from both trees sells as white ash. The Bhe Ash wood is, however. rather brittle, and for such purposes as beams, where strength is the first requirement, it is inferior to both white and green ash. But for other purposes, such as flooring, carriage and attomobile tops, and the like. it is as useful as the wood of other ashes. Formerly, a blue dye was obtained from the inner bark of the [Blue Ash, but its manufacture and use have been superseded largely by the more recent aniline dyes and certain vegetable dyes.

\section{FRAXINUS NIGRA MARSHALL}

\section{Black Ash Brown Ash}

The Black Ash is commonly a tree of rather more than moderate height, with a narrow, shallow crown of many up-tilted branches capping its tall, clean bole. The dark-green leaves, between 12 and 16 inches long, are made up of $\%, 9$, or 11 small-toothed leaflets, the lateral leaflets

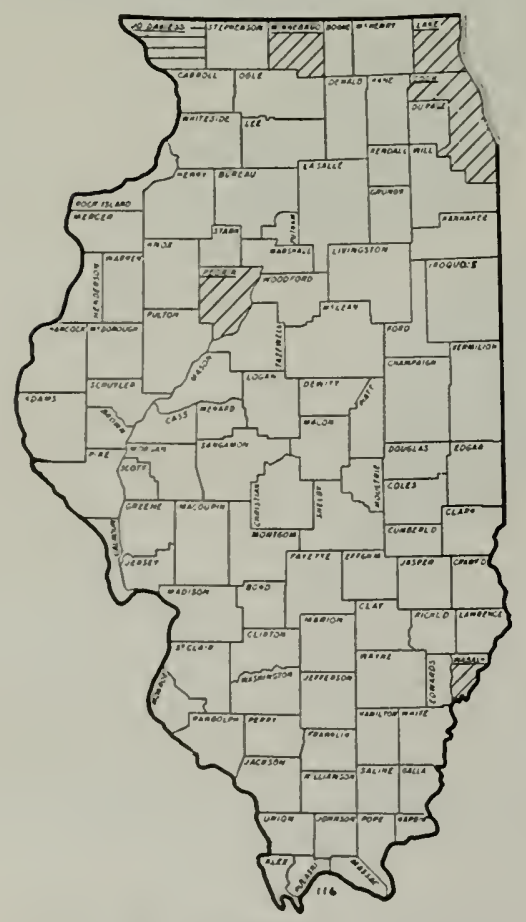
being set directly on a stalk sometimes an inch long. The flower clusters. usually nearly terminal on the yearold growth, are 4 or $;$ inches long. The keys, their wings inclosing the seeds, are 1 to $1 \frac{1}{2}$ inches long by a little more than $\mathrm{I} / 4 \mathrm{inch}$ wirle, and they hang in loose, open clusters $\&$ to 10 inches long. The ashy-gray to orange twigs bear blunt buds above the oval leaf-scars. The trunk, covered by thin, red-tinted, gray bark irregularly plated and separating into papery scales, ittains exceptionally a dianeter of 18 inches; and the trees become 0 or even 100 feet high.

Distribution: From the Gulf of St. I-awrence westward across Canada to Lake Minnipeg and southward to West Virginia and Arkansas, the Black Ash grows on low, swampy stream-banks and in deep swamps.

FIG. 116. Distribution of Black Ash. It is, as should be expected, an un- 
conmon tree in fllinois and is to be found only in swampy situations. Its connum associates to the north of Illinois are the swanp-inhabiting conifers, but in our state it is associated entirely with deciduous trees.

Uses: The Black. Ish is far too rare in Illinois to be counted as connmercially valuable, though it is an important timber tree in Wisconsin and Michigan. Thougl rather soit and weak, its wood is tough and durable and has a large varicty of uses, among which are furniture, calbinet making. vencers for crates and baskets, interior finishing of houses. cooperage. and lanndry, creanery, and refrigerating appliances. The Indians linew that by pounding the wood they could separate it, along the annual layers, inte thin strips. which they used for making baskets; and they called the B!ack Ash the Basket Tree.

\section{CATALPA SCOPOLI}

\section{Family BIGNONIACEAE}

Moderate to very large, deciduous trees, with large, heart-shaped leaves borne oppositely in pairs or in whorls of three. Flowers large, rather showy, and spotted inside, borne in terminal, branched clusters. Fruit a long, narrow, pod which splits into halves to liberate numerous brown to gray, winged, hairy seeds. Twigs stout, with large, round pith and with globular buds set above round to oval leat-scars, there being : large and 1 small lea-scar at each node. Bark thin and scaly.

Catalpa, with : species, occurs in southeastern North Anerica. eastern China, and the West Indies. Though now embracing comparatively few forms, with only a linited distribution, this genus is known from fossils to have flourished widely through the ages from a time antedating the Ice Age by many centuries. There are 2 modern American species, one of which, the Indian Bean, with a range to the south and east of Illinois, has been planted extensively as a decorative tree, while the native Illinois catalpa has been employed more often as a timber tree.

\section{CATALPA SPECIOSA ENGELMANN}

\section{Catalpa}

The Catalpa is usually a tree of only moderate height, though it sometimes becomes exceptionally tall, with a round-topped but narrow crown of slender branches. The firm, dark-green, pointed leaves, nearly a foot long and more than half as wide, are heart-shaped and stand on stout 


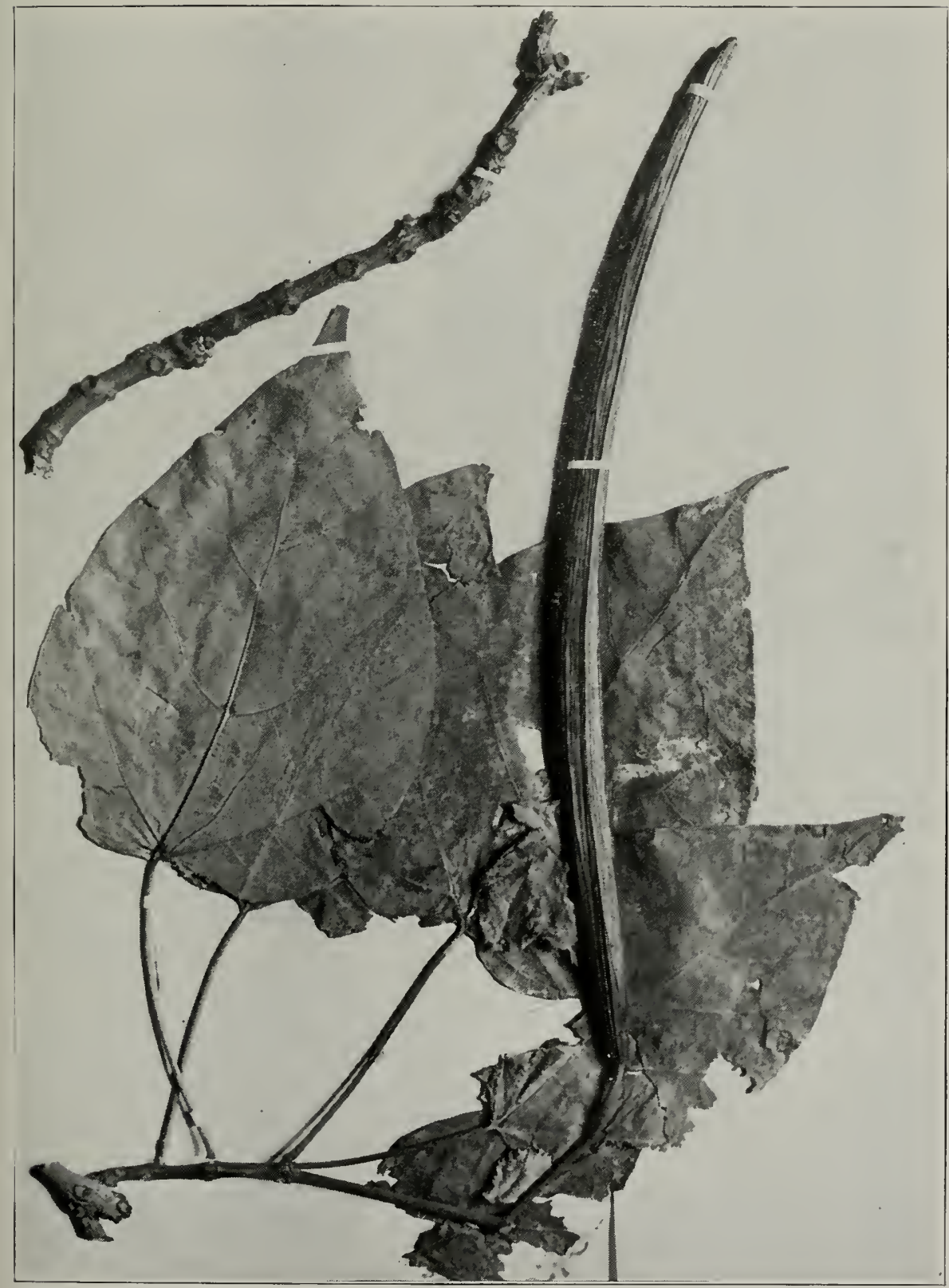

$$
\text { PLATE } 98
$$
CATALPA SPECIOSA ENgelmanN
CATALPA 


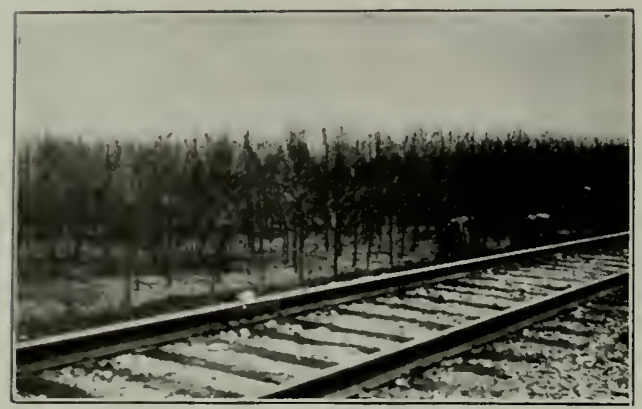

Fig. 117. The Chicago, Burlington and Quincy railroad's Catalpa plantation at Gladstone, producing fence posts at 17 years old. petioles 4 to 6 inches long. The bright, purple-spotted, white flowers, each about 's inches long, stand in open, few-flowered clusters. The thin-walled pods, $S$ to 20 inches long but only a little more than $1 / 2$ inch wide, contain a number of light-lorown seeds. Each seed is about 1 inch long by $1 / 4$ inch wide and is inclosed by 2 terminal wings, from the ends of which a fringe of short hairs extends. The orange to reddish-brown twigs bear chestnut-brown buds above the oval leaf-scars. The trunk, covered by rather thin, red-tinted, brown bark broken into thick scales, is short and usually not more than 2 feet in diameter, though it may grow to a much larger size; and the tree, usually less than 80 feet tall, may attain heights in excess of 100 feet.

Distribution: Naturally an inhabitant of bottomlands, the Catalpa ranges throughout the wet floodplains and swampy riversides of the Mississippi valley from southern Illinois to Tennessee and Arkansas. Its extreme northern station in Illinois is in Richland County, and from this point it becomes increasingly common as it follows the $\mathrm{V}$ abash River southward to the Ohio, and thence to the Mississippi. The usual dimensions of the larger Catalpas in the Wabash Valley range between $i()$ and 90 feet for height and between 2 and 3 feet for trunk diameter. Its associates are chiefly Pin Oak. Sweet Gum, Sugarberry, Big Shellbark, Hickory, and Pecan, though in Gallatin County it grows also with White Oak, Red Gum, ashes, Honey Locust, and IVhite Elm.

Uses: The light-brown, coarse-grained wood of the Catalpa, with its thin, nearly white sapwood, is neither heavy nor strong nor hard, and though occasionally employed in the manufacture of furniture and in funishing the interior of houses, its common uses are limited to much rougher purposes. Its durability in the soil is exceptional, and on this account it is used chiefly for fence posts and poles. A Catalpa in Richland County, which was cut in 1900 , yielded $2+r$ fence posts, thougl the entire stump) and trunk were hollow.

Catalpa has become an extensively, though of ten unsuccessfully. cultivated tree. from which the only expected yield is posts; and some rail- 
roads now produce the posts for their right-of-way fences by growing this tree for the purpose. From seedling to post size requires between 1.) and 20 years of growth, during which time the trees, unless carefully pruned and cultivated, are continually in langer of destruction by the larvae of the Catalpa Sphinx Moth and a brown-rot fungus which enters the tree through the dead, unpruned branches and rots the wood. Soil, also, is an important consideration; for on poor. sandy, or gravelly soils this tree will not make a satisfactory growth. In Stark County, a plantation situated on good prairie soil has yielded posts and stakes after 15 years, producing wood at an average rate per year of 162 culic feet per acre and returning. thereby, a good rate of interest on the investment.

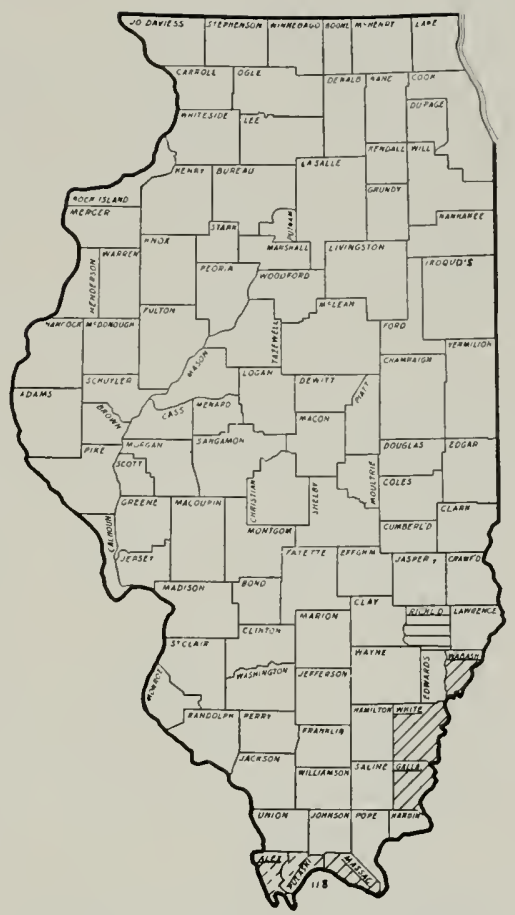

Fra. 118. Distribution of the Catalpa.

\section{LIST OF MINOR VARIETIES AND SPECIES OF TREES REPORTED TO OCCUR IN ILLINOIS}

Acer Negundo violaceum Kirch. The opinion of E. J. Palmer, as expressed in correspondence, is that this is the common Box Elder in Northern Illinois.

Acer nigrum. Palmeri Sarg. A specimen in the Field Columbian Mnseum collected by Agnes Chase (No. 1:58) in woods at New Lenox May $\hat{i}$ and September $2: 2,190 \%$, has been determined as this variety by H. Teuscher.

Acer rubrum tomentosum Kirch. There are? specimens in the University of Illinois herbarium, one from Herod, Pope County, the other from Mt. Carmel, Wabash County.

Acsculus discolor Pursh. Represented by a single specimen in the Morton Arboretum. The locality is in Pope County. 
Cary glabra mogacurpa Sarg. In the Armold Arboretum there are : specinens, one collected by E. J. Palmer in Gallatin Comnty, the other by B. F. Bush in Johnson County.

Carla oralis obcordata Sarg. Specimens in the Arnold Arboretum show that this variety has been found in Gallatin, Jolnson, Popc, Richland, and Union counties.

Carly or'ulis oboralis Sarg. Arnold Arboretum specimens have licen taken from Richland, Wabash, and White counties.

Carya oralis odorata Sarg. Specimens in the Armold Arboretum came from Richland, Johmson, and Wabash counties.

Carya ocata Nuttallii Sarg. A specimen collected in Johnson County by E. J. Palmer is deposited with the Field Columbian Museum.

Curlu orata pubescons Sarg. has been collected in Pope and Richland counties by Robert Ridgway and in Gallatin County by E. J. Palmer. The specimens are in the Armold Arboretum collection.

Coltis occidculalis crassifolia A. Gray. Represented at the Armold Arboretum by specimens taken in Alexander, Gallatin, Jackson, Richland, and Pope counties, and in the University of Illinois herbarium by specimens from Richland and Kane counties.

Collis occidcutalis canina Sarg. Specimens from Richland and Johnson counties, collected respectively by E. J. Palmer and B. F. Bush, are deposited with the Field Columbian Museum.

Coltis pumila Pursh. A specimen from Richland County, collected by Robert Ridgway, is in the University of Illinois herbarium.

Cladastris lutca Michaux. A typical specimen collected by R. B. Miller near Olive Branch, Alexander County, is deposited in the University of Illinois herbarium.

Diosfyros airyiniana pla!ycarpa Sarg. "This variety with suljcordate lubescent leaves and larger earlier ripening fruit is found with the specics in southern Illinois."-E. J. Palmer, in correspondence.

Firmus grandifolia carolinicua Fern. \& Rehd. A specimen collected in the chestnut grove in Pulaski County by William Trelease is deposited in the University of Illinois herbarium.

Qucrus alba pimatifida - A specimen determined by William Trelease is in the Field Columbian Museum's collection. It was collected at Fountaindale by M. S. Bebb and was called by him variety ropanda.

Sussufras officinale albidum Blake. A typical specimen, collected by A. Stanley Pease at White Heath, Piatt County, is in the possession of the Arnold Arboretum. 


\section{Botany and Forestry}

For students and for teachers, whether they are in colleges, high schools. or academies, and for everyone with a real interest in trees, there is an opportunity to do work of scientific value in almost every region in Illinois. A glance at the ma1s which indicate the distribution of the trees described in the preceding pages will show how very imperfect is our knowledge of the exact range, the local habitats, and the particularly interesting isolated and local occurrences of even our most common trees. This is a lind of information that can be obtained only with the greatest labor and expense when done at public cost: but with the help of enthusiastic tree lovers a great deal can easily be accomplished toward filling in the gaps in our present knowledge.

\section{THE BOTANY OF TREES}

It is not necessary for one to travel widely in order to learn about trees. The home county, so accessible in every part in these days of automobile travel, always contains a surprisingly large number of trees of different linds. Somewhere there is almost certain to be a stranger. removed from its usual range, which has persisted and perhaps multiplied. Instances of this kind are not too frequent. but when they are found they afford an indescribable satisfaction to the discoverer. It is one of the tree enthusiast's greatest delights to be able to show that a tree does grow beyond the range given it by technical botanists, and in this he is justified. for he has succeeded in making the world's store of knowledge just a little greater.

Neither will the lover of trees find it necessary to spend his money lavishly, in order to enjoy his avocation. His first need is a good book to use as a guide in becoming familiar with the trees, their names, and their habits. Thereafter, his only requirenents will be a quantity of old newspapers, between which to press and dry the specimens he collects. a note-pad and pencil to record his observations, a corner of a room at home. where he may keep and study his collections. and such books as his particular interests thereafter demand.

Collecting trec spacincus: So prone to error are humans, that botanists have made a rule for themselves, which ought to be adopted by every person who plans to make more than a superficial study of trees. This rule is, that in every case where a tree is found a specimen of it must 
be taken and preserved as a positive proof of its existence in that place. The custom amongst botanists is to secure a rather large specimen, so that after it has been dried it can be divided into two or three portions, one of which the collector keeps for himself, sending the others to be deposited in large herbaria. The result is that a permanent record is kept, not only in the collector's personal possession, but also in one or more places open to all students: and if by chance his own collection is destroyed by fire or some other hazard, the results of his labors are still preserved. Moreover, our knowledge of the classification of trees, of their relationships to one another, and of their similarities and differences, is constantly increasing, and there goes with this an equal advance in the differentiating of linds. the result being that years hence differences among trees will be known to exist where today we can see none. We therefore should preserve specimens for the salie of the students who come after us, in order that they may know exactly. in the light of their fuller lnowledge, with what we have dealt. Errors in determining the species of a tree are by no means infrequent, even among trained botanists; and the beginmer will find himself very apt to make them, but if he maintains a careful record of his studies in the form of specimens, he will, as he advances in linowledge, be able to retrace his early steps and correct his errors.

The gathering of a specimen is a thing that should always be done with care. Some trees are identified readily by their leaves, some by their flowers, others by their fruits, and still others by their twigs; yet all of these structures, and others besides, which are required to make up the tree, will need to be noticed by the collector. Consequently, he will wish to visit the same tree several times during a year, in order to become familiar with its aspect and characters in the spring when the new leaves and the flowers are coming out, in the summer when it stands fully clothed in green, in the autumn when its fruits are ripe and its foliage is gloriously colored, and in the winter when, devoid of leaves, only its skeleton remains. For each of these seasons, the enthusiastic collector will wish to preserve suitable specimens, so that the things he has learned in the stmmer will be preserved to him in the winter and in order that he may find foreshadowed in the flowers of spring the fruit of the fall. There is but one criterion to be observed in gathering these specimens. which is that, whether it be flowers, leaves, or fruit, the individual example ought not to be either the largest or the smallest but rather the nearest possible to the average of those that make up the tree.

At the same time that the specimen is secured, notes ought to be made concerning the location of the tree, its size, its probable age, and the 
habitat in which it grows. Many experienced collectors have found that they can do this best by keeping a notebook in which these facts are set down in connection with a series of numbers, and the specimens, as they are collected, are marked with the same numbers, so that each specimen and each set of notes will be properly and conveniently connected.

Though many persons have elaborate collecting and drying kits to carry with them on their trips to the woods, the actual necessities are few. For almost everyone, the opportunity to become acquainted with trees will be found on those occasions when a day or an afternoon is given to an outing away from town or away from the duties of the farm; and the specimens that are likely to be collected at such times can be carried home either in the hands or the pockets, or in a small basket. It is best to keep separate the pieces taken from different trees by wrapping them closely in a scrap of newspaper, which will serve also to keep them from wilting unduly.

Drying the specimcus: When the specimens have been taken home, they should be placed as soon as possible in a drying apparatus. For this purpose, professional botanists usually have special sets of heavy blotters and often corrugated cardboards and heaters also. But even the most inexperienced person can, with a little care, secure excellent results by using only the old newspapers with which every home is so well supplied. The first thing to do is to cut a newspaper into single sheets the size of the usual page and fold each of these sheets cross-wise. When a sufficient number of them has been provided, the collected specimens should be unwrapped, one by one, and placed within the folded papers, upon the margins of which should be written the identifying numbers. In arranging the specimens, it is well to lay out the leaves and flowers in as natural a position as possible; but one or two leaves should be turned with the lower face outward, so that later when the specimens are studied the characters of both surfaces of the leaves may be compared readily.

In place of the heavy blotters used by botanists, thick pads of newspapers will be found to serve most admirably. One of these newspaper pads should be laid on the floor to serve as the bottom of the pile; on it is laid the first specimen, in its folded sheet; then comes another pad, another enfolded specimen, another pad, and so on, until the fresh specimens all have been arranged in an orderly pile capped by a heavy pad of paper. Now, all that is needed is a board, or a lattice of lathes, of the same dimensions as the folded sheets, which is laid on the top of the pile and pressed down firmly by having several heavy bricks or some other heavy article laid upon it. 
At first, the paper pads between the specimens will need to be changed daily. for they absorb water from the plants quite rapidly; and if the stack is left in a (lamp condition, the specimens are apt to become moldy. As the pressing and drying progresses, changes need be made less often; and when the tree samples are thoroughly dried they can be removed from the dryer and, still folded within the newspaper sheets, tied in convenient bundles for later study.

The personal herbarimm: After having taken the pains to collect and dry a number of tree samples, the average person will find a real satisfaction in preserving his specinens in such a way as will allow them to be examined conveniently by himself and his friends. Botanists have developed a method for doing this, which, modified to suit the needs and desires of the individual, will furnish him, in the doing, with many hours of pleasant memories and, when finished, with a collection which he may exhibit with pride and which he will constantly be wishing to increase.

Botanists have found that the most convenient method for preserving a collection is to mount the individual specimens upon sheets of heavy white paper, of such a grade as the individual can afford, the specimens being attached to the paper by glue or by means of small strips of gummed cloth tape. The customary size of these sheets, as used in all the large herbaria, is $16 \mathrm{~T} / 2$ inches long by $11 \mathrm{I} / 2$ inches widle. After the specimen has been attached, a label should be pasted to the lower right-hand corner of the sheet, showing not only the name of the tree but also whatever other information may be necessary, such as its collection number, the date and place of collection, whether it is a native or cultivated tree, and notes on its habits of growth. The illustration on the opposite page is a photograph of such a sheet.

To keep the mounted specinens in good condition, some kind of storage is required; and in large herbaria costly metal cabinets are provided; but the individual with a small collection can easily store it at much less expense. If he values it highly he may prefer to purchase nicely finished wooden cabinets, or if he is handy with tools he may enjoy the making of his own cases. The best form of cabinet is one 5 or 6 feet high, with 2 full-length doors on the front, which fit tightly together at the midlle of the case. The interior is divided into halves, corresponding to the doors, each half being wide enough to allow the specimen sheets to be placed upon shelves set 5 or 6 inches apart, and the depth of the cabinet corresponding to the length of the sheets.

As the main requirement in providing storage for the specimens is to keep out dust, the ingenious person will not find it hard to substitute 


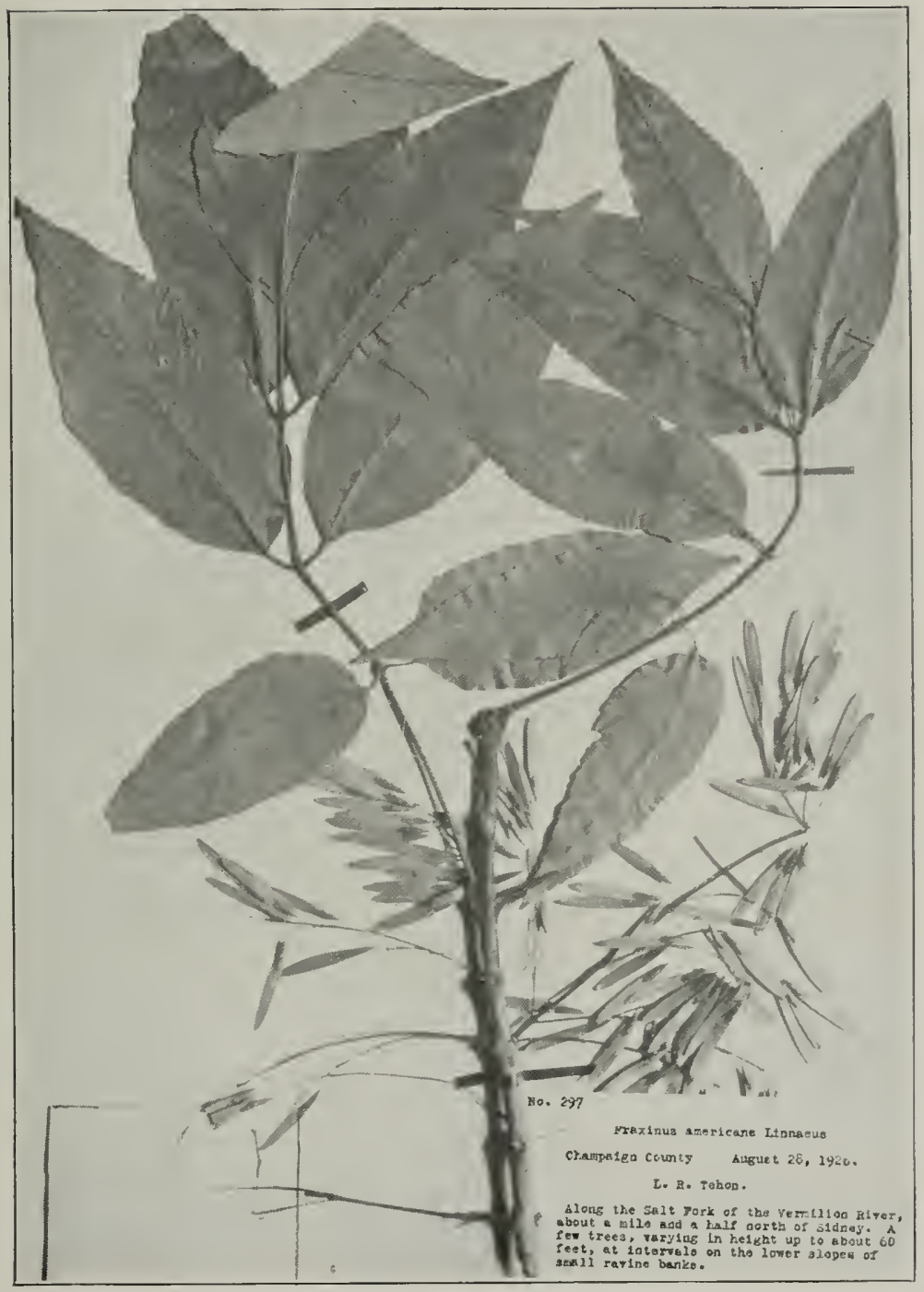

Fig. 119. A Property Prepared Herbalucar Spechuen. This specimen of White Ash shows the leaves, a twig, and the mature fruit. A leaf has been turned to show the underside; a small packet has been glued to the lower left hand corner of the sheet to hold the keys that fall off; and the label on the lower right-hand cormer gives the name of the plant, the date and locality of collection, and other desirable notes. 
other means when cabinets prove too costly. As an example of what may be usecl. we have found cardboard boxes to be quite satisfactory. We have them made of a substantial grade of cardboard, cloth-bound at the corners, 12 inches wide, 13 inches long and is inches deep inside. covered without by a black paper of some neat design, and provided on one end with a brass pull handle and label holder. Each of these boxes will hold .5. or more specimens, and in the quantities in which we have purchased them they have cost between fifty and sixty cents apiece.

For the sake of conrenience, the specimens should be sorted so that all those belonging to each genus and each species are together. An adcled convenience is to have all the sheets for one genus, or all those for one species if the species has been collected several times, laid together in a labeled folder of heavy, serviceable paper. Such folders are usually arranged in the cases by Families, in the order given by some good botanical manual, though for ready reference the genera of each Family are usually placed in alphabetic order.

Insects may be kept away from the specimens by sprinkling them from time to time with naphthaline powder or paradichlorobenzine crystals or by painting them, when they are being mounted, with a saturated solution of corrosive sublimate mixed with alcohol to make it dry quickly. For mice, which are apt to be attracted by seeds and nuts. traps are more dependable and safer than poisons.

Classification of tress: The first need of the amateur student of trees is a means of identifying those with which he is not familiar. This need he is usually able to find supplied in the form of lieys, such as those given on pages $1 \check{-}-2,2$, the use of which does not require more than a small amount of botanical knowledge coupled with a little careful observation. But as he progresses in his studies, he will be impressed with the similarities and differences among trees, especially as regards their flowers, their fruits, and their leaves, and he will be impelled to wonder what the significance of these facts may be.

Trees. like all other living things, are supposed to be related to one another, and among them, as among all other living things, size and bulk are of no great significance as an indication of relationships. for these may be judged far more accurately by smaller and often less evident characters. Few people. for example, could be misled after seeing the acorn of the Willow Oak, though the leaves alone might not suggest an oak tree; having once seen the fruit of the Hop Hornbeam, no one would mistake its erident relation to the Birches, though with only the leaves and twigs it might readily be thought an elm; and the Hackberry, 
known only by its fruit, would not easily be allied to the elms until its leaves and flowers had been seen. So, among all our trees there are characteristics which, however much the trees may vary otherwise, serve to bring them together into larger and smaller groups of related forms.

All the Illinois trees, however, have one characteristic in common, which is that they all produce seeds as a means of reproduction, and upon this is based the largest and most important botanical division of plants, namely, the Spermatophytes. In contrast with this group, there are others such as the thread-like plants, or Thallophytes, the noss-like plants, or Pryophytes, and the fern-like plants or Pteridophytes. The Spermatophytes themselves are divided into two classes, the Gymosperms and the Angiosperms.

Gymnosperms: This is an exceedingly ancient, though not an overly large, group of plants. The dense forests of remote geologic periods, the remains of which constitute coal beds, were partly made up of Gymnosperms. This group is represented in the world today chiefly by pines, spruces, and cedars and in Illinois especially by pines, the Tamarack, the Cypress, and the Red Cedar. Our Illinois Gymmosperms are all conifers, which is to say that they bear their seeds in a typical cone; but they do not have flowers in the sense in which flowers are commonly recognized. They have in common, also, the character of long, needlelike leaves, which are usually evergreen. The wood of coniferous trees is generally termed "softwood," and it has in addition a very regular grain, which renders it easy to split.

Angiosperms: This great group of plants contains all of our trees that are not classed among the conifers. Its outstanding characteristic is the production of structures readily recognized as flowers. The treesize Angiosperms of Illinois are, in addition, deciduous, their leaves are broad-bladed and distinctly veined, and the wood is of the type generally called "hardwood." In this class, there are two botanical subdivisions, the Monocotyledons and the Dicotyledons, the former characterized chiefly by the possession of just one leaf in the seed, as n1ny be seen in the seedlings of wheat or corn, the latter having 2 seed leaves, such as are conmmonly observed on the seedlings of radishes and beans. Although the Monocotyledons are faniliar to us in the form of native grasses and cultivated crops, such as wheat, oats, and corn, none of the tree forms such as Bamboo, Date Palms, and Bananas, occur in Illinois. Our deciduous trees belong, without exception, to the Dicotyledons.

Dicotyledons: Two subdivisions of this class of plants have been recognized generally by botanists, according to the nature of the parts 
of the flower. A dicotyleclonous tree can be recognized by the fact that the parts of its flowers occur in t's or 5's (or in multiples thereof), the flower parts of Afonocotyledons being commonly in 3 's, but it is a fact familiar to almost everyone that the flowers of some trees, such as the willows, hickories, and birches, appear to lack the sepals and petals usually ansociated with the word flower. while those of other trees, such as the Tulip Tree. Wild Crabs. Plums, and Haws, have all the conspicuous flower parts hut keep the individual sepals and petals as distinct and separate members of their flowers. When the flowers are of this general type, the trees possessing them are grouped in a division to which the rechnical name Archichlamydae is applied. But when, as is true with the flowers of the Ashes and Catalpa, the petals are almost completely joined together along the sides, the trees with such flowers are classed in a second and higher subdivision, to which the name Sympetalae is give11. The first of these two groups contains by far the greater number of kinds of trees.

Further botunical subdizisions: By an even closer examination of the characteristics of trees, they are segregated into several still smaller suldivisions. The largest of these are calied Orders, and they in turn are made up of Families, which are still further subdivided into Genera, the Genera into Species, and the Species into Varieties. As a rule, the Genus is the smallest division into which similar kinds of trees are grouped, and the particular kind of tree is known as a Species. All the hickories for example. belong to the genus Carya, and each particular kind of hickory is designated as a species under a particular name. The Shellbark Hickory is known under the name oz'ata, from the shape of its nuts, and its complete name is Carya ovata.

Varieties within a species are regarded in various ways, but the most common acceptance of their position is that they are not sufficiently different from species to be regarded as different kinds of trees.

Not being the creators of the plants with which they deal, botanists are ly no means agreed as to the exact relationships that exist between plants, and they endeavor to express their different opinions by proposing new or modified classifications. The result is that there are now several prevalent beliefs regarding the most acceptable, the most usable, and the most accurate systems of classifications. To the unexperienced, the prevalence of these different systems, with their accompanying differences in scientific names for certain trees, may seem confusing, but if one accepts at the beginning of his studies the names given by a competent authority and uses them consistently until he is thoroughly familiar with his trees, he will encounter no real trouble. 
The economic importunce of trecs: In addition to the pleasure that one derives from an intimate acquaintance with the kinds of trees and the places in which they grow, the tree enthusiast will, no doubt, find considerable satisfaction in observing the important ways in which they serve mankind. The uses to which trees are put are many and range from the homeliest needs of the farm to purposes of the highest inportance to industries. The living trees provide shade and fruit, protect the soil, and conserve the rains. And when they are cut, they furnish many of the necessities of life, including food, shelter, and healing medicines, and there is no human endeavor which does not in some measure depend upon the use of wood or upon articles in the manufacture of which wood has played an inportant part.

IV ith so varied a range of usefulness, woods must necessarily be selected for each purpose, in accordance with the particular demands to be made of them. For some purposes, rood must be soft, for some it must be hard, for others tough, and for still others strong. The woods of different trees possess these characters in different combinations, and the particular combination for any wood is designated as its "technical qualities."

Softrood and hardwood: It is generally understood that softwoods are derived from pines or other coniferous trees, while hardwoods are produced by deciduous trees. It does not hold true, however, that all softwoods are softer than all hardwoods or that all hardwoods are harder than all softwoods. Like many another of our common expressions, this generalization of the difference between the woods derived from evergreen trees and those derived from deciduous trees is really based on much finer differences.

Structure of wood: When a tree is cut down, the ends of the logs or the top of the stump can be seen to consist of three distinct regions. On the outside, there is the bark; in the center, there is a larger or smaller circle of pith; and intervening between these two is the woody bulk of the tree, from which lumber is sawed. Upon smoothing the roughly sawed end of the trunk with a knife or plane, one sees that the wood is made up of a series of concentric rings - the growth rings which mark the extent of each year's additional growth. And if one looks a little closer, he may observe that much of the central part of the wood is of a dark color, while surrounding it is a narrow zone of lighter color. The first, which serves as a supporting structure for the tree, is the heartwood, while the light wood at the outside, which serves to carry the sap, is called the sapwood. As the tree grows, the sapwood of one year becomes the heartwood of succeeding years, and new sapwood is adcled to take its place. 
One will already have noticed that there are numerous fine streaks or lines radiating from the center of the stump and from each annual ring outward through the wood to the bark. These are the rays, more accurately called medullary rays or pith rays, to which is due the beatiful or striking "silver grain" figures displayed by the lumber from such trees as the oaks, the Sycamore, and the Beech.

The grain of the wood is related especially to the relative widtin of the annual growth rings and to the longitudinal directions of the microscopic elements, or fibers, which make up the wood. Fine-grained woods come from trees that grow slowly and exhibit narrow rings, while coarsegrained woods are of rapid growth and wide rings. Straight-grained wood is taken from trees that have the wood elements arranged in a perpendicular direction, while spiral or twisted grain results from the wool fibers being arranged in spirals about the axis of the tree. Cross-grained wood, such as is found in the tupelos, Ohio Buckeye, and Sweet Gum, results from the interweaving of the wood fibers: and the way or curly grain found in the wood of the maples, ashes, and birches is caused by the wary growth of the fibers. These variations in grain are important characteristics in determining the uses of woods. Straight-grained woods are generally strong, cross-grained woods are tough, curly-grained woods are both strong and decorative, and coarse- and fine-grained woods are apt to be light and heary, respectively.

Microscopic structure of anod: In addition to the evident gross structure just described, the wood is made up of numerous linds of fibers, cells, and ducts, the purpose of which in the living tree is to furnish strength, transfer water and food material from one part to another, and to store reserves of food. These structures differ in different linds of trees, their particular variation in kind, size, and location being as characteristic of the species as are the flowers, fruits, leaves, and buds. Our conmmercial woods, as suggested in the paragraph on hardwoods and softwoods, are divided into two classes, upon the microscopic difference between the woods of conifers and of deciduous trees.

If one cuts a $\log$ into small, square pieces, or blocks, by sawing crosswise and splitting longitudinally both in a radial direction and in a direction tangential to the growth rings of the wood, the essential points of the gross structure can be studied. Such a block will show, on its cross-cut face, the annual rings, divided into heavy summer wood and light spring wood, the pith rays, and cross-sections of all the finer elements; the side on which the radial split was made, and also that on which the tangential split was made, will also show all these things, but from two different sides. 
Now if it be inagined that one of these blocks has been cut so very small that an exceedingly thin shaving can be taken from its cross, radial, and tangential faces and put under the microscope and photographed (as actually can be done in a laboratory), the three photographs could be so arranged, by pasting them on a small block, as to show in detail the arrangement and interrelation of all the minute woody parts. This is exactly what has been done in preparing the blocks used in Figures 120 and 121 to illustrate the microscopic structure of soft and hard woods.

Microscopic structure of softwood: When one sees a thin slice of wood under a microscope, his first observation is that it is made up of a great number of cells, resenting in this respect the surface of a honey comb. Lpon more careful examination, these cells are seen to differ from one another in a regular and orderly manner. If the first section seen is that of a softwood, it will be very much like the top of the block shown in Figure 120. The large cells, very like to, though lesis regular than, the cells of a honey comb, extend in orderly rows from the center to the outer edge of the wood, becoming smaller and more heavily walled and then suddenly larger and thin-walled at regular intervals. These cells are the cross-sections of the tracheids; and the regions where heary walls prevail mark the slow summer growth, while the bands of thin-walled cells mark the rapid growth of spring. Narrow strands of fine, long cells, two of which appear as dark lines in the

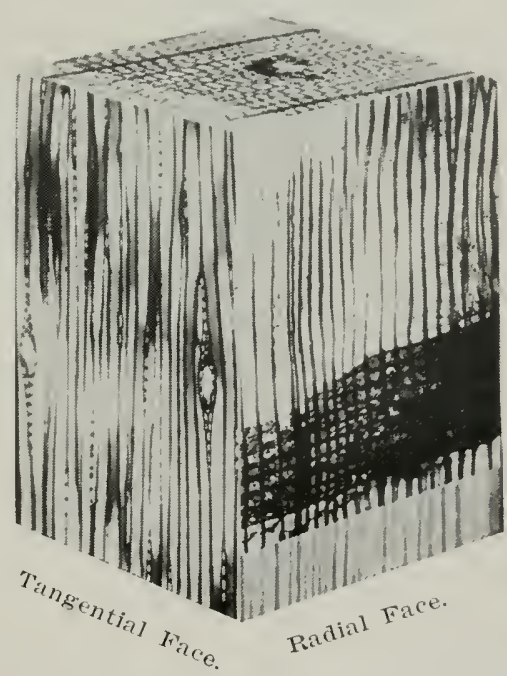

FIG. 120. Composite photomicrograph showing the microscopic structure of a softwood. photograph, traverse the section in a direction parallel to the rows of fiber cells. These are the fine medullary rays. Here and there one will observe also a large, round space in the wood, surrounded by a ring of compressed, oval, thin-walled cells. These structures, one of which may be seen in the top of Figure 120, are the resin-ducts, wherein is stored the resin from which we derive turpentine and rosin after the trees have been bled.

If, next, we place a radial section of a softwood beneath our microscope, we will see something very much like the radial view in Figure 120. Running lengthwise of the section are long, narrow cells which 
fit together at their cuds by means of a long bevel. These cells we. readily understand to be the tracheids which we have already seen in cross-section, and we can see that the straight grain of coniferous wouds results from the straightness of these cells, while the strength of the wood results not only irom the enormous number of these tiny fibers that is required to make even a small timber but also from the closefitting and interjoining of the ends of the fibers. Here and there across the tracheids rum broad plates of nearly rectangular cells, thinnerwalled than the tracheids. These are the medullary rays, one of which appears as a dark band across the radial face of the figure. The round "frog-eyc" marks which appear at frequent intervals in the walls of the tracheids a re called "bordered pits." but their function is to serve as connections between the tracheids, through which water and food can pass easily.

Finally, we look at a tangential section and find it much like the tangential face of the block in Figure 120. The tracheids show as long, narrow cells joined by beveled ends, just as they did in the radial section; but the pith rays we now see as long. spindle-shaped rows of oval cells, scattered at intervals between the closely pressed tracheids. Here and there a broader and larger ray appears, with a space in its center about which are the oval cells characteristic of resin-ducts. With careful scrutiny under the high power of the microscope. we might make out also the structure of the bordered pits and see how the wonderful little door with which each of them is equipped can close the openings of the pits, now on one side and now on the other, and so regulate the flow of water and food from cell to cell.

Microsicopic structure of a harda'ood: There are a large number of differences between softwoods and hardwoods, as may readily be understood from Figure 121, which is a composite microphotograph of the wood of White Oak. On the top of the block is the cross-section. A little to the left of its mion with the tangential face is a thin, dark line of heavily walled cells which mark the end of a year's growth. while just beyond this line may be seen the very large, round openings of the pores, or waterconducting vessels. Around and beyond them are the heavily and densely walled woody fibers. Parallel to the radial face, a broad medullary ray divides the section into halves, and finer rays can be seen at frequent intervals.

On the radial face of Figure 121, the pores appear as long. connected tubes filled with a kind of spongy growth (called tyloses by botanists), and the woody cells are seen to be of several kinds, some long and some short, some marked with pits and some with spirals and ladder-rungs, 
some square at the ends, some beveled, and some jointed by interlocking forks - an array too formidable to be discussed outside of a text-book. Across these fibers extend the medullary rays. and their abundance and variety of shapes, when logs are quarter-sawed to show them to advantage in the lumber, give the "silver grain" effects so desirable in woods used for decorative purposes and for furniture.

Though the tangential face of our block does not show all the wood constituents, the

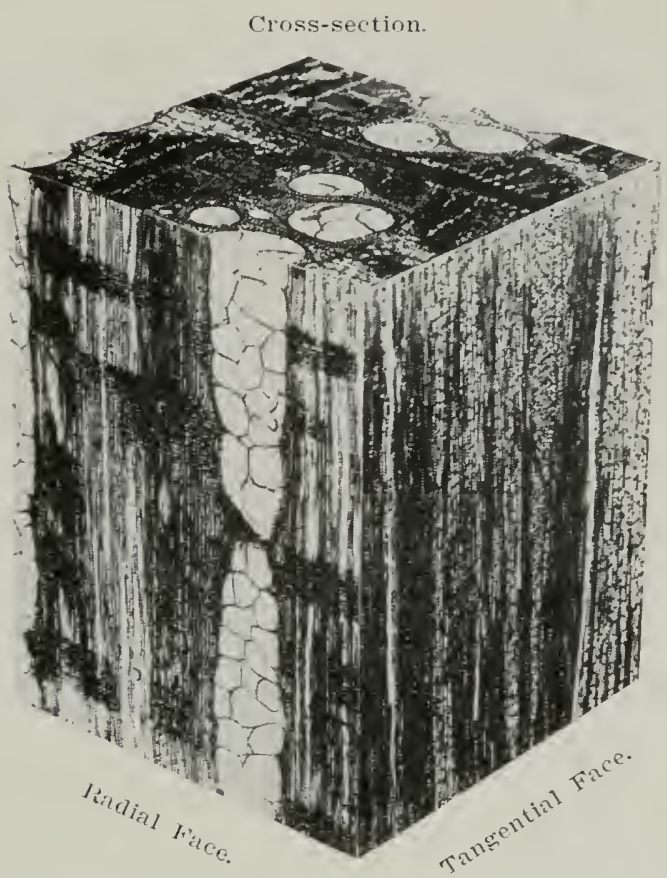

FIG. 121. Composite photomicrograph showing the microscopic structure of a hardwood. nedullary rays and the heavy, woody fibers can be seen plainly, while the appearance of the pores can be imagined as similar to that shown on the radial face.

Differences in hardarood structure: Although the soft woods are in general quite similar to each other, the hardwoods exhibit striking dissimilarities in their microscopic structure; and the differences, usually quite characteristic for each species of tree, determine the technical qualities possessed by the wood of every tree and, consequently, the uses to which it can be put.

One of the most obvious differences, and one that can be seen sometimes without the aid of a hand-lens, is the difference in the size and distribution of the pores. If they are exceptionally large and concentrated in a narrow ring in the spring growth of each year, the wood is described as ring-porous; but if they are smaller and scattered thronghout the year's growth, the wood is said to be diffuse-porous. In general, ring-porous wood is apt to be weak, unless there is, as in the oaks, a strong development of heavily walled woody cells, while diffuse-porous wood is apt to be strong, unless the walls of the woody cells are thin and light. 
Differences in the medullary rays are also of importance in determining the uses of woods. If the ray's are narrow the wood usually has little decorative value; but those woods, such as oak, sycamore, and beech, which have wide rays are in great demand for cabinet making, furniture, and interior finishing, where the decorative effect of the rays can be displayed to good advantage.

By talking note of such differences as these, it is possible for the expert to determine exactly, from a very small black, the species of tree from which a wood is taken, and to suggest at the same time the uses to which it may be put advantageously. A complete discussion of these characters would be far too technical for the usual reader: but from what hats already been saicl he will be enabled to see, in the photomicrographs which appear on the following pages, the most outstanding characteristics of the important woods taken from the trees native to Illinois. 


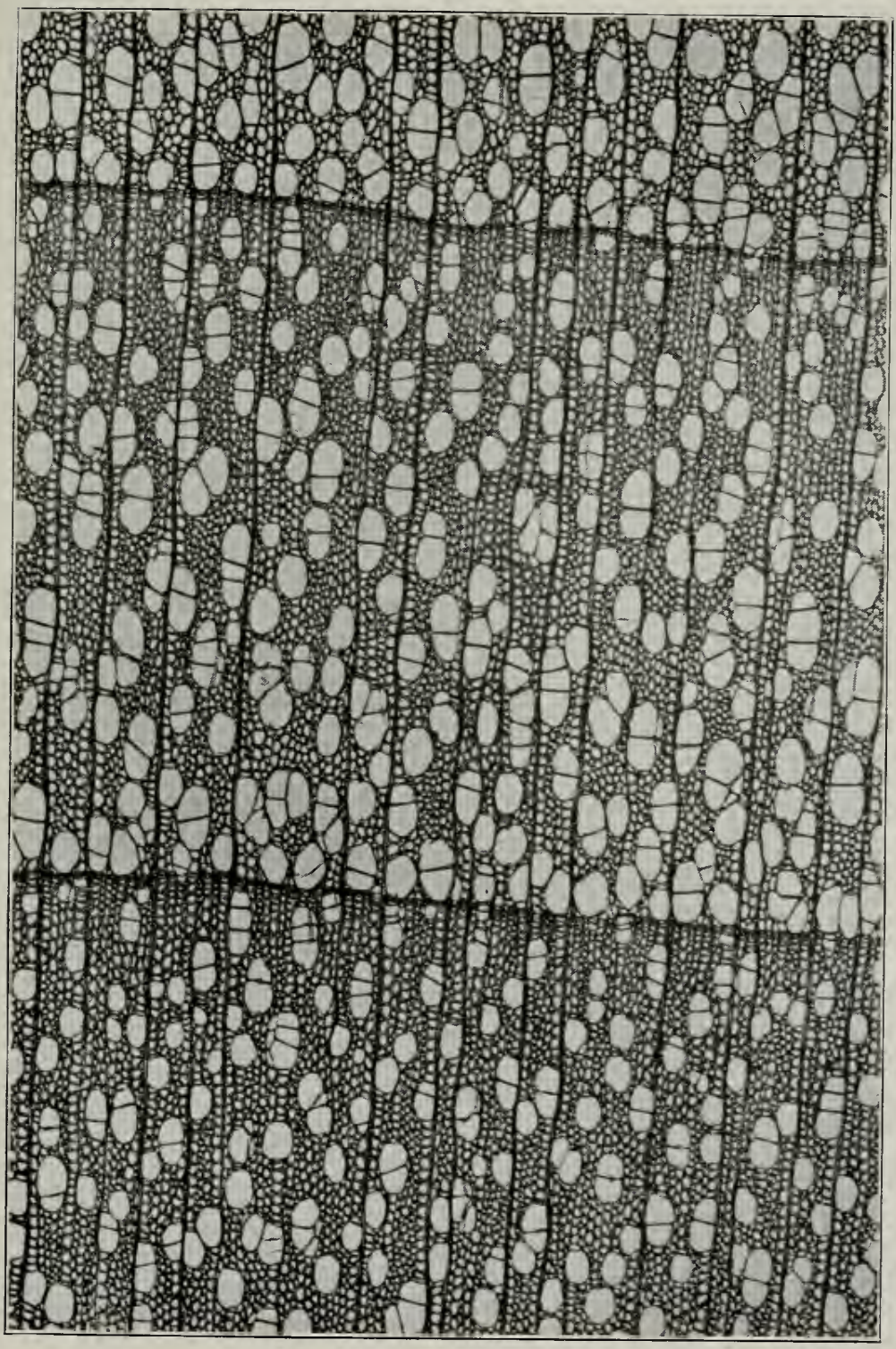

Fig. 122. Cross-section of the wood of the Aspen. A light-brown to silvery wood, with a fine texture and thin, inconspicuous rays. The pores are small and scattered through the year's growth. 


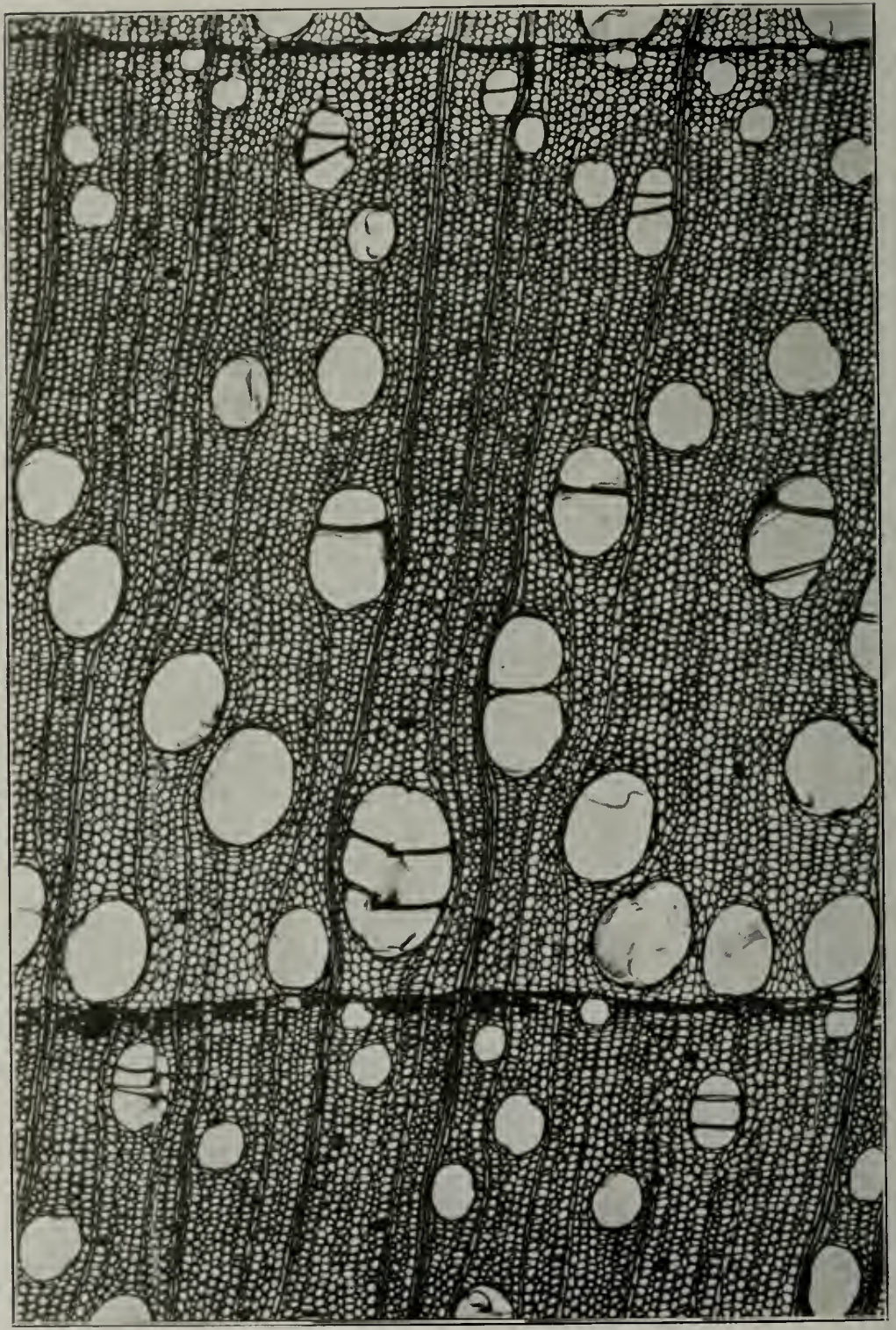

FIG. 123. Cross-section of Black Walnut. The pores are large and abundant in the spring wood, but become smaller and fewer in the later growth; and the rays are thin but numerous. 


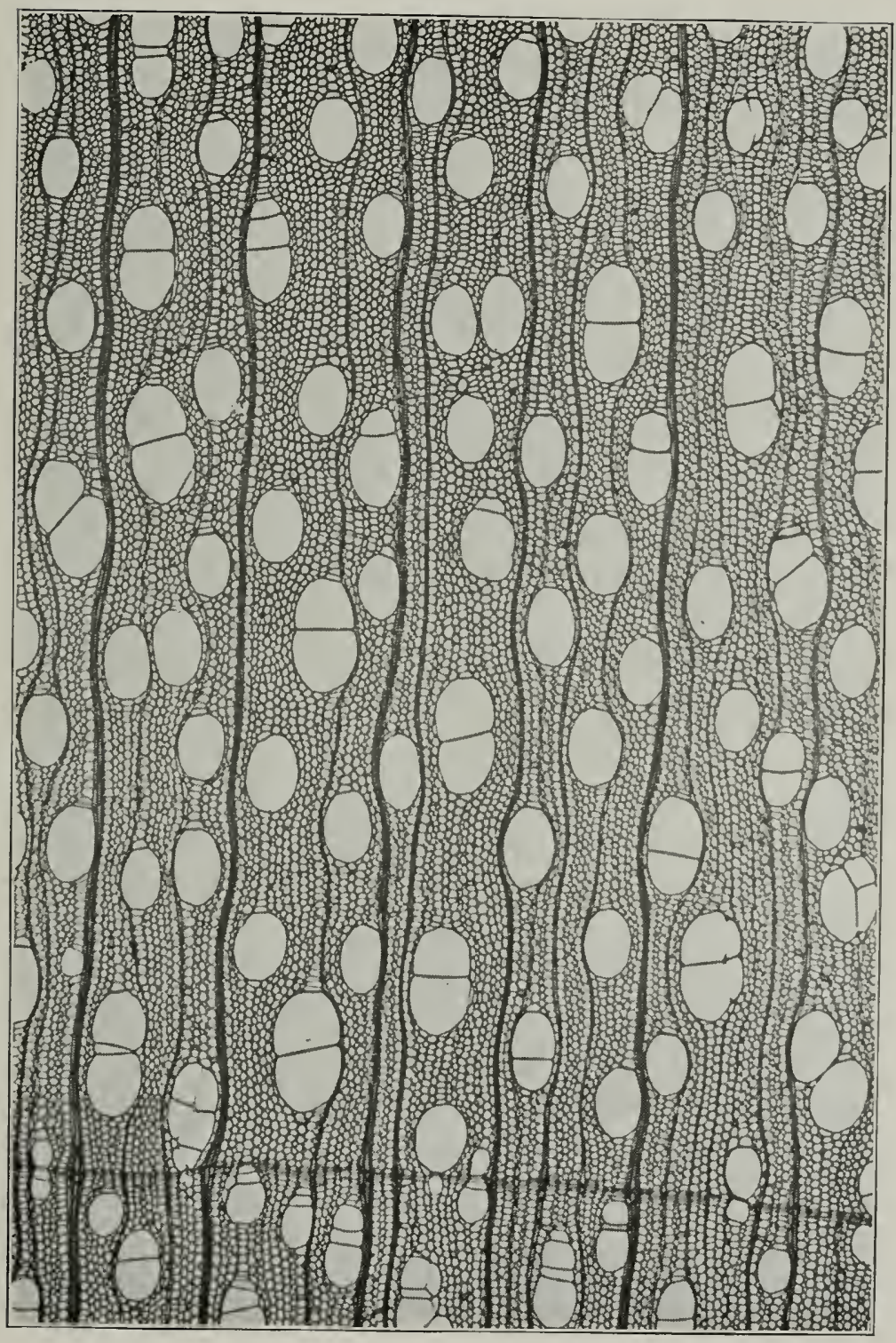

Fig. 124. Cross-section of the wood of the River Birch. The pores are small and uniformly scattered through the year's growth, the rays are straight and even but thin, and the wood fibers are thin walled. A light and soft but moderately strong wood. 


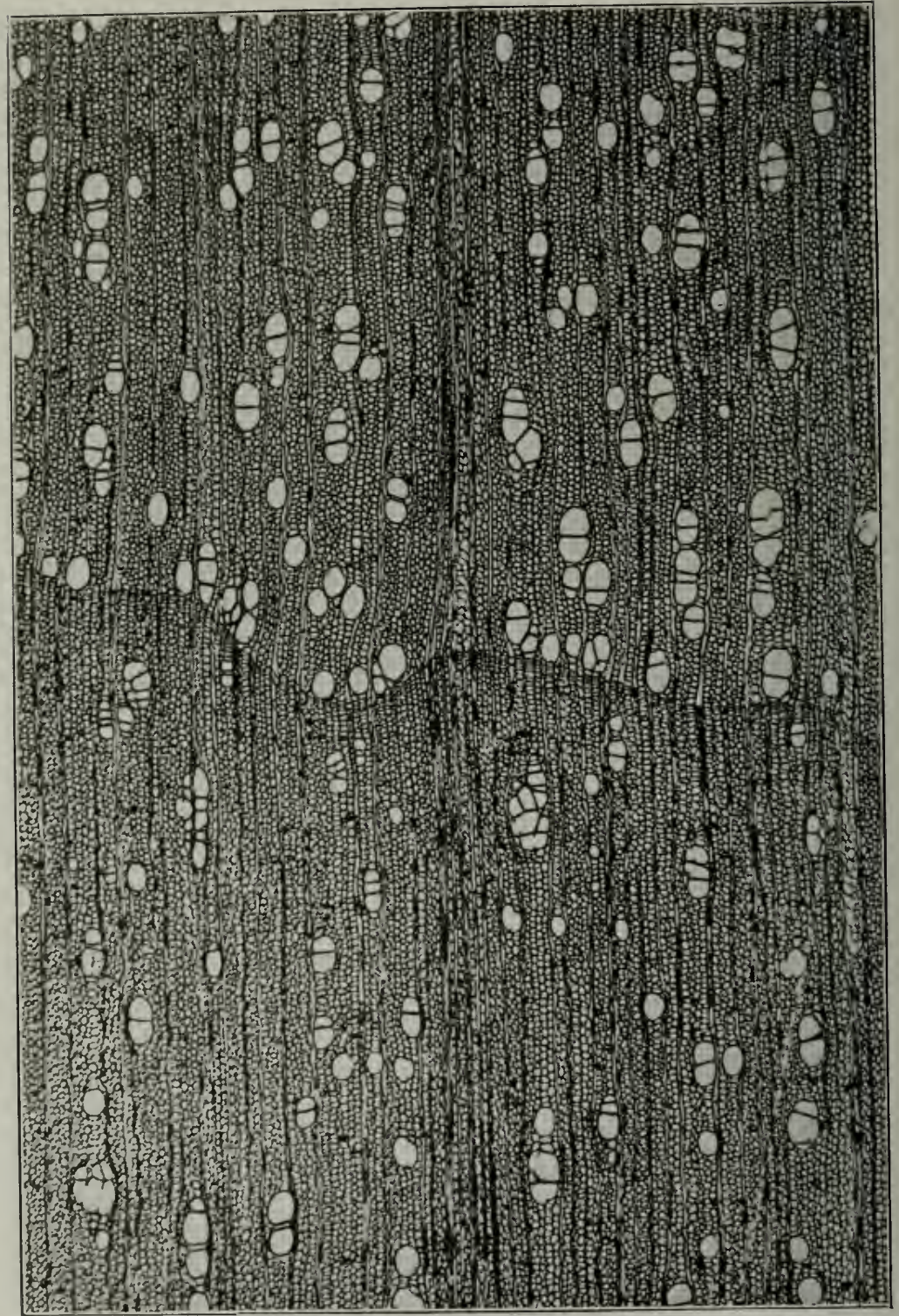

FIG 125. Cross section of Blue Beech (Hornbeam). The pores are few, small, and scattered; the rays are very narrow and indistinct; the growth rings are uneven; and the woody fibers are small and heavy walled. A very heavy, hard, and tough wood. 


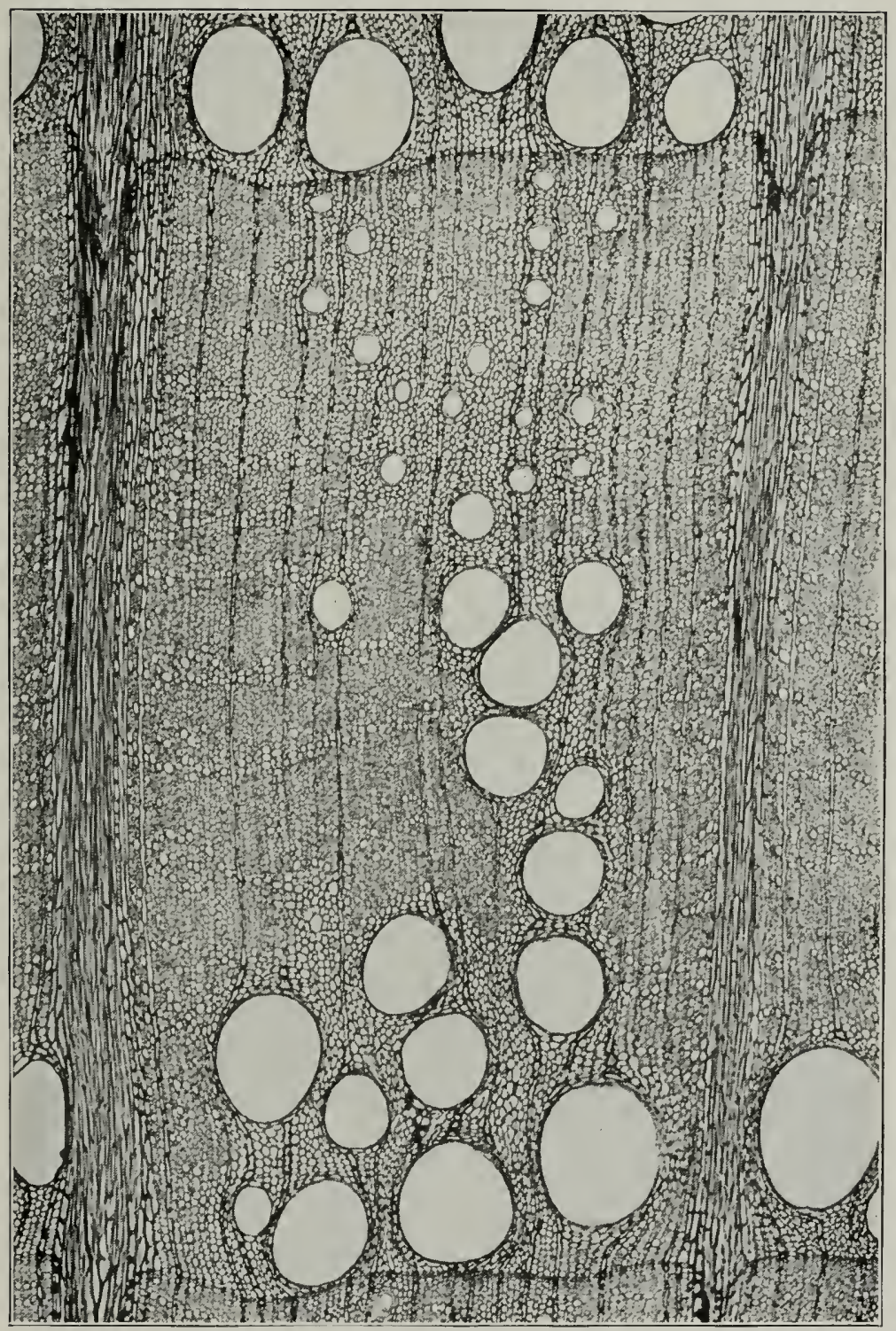

FIG, 126. Cross-section of Red Oak. The large pores are grouped conspicuously in the spring wood; there are both wide and distinct and fine, inconspicuous rays; and the woody cells have thick walls. The wood is hard and strong but coarse-grained. 


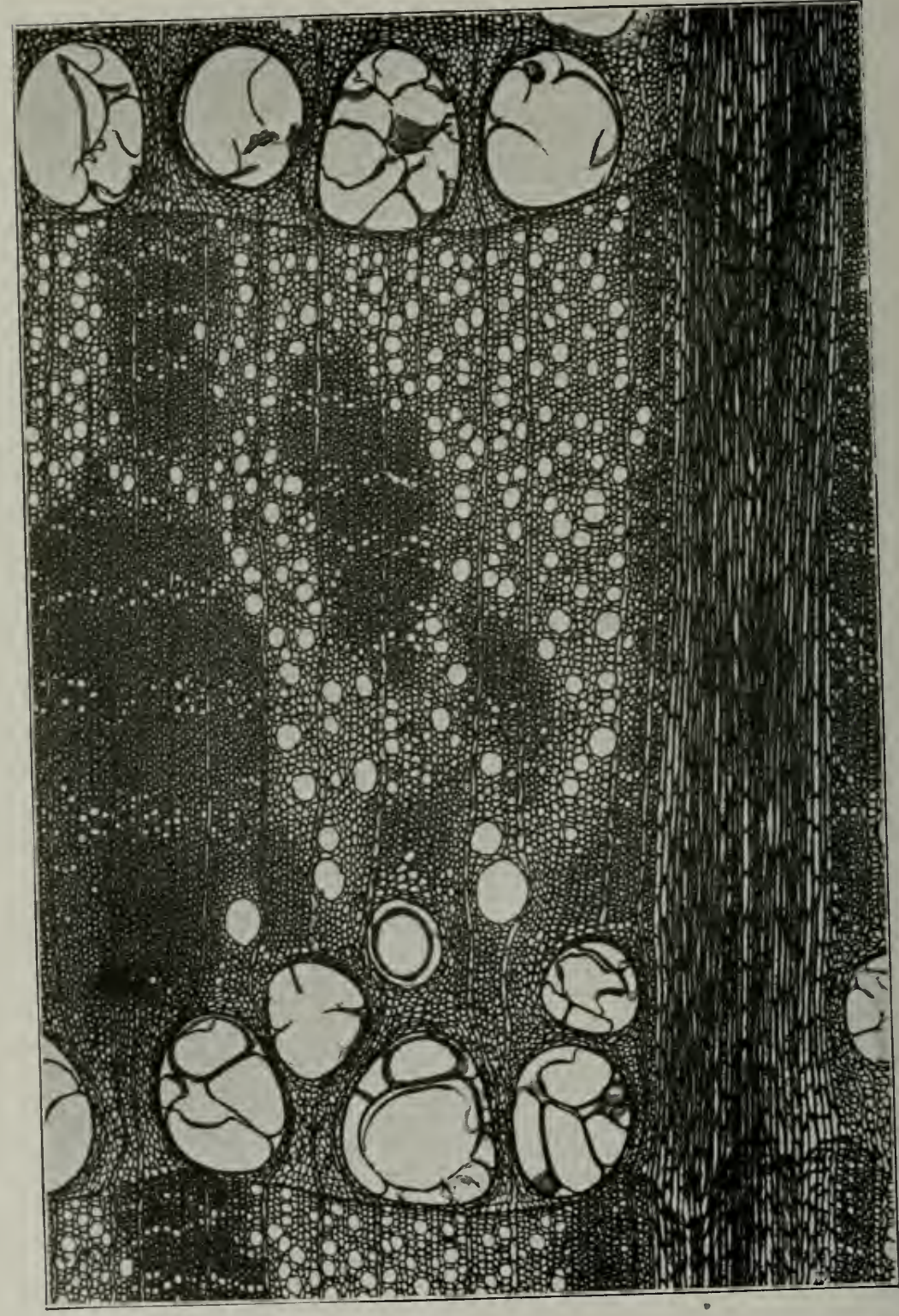

127 Cross-section of White Oak. Ring-porous, with a few very large pores in the spring growth and many much smaller pores in in the late growth; rays very broad and and hard wood which gives cells very abundaive effects. 


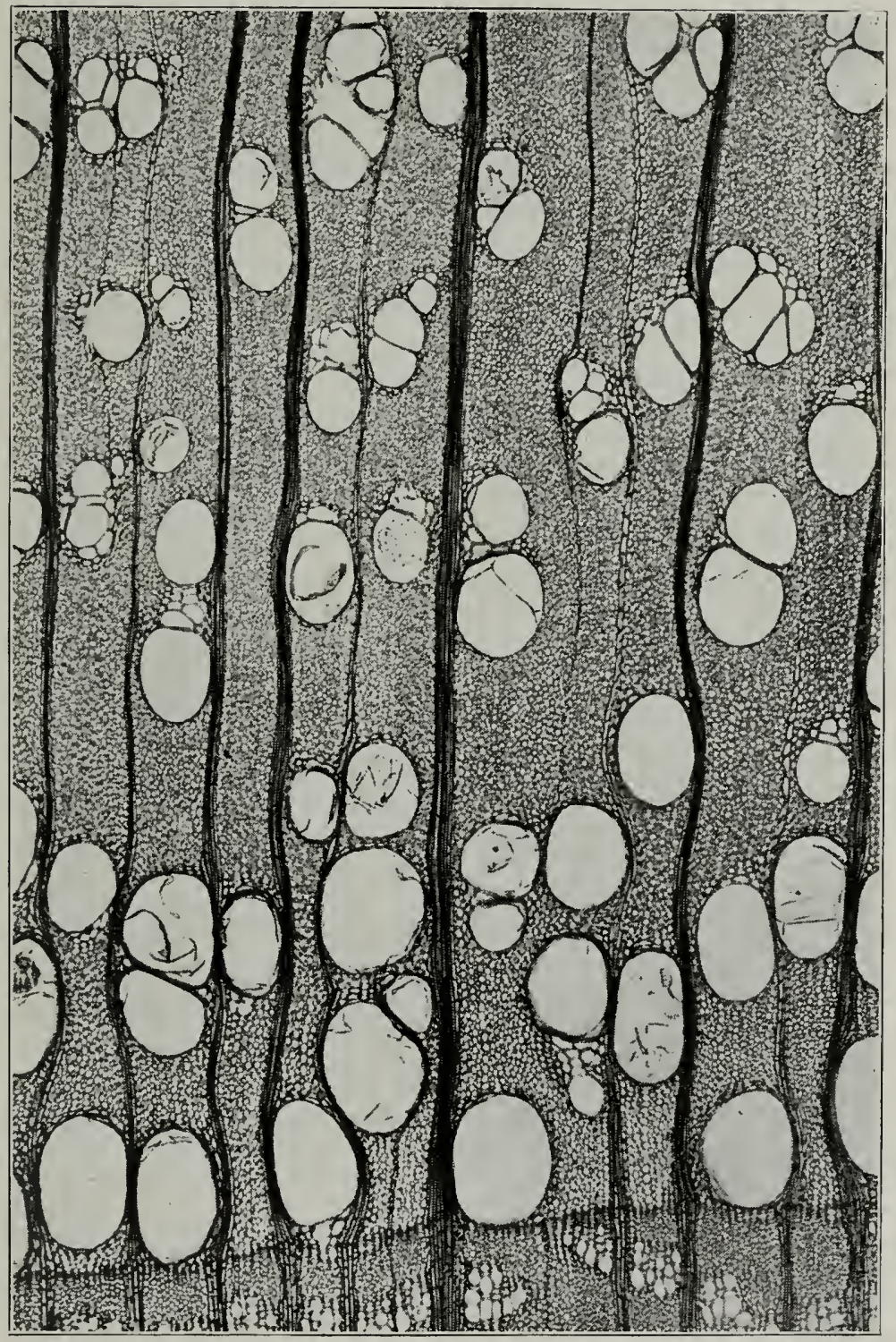

Frg. 128. Cross-section of the wood of the Hackberry. Pores in the spring wood are large, those in the later growth rather large and grouped; the rays, though narrow, are very distinct; and the woody cells are very abundant. Though heavy, the coarse-grained wood is neither hard nor strong. 


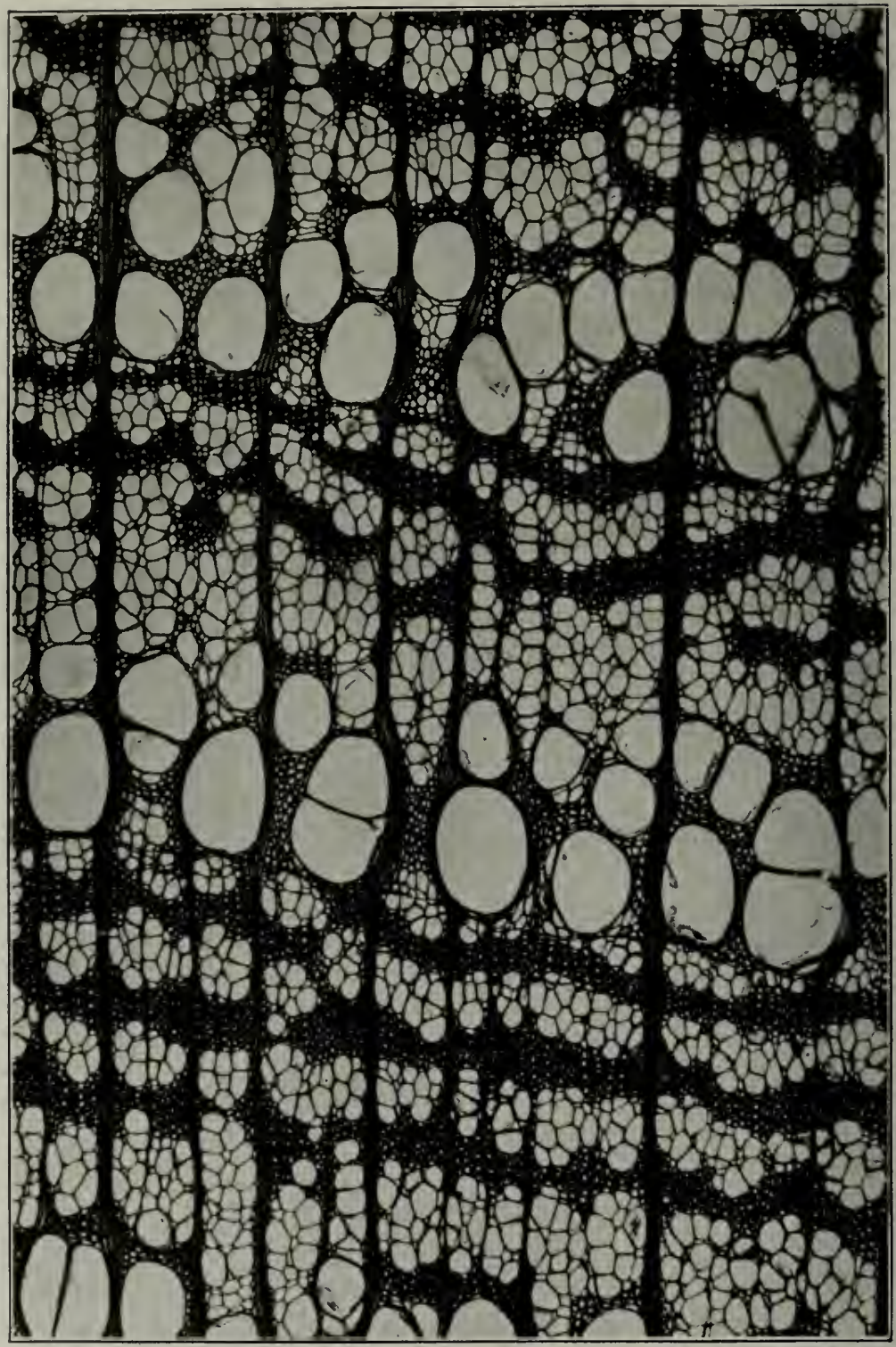

Fig. 1\%9. Cross-section of Elm. The pores in the spring wood are very large while those in the later growth are smaller and are arranged in bands separated by bands of heavily walled woody cells. The rays are thin, though not indistinct. A moderately heavy, coarse-grained wood that is hard, strong, and tough. 


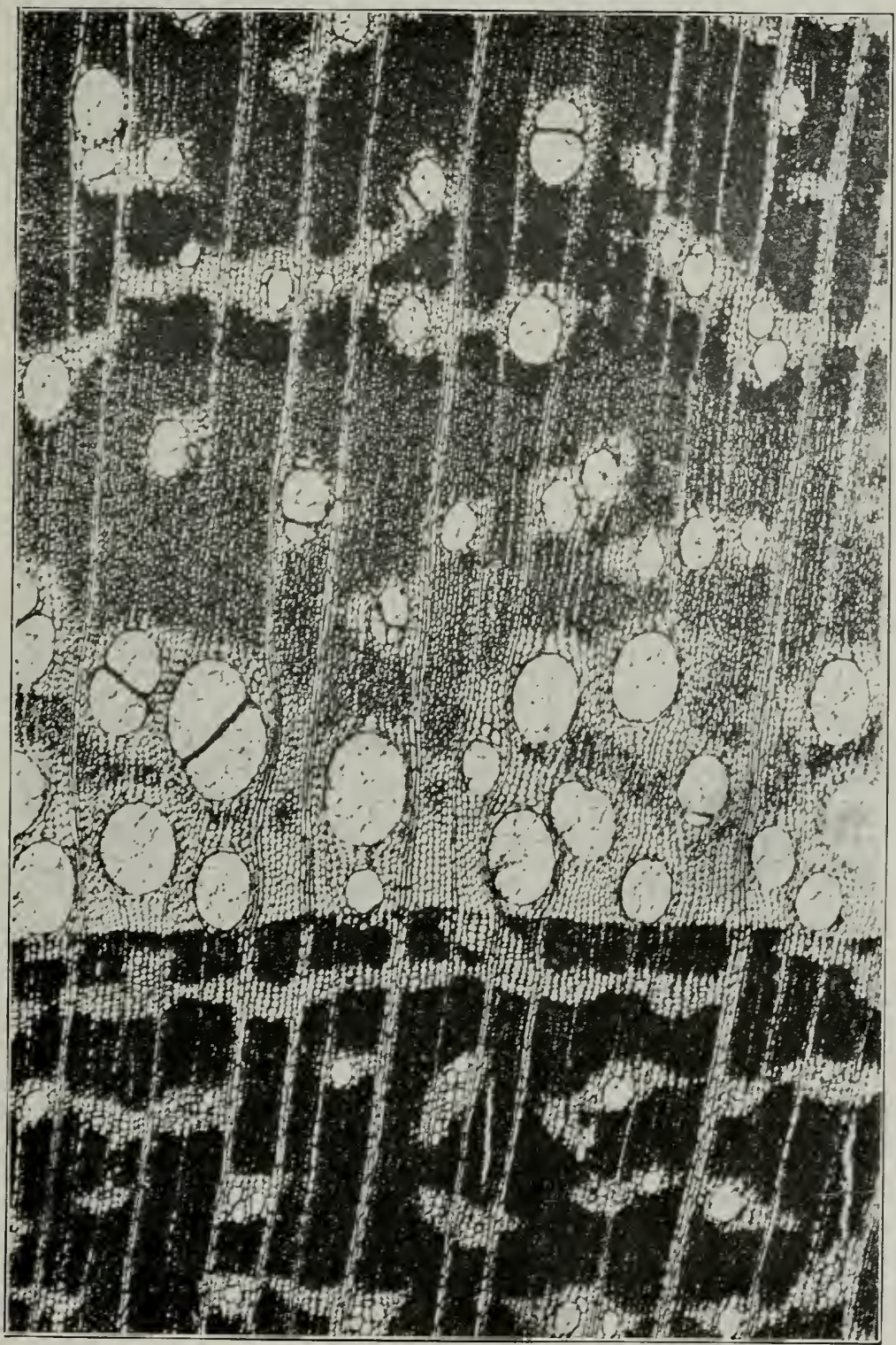

Fig. 130. Cross section of Osage Orange. The large pores are in a conspicuous zone in the spring wood; the numerous rays are narrow and fine; and the woody cells are extremely abundant. An exceedingly hard and durable wood that is both strong and flexible. 


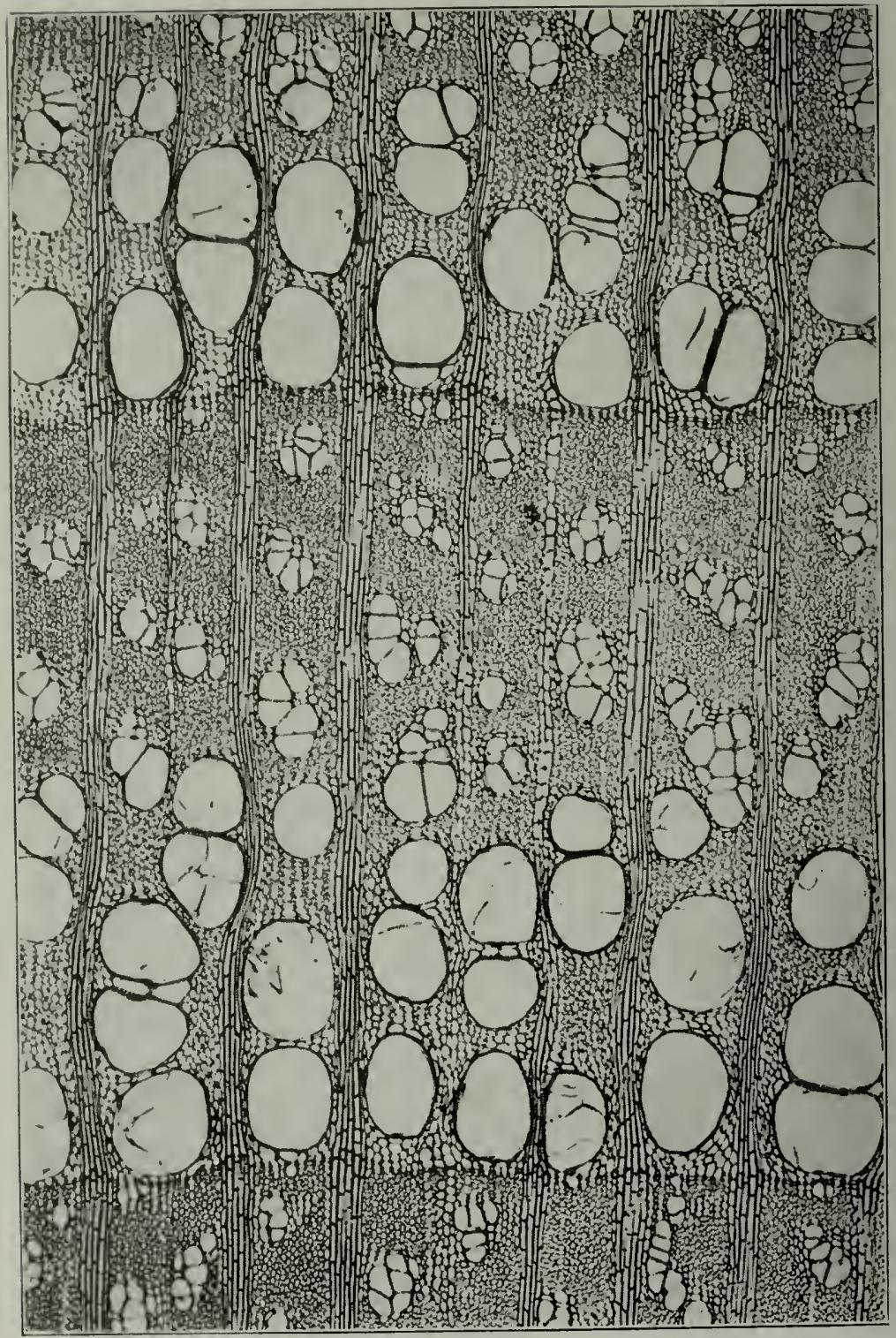

Fig. 131. C'ross-section of Red Mulberry wood. The large pores are arranged in a wide zone in the early wood and the smaller pores stand in groups in the later wood; the rays are numerous and rather wide; and the woody cells, though abundant, are not heavy-walled. Though rather tough and coarse-grained, the wood is only moderately hard and strong. 


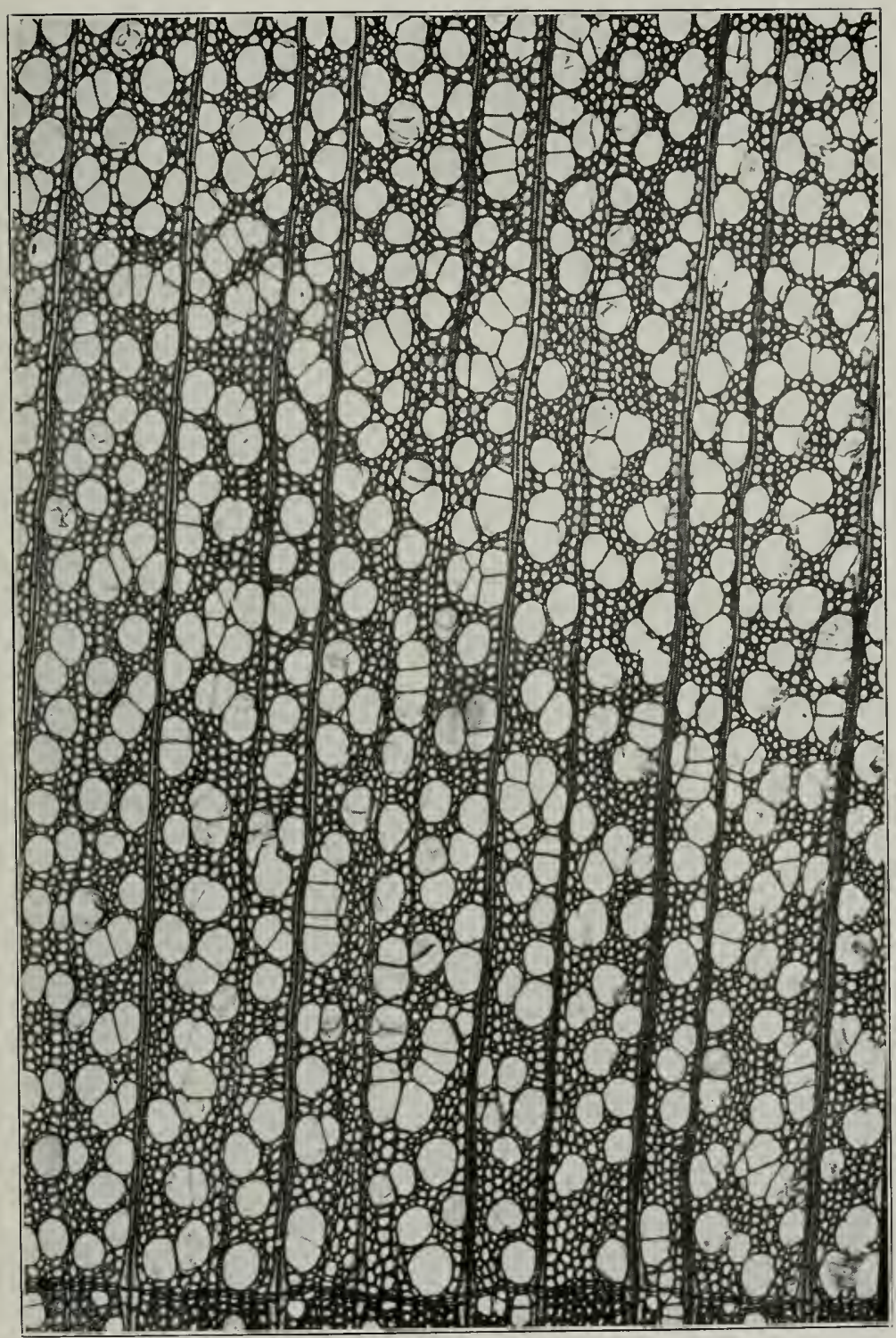

F1g. 132. Cross-section of Yellow Poplar. The pores are small, crowded, and through the year's growth; the rays are abundant and distinct, though narrow; and the woody fiber's have thin, rounded walls. A fine-textured, easily worked, wood that is soft and brittle as well as light and weak. 


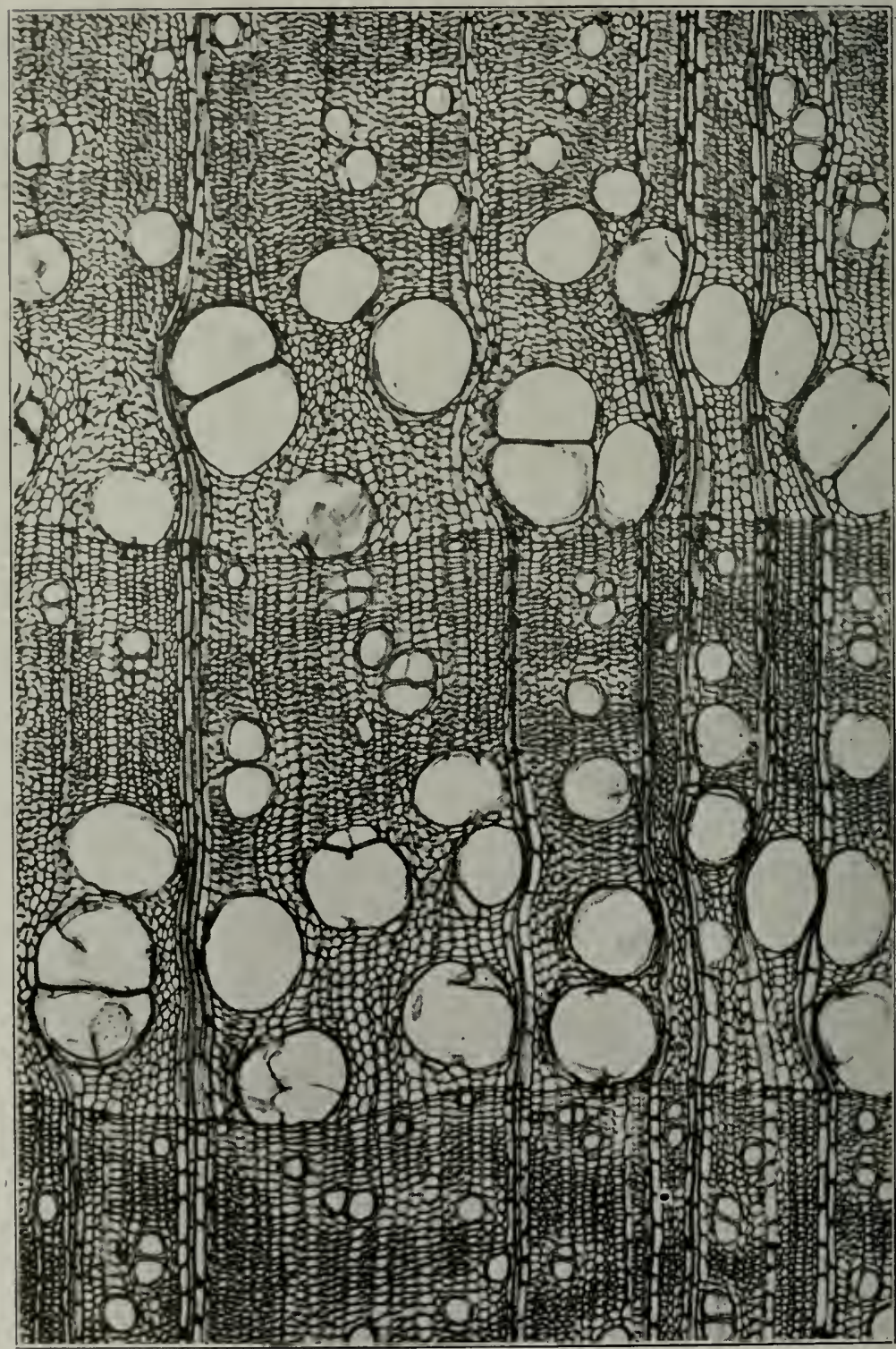

Fig. 133. Cross-section of Sassafras. The large pores in the spring wood are in a conspicuous, broad zone; the small pores in the later wood are in small, scattered groups; the rays are fine and narrow; and the woody cells are large and thin-wailed. A light, softwood that, though durable, is coarse-grained, brittle, and weak. 


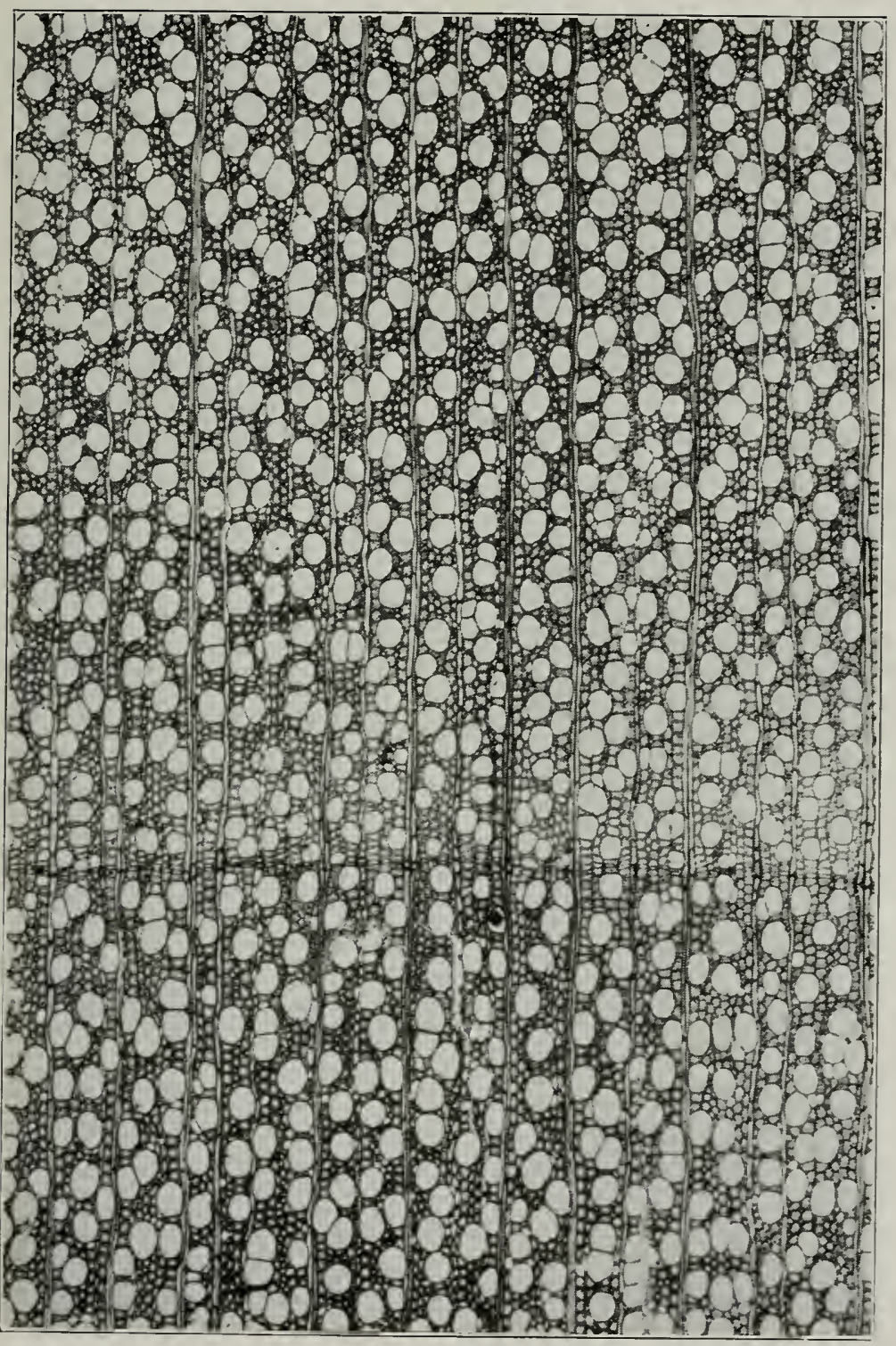

Fig. 134. Cross-section of the wood of the Sweet Gum. The small, crowded pores are uniformly scattered through the growth rings and are separated by numerous thick-walled woody cells. The rays are very fine and narrow, and the growth rings are indistinctly separated. A rather heavy, hard wood with crossed or interlocked grain, diffcult to work but of a fine texture. 


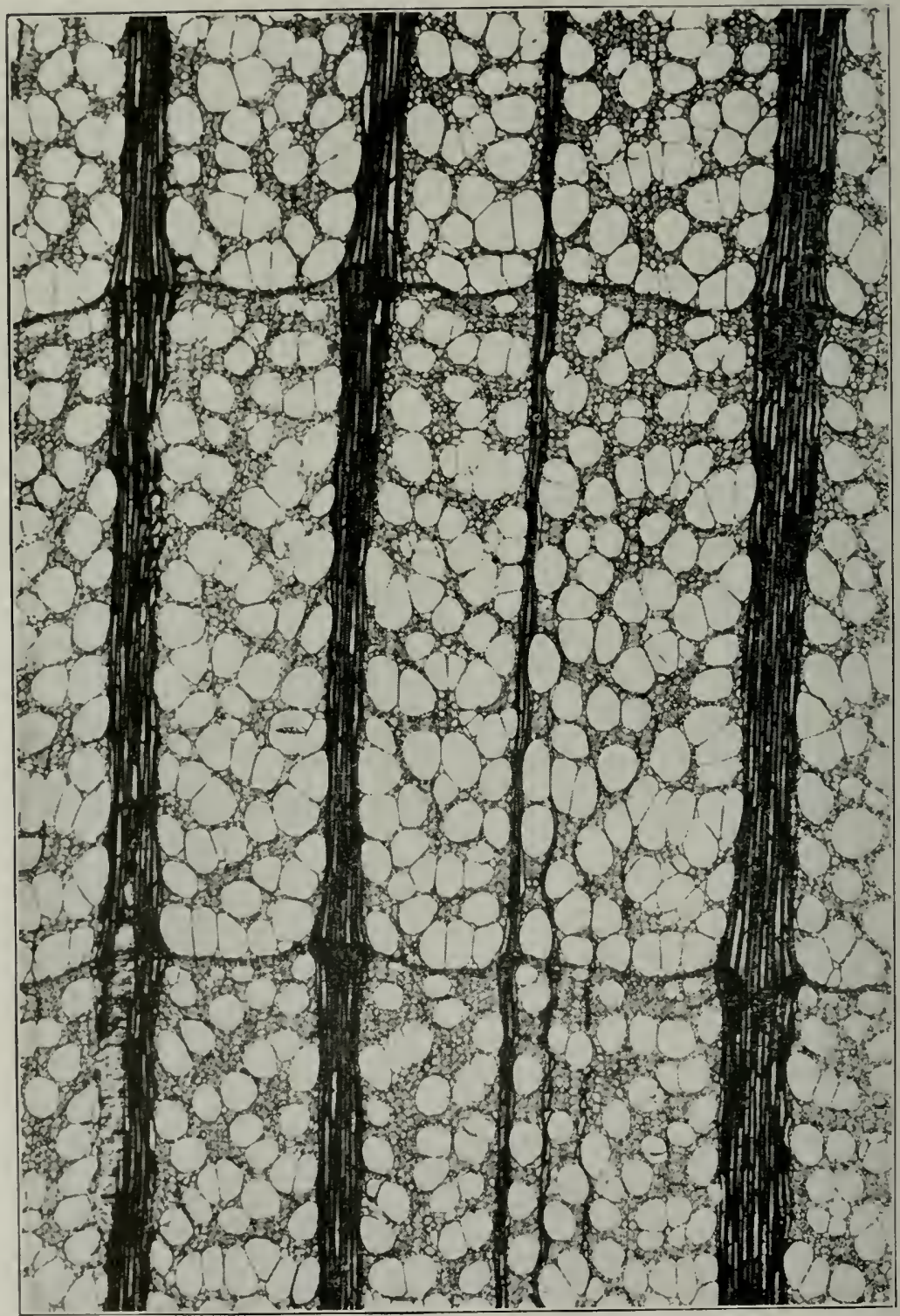

Fili. 135. Cross-section of Sycamore wood. The pores, somewhat more numerous in the early wood, are very small and crowded; the rays are all broad and high; and the woody cells are thick- and heavy-walled. A moderately hard, fairly heavy but not very strong wood, with a beautiful "silver grain." 


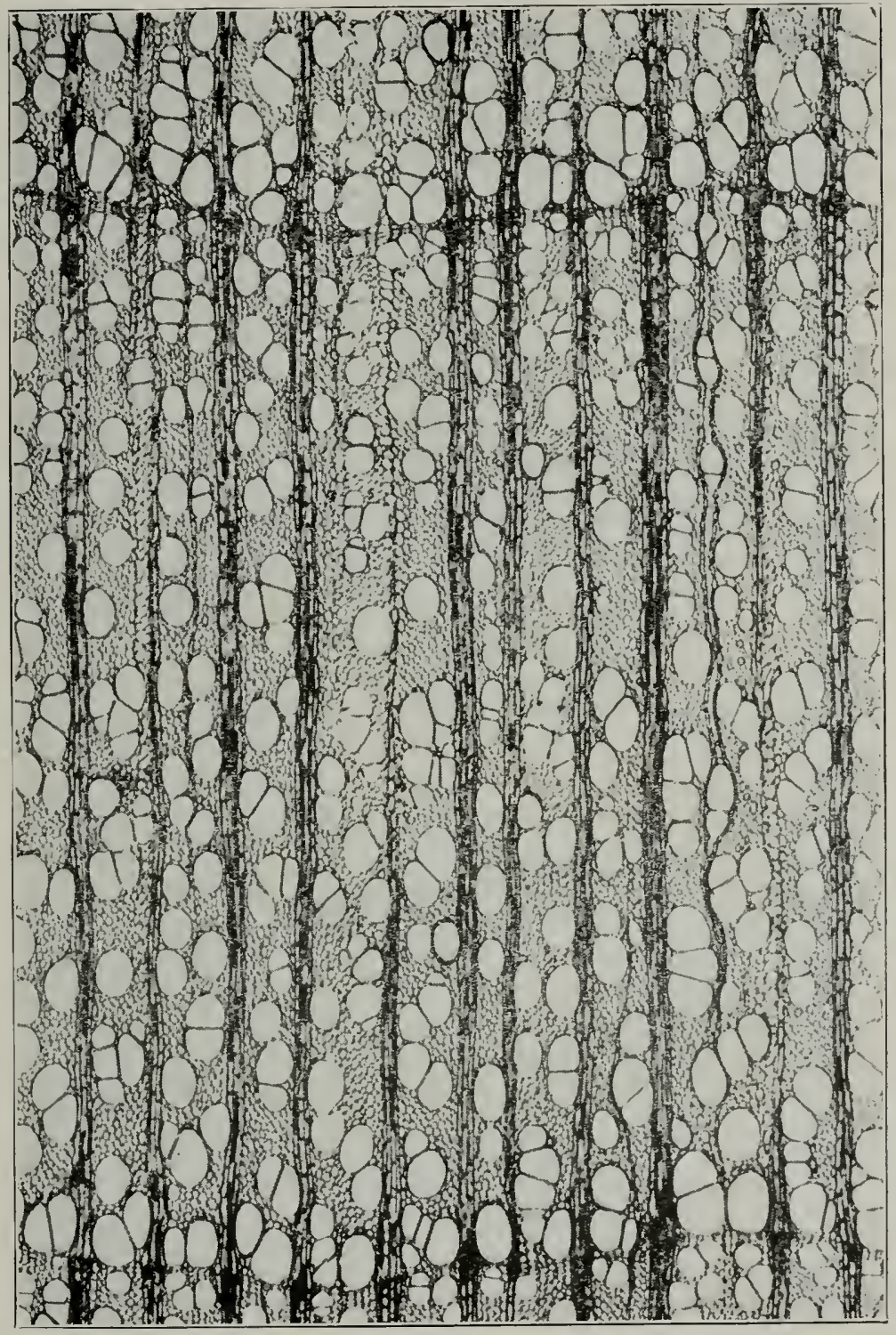

F16. 136. Cross-section of Black Cherry wood. The numerous groups of small pores are well distributed through the growth rings; the rather thin-walled woody cells are abundant; and the rays are fine but conspicious and gummy. A rather light and hard closegrained, strong wood with a satiny texture and a beautiful "silver grain." 


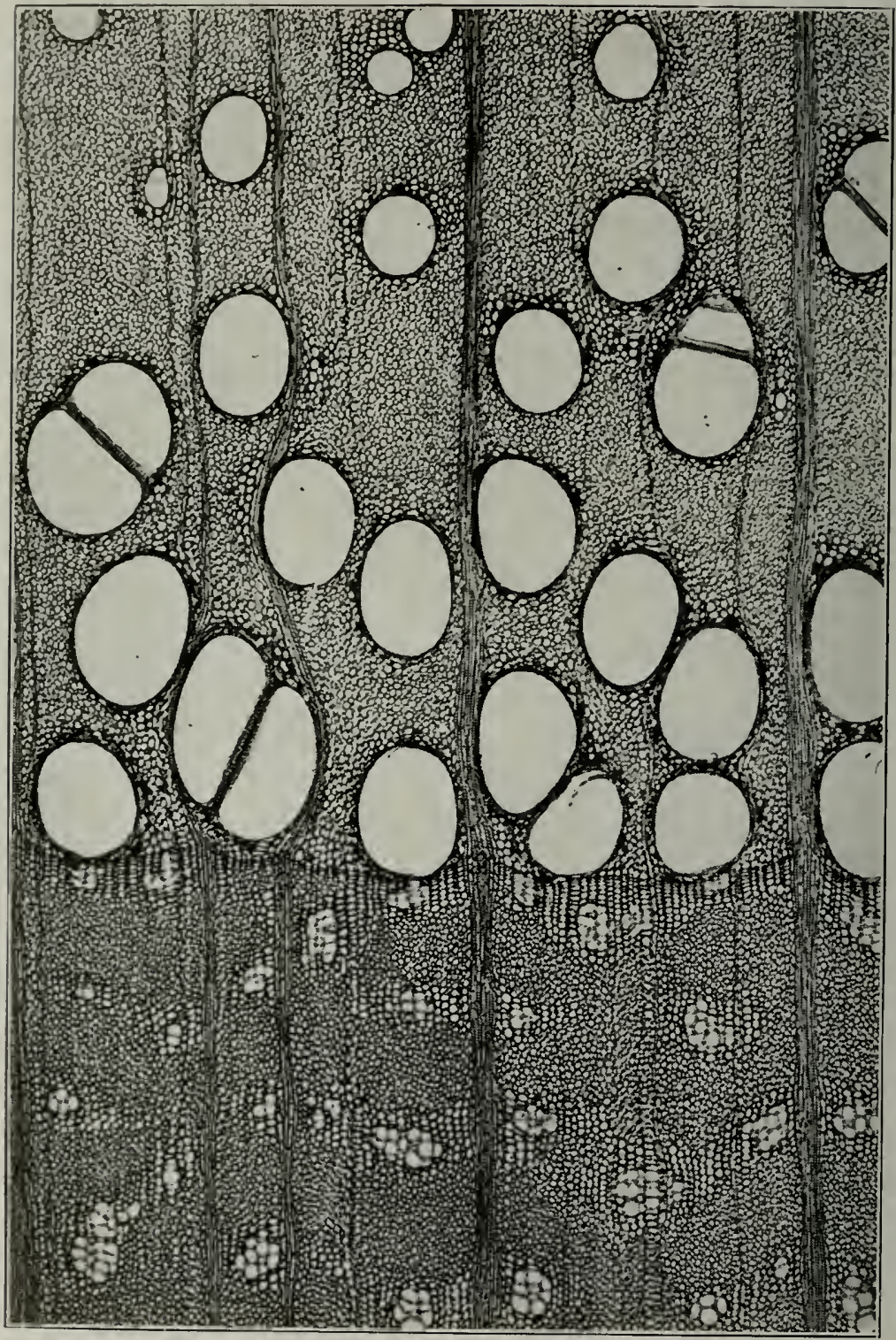

FIG. 137. Cross-section of the wood of the Honey Locust. The large pores in the early growth are arranged in a very broad band, and the small ones in the late wood are in small groups joined by bands of thin-walled woody cells. The bulk of the woody cells, are very small; and the rays are but conspicuous. A heavy, hard wood that is coarse-grained, and durable. 


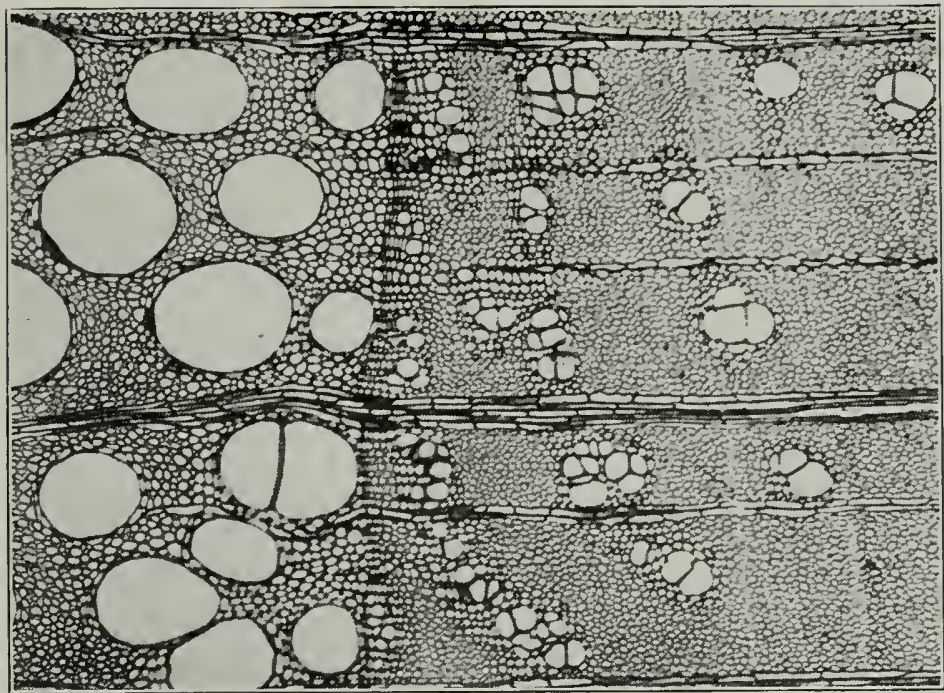

Fig. 138. Cross-section of the wood of the Kentucky Coffee Tree. Large pores of the early wood in a broad zone, small pores in the late wood grouped; woody cells thin-walled but very small and abundant; rays thin but distinct. Woor heavy, hard, strong, and coarse-textured.

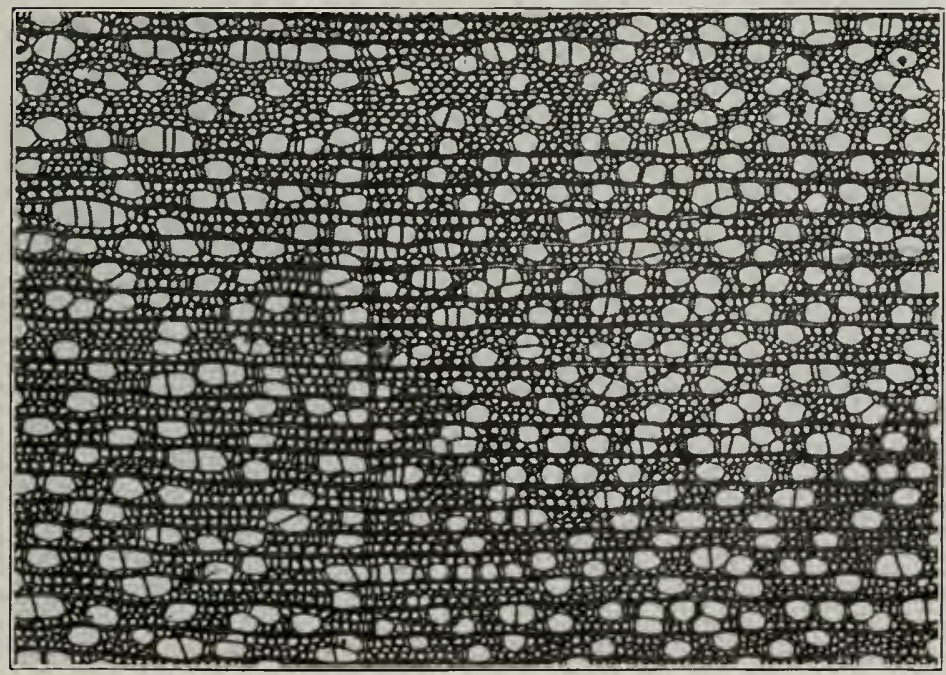

F1G. 139. Cross-section of the wood of the Ohio Buckeye. The pores very numerous, minute, and scattered; rays very fine and indistinct; woody cells abundant but large and thin-walled; growth rings indistinct. A fairly heavy wood that is strong but soft and coarse-grainet. 


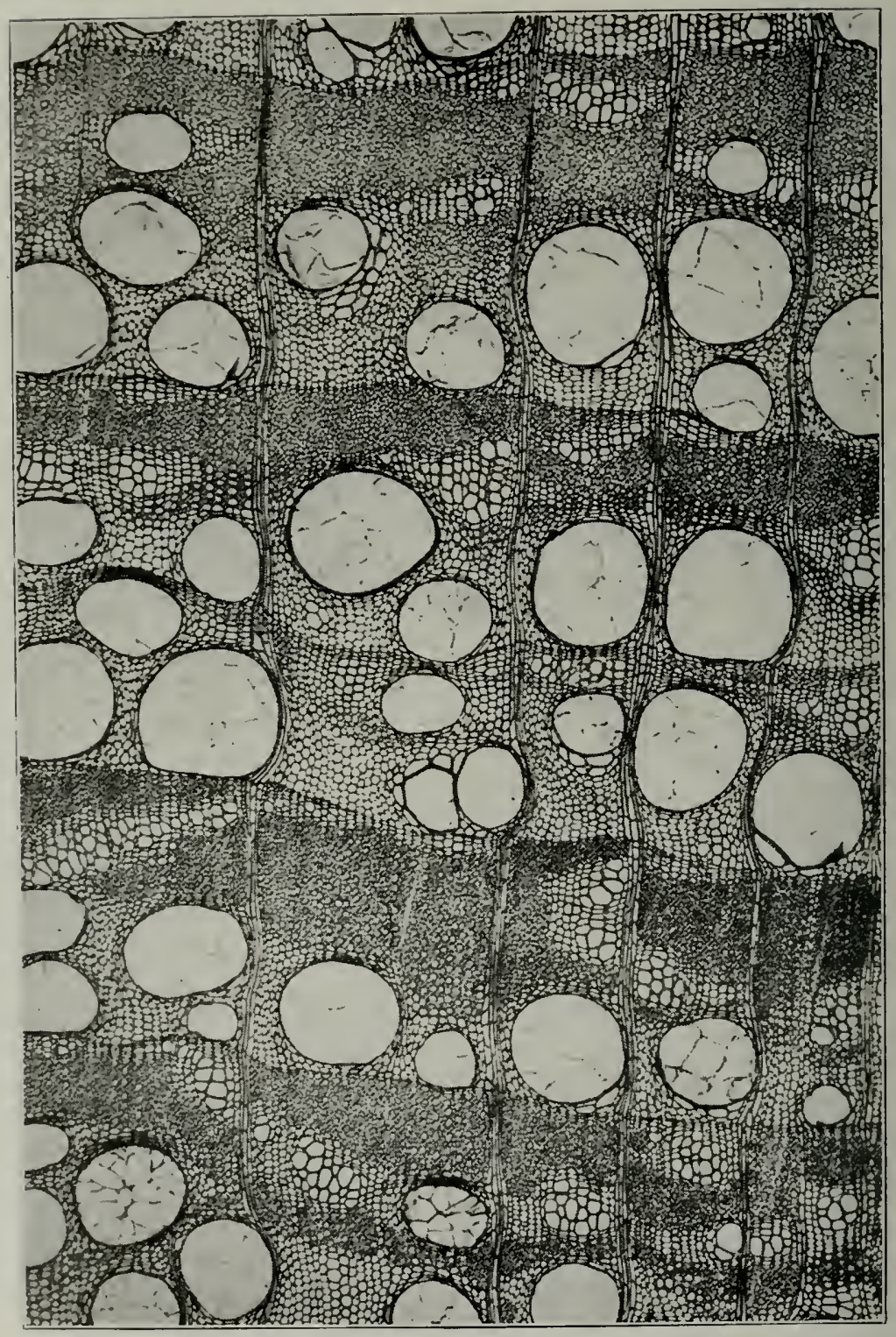

Fig. 140. Cross-section of the wood of the Black Locust. Large pores in a narrow band in the spring wood, the later growth of compact, heavy-walled wood cells; the rays fine or narrow and rather conspicuous. An extremely hard, heavy, strong wood that is close-grained and durable. 


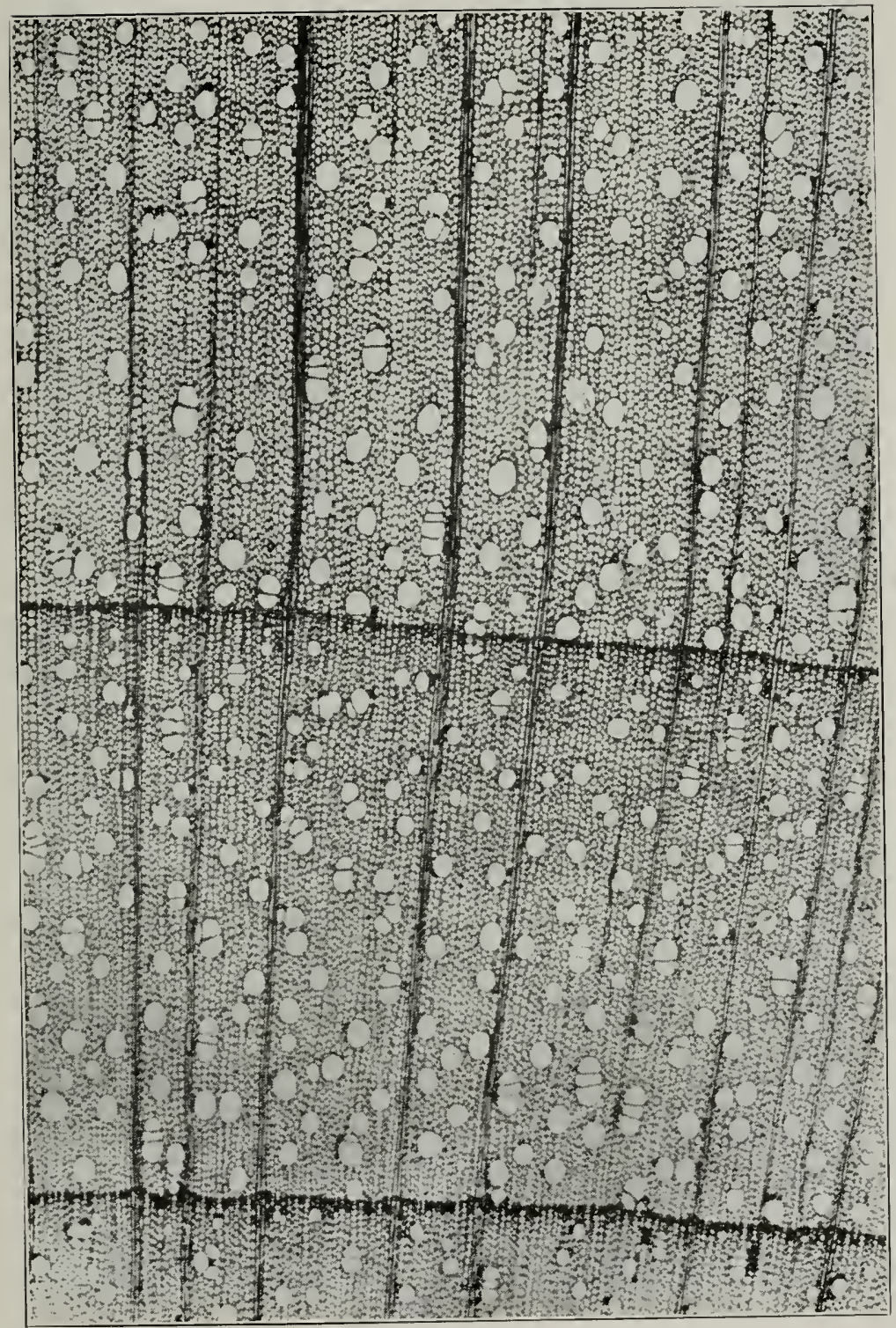

FIG 141. Cross-section of the wood of the Sugar Maple. The small pores are numerous but not crowded; the woody cells are thin-walled but small and very numerous; and there are both fine and conspicuous rays. A very hard and heavy, strong wood that is both close-grained and tough. 


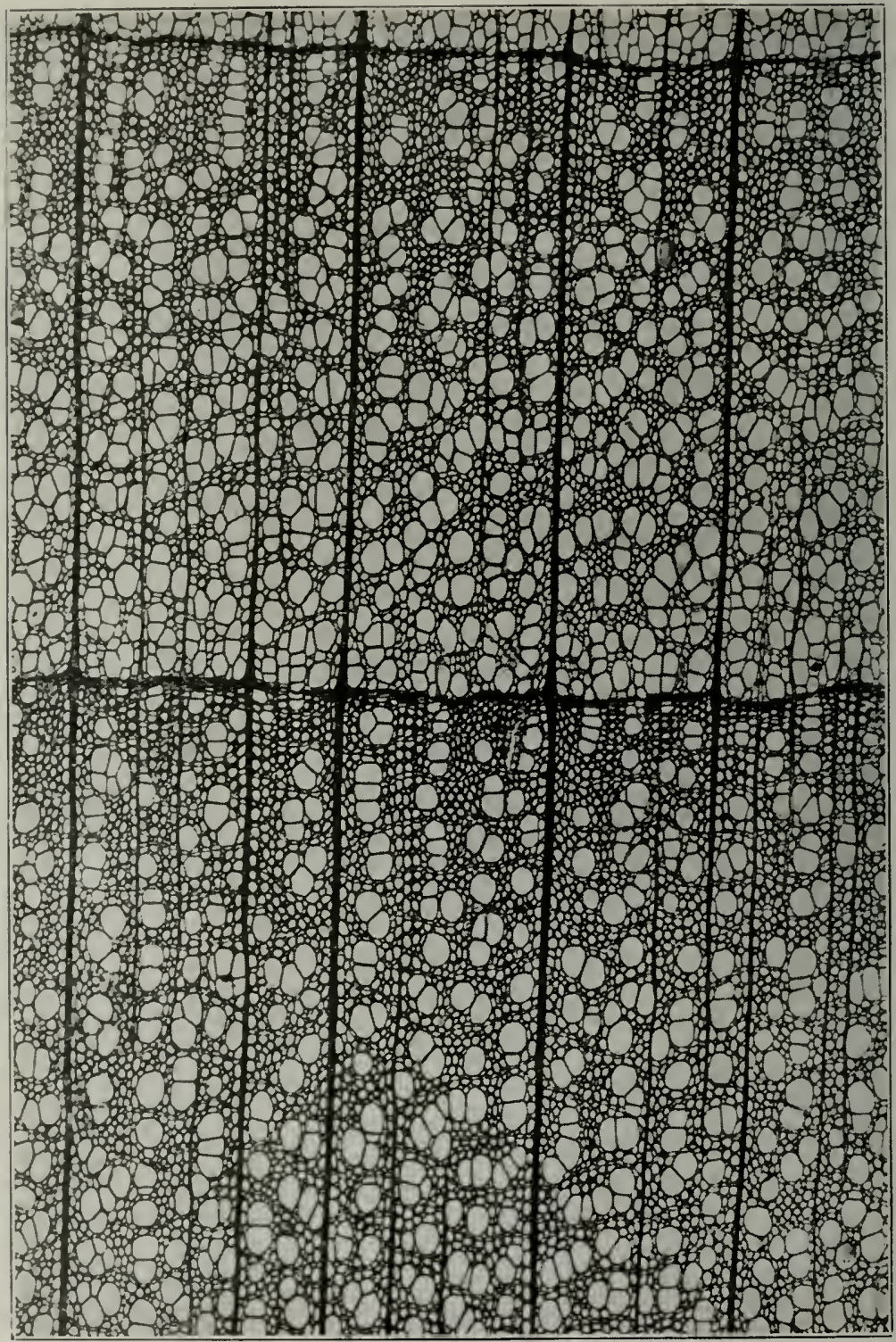

Fig. 142. Cross-section of Bass Wood. The pores are small, exceedingly numerous, and well distributed throughout the growth ring; the woody cells are rather large and thin-walled; and the rays are fine but often high. A compact but light wood that is both soft and strong. 


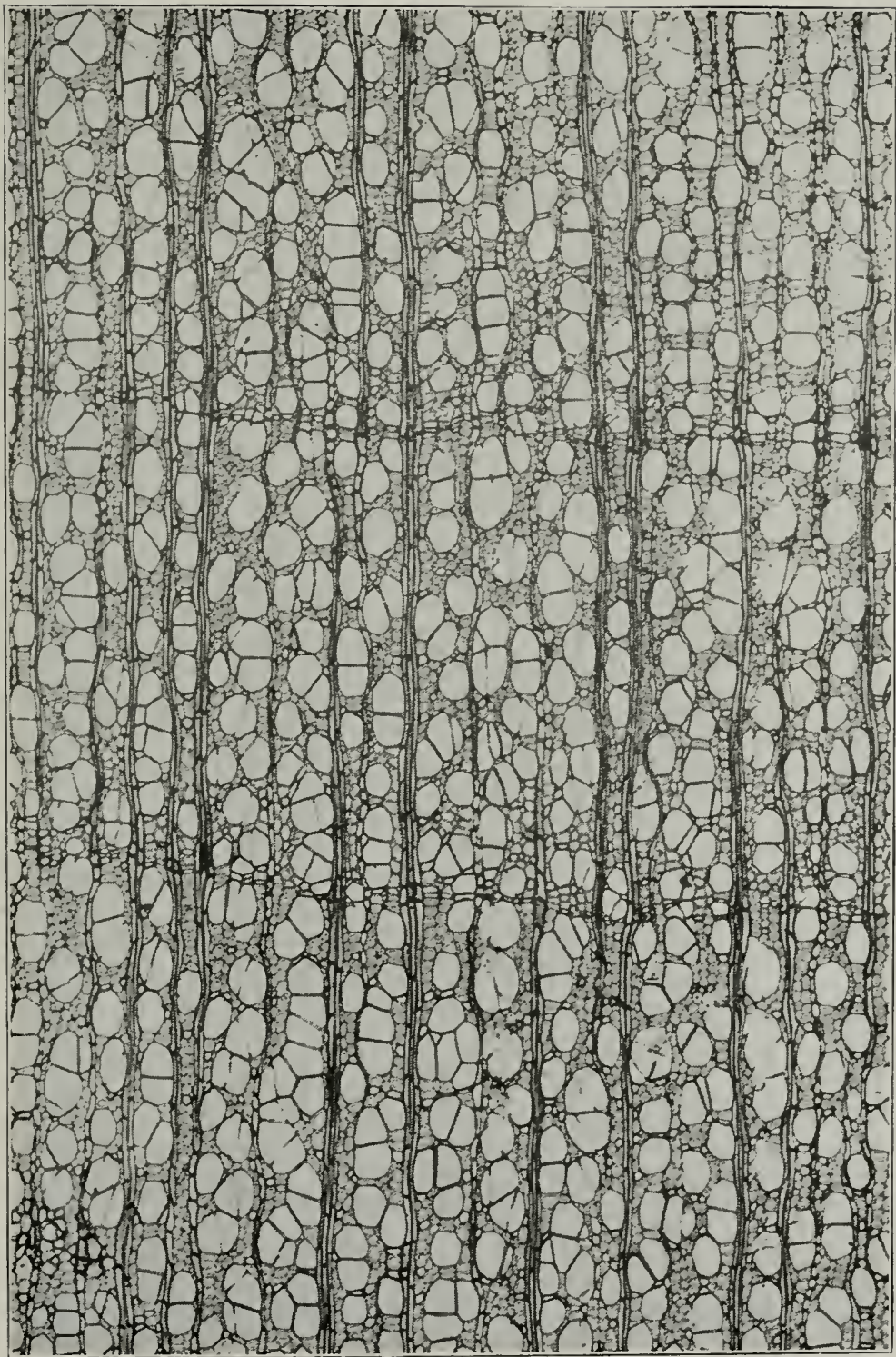

Fig. 143. Cross-section of the wood of the Tupelo. The pores are small, abundant, crowded, and evenly distributed throughout the growth rings; the rather large woody cells have thick walls and small cavities; and the rays are fine and narrow. A comparatively heavy wood that is strong and tough, though not very hard. 


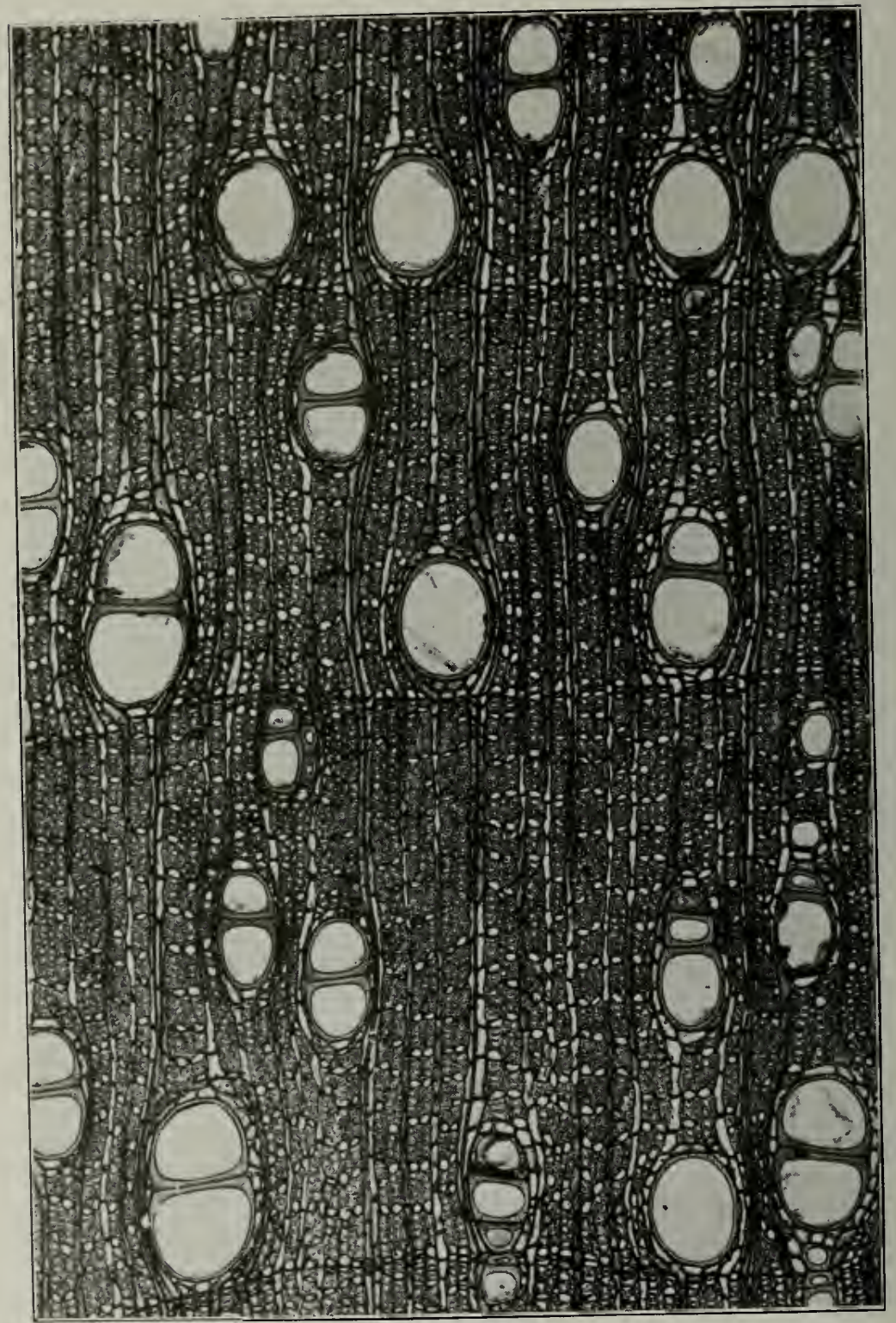

Fig. 144. Cross-section of the wood of the Persimmon. The pores in the spring wood large and in a narrow irregular zone, those in the late wood fewer but also large; the rays are fine, 1 or 2 cells wide; and the woody cells are small and abundant and very thickand heavy-walled. A wood so exceptionally heavy, hard, and strong that it is called "American ebony." 


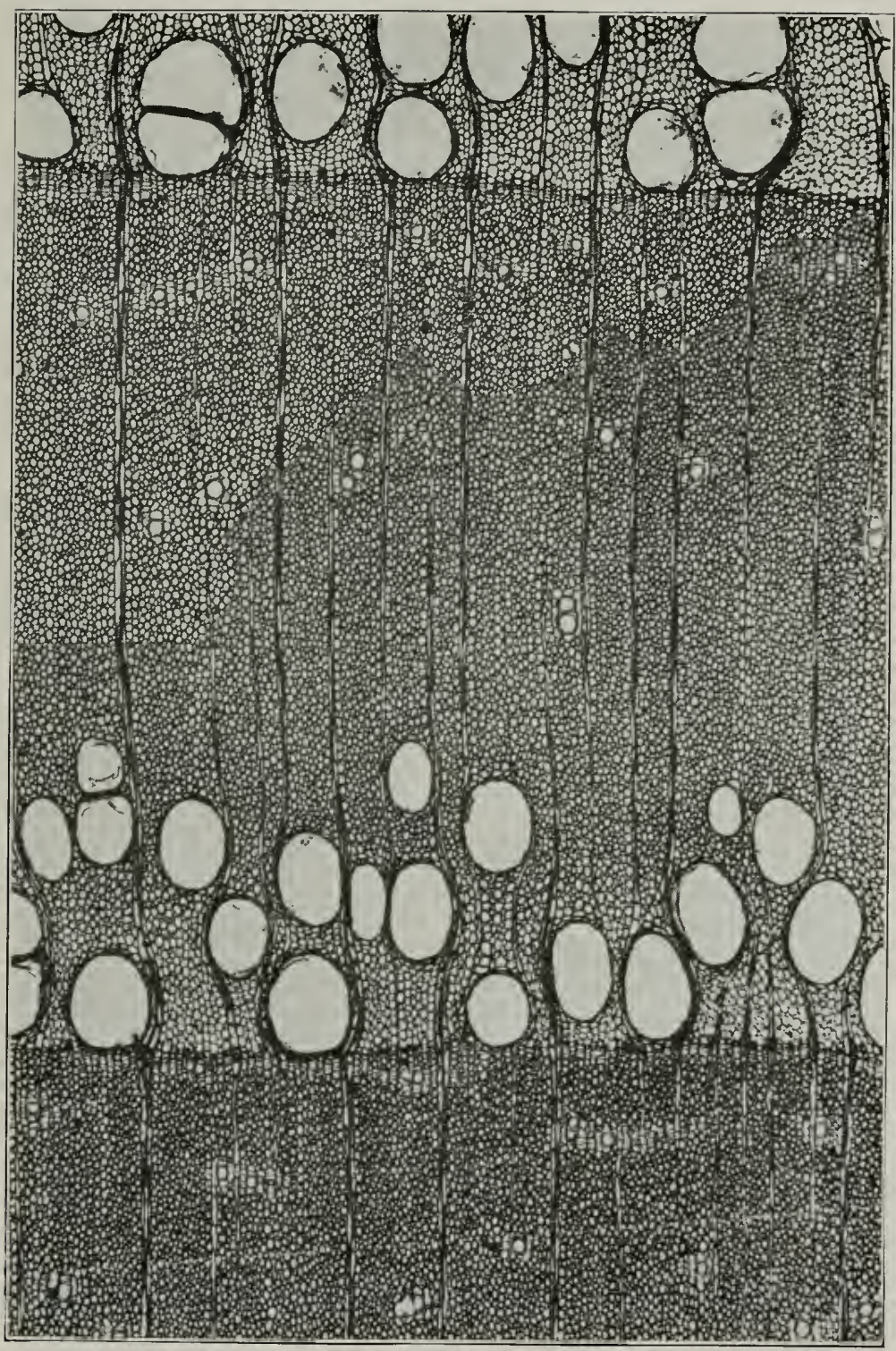

Fig. 145. Cross-section of the wood of the Black Ash. The pores in the early wood are large and arranged in a broad band, those in the late wood being few, small, and scattered; the woody cells are abundant and small but thin-walled; and the rays are fine though distinct. A rather soft and weak wood that is, nevertheless, heavy, tough, and durable. 


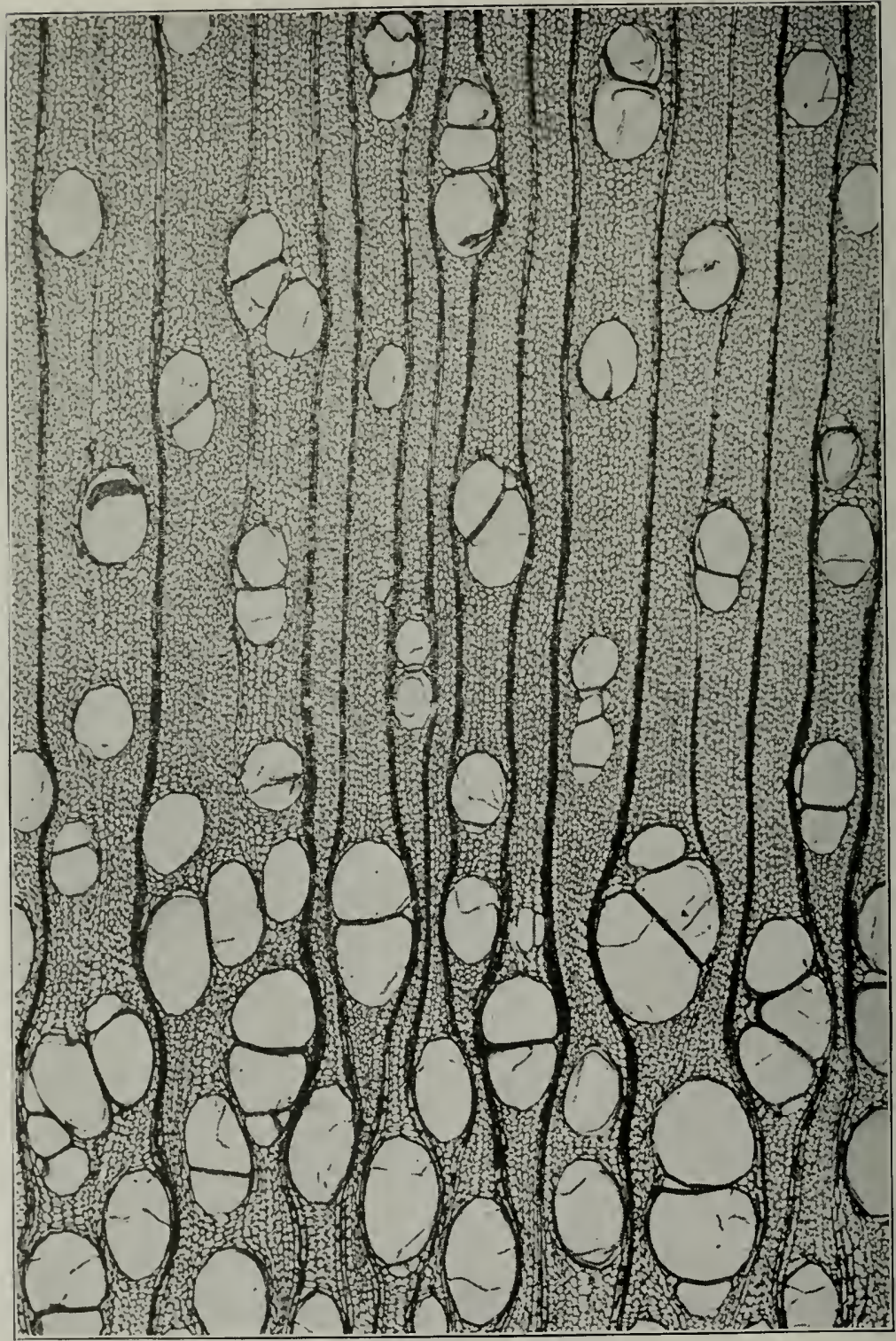

FIg. 146. Cross-section of Catalpa wood. The pores are large, abundant, and unevenly distributed; the woody cells are numerous, rather large, and thin-walled; and the rays are narrow and inconspicuous. A satiny-textured, very light and soft wood that is coarsegrained and durable. 


\section{FOREST INTEREST AND FOREST PRESERVATION}

Interest in the trees of Illinois dates back to the closing years of the Eighteenth Century. In 19.5. Andre Michaux, a distinguished French botanist, visited Illinois in search of plants which he intended to send home to enrich the gardens and pleasure grounds of his own country. Of the many interesting notes in his journal, ${ }^{1}$ only two need be mentioned. Concerning the Hackberry, he said (December $\hat{\imath}$ ): "I have confirmed my opinion that the second hark of Collis occidcululis (called in the Illinois country Bois connu and towards New Orleans Bois inconnu) is an excellent remedy for curing jaundice; a handful of the roots or leaves of Smila.r sarsaparilla is added to it; it is used for about eight days as a decoction." And about the oaks he remarked (January ?, 1i96i): "Having nothing to do. I made ink with gall nuts which I gathered on the oaks in the vicinity of the spot where we camper. It was made in less than five minutes and will serve me as a sample."

Thomas Nuttall, a well known botanist from Massachusetts, made a journey down the Ohio and up the Mississippi to the "Arkansana Territory" in $18: 1$ and made many notes regarding our trees. J. A. Lapham. a Milwankee botanist, made journeys into Illinois as early as 1s:36, and subsequently, in 18.56 , he published a catalog of Illinois plants. It the State Fair of 1833, which was held in Chicago, Robert Kennicott, Emil Clausen, and some others exhilited a collection of plants, among which there were specimens of $i 0$ species of trees. Dr. Frederick Brendel of Peoria suggested, in 1s.5, that the members of the Natural History Society should unite in an effort "to ascertain the northern and sonthern limits of trees," and in accordance with this suggestion Samuel Bartley, of Murphysboro, and C. Thomas, of Marion, made and reported some observations in their own comnties. At the same time, Dr. Brendel read to the Natural History Society a paper on "Forests and Forest Trees," in which he enmmerated the fi conifers present in Illinois today and listed 60 deciduous trees, 40 of which were of large size.

In 1866, Dr. A. H. Worthen, the first State Geologist of Illinois, made many very detailed observations about trees, especially with reference to their relation to geology and soils, in St. Clair. Madison, Hancock, Hardin, Pulaski, Massac, and Pope counties. Twelve years later, Professor T. J. Burrill and Mr. W. C. Flagg prepared a list of Illinois plants,

${ }^{1}$ Proc, Am. Phil. Soc. 26:1-145. 
in which the native stand of Chestnut in Pulaski County was mentioned for the first time. Another list of plants was prepared by William $\mathrm{K}$. Higley and Charles S. Raddin and pttblished in 1891 as a "Flora of Cook County. Illinois, and part of Lake Comnty, Indiana."

Dnring the three decades which have intervened, many special stuclies have been made of the plants and trees of Illinois, chicfly from the standpoint of ecology. Nost of these have been referred to in the discussion of the inclividual trees.

Interest in trees, as a matter of tree planting and forestry, received a decided stimulus between $18: 0$ and 1880 , and many of the tree plantations now growing in Illinois date back to that period. Arbor day was inaugurated by Governor Morton of Nebraska in 18it, and the American Forestry Association was organized in Chicago in January, 18i5. John A. Warder, of Ohio, in speaking before the Illinois Horticultural Society in 18 is referred to the fact that the railroads of the country were using 40 million ties annually (they now use 125 million) and that measures should be taken to provide for a future stuply; and in 1882. Franklin P. Hough, who held a position corresponding to the present Chief Forester of the United States, also spoke of the tie situation, estimating the number used at that date as $56,5.1 .428$. for which at least 565.514 acres of land had to be cut over annually, supposing a production of 100 ties per acre and a durability of seven years for each tie.

At about this time, the University of Illinois secured an appropriation of money from the State Legislature, by means of which a Forest Tree Plantation was established. Planting was begun in the spring of $18: 1$, and 30 species of trees were set out, 4 of them being European, 3 from other states, and 23 native forest trees of Illinois. The larger part of this plantation still remains, as a demonstration that Black WValnut, Green Ash, European Larch, Catalpa, Soft Maple, and Bass Wood can make good growths on black clay-loam soils. It has shown, too, that White Pine, White and Burr oaks, and Hickory grow very slowly on stuch soils, and that, on the whole, forests should be grown on cheaper lands.

One of the largest plantations in the State was established between $18 i 1$ and $18 i t$ by Mr. J. B. White in Christian County. It consisted of a strip of trees 100 yards wide placed along the north. west, and south sides of a quarter section and a block of $1: 3$ acres on the east side of the quarter. The species planted were Ash, Osage Orange, and Catalpa. with a small proportion of Larch, Norway Spruce, Austrian and Scotch pines. Sugar and Silver maples, Honey Locust, Burr Oak, and Hickory. Mr. A. N. Abbott, of Morrison, who has planted 50,000 trees with his own 
hands, has demonstrated that planting will stop "blow sand," the Cottonwood being perhaps the best tree for that purpose. The Chicago Burlington and Quincy railway has also planted thousands of Catalpa trees along its right-of-way, some of which are large enough for fence posts; but it is a question if they can be brought to tie size within a reasonable length of time without underplanting. Due to the extensive sale of catalpa some years ago by unscrupulous salesmen who recommended it for all purposes and on land not suited for growing it, to the planting of Black Locust on sand where it has made a complete failure because it was attacked by the locust borer, and to the high prices charged for nursery stock, our area of forest plantations in Iflinois is about at a stancl-still. Enough information is now in possession of our State and Extension Foresters, however, to enable them to give intelligent advice on the usefulness of most species and so at least help planters not to make costly mistakes. With nursery stock obtainable at reasonable prices, another stimulation may come soon in forest and windbreak planting. which will place them on a sane and permanent basis.

A further indication of the present interest in trees is found in the fact that there are now two splendid arboretums in Illinois. The Morton Arboretum, located near Lisle, has been established only recently, while "Bird Haven," the personal property of Robert Ridgway, has been under development for many years.

The Morton Arborctum: The Morton Arboretum at Lisle, Dupage County, Illinois, was founded in 1921 by Joy Morton. Its purposes and aims are thus expressed in the declaration of trust establishing it: "creating a foundation to be known as the Morton Arboretum. for practical, scientific research work in horticulture and agriculture, particularly in the growth and culture of trees, shrubs and vines by means of a great outdoor museum arranged for the convenient study of every species, variety and hybrid of the woody plants of the world able to endure the clinate of Illinois, such museum to be equipped with an herbarium, a reference library, and laboratories for the study of trees and other plants. with reference to their characters, relationships. economic value, geographical distribution and their improvenent by selection and hybridization; and for the publication of the results obtained in these latoratories by the officials and students of the arboretum, in order to increase the general knowledge and love of trees and shrubs and bring about an increase and improvement in their growth and culture."

The four hundred acre tract selected for the Arboretum is situated one mile north of Lisle and about twenty-five miles west of Chicago, and 
is easily reached by motor cars over Ogden Avenue or Roosevelt Road or by train to Lisle on the Chicago Burlington and Quincy railway. Over 4.000 different species of woody plants are already growing at the Arboretum, and its usefulness is being increased by the issuing of bulletin: of popular information.

Bird Haz'n: At Olney, in Richland County, not far from the celebrated lower Wabash Valley region of Indiana and Illinois, stands Robert Ridgway's Bird Haven. It is remarkable because it has been built up by a nan of limited resources who has been occupied in other scientific pursuits. Much of the planting and transplanting has been done with his own hands or under his personal supervision. Mr. Ridgway has also in the town of Olney his home place, called Larchmound, which covers about five acres, where many trees and shrubs, strangers to Richland County and even to America, are growing around the house and in the gardens. On these grounds he also maintains a small nursery, where the less hardy plants are carefully nurtured before they are transferred to the woods at Bird Haven. Mr. Ridgway tells in his own words the objects and accomplishments of Bird Haven:

"Bird Haven is situated two and one-fourth miles north of Olney. Richland County, Illinois, on the east side of the Macksburg road. Its area is about 18 acres. It is bordered along the south side by a 6.5 acre tract of heavily culled woodland; on the north and east sides by open fields. The higher grounds, which occupy more than half of the total area, are elevated about 36 feet above low water level in the creek, the east fork of Fox River, which intersects the northeastern portion. This stream is constantly fed by springs which emerge beneath the surface of the water along the south side, a depth of not less than three feet being thus maintained during the driest seasons. The steeper hillsides face the north, those facing the west and east having longer and more gentle slopes. A secondary stream, becoming dry in summer, intersects the western portion, entering the main stream just outside the northwestern corner of the property. The higher grounds are mostly wooded and there are many trees in the bottoms of the smaller stream; but the bottons between the hills and the main stream, comprising an area of about three acres, are completely cleared, except along the banks of the creek and along the eastern border.

"Bird Haven represents a modest effort at conservation of wild life on a small area. Its establishment was prompted by a sad realization that our beautiful and interesting forests are disappearing so rapidly that the original virgin forest is now a memory only to the oldest inhabitant, while 
the change in the woods that are left is so great that a real virgin forest is almost if not quite beyond the conception of the present generation.

"The ground selected is not the best for the purpose that could be found but was the only one available under the purchaser's linitations. The timber. which occupies about three-fourths of the area, is second growth, the land having been under cultivation as late as 18:2. The soul on the hills is very poor. owing to exhaustion and washing during the period of cultivation: and the bottomlands are subject to frequent inundations. These disadvantages, however, are off-set, in a measure, by the very unusual richness or variety in the tree growth, and convenient access from the town.

"As previously stated, about one-fruth of the surface of Bird Haven is treeless. There are. therefore, approximately 13 acres that are more or less thickly wooded. On these few acres there are growing naturally. .3 species and varieties of trees, three of which, however, are naturalized extralimital species, leaving a total of 60 indigenous species and varieties. This is a larger number of diconledonous (broad leaved) trees than are native to the entire Pacific coast. from southern California to Alaska, inclusive: while of the oaks alone ( 10 species) there are only two less than the number of species of oaks growing naturally on the is.4:4 square miles of the six New England States.

"A few old white oak stumps are all that remain of the original growth. As to the character of this growth. I have been so fortunate as to learn much from the man who sawed the timber-Mr. John Fahs, now of Los Angeles. California. According to him on the hills it consisted principally of splendid white oaks and sugar maples, though many other species were mingled with them. On the bottomland other oaks, chiefly the bur1 oak, swamp white oak, pin oak, bottom red onk (Q. Scluncckii) sweet gum. red maple. sugar maple, American elm, and other moistureloving species predoninated.

"Although conservation of the wild life was the chief motive in establishing Bird Haven. I had other objects in view. It had long been my desire to experiment with the planting of numerous kinds of woody plants that had never been grown in this part of the country, in order to test their adaptability to the climate and other local conditions; and when a "census" had been made of the ligneous species that were growing on the selected tract the idea naturally suggested itself of adding other Illinois species until the ligneous flora of the State became completely represented. Thus my plan included (1) the conservation of the original flora, $(2)$ the development from the nucleus already there of a state 
arhoretum and (3) the experimental planting of previously untested extralinital species, both American and exotic. In accordance with this plan there have been adcled to the 73 kinds of trees growing there naturally s!) species of Illinois trees: to the 22 shrubs, 51 species: and to the 1 ; woody climbers 14 species, making a total of 162 species and varieties of Illinois trees, :; Illinois shrubs, and 31 Illinois woody climbers-a total of 266 species and varieties of woody plants native to or naturalized in Illinois-that are now established on Bird Haven.

"Of species extralinital to Illinois but indigenous to other parts of the United States there have been planted 38 species of trees, 13 shrubs, and \& woody climbers. These include the more interesting or ornamental kinds, among which may be mentioned the Magnolias, of which $:$ of the 8 North American species are represented, the only one wanting being the rare and local Magnolia pyramidata.

"Of exotic species (chiefly from eastern Asia), there have been planted 25 species of trees, 28 shrubs and 14 woody climbers. Thus there are now growing on Bird Haven 225 species and varieties of trees, 114 shrubs and jo woody climbers, a total of 391 ligneous plants."

\section{Forest Preserves for Recreation}

One of the greatest purposes to which a forest can be put is that of furnishing recreation; and for this purpose alone, without the need of any additional weight of practical and sentimental reasons, steps should be taken to preserve the few remaining forests of our State. The rest, the health, and the contact with nature that could be gained every year by an ever-increasing number of people would be an "annual crop" fully as valuable as any amount of timber that could be harvested.

Some attempts have been made already to preserve the fast-vanishing woodlands, and there is among our State's laws a Forest Preserve Act which enables the counties to set aside and maintain valuable tracts of land for the growing of trees. Cook County was the first to take advantage of the Forest Preserve Act, and its example has been followed by DuPage and II innebago counties, while movenents are being inaugurated in other counties with the same end in view.

Cook County Forest Prescries: The Forest Preserves of Cook County add to the city of Chicago an outer belt or system of parks in which recreation is the outstanding feature. The strength of man's elemiental craving for the great open spaces is shown by the fact that in $192 \mathrm{~J}$ over $10,000,000$ people visited these preserves, which now include a total 
of 30,142 acres. All of this land has been acquired since 1913 , and the ultimate goal is about 35,000 acres. Not all of this acreage is wooded. Some is given over to golf courses, baseball diamonds, tennis courts, and parking places, and there are natural open spaces in the woods. The Forest Preserve District has also acquired title to more than 1,000 acres of the Skokie Marsh, and this entire mootland. which amounts to over 2,000 acres, may in tine be preserved from drainage projects and liept in its primitive condition. The average cost of land for the preserves has been $\$ .500$ an acre, a very reasonable figure when the values of property in many surrounding districts are considered; and many of the tracts have increased greatly in value since they were acquired.

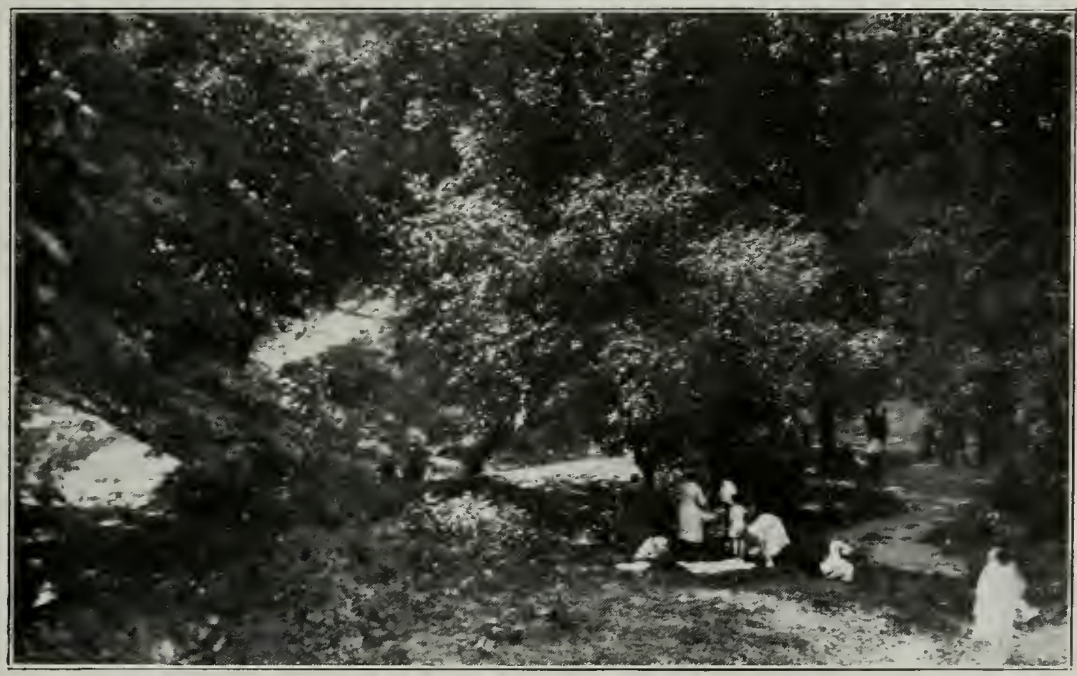

F1G. 147. Forest recreation: A picnic in a Cook County Forest Preserve.

The activities of the preserves can best be learned by a trip through them, which will require much longer than a day, although a great deal of ground can be covered in that time on the excellent roads which stretch from one preserve to another and through the preserves themselves. Good roads are a first essential, but there must also be means for handling the public efficiently and for increasing the recreational facilities, anong which are the deepening of ponds and streams, the construction of shelters and conffort stations, building of cabins and fire places, drilling of deep wells, erection of tables for. campers and picnic parties, providing parking places for automobiles, looking after concessions of various sorts, etc. One rather original feature is the construction of dams on the Des Plaines 


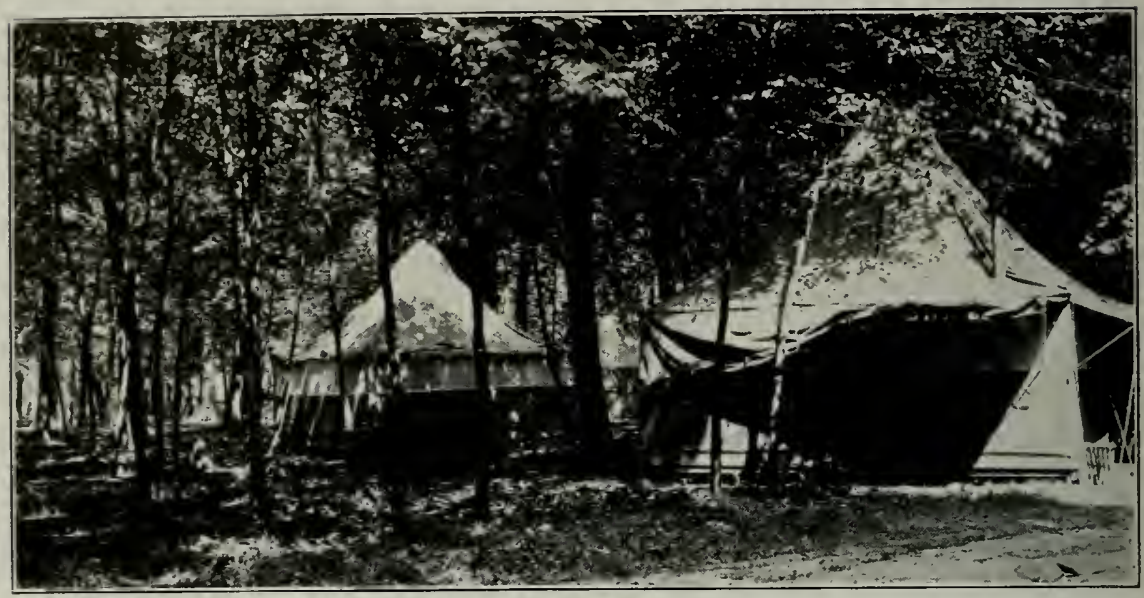

Fici. 148. Forest recreation: Summer camps in a Cook County Forest Preserve.

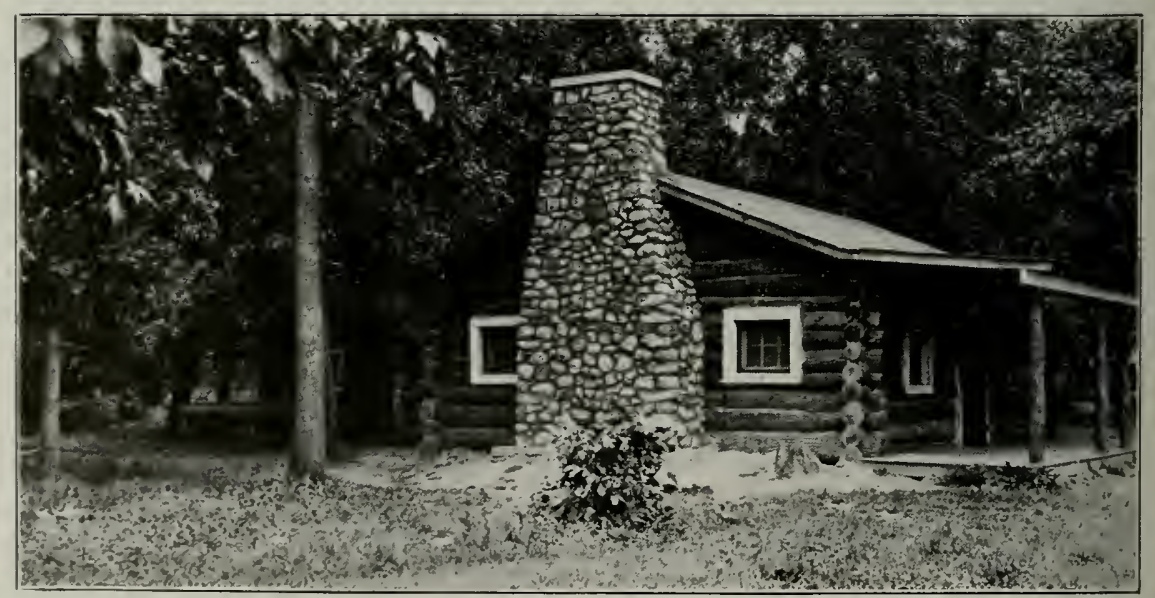

FIg. 149. Forest recreation: Girl scout camp in a Cook County Forest Preserve. 
River, in order to increase the depth of the water in summer and provide better facilities for boating and bathing. These are combination dams and fords, built of reinforced concrete, so arranged that at the flood times of the river the water can flow over them after the iron railings are removed. Permanent cabins for Boy and Girl Scouts and a Fresh Air Camp are also maintained, and camping privileges are allowed to private individuals.

The management of preserves where recreation is a paramount feature places a great responsibility upon the forester in charge of them. He is not only confronted with the task of providing for the connfort of visitors and furnishing them with recreation of various kinds, but he is at the sane time responsible for the perpetuation of the woods. since the admission of the public adds greatly to the danger of fires, of trespass, and of destruction by the vandals who will pick flowers and destroy the trees and shrubbery. The problem of maintaining the requisite number of trees per acre by natural reproduction is also exceedingly difficult even if there is a very large acreage, when the forest preserve is subjected to the trampling of thousands of persons. This may necessitate the rotation of areas, just as is done on grazed forests, so that a certain area after being open, is closed until it recovers from the destructive effects of trampling out the undergrowth.

Wimebago County Forest Prescres: The Winnebago County Forest Preserves came into being July 19,1924 , when $M r$. T. G. Lindrutist, a graduate of the Michigan Agricultural College, was employed as Chief Forester and placed in charge of a newly purchased tract of 9.) acres. This tract, known as Hononegal Park, is situated some 1, niles to the north of Rockiford and borders on the Rock River. Approximately onethird of it is creek bottomland, another third is upland timbered almost entirely by oak, and the last third is river bottomland shaded by stately elms. annongst which are ashes, maples. willows. Box Eliler, and nut-trees as well as hawthorns and oaks.

Another tract, $i 5$ acres in extent, is located on the banks of Kilbuck Creek. 10 miles south of Rockford, and is known as Kilbuck Bluffis.

By successive acpuisitions of land, there are now $i f f$ acres included in these preserves, and an ultimate goal of 3.000 acres has been set. So far, the greater part of the work that has been done has been in Hononegah Park and has included the clearing away of old buildings, remodeling of buildings for a caretaker. the building of roads, and providing for the comfort of the public.

In 192i, over half a million people visited the Winnebago County Forest Preserves. But in order to increase the usefulness of the preserves, the program calls for the reforestation of open or cleared spaces 
by the planting of 50,000 young trees yearly and the construction of good roads. The yearly budget, including provisions for salaries and for the purchasing of new lands, is now about $\$ 63,000$.

Municipal Prescrocs: In addition to the large preserves maintained by counties, there are many towns in the State which maintain timbered areas. Among these towns are Monmouth, Knoxville, Joliet, Dixon, Galesburg, and Ottawa. Here, also, recreation is the principal purpose for which woodlands are kept. 


\section{INDEX}

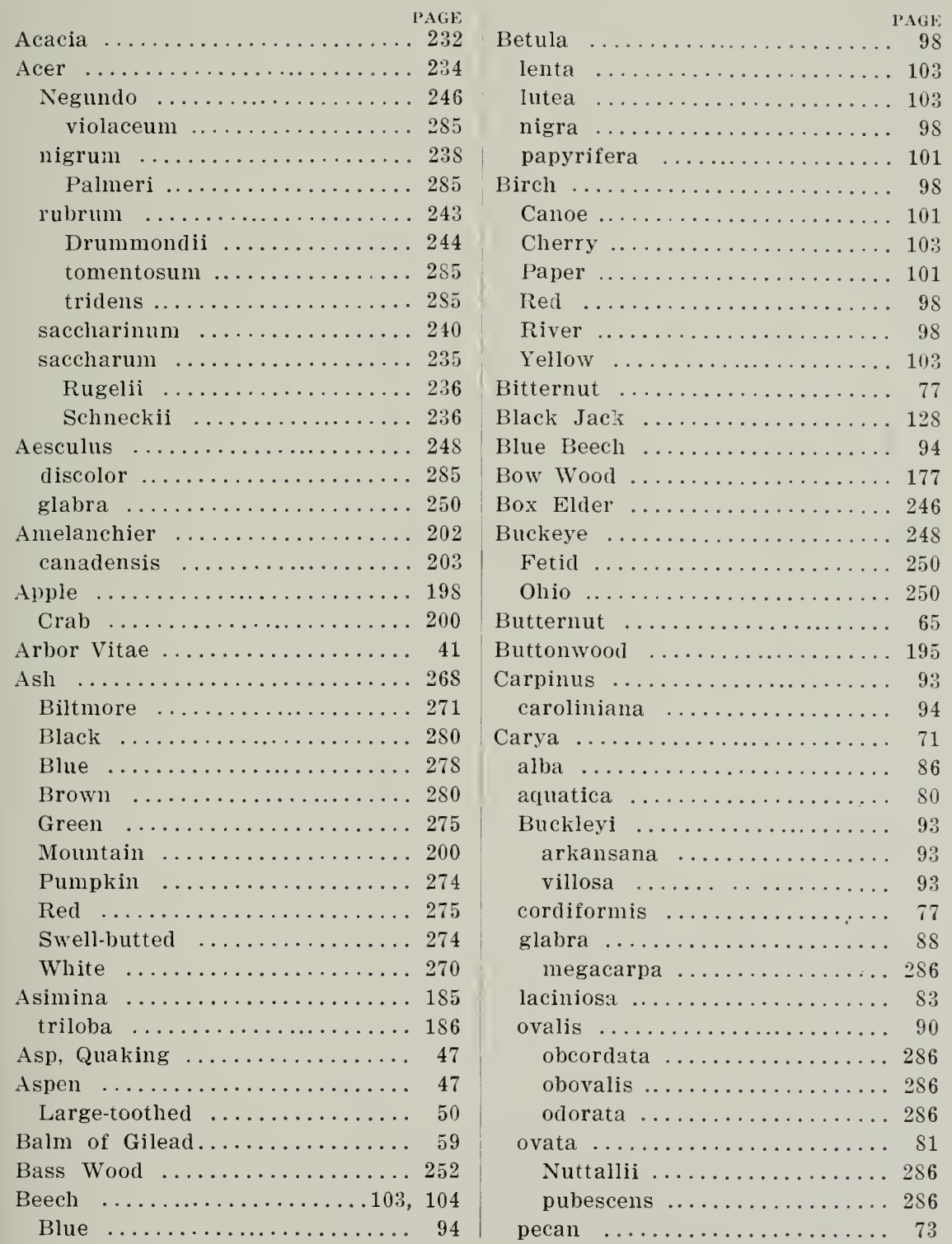




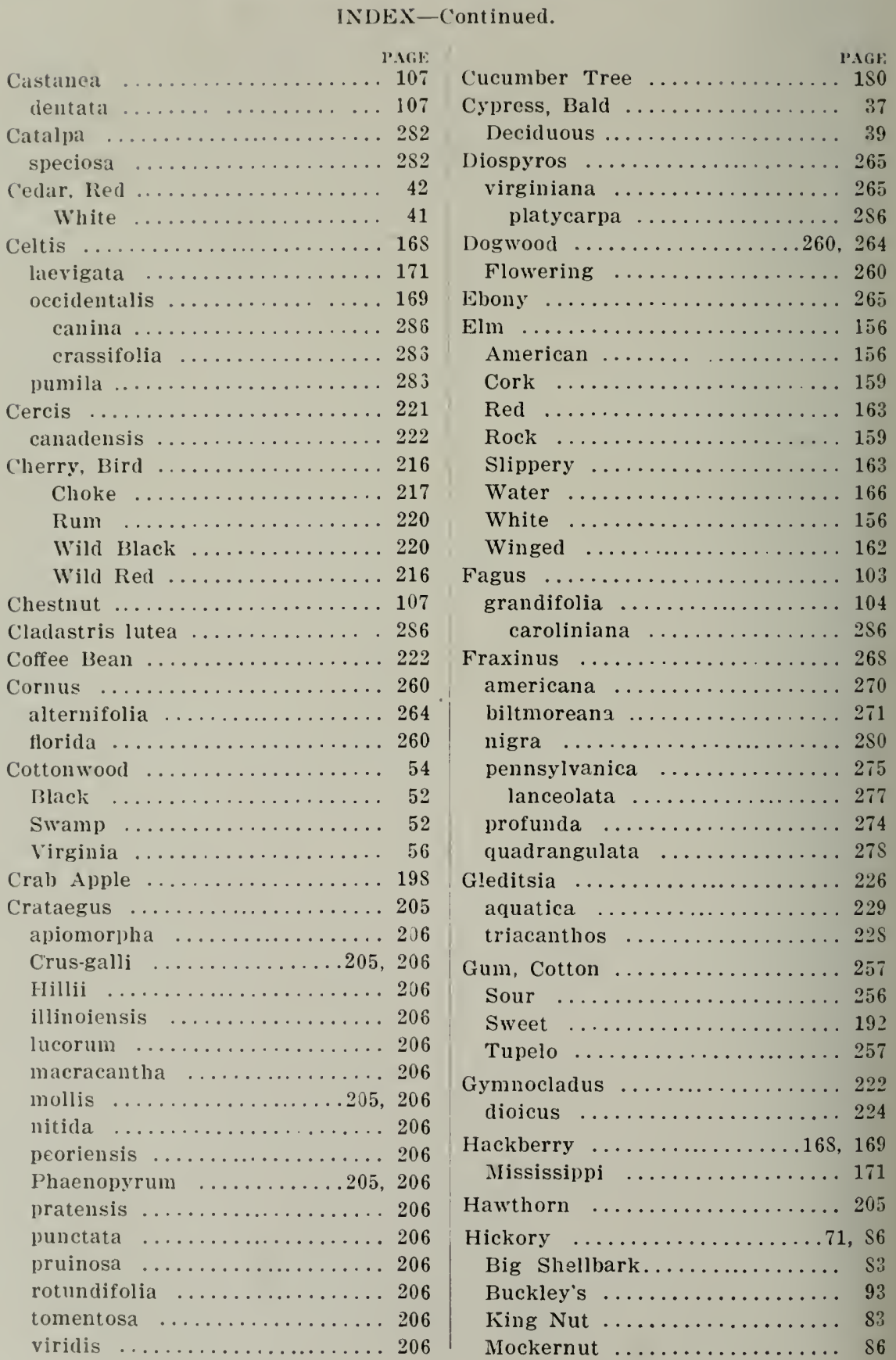


INDEX-Continued.

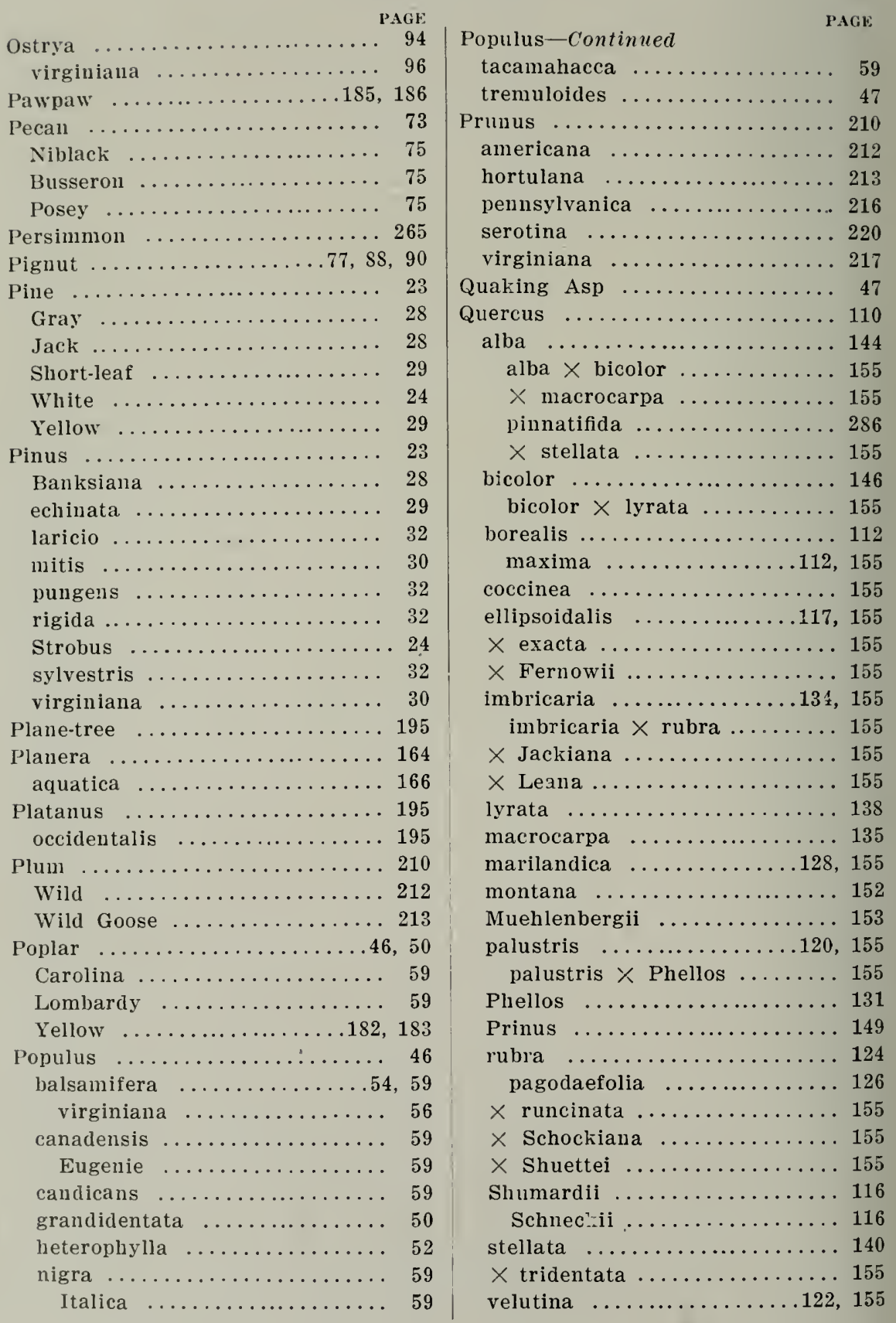


INDEX-Concluded.

\begin{tabular}{|c|c|}
\hline Red Cedar $\ldots \ldots \ldots \ldots \ldots \ldots{ }^{\text {PAGE }}{ }_{42}$ & Tilia-Continuert \\
\hline Redbud $\ldots \ldots \ldots \ldots \ldots \ldots \ldots \ldots 222$ & glabra $\ldots \ldots$ \\
\hline Robinia & heterophylla Nichauxii \\
\hline Pseudoacacia ............. 232 & neglecta $\ldots \ldots \ldots \ldots \ldots \ldots$ \\
\hline Salix $\ldots \ldots \ldots \ldots \ldots \ldots \ldots \ldots$ & Tulip Tree .............. 183 \\
\hline amygdaloides $\ldots \ldots \ldots \ldots \ldots$ & Tupelo $\ldots \ldots \ldots \ldots \ldots \ldots 254,256$ \\
\hline nigra $\ldots \ldots \ldots \ldots \ldots \ldots \ldots$ & Tupelo gum ............... 257 \\
\hline Sassafras $\ldots \ldots \ldots \ldots \ldots \ldots 188,189$ & Ulmus $\ldots \ldots \ldots \ldots \ldots \ldots \ldots \ldots \ldots$ \\
\hline officinale . & alata .... \\
\hline albirum $\ldots \ldots \ldots \ldots \ldots$ & americana \\
\hline Savin $\ldots \ldots \ldots \ldots \ldots \ldots \ldots \ldots .43$ & fulva $\ldots \ldots \ldots \ldots \ldots \ldots \ldots \ldots$ \\
\hline Service Berry . . . . . . . . . 203 & racemosa $\ldots \ldots \ldots \ldots 159,162,163$ \\
\hline Shad Bush . . . . . . . . . . 203 & 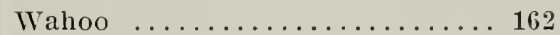 \\
\hline Sorbus $\ldots \ldots \ldots \ldots \ldots \ldots \ldots 200$ & Walnut $\ldots \ldots \ldots \ldots \ldots \ldots \ldots \ldots$ \\
\hline americana .............. 202 & Black ................. \\
\hline Sugarberry $\ldots \ldots \ldots \ldots \ldots \ldots 169,171$ & Ohio $\ldots \ldots \ldots \ldots \ldots \ldots \ldots$ \\
\hline Sycamore ................ 195 & Stabler $\ldots \ldots \ldots \ldots \ldots \ldots$ \\
\hline Tacamahac $\ldots \ldots \ldots \ldots \ldots \ldots . . \ldots 9$ & Thomas $\ldots \ldots \ldots \ldots \ldots \ldots$. \\
\hline 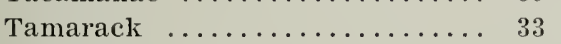 & White $\ldots \ldots \ldots \ldots \ldots \ldots$ \\
\hline Taxodium $\ldots \ldots \ldots \ldots \ldots \ldots$ & Water Elm ................. \\
\hline distichum $\ldots \ldots \ldots$ & White Cedar \\
\hline Thuja ....... & Willow ..... \\
\hline occidentalis . & Almond ... \\
\hline Tilia $\ldots \ldots \ldots \ldots \ldots \ldots \ldots \ldots . . \ldots 251$ & Black $\ldots \ldots \ldots \ldots \ldots \ldots$ \\
\hline floridlana $\ldots \ldots \ldots \ldots \ldots \ldots \ldots 251$ & Peach $\ldots \ldots \ldots \ldots \ldots \ldots \ldots$ \\
\hline
\end{tabular}

